UNIVERSIDADE DE SÃO PAULO

INSTITUTO DE GEOCIÊNCIAS

\title{
MINERALOGIA, INCLUSÕES FLUIDAS E ASPECTOS GENÉTICOS DO TOPÁZIO IMPERIAL DA REGIÃO DE OURO PRETO, MINAS GERAIS.
}

Antonio Luciano Gandini

Orientador: Prof. Dr. Darcy Pedro Svisero

DISSERTAÇÃO DE MESTRADO

Programa de Pós-Graduação em Mineralogia e Petrologia

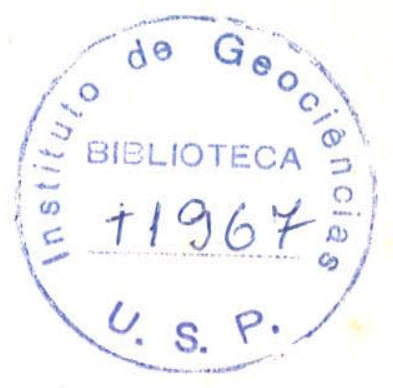

São Paulo 
UNIVERSIDADE DE SÃO PAULO

INSTITUTO DE GEOCIÊNCIAS

\section{MINERALOGIA, INCLUSÕES FLUIDAS E ASPECTOS GENÉTICOS DO TOPÁZIO IMPERIAL DA REGIÃO DE OURO PRETO, MINAS GERAIS.}

Antonio Luciano Gandini

Orientador: Prof. Dr. Darcy Pedro Svisero

DISSERTAÇÃO DE MESTRADO

COMISSÃO JULGADORA

nome

Presidente: Dr. D.P.Svisero

Examinadores: Dra R.M.da S.Bello

Dr. E.Wernick

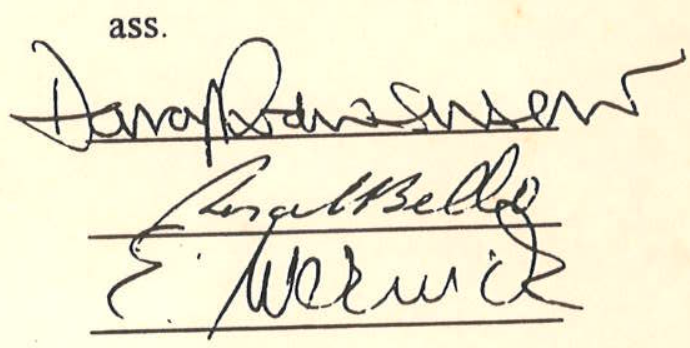

São Paulo 
À minha esposa Cida, pelos inúmeros momentos que deixei de desfrutar de sua companhia e por ter agüentado pacien temente meu mau humor; a meus filhos Maria Luiza e Pedro Henrique, pelas centenas de horas com quem não brinquei; a meus pais, Ugo e Célia; a meus irmãos, Rita, Huguinho, Neta e Regina e a minha tia Elvira, pelo grande incentivo que recebi, dedico este trabalho. 


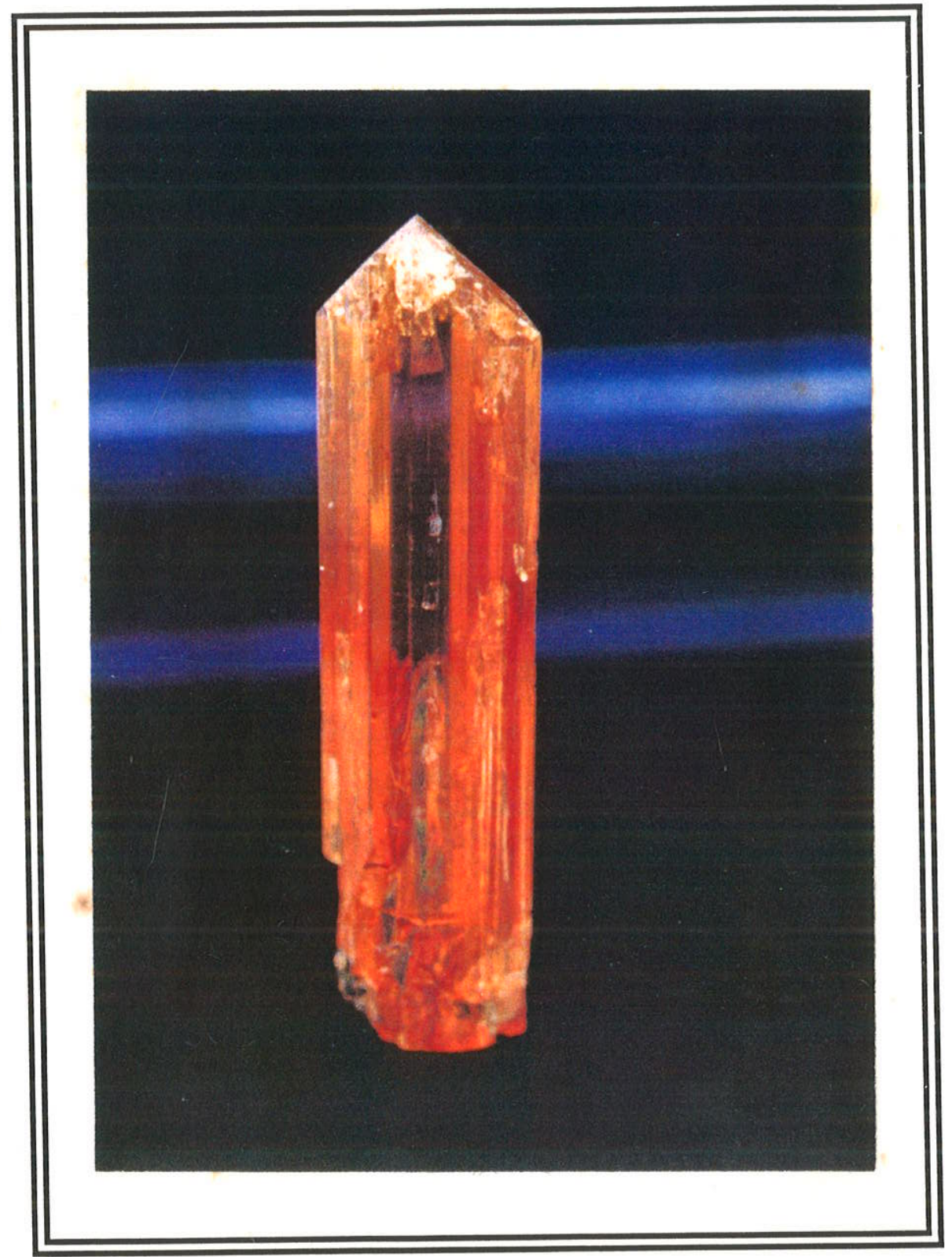

Cristal de topázio imperial de $13 \mathrm{~cm}$ de comprimento, coletado na região de Antônio Pereira, distrito de Ouro Preto, Minas Gerais, pertencente à coleção do Museu da Escola de Minas de Ouro Preto. Fotografia de José Ricardo e cortesia da ITAFOTO. 


\section{ÍNDICE GERAL}

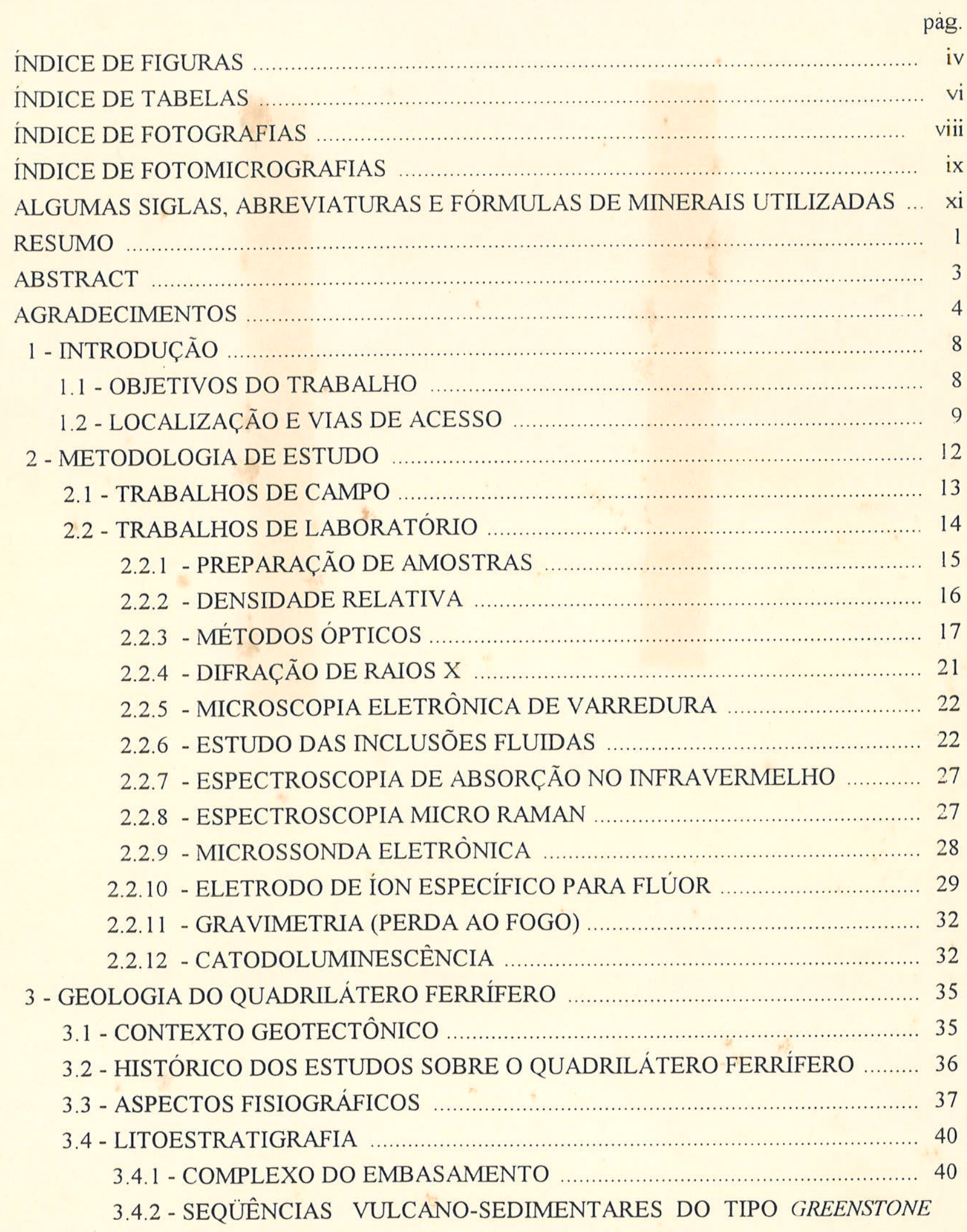
BELT 
3.4.2.1 - SUPERGRUPO RIO DAS VELHAS ....................................... 42

3.4.2.1.1 - GRUPO QUEBRA OSSO .................................... 42

3.4.2.1.2 - GRUPO NOVA LIMA ....................................... 42

3.4.2.1.3 - GRUPO MAQUINÉ ........................................... 43

3.4.3 - ROCHAS CUJAS IDADES SÃO ATRIBUIDAS AO PROTEROZÓICO

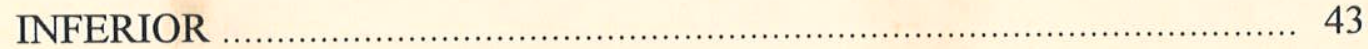

3.4.3.1 - SUPERGRUPO MINAS ................................................. 44

3.4.3.1.1 - GRUPO TAMANDUÁ …..................................... 44

3.4.3.1.2 - GRUPO CARAÇA ….............................................. 45

3.4.3.1.3 - GRUPO ITABIRA …........................................ 45

3.4.3.1.4 - GRUPO PIRACICABA …................................ 46

3.4.3.1.5 - GRUPO ITACOLOMI ….................................... 47

3.4 .4 - COBERTURAS SEDIMENTARES FANEROZÓICAS _........................... 47

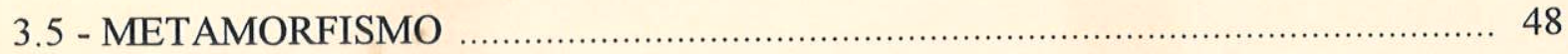

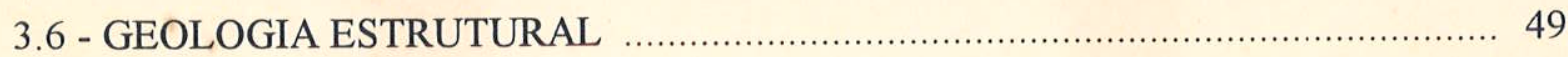

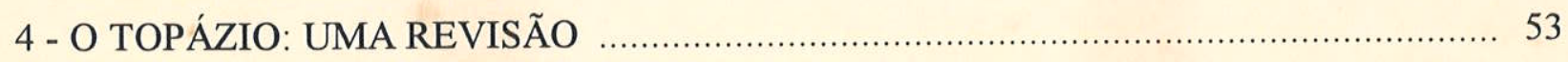

4.1 - MINERALOGIA E GEOLOGIA ............................................................. 54

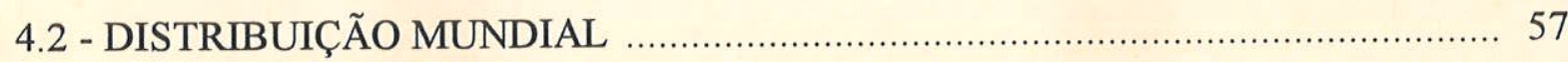

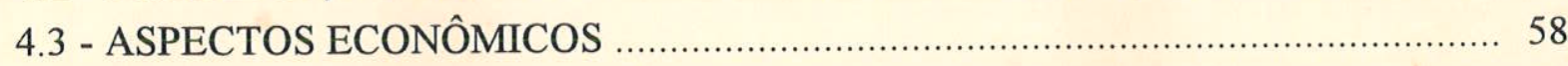

5 - O TOPÁZIO IMPERIAL DA REGIÃO DE OURO PRETO _..................................... 64

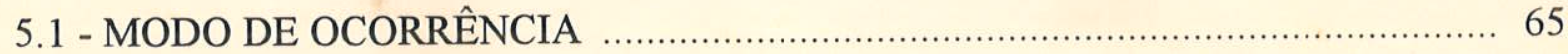

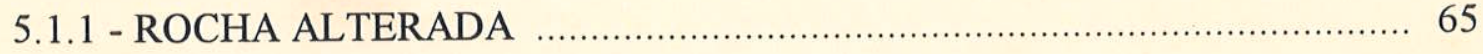

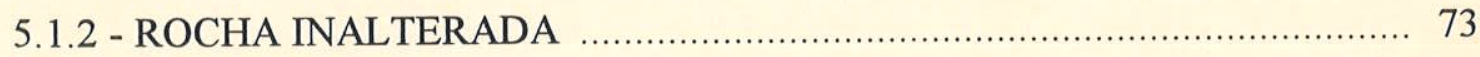

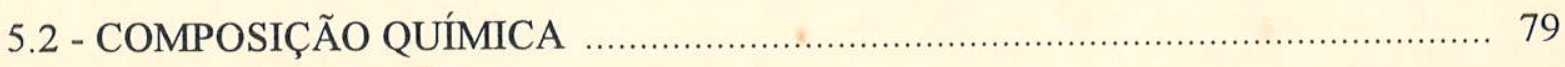

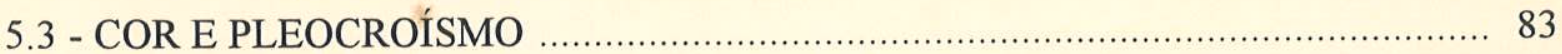

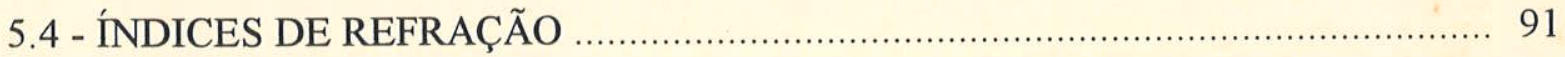

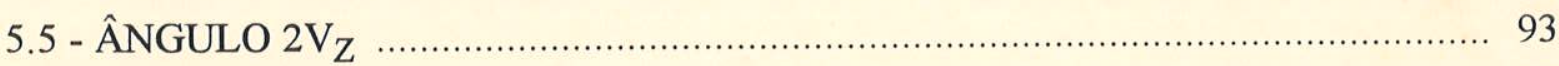

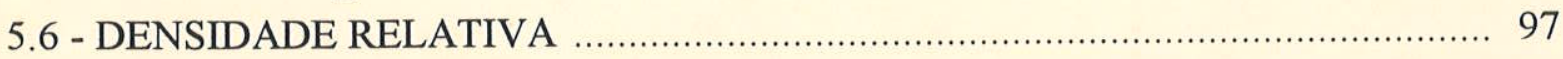

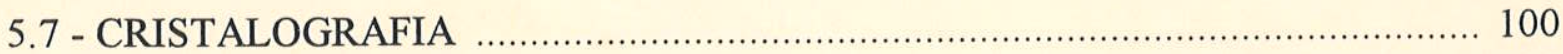

5.7.1 - MORFOLOGIA CRISTALINA ….............................................. 101

5.7.2 - PARÂMETROS DE CELA UNITÁRIA ............................................ 104

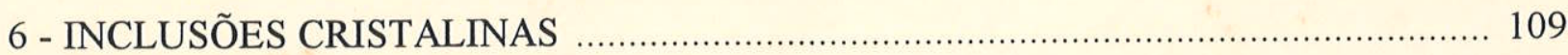

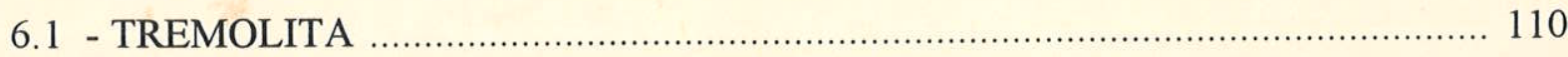

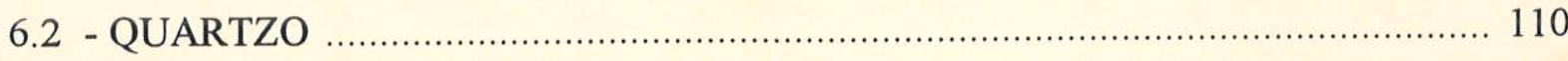

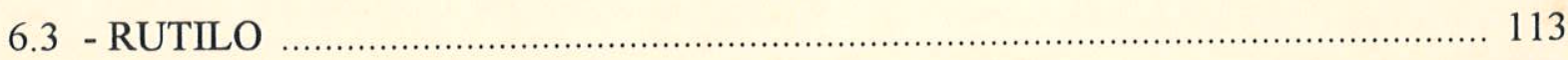

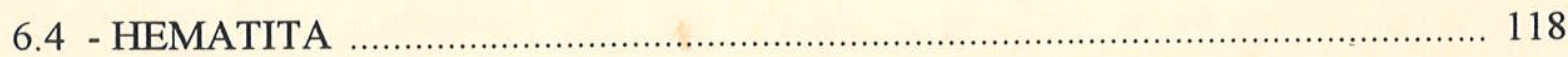

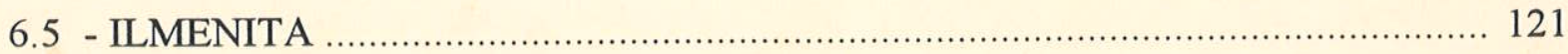


6.6 - EUCLÁSIO

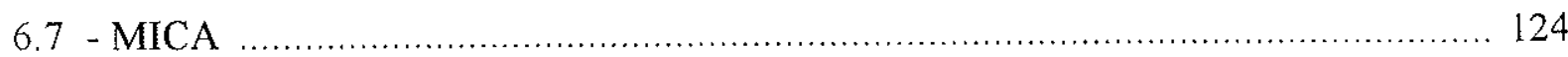

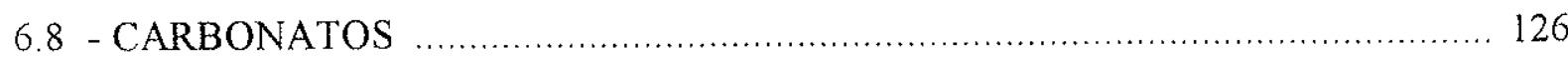

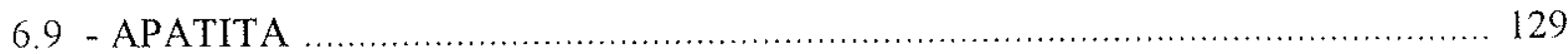

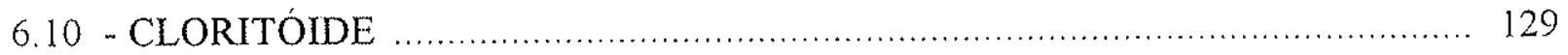

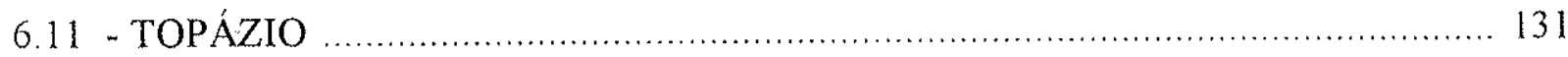

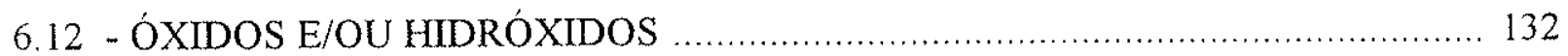

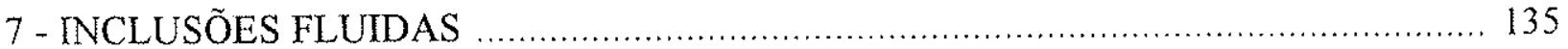

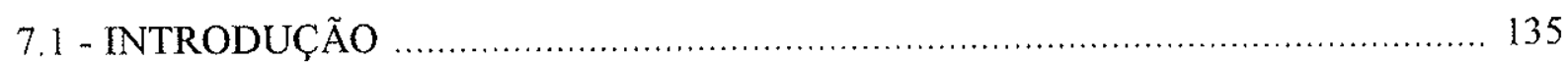

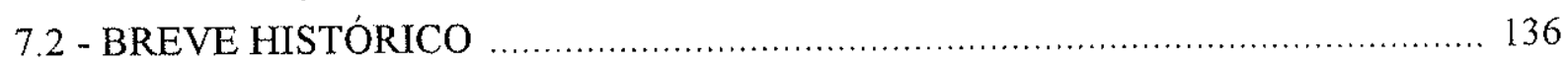

7.3 - CARACTERÍSTICAS GERAIS DAS INCLUSÕES FLUIDAS …………......... 136

7.4 - ORIGEM E CLASSIFICAÇÃO DAS INCLUSÕES FLUIDAS …….................. 138

7.5 - EXECUÇÃO DO MÉTODO MICROCALORIMÉTRICO ……………….......... 139

7.6 - INCLUSÕES FLUIDAS DOS TOPÁZIOS IMPERIAIS DA REGIÃO DE OURO PRETO

7.6.1 - DADOS MICROTERMOMÉTRICOS ……….................................... 154

7.6.1.1 - TEMPERATURA DE FUSÃO DO $\mathrm{CO}_{2}\left(\mathrm{Tf}_{\mathrm{CO}_{2}}\right) \ldots \ldots \ldots \ldots \ldots \ldots \ldots . . . . . . . . . .157$

7.6.1.2 - TEMPERATURA DE FUSÃO DO CLATRATO $\left(\mathrm{Tf}_{\mathrm{cl}}\right) \ldots \ldots \ldots \ldots \ldots . . .159$

7.6.1.3 - TEMPERATURA DE HOMOGENEIZAÇÃO DO $\mathrm{CO}_{2}$

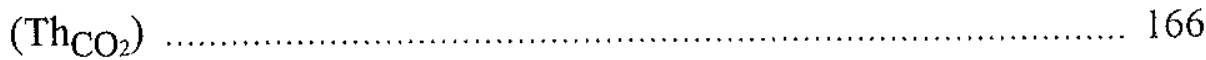

7.6.1.4 - TEMPERATURA DE HOMOGENEIZAÇÃO TOTAL $\left(\mathrm{Th}_{\text {tot }}\right) \ldots 167$

7.6.1.5 - DETERMINAÇÃO DOS PARÂMETROS FÍSICO-QUÍMICOS DOS FLUIDOS

8 - ASPECTOS GEOLÓGICOS E GENÉTICOS DAS JAZIDAS E/OU OCORRÊNCIAS DE TOPÁZIO IMPERIAL DA REGIÃO DE OURO PRETO

\section{1 - TRABALHOS ANTERIORES}

8.2 - PRESSÕES E TEMPERATURAS DE FORMAÇĂO DOS DEPÓSITOS DO TOPÁZIO E NATUREZA DOS FLUIDOS MINERALIZANTES

8.3 - CORRELAÇÃO DOS ASPECTOS GENÉTICOS DO TOPÁZIO IMPERIAL DA REGIÃO DE OURO PRETO COM OS DO PAQUISTÃO ……................... 183

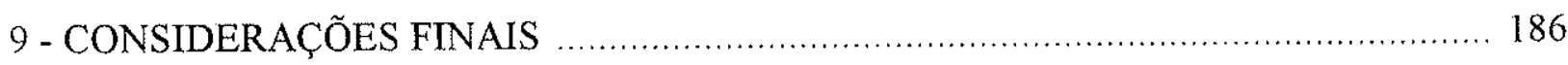

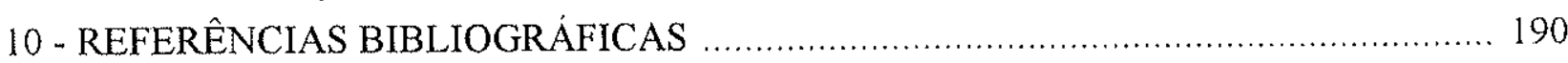




\section{ÍNDICE DE FIGURAS}

pág.

FIGURA 1 -Localização geográfica das várias jazidas e/ou ocorrências de topázio imperial na região de Ouro Preto, Minas Gerais ….................................. 11

FIGURA 2 - Modelo de um refratômetro gemológico …......................................... 19

FIGURA 3 - Diagrama esquemático de um refratômetro gemológico …........................... 19

FIGURA 4 - Modelos de dicroscópios de calcita e de placa polaróide .............................. 20

FIGURA 5 - Gráfico mostrando a interferência do alumínio na análise do flúor .................. 31

FIGURA 6 - Curva de calibração usada na análise do flúor ........................................ 31

FIGURA 7 - Localização do Quadrilátero Ferrífero no cráton do São Francisco ................. 36

FIGURA 8 - Esboço geológico simplificado do Quadrilátero Ferrífero ............................... 40

FIGURA 9 - Coluna estatigráfica do Quadrilátero Ferrífero ….................................... 41

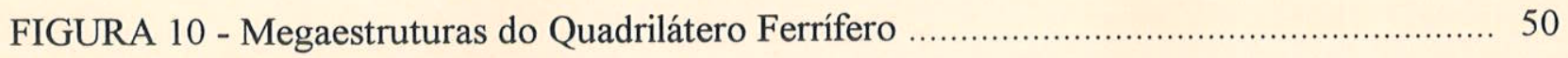

FIGURA 11 - Modelo da estrutura cristalina do topázio .............................................. 55

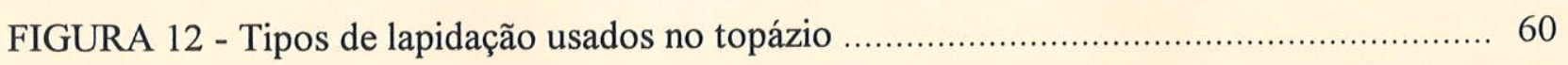

FIGURA 13 - Gráfico da variação do preço do topázio no mercado ................................. 63

FIGURA 14 - Mapa geológico da área produtora de topázio imperial no Quadrilátero

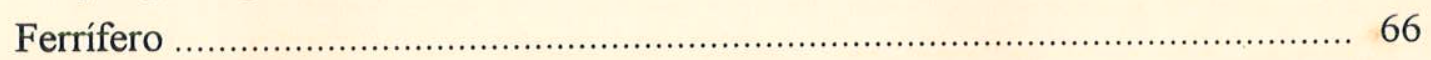

FIGURA 15 - Mapa simplificado destacando as ocorrências de rochas metacalcárias na região de Ouro Preto

FIGURA 16 - Histogramas de freqüências da razão $\mathrm{F}^{-} / \mathrm{OH}^{-}$, para topázios da região de Dom Bosco

FIGURA 17 - Diagramas mostrando a variação dos teores de $\mathrm{F}^{-} \mathrm{xOH}^{-}$em topázios da região de Dom Bosco

FIGURA 18 - Diagrama mostrando relação linear entre os teores de $\mathrm{F}^{-} \mathrm{xOH}^{-}$, em topázios da região de Dom Bosco

FIGURA 19 - Diagramas $\mathrm{Cr}^{3+}-\mathrm{V}^{3+}-\mathrm{Fe}^{3+}$ mostrando a distribuição isoladamente desses elementos nas diversas variedades de topázios da região de Dom Bosco

FIGURA 20 - Diagrama $\mathrm{Cr}^{3+}-\mathrm{V}^{3+}-\mathrm{Fe}^{3+}$ ressaltando a ausência de um padrão definido sobre as cores dos topázios estudados

FIGURA 21 - Variação do índice de refração dos topázios em função do teor de flúor ........... 93

FIGURA 22 - Variação do $2 V_{Z}$ dos topázios em função do teor de flúor ............................. 94

FIGURA 23 - Variação da densidade dos topázios em função do teor de flúor ...................... 99

FIGURA 24 - Morfologia de topázios da região de Ouro Preto comparada com topázios de outros locais

FIGURA 25 - Morfologia cristalina de um topázio da jazida de Saramenha 104 
FIGURA 26 - Variação do parâmetro $b_{0}$ com o teor de flúor 107

FIGURA 27 - Variação do volume da cela unitária em função do teor de flúor ................... 108

FIGURA 28 - Diagrama de pó de uma inclusão de tremolita .................................. 111

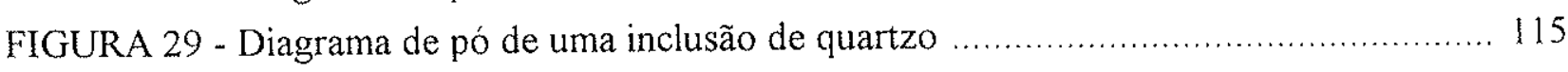

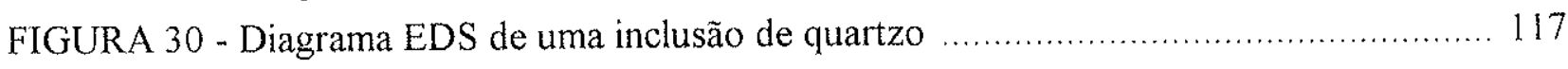

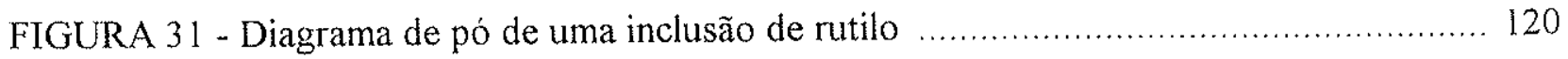

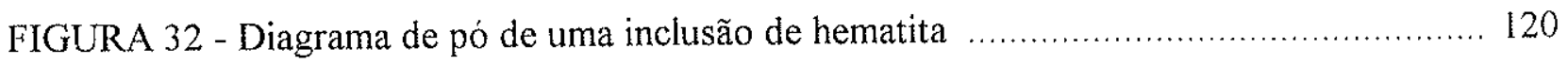

FIGURA 33 - Diagrama EDS de uma inclusão de mica ......................................... 126

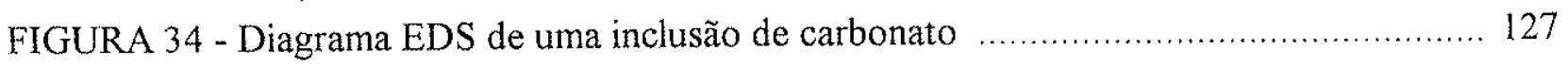

FIGURA 35 - Diagrama EDS de uma inclusão de cloritóide …............................. 130

FIGURA 36 - Mapeamento manual das inclusões fluidas do topázio .......................... 151

FIGURA 37 - Mapeamento das inclusões fluidas do topázio feito em câmara clara ......... 152

FIGURA 38 - $\mathrm{Tf}_{\mathrm{CO}_{2}}$ das inclusões fluidas dos topázios das jazidas Capão do Lana, Caxambu

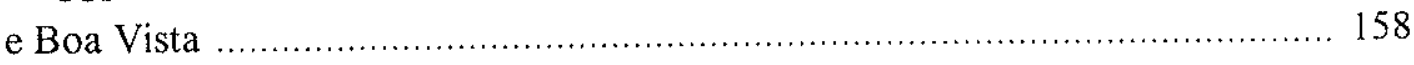

FIGURA 39 - Espectros infravermelhos destacando os componentes das inclusões fluidas de topázios da região de Dom Bosco ................................................. 160

FIGURA 40 - Espectro micro Raman de inclusão fluida de topázio ............................ 161

FIGURA $41-\mathrm{Tf}_{\mathrm{Cl}}$ das inclusões fluidas dos topázios das jazidas Capão do Lana, Caxambu e Boa Vista

FIGURA 42 - Salinidades das inclusões fluidas dos topázios do Capão do Lana, Caxambu e Boa Vista pertencente ao grupo 3

FIGURA 43 - Salinidades das inclusões fluidas dos topázios de Boa Vista dos grupos 1 e $2 \ldots 165$

FIGURA $44-\mathrm{Th}_{\mathrm{CO}_{2}}$ de inclusões fluidas distintas de topázios do Capão do Lana ............... 167

FIGURA $45-\mathrm{Th}_{\mathrm{CO}_{2}}$ de inclusões fluidas distintas de topázios de Caxambu ..................... 168

FIGURA $46-\mathrm{Th}_{\mathrm{CO}_{2}}$ de inclusões fluidas distintas de topázios de Boa Vista .................... 169

FIGURA 47 - $\mathrm{Tf}_{\mathrm{cl}}$ das inclusões fluidas dos topázios das jazidas Capão do Lana, Caxambu e Boa Vista

FIGURA 48 - Isócoras dos vários grupos de inclusões fluidas dos topázios da jazida Capão do Lana

FIGURA 49 - Isócoras dos vários grupos de inclusões fluidas dos topázios da jazida Caxambu

FIGURA 50 - Isócoras dos vários grupos de inclusões fluidas dos topázios da jazida Boa Vista

FIGURA 51 - Correlação de algumas propriedades do topázio com o teor de flúor 188 


\section{ÍNDICE DE TABELAS}

pág.

TABELA 1 - Resumo das principais propriedades gerais do topázio .............................. 56

TABELA 2 - Tabela de preços de topázios e de alguns substitutos ..................................... 62

TABELA 3 - Análises químicas de elementos principais e menores de topázios de cores diferentes obtidas pela microssonda eletrônica ….................................... 81

TABELA 4 -Análises químicas de topázios de vários locais do mundo, extraídos da

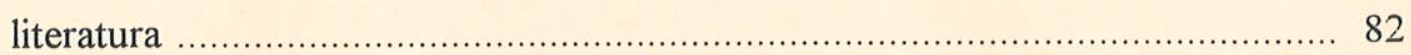

TABELA 5 - Porcentagens de $\mathrm{H}_{2} \mathrm{O}^{-}, \mathrm{H}_{2} \mathrm{O}^{+}$e de $\mathrm{F}^{-}$dos topázios da região de Ouro Preto .... 84

TABELA 6 - Índices de refração do topázio medidos nos três planos principais ................... 92

TABELA 7 - Índices de refração de topázios de cores diferentes da região de Dom Bosco ... 92

TABELA 8 - Valores dos ângulos $2 V_{Z}$ de topázios de cores diferentes da região de Dom Bosco

TABELA 9 - Valores de densidades obtidos a partir de uma balança eletrônica, de topázios de cores distintas de várias jazidas da região de Ouro Preto ......................... 98

TABELA 10 - Determinação do erro relativo da densidade do topázio através do uso do pic nômetro

TABELA 11 - Densidades dos topázios medidos no picnômetro 100

TABELA 12 - Diagramas de pó de topázios de cores distintas comparados com o padrão JCPDS

TABELA 13 - Parâmetros unitários de topázios coloridos da região de Dom Bosco 107

TABELA 14 - Diagrama de pó de uma inclusão de tremolita 112

TABELA 15 - Diagrama de pó de uma inclusão de quartzo 116

TABELA 16 - Diagrama de pó de uma inclusão de rutilo 118

TABELA 17 - Diagramas de pó de duas inclusões de hematitas

TABELA 18 - Composição de uma inclusão de ilmenita em topázio obtida no MEV

TABELA 19 - Diagrama de pó de uma inclusão de euclásio

TABELA 20 - Composição de uma inclusão de mica em topázio de Antônio Pereira obtida no MEV

TABELA 21 - Composição de uma inclusão de mica em topázio do Capão do Lana obtida no MEV

TABELA 22 - Composição de uma inclusão de carbonato em topázio obtida no MEV 126

TABELA 23 - Composição de uma inclusão de cloritóide em topázio obtida no MEV 130

TABELA 24 - Mudanças de fase das inclusões fluidas de topázios do Capão do Lana 155

TABELA 25 - Densidades, salinidades e frações molares dos componentes químicos das inclusões fluidas de topázios do Capão do Lana 
TABELA 26 - Mudanças de fase das inclusões fluidas de topázios de Caxambu

TABELA 27 - Densidades, salinidades e frações molares dos componentes químicos das inclusões fluidas de topázios de Caxambu 156

TABELA 28 - Mudanças de fase das inclusões fluidas de topázios de Boa Vista 156

TABELA 29 - Densidades, salinidades e frações molares dos componentes químicos das inclusões fluidas de topázios de Boa Vista

TABELA 30 - Variação da salinidade das inclusões fluidas de topázios do Capão do Lana .... 166

TABELA 31 - Temperaturas e pressões minimas de aprisionamentos das inclusões fluidas .... 183 


\section{ÍNDICE DE FOTOGRAFIAS}

pág.

FOTOGRAFIA 1 - Vista da Escola de Minas mostrando a cidade de Ouro Preto e ao fundo

a jazida de topázio imperial da Alcan ............................................... 10

FOTOGRAFIA 2 - Lote de cristais de topázio imperial ……….................................. 13

FOTOGRAFIA 3 - Vista do morro do Caxambu com a serra da Moeda ............................ 38

FOTOGRAFIA 4 - Serra do Itacolomi com o pico homônimo ………............................... 39

FOTOGRAFIA 5 - Vista panorâmica da jazida do Capão do Lana destacando a morfologia suave da região ...................................................................6 60

FOTOGRAFIA 6 - Transporte do minério na jazida Capão do Lana ………..................... 61

FOTOGRAFIA 7 - Vista panorâmica da jazida Capão do Lana ………….......................... 67

FOTOGRAFIA 8 - Retirada do capeamento do minério da mina do Capão do Lana ............ 68

FOTOGRAFIA 9 - Vista parcial da jazida do Capão do Lana ………….......................... 68

FOTOGRAFIA 10 - Desmonte hidráulico do veio mineralizado na jazida do Capão do Lana .. 69

FOTOGRAFIA 11 - Cata manual do topázio ....................................................... 70

FOTOGRAFIA 12 - Topázios rolados ................................................................ 71

FOTOGRAFIA 13 - Vista parcial da jazida de Antônio Pereira ……………………........... 72

FOTOGRAFIA 14 - Rocha portadora dos veios mineralizados em topázio imperial .............. 74

FOTOGRAFIA 15 - topázios coloridos encontrados na região de Ouro Preto ………........... 86

FOTOGRAFIA 16 - Topázio com níveis de quartzo granular orientados …..................... 113 


\section{ÍNDICE DE FOTOMICROGRAFIAS}

pág.

FOTOMICROGRAFIA 1 - Cristais de florencita associados ao topázio no colúvio

FOTOMICROGRAFIA 2 - Textura granuloblástica fina do mármore dolomítico da Formação Fecho do Funil

FOTOMICROGRAFIA 3 - Contato de um veio de quartzo e um de dolomita com o mármore dolomítico

FOTOMICROGRAFIA 4 - Núcleo de calcita em um cristal de dolomita destacada pela alizarina

FOTOMICROGRAFIA 5 - Contato do veio mineralizado com o mármore dolomítico ......... 76

FOTOMICROGRAFIA 6 - Seção de um cristal de florencita presente no veio mineralizado ....... 77

FOTOMICROGRAFIA 7 - Topázio imperial em contato com o mármore dolomítico .......... 77

FOTOMICROGRAFIA 8 - Cristais de dolomita com início de alteração ("borra de café") .... 78

FOTOMICROGRAFIA 9 - Seções basais de topázios mostrando zoneamento de cor .......... 78

FOTOMICROGRAFIA 10 - Seção basal de topázio exibindo pleocroísmo .......................... 90

FOTOMICROGRAFIA 11 - Anomalias ópticas vistas no topázio …............................... 95

FOTOMICROGRAFIA 12 - Anomalias ópticas observadas em seções basais de topázios ....... 96

FOTOMICROGRAFIA 13 - Intercrescimento de dois cristais de topázio …...................... 102

FOTOMICROGRAFIA 14 - Cristais de tremolita observados pelo MEV …..................... 111

FOTOMICROGRAFIA 15 - Grãos de quartzo orientados no interior do topázio ................. 114

FOTOMICROGRAFIA 16 - Núcleo de um topázio preenchido com grãos de quartzo .......... 114

FOTOMICROGRAFIA 17 - Grãos de quartzo observados no MEV ................................ 115

FOTOMICROGRAFIA 18 - Grupos de rutilos inclusos em topázios .............................. 117

FOTOMICROGRAFIA 19 - Cristal de topázio com inclusões de hematita (especularita) ....... 119

FOTOMICROGRAFIA 20 - Lâmina delgada de um topázio com inclusões de hematita ......... 121

FOTOMICROGRAFIA 21 - Inclusões de mica e quartzo no topázio ................................ 124

FOTOMICROGRAFIA 22 - Cristais de mica observados no MEV ….............................. 125

FOTOMICROGRAFIA 23 - Grãos de carbonato corroído observados no MEV ….............. 127

FOTOMICROGRAFIA 24 - Cristais romboédricos de carbonatos inclusos em topázios ........ 128

FOTOMICROGRAFIA 25 - Detalhe da fotomicrografia anterior observado em lâmina delgada ................................................................... 128

FOTOMICROGRAFIA 26 - Cristal de apatita revestido por carbonato observado no MEV ...... 129

FOTOMICROGRAFIA 27 - Cristal de cloritóide observado no MEV ............................... 130

FOTOMICROGRAFIA 28 - Topázio fraturado incluso em outro cristal da mesma espécie .... 131

FOTOMICROGRAFIA 29 - Cristal de topázio com núcleo de quartzo incluso em outro topázio 
FOTOMICROGRAFIA 30 - Nódulos de limonita na fratura de um topázio 133

FOTOMICROGRAFIA 31 - Agregado dentrítico presente na fratura de um topázio 133

FOTOMICROGRAFIA 32 - Inclusão fluida de topázio preenchida por limonita

FOTOMICROGRAFIA 33 - Inclusões fluidas de contornos regulares distribuídas paralelamente ao eixo c

FOTOMICROGRAFIA 34 - Inclusões fluidas com prolongamentos paralelos ou perpendiculares ao eixo $\mathbf{c}$ e inclusões escalonadas

FOTOMICROGRAFIA 35 - Inclusões fluidas inclinadas em relação ao eixo c ou distribuídas aleatoriamente no cristal

FOTOMICROGRAFIA 36 - Inclusões fluidas estranguladas (necking down) e com escape (leakage)

FOTOMICROGRAFIA 37 - Inclusões fluidas em fraturas parcialmente cicatrizadas 149 FOTOMICROGRAFIA 38 - Inclusões fluidas trifásicas e polifásicas 153 


\section{ALGUMAS SIGLAS, ABREVIATURAS E FÓRMULAS DE MINERAIS UTILIZADAS}

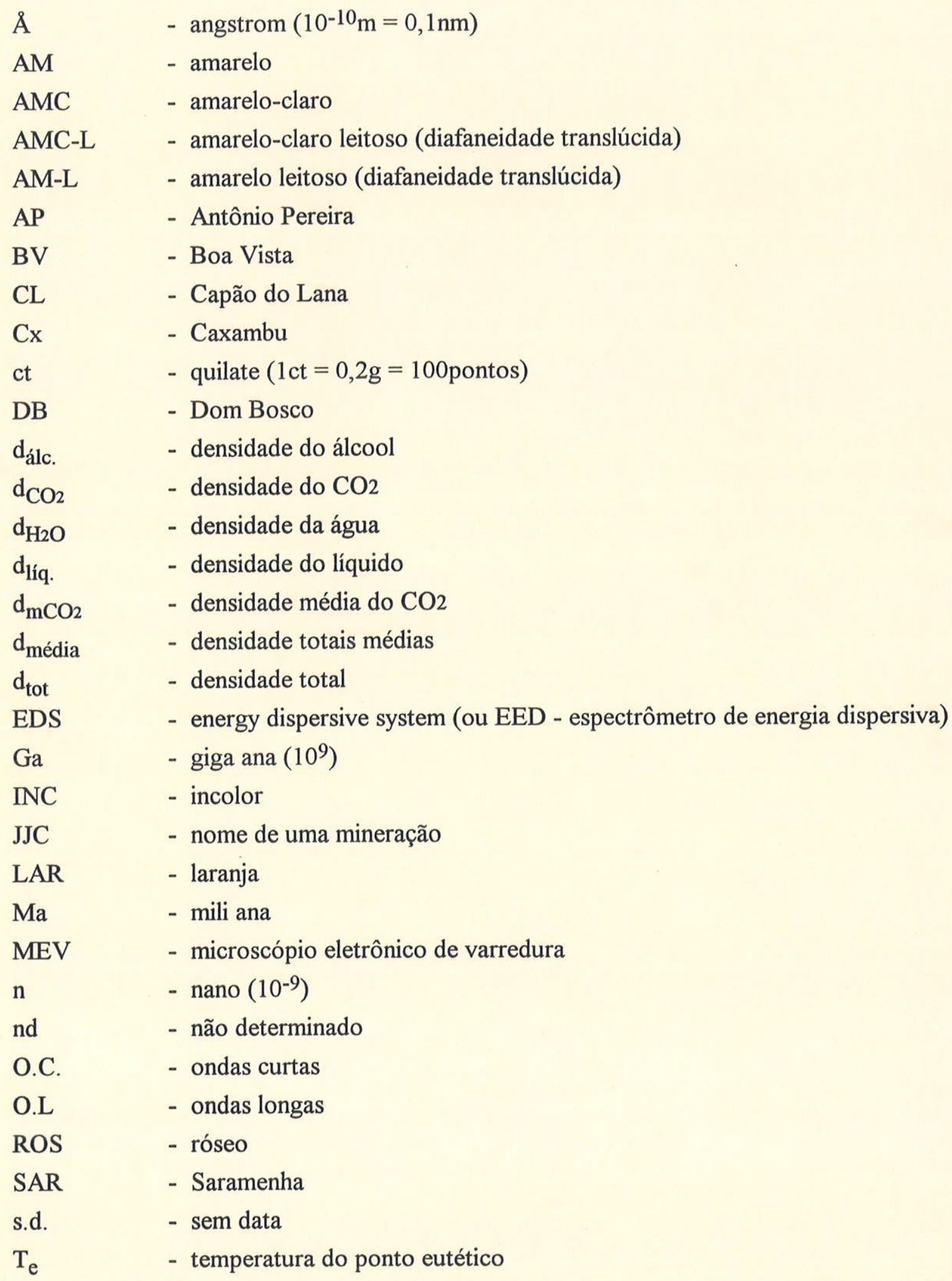




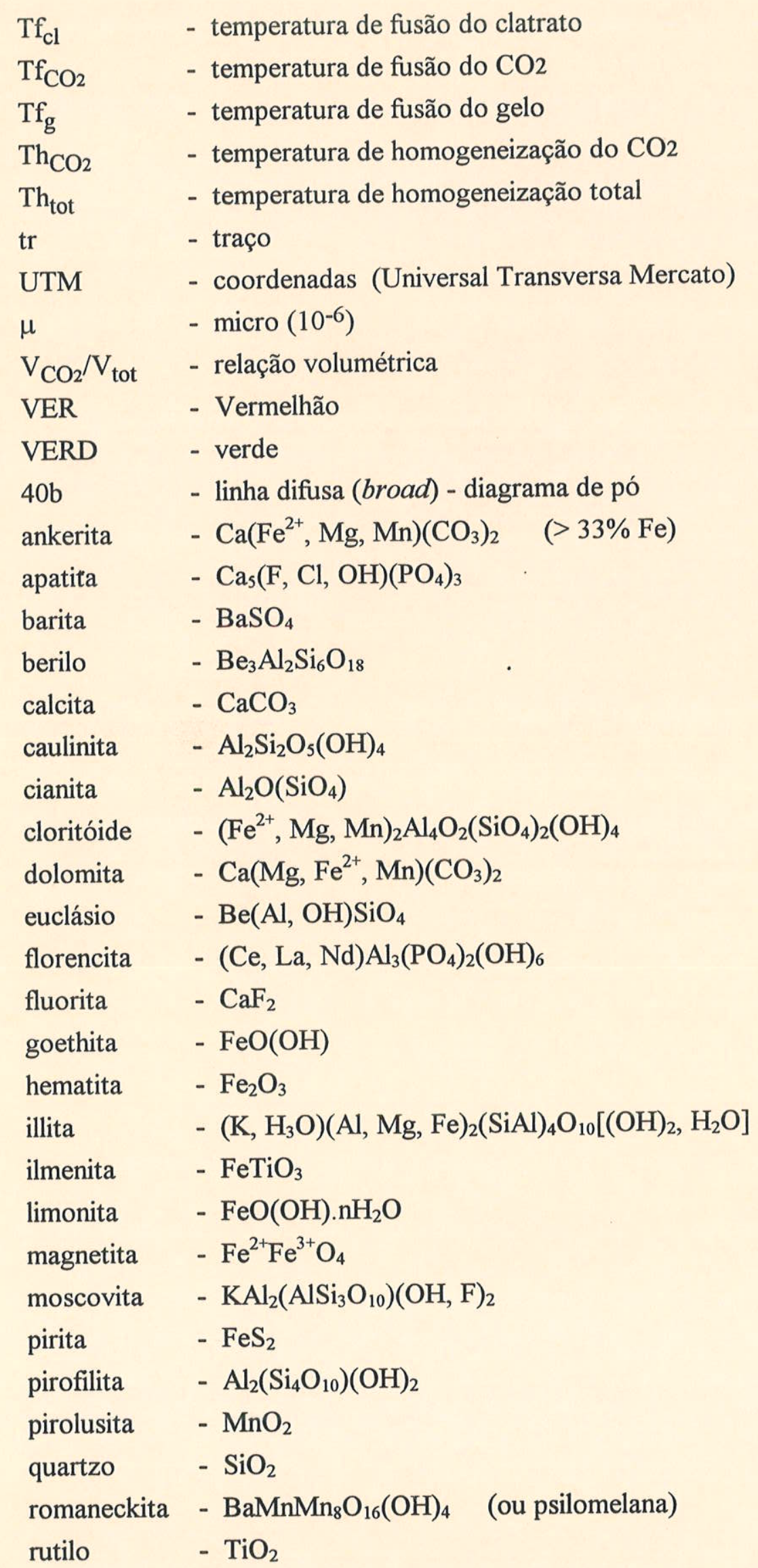




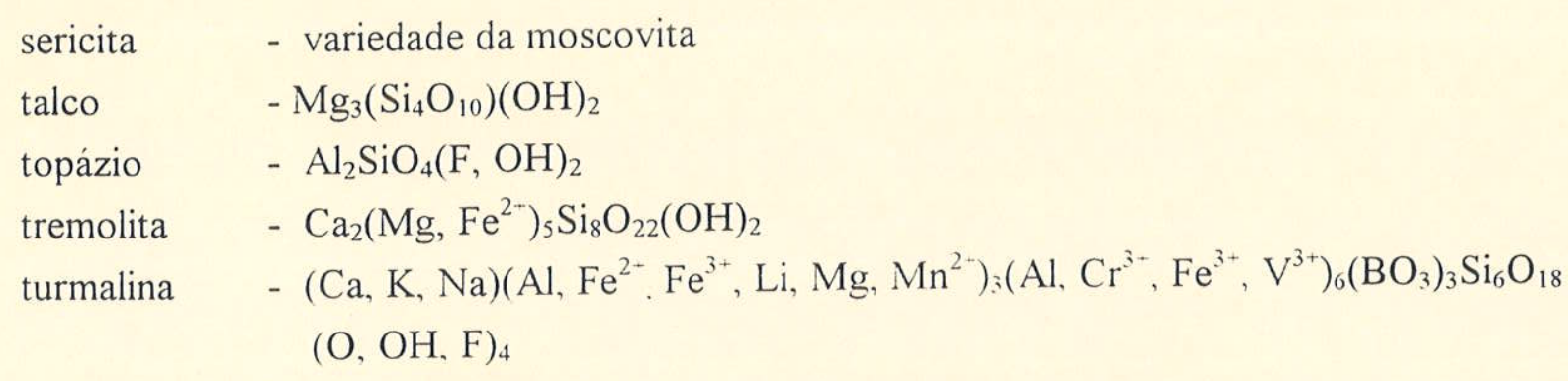




\section{RESUMO}

O topázio imperial da região de Ouro Preto, Minas Gerais, ocorre sob a forma de cristais prismáticos, sendo raros os exemplares biterminados. Apesar de normalmente ocorrerem sob a forma de agregados e fragmentos, predominam os tipos idiomórficos constituídos de dois prismas rômbicos verticais terminados por uma bipirâmide rômbica. As dimensões variam desde alguns milímetros até $20 \mathrm{~cm}$ aproximadamente, predominando a faixa em torno de 1 a $4 \mathrm{~cm}$. As análises

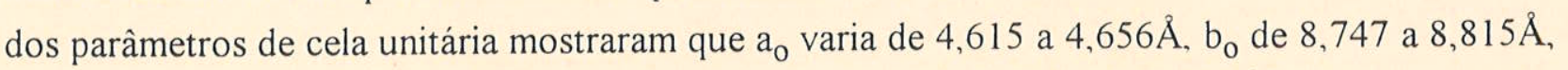
$\mathrm{c}_{\mathrm{o}}$ de 8,375 a $8,412 \AA$ e o volume (V) da cela unitária de 340,639 a $343,823 \AA^{3}$. A cor, uma das propriedades mais notáveis desse mineral-gema, varia de amarelo-dourado a vermelho-conhaque, apresentando matizes transicionais entre esses dois tipos. Análises químicas de topázios coloridos obtidas a partir de microssonda eletrônica indicaram ser o $\mathrm{Cr}^{3+}, \mathrm{V}^{3+}$ e $\mathrm{Fe}^{3+}$ os possíveis cromóforos deste mineral-gema. Para os topázios da região de Ouro Preto, o teor médio de $\mathrm{SiO}_{2}$ é de $32,50 \%$, o de $\mathrm{Al}_{2} \mathrm{O}_{3} 54,90 \%$ e o de $\mathrm{F}^{-}$16,00\%. Com relação aos índices de refração, nX varia de 1,615 a 1,628, nY de 1,618 a 1,631 e nZ de 1,625 a 1,639; a birrefringência, por sua vez, varia de 0,008 a 0,015 . O valor do ângulo $2 V_{Z}$ varia de 62 a $67^{\circ}$. A densidade relativa está compreendida no intervalo de 3,40 a 3,59. As inclusões cristalinas foram estudadas principalmente por difração de raios $\mathrm{X}$ e pelo microscópio eletrônico de varredura, sendo representadas por carbonatos, topázio, hematita, ilmenita, mica, rutilo, quartzo, tremolita, euclásio, cloritóide e apatita. Estas ocorrem em número bem menor em relação às inclusões fluidas, que são bem mais freqüentes e abundantes. As inclusões fluidas são predominantemente bifásicas à $25^{\circ} \mathrm{C}$, sendo constituídas essencialmente por soluções aquosas salinas, $\mathrm{CO}_{2}, \mathrm{~N}_{2}$ e $\mathrm{CH}_{4}$. Elas foram estudadas por vários métodos (platina de aquecimento/resfriamento, espectroscopia de infravermelho e espectroscopia micro Raman), que permitiram a identificação de suas composições, densidades, salinidades e condições de $\mathrm{T}$ e $\mathrm{P}$ de aprisionamento. A temperatura mínima média de formação dessas inclusões é de $300^{\circ} \mathrm{C}$, com a pressão média variando entre 2.000 a 3.000 bar.

As ocorrências primárias de topázio imperial da região de Ouro Preto estão relacionadas à rochas carbonáticas do Supergrupo Minas, pertencente ao Quadrilátero Ferrifero. Entre os litotipos principais, podem ser citados os filitos carbonáticos que transicionam para mármores impuros, tanto lateralmente como verticalmente. As mineralizações de topázio imperial ocorrem em veios centimétricos e descontínuos nessas rochas, e estão associadas a uma zona de falhas normais em bloco, resultante de um processo de distensão, apresentando direção predominante $\mathrm{N} 60^{\circ} \mathrm{W}$. Estas falhas foram, provavelmente, reativadas durante um evento tectônico no final do Cretáceo ou inicio do Terciário, dando origem a vários focos de vulcanismo, que produziram soluções saturadas em sílica. Não se observa nenhuma feição de metamorfismo nessas rochas vulcânicas. 
As rochas metamórficas encaixantes e os veios mineralizados encontram-se intensamente decompostos. Contudo, nessas litologias podem ser observadas algumas de suas estruturas antigas e a presença de certos minerais primários como quartzo, hematita, topázio, rutilo, euclásio e sericita. O topázio normalmente é encontrado em massas de caulim e nos produtos de decomposição de niveis carbonáticos, denominados pelos garimpeiros de "borra de café".

Os dados microtermométricos indicam que a gênese do topázio imperial da região de Ouro Preto está relacionada a processos hidrotermais. Temperaturas de homogeneização total por volta de $300^{\circ} \mathrm{C}$ e isócoras construidas a partir das composições das inclusões fluidas, revelaram pressões da ordem de $2,5 \mathrm{kbar}$ sugerindo portanto um ambiente hidrotermal de pouca profundidade. 


\section{ABSTRACT}

The imperial topaz of the Ouro Preto area, in the state of Minas Gerais, occurs in the form of prismatic crystals. Doubly terminated samples are rare. Although these topazes usually occur as aggregates and fragments, idiomorphic types predominate. They consist of two vertical rhombic prisms terminated by a rhombic dipyramid. The size varies from a few milimeters to approximately $20 \mathrm{~cm}$, with a predominance of the range 1 to $4 \mathrm{~cm}$. Analyses of the parameters of the unit-cell presented the following value variations: $a_{0}=4.615$ to $4.656 \AA, b_{0}=8.747$ to $8.815 \AA, \mathrm{c}_{\mathrm{o}}=8.375$ to $8.412 \AA$ and $\mathrm{V}=340.639$ to $343.823 \AA^{3}$. The color, one of the most spectacular properties of this gem-mineral, varies from golden yellow to dark reddish sherry, showing transitional hues between these two types. Chemical analyses of colored topazes obtained by electron micro probe techniques indicated that $\mathrm{Cr}^{3+}, \mathrm{V}^{3+}$ and $\mathrm{Fe}^{3+}$ are the possible cromophores of this gem-mineral. The average rate of $\mathrm{SiO}_{2}$ was $32.50 \%, \mathrm{Al}_{2} \mathrm{O}_{3}$ was $54.90 \%$ and $\mathrm{F}^{-}$was $16.00 \%$. The refractive index presented a certain range of variation, in which $\mathrm{nX}=1.615$ to $1.628, \mathrm{nY}=1.618$ to $1.631, \mathrm{nZ}=1.625$ to 1.639 and $\mathrm{B}=0.008$ to 0.015 . The value of the angle $2 V_{Z}$ varied from 62 to $67^{\circ}$. The density varied from 3.40 to 3.59 . Crystalline inclusions identified mainly by X-ray difraction methods as well as by scanning electron microscopy are carbonates, topaz, hematite, ilmenite, mica, rutile, quartz, tremolite, euclase and apatite. Fluid inclusions were identified as predominantly two-phase (saline aqueous solution $+\mathrm{CO}_{2}$ ) at $25^{\circ} \mathrm{C}$, with a larger percentage of the liquid phase. Various methods such as cooling/heating, infrared spectroscopy and micro-Raman spectroscopy were used in the study of fluid inclusions. Fluid compositions were identified as water, carbonic gas, nitrogen and hydrocarbonates $\left(\mathrm{CH}_{4}\right)$. The minimum average temperature of formation of the deposits is $300^{\circ} \mathrm{C}$ with an average medium pressure varying from 2.000 to $3.000 \mathrm{bar}$.

The primary occurrences of imperial topaz in the Ouro Preto area are associated with carbonate rocks of the Piracicaba Group of the Minas Supergroup. These unit vary laterally and vertically with regard to lithology and internal struture. Topaz mineralization occurs in centimeter-scale discontinuous veins and are associated with an extensional fault zone. This fault zone was later reactivated. It predominantly trends $\mathrm{N} 60^{\circ} \mathrm{W}$ and crosses the metamorphic rocks of the Minas Supergroup. This fault was probably related to Cretaceous or Tertiary tectonis in related to silica-saturated volcanism that occurred in various parts of the region.

The mineralized veins and the host metamorphic rocks are intensely decomposed and only a few original structures and primary minerals such as quartz, hematite, topaz, rutile, euclase and sericite are found. Topaz usually occurs in masses of kaolin and in carbonate weathering products called "borra de café" (brown terrena) by garimpeiros.

The topaz is interpreted to have been generated by hydrothermal processes related to the final phase of Late Cretaceous or Early Tertiary volcanism that affected the area. 


\section{AGRADECIMENTOS}

Ao concluir um trabalho desta natureza, que durou alguns anos, inúmeras são as entidades e pessoas a agradecer.

Agradeço ao Departamento de Geologia da Escola de Minas da Universidade Federal de Ouro Preto (DEGEO/EM/UFOP) o afastamento concedido e à Coordenadoria de Pesquisa e PósGraduação da UFOP na pessoa de Clotilde Maria de Assis; ao Programa Institucional de Capacitação de Docentes - Coordenação de Aperfeiçoamento de Pessoal de Nível Superior (PICD/CAPES), a concessão de bolsa no período de 03/88 a 02/91; ao Centro de Desenvolvimento de Tecnologia Nuclear da Comissão Nacional de Energia Nuclear, em Belo Horizonte (CDTN/CNEN/BH); ao Centro de Pesquisa Professor Manuel Teixeira da Costa (CPMTC) e ao Instituto de Geociências (IGC), ambos da Universidade Federal de Minas Gerais (UFMG); aos Departamentos de Física e Química do Instituto de Ciências Exatas (DF e DQ/ICEX/UFMG); ao Instituto de Geociências da Universidade de Brasília (IGC/UnB); ao Instituto de Geociências da Universidade de Campinas (IG/UNICAMP); ao Laboratório de Microanálise do Núcleo de Pesquisas em Geoquímica e Geofísica da Litosfera (NUPEGEL), instalado nas dependências do Instituto de Astronomia e Geofísica da Universidade de São Paulo (IAG/USP); ao Forschunsinstitut für Mineralische und Metalleische Werkstoffé Elelsteine/Edelmetalle-GmbH, Idar-Oberstein, na Alemanha; ao Instituto de Pesquisa e Tecnologia do Estado de São Paulo (IPT/SP), por permitirem a obtenção de algumas análises e às empresas Topázio Imperial Mineração, Comércio e Indústria Ltda (TIMCIL) e JJC (Joaquim, José e Celso). Sem o apoio dessas entidades nada teria sido possível.

Agradeço ao Prof. Dr. Darcy Pedro Svisero, orientador desta Dissertação, a ajuda e incentivo durante a realização deste trabalho e pelas inúmeras viagens ao campo.

Agradecimentos especiais são devidos à $\mathrm{Dr}^{\mathrm{a}}$ Rosa Maria da Silveira Bello, responsável pelo Laboratório de Inclusões Fluidas do DMP/IG/USP e ao Prof. Dr. Kazuo Fuzikawa do CDTN/CNEN/BH, a estimada e incansável ajuda durante toda a fase de obtenção e interpretação dos dados microtermométricos, bem como as sugestões e críticas ao trabalho. A estes dois pesquisadores, que desempenharam atividades equivalentes a de co-orientadores, meu muito obrigado. Agradeço também ao Prof. Dr. José Vicente Valarelli, ao técnico Flávio Machado de Souza Carvalho ambos do DMP/IG/USP e ao técnico Dailto Silva do IG/UNICAMP as discussões e interpretações de dados, e finalmente ao técnico Nilson de Paula do IPT a confecção das lâminas delgadas para os estudos microtermométricos.

Agradecimentos especiais são devidos também ao Prof. Ms. Júlio César Mendes do DEGEO/EM/UFOP a ajuda na preparação das amostras, no tratamento dos dados, além da revisão final do texto, realizando também trabalho equivalente a de co-orientador. 
Aos Profs. César Mendonça Ferreira e Március Machado Costa, ambos do DEGEO/EM/UFOP, as inúmeras idas ao campo para coleta de amostras, confecção de mapa e troca de informações, meu profundo reconhecimento.

À Prof Ms. Vitória Régia Péres da Rocha Oliveira Marciano do CPMTC/IGC/UFMG, a sua incansável disposição na ajuda de obtenção e interpretação de dados de espectroscopia no infravermelho, de densidade através de balança analítica e de gravimetria $\left(\mathrm{H}_{2} \mathrm{O}^{+} \mathrm{e} \mathrm{H}_{2} \mathrm{O}^{-}\right)$.

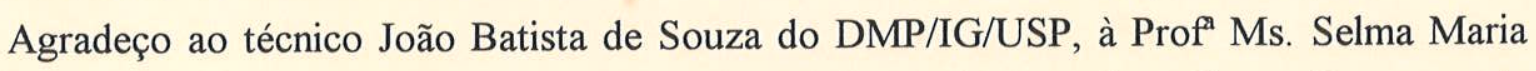
Fernandes, ao técnico Vanderlei Ferreira de Souza e Silva e à aluna Luziene Costa Alves, os três últimos do DEGEO/EM/UFOP a ajuda pela obtenção e interpretação dos difratogramas de raios $\mathrm{X}$.

Aos Profs. Dr. José Carlos Gaspar e Dr. Nilson Francisquini Botelho e ao técnico José Antônio Joaquim Guerra da Silva, todos da UnB, as análises químicas de microssonda eletrônica. À ex-aluna do DEGEO/EM/UFOP, Ms. Adalene Moreira Silva, a indispensável ajuda de tratamento de dados dos topázios através do programa MINFILE. Aos Dr. Tiaki Kawashima do IPT (Laboratório de Química) e George Humberto Bezerra (Laboratório de Metalografia), a obtenção de algumas análises de EDS.

Agradeço ao Prof. Dr. Marco Assunção Pimenta do DF/ICEX/UFMG a obtenção das análises de espectroscopia micro Raman.

À pesquisadora $\mathrm{Dr}^{\mathrm{a}}$ Solange Vaz Coelho e aos técnicos Zilmar Lima Lula e Luiz Carlos da Silva, todos do Laboratório de Química da CDTN/CNEN/BH, agradeço a obtenção dos dados de densidades com o picnômetro e as análises de flúor pelo método do eletrodo de íon específico.

Ao Prof. Dr. Newton Souza Gomes a ajuda na descrição das lâminas petrográficas e no uso da catodoluminescência. Aos Profs. Dr. Paulo César Souza, $\mathrm{Dr}^{\mathrm{a}}$ Hanna Jort Evangelista, César Mendonça Ferreira e Ms. Mariângela Garcia Praça Leite, todos do DEGEO/EM/UFOP, além do Prof. Ms. Gergely Andrés Júlio Szabó do IG/USP e da geóloga Ms. Sílvia Regina Soares da Silva Vieira da Associação Brasileira de Cimento Portland, o meu muito obrigado pelas sugestões sobre a petrografia dos depósitos.

Agradeço também ao Prof. Ms. Leonardo Evangelista Lagoeiro do DEGEO/EM/UFOP a ajuda na obtenção de algumas medidas do ângulo $2 V_{Z}$; ao Dr. Dietmar Schwarz (Forschunsinstitut für Mineralische und Metalleische Werkstoffé - Elelsteine/Edelmetalle-GmbH, Idar-Oberstein, Alemanha) na identificação das inclusões cristalinas por meio do microscópio eletrônico de varredura e também ao doutorando do IG/USP, Ms. Fernando Helí Romero Ordóñez, a ajuda prestada na identificação das inclusões cristalinas por meio do microscópio eletrônico de varredura, obtidas no Departamento de Geofísica/IAG - NUPEGEL - USP, com ajuda do Dr. Eronaldo Bonfim Rocha .

Agradeço o auxílio e sugestões em várias etapas deste trabalho de tradução de textos em alemão dada pelos Profs. Dr. Fernando Flecha Alkmim, Dr. Paulo César Souza, Dr. Hubert 
Mathias Peter Röeser, Dr ${ }^{\mathrm{a}}$ Caroline Janette Souza Gomes e $\mathrm{Dr}^{\mathrm{a}}$ Hanna Jort Evangelista, e em francês pelo Ms. Messias Gilmar de Menezes, todos do DEGEO/EM/UFOP. Agradeço à Prof . Ciomara Ferreira Campos e ao Dickson Cunningham pela revisão do Abstract.

Agradeço aos Profs. Ms. Marco Antônio Fonseca e Ms. Messias Gilmar de Menezes do DEGEO/EM/UFOP a revisão e as sugestões do capítulo sobre a geologia do Quadrilátero Ferrífero e ao Prof. Ms. Pedro Luiz Juchem, do Departamento de Mineralogia e Petrologia do Instituto de Geociências da Universidade Federal do Rio Grande do Sul do DMP/IG/UFRGS, as críticas e sugestões sobre os dados microtermométricos.

De um modo especial, agradeço à equipe do Laboratório de Computação Científica (LCC) nas pessoas de Marcelo Teixeira Duarte, Puca Huachi Vaz Penna, Ângelo Paiva Gomes, Marcílio Andrade Pedrosa, César Teixeira de Carvalho, Andréa Luíza da Silva, Andréa Regina Dias da Silva, Jussara Pinto Moura, Fátima Aparecida Lopes, Kênia Cristina Araújo Nascimento e às pessoas do Centro de Editoração Eletrônica (CEEL), Maria Zélia Milagres Alfenas, Silviane Rodrigues Pedrosa e Beatriz Moyle Baêta as inúmeras ajudas no uso de programas de computação, e às duas últimas, a impressão final deste trabalho. Ao Petrus Júnior Evangelista, do LCC, a paciência na ajuda dos desenhos e na confecção de slides através de programas adequados. Aproveito também para agradecer a aluna Zulmeire da Cruz Cotta, do DEGEO/EM/UFOP, a confecção do mapa geológico da área estudada, do mapa de localização das diversas jazidas e/ou ocorrências de topázios, além do desenho de espectros no infravermelho. Agradeço também à Prof. Maria Paula Delício, pela ajuda da utilização do programa Word for Windows 2.0 e ao Prof. Dr. Jório Coelho pela impressão do mapa geológico.

Não poderia deixar de agradecer, também de forma especial, aos donos da TIMCIL, Dr. Wagner Colombarolli e Edmar Evanir da Silva, aos Eng ${ }^{\circ}$ Vicente Alves e Antônio Roberto Colombaroli Inez e aos funcionários Dilermano da Costa, Fausto Hermano Leal Vallias e Marcionílio Furmino Bretas a imprescindível colaboração em várias etapas deste trabalho, quer na obtenção de amostras de topázio, amostras do colúvio e informações técnicas fornecidas ao longo da pesquisa. Agradeço, da mesma forma, as amostras cedidas ou emprestadas ao Prof. César Mendonça Ferreira do DEGEO/EM/UFOP e ao Prof. Osmar Alves de Oliveira Júnior do Departamento de Mineração da EM/UFOP, ao Dr. Dietmar Schwarz (Alemanha), ao Dr. Emílio Garibaldi do DNPM/BH, ao Sr. Antônio Nery (dono da jazida de Caxambu), à Mineração JJC e ao Sr. Pedro Luíz Cardoso, proprietário de algumas jazidas de topázio sem designações próprias.

Igualmente muito importante foi a ajuda prestada pelos funcionários do DEGEO/EM/UFOP. Ao José Leite Simplício Filho agradeço a ajuda nos laboratórios de aerofotogeologia e fotografia, à Mara Nei Mesquita Teodoro Faria a parte administrativa/burocrática, ao José Vitorino dos Santos a ajuda na coleta de rochas no campo, ao Paulo Gonzaga de Lima e Deusilene Alves Botelho as lâminas delgadas confeccionadas e ao Vandir Geraldo Maia a ajuda na obtenção de algumas análises químicas. Também participaram de 
discussões sobre química, a técnica Ms. Sandra Andrade e a aluna Ms. Silvana Maria Netto, ambas do DMP/IG/USP, a quem deixo registrado meu muito obrigado.

Acrescentam ainda os meus sinceros agradecimentos à Maristela Prestes Severino do IG/USP, a sua incansável paciência e dedicação na correção das inúmeras cópias que trouxe para ela corrigir. Também não poderia deixar de agradecer à Maria Aparecida Bezerra do IG/USP e às bibliotecárias de DEGEO/EM/UFOP, Judith Conceição Gomes Alves, Terezinha Alexandrina Costa e Silva, Neide Aparecida Gomes, Jussara Santos Silva e Eni Lucas de Carvalho Moreira

Ao aluno de Pós-Graduação do DEGEO/EM/UFOP Francisco Vladimir Castro de Oliveira, agradeço a ajuda na obtenção de slides e fotomicrografias.

Infelizmente, não tenho a relação de todos os trabalhadores das empresas ou garimpos onde coletei amostras ou fotografei algumas jazidas, mas gostaria de deixar registrado meus agradecimentos a essas pessoas simples e humildes que sempre me trataram com muito respeito e, também, de quem ganhei algumas amostras, principalmente do garimpeiro João Bosco, de Antônio Pereira.

A todos os colegas do DEGEO/EM/UFOP, aos colegas dos vários cursos do IG/USP e a todos de outras instituições e localidades que colaboraram e participaram direta e indiretamente na execução deste trabalho, meu muito obrigado. Desculpem-me se me esqueci de alguém.

Não diria como uma conclusão, mas não existem palavras que possam expressar meus sentimentos de eterna gratidão pela ajuda e compreensão de minha esposa, filhos, pais, irmãos e tia por toda fase decorrida durante este trabalho, pelas infindáveis noites, sábados e domingos que jamais serão repostos. A todos, MEU MUITO OBRIGADO. 


\section{1 - INTRODUÇÃO}

As jazidas de topázio imperial da região de Ouro Preto localizam-se no Quadrilátero Ferrifero, em rochas pertencentes ao Supergrupo Minas, numa região clássica por suas ocorrências de ouro, ferro, manganês, diamante em menor escala, além do topázio imperial.

Levando-se em conta que o Quadrilátero Ferrifero é uma das áreas pré-cambrianas mais importantes do Brasil, pelas suas mineralizações de ouro e ferro, não se pode deixar de destacar a importância das jazidas de topázio imperial, hoje uma das gemas mais apreciadas no comércio internacional. Pedras de boa qualidade, transparentes e de cor conhaque acentuada, podem alcançar a cifra de US\$ $1,200.00$ o quilate $(1 \mathrm{ct}=0,2 \mathrm{~g}=100$ pontos), competindo com outras gemas famosas como o diamante, a esmeralda e a água-marinha.

De um modo geral, os trabalhos disponíveis na literatura sobre a região abordam mais aspectos da geologia regional, principalmente problemas de estratigrafia e tectônica, sendo poucos os trabalhos essencialmente mineralógicos, referentes ao topázio imperial.

No Brasil, o topázio imperial ocorre somente na região de Ouro Preto. Outras ocorrências encontram-se na Sibéria, cujas jazidas estão praticamente exauridas, e no Paquistão (Sauer 1982, Gübelin et al. 1986). A grande vantagem do Brasil, em relação aos outros países, é que aqui o topázio imperial ocorre em rochas altamente intemperizadas, fato que facilita a sua extração e aumenta a rentabilidade desse empreendimento.

Não se pode deixar de levar em conta outro fator importante que é a localização das mineralizações do topázio da região de Ouro Preto. Todas as jazidas e/ou ocorrências estão localizadas numa região relativamente restrita e pequena, onde seu acesso se faz, na maioria das vezes, por rodovias pavimentadas ou por estradas de terra em bom estado de conservação.

\section{1 - OBJETIVOS DO TRABALHO}

A existência de grandes jazidas de minerais metálicos, fez com que a região do Quadrilátero Ferrífero se tornasse um dos locais mais estudados do País. Já se mencionou o alto grau de detalhamento dos trabalhos existentes sobre a estratigrafia, a tectônica e a geocronologia, 
e também se destacou o pequeno número de trabalhos, pouco mais que duas dezenas, sobre as ocorrências de topázio imperial encontrados na literatura.

O objetivo dessa Dissertação de Mestrado, é justamente tentar contribuir para o aprimoramento do conhecimento dessas jazidas e/ou ocorrências. cujo potencial econômico ainda não é bem conhecido. Diante da magnitude dos problemas, foi dada ênfase maior aos aspectos mineralógicos. Foram explorados, em maior profundidade, as inclusões cristalinas e fluidas, com vista a obter dados para um possível modelo genético das jazidas de topázio imperial. Assim sendo, destacam-se como objetivos principais desse trabalho, os itens citados a seguir:

- Caracterização mineralógica das associações minerais das principais minerações e/ou garimpos;

- - Levantamento das ocorrências e/ou jazidas existentes na região;

- - Determinações cristalográficas do topázio, incluindo morfologia e cela unitária;

- - Estudos mineralógicos do topázio incluindo densidade, pleocroísmo, cor, índices de refração, $2 V_{Z}$ e composição química;

- - Estudos das inclusões fluidas e alguns aspectos das inclusões cristalinas;

- - Modelo genético para o topázio imperial da região de Ouro Preto.

\section{2 - LOCALIZAÇÃO E VIAS DE ACESSO}

As várias ocorrências e/ou jazidas de topázio imperial estão localizadas no centro-sudeste do estado de Minas Gerais, aproximadamente a $96 \mathrm{~km}$ a sudeste da capital mineira, Belo Horizonte, nos arredores da cidade de Ouro Preto. A área estudada possui uma superfície de, aproximadamente, $700 \mathrm{~km}^{2}$, compreendida entre as coordenadas UTM $(626 ; 7.737)$ e $(667$; 7.754,5).

A cidade de Ouro Preto pode ser alcançada pelo acesso principal, a partir de Belo Horizonte, através das rodovias pavimentadas BR-040 (Rio de Janeiro a Belo Horizonte) até o quilómetro 28, de onde inicía-se, à esquerda, a BR-356 (dos Inconfidentes), passando-se pela cidade de Itabirito. As jazidas e/ou ocorrências mais próximas à Ouro Preto (Vermelhão e JJC José, Joaquim e Celso), distam cerca de $4 \mathrm{~km}$ do centro urbano, nas vizinhanças da fábrica da Alcan, no bairro de Saramenha de Baixo. Estas ocorrências podem ser vistas da Escola de Minas, localizada no centro da cidade (Fotografia 1). Outra jazida, a de Antônio Pereira (AP), localizada no distrito homônimo de Ouro Preto a nordeste, é alcançada pela rodovia que liga Ouro Preto a Mariana e depois pela estrada que liga esta última cidade à Mineração Samarco, ambas asfaltadas. A referida jazida situa-se na margem desta estrada ao lado do povoado de Antônio Pereira. A jazida do Capão do Lana, outra importante mineração, dista, aproximadamente, $12 \mathrm{~km}$ pela Rodovia dos Inconfidentes até 
alcançar a Mineração Bemil, perto do viaduto do Funil, onde há uma estrada não pavimentada até o vilarejo de Rodrigo Silva a mais ou menos $7 \mathrm{~km}$, e até a Mina do Capão tem-se que percorrer mais uns $4 \mathrm{~km}$, também em estrada não pavimentada. As demais jazidas e/ou ocorrências são atingidas também pela Rodovia dos Inconfidentes e estradas de terra, em bom estado, que ligam os distritos de Rodrigo Silva e Dom Bosco a Ouro Preto, seguindo-se após estes vilarejos, através de pequenas e tortuosas estradas de terra até as lavras ou garimpos de topázios (Figura 1).

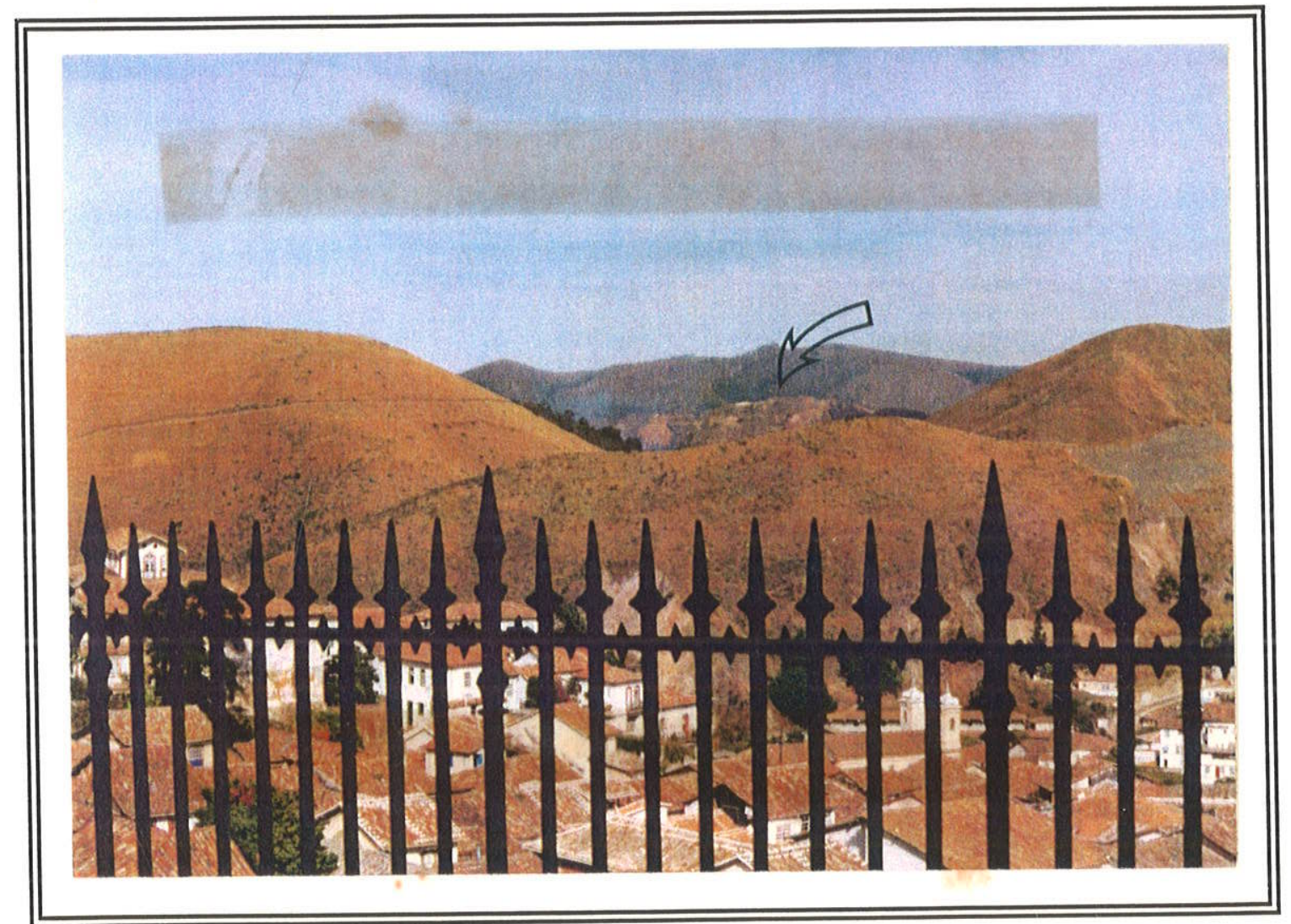

FOTOGRAFIA 1 - Vista a partir da Escola de Minas, na cidade de Ouro Preto, da jazida de topázio imperial da Alcan, uma das continuações do veio mineralizado que também constitui a jazida do Vermelhão. 


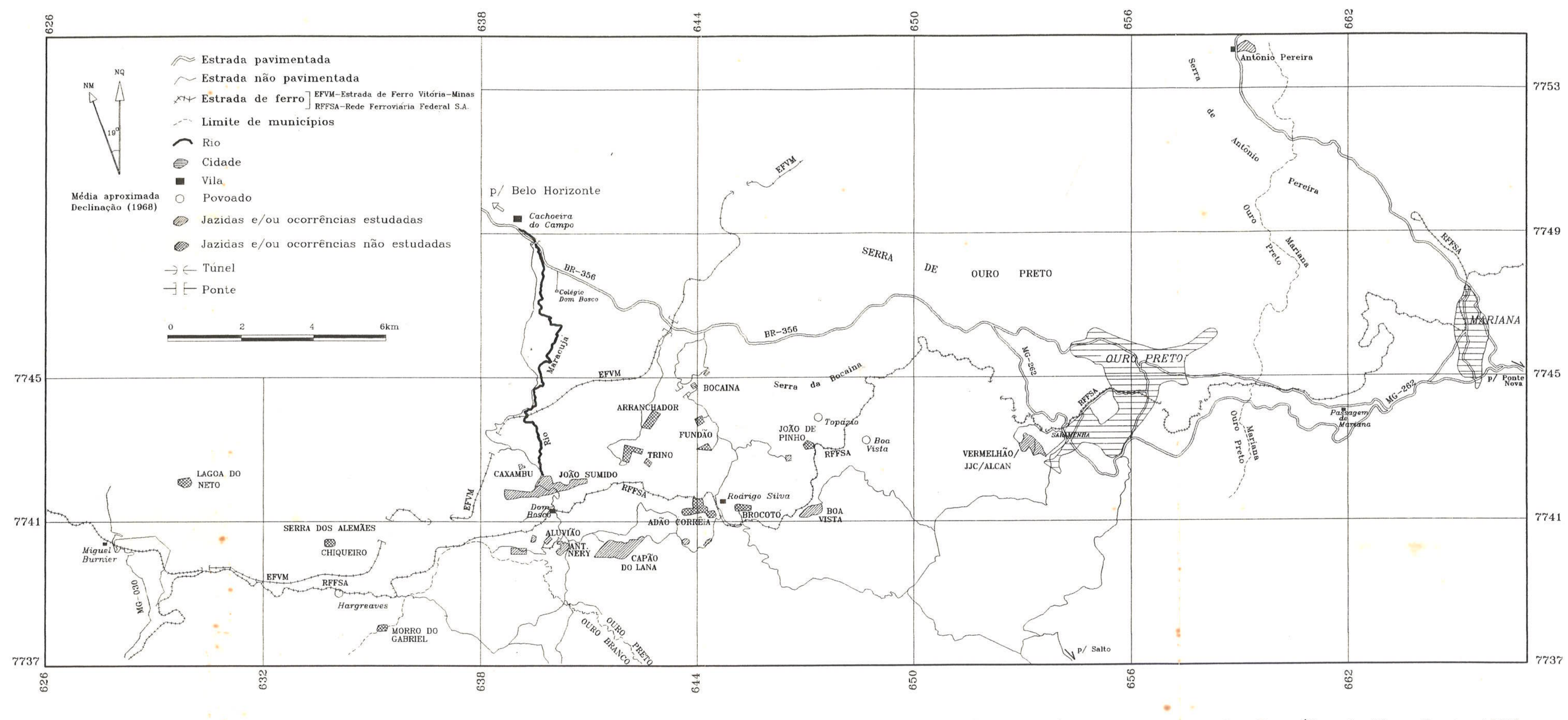

Figura 1 - Localização geográfica das jazidas e/ou ocorrências de topázio imperial da região de Ouro Preto, Minas Gerais (Adaptado da Companhia Energética de Minas Gerais, 1987). 


\section{2 - METODOLOGIA DE ESTUDO}

Antes de se iniciar a descrição da metodologia, faz-se necessário algumas observações. Um dos grandes problemas encontrados, na realização desta Dissertação, foi a coleta de amostras. Por tratar-se de um mineral gemológico, podendo alcançar algumas gemas a cifra de US\$ 1,200.00 o quilate, não foi permitida a coleta in situ dos topázios quer nas empresas mineradoras, quer nos garimpos. As amostras estudadas foram cedidas por proprietários de garimpos na forma de pequenos lotes constituídos em geral por cristais jaçados, ou seja, aqueles que apresentam manchas, trincas ou inclusões cristalinas no seu interior, que são chamados de cascalhos, sem valor significativo para o comércio ( $1 \mathrm{~kg}$ de cascalho $=$ US\$30.00).

Outro ponto é o tamanho dos cristais estudados que na sua quase totalidade variaram em torno de $1 \mathrm{~cm}$ de comprimento (Fotografia 2), com pesos de 1 a $8 \mathrm{~g}$, e média em torno de $3 \mathrm{~g}$. Isto limitou de certa forma os resultados obtidos, pois não foi possível fazer alguns tipos de análises combinadas em um mesmo cristal. No caso das análises químicas de flúor e de hidroxila, por exemplo, foram utilizadas $2 \mathrm{~g}$ e $1 \mathrm{~g}$ respectivamente, do mineral pulverizado sem haver recuperação, ou seja, além da análise ser destrutiva, não foi possível fazer nenhum outro ensaio nessas amostras.

Outro problema encontrado no decorrer desse trabalho foi a necessidade de se recorrer a centros diferentes durante a fase de obtenção de dados analíticos. Considerando que geralmente os laboratórios raramente reúnem metodologias diversificadas, e levando em conta que muitos centros instalados não permitem a obtenção de dados rotineiros, foi preciso recorrer, além do Departamento de Mineralogia e Petrologia do Instituto de Geociências da Universidade de São Paulo (DMP/IG/USP), a outros laboratórios tais como o Departamento de Geologia da Escola de Minas da Universidade Federal de Ouro Preto (DEGEO/EM/UFOP), Centro de Desenvolvimento de Tecnologia Nuclear da Comissão Nacional de Energia Nuclear em Belo Horizonte (CDTN/CNEN-BH), Instituto de Pesquisa e Tecnologia do Estado de São Paulo (IPT/SP), Centro de Pesquisa Professor Manuel Teixeira da Costa do Instituto de Geociências da Universidade Federal de Minas Gerais (CPMTC/IGC/UFMG), Departamento de Física e de Química do Instituto de Ciências Exatas da Universidade Federal de Minas Gerais (DF e DQ/ICEX/UFMG), Instituto de Geociências da Universidade de Brasília (IG/UnB), Instituto de Astronomia e Geofísica da Universidade de São Paulo (IAG/USP), Forschunsinstitut für 
Mineralische und Metalleische Werkstoffé - Elelsteine/Edelmetalle GmbH Idar-Oberstein, na Alemanha e Instituto de Geociências da Universidade de Campinas (IG/UNICAMP), em épocas diferentes.

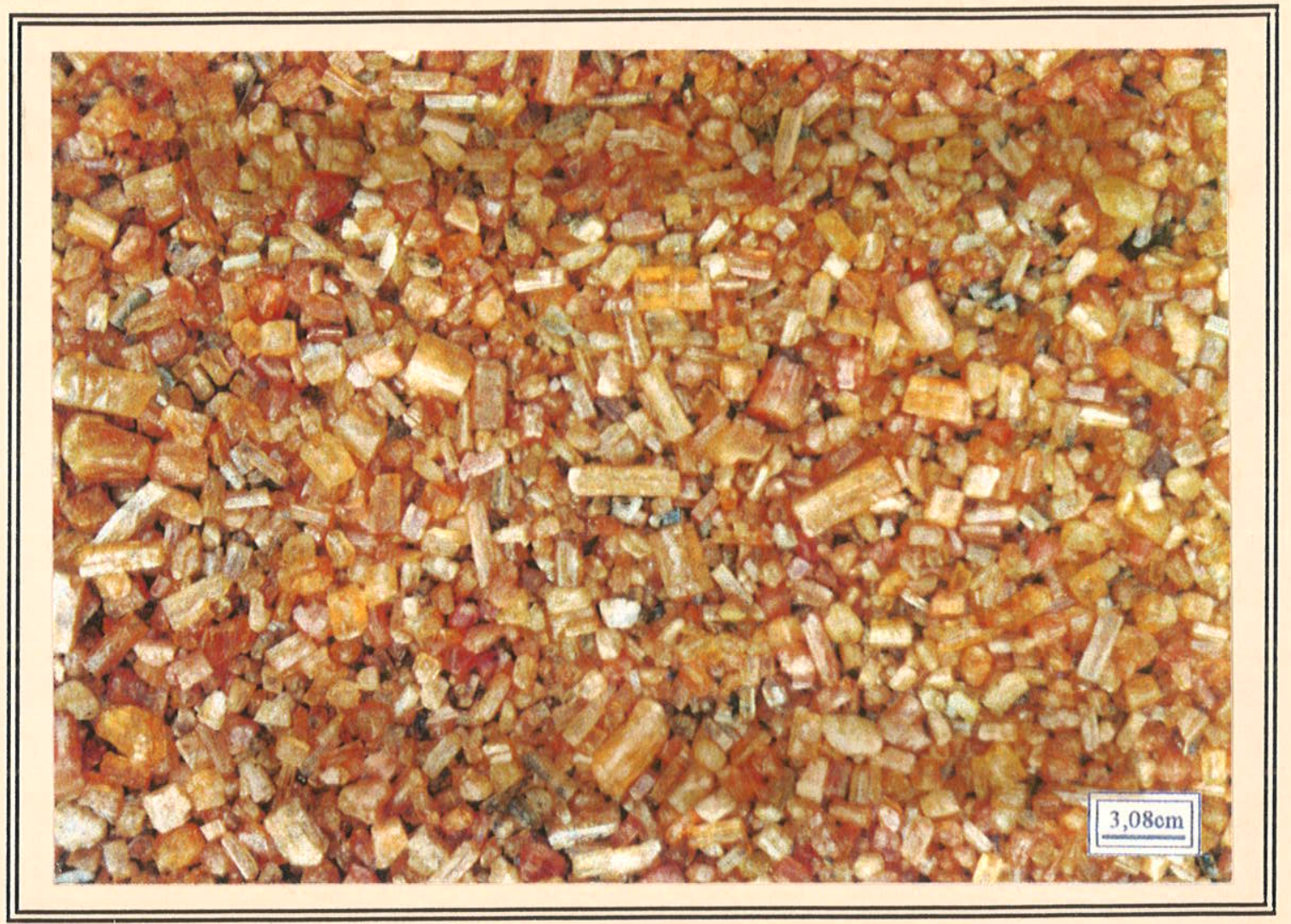

FOTOGRAFIA 2 - Lote com mais de mil cristais de topázio imperial de cores e tamanhos variáveis. Predominam indivíduos clivados com dimensões em torno de $1 \mathrm{~cm}$.

\section{1 - TRABALHOS DE CAMPO}

Nesta fase da pesquisa, foi feita a verificação da geologia das áreas de ocorrência e/ou jazida em mapas geológicos elaborados pelo convênio USGS/DNPM, bem como em fotografias aéreas da região. Durante os trabalhos de campo, foi amostrado um total de dez localidades distintas, incluindo-se jazidas desativadas, ocorrências e jazidas em fase de lavra. Como o topázio ocorre em rocha totalmente intemperizada, exceção de Bocaina que ocorre em rocha inalterada, foram coletados cristais de topázio e concentrados obtidos pela lavagem do material alterado para estudos mineralógicos. 


\section{2 - TRABALHOS DE LABORATÓRIO}

Os cristais de topázio foram classificados de acordo com a sua morfologia e a sua coloração. Eles foram separados com a utilização de uma lupa binocular e agrupados para os estudos posteriores. O material selecionado foi estudado por uma combinação de diversos métodos analíticos cujos dados estão resumidos esquematicamente logo a seguir.

Considerando-se que os princípios básicos da maior parte dos métodos relacionados abaixo, são encontrados na literatura mineralógica dos últimos anos, seja em manuais específicos e/ou livros (Formoso 1980; Gomes 1980 e 1984), ou em teses de mestrado e doutorado, será feito um pequeno comentário a respeito de cada uma dessas técnicas. Contudo, certos equipamentos tais como o dicroscópio, o refratômetro gemológico e o eletrodo de íon específico ainda pouco divulgados, serão discutidos com mais detalhes, de acordo com o quadro sinótico abaixo.

\section{PREPARAÇÃO DE AMOSTRAS:}

- separação dos cristais em vários lotes para análises distintas.

\section{DETERMINAÇÃO DA DENSIDADE RELATIVA:}

- medidas em amostras de colorações diferentes.

\section{MÉTODOS ÓPTICOS:}

- separação de amostras;

- determinação dos índices de refração;

- determinação do ângulo $2 \mathrm{~V}_{\mathrm{Z}}$;

- determinação do pleocroísmo;

- identificação dos espécimes cristalinos inclusos no topázio.

\section{DIFRAÇÃO DE RAIOS X:}

- identificação de inclusões cristalinas;

- cálculo dos parâmetros e volume da cela unitária do topázio.

\section{MICROSCÓPIO ELETRÔNICO DE VARREDURA:}

- determinação da composição química de algumas fases cristalinas inclusas no topázio.

\section{MÉTODO MICROTERMOMÉTRICO:}

- determinação das composições, densidades, salinidades e condições de P e T de aprisionamento das inclusões fluidas.

\section{ESPECTROSCOPIA DE ABSORÇÃO NO INFRAVERMELHO:}

- identificação das bandas de absorção dos diversos componentes químicos, tanto das inclusões fluidas como do próprio topázio. 


\section{ESPECTROSCOPIA MICRO RAMAN:}

- obtenção de dados químicos do topázio e das inclusões fluidas.

\section{MICROSSONDA ELETRÔNICA:}

- determinação da composição química do topázio e das inclusões cristalinas.

\section{ELETRODO DE ÍON ESPECÍFICO PARA FLÚOR:}

- determinação da porcentagem de flúor presente na estrutura cristalina do topázio.

\section{GRAVIMETRIA (PERDA AO FOGO):}

- determinação da porcentagem de $\mathrm{H}_{2} \mathrm{O}^{-}$e $\mathrm{H}_{2} \mathrm{O}^{+}$presentes na estrutura do topázio.

\section{CATODOLUMINESCÊNCIA:}

- identificação de alguns elementos químicos presentes no topázio e em minerais da rocha encaixante.

Com base no esquema apresentado acima, segue-se uma descrição resumida de cada um dos métodos utilizados neste trabalho.

\subsection{1 - PREPARAÇÃO DE AMOSTRAS}

A coleta de amostras de cristais de topázio na rocha alterada (colúvio), bem como na rocha inalterada, realizou-se basicamente nas diversas jazidas e/ou ocorrências, tentando-se cobrir uma distribuição ao longo do Sinclinal Dom Bosco, de direção aproximadamente E-W, e do Anticlinal de Mariana. Cada tipo de amostra recebeu um código referente à procedência seguida de uma numeração.

No estudo mineralógico do topázio, foram utilizados vários lotes, variando entre 10 e 500 exemplares, cedidos ou emprestados pelos respectivos proprietários. Como características gerais, esses cristais apresentam dimensões entre 1 a $4 \mathrm{~cm}$, coloração amarela a alaranjada e um grande número de defeitos internos. Essas amostras sem valor econòmico sob o ponto de vista gemológico, são de grande valor mineralógico, especialmente no que se refere ao estudo das inclusões fluidais e cristalinas, da morfologia, entre outras propriedades.

O colúvio que contém o topázio foi lavado para a retirada da fração silte/argila em bateia, sendo o material restante separado por bromofórmio $\left(\mathrm{CHBr}_{3}\right)$, de densidade 2,89. Basicamente, o material pesado é constituído predominantemente por fragmentos de rochas alteradas, fragmentos e cristais de quartzo, magnetita, hematita, rutilo. Pela difração de raios $\mathrm{X}$, a fração silte/argila foi caracterizada pela presença dos argilominerais caulinita e illita, além de traços de hidróxido de ferro, provavelmente goethita.

Com relação ao afloramento de rocha inalterada, foram confeccionadas cerca de 30 lâminas delgadas do veio mineralizado e da rocha encaixante. Algumas dessas lâminas, sem a laminula, foram atacadas com alizarina $(0,1 \mathrm{~g}$ de alizarina red em $100 \mathrm{ml}$ de $\mathrm{HCl}$ a $0,04 \mathrm{~N})$, para verificar a presença de calcita. A separação da calcita da dolomita no mármore é muito fácil por 
este método colorimétrico. Após dois a três minutos do ataque da alizarina sobre a lâmina, a calcita adquire tons avermelhados.

\subsection{2 - DENSIDADE RELATIVA}

A densidade relativa (d) do topázio foi determinada por dois métodos; o primeiro mais fácil e rápido, por uma balança analítica eletrônica e o segundo, através do uso de picnômetro, sendo este mais preciso.

Para o primeiro caso, a densidade foi determinada com a utilização de uma balança analítica eletrônica Mettler, modelo H 54AR, do CPMTC/IGC/UFMG, cuja precisão é de 0,0001g e com capacidade de $1.200 \mathrm{mg}$. Primeiramente, pesou-se o cristal, estando este amarrado a um fio metálico extremamente fino $\left(\mathrm{P}_{1}\right)$. Em seguida, mergulhou-se o cristal ainda amarrado ao fio em um copo com água, destilada e deionizada, sobre uma plataforma, não apoiada ao prato da balança $\left(\mathrm{P}_{2}\right)$. Para o cálculo, utilizou-se a seguinte fórmula: $\mathrm{d}=\left[\mathrm{P}_{1} /\left(\mathrm{P}_{1}-\mathrm{P}_{2}\right)\right] \cdot \mathrm{d}_{\text {líq }}$, onde $\mathrm{d}_{\text {líq }}=\mathrm{d}_{\mathrm{H}_{2} \mathrm{O}}=1$.

$\mathrm{O}$ segundo método utilizado no cálculo da densidade foi o uso do picnômetro. Talvez o único inconveniente deste processo, é que variações de temperatura durante as pesagens podem acarretar erros. Para esta técnica, necessita-se de pelo menos $1 / 3$ do volume do picnômetro de material, ou seja, para um picnômetro de $5 \mathrm{ml}$ necessita-se de, aproximadamente, $5 \mathrm{~g}$ de amostra. Amostras com pesos menores acarretarão em erros. As amostras foram quebradas no morteiro de Abich e pulverizadas em gral de ágata para obter uma granulometria abaixo de 200mesh [0,074mm na escala Tyler (Silva 1979)]. Considerando que o topázio, em geral, contém impurezas de carbonatos, o material pulverizado foi transferido para um béquer de $100 \mathrm{ml}$ onde foi adicionado $25 \mathrm{ml}$ de $\mathrm{HCl}(1 / 1)$ e colocado numa chapa branda por 30 minutos. Decorrido este tempo, a solução ficou bem amarela devido à presença de $\mathrm{FeCl}_{3}$. Depois de esfriar, o material foi lavado para retirar o $\mathrm{HCl}$ e a lavagem final foi feita com álcool para facilitar a secagem do referido material na estufa a $110^{\circ} \mathrm{C}$. Para verificar se ainda havia outras impurezas, foi executada a operação no meio denso. Colocou-se $50 \mathrm{ml}$ de bromofórmio $(\mathrm{d}=2,89)$ num béquer de $100 \mathrm{ml}$. A amostra moída foi colocada neste bequer e fez-se uma agitação do líquido juntamente com o material para haver uma distribuição homogênea do material. Após 30 minutos de decantação, não observou-se sobrenadantes. O bromofórmio foi eliminado e em seguida foi feita uma lavagem do material com álcool para eliminar o resto deste líquido denso. Novamente foi colocado na estufa a $110^{\circ} \mathrm{C}$ por 30 minutos, para secar.

Após a secagem, foi executada a operação de determinação da densidade. Numa primeira etapa, foram utilizados dois picnômetros de $5 \mathrm{ml}$, previamente secos em estufa e no dessecador, com a finalidade de se obter um valor médio das medidas. Como o erro relativo foi pequeno, da ordem de $0,007 \mathrm{~g}$, as demais medidas foram feitas em amostras únicas, sem duplicatas, devido a 
pequena disponibilidade de material. Para o cálculo da densidade, em primeiro lugar pesou-se o picnômetro vazio obtendo-se o valor $\mathrm{P}_{1}$. Em seguida, a amostra já pulverizada foi colocada dentro do picnômetro e feita nova pesagem obtendo-se o valor $\mathrm{P}_{2}$. Não se pesou separadamente a amostra do picnômetro, por causa de possíveis perdas na colocação desta no referido frasco. Desta maneira, a diferença $\left(\mathrm{P}_{2}-\mathrm{P}_{1}\right)$ nos dá o peso da amostra utilizada com precisão. $\mathrm{O}$ passo seguinte consistiu na adição de álcool (até $2 / 3$ do volume do picnômetro), sendo o conjunto colocado em dessecador sem sílica, conectado a um sistema de vácuo, o qual por sua vez permaneceu durante 40 minutos numa pressão constante de $600 \mathrm{mmHg}$. Depois desta etapa, completou-se o volume de álcool, seguindo-se nova pesagem $\left(\mathrm{P}_{3}\right)$. A utilização do álcool, ao invés de água, é devido a menor densidade deste, que com isto facilita a liberação das bolhas de ar aderidas aos fragmentos durante a operação no vácuo. Utilizou-se o álcool da Merck, cuja densidade é de 0,82. Finalmente, o material foi descartado, o picnômetro lavado com álcool e secado em estufa, e novamente avolumado com álcool, seguido da última pesagem $\left(\mathrm{P}_{4}\right)$.

Após todas essas operações, o cálculo da densidade foi realizado de acordo com a fórmula mostrada abaixo:

$$
\begin{aligned}
& \mathbf{d}=(\mathbf{m} / \mathbf{V}) \cdot d_{\text {líq }}=\left\{\left(\mathbf{P}_{2}-\mathbf{P}_{1}\right) /\left[\left(\mathbf{P}_{2}-\mathbf{P}_{1}\right)-\left(\mathbf{P}_{3}-\mathbf{P}_{4}\right)\right]\right\} \cdot d_{\text {álc }} \\
& \text { onde: } \quad \begin{array}{l}
\mathrm{d}_{\text {líq }}=\text { densidade do líquido utilizado } \\
\mathrm{d}_{\text {álc }}=\text { densidade do álcool }
\end{array}
\end{aligned}
$$

\subsection{3 - MÉTODOS ÓPTICOS}

Durante a realização deste trabalho, diversos métodos ópticos foram utilizados na investigação das diversas características mineralógicas do topázio.

Os cristais foram examinados em uma lupa binocular e separados em lotes para trabalhos posteriores, visando a obtenção de dados morfológicos, inclusões cristalinas e fluidas.

O microscópio petrográfico foi intensamente usado no decorrer deste trabalho, tanto na descrição das características do topázio como na análise das diversas seções delgadas estudadas das rochas encaixantes, bem como dos veios mineralizados.

As lâminas petrográficas foram analisadas e descritas em microscópio Carl Zeiss e Leitz Wetzlar, modelos Ortholux (luz transmitida) do DEGEO/EM/UFOP. As fotomicrografias das seções delgadas foram obtidas em um fotomicroscópio Carl Zeiss, também do DEGEO/EM/UFOP. Alguns dos espécimes, destinados à fotomicrografias, foram preparados em lâminas delgadas convencionais ou em plaquetas, de aproximadamente $0,1 \mathrm{~mm}$ de espessura, com polimento em ambas as faces, todas adequadamente orientadas em relação ao eixo cristalográfico 
c do topázio. Em alguns casos, as fotomicrografias foram obtidas de cristais brutos. Para a determinação do ângulo $2 \mathrm{~V}_{\mathrm{Z}}$, utilizou-se a platina universal Carl Zeiss, a quatro eixos, pertencente ao DEGEO/EM/UFOP.

Inicialmente, o estudo óptico teve início com uma observação preliminar dos topázios em lupa binocular Carl Zeiss de até $40 \mathrm{X}$ de aumento, tendo como objetivo distinguir detalhadamente as principais características morfológicas e, em especial, fazer uma seleção prévia de exemplares para o estudo das inclusões fluidas e cristalinas.

As amostras pré-selecionadas para o estudo das inclusões fluidas e cristalinas foram cuidadosamente observadas em microscópio gemológico SCHNEIDER pertencente ao DEGEO/EM/UFOP, sob diversos aumentos, para um devido mapeamento e caracterização dessas inclusões. A vantagem deste instrumento é a de permitir o estudo óptico das inclusões em seu cristal hospedeiro. Esse aparelho possui uma cuba, na qual são colocados liquidos de índices de refração definidos, onde são imersas as amostras a serem analisadas. Além disso, possui um sistema de iluminação horizontal, ou seja, o microscópio é horizontal em vez de ser vertical. Outro fator interessante é que a fonte luminosa é móvel, podendo o cristal ser estudado sob luz transmitida, refletida ou na penumbra. O líquido para imersão deve apresentar índice de refração igual ou semelhante ao do mineral a ser analisado, minimizando assim a dispersão da luz ao atravessá-lo. Neste trabalho utilizou-se o ácido benzóico benzylester $\left(\mathrm{C}_{6} \mathrm{H}_{5} \mathrm{CO}_{2} \mathrm{CH}_{2} \mathrm{C}_{6} \mathrm{H}_{5}\right.$, Schwarz 1987), de índice de refração igual a 1,568, próximo aos índices do topázio, que segundo Deer et al. (1982) variam de 1,606 a 1,644. Os espécimes escolhidos, por conter inclusões fluidas e cristalinas, foram devidamente selecionados e preparados para o estudo de identificação, através da microtermometria e da difração de raios X.

Os índices de refração do topázio imperial da região de Ouro Preto foram medidos através de um refratômetro para sólidos, modelo TOPCON, disponivel no DEGEO/EM/UFOP (Figura 2). Este aparelho tem como finalidade principal, medir o(s) índice(s) de refração de um determinado sólido. Além do índice, podem ser conhecidos o caráter axial, a birrefringència e o sinal óptico.

Para a medida, a amostra deve possuir uma superficie natural plana ou ser polida, e ser colocada sobre a parte plana de uma semiesfera de vidro de índice de refração alto $(1,81)$, com um meio de imersão entre ambas. Esse meio de imersão é constituído pelo iodeto de metileno $\left(\mathrm{CH}_{2} \mathrm{I}_{2}\right)$, cujo índice de refração é igual a 1,742 .

O princípio de funcionamento deste equipamento está fundamentado no ângulo crítico de reflexão total da luz (Figura 3). As leituras são feitas com uso de uma fonte monocromática amarela (luz de sódio), ou com filtro de luz, cujo comprimento de onda é igual a $589 \mathrm{~nm}$. Caso o filtro seja de cor vermelha ou azul, o valor do índice de refração será outro. No limite vidro/mineral, a luz reflete-se totalmente em função do ângulo crítico de reflexão total do mineral. O refratômetro gemológico só permite a determinação dos índices de refração de minerais, cujos índices sejam inferiores ao indice da semiesfera. $\mathrm{O}$ valor do indice de refração do mineral é lido. 
em cima da escala graduada, situada no limite de um campo claro com um campo parcialmente escuro.

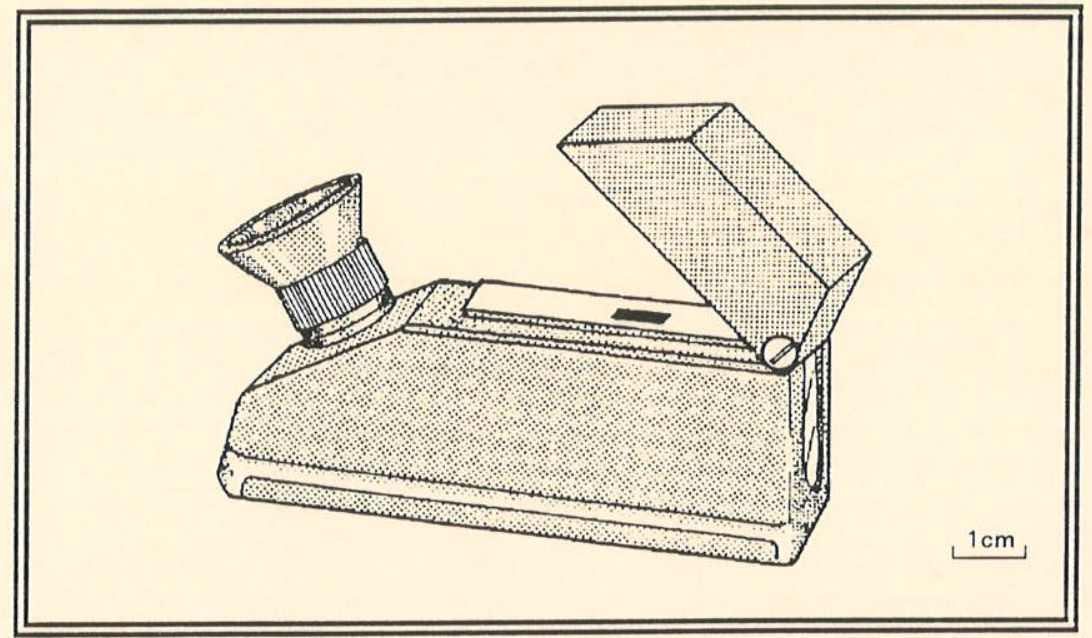

FIGURA 2 - Modelo esquemático de um refratômetro gemológico, que permite obter algumas características ópticas dos minerais tais como o(s) índice(s) de refração e o sinal óptico (Extraído de Cipriani 1986).

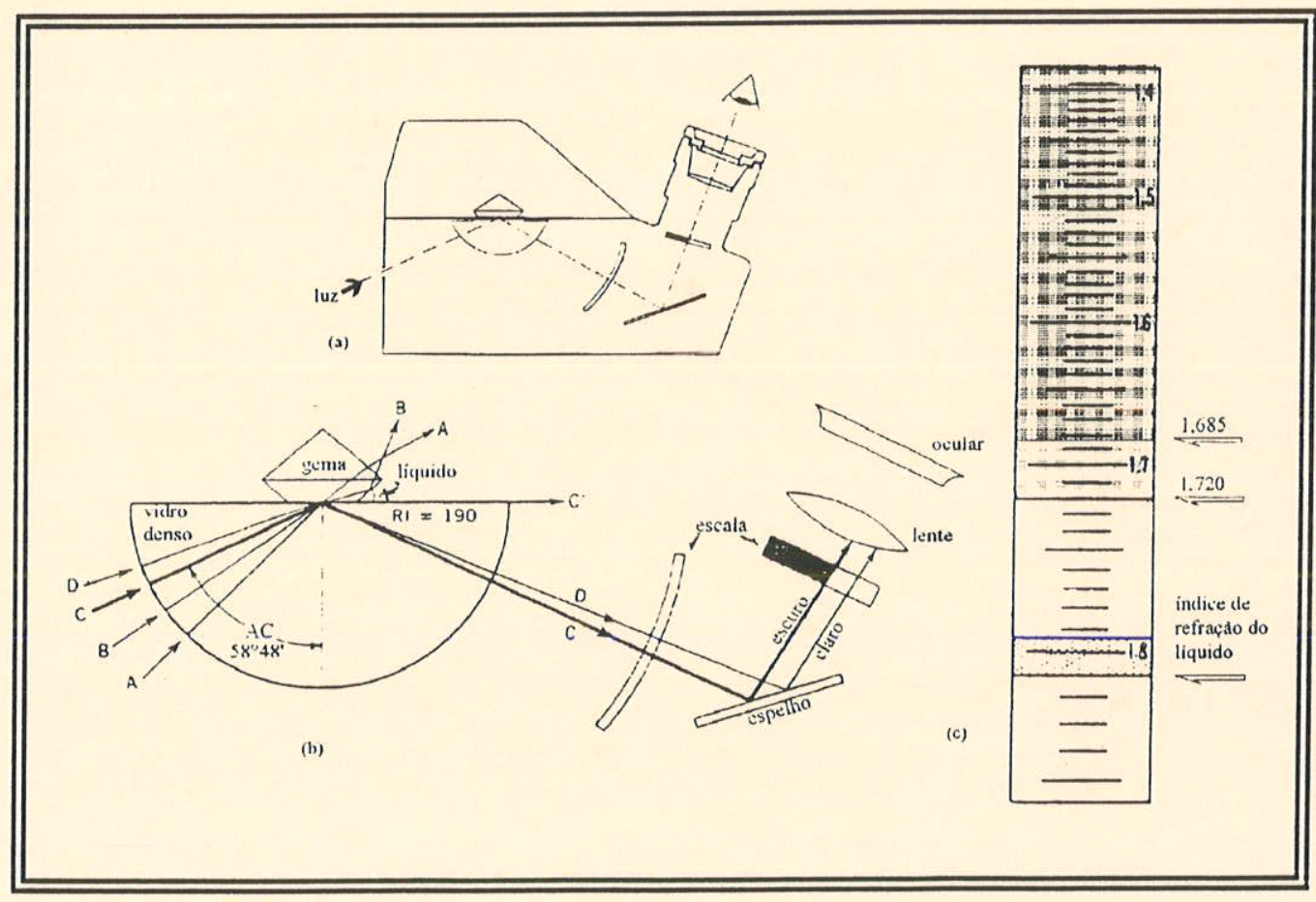

FIGURA 3 - Esquema de um refratômetro gemológico. O princípio de funcionamento, baseado no ângulo crítico de reflexão total é mostrado nas seções (a) e (b). Os raios A e B, menores que o do ângulo crítico (AC), atravessam a gema, enquanto os maiores que $\mathrm{AC}$. são totalmente refletidos através da semiesfera de vidro. Finalmente o esquema (c) mostra a imagem da escala onde se lê os valores 1,685(nX) e 1.720(nZ). O valor de 1.81 é o do líquido de contato [(a) (modificado de Lenzen et al. 1984), (b) e (c) modificados de Klein \& Hurlbut Jr. 1985]. 
Os cristais foram serrados num plano inclinado em relação ao eixo cristalográfico c do topázio e polidos para a obtenção das leituras. Como o mineral pertence ao sistema ortorrômbico, foram medidos os índices $\mathrm{nX}$ e $\mathrm{nZ}$, sendo o $\mathrm{nY}$ calculado através de uma fórmula matemática simples, que envolve a média aritmética dos valores das várias leituras obtidas. Desta forma, além dos índices, obtêm-se também o sinal óptico e o valor da birrefringência.

O pleocroísmo deste mineral tricóico é bem nítido quando utiliza-se o dicroscópio ou pleocroscópio (Figura 4). Este aparelho óptico serve para observar a mudança de cor nas diferentes direções cristalográficas do mineral, fenômeno este conhecido como pleocroísmo. Nestas operações foi utilizado um dicroscópio SCHNEIDER pertencente ao DEGEO/EM/UFOP, esquematizado na Figura 4b. Este instrumento constitui-se de um tubo metálico de $4 \mathrm{~cm}$ de comprimento por $1,5 \mathrm{~cm}$ de diâmetro onde uma das extremidades contém uma lente e a outra duas placas de polaróides, lado a lado, com as direções de vibração perpendiculares entre si.

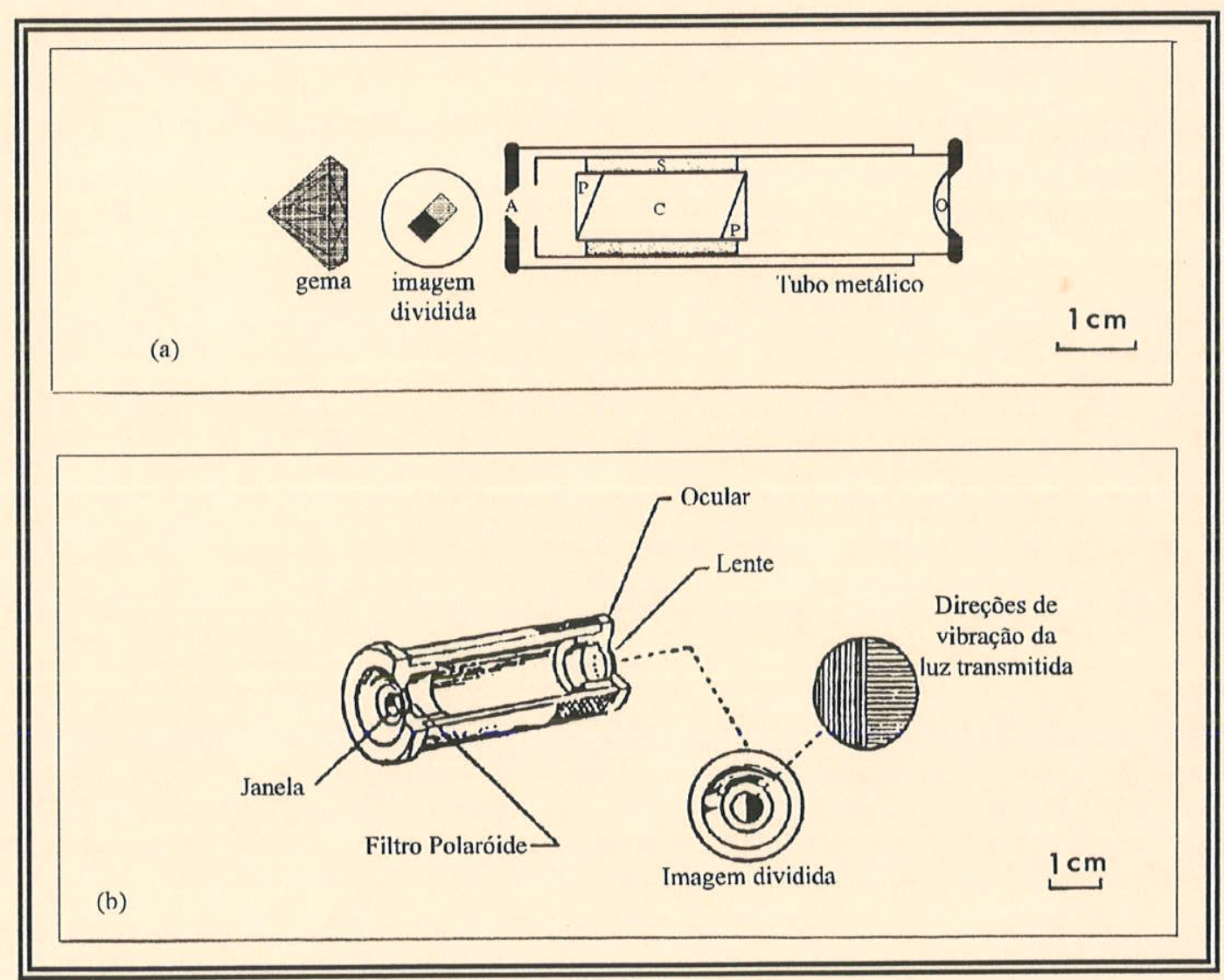

FIGURA 4 - Modelos de dicroscópios, onde pode ser visto em (a) um corte esquemático de um dicroscópio de calcita, destacando-se o fenômeno do pleocroísmo de uma dada gema (Modificado de Lenzen et al. 1984). Em (b) vê-se um modelo de um dicroscópio com placas de polaróide (dicroscópio de filtro), onde essas placas são colocadas de maneira que a direção de vibração de uma parte da placa fique perpendicular à direção de vibração da outra parte da placa (Modificado de The Asian Institute of Gemological Sciences s.d.). Símbolos usados em (a): S - suporte de cortiça, C - romboedro de calcita (separação da luz em dois raios), A - abertura (janela), O - ocular (lente) e P - prisma de vidro colado à calcita para que a luz ao passar pelo romboedro não desvie de direção. 
O exame do mineral se faz de preferência na luz do dia. Através da polarização da luz vista pelo dicroscópio, observam-se ao mesmo tempo duas cores ou dois tons distintos simultaneamente. Desta maneira, girando-se o mineral em várias posições, ocorrerão as várias situações possiveis de pleocroísmo. Sendo o topázio biaxial, o seu pleocroísmo será tricróico.

Os valores do ângulo $2 \mathrm{~V}_{Z}$ foram obtidos através de uma platina universal Carl Zeiss, a quatro eixos existente no DEGEO/EM/UFOP. Foram confeccionadas lâminas delgadas de diversos cristais, previamente orientados de tal forma que o corte fosse praticamente perpendicular ao eixo c, o que facilitou a obtenção dos dados.

\subsection{4 - DIFRAÇ̃̃O DE RAIOS X}

Uma das técnicas de difração de raios $X$ mais importantes, para a identificação das espécies minerais, é a do método do pó. Além de identificar, ela permite a medida dos parâmetros de cela unitária dos minerais (Azároff \& Buerger 1958). Neste trabalho, este método serviu para identificação das inclusões cristalinas associadas ao topázio, além da determinação do cristal hospedeiro. A câmara utilizada foi a de Gandolfi (Gandolfi 1967), pertencente ao IG/USP, com diâmetro de 114,6mm, sob exposição e condições variáveis de acordo com cada tipo de amostra.

Após o exame das inclusões cristalinas sob o microscópio gemológico, topázios selecionados foram fraturados em um Morteiro de Abich. As inclusões cristalinas liberadas e caracterizadas, com uma lupa binocular, foram isoladas com auxilio de uma agulha e guardadas em cápsulas de plásticos para que fossem futuramente identificadas pelo método do pó.

Os diagramas de pó foram obtidos difratando-se cada uma das inclusões separadamente em uma câmara de Gandolfi, por meio de um aparelho JEOL, modelo JDX-7E do IG/USP. Este tipo de câmara fornece diagramas de pó a partir de monocristais de dimensões de até $10 \mu \mathrm{m}$, os quais são produzidos por dois movimentos de rotação simultâneos com uma inclinação de $45^{\circ}$. A única desvantagem da câmara de Gandolfi é o tempo de montagem e centragem.

Dependendo da natureza, da forma e do tamanho das inclusões, o tempo de exposição aos raios X varia de 18 a 24 horas. Os respectivos diagramas de pó foram obtidos utilizando-se radiação $\mathrm{CuK}_{\alpha}$ e filtro de $\mathrm{Ni}$.

Algumas inclusões transparentes, incolores e de tamanho muito reduzido, que não puderam ser devidamente isoladas, deixaram de ser determinadas por este método. Para esses casos, a identificação foi complementada por microssonda eletrônica (Sistema Dispersivo de Energia - EDS) ou por microscopia eletrônica de varredura (MEV) associado a um espectrômetro de energia dispersiva (EED).

Para o cálculo dos parâmetros unitários do topázio, utilizou-se um programa de computação denominado de Miller 2, em uso no DEGEO/EM/UFOP e cedido pelo Prof. Dr. José 
Marques Correia Neves (IGC/UFMG). Os dados utilizados neste programa foram os "d $\mathbf{s}_{\mathbf{s}}$ " observados das diferentes reflexões e os possiveis índices (hkl) de cada plano reticular compilados do fichário JCPDS. Para a obtenção desses dados, utilizaram-se diagrama de pó obtidos em câmara de Debye-Scherrer de $114,6 \mathrm{~mm}$ de diâmetro. As amostras foram quebradas no Morteiro de Abich e pulverizadas no gral de ágata até alcançar uma granulometria abaixo de 200 mesh.

\subsection{5 - MICROSCOPIA ELETRÔNICA DE VARREDURA}

Este método tem como princípio a incidência de um feixe eletrônico fino, produzido por um filamento de tungstênio, que varre a superfície da amostra previamente metalizada, que é colocada no interior de uma câmara de vácuo do microscópio eletrônico de varredura (MEV). Em decorrência dessa irradiação de elétrons, são emitidos elétrons secundários e retroespalhados, além de outros componentes, a partir da superficie da amostra. Esses sinais são detectados, ampliados e enviados à tela de um tubo de raios catódicos mostrando uma imagem da amostra, varrida sincronicamente. Esta técnica permite uma análise da composição, através do número atômico, da fase estudada além de sua morfologia.

As amostras de topázio, contendo inclusões cristalinas, foram quebradas no Morteiro de Abich e, as inclusões liberadas foram separadas com auxílio de uma agulha, em uma lupa binocular. Essas inclusões foram devidamente metalizadas. Para as inclusões transparentes, incolores e de tamanho muito reduzido, metalizou-se todo o material quebrado, uma vez que não foi possivel isolar essas inclusões.

Os dados referentes às inclusões cristalinas foram obtidos com a utilização de um sistema composto por um MEV, marca JEOL-T330A associado a um espectrômetro de energia dispersiva (EED), Séries II da Noran Instruments, do NUPEGEL - IAG/USP, além de um equipamento semelhante do Forschunsinstitut für Mineralische und Metalleische Werkstoffé Elelsteine/Edelmetalle - GmbH, Idar-Oberstein, na Alemanha.

\subsection{6 - ESTUDO DAS INCLUSÕES FLUIDAS}

As inclusões fluidas são, de modo geral, analisadas através de métodos que podem ser classificados como destrutivos e não destrutivos (Roedder 1979, Hollister 1981). Geralmente, as técnicas analíticas destrutivas têm sido bastante utilizadas na tentativa de se determinar qualitativa e quantitativamente os componentes químicos das inclusões fluidas. $\mathrm{O}$ grande problema referente a esta técnica é relativo à limitação do resultado, devido a possibilidade de contaminação, perda ou mistura de fluidos de inclusões de diferentes gerações. Por esses motivos, os métodos não 
Entre os métodos destrutivos, pode-se citar a platina de esmagamento, que nos fornece uma análise qualitativa e semiquantitativa dos gases aprisionados sob pressão nas inclusões fluidas, havendo mesmo aquelas que permitem a realização de leituras termobarométricas, como a apresentada por Ypma (1966). Outro método que pode ser empregado é o de microscopia eletrônica de varredura (MEV), para a identificação direta dos minerais de saturação e outros residuos de evaporação das inclusões fluidas. Por último, podemos citar a espectroscopia no infravermelho. que permite a identificação das bandas de absorção, tanto do mineral hospedeiro, como de várias substâncias presentes nas inclusões fluidas.

Entre os vários métodos não destrutivos, o da microtermometria é o mais simples e. por isso, o mais utilizado. A grande vantagem deste método é a de permitir a repetição do mesmo teste ou a realização de testes diferentes na mesma inclusão, quando não houver vazamento de fluidos, mesmo que parcial, ou crepitação das inclusões, durante os processos de aquecimento ou resfriamento. Também, podemos citar entre esses métodos a espectroscopia micro Raman. que possibilita a realização de análises qualitativas e quantitativas das fases individuais de inclusões fluidas com dimensões que podem chegar até $2 \mu \mathrm{m}$. Análises quantitativas de $\mathrm{CH}_{4}, \mathrm{C}_{2} \mathrm{H}_{6}, \mathrm{C}_{3} \mathrm{H}_{8}$, $\mathrm{CO}_{2}, \mathrm{~N}_{2}$ e $\mathrm{H}_{2} \mathrm{~S}$ têm sido efetuadas desde 1979 (Fuzikawa 1985). Roedder (1972), faz referência a outros métodos não destrutivos pouco comuns, entre eles pode ser citada a ressonância magnética nuclear.

Pelo exposto, optou-se pelo método da microtermometria para o estudo das inclusões fluidas, além da espectroscopia de absorção no infravermelho e micro Raman. Este estudo possui interesse tanto científico, como econômico. No primeiro caso, os dados obtidos permitem determinar as condições físico-químicas reinantes durante os processos petrogenéticos, ou relacionados a eventos posteriores à cristalização ou recristalização dos minerais. No segundo caso, por possibilitar o conhecimento da natureza dos processos envolvidos na formação de certos depósitos minerais, pode auxiliar na sua prospecção; além disso, permite fazer uma análise dos fluidos que controlam a geração e a alteração dos vários tipos de depósitos minerais (Urabe \& Sato 1978, Roedder 1984, Fuzikawa 1985, Xavier 1987).

Desde a época de Sorby (1858), que estabeleceu os principios de uma geotermometria com base no aquecimento das inclusões fluidas, sua interpretação tem sido realizada através do método da microtermometria. Ele é realizado com o auxilio de uma platina de resfriamento/aquecimento adaptada a um microscópio petrográfico comum sob luz transmitida, que permite uma variação de temperatura entre -190 e $+600^{\circ} \mathrm{C}$ (Poty et al. 1976, Hollister \& Crawford 1981).

O método baseia-se na observação in loco das mudanças de fases dos fluidos inclusos, nas cavidades dos minerais, durante os processos de resfriamento e de aquecimento, com registro simultâneo das respectivas temperaturas, através de um termòmetro digital. A comparação dos resultados obtidos, com outros relativos a sistemas estudados experimentalmente, permite a determinação de dados relevantes sobre a composição, a salinidade, a densidade dos fluidos 
simultâneo das respectivas temperaturas, através de um termômetro digital. A comparação dos resultados obtidos, com outros relativos a sistemas estudados experimentalmente, permite a determinação de dados relevantes sobre a composição, a salinidade, a densidade dos fluidos envolvidos, bem como das condições de temperatura e pressão do seu aprisionamento ou mesmo da formação do mineral (Weisbrod et al. 1976, Collins 1979, Hollister 1981, Roedder 1984, Fuzikawa 1985, Nicholls \& Crawford 1985). Em determinados casos, quando as inclusões fluidas são aprisionadas a partir de sistemas heterogêneos, consegue-se a temperatura real de formação do cristal, ou um valor bastante próximo da mesma (Roedder 1984).

A parte experimental deste trabalho foi executada no Laboratórios de Inclusões Fluidas do IG/USP e do CDTN/CNEN-BH, utilizando-se um microscópio da marca Leitz Wetzlar, binocular, com várias associações de oculares de $10 \mathrm{x}$ e $25 \mathrm{x}$, e de objetivas de $3,5 \mathrm{x}$, 10x e $32 \mathrm{x} / \mathrm{UT}-50$, esta última caracterizada por possuir aumento relativamente elevado, conservando uma distância focal de $6 \mathrm{~mm}$. O equipamento microtermométrico, basicamente, é constituído de três partes, que são descritas a seguir. A platina de resfriamento/aquecimento da marca CHAIXMECA, cujos princípios foram descritos por Poty et al. (1976), tipo MTM8S apresenta os seguintes componentes; a) um anel metálico que permite a adaptação de uma lente de sílica transparente e polida e de uma luva de plástico que isola a amostra da atmosfera ambiente durante o aquecimento e resfriamento, respectivamente; b) um sistema xy que possibilita um pequeno deslocamento horizontal através de dois parafusos e c) uma lente condensadora embutida no seu interior, que permite uma iluminação excepcional da amostra, possibilitando que inclusões minúsculas, de aproximadamente $10 \mu \mathrm{m}$, possam ser estudadas facilmente. A falta desta lente limita enormemente a capacidade de utilização do aparelho. Outra parte do instrumento é o leitor/controlador de temperatura da marca Newport, modelo 871. Este aparelho é acoplado à platina microtermométrica e possibilita leituras de $-200 \mathrm{a}+780^{\circ} \mathrm{C}$, com uma resolução de $0,1^{\circ} \mathrm{C}$. Por meio de uma impressora digital, alimentada por papel sensível ao calor, são registradas as várias temperaturas de fusão e homogeneização observadas. Finalmente, um container de nitrogênio líquido (botijão criogênico), dotado de um tubo de saída e acessórios para auto pressurização e válvula de segurança, é conectado à platina microtermométrica.

O corpo da platina contém em seu interior uma resistência que permite o aquecimento até temperaturas de $600^{\circ} \mathrm{C}$ e um canal de circulação de nitrogênio líquido que possibilita seu resfriamento até, aproximadamente, $-190^{\circ} \mathrm{C}$. Para outros modelos de platina, podem ser atingidas por aquecimento temperaturas de até $1.200^{\circ} \mathrm{C}$.

Equipamentos semelhantes, pertencentes aos laboratórios do IG/UNICAMP e DEGEO/EM/UFOP, foram também utilizados para a obtenção de algumas medidas de temperaturas relativas à fase do aquecimento.

Antes do estudo microtermométrico propriamente dito, foi feita uma análise inicial detalhada e seleção dos cristais de topázio no microscópio gemológico. Nesta interpretação preliminar, foi possível reconhecer e mapear as inclusões fluidas, destacando-se seus aspectos morfológicos, distribuição espacial, dimensões, número de fases, índice de refração, birrefringência, cores das fases fluidas e, finalmente, classificá-las como primárias, secundárias ou 
pseudosecundárias. Um mapeamento mais detalhado foi realizado posteriormente, já a partir das seções próprias para estudo, utilizando-se um microscópio petrográfico, onde, em alguns casos, foi acoplada uma câmara clara. Estas observações quanto aos tipos de inclusões são muito importantes, pois um bom estudo petrográfico inicial ajudará na compreensão de questões que possam surgir no decorrer do exame microtermométrico, ou mesmo na interpretação dos dados. Outro aspecto importante, na descrição petrográfica, é a escolha de áreas ou subáreas com inclusões fluidas representativas, a serem estudadas pelo método microtermométrico.

Para os estudos microtermométricos, os cristais selecionados foram serrados na forma de lâminas de faces planas e paralelas, sendo posteriormente polidas em ambas as faces, com objetivo de atenuar os efeitos da difusão da luz e da reflexão total nos contornos das inclusões fluidas. Desse modo, foram obtidas seções com espessura de, aproximadamente, $1 \mathrm{~mm}$, ou seja, maior do que a das lâminas petrográficas comuns, uma vez que, por não serem aderidas às lâminas de vidro, podem fraturar-se com o manuseio, se forem muito finas. De modo geral, as espessuras podem variar de 0,1 a $5 \mathrm{~mm}$, dependendo de cada caso, como discutem diversos autores, citados em Fuzikawa (1985). A confecção dessas lâminas requer muita habilidade, pois durante o preparo não podem ser aquecidas acima de $30^{\circ} \mathrm{C}$, para evitar problemas de vazamento de fluido ou crepitação das inclusões.

Após a obtenção de um número de medidas significativas para cada grupo de inclusões, são construídos histogramas de freqüência para inclusões fluidas semelhantes. Esses histogramas são muito importantes pois, muitas vezes, mostram mais de uma região de maior freqüência de medidas indicando que inclusões aparentemente semelhantes, quanto ao modo de ocorrência e morfologia, podem pertencer a grupos distintos. Neste caso, devem ser consideradas pelo menos duas interpretações: ou elas constituem populações de inclusões de origens distintas ou foram aprisionadas durante um amplo intervalo de temperatura e pressão podendo, conseqüentemente, ter havido uma evolução do fluido.

Os histogramas também nos fornecem os dados que serão utilizados para o cálculo dos demais paràmetros como a densidade, salinidade, fração molar dos componentes presentes, além das temperaturas e pressões mínimas de aprisionamento. Essas interpretações são realizadas comparando-se esses dados obtidos, com resultados fornecidos por sistemas estudados experimentalmente e, portanto, com parâmetros P-V-T-X conhecidos (Hollister \& Crawford 1981). Na realidade, a composição raramente é obtida com grande precisão, exceto para os constituintes maiores. Entretanto, isso não constitui um empecilho, uma vez que são poucos os dados experimentais para sistemas muito complexos, sendo utilizados principalmente os constituídos por $\mathrm{CO}_{2} ; \mathrm{H}_{2} \mathrm{O} ; \mathrm{H}_{2} \mathrm{O}+\mathrm{CO}_{2} ; \mathrm{H}_{2} \mathrm{O}+\mathrm{NaCl}+\mathrm{CO}_{2}$ e $\mathrm{CO}_{2}+\mathrm{CH}_{4}$ entre outros, que possuem parâmetros termodinâmicos bem determinados. No caso de sistemas onde o número de componentes é maior, a complexidade do diagrama de P-V-T-X aumenta. No entanto, como as 
composições das inclusões fluidas são fixas e o sistema apresenta um volume constante, podem ser feitas algumas simplificações que facilitam as interpretações.

Dependendo da composição dos fluidos presentes nas inclusões, podem-se ter valores distintos das temperaturas de fusão dos seus componentes (Collins 1979, Nicholls \& Crawford 1985). Por exemplo, se a temperatura de fusão de uma das fases da inclusão ocorrer a $-56,6^{\circ} \mathrm{C}$, isso implica na presença de $\mathrm{CO}_{2}$ puro, enquanto que valores inferiores indicam que outros voláteis estão dissolvidos na fase carbônica, os quais nem sempre podem ser determinados pela microtermometria. Nesses casos, são de grande utilidade outros métodos de análises, como por exemplo as espectroscopias de absorção no infravermelho e a micro Raman (Moenke 1966, Farmer 1974, Gadsden 1975). Do mesmo modo, se a temperatura de fusão da fase aquosa apresentar valores menores que $0^{\circ} \mathrm{C}\left(\mathrm{H}_{2} \mathrm{O}\right.$ pura), isso implica a presença de íons dissolvidos na solução, os quais podem ser determinados, de modo aproximado, através das temperaturas dos seus pontos eutéticos.

O conjunto das várias temperaturas de mudanças de fase dos fluidos das inclusões permitem a obtenção de dados relativos à sua composição, salinidade, densidade, além da T e P reinantes na época do aprisionamento. Observa-se, desse modo, que o estudo das inclusões fluidas pode constituir uma ferramenta importante para a compreensão das condições de cristalização e da origem dos minerais que as contêm.

É importante destacar que para o estudo das inclusões fluidas devem ser consideradas determinadas premissas, como, por exemplo, a não existência de modificações na composição ou densidade do fluido desde a época do seu aprisionamento e, caso estas tenham ocorrido, a possibilidade de detectá-las com a observação cuidadosa da amostra ou durante os processos de resfriamento e aquecimento.

Nesta Dissertação foram estudadas inclusões fluidas possuindo desde contornos regulares até irregulares, havendo gradações entre esses tipos. As inclusões, de modo geral, apresentam dimensões extremamente variáveis, tendo sido selecionadas para as determinações microtermométricas apenas aquelas situadas entre 15 e $50 \mu \mathrm{m}$ (comprimento do maior eixo), pois inclusões muito grandes podem apresentar problemas de crepitação ou escape de fluidos quando aquecidas.

Outras técnicas utilizadas para o estudo das inclusões fluidas foram as de espectroscopia no infravermelho e micro Raman para os casos onde a temperatura de fusão do $\mathrm{CO}_{2}$ foi menor que $-56,6^{\circ} \mathrm{C}$, indicando a presença subordinada de outros elementos não identificados pela microtermometria. 


\subsection{7 - ESPECTROSCOPIA DE ABSORÇÃO NO INFRAVERMELHO}

Segundo Povarennykh (1978), essa técnica destrutiva é útil para a identificação de minerais, a determinação do arranjo e da simetria dos grupamentos atômicos e moleculares, o estudo da influência das substituições iônicas na estrutura dos minerais, a identificação de componentes orgânicos, entre outras.

No decorrer deste trabalho, ela foi usada basicamente para a identificação dos grupamentos moleculares presentes nas inclusões fluidas, tais como, água, gás carbônico e hidrocarboneto.

Os espectros de absorção no infravermelho foram obtidos utilizando-se um espectrofotômetro Perkin Elmer, modelo 283B, pertencente ao DQ/ICEX/UFMG. Os diagramas foram obtidos a partir de $1 \mathrm{mg}$ de cada cristal de topázio, finamente moído, porém com tamanho

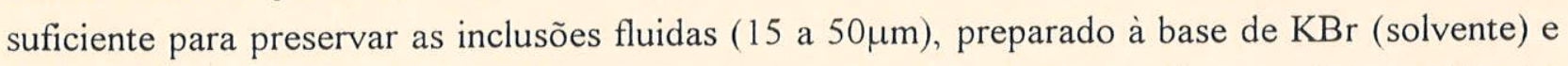
amálgama de dentista até formar uma pastilha transparente. Para a calibração do aparelho foi utilizado o poliestireno. Os espectros foram tomados na região de 4.000 a $600 \mathrm{~cm}^{-1}$, com uma exposição de 50 minutos.

Como neste método as substâncias homopolares não são detectadas, por exemplo o nitrogênio $\left(\mathrm{N}_{2}\right)$ e, sendo esta substância passível de estar presente na fase fluida, recorreu-se à espectroscopia micro Raman.

\subsection{8 - ESPECTROSCOPIA MICRO RAMAN}

O efeito Raman consiste na modificação do comprimento de onda de uma radiação eletromagnética que é espalhada por uma superfície. O fenômeno é utilizado nos espectrógrafos Raman, onde se medem, através de um registro específico, os comprimentos de onda da radiação refletida, obtendo-se assim, informações quanto a estrutura molecular da sustância refletora (Fuzikawa 1985).

A grande vantagem do uso deste método é permitir uma análise pontual, ou seja, o diâmetro do feixe de raio de elétrons que incide na amostra é da ordem de $1 \mu \mathrm{m}$; com isto, podese estudar inclusões cristalinas ou fluidas muito pequenas. Outra vantagem, é a possibilidade de se repetir a análise na mesma inclusão ou efetuar outro tipo de teste na amostra, pois este método não é destrutivo. Talvez, em alguns casos, uma limitação seja o grau de diafaneidade do mineral hospedeiro das inclusões fluidas, da amostra estudada. Outra limitação é que determinadas substâncias interagem com a radiação incidente e produzem espectro Raman, ao passo que outras, cuja interação é muito fraca, não conseguem produzir os efeitos espectrais. Como exemplos do primeiro grupo podemos citar as substâncias $\mathrm{CO}_{2}, \mathrm{H}_{2} \mathrm{O}, \mathrm{CH}_{4}$ e $\mathrm{N}_{2}$; entre as segundas, íons como o $\mathrm{Na}^{+}, \mathrm{Cl}^{-}, \mathrm{K}^{+}$que podem estar presentes nas inclusões fluidas. 
Analogamente à espectroscopia de absorção no infravermelho, há picos do mineral e dos componentes fluidos. Nestas duas últimas técnicas os picos são, de um modo geral, inversamente proporcionais; quando um é ativo no infravermelho é fraco no Raman, e vice-versa (Ewing 1989).

As amostras de topázio da região de Ouro Preto, estudadas por este método, foram as mesmas lâminas preparadas para o estudo das análises microtermométricas. $\mathrm{O}$ equipamento utilizado foi um espectroscópio micro Raman DILOR, modelo XY, pertencente ao DF/ICEX/UFMG.

\subsection{9 - MICROSSONDA ELETRÔNICA}

É o mais importante método de análise química mineral da atualidade, que vem sendo divulgado em vários manuais e/ou livros (Gomes 1980 e 1984) e teses nos últimos anos.

A técnica consiste na determinação da composição química de um pequeno ponto da superficie de um mineral a partir de uma montagem polida e metalizada. Essa leitura se dá através da incidência de uma corrente de elétrons de alta energia, gerados em alto vácuo, na amostra, de onde são emitidos os comprimentos de ondas característicos dos elementos presentes no mineral. Este feixe de elétrons incide na amostra com um diâmetro da ordem de $1 \mu \mathrm{m}$. A incidência do feixe eletrônico na superfície da amostra provocará a formação de raios $\mathrm{X}$, em conseqüência da interação de elétrons de alta energia com os átomos dos elementos presentes na amostra (Gomes \& Girardi 1973).

O princípio da análise está na comparação da intensidade de uma dada linha de emissão de raios X gerada na amostra com aquela produzida pelo padrão, mantida a corrente incidente constante. Entre as vantagens desta técnica figuram a possibilidade de se obter dados químicos de minerais a partir de amostras de dimensões reduzidas; de possuir caráter não destrutivo; de se observar o mineral no decorrer da análise, bem como da rapidez (alguns segundos ou poucos minutos) na obtenção dos resultados devido a automatização do aparelho por computadores interligados.

Quanto às amostras utilizadas, neste trabalho, foram confeccionadas lâminas delgadas e montagem em acrílico, ambas polidas, que receberam uma metalização de carbono.

As condições de análise dos topázios variaram de acordo com os elementos químicos investigados. Para o $\mathrm{Si}^{4+}, \mathrm{Al}^{3+}$ e $^{-}$, as condições utilizadas foram de $15 \mathrm{kV}$ e $20 \mathrm{nA}$, com um tempo de contagem que variou entre 10 a 20s. Os demais elementos, $\mathrm{P}^{5+}, \mathrm{Ti}^{4+}, \mathrm{Ge}^{4+}, \mathrm{Zr}^{4+}, \mathrm{V}^{3+}$, $\mathrm{Cr}^{3+}, \mathrm{Fe}^{3+}, \mathrm{Mg}^{2+}, \mathrm{Ca}^{2+}, \mathrm{Mn}^{2+}, \mathrm{Ni}^{2+}, \mathrm{Sr}^{2+}, \mathrm{Ba}^{2+}$ e $\mathrm{K}^{+}$, tiveram um tempo de contagem entre 40 e $60 \mathrm{~s}$, com $20 \mathrm{kV}$ e $30 \mathrm{nA}$. Os padrões utilizados incluíram minerais naturais, substâncias sintéticas e metal puro como no caso do Ge. Apesar das duas condições diferentes utilizadas nas análises, todos os elementos foram dosados no mesmo ponto com o equipamento mudando as condições 
automaticamente. Esses trabalhos foram executados em uma microssonda CAMECA, modelo SX 50 , pertencente ao $\mathrm{IG} / \mathrm{UnB}$.

\subsubsection{0 - ELETRODO DE ÍON ESPECÍFICO PARA FLÚOR}

Este equipamento foi usado para a determinação do flúor na estrutura do topázio. O método baseia-se na atividade iônica que o íon fluoreto apresenta, quando se encontra em solução aquosa de citrato de sódio. Esta atividade pode ser medida através de um eletrodo de ín específico para o flúor combinado com um eletrodo de referência, utilizando-se um potenciômetro de precisão para íon específico.

O eletrodo especifico para fluoreto é constituído de um cristal de fluoreto de lantânio, o qual é combinado com um eletrodo de referência com solução interna de cloreto de potássio (KCl) $3 \mathrm{M}$.

A solução de fluoreto deve ter o pH ajustado entre 5 e 7 e, em seguida, é adicionado o reagente estabilizador de força iônica com $\mathrm{pH}$ ajustado em 5,6 e, nestas condições, o potencial da concentração do íon fluoreto é medido. O flúor deve estar completamente ionizado na solução final, porque o eletrodo de íon específico somente analisa o íon fluoreto e não o complexo de flúor. Como na estrutura do topázio o alumínio está presente, este, em solução reage com o flúor $\left(\mathrm{Al}^{3+}+6 \mathrm{~F}^{-} \leftrightarrow \mathrm{AlF}_{6}{ }^{3-}\right)$, causando uma interferência no resultado final. Para isto, há necessidade de se fazer uma diluição mais forte da solução para eliminar este problema (Edmond 1969, Troll et al. 1977, Vernet et al. 1987), (Figura 5).

Por se tratar de uma técnica por via úmida, o instrumental adicional foi bem grande, como por exemplo: a) pH-metro com eletrodo de íon específico $\left(\mathrm{F}^{-}\right)$; b) agitador magnético; c) balança analítica com precisão de $0,0001 \mathrm{~g}$; d) cadinho de platina; e) chapa elétrica; f) bico de Bunsen; g) vidraria comum de laboratório.

Durante o procedimento das análises, foram utilizados reagentes de grau p.a. (reagentes para análises) e diversos tipos de soluções enumerados nos itens a seguir. 1) Solução padrão de flúor preparada pesando-se $0,2232 \mathrm{~g}$ de $\mathrm{NaF}$, previamente seco em estufa a $110^{\circ} \mathrm{C}$, dissolvidos em água destilada e transferida para um balão de $1.000 \mathrm{ml}$; 2) Citrato de sódio em solução de $1 \mathrm{M}$ e $\mathrm{pH}=5,6$. Para prepará-la, dissolveu-se $294 \mathrm{~g}$ de citrato trissódico dihidratado $\left(\mathrm{C}_{6} \mathrm{H}_{5} \mathrm{Na}_{3} \mathrm{O}_{7}-2 \mathrm{H}_{2} \mathrm{O}\right)$ em um béquer de $1.000 \mathrm{ml}$, ajustou-se o $\mathrm{pH}$ para $5,6 \mathrm{com}$ ácido cítrico e, avolumou-se o conjunto para $1.000 \mathrm{ml}$; 3) Ácido clorídrico em solução aquosa V/V (Volume/Volume); 4) Hidróxido de sódio em solução aquosa $10 \% \mathrm{P} / \mathrm{V}$ (Peso/Volume); 5) Verde-bromocresol em solução indicadora $0,1 \% \mathrm{P} / \mathrm{V}$ em álcool; 6) Hidróxido de sódio em lentilhas e 7) Ácido clorídrico em solução aquosa $10 \% \mathrm{~V} / \mathrm{V}$. 
Para a obtenção dos resultados para esta Dissertação, o primeiro passo foi construir uma curva de calibração. Para isto, prepararam-se padrões de $50 \mathrm{ml}$ contendo 10 e $\mathrm{lppm}$ de $\mathrm{F}^{-}$, transferindo-se o volume total de $50 \mathrm{ml}$ para um béquer de $100 \mathrm{ml}$ e adicionando-se $15 \mathrm{ml}$ do tampão de citrato com $\mathrm{pH}=5,6$. Colocou-se esta solução sob agitação por 5 minutos, com agitador magnético. A leitura foi feita $\mathrm{em} \mathrm{mV}$ (mili volts) e após concluir todas as leituras, lançaram-se os valores em papel monolog, onde os valores de concentração são marcados na escala logarítimica e a leitura na escala cartesiana (Figura 6). Depois da curva pronta, o passo seguinte foi preparar o material a ser analisado. Após o topázio ser pulverizado abaixo de 200mesh, usou-se a seguinte metodologia: a) pesou-se $0,50 \mathrm{~g}$ com precisão de $0,0001 \mathrm{~g}$ e transferiu-se para um cadinho de platina; b) adicionou-se $2,5 \mathrm{~g}$ de $\mathrm{NaOH}$ em lentilhas e fundiu-se em bico de Bunsen usando chama branda; c) aguardou-se o resfriamento de toda massa fundida; d) colocou-se o cadinho em béquer de $300 \mathrm{ml}$ de $\mathrm{H}_{2} \mathrm{O}$ destilada; e) aqueceu-se de forma branda em chapa elétrica até que toda a massa fundida se desprendesse do cadinho; f) retirou-se o cadinho, lavou-se com água quente e adicionou-se solução de $\mathrm{HCl} \mathrm{V/V}$ até dissolver todos os hidróxidos. Adicionou-se um ligeiro excesso; g) transferiu-se para balão de $250 \mathrm{ml}$ (a solução mãe) e avolumou-se com $\mathrm{H}_{2} \mathrm{O}$ destilada; h) pipetou-se $2 \mathrm{ml}$ para balão de $50 \mathrm{ml}$ adicionando-se 2 gotas de indicador verde-bromocresol e, usando solução de $\mathrm{NaOH} 10 \% \mathrm{P} / \mathrm{V}$, fez-se a viragem para azul. Voltou-se para verde azulado, usando gotas de solução de $\mathrm{HCl} 10 \% \mathrm{~V} / \mathrm{V}$ avolumada com água destilada, homogeneizou-se e transferiu-se para béquer de $100 \mathrm{ml}$ e finalmente i) adicionou-se $15 \mathrm{ml}$ de solução de citrato $(\mathrm{pH}=5,6)$ e sob agitação magnética fez-se a leitura em $\mathrm{mV}$.

De posse de todas as leituras, o cálculo da concentração do flúor foi obtido pela expressão:

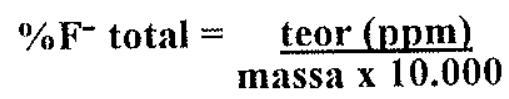

onde: teor $(\mathrm{ppm})=$ o valor lido no gráfico; massa $=$ peso da amostra dividido pela(s) diluição(ões).

O uso do eletrodo de íon específico exige um rigoroso controle da temperatura durante as leituras das amostras, pois uma variação de apenas $1^{\circ} \mathrm{C}$, causará um erro de, aproximadamente, $3 \%$ no resultado final.

A precisão associada ao método é da ordem de, aproximadamente, $6 \%$ e ela diminui a medida que o teor de $\mathrm{F}^{-}$aumenta.

Durante esse trabalho utilizou-se um equipamento DIGITAL IONALYZER, modelo 9418 da ORION RESEARCH, pertencente ao CDTN/CNEN-BH. 


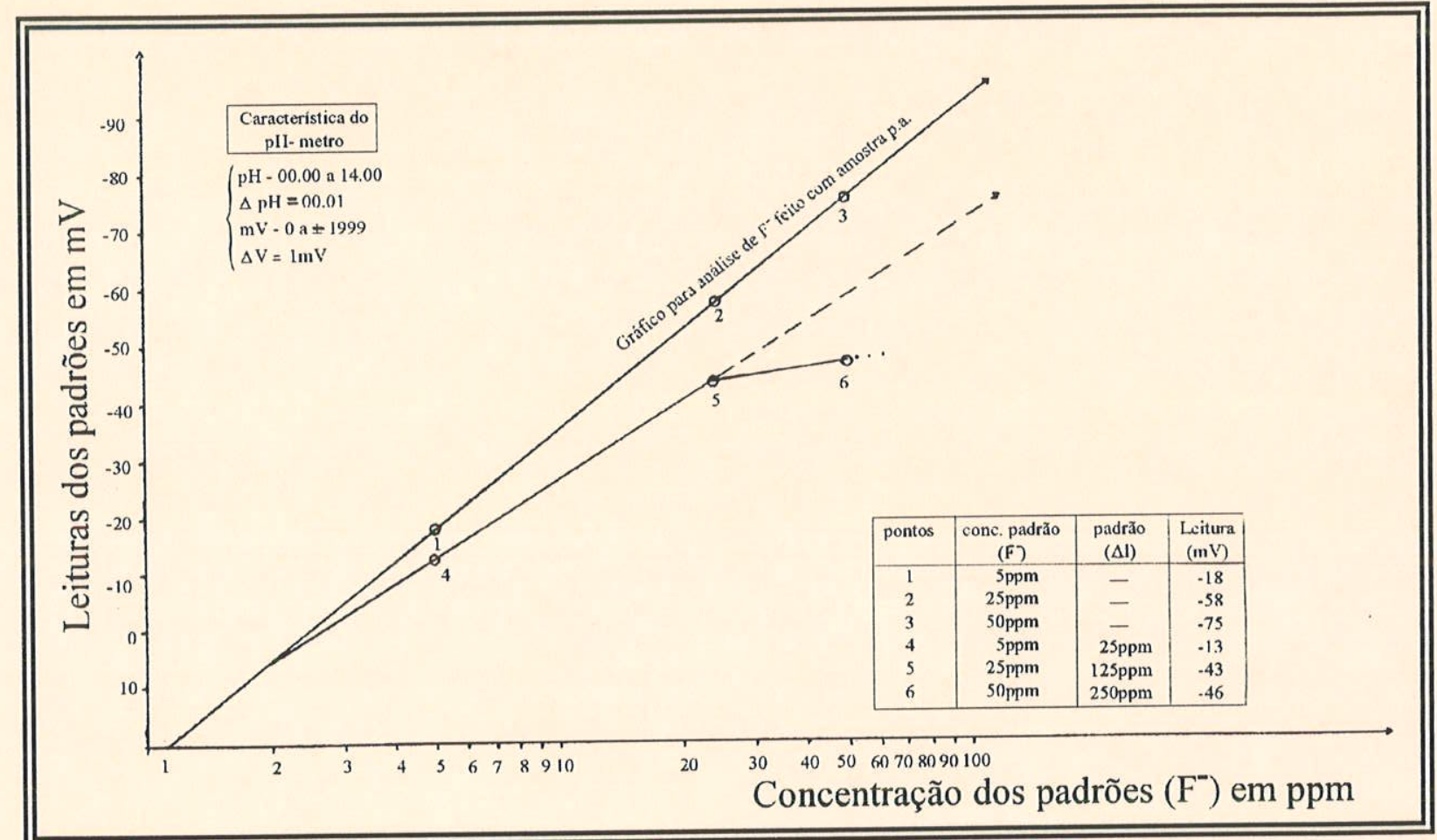

FIGURA 5 - Gráfico construído para analisar a interferência do alumínio na análise do íon fluoreto, usando o eletrodo seletivo de $\mathrm{F}^{-}$, marca ORION, modelo 9418 e o METROHM, modelo E603 pH-metro. (p.a. - reagente para análise).

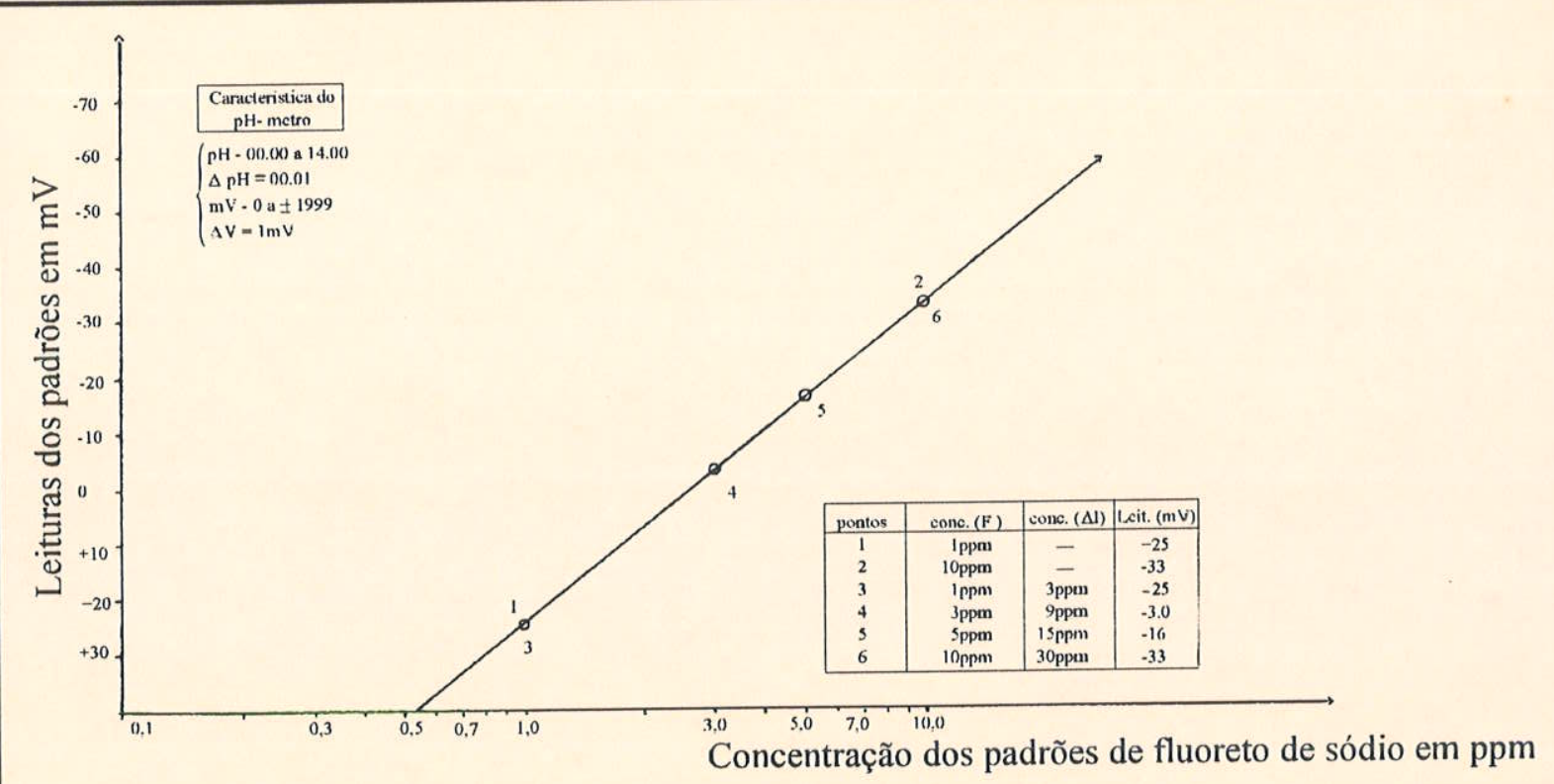

FIGURA 6 - Gráfico da curva de calibração para correção da interferência do alumínio sobre a análise do íon fluoreto, através de eletrodo seletivo de $\mathrm{F}^{-}$, marca ORION, modelo 9418 e o METROHM, modelo E603 pH-metro. 


\subsubsection{1 - GRAVIMETRIA (PERDA AO FOGO - PF)}

Neste método, podem-se determinar as porcentagens de $\mathrm{H}_{2} \mathrm{O}^{-}$(água não essencial ou adsorvida) e $\mathrm{H}_{2} \mathrm{O}^{+}$(água essencial), além de possíveis voláteis presentes na estrutura cristalina. Através da calcinação do material em mufla (forno) e de suas respectivas pesagens, obtêm-se os dados relativos a esses voláteis.

Primeiramente, foram selecionados os cristais de topázio isentos de inclusões cristalinas, seguindo-se uma moagem até uma granulometria inferior a 200mesh para cada amostra separadamente. Embora seja conveniente trabalhar com duplicatas, não foi possível usar esse procedimento tendo em vista o tamanho reduzido dos cristais $(<3 \mathrm{~g})$.

A presença de $\mathrm{H}_{2} \mathrm{O}^{-}$está ligada, principalmente, à moagem, pois a amostra fica com uma área muito maior exposta à umidade atmosférica. Para a determinação da porcentagem de $\mathrm{H}_{2} \mathrm{O}^{-}$, as amostras foram pesadas em um cadinho de liga platina-ouro, previamente seco em estufa. É necessário que o cadinho seja calcinado antes do processo e resfriado no dessecador até obter a constância do peso. Após permanecerem em mufla à $110^{\circ} \mathrm{C}$ por uma hora, aproximadamente, e esfriadas em dessecador, as amostras foram novamente pesadas. Este procedimento é repetido até obter-se uma constância do peso. Considera-se aqui constância de peso, se duas pesagens feitas dentro de um intervalo de uma hora não diferirem mais do que $0,01 \mathrm{~g}$. A diferença da pesagem forneceu o valor de $\mathrm{H}_{2} \mathrm{O}^{-}$. Quanto ao valor da perda ao fogo, ou seja, a soma das substâncias volatilizadas pela calcinação na estrutura cristalina do mineral, o procedimento foi análogo, com a ressalva de que a temperatura usada na mufla foi em torno de $1.000^{\circ} \mathrm{C}$. A calcinação é repetida até a constância do peso. Os valores encontrados nesta segunda etapa nem sempre refletem a porcentagem de $\mathrm{H}_{2} \mathrm{O}^{+}$pura, pois outros voláteis, como por exemplo o flúor e o boro, podem estar presentes na estrutura. A porcentagem da $\mathrm{PF}$ ou $\mathrm{H}_{2} \mathrm{O}_{\text {total }}$ é dada pela soma das porcentagens de $\mathrm{H}_{2} \mathrm{O}^{+}$e da $\mathrm{H}_{2} \mathrm{O}^{-}$.

Os dados para o topázio imperial da região de Ouro Preto, foram obtidos em uma mufla LAVOISIER, modelo 400D (18A, 220V, 3980W) e balança analítica eletrônica de marca METTLER, modelo H54AR, com precisão de 0,0001g e capacidade de $1200 \mathrm{mg}$, ambas do CPMTC/IGC/UFMG.

\subsubsection{2 - CATODOLUMINESCÊNCIA}

Algumas substâncias são capazes de emitir radiação luminosa, sendo este fenômeno conhecido como luminescência. Este fato já era conhecido pelos chineses a 1.500 A.C., mas foi o alquimista Vincezo Cascierolo, em 1604 (in Zinkernagel 1978) que fez a primeira descrição do 
fenômeno em cristais, observando a luminescência em barita pulverizada quando aquecida em presença de carvão.

O princípio baseia-se na excitação de elétrons. Caso uma energia seja suficiente para transportar elétrons para um nível de energia maior, estes após alguns segundos (10s), tendem a retornar ao nível original de menor energia, liberando entre outras, radiações luminosas não térmicas, que constituem a catodoluminescência. Em outras palavras, é a emissão da radiação luminosa oriunda dos fenômenos de fluorescência e fosforescência, emitida pelos centros luminogênicos de minerais bombardeados por um feixe de elétrons, cuja aceleração varia de 5 a $30 \mathrm{kV}$.

Uma das principais aplicações deste método, é a obtenção de informações sobre a composição química de certos grupos de minerais (Smith \& Stenstrom 1965). O método tem grande aplicação no estudo de rochas carbonáticas que sofreram intensa recristalização. Nesse caso, os grãos e o cimento tornam-se praticamente indistintos ao microscópio petrográfico comum, mas podem ser distinguidos no luminoscópio. Ainda em se tratando de carbonatos, o método pode mostrar a natureza variada e heterogênea dos mecanismos envolvidos na formação de microestruturas deformadas em cristais de calcita (Dorobek \& Watkinson 1988). De uma maneira geral, a catodoluminescência permite obter informações sobre a proveniência, a evolução diagenética e a geoquímica de rochas sedimentares (Gomes 1990).

$\mathrm{O}$ primeiro pesquisador a descrever o fenômeno da catodoluminescência foi Crookes (1879, in Long \& Agrell 1965). Este pesquisador estudou a luminescência de minerais sob condições de alto vácuo, quando submetidos a descargas elétricas. A observação deste fenômeno com auxílio do microscópio petrográfico coube a Nicchols et al. (1928, in Marshall 1988) e Gallup (1936, in Marshall 1988). Com o uso da microssonda eletrônica, consegue-se determinar os elementos químicos ativadores e restritivos da radiação em certos minerais que apresentam a catodoluminescência (Long \& Agrell 1965).

A luminescência pode ser dividida em dois tipos; a primeira, fosforescente, quando a emissão de luz independe de uma radiação excitante e, a segunda, fluorescente, quando a emissão de luz depende de uma radiação excitante, cuja luminescência cessa logo após o término da exposição. Pelo fato da catodoluminescência cessar logo após o término do bombardeamento de elétrons, parece que o termo mais correto seria catodofluorescência (Long \& Agrell 1965).

As cores emitidas pelos minerais sob o efeito da catodoluminescência dependem não somente das características mineralógicas, mas também da natureza geoquímica dos elementos traços inclusos na rede cristaloquímica, dos parâmetros físicos da solução original $(\mathrm{T}, \mathrm{pH}, \mathrm{Eh})$ ou mesmo de defeitos na rede cristalina do mineral (Onasch \& Davis 1988). De um modo geral, o $\mathrm{Mn}^{2+}$ é um dos elementos mais importantes como ativadores da fluorescência, enquanto os inibidores de cor, são o $\mathrm{Fe}^{2+}$, o $\mathrm{Fe}^{3+}, \mathrm{o} \mathrm{Co}^{2+}$ e o $\mathrm{Ni}^{2+}$, entre outros (Hemming et al. 1989). Segundo Miller (1988), outros fatores de natureza operacional que interferem nas cores ou na 
intensidade do fenômeno são a voltagem e corrente utilizadas, a natureza da superficie da amostra e a temperatura de exposição, entre outros.

Quanto à preparação das lâminas de topázio da região de Ouro Preto ou de suas rochas encaixantes contendo veios mineralizados, estas foram confeccionadas na forma tradicional, ou seja, uma lâmina petrográfica polida de espessura $0,3 \mu \mathrm{m}$, mas sem a cobertura da lamínula. Estas lâminas foram estudadas com o equipamento CITL - COLD CATHODE LUMINESCENCE, $8200 \mathrm{mk} 3$ acoplado a um microscópio petrográfico Zeiss, modelo AXIOPHOTO, ambos em utilização no DEGEO/EM/UFOP. A voltagem utilizada no equipamento da catodoluminescência foi de $25 \mathrm{kV}$, a intensidade da corrente elétrica foi de $250 \mathrm{~mA}$ e a condição de alto vácuo de 0,05 Torr. 


\section{3 - GEOLOGIA DO QUADRILÁTERO FERRÍFERO}

Trata-se de uma das áreas mais investigadas do país, pelo fato de conter mineralizações variadas, entre as quais se destacam ferro, ouro, bauxita, manganês e topázio imperial. Acreditase que qualquer discussão sobre o topázio ficaria prejudicada sem que antes se apresentasse uma revisão dos principais aspectos geológicos do Quadrilátero Ferrífero. Assim sendo, embora essa Dissertação não tenha por objetivo levantar questões fundamentais da geologia regional dos depósitos de topázios, entende-se que a compreensão da geologia do Quadrilátero poderá ser útil para o entendimento das características e da origem dos depósitos de topázio de Ouro Preto.

\section{1 - CONTEXTO GEOTECTÔNICO}

O Quadrilátero Ferrífero foi assim denominado por Gonzaga de Campos (in Dorr II 1959), devido aos vastos depósitos de minério de ferro que ocorrem em um polígono limitado aproximadamente pelas cidades de Itabira, Rio Piracicaba, Mariana, Congonhas do Campo, Casa Branca e Itaúna, correspondendo a uma área de $7.000 \mathrm{~km}^{2}$ entre as latitudes $19^{\circ} 45^{\prime}$ e $20^{\circ} 30^{\prime} \mathrm{S}$ e as longitudes $43^{\circ} 22^{\prime} 30^{\prime \prime}$ e $44^{\circ} 07^{\prime} 30^{\prime \prime} \mathrm{W}$. Essa área é limitada ao norte pelas serras do Curral, da Piedade e do Cipó; ao sul pelas serras de Ouro Branco e Itatiaia; a leste pela serra do Caraça e a oeste pela serra da Moeda (Dorr II 1959).

Do ponto de vista geotectônico, o Quadrilátero Ferrífero está inserido na Província São Francisco (Almeida 1977), situando-se no extremo sul do cráton homônimo, representando o prolongamento fisiográfico da serra do Espinhaço Meridional (Figura 7). É constituído por vários complexos granítico-gnáissicos arqueanos e transamazônicos, que o circundam, além do Complexo do Bação situado no seu interior. Além desses terrenos, ocorrem ainda duas seqüências de rochas supracrustais: os Supergrupos Rio das Velhas, um greenstone belt de idade arqueana e, o Supergrupo Minas, uma seqüência plataformal, cuja idade é atribuída ao proterozóico inferior (Chemale Jr. et al. 1991). 


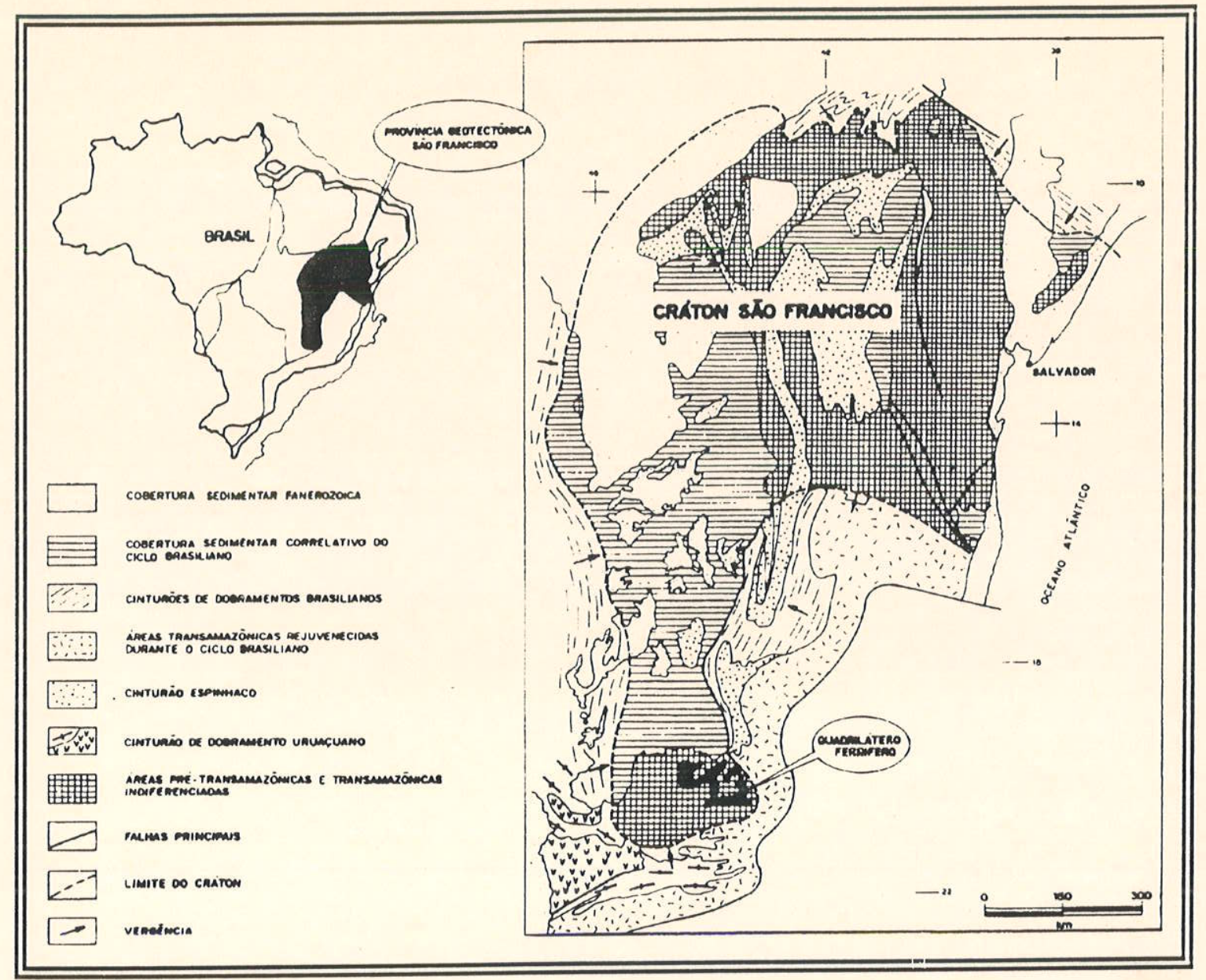

FIGURA 7 - Localização geológica do Quadrilátero Ferrifero no cráton do São Francisco (Segundo Almeida 1977 e 1981, com modificações de Fonseca 1990).

\section{2 - HISTÓRICO DOS ESTUDOS SOBRE O QUADRILÁTERO FERRÍFERO}

A literatura sobre o Quadrilátero Ferrifero é muito vasta, sobretudo no que tange à geologia regional. Os trabalhos pioneiros foram executados por Eschwege (1822, 1832, 1833), Gorceix $(1881,1884)$ e Derby $(1879,1906)$, embora a região já fosse conhecida pelas ocorrências de ouro em Ouro Preto (antiga Vila Rica), desde o século XVIII.

A primeira coluna estratigráfica de cunho regional foi proposta por Harder \& Chamberlin (1915a), e o primeiro mapa geológico da folha de Ouro Preto, na escala de 1:200.000, foi apresentado por Lacourt (1936). Porém, no período entre 1946 e 1962 é que houve o grande avanço no conhecimento geológico do Quadrilátero Ferrifero, com o programa de mapeamento geológico na escala de 1:25.000 de toda a região, que foi então dividida em 47 quadrículas. Tal programa foi executado através do convênio United States Geological Survey (USGS) e o 
Departamento Nacional da Produção Mineral (DNPM), cujos resultados estão sumarizados em Dorr II (1969). Nesse trabalho, o autor apresenta uma coluna estratigráfica que durante muitos anos serviu de base para os estudos pertinentes à região.

Ladeira (1980), propôs alterações na coluna estratigráfica padrão, principalmente no que diz respeito ao Supergrupo Rio das Velhas. Trabalhos mais recentes com ênfase na evolução tectônica são devidos a Ladeira \& Viveiros (1984), Quade (1985), Alkmim et al. (s.d.), Marchak \& Alkmim (1989) e Chemale Jr. et al. (1991). Alkmim et al. (s.d.) compilando dados de diversos autores, propôs uma coluna estratigráfica mais moderna para o Quadrilátero Ferrífero. Este estudo tem como base a faciologia e os sistemas deposicionais dos Grupos Tamanduá, Itacolomi e Supergrupo Minas. Tais sistemas deposicionais são englobados em dois complexos: o primeiro, aluvial associado à uma sedimentação de plataforma, sendo representado pelos Grupos Tamanduá, Itacolomi e pela Formação Moeda do Grupo Caraça e, à uma sedimentação de plataforma carbonática representada pela Formação Batatal e pelo Grupo Itabira. O segundo sistema é dominantemente deltáico com turbiditos, sendo caracterizado pelo Grupo Piracicaba.

\section{3 - ASPECTOS FISIOGRÁFICOS}

Em relação à morfologia, a região do Quadrilátero apresenta contrastes muito bruscos em suas elevações (Rodrigues 1967a, Dorr II 1969), principalmente em certos trechos, onde o tectonismo provocou fortes desnivelamentos. As cotas mais elevadas estão situadas no maciço quartzitico do Caraça $( \pm 2.000 \mathrm{~m})$ e as mais baixas a nordeste de Ouro Preto $(600 \mathrm{~m})$ nas proximidades do rio Piracicaba.

Como províncias topográficas definidas, merecem destaque especial por suas características morfológicas, o maciço do Caraça; a serra de Ouro Branco; a serra da Moeda (Fotografia 3); a serra do Curral e, finalmente o batólito de Itabirito com formas onduladas e colinas arredondadas. Este conjunto de morfologias distintas, com serras íngremes, desfiladeiros profundos, planícies elevadas e vales abertos mantém correspondência com as características litológicas e estruturais da região (Dorr II 1969), havendo sempre um domínio altimétrico por parte dos trechos correspondentes aos terrenos resistentes do Supergrupo Minas que resistiram ao forte trabalho erosivo diferencial.

O Quadrilátero é caracterizado pelos contornos elevados de seus limites externos, tendo na parte central cotas variando entre 800 a 900m. Segundo Penteado (1978), trata-se de um relevo policíclico em que se distinguem duas ou mais superficies de erosão elaboradas por peneplanização.

King (1957) separou o Quadrilátero Ferrifero em duas regiões quanto ao relevo; na parte superior, estão presentes as superfícies cíclicas do Gondvana e na base a Sul-Americana. Barbosa 
(1980) caracterizou os aplainamentos do Quadrilátero Ferrífero em grupos distintos; a) superfícies cimeiras: os níveis mais elevados de até $2.122 \mathrm{~m}$ estão localizados no conjunto quartzítico da serra do Caraça. Tanto a área do Itacolomi (Fotografia 4), quanto Caraça guardam os mais antigos aplainamentos; b) segunda geração de aplainamento: estão representadas pelos restos de relevos dobrados relacionados a última fase orogênica marcada pelo granito de 550Ma, que constituem as cristas sustentadas pelos quartzitos do Grupo Moeda e pelos itabiritos do Grupo Itabira; c) períodos de dissecação: são representados por certos níveis de erosão controlados pelos concrecionamentos ferruginosos ou por litologias especiais. De um modo geral, a dissecação no Quadrilátero Ferrífero é generalizada.

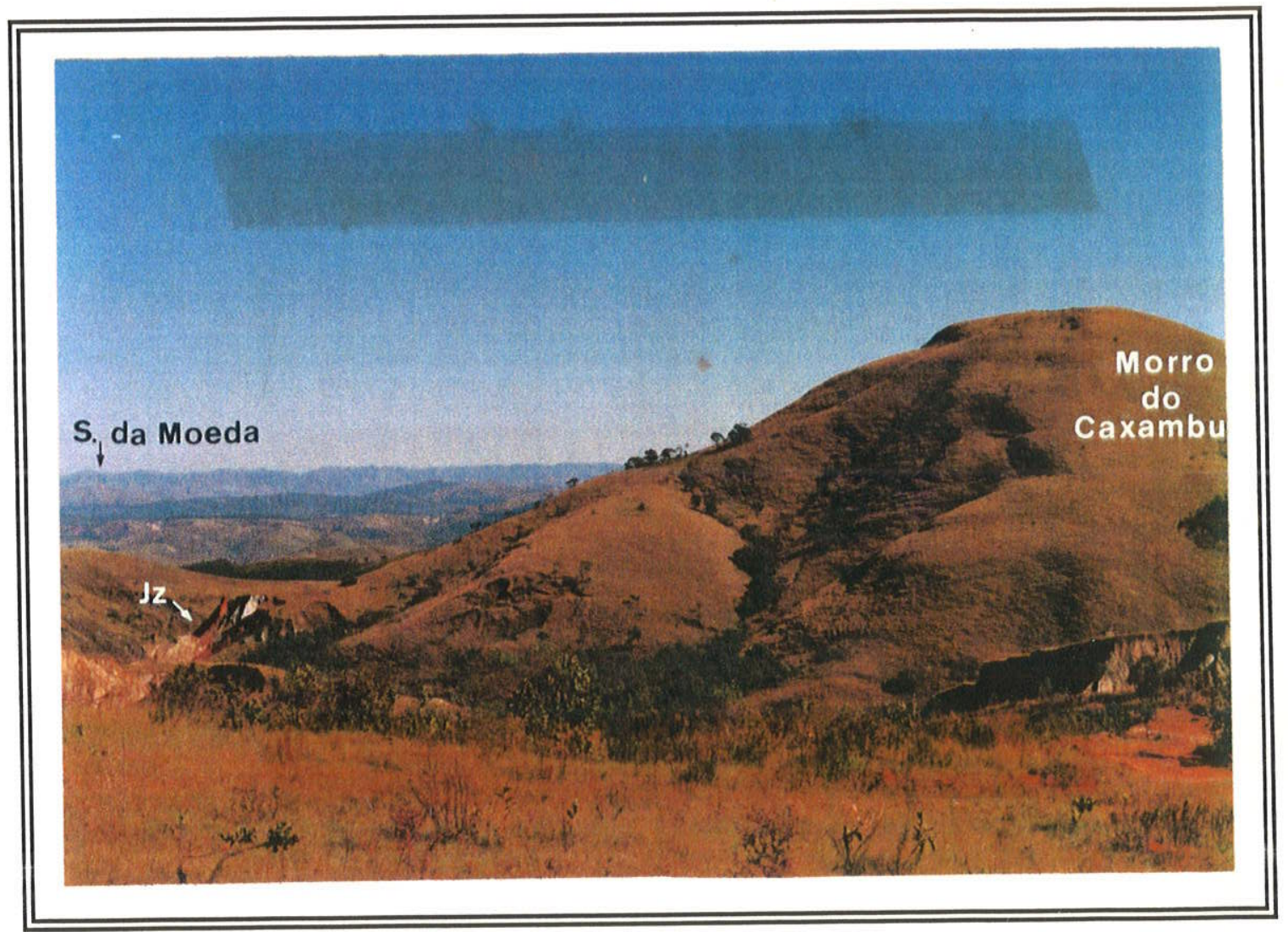

FOTOGRAFIA 3 - No primeiro plano vê-se o Morro do Caxambu com uma jazida (Jz) de topázio imperial e ao fundo, a serra da Moeda.

Quanto ao sistema de drenagem (Dorr II 1969), há um divisor de águas condicionado a certas estruturas, originando as bacias do rio São Francisco e seus afluentes Paraopeba a oeste e rio das Velhas na parte central e, a bacia do rio Doce com seus afluentes Piracicaba, Gualaxo e Ribeirão do Carmo. O rio São Francisco drena a maior parte da região (Barbosa 1980). 
O clima é do tipo tropical chuvoso com inverno seco (Barbosa 1980). As elevações da serra do Espinhaço afetam as oscilações térmicas e pluviométricas a partir do trecho sul deste grande conjunto estrutural, na região do Quadrilátero Ferrifero (Rodrigues 1967b).

Segundo Dorr II (1969), a média anual de temperatura era de $20^{\circ} \mathrm{C}$; entretanto elas são hoje mais altas devido ao desmatamento e à poluição ambiental. Para este mesmo autor, em regime de chuva, seus índices pluviométricos oscilavam entre 1.500 a $2.000 \mathrm{~mm}$. Estas características indicam um clima semitropical. Para Rodrigues (1967b), a maior parte do Quadrilátero está dominado pelo clima tropical de altitude, aliado às condições fitogeográficas e hidrológicas da área.

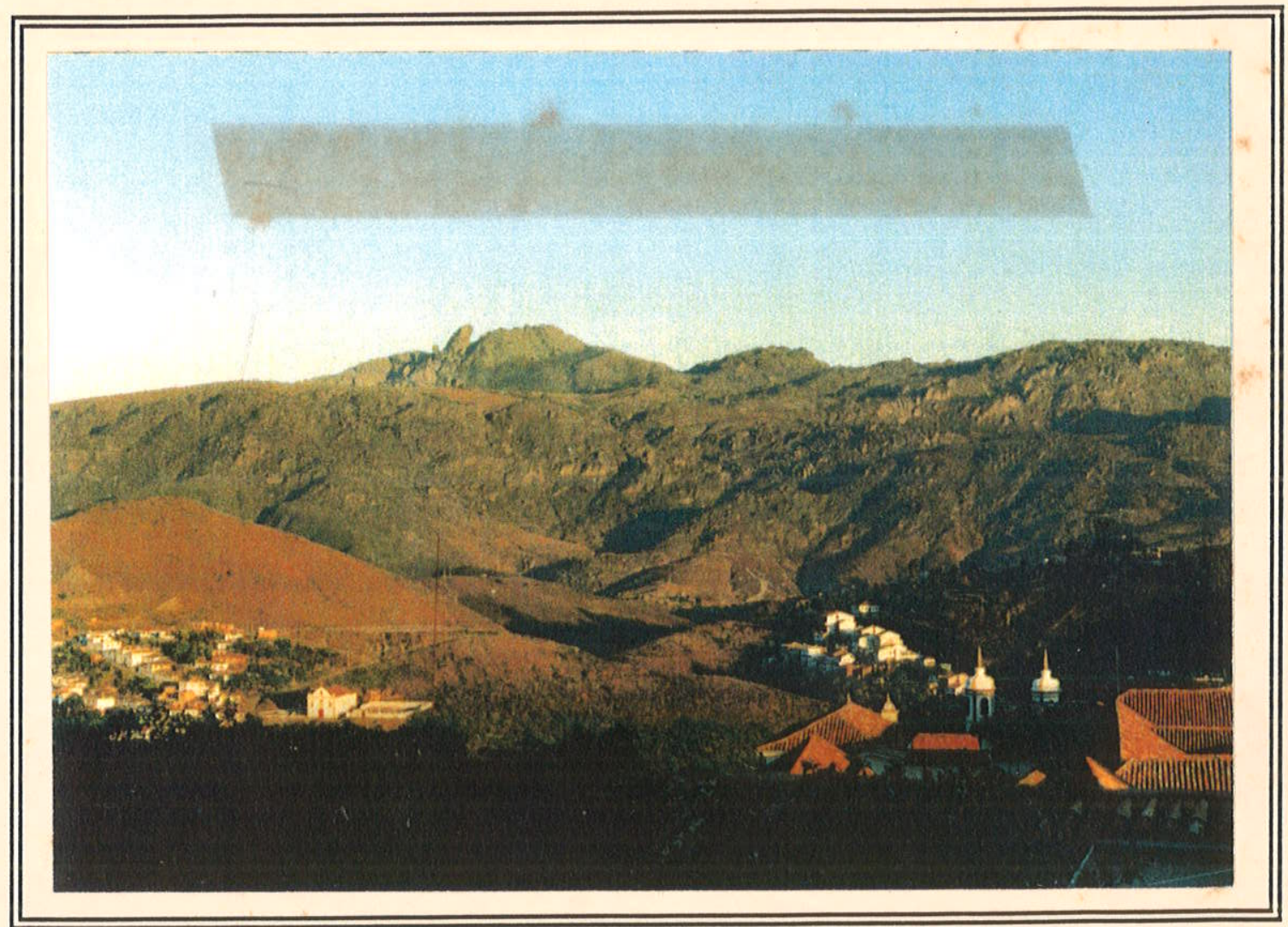

FOTOGRAFIA 4 - Vista parcial da serra do Itacolomi, com o pico homônimo ao fundo, exibindo o conjunto de rochas quartzíticas e mostrando a superfície Gondvânica. definida por King (1957). No primeiro plano, aparece parte da cidade de Ouro Preto.

A vegetação é representada por florestas densas (Barbosa 1980) hoje restritas à pequenas áreas, matas secas, cerrados e campos limpos. Hoje, são muito comuns reflorestamentos de eucaliptos e pinhos para fins diversos. Para Rodrigues (1967b) as florestas são divididas em matas de encostas e de fundo de vales. 


\section{4 - LITOESTRATIGRAFIA}

O Quadrilátero engloba, além dos terrenos gnáissico-migmatíticos associados ao embasamento cristalino, as seqüencias metavulcânicas e metassedimentares mais antigas do cinturão orogênico Rio das Velhas, do tipo greenstone belt, e grande parte do cinturão orogênico Minas representado pelas coberturas sedimentares plataformais (Figura 8). Além destas unidades, ocorrem em pequenas áreas, rochas correlacionadas às bacias sedimentares fanerozóicas.

A Figura 9, ilustra a coluna estratigráfica mais recente do Quadrilátero Ferrífero.

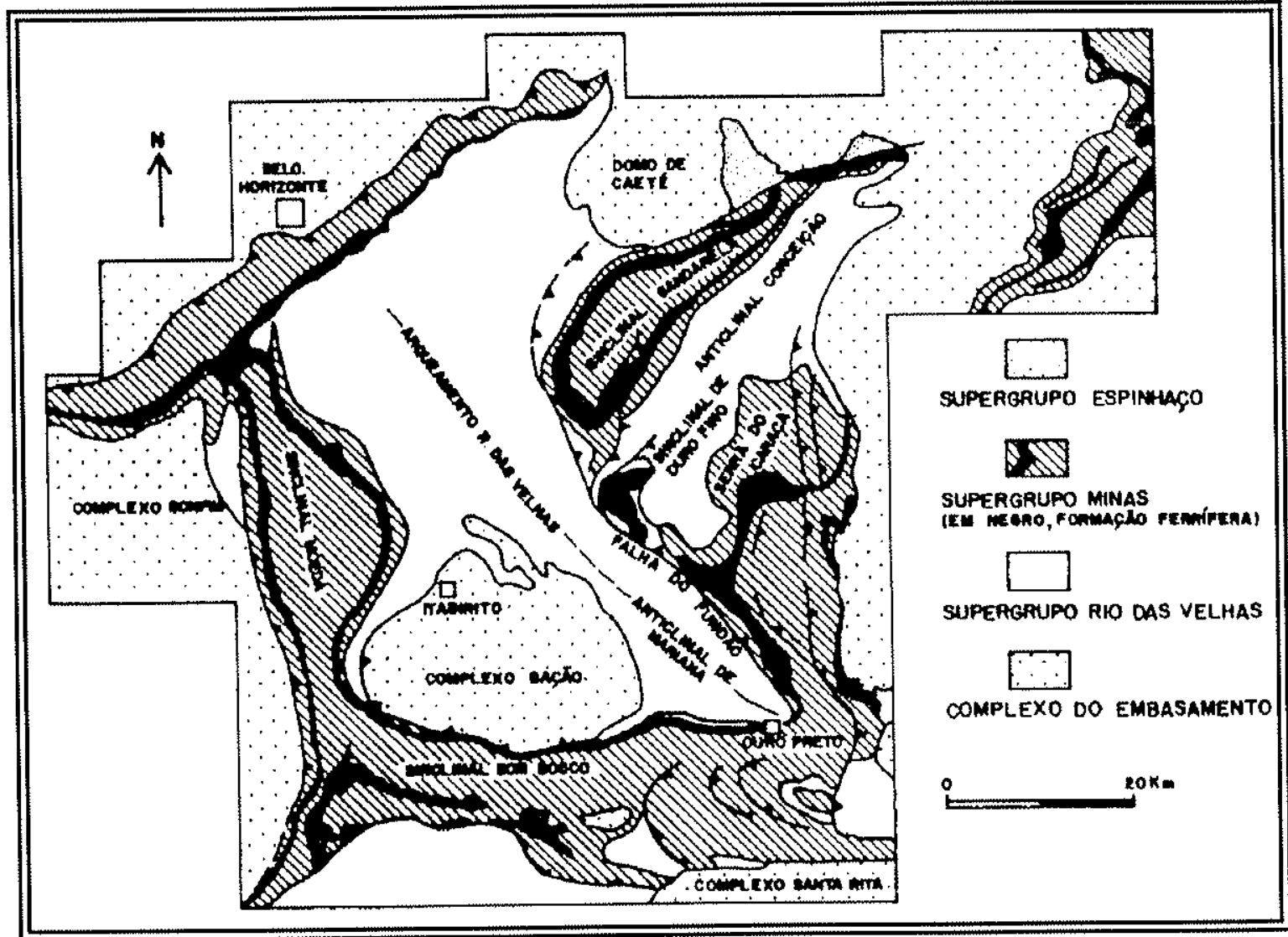

FIGURA 8 - Esboço geológico simplificado do Quadrilátero Ferrifero (Segundo Dorr ll 1969), com modificações de Fonseca 1990).

\subsection{1 - COMPLEXO DO EMBASAMENTO}

As rochas pertencentes ao embasamento ocorrem essencialmente na forma de complexos. Esses são constituídos por gnáisses-migmatíticos de composição tonalítica-throndjeníticagranodiorítica e migmatítica (Herz 1970, Röeser et al. 1982). Os complexos periféricos ao Quadrilátero Ferrífero são denominados de Caeté, ao norte; Santa Rita, a sudeste; Bonfim, a oeste entre outros. O central, é chamado de Complexo do Bação, sendo constituído por gnaisses, migmatitos estromáticos e agmáticos (Endo 1992), seguido das seqüências supracrustais. Este complexo situa-se na parte sul do Quadrilátero apresentando forma dômica (Guimarães et al. 1967). Alem destas rochas, săo encontrados corpos de antibolitos, granitoides e pegmatitos no 
Complexo do Bação (Gomes 1985) e corpos menores de talco xistos, esteatitos e serpentinitos nos demais complexos (Röeser et al. 1980).

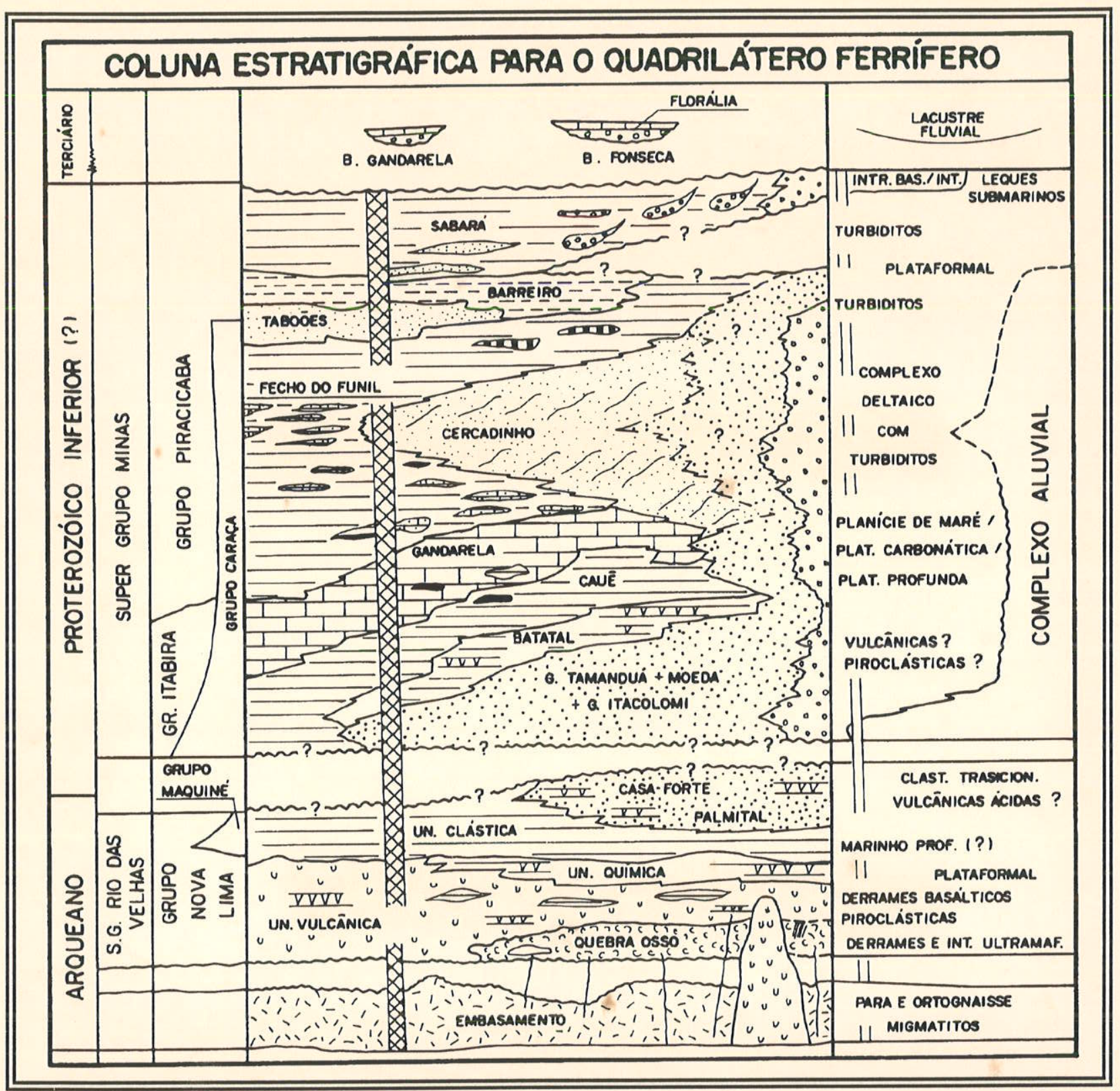

FIGURA 9 - Diagrama esquemático da coluna estratigráfica do Quadrilátero Ferrífero (Extraído de Alkmim et al. s.d.). Para as respectivas litologias ver texto.

Dorr II (1969), interpretou essas rochas como sendo intrusivas e não pertencentes ao embasamento. No entanto, Cordani et al. (1980), Ladeira (1980) entre outros, mostraram que o contato dessas rochas com as supracrustais apresenta uma relação complexa sugerindo a possibilidade da existência de um embasamento para as supracrustais.

Quanto à idade do Complexo do Bação, Gomes (1985) estimou que o processo de migmatização parcial ocorreu a $2,7 \mathrm{Ga}$., com temperaturas da ordem de $700^{\circ} \mathrm{C}$. 


\subsection{2 - SEQÜÊNCIAS VULCANO-SEDIMENTARES DO TIPO GREENSTONE BELT}

Essas seqüências, de idade arqueana, são representadas pelo Supergrupo Rio das Velhas, caracterizado por um cinturão de rochas verdes complexas.

\subsubsection{1 - SUPERGRUPO RIO DAS VELHAS}

A "Série" Rio das Velhas de Dorr II et al. (1957) não possui uma idade segura, pelo fato dos dados geocronológicos relativos aos métodos $\mathrm{K} / \mathrm{Ar}$, U/Pb e $\mathrm{Rb} / \mathrm{Sr}$ terem sido obtidos de minerais isolados. Os dados de Herz \& Dutra (1958) indicaram valores variando entre 500, 740, 1.350 e $2.520 \mathrm{Ma}$; os de Dorr II (1969) 2.800 Ma e os de Barbosa (1966) 2.400 Ma. Um dos últimos trabalhos a respeito, o de Machado \& Carneiro (1992) estimaram uma idade mínima de $2.780^{+3 /-2}$ Ma para este Supergrupo, datado em zircão pelo método U/Pb.

O Supergrupo compõe-se de três Grupos; Quebra Osso (rochas metaultramáficas, vulcânicas-metakomatíticas); Nova Lima (vulcano-sedimentar, máfico) e, Maquiné (clástico). O primeiro Grupo foi proposto por Schorscher (1978) e os demais por Dorr II et al. (1957).

\subsubsection{1 - GRUPO QUEBRA OSSO}

Proposto por Schorscher (1978), esta unidade inferior é representada por dois tipos de rochas; a) efusivas, com estruturas spinifex macro e microscópicas, cuja composição geoquímica é de komatítos peridotíticos e, b) intrusivas ultramáficas.

Para Schorscher \& Brito (1979); Inda et al. (1984) e Schorscher (1992), este grupo é constituído quase que exclusivamente de rochas metaultramáficas extrusivas subaquáticas, de derrames maciços almofadados, de lavas brechadas e spinifex. Ocorrem também vulcanoclásticas grossas a finas em níveis interderrames.

\subsubsection{2 - GRUPO NOVA LIMA}

O Grupo Nova Lima ocorre com maior expressão no Distrito de Nova Lima, onde tem espessura mínima estimada de $4.000 \mathrm{~m}$, ocupando a maior área de afloramento do Supergrupo Rio das Velhas. É constituído predominantemente por rochas vulcânicas e vulcanoclásticas básicas a intermediárias. Os metassedimentos incluem tipos químicos com formações ferríferas e dolomitos, 
além de clásticos com grauvacas, xistos máficos e metapelitos. O ambiente é caracterizado por uma bacia marinha tectonicamente ativa (Schorscher 1992).

A importância econômica deste grupo é a presença de grandes mineralizações de ouro, tais como Nova Lima e Raposos.

O grupo foi subdividido por Ladeira (1980) em três unidades: metavulcânica, metassedimentar química e metassedimentar clástica, respectivamente da base para o topo. A primeira é formada por metabasaltos, metaultramafitos, filitos grafitosos e metacherts. Ela equivale ao Grupo Quebra Osso, de Schorscher (1978). A segunda é composta por formação ferrífera bandada, xistos, carbonatos e filitos. Estas formações ferriferas alcançam, por vezes, mais de $100 \mathrm{~m}$ de espessura, mas de baixo teor econòmico, sendo no entanto, portadoras de depósitos auríferos como a jazida de Raposos. Finalmente, a unidade metassedimentar clástica com quartzitos, quartzo xistos e metaconglomerados.

\subsubsection{3 - GRUPO MAQUINÉ}

Caracterizado por metassedimentos clásticos, este grupo superior, em discordância erosiva localmente e possivelmente angular, constituí-se basicamente de quartzitos sericíticos, quartzo xistos e filitos, com espessura em torno de $1.800 \mathrm{~m}$. Ele é dividido em duas Formações: a basal, Palmital, composta por filitos, filitos quartzosos com intercalação de lentes de quartzitos e metaconglomerado basal subordinado, definida por O'Rourke (1957); e, a de topo, Casa Forte, composta por quartzitos sericíticos e cloríticos, xistos e lentes de metaconglomerados com filitos, proposta por Gair (1962). Esse grupo ocorre preferencialmente em faixas de direção NNW, no sinclinal Vargem do Lima

As rochas são representadas por quartzitos quase puros, que apresentam estratificação cruzada de granulometria grossa a microconglomerática (Schorscher 1992).

\subsection{3 - ROCHAS CUJAS IDADES SÃO ATRIBUÍDAS AO PROTEROZÓICO INFERIOR}

Essas rochas são caracterizadas pelas coberturas sedimentares plataformais. A unidade estratigráfica que as engloba, foi introduzida na literatura geológica por Derby (1906), com o nome de "Série" Minas. Posteriormente, Guimarães (1931) separou deste Supergrupo um espesso pacote predominantemente quartzítico, criando a "Série" Itacolomi, discordante e sobreposta a então "Série" Minas. Mais tarde, Ladeira (1986) propôs a designação de Supergrupo Minas, em lugar de "Série" Minas. 
então "Série" Minas. Mais tarde, Ladeira (1986) propôs a designação de Supergrupo Minas, em lugar de "Série" Minas.

\subsubsection{1 - SUPERGRUPO MINAS}

A importância deste Supergrupo neste trabalho e devida à presença das mineralizações de topázio imperial. As ocorrências deste mineral, na região de Ouro Preto, estão distribuidas no Anticlinal de Mariana em rochas do Grupo Itabira (jazida de Antônio Pereira) e ao longo de uma faixa leste-oeste de aproximadamente $40 \mathrm{~km}$ de extensão, no eixo do sinclinal Dom Bosco, principalmente em rochas do Grupo Piracicaba (demais jazidas e/ou ocorrências) pertencentes ao referido Supergrupo (D'Elboux \& Ferreira 1975, Pires et al. 1983a). Normalmente os cristais de topázio ocorrem em veios de dimensões e espessuras variáveis, constituidos por um solo lateritico avermelhado. profundamente alterado, que cortam as rochas dos dois grupos anteriormente citados.

Este Supergrupo foi dividido em quatro Grupos: Tamanduá, Caraça, Itabira e Piracicaba.

\subsubsection{1 - GRUPO TAMANDUÁ}

O nome Tamanduá advém da serra onde ocorre, entre Cocais e Barão de Cocais. Dois membros da equipe DNPM/USGS, Simmons \& Maxwell (1961), incluíram esse Grupo no topo do Supergrupo Rio das Velhas em discordância angular. Composto de quartzitos variegados, este Grupo foi correlacionado ao Supergrupo Espinhaço por Ladeira \& Viveiros (1984), aflorando além dos limites do Quadrilátero ao norte na cordilheira homònima. Ele é constituido por duas formações sendo uma a Cambotas e outra sem denominação formal (Simmons 1968).

A Formação Cambotas é caracterizada por filitos, xistos e quartzitos. A característica marcante deste quartzito é a presença de estruturas sedimentares preservadas, como marcas ondulares, estratificações cruzadas, etc. Os grãos de quartzo, no entanto, em análises mais minuciosas, mostram evidências de metamorfismo dinâmico. Ela possui posição estratigráfica distinta. não sendo correlacionável às três maiores unidades de quartzitos do Quadrilátero que são os Grupo Maquiné, Formação Moeda e Grupo Itacolomi.

A Formação do topo é constituida por filitos, xistos, quartzitos e uma formação ferrifera. O'Rourke (1957) denominou este pacote de Formação Chacrinha.

A existência deste Grupo é questionada pela falta de expressão regional. Além disso o posicionamento estratigráfico é duvidoso. Segundo Crocco-Rodrigues et al. (1992), as seqüências Minas e Espinhaço não têm a mesma idade: para certos autores, como Freitas et cll. (1992), essas unidades são correlacionáveis entre si. 


\subsubsection{2 - GRUPO CARAÇA}

Este Grupo está em contato discordante com o anterior, sendo composto de sedimentos clásticos de granulação fina a grosseira. Subdivide-se em duas formações, denominadas Moeda (Wallace 1958) e Batatal (Maxwell 1958).

A Formação Moeda tem espessura média de $200 \mathrm{~m}$, podendo atingir até $1.200 \mathrm{~m}$. A variação de espessura brusca é uma de suas características. Observa-se este fato ao longo da serra do Tamanduá, serra do Caraça e na Quadrícula do Bação, onde em alguns quilômetros de extensão a espessura passa de mais de $1.000 \mathrm{~m}$ a menos de $100 \mathrm{~m}$. Este adelgaçamento parece estar relacionado com o aumento, de oeste para leste, da distância em relação à área de proveniência dos sedimentos com a profundidade da bacia (Barbosa 1968). No topo, esta Formação é constituída por quartzitos sericíticos, sendo a proporção de sericita muito variável. Ocorrem também alguns conglomerados uraníferos descritos por Villaça (1981). Para este último autor, esta formação, de uma maneira geral, é constituída por três ciclos deposicionais. Na região central, no sinclinal do Gandarela, ela é constituída de conglomerados e arenitos; na região ocidental da serra da Moeda, ocorrem conglomerados, arenitos e pelitos e, finalmente, na parte meridional do Quadrilátero ela é representada por sedimentos litorâneos.

Capeando a Formação Moeda, em contato de transição, está a Formação Batatal, assim denominada originalmente por Harder e Chamberlin (1915a). Basicamente, esta Formação compõe-se de filitos e xistos, cujas camadas afloram raramente, só aparecendo nos pontos com fortes declives e nos cortes artificiais. Pires (1983) descreve ocorrências de rochas vulcânicas ligadas a esta Formação.

\subsubsection{3 - GRUPO ITABIRA}

É constituído por sedimentos químicos, originados da peneplanização completa da área de abastecimento onde apenas os produtos de decomposição química foram capazes de serem transportados em solução ou no estado coloidal para a bacia de sedimentação. A condição reinante era de uniformidade climática e de grande estabilidade tectônica (Barbosa 1968, 1979). De acordo com Dorr II (1958), o Grupo Itabira divide-se nas Formações Cauê e Gandarela.

A Formação Cauê, basal, concorda com o aleitamento da Formação Batatal e é provavelmente uma superficie isócrona. A rocha típica é o itabirito de composição variada, formação ferrífera tipo Lake Superior. Trata-se de uma rocha bandada, com leitos alternados de quartzo sacaroidal e hematita. O tamanho dos grãos desses componentes varia sistematicamente com o grau de metamorfismo (James 1954). Em algumas zonas, o quartzo é substituído parcial ou totalmente por dolomita, formando itabiritos dolomíticos. Do ponto de vista econômico, essa é 
a mais importante unidade do Quadrilátero Ferrífero acomodando os grandes depósitos de minérios de ferro de Minas Gerais.

Acima da Formação Cauê, com contato de transição e interdigitado, repousa a Formação Gandarela. A sedimentação do tempo Itabira se caracterizou por ser predominantemente ferrífera no início e dolomitica no final, sendo que uma litologia não exclui a outra, constituindo-se as duas Formações litofácies em grande parte sincrônicas. Esta Formação é composta essencialmente de mármores, possuindo considerável significado econômico. Dela são exploradas pedras para construção e ornamentação, além de numerosos depósitos de manganês e de hematita de alto teor. Em certos pontos, constitui solo de excelente qualidade. Na região de Antônio Pereira, ocorre as mineralizações de topázio (D’Elboux \& Ferreira 1978). Pires (1983) identificou a presença de rochas típicas de greenstone belt nessa Formação.

\subsubsection{4 - GRUPO PIRACICABA}

Este Grupo, de acordo com Dorr II (1969), é separado do Grupo Itabira, subjacente, por uma discordância. O contato, quase sempre, é marcado por um conglomerado basal, que contém fragmentos erodidos da Formação Gandarela.

Na parte ocidental do Quadrilátero, o grupo foi dividido em cinco Formações, onde têmse, da base para o topo, Cercadinho, Fecho do Funil, Taboões, Barreiro e Sabará, (Pomerene 1958a, 1958b e 1958c; Simmons 1958; Gair 1958). A única Formação deste grupo com distribuição regional é a Formação Cercadinho (Dorr II 1969); as demais tem ocorrência restrita. A grande maioria das jazidas e/ou ocorrências de topázio imperial estão localizadas nas Formações Cercadinho, Fecho do Funil e Sabará (Olsen 1971, Fleischer 1972, Pires et al. 1983a).

A deposição da Formação Cercadinho ocorreu com progressiva instabilidade dentro do Quadrilátero Ferrifero. A sedimentação típica plataformal foi interrompida por uma regressão. A manifestação mais precoce dessa instalação foi a elevação moderada do bordo ocidental do Quadrilátero Ferrífero e de áreas adjacentes ao cráton do São Francisco. Na parte emersa da bacia, as camadas superiores do Grupo Itabira foram desgastadas pela erosão, mas, depois de um pequeno intervalo, esta região ocidental também voltou a se submergir. Os sedimentos formados graças ao suprimento de detritos relativos pela reelevação do referido cráton, constituem esta Formação e a subseqüente Fecho do Funil (Barbosa 1983). A Formação Cercadinho é constituída de quartzitos, filitos, quase sempre em intercalações rítmicas. Devido a esta característica e, aliado ao fato da sua constância no Quadrilátero Ferrífero, tal unidade é usada como um excelente guia estratigráfico. As demais Formações deste Grupo são caracterizadas por uma seqüência transgressiva (Alkmim et al. s.d.). Segundo Schorscher (1992), esta formação é marcada pelo final de uma sedimentação química, com o reinício da subsidência do antiformal regional e o envolvimento do domínio dos sedimentos químicos. 
O contato entre a Formação Fecho do Funil e a Formação Cercadinho é gradacional, sendo resultante da mudança do caráter da sedimentação, com o aprofundamento maior da bacia. Predominam aqui, os filitos dolomíticos, filitos silicosos, dolomitos silicosos e quartzitos ferruginosos. Devido à fragilidade de suas rochas, esta formação vem sendo rapidamente erodida, sendo observada em poucas exposições naturais.

A Formação Taboões é constituída por um quartzito lenticular, de granulação muito fina. Facilmente erodido, por ser friável, apresenta-se alterado na maioria das exposições.

A Formação Barreiro caracteriza-se por conter um filito preto, grafitoso e, intercalações de um xisto vermelho muito físsil, que geralmente se encontra decomposto, podendo se alternar com filitos sericíticos de cor cinzenta.

Por fim, a Formação Sabará é composta de xistos, filitos e diamictitos. A espessura dessa formação é desconhecida, uma vez que seu limite superior parece estar em contato com um granito intrusivo, ou ter sido erodido. Segundo Dorr II (1969), a espessura é estimada em mais de $1.000 \mathrm{~m}$. O significado geológico e a divisão estratigráfica dessa Formação são ainda pouco conhecidos por falta de estudos pormenorizados. Para Schorscher (1992), esta Formação apresenta mudanças drásticas nas condições sedimentares do Supergrupo Minas, de bacia shelf e plataforma continental relativamente estável, para condições eugeossinclinais com sedimentação tipo flysch, turbiditos e vulcanismo básico.

\subsubsection{5 - GRUPO ITACOLOMI}

De idade possivelmente proterozóica, esta unidade ocorre no topo da coluna estratigráfica do Quadrilátero Ferrífero. Foi descrito originalmente como "quartzito Itacolomi" por Harde \& Chamberlin (1915a), sendo esses os primeiros a individualizar a seqüência de quartzitos, ao sul de Ouro Preto, como unidade estratigráfica distinta e como topo da unidade Minas. Guimarães (1931) propôs o termo "Série" Itacolomi. Segundo Lacourt (1936), apresenta três unidades da base para o topo: a primeira constituída por quartzitos e metaconglomerados; a segunda por filitos e a terceira por quartzitos. Num trabalho mais recente, Glöckner (1981) interpretou a segunda e terceira unidades como sendo pré-Minas.

\subsection{4 - COBERTURAS SEDIMENTARES FANEROZÓICAS}

Estas coberturas são de ocorrência bem restrita, estando representadas por pequenas bacias interiores terciárias.

Segundo Rodrigues (1967c), as formações terciárias mencionadas por Eschwege (1833), e estudadas por Gorceix (1884), permaneceram durante muito tempo como as únicas representantes da deposição cenozóica e localizam-se na fazenda do Gandarela e no município de 
Alvinópolis, sendo ambas conhecidas na literatura por bacia do Gandarela e bacia do Fonseca, respectivamente. A disposição estratigráfica destas unidades exibe uma sucessão de argilas, cobertas por linhitos e ocorrência esparsa de capeamento limonítico.

Outras bacias ocorrem nos trechos correspondentes ao sopé do sinclinal Moeda, como a da Vargem dos Óculos com ocorrência de bauxita, a da Lagoa das Codornas e a da Lagoa do Miguelão. Quanto à idade. Duarte (1958) identificou, em linhitos fósseis, folhas do gênero Oxandra emygdiana na bacia do Fonseca obtendo idade pliocênica. Pomerene (1964) coletou material idêntico na Lagoa do Miguelão em arenitos. Tais dados, levaram Rodrigues (1967c) a correlacionar o ambiente e a idade dos sedimentos do Fonseca e Gandarela com material depositado na Lagoa do Miguelão. No tocante aos depósitos da Vargem dos Óculos e da Lagoa das Codornas, suas datações, como terciárias, resultam de interpretações geomorfológicas, que supõem idade pós-cretácea. Num estudo mais recente, Lima \& Salard-Cheboldaeff (1981), através de pólens, obtiveram idade eocênica para as Bacias do Gandarela e Fonseca.

\section{5 - METAMORFISMO}

Embora a literatura sobre o Quadrilátero Ferrifero seja muito vasta, trabalhos com informações sobre o metamorfismo propriamente dito, são raros. No entanto, pode-se destacar o trabalho de Herz (1978), que trata especificamente deste assunto. O metamorfismo desta região possui um caráter complexo e policíclico. Os dados geocronológicos disponiveis além de pouco numerosos são restritos a rochas do embasamento cristalino. As idades modais são de 2,7Ga; 2,1-2,0Ga e 0,6-0,5Ga (Herz et al. 1961, Herz 1970, Cordani et al. 1980, Röeser et al. 1982, Teixeira 1985), que são interpretadas como registro dos três eventos metamórficos principais da região.

O primeiro, de alto grau, e $2,7 \mathrm{Ga}$, está relacionado ao embasamento cristalino acompanhado de migmatização generalizada (Cordani et al. 1980, Röeser et al. 1982). Para o Complexo do Bação, Guimarães et al. (1967), sugeriram cinco fases de remobilização. Este metamorfismo de alto grau é representado pela fácies anfibolito superior (Gomes 1985). Para Abreu et al. (1986), o evento é de grau médio e de idade arqueana.

O segundo, talvez o principal, de idade 2,0Ga, e dentro do Ciclo Transamazônico, relaciona-se com o diastrofismo Minas, de caráter sindeformacional que afetou as seqüências supracrustais de fácies xisto verde a anfibolito (Cordani et al. 1980, Röeser et al. 1982, Teixeira 1985). Para esta evolução, o metamorfismo progressivo segundo Alkmim et al. (s.d.), atingiu a fácies anfibolito inferior. De acordo com Ladeira et al. (1983), no segundo evento, datado pelo método $\mathrm{Rb} / \mathrm{Sr}$ em moscovita, houve uma transformação da sucessão original do Cinturão de Rochas Verdes Rio das Velhas em vários metamorfitos. 
Durante o Brasiliano, no final do Proterozóico Superior, um evento termo-tectônico afetou o embasamento e todas as seqüencias supracrustais, sendo, provavelmente, o último evento metamórfico do Quadrilátero Ferrífero, de caráter regressivo segundo os autores anteriormente citados. O metamorfismo é de baixo grau, inferido pela paragênese filitos e sericitaquartzo milonitos (Alkmim et al. s.d.). Este último evento está relacionado ao ciclo pós-Minas, que transformou os sedimentos do Supergrupo Minas, de idade proterozóica, em xistos, filitos, quartzitos, itabiritos, mármores e dolomitos (Ladeira et al. 1983).

De um modo geral, pode-se dizer bem resumidamente que o metamorfismo regional do Quadrilátero Ferrífero, acentua-se de oeste para leste e, de nordeste para sudeste, passando da fácies xisto verde para anfibolito ou mesmo granulito (Ladeira 1986).

\section{6 - GEOLOGIA ESTRUTURAL}

A análise do mapa geológico do Quadrilátero Ferrífero mostra duas feições distintas: a primeira é representada por sinformais e antiformais que expõem as seqüências estratigráficas, e a segunda pelo cruzamento de megaestruturas distribuídas em todas direções, resultantes da superimposição de dobramentos e falhamentos (Figura 10).

Segundo Dorr II (1969), essas megaestruturas são representadas por grandes dobramentos pertencentes ao Supergrupo Minas, como os Sinclinais Moeda, Dom Bosco, Santa Rita, Gandarela e Ouro Fino, além do homoclinal da serra do Curral Os grandes falhamentos estão representados pelo sistema do Fundão, do Engenho e o de Água Quente. Finalmente, dentro das grandes estruturas, destaca-se o arqueamento Rio das Velhas, cuja extremidade sudeste é caracterizada pelo Anticlinal de São Bartolomeu-Mariana.

Harder \& Chamberlin (1915a, 1915b) afirmaram que os dobramentos e falhamentos foram responsáveis pela deformação das rochas desta região em tempos e direções distintas, resultando em estruturas superimpostas. Segundo Guimarães (1931), houve uma fase diastrófica anterior à "Série" Itacolomi.

Tratando das séries proterozóicas, Barbosa (1949) reconheceu duas fases de deformação. Primeiramente, dobramento e levantamento do Supergrupo Minas, sendo este intensamente erodido, seguido da deposição do Grupo Itacolomi pelo abaixamento provocado pelos ajustamentos isostáticos. Após a deposição do Grupo Itacolomi, as principais estruturas foram afetadas pelo diastrofismo Itacolomi (Barbosa 1961). Neste evento, há duas etapas: numa primeira produziu-se compressão de $\mathrm{E}$ para $\mathrm{W}$, enquanto numa segunda produziu compressão de $\mathrm{S}$ para N. Segundo este mesmo autor, as supracrustais foram deformadas por "domos graníticos". 


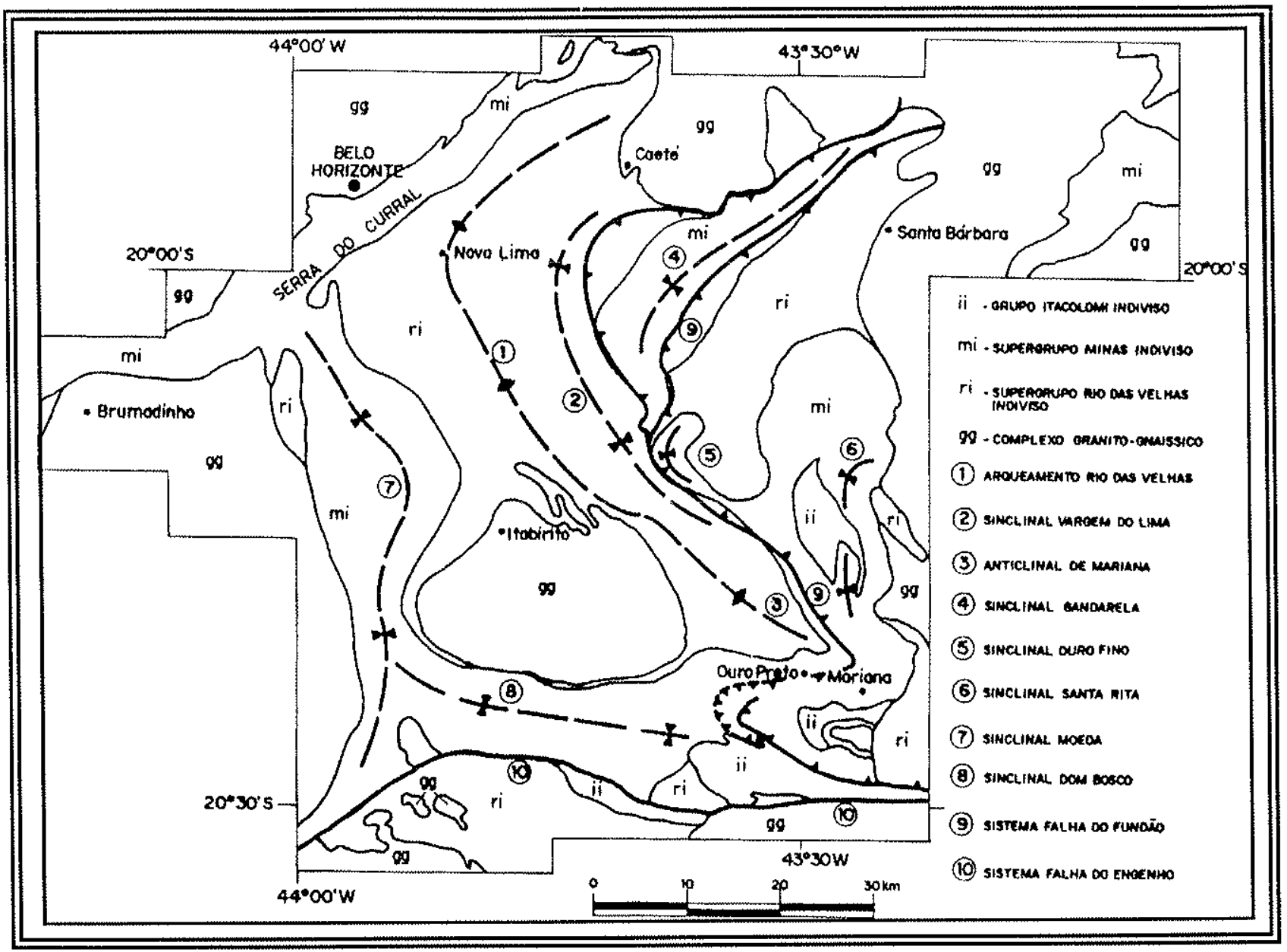

FIGURA 10 - Esboço estrutural mostrando as principais megaestruturas mapeadas no Quadrilátero Ferrifero (Segundo Dorr II 1969, com modificações de Fonseca 1990).

Durante o diastrofismo, o embasamento atuou intensamente; Guimarães et al. (1967) admitem que o Complexo do Bação tenha evoluído a partir de um núcleo ígneo gabro-diorito, sendo polimetamorfizado em cinco fases.

Segundo Dorr II (1969), a região do Quadrilátero sofreu uma evolução polifásica marcada por três eventos de deformação, sendo os dois primeiros de difícil interpretação, enquanto o terceiro é mais característico. Esses três eventos podem ser assim resumidos: a) idade pós-Rio das Velhas e pré-Minas; b) pós-Minas e pré-Itacolomi; c) pós-Itacolomi, afetando todas as sequêencias metassedimentares. Inda et al. (1984) também divide em três eventos geotectônicos o complexo arqueano.

Ladeira \& Viveiros (1984) descreveram seis eventos deformacionais sucessivos que afetaram as seqüências supracrustais. O primeiro seria o pré-Minas; o segundo, pós-Minas; o terceiro e o quarto, coaxiais; o quinto teria gerado estruturas planares orientadas N-S e o último teria produzido fraturamento generalizado.

Quade (1985) correlaciona quatro eventos deformacionais em seu modelo evolutivo: a) compressão de direção NE/SW associado à ascensão de blocos do embasamento, 
principalmente do Complexo do Bação; b) compressão com transporte tectônico de SE para NW falhamentos e fraturamentos devido à ascensão de blocos do embasamento periféricos ao Quadrilátero, no estado sólido; c) dobras e falhas de empurrão com direção N-S, em conseqüência da compressão E-W; d) generalizados em nível crustal superior.

Quanto à história de deformação e o acervo estrutural dos metassedimentos Minas e Itacolomi, estes são apresentados por Alkmim et al. (s.d.) em cinco eventos de deformação $\left(\mathrm{D}_{\mathrm{i}}\right)$. $\mathrm{O}$ primeiro deles, $\mathrm{D}_{1}$, é representado por falhas de empurrão, dobras inversas e zonas de cisalhamento de escalas diferentes e inclinação para NW sob a ação de vetores tectônicos orientados de SE para NW. Neste evento ocorreu um metamorfismo progressivo que atingiu a fácies anfibolito inferior. Essas transformações metamórficas são sintectônicas ou pós-tectônicas. No evento $D_{2}$ houve ascensão de blocos do embasamento, fora e dentro do Quadrilátero, principalmente no Complexo do Bação causando o redobramento das supracrustais. No evento $\mathrm{D}_{3}$ ocorreu compressão E-W gerando estruturas com direção N-S orientadas uniformemente. No $\mathrm{D}_{4}$ houve um "relaxamento", ou seja, um evento extencional posterior a compressão E-W do terceiro evento. Finalmente no $\mathrm{D}_{5}$, houve atividades tectônicas no Cretáceo e início do Terciário evidenciadas pelo menos por duas bacias terciárias no Quadrilátero, além de falhamentos em coberturas de canga e anomalias morfológicas.

Com este conjunto de dados, Alkmim et al. (s.d.), determinaram três domínios estruturais denominados I, II e III. O domínio I é caracterizado por estruturas importantes do primeiro evento deformativo; o II por estruturas do segundo evento de importância regional, ligadas às estruturas do primeiro evento e, o III, associação do $1^{\circ}$ e $2^{\circ}$ eventos com fenômenos de reativação e falhas de terceira geração.

No trabalho de Marshak \& Alkmim (1989), foram propostas apenas quatro fases de deformação ligadas aos eventos tectônicos que afetaram o cráton do São Francisco na porção sul. A fase $D_{1}$ - Transamazônica, de natureza compressional gerando uma cadeia dobrada com falhas de empurrão e zonas de cisalhamentos associadas, inclinadas para NW. A fase $\mathrm{D}_{2}$ - Uruaçuana, de natureza compressional, gerou dobras abertas e falhas reversas de alto ângulo seguidas pela ascensão de corpos do embasamento de direção geral N-S. A terceira fase, denominada $\mathrm{D}_{\mathrm{E}}$, pósUruaçuana, de natureza extensional, produziu falhamento normal e intrusões associadas de diques máficos e, finalmente, uma quarta fase denominada $\mathrm{D}_{3}$, Brasiliana, de natureza compressional com inclinação para W. Além do Quadrilátero Ferrífero, a cordilheira do Espinhaço e a bacia do São Francisco apresentam estas deformações.

Um dos trabalhos mais recente acerca da evolução geológica do Quadrilátero Ferrífero é devido a Chemale Jr. et al. (1991), onde são propostos dois eventos deformacionais: a) caráter extensional do Proterozóico inferior; e b) caráter compressivo do Proterozóico superior. O primeiro evento, em termos gerais, definiu o formato do Quadrilátero Ferrífero pela formação dos megassinclinais interconectados pelos Complexos granito-gnáissicos de Santa Rita, Bonfim, do 
Bação, de Belo Horizonte e Caeté. O segundo está associado ao fechamento do proto-oceano Brasiliano/Africano a leste do Quadrilátero, com a vergência para W caracterizada pela porção intermediária a distal de um cinturão de dobramentos. 


\section{4 - O TOPÁZIO: UMA REVISÃO}

$\mathrm{Na}$ literatura, a etimologia da palavra topázio é um pouco confusa sendo que alguns autores fazem menção a este mineral com os mais variados significados. Segundo Webster (1980), nos primórdios das civilizações, qualquer mineral de cor amarelada era chamado de topázio. Ainda hoje, no comércio de gemas, algumas delas recebem o nome de topázio, erroneamente. Uma dessas confusões ocorre com o citrino natural, ou com o produto do tratamento térmico da ametista, ambos denominados também de topázio.

A origem do nome topázio é fundamentada em duas teorias. Na primeira, o escritor romano Plínio, do século I, sugeriu que o nome provinha da palavra grega topazos ou topazion, cujo significado era procura, relacionado a um nome antigo de uma ilha do Mar Vermelho, pois a ilha era freqüentemente envolvida por neblina. Esta ilha, provavelmente é Zebirget (ou também Saint John, pertencente ao Egito, localizada ao norte do Trópico de Câncer) e nela era encontrado peridoto verde ou verde amarelado chamado de topázio. Pela segunda teoria, o termo topázio teria originado da palavra sânscrita tapas, cujo significado é fogo, e ao qual esta associada a cor amarela (Gonsalves 1949, Eppler 1973, Webster 1980, Deer et al. 1982). Para Perkins (1981), a palavra topázio provém do nome da ilha de Zebirget, cujo significado é peridoto. Para Ferreira (1975), a palavra em grego topazion ou em latim topaziu tem o significado de fogo.

Talvez uma das mais antigas citações sobre o topázio está na Búblia, onde as doze tribos de Israel eram representadas por doze pedras diferentes cravadas no peitoril de Aarão, SumoPontífice dos sacerdotes dos judeus. Uma dessas pedras era o topázio. Para os hebreus era a segunda peça da primeira linha do racional do Sumo-Pontífice e trazia gravado o nome da tribo dos Siméons (Gonsalves 1949, Metais de Minas Gerais S/A 1981). Segundo Perkins (1981), na verdade se tratava de peridoto e não topázio.

Desde os gregos e romanos, grande eram os conhecimentos dos "amuletos mágicos" das gemas como, por exemplo, aquele que carregasse um cristal de topázio, adquiria horror a sangue e à violência. Com isto, sugeria-se presentear com um cristal de topázio todas as pessoas que decidissem sobre guerras. $\mathrm{Na}$ antiguidade, era atribuído ao topázio o favorecimento à concentração mental, calmante para os nervos e continha hemorragias. Já na idade contemporânea admite-se que favoreça a eloqüência e a boa expressão para escrever. Quando levado ao peito, 
protege contra as intrigas e permite o reconhecimento de pessoas de má sombra (Gonsalves 1949, Metais de Minas Gerais S/A 1981, Branco 1984).

Com relação aos signos do zodíaco, Gonsalves (1949) refere-se a outros autores na divergência das informações. Para o referido autor, o topázio esta relacionado à virgem e à balança, enquanto Branco (1984) refere-se aos nascidos sob o signo de sagitário.

\section{1 - MINERALOGIA E GEOLOGIA}

O topázio é um nesossilicato de fórmula $\mathrm{Al}_{2}\left(\mathrm{SiO}_{4}\right)(\mathrm{F}, \mathrm{OH})_{2}$, com solução sólida incompleta entre o flúor e a hidroxila (Webster 1980). A cela unitária é caracterizada pelos parâmetros $a_{0}=4,65 \AA ; b_{0}=8,80 \AA$ e $c_{0}=8,39 \AA$, sendo $Z=4$ (Deer et al. 1982). A Tabela 1 mostra um resumo das principais propriedades fisicas e geológicas do topázio. O grupo espacial e as dimensões do retículo cristalino foram determinados por Leonhardt (1924, in Deer et al. 1982), enquanto que a estrutura foi determinada pela primeira vez por Pauling (1928, in Magalhães 1989) e por Alston \& West (1928, in Magalhães 1989).

A estrutura cristalina, relativamente densa, é uma combinação entre um empacotamento fechado do tipo hexagonal e cúbico dos átomos de oxigênio e de flúor, sendo seus raios iônicos aproximadamente iguais (Rosenberg 1967). Ela é constituída por um arranjo independente de grupos $\mathrm{SiO}_{4}$ tetraédricos, com uma relação $\mathrm{Si}: \mathrm{O}$ de $1: 4$, ligados a alumínios $\left(\mathrm{Al}^{3+}\right)$ intersticiais em sítios octaédricos $\left(\mathrm{AlO}_{4} \mathrm{~F}_{2}\right)$, numa cadeia paralela ao eixo c. Quatro dos seis ânions que rodeiam cada alumínio são oxigênios pertencentes aos grupos $\mathrm{SiO}_{4}$, e os outros dois são flúor e/ou hidroxila que estão presentes em proporções variáveis, o que torna a simetria local do ín alumínio consideravelmente menor que a octaédrica (Figura 11). Esta disposição dos átomos confere ao mineral um hábito prismático observado comumente em cristais bem formados do mineral. A clivagem basal perfeita $\{001\}$ é advinda da quebra das ligações Al-O e Al-F em igual número e nunca pela ligação Si-O (Deer et al. 1982). Nos nesossilicatos não ocorre a substituição de $\mathrm{Al}^{3+}$ por $\mathrm{Si}^{4+}$ (Mauriño 1976). Segundo este último autor, o tamanho dos raios iônicos dos constituíntes do topázio são aproximadamente $\mathrm{O}^{2-} \cong 1,35 \AA, \mathrm{OH}^{-} \cong 1,35 \AA, \mathrm{F}^{-} \cong 1,35 \AA, \mathrm{Si}^{4+} \cong 0,35 \AA$ e o $\mathrm{Al}^{3+} \cong 0,57 \AA$.

Comumente, as dimensões do topázio variam entre milímetros a alguns centímetros, e mesmo alguns decímetros. Em 1966, foi encontrado na Ucrânia um topázio de $82 \mathrm{~cm}$ de altura pesando $117 \mathrm{~kg}$ (Milovsky \& Kononov 1985). Brocardo (1986) cita outro cristal de $250 \mathrm{~kg}$, sem mencionar seu tamanho e cor. Um topázio imperial de $504 \mathrm{~g}$ descrito por Cassedanne (1989) constitui, talvez, o maior cristal encontrado até hoje no distrito de Rodrigo Silva, na região de Ouro Preto. Em Antônio Pereira, também foi achado um exemplar pesando $180 \mathrm{~g}$ com $13 \mathrm{~cm}$ de comprimento, e que se encontra em exposição no Museu de Mineralogia da Escola de Minas. 
Outro de aproximadamente $13 \mathrm{~cm}$ foi encontrado em Saramenha, sendo este biterminado (Cassedanne 1989). Outra citação desse mesmo autor, refere-se a um cristal com mais de $30 \mathrm{~cm}$ de comprimento por $10 \mathrm{~cm}$ de diâmetro achado nas imediações de Ouro Preto.

O topázio altera-se em margarita, fluorita, caulinita, moscovita (sericita, gilbertita, damourita), hidromoscovita e mullita (Deer et al. 1982). Segundo Knecht (1958), os cristais de topázio de Ouro Preto (Morro do Caxambu) apresentam um estágio inicial de alteração, atestado por finíssimas fendas irregulares preenchidas por nacrita $\left[\mathrm{Al}_{2} \mathrm{Si}_{2} \mathrm{O}_{5}(\mathrm{OH})_{4}\right]$. Na parte externa dos cristais, estes não exibem qualquer grau de alteração intempérica.

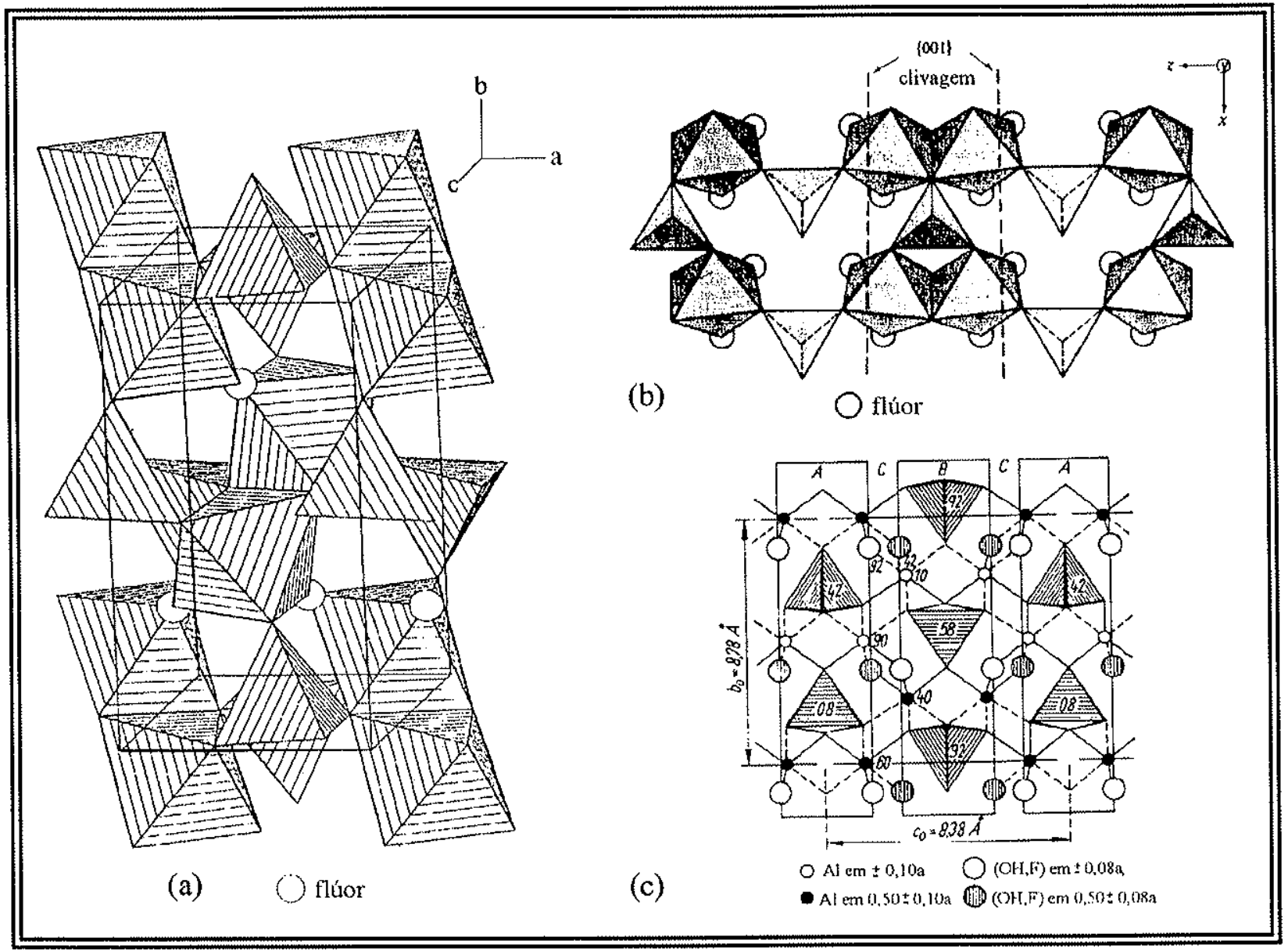

FIGURA 11 - Três projeções da estrutura cristalina do topázio; (a) perspectiva da projeção do eixo c, com b vertical (Extraído de Smyth \& Bish 1988); (b) um destaque nos planos de clivagens (Extraído de Deer et al. 1982). Tanto em (a) como em (b), vêem-se os tetraedros de $\mathrm{SiO}_{2}$ e os octaedros de $\mathrm{AlO}_{4} \mathrm{~F}_{2}$, onde o flúor somente se liga ao alumínio. Em (c), tem-se a projeção no plano $\mathbf{b} / \mathbf{c}$, destacando-se três regiões. A região $A$ e $B$ são representadas pelos tetraedros de $\mathrm{SiO}_{4}$ e o intervalo $C$ pelos octaedros $\mathrm{AlO}_{4} \mathrm{~F}_{2}$ (Extraido de Rösler 1981). 
TABELA 1 - Propriedades fisicas e dados geológicos do topázio.

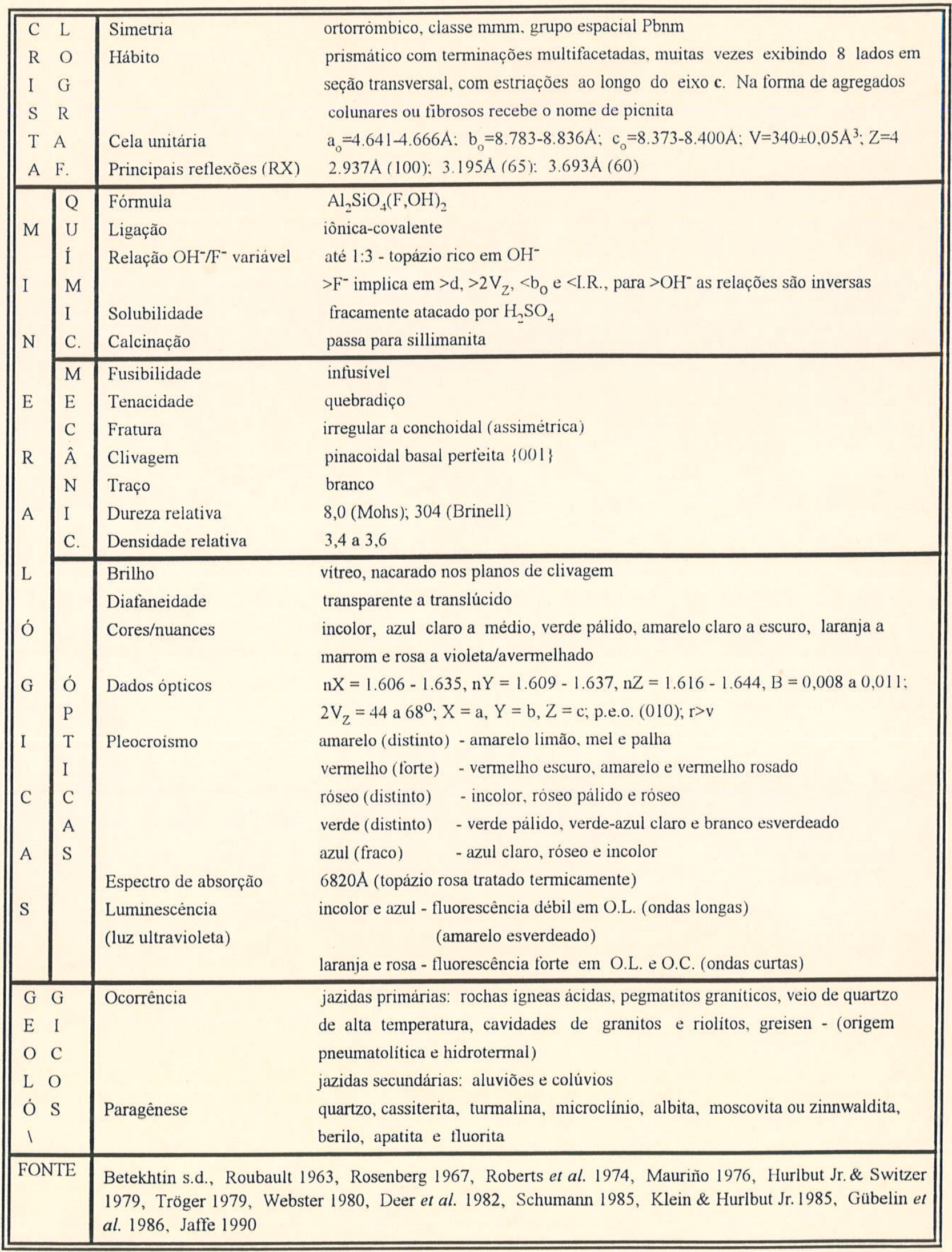


Sob o aspecto geológico, são conhecidas ocorrências em vários tipos de rochas, podendo ser citadas as cavidades de rochas ígneas ácidas, como granitos e riolitos. Sua gênese estaria ligada a ação de gases quentes ricos em flúor que percolam a rocha após a solidificação do magma, como por exemplo, o último estágio de solidificação de lavas riolíticas. Também são encontrados em zonas de metamorfismo de contato e em diques pegmatíticos, particularmente aqueles que contêm estanho. Outro tipo de depósito, são aqueles junto a cascalhos em aluvião onde o topázio aparece como seixo rolado (Lapedes 1977, Webster 1980). Para Petricorena (1989), o topázio, de um modo geral, está ligado a depósitos hidrotermais. Segundo Rosenberg (1967), a gênese do topázio também pode ser interpretada com base na razão $\mathrm{OH}^{-} / \mathrm{F}^{-}$. Para os topázios ricos em flúor [razão $\mathrm{OH}^{-} / \mathrm{F}^{-}$baixa], estes estariam ligados à cavidades riolíticas, enquanto os ricos em hidroxilas [razão $\mathrm{OH}^{-} / \mathrm{F}^{-}$alta], a pegmatitos e a greisens. Segundo Foord et al. (1988), os topázios ricos em hidroxila estariam ligados a veios hidrotermais.

\section{2 - DISTRIBUIÇÃO MUNDIAL}

No Brasil, especificamente em Minas Gerais, ocorre uma das áreas mais importantes da produção de gemas coradas do mundo. Segundo Bastos (1961), "Minas Gerais tem um coração de ouro e gemas num peito de ferro". Em Minas, pode-se encontrar algumas das mais importantes jazidas de esmeralda, água-marinha, morganita, heliodoro, turmalina, crisoberilo, alexandrita, hiddenita, kunzita além de outros minerais-gemas mais raros, tais como fenacita, andaluzita, diopsídio, escapolita, brasilianita, euclásio e topázio imperial entre outros (Bello et al. 1990). Os dois últimos minerais são encontrados na região de Ouro Preto.

A literatura registra várias localidades com ocorrências de topázio, destacando-se entre outros locais: Brasil (nos estados de MG, BA, CE, ES, RO e AM), Paquistão, Estados Unidos, Ilhas Britânicas, Noruega, Suécia, Alemanha, Bósnia (ex-Iuguslávia), Madagascar, Austrália (Tasmânia), Sri Lanka, Índia, Burma, México, Japão, Egito, Nigéria, Zimbabue, Namíbia, Rodésia e Comunidade dos Estados Independentes (ex-URSS) (Gonsalves 1949, Sinkankas 1966, Suszczynski 1975, Jahns 1975, Webster 1980, Perkins 1981, Alecrim 1982, Schumann 1985, Petricorena 1989). No Brasil, o topázio é abundante em vários locais, encontrando-se normalmente, relacionados à pegmatitos. A área de maior ocorrência é a Província Pegmatítica Oriental, que inclui porções dos estados de Minas Gerais, Espirito Santo e Bahia, onde os cristais se caracterizam pela cor pardo-amarelado. Os de cores amarelo a alaranjado, designados de topázio imperial, ocorrem exclusivamente em Ouro Preto, fora da área pegmatítica tradicional (Suszczynski 1975).

As várias ocorrências e/ou jazidas de topázio imperial da região de Ouro Preto, quase todas a sudoeste desta cidade, são conhecidas na literatura desde o início do século passado 
(Mawe 1812). Apesar do caráter único desses depósitos, do potencial considerável verificado no decorrer desses anos, e da alta qualidade gemológica desse mineral-gema, os trabalhos focalizando a gênese são relativamente escassos. e os poucos existentes, são controvertidos (Olsen 1971; Pires 1983; Ferreira 1983, 1987, 1990; Cassedanne 1989).

Os cristais de topázio imperial da região de Ouro Preto são encontrados em rochas carbonáticas já totalmente decompostas (Ferreira 1991). Essa variedade é encontrada também em veios que cortam mármores não alterados e, em uma pequena ocorrência nas colinas de Ghundao, no vale de Katlang, no Paquistão. Nesse pais. o contexto geológico é semelhante às ocorrências do Quadrilátero Ferrifero. Na Sibéria Oriental, nas montanhas de Adun-Tschilon, no distrito de Nerchinsk (Transbaikalia), e no distrito de Sanarka (Chkalov), todos na ex-URSS, as reservas estão praticamente exauridas (Sinkankas 1966, Hurlbut Jr. 1971, Webster 1980, Sauer 1982, Spengler 1985, Gübelin et al. 1986, Petricorena 1989). Röeser et al. (1989) cita uma ocorrência de topázio amarelo similar ao de Ouro Preto, na serra das Éguas, em Brumado, na Bahia.

\section{3 - ASPECTOS ECONÔMICOS}

$\mathrm{Na}$ indústria, o topázio é empregado como abrasivo, devido à sua elevada dureza (8 na escala de Mohs), principalmente em lixas para madeiras. Apesar de não ser a fonte principal, o topázio pode também ser uma fonte de flúor. Quando aquecido em temperatura elevada, perde o flúor na forma de $\mathrm{SiF}_{4}$, transformando-se em sillimanita, que é usada na fabricação de materiais refratários (Leprevost 1978). É utilizado também em trabalhos de artesanatos como quadro de cascalhos, colares de pedaços polidos e, finalmente, como gema, sendo este último emprego o de maior expressão econômica. Dentre todos os tipos de topázio, o imperial, nas suas diversas cores que variam do amarelo ao rosa-pêssego com matiz avermelhado, é o mais valorizado.

A exemplo de outras gemas, o topázio também é reproduzido sinteticamente, mas este só tem interesse científico, não havendo uma produção comercial (Petricorena 1989). Segundo Deer et al. (1982), basicamente há dois tipos de síntese. A primeira é caracterizada por uma hidrólise termal de $\mathrm{AlF}_{3}$ e $\mathrm{SiO}_{2}$, em temperaturas de 750 a $850^{\circ} \mathrm{C}$, e a segunda, pelo aquecimento da mistura $\left[\mathrm{Na}_{2} \mathrm{SiF}_{6}+\mathrm{Al}_{2} \mathrm{O}_{3}\right.$ (amorfa) $\left.+\mathrm{H}_{2} \mathrm{O}\right]$, a $500^{\circ} \mathrm{C}$ e 4.000 bar durante nove dias. Rosenberg (1972) descreve condições de síntese diferentes em condições hidrotermais, para um sistema quaternário $\left[\mathrm{AlF}_{3}+\mathrm{Al}_{2} \mathrm{O}_{3}+\mathrm{SiO}_{2}+\mathrm{H}_{2} \mathrm{O}\right]$, com temperaturas entre 350 e $950^{\circ} \mathrm{C}$ e pressões de 2.000bar. O que se encontra freqüentemente no comércio, são seus substitutos naturais e suas imitações confeccionadas com outros materiais. Talvez o maior problema no comércio é que muitas outras gemas, normalmente de cores amareladas, são vendidas como topázio imperial sob nomes falsos. O termo topázio vem sendo empregado para designar, erroneamente, produtos amarelos de natureza as mais variadas possíveis. Branco (1984) cita mais de quarenta exemplos 
de substitutos e imitações deste mineral. sendo a mais comum, o emprego do termo para designar quartzo amarelo proveniente do aquecimento de ametista. que nesse caso particular recebe o nome de topázio Rio Grande. Há ainda os casos do topázio Bahia, que nada mais é do que quartzo natural amarelo (citrino), do topázio Madeira que corresponde a quartzo morion (variedade de quartzo enfumaçado), e do topázio oriental que corresponde a safira amarela, natural ou sintética. O termo é aplicado também para vidros e plásticos amarelos, e até para espinélios e coríndons sintéticos amarelos. Esta última imitação é possivel devido a gama muito grande de cores e tons desse mineral. Um teste muito simples é o da densidade; enquanto o coríndon sintético flutua em iodeto de metileno $\left(\mathrm{CH}_{2} \mathrm{I}_{2}, \mathrm{~d}=3,32\right)$, o topázio afunda ( $\mathrm{d}$ entre 3,4 e 3,6) (Webster 1980). Outros minerais que substituem o topázio são: turmalina, berilo, crisoberilo, zircão, andradita, apatita, brasilianita, escapolita e espodumênio, entre outros (Metais de Minas Gerais S/A 1981, Branco 1984, Schumann 1985). Outra confusão é com a topazolita, que é uma variedade de cor amarelada da andradita (granada). 80\% das gemas amarelas comercializadas como topázio correspondem a citrino, natural ou tratado (Branco 1984).

Levando-se em conta que este mineral possui um hábito prismático alongado, as formas de lapidação mais adequadas são: oval, em lágrima (ou pendeloque), navete (ou marquesa), retangular e esmeralda (Figura 12), as quais propiciam o máximo de brilho e cor à gema (Webster 1980, Metais de Minas Gerais S/A 1981). No caso do topázio azul ou incolor, a forma mais usual é a brilhante (Figura 12) (Hurlbut Jr. \& Switzer 1979). O brilho excepcional é conseguido devido a elevada dureza que permite um polimento de altíssima qualidade. Segundo Bastos (1961), raramente se acha um topázio imperial com mais de 10 quilates $(2 \mathrm{~g})$ e desprovido de jaça. Quando o cristal apresenta-se jaçado ou fissurado, seu valor cai enormemente e por isso, costuma-se fazer cabochões (Figura 12) ou peças polidas; quando não, utiliza-se o próprio cristal como pingente preso por um aro de ouro.

Para se lapidar um topázio, o grande cuidado a ser tomado é com relação à clivagem, pois qualquer esforço maior pode partir a pedra ao longo do plano (001) (Figura 12). A clivagem afeta também o polimento da pedra. Para se obter um acabamento perfeito, não se deve colocar a mesa da pedra paralela ao plano de clivagem, mas sim, com uma inclinação de pelo menos 10 a $15^{\circ}$ (Gemological Institute of America 1980, Fischer 1986). Devido a presença da clivagem basal excelente, não se conseguirá dar o polimento adequado (Figura 12). O ângulo ideal entre a cintura e as facetas da coroa deve ser de $43^{\circ}$, e entre a cintura e o pavilhão $39^{\circ}$ (Figura 12), permitindo assim uma melhor reflexão da luz no interior da gema (Gemological Institute of America 1980). 


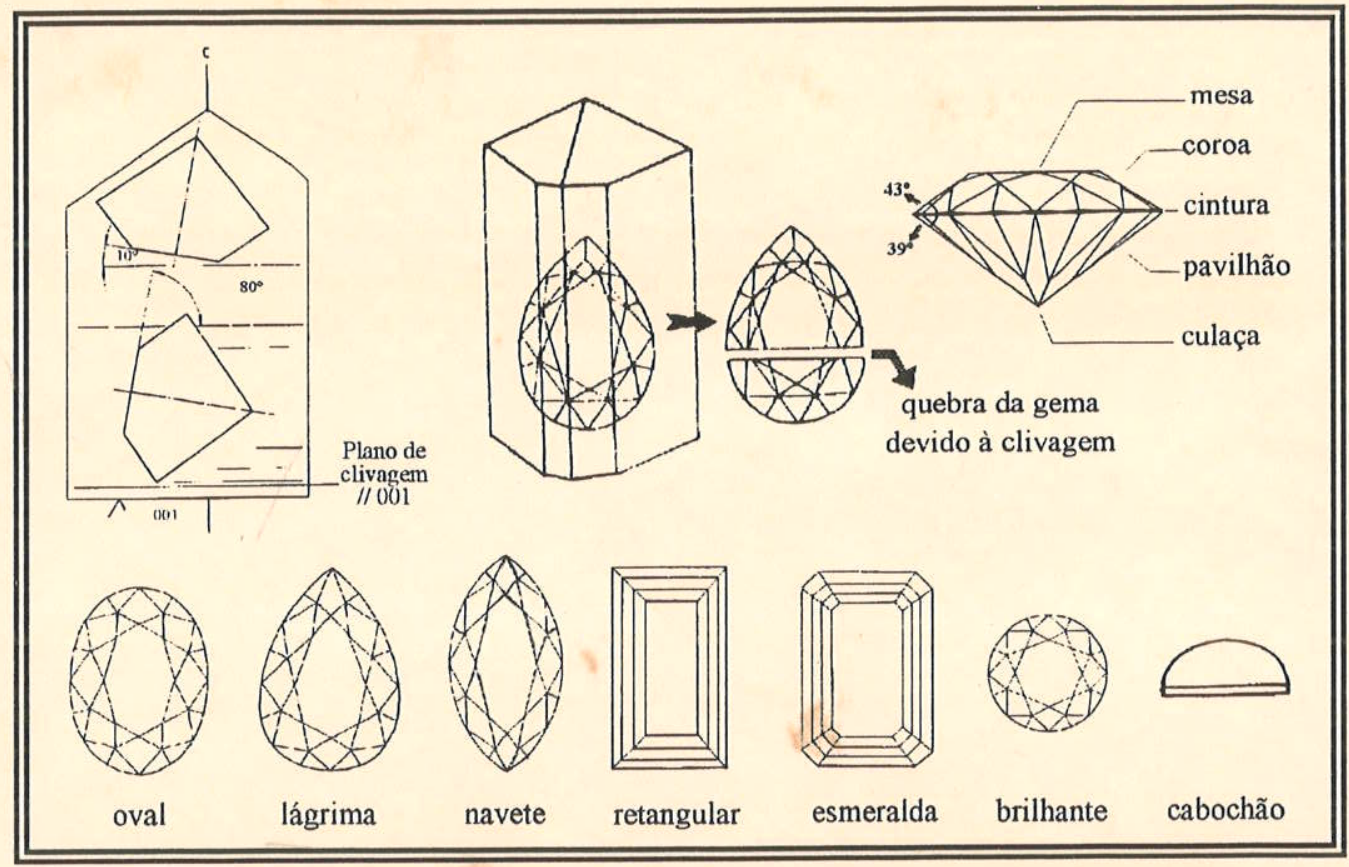

FIGURA 12 - Esquema ideal para a lapidação de um topázio e os vários tipos de lapidações utilizadas para esse mineral-gema (Extraído de Fischer 1986, Webster 1980, Cipriani 1986 e de Branco 1984).

Segundo informações verbais (23.08.91) do engenheiro responsável pela Mina do Capão do Lana (Fotografia 5), retira-se cerca de $400 \mathrm{~m}^{3}$ de material alterado a cada dia de trabalho, com duas drag lines funcionando (Fotografia 6). De cada $100 \mathrm{~m}^{3}$ desse material argiloso, tem-se $1 \mathrm{~m}^{3}$ de rocha inalterada e minerais livres, de onde são extraídos $1 \mathrm{~kg}$ de topázio. De todo este topázio beneficiado, somente cerca de $1 \%(10 \mathrm{~g})$ constitui-se em mineral-gema. Também, de acordo com Keller (1983), de cada tonelada de material extraído na região de Ouro Preto, tem-se $10 \mathrm{~g}$ de topázio gemológico. Portanto, o topázio imperial é uma gema rara, também na região de Ouro Preto.

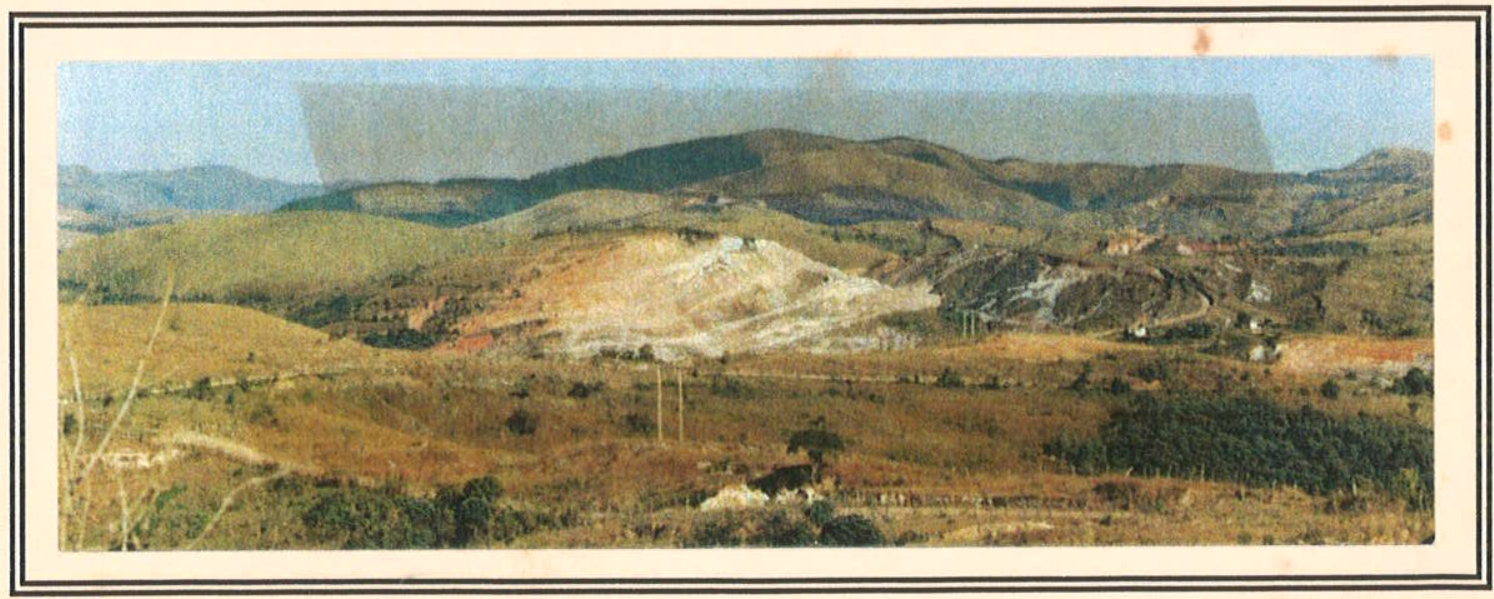

FOTOGRAFIA 5 - Vista panorâmica da mina do Capão do Lana, destacando o relevo suave da região. 


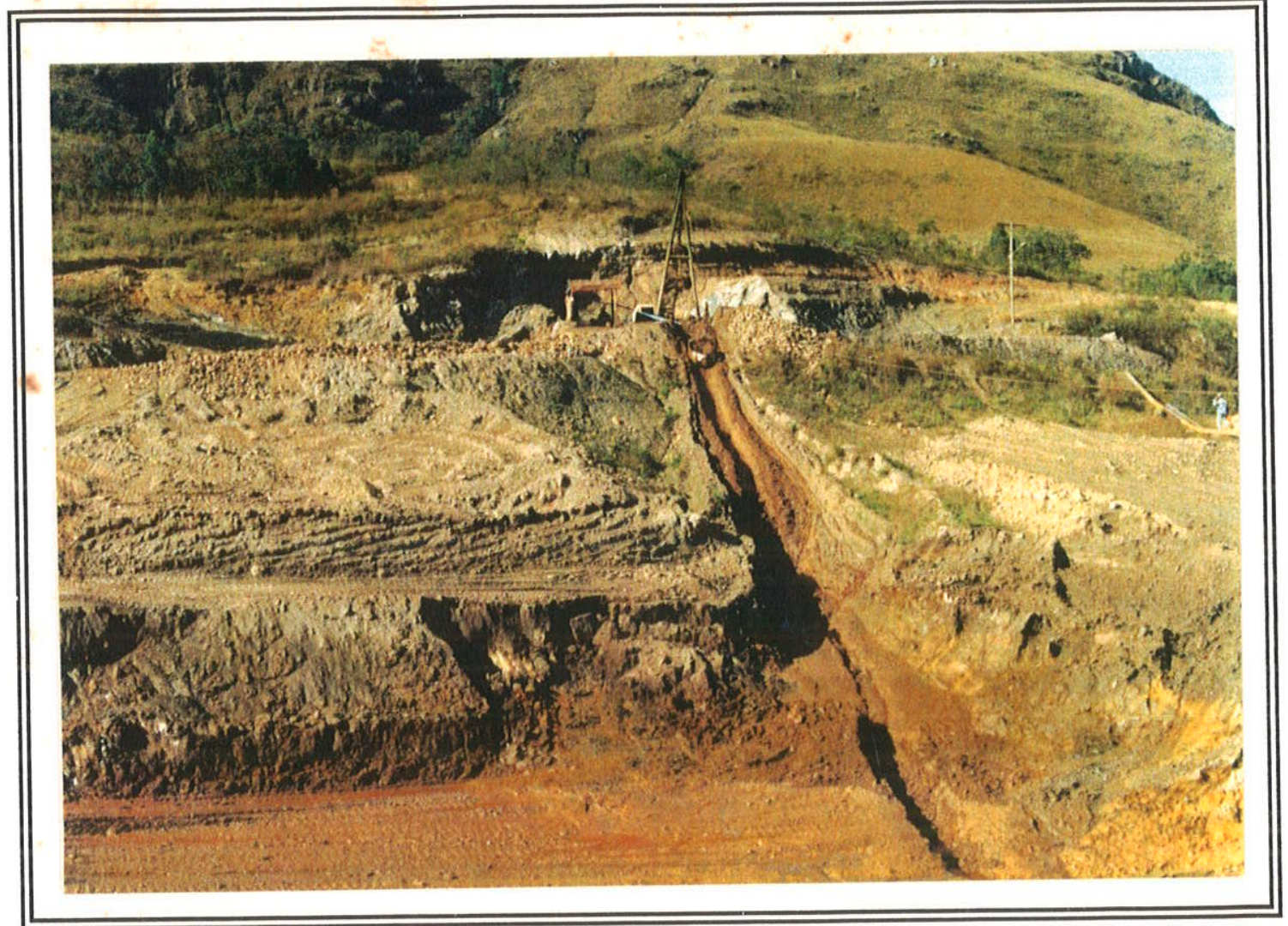

FOTOGRAFIA 6 - Uma vista perpendicular do veio mineralizado, vendo-se a caçamba retirando o material mineralizado em topázio imperial, na jazida do Capão do Lana.

A produção de topázios róseos gemológicos do Paquistão, no ano de 1984, foi de $72.076 \mathrm{ct}$, apresentando uma queda significativa nos anos de 1985 (20.000ct) e de 1986 (30.000ct) (Gübelin et al. 1986).

De um modo geral, a exportação é feita de acordo com a conveniência do mercado internacional, que manipula estoques e tendências da moda, impondo condições e preços. A Tabela 2, referente a preços de topázios e algumas variedades de quartzos lapidados, apesar de ser do primeiro trimestre de 1993, mantêm as mesmas proporções de valores, ao longo dos últimos anos. No caso das pedras brutas, um quilo de topázio imperial jaçado custa cerca de US\$ 30.00; já nos cristais límpidos sem jaças, os preços variam muito. O mercado internacional tende a comprar sempre as pedras brutas, acarretando uma defasagem na balança econômica brasileira. De um modo geral, o valor das pedras lapidadas é várias vezes maior que a pedra bruta.

A grande totalidade da produção brasileira de gemas resulta da garimpagem, inclusive aquela da região Ouro Preto. Sendo o Brasil, uma das maiores províncias gemológicas do mundo, poder-se ia aumentar consideravelmente esta produção, através de métodos de extração mais eficazes (mecanizados), o que implicaria num acréscimo de receitas. 
TABELA 2 - Tabela de preços de exportaçâo de algumas variedades de quartzos e de topázios azul, incolor e imperial.

\begin{tabular}{|c|c|c|c|c|c|c|}
\hline \multirow{2}{*}{ gema } & \multirow{2}{*}{$\begin{array}{c}\text { peso em } \\
\text { quilate (ct) }\end{array}$} & \multicolumn{5}{|c|}{ valores em USS /ct de acordg com a } \\
\hline & & extra & forte & média & fraca & clara \\
\hline citrino $^{1}$ & 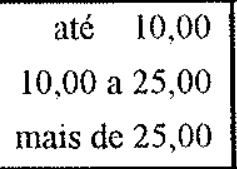 & $\begin{array}{l}1.50 \\
2.00 \\
3.00\end{array}$ & $\begin{array}{l}1.00 \\
1.00 \\
1.50\end{array}$ & $\begin{array}{l}0.50 \\
0.50 \\
1.00\end{array}$ & $\begin{array}{l}0.30 \\
0.30 \\
0.50\end{array}$ & $\begin{array}{l}0.20 \\
0.20 \\
0.20\end{array}$ \\
\hline $\begin{array}{l}\text { citrino } \\
\text { "Rio } \\
\text { Grande" }\end{array}$ & $\begin{array}{c}\text { até } \quad 3,00 \\
3,00 \text { a } 5,00 \\
5,00 \text { a } 10,00 \\
10,00 \text { a } 25,00 \\
\text { mais de } 25,00\end{array}$ & $\begin{array}{r}1.50 \\
6.00 \\
8.00 \\
13.00 \\
15.00\end{array}$ & $\begin{array}{l}1.00 \\
1.50 \\
3.00 \\
4.00 \\
5.00\end{array}$ & $\begin{array}{l}0.30 \\
0.50 \\
1.00 \\
1.50 \\
2.00\end{array}$ & $\begin{array}{l}0.30 \\
0.30 \\
0.80 \\
0.80 \\
2.00\end{array}$ & $\begin{array}{l}0.30 \\
0.30 \\
0.30 \\
0.30 \\
0.50\end{array}$ \\
\hline $\mathrm{T}$ incolor & até $\quad 10,00$ & 0.40 & - & - & - & - \\
\hline T azul & até 25,00 & 15.00 & 8.00 & 5.00 & 1.50 & 0.60 \\
\hline $\begin{array}{l}\text { Topázio } \\
\text { imperial } \\
\text { amarelo }\end{array}$ & $\begin{array}{r}\text { até } \quad 10,00 \\
10,00 \text { a } 15,00 \\
15,00 \text { a } 25,00\end{array}$ & $\begin{array}{l}35.00 \\
45.00 \\
60.00\end{array}$ & $\begin{array}{l}20.00 \\
25.00 \\
35.00\end{array}$ & $\begin{array}{l}10.00 \\
15.00 \\
20.00\end{array}$ & $\begin{array}{r}2.00 \\
5.00 \\
10.00\end{array}$ & $\begin{array}{l}- \\
-\end{array}$ \\
\hline $\begin{array}{l}\text { Topázio } \\
\text { imperial } \\
\text { pêssego }\end{array}$ & $\begin{array}{rr}\text { até } & 3,00 \\
3,00 \text { a } 5,00 \\
5,00 \text { a } 10,00 \\
10,00 \text { a } 15,00 \\
15,00 \text { a } 20,00\end{array}$ & $\begin{array}{l}150.00 \\
200.00 \\
250.00 \\
300.00 \\
350.00\end{array}$ & $\begin{array}{r}- \\
80.00 \\
100.00 \\
120.00 \\
130.00\end{array}$ & $\begin{array}{r}- \\
- \\
50.00 \\
55.00 \\
60.00\end{array}$ & $\begin{array}{l}- \\
- \\
- \\
- \\
-\end{array}$ & $\begin{array}{l}- \\
- \\
- \\
-\end{array}$ \\
\hline $\begin{array}{c}\text { T imp róseo } \\
\text { avermelhado } \\
\text { ou } \\
\text { lilás }\end{array}$ & $\begin{array}{rr}\text { até } & 5,00 \\
5,00 \text { a } 10,00 \\
10,00 \text { a } 15,00 \\
15,00 \text { a } 20,00\end{array}$ & $\begin{array}{r}400.00 \\
600.00 \\
1,000.00 \\
1,200.00\end{array}$ & $\begin{array}{c}150.00 \\
200.00 \\
300.00 \\
-\end{array}$ & $\begin{array}{r}60.00 \\
80.00 \\
100.00 \\
-\end{array}$ & $\begin{array}{l}- \\
- \\
- \\
-\end{array}$ & $\begin{array}{l}- \\
- \\
-\end{array}$ \\
\hline \multicolumn{7}{|c|}{$\begin{array}{l}\text { lct }=0,2 \mathrm{~g}=100 \text { pontos } \\
\mathrm{T}=\text { topázio } \\
\text { citrino }{ }^{1}=\text { variedade do quartzo de cor amarelada } \\
\text { citrino }{ }^{2}=\text { ametista (var. do quartzo de cor roxa) tratada termicamente }\end{array}$} \\
\hline $\begin{array}{l}\text { Extraído do } \\
\text { Mineral - } 1\end{array}$ & $\begin{array}{l}\text { letim de Preç } \\
\text { rimestre de } 19\end{array}$ & 3 do Dep & mento & acional & de Pro & \\
\hline
\end{tabular}

A Figura 13 mostra a flutuação de preços de topázio lapidado, no período de 1973 a 1980. Nesta figura, pode ser visto que o preço do topázio imperial apresentou um aumento considerável neste período. 


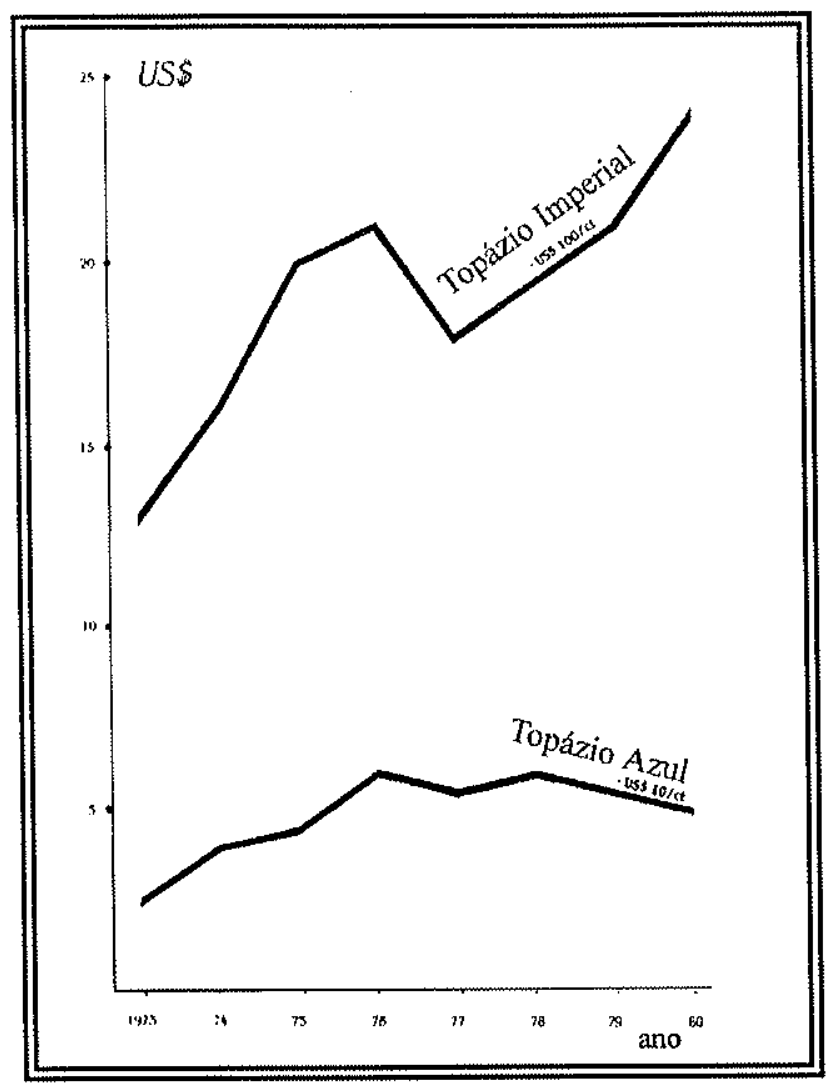

FIGURA 13 - Variação de preço de topázio lapidado de cores distintas no intervalo de 1973 a 1980 . Observa-se que o preço do topázio azul permaneceu praticamente estável, enquanto o do topázio imperial apresentou um aumento considerável (Extraído de Metais de Minas Gerais S/A 1981). 


\section{5 - O TOPÁZIO IMPERIAL DA REGIÃO DE OURO PRETO}

O estado Minas Gerais é um dos mais importantes produtores de gemas do Brasil, sendo o responsável por mais de $70 \%$ da produção nacional (Alecrim 1982). Nesse contexto, Ouro Preto se destaca pelas suas jazidas e ocorrências de topázio imperial, cuja qualidade é uma das melhores do mundo. Esse mineral-gema foi descoberto por volta de 1772, no Morro de Saramenha, atualmente um bairro de Ouro Preto. Essa descoberta, foi responsável pela queda do imposto cobrado sobre o ouro, designado de "quinto" e representava vinte por cento sobre o metal garimpado, que neste período já estava quase exaurido nos aluviões, e sua extração a partir da rocha primária era consideravelmente difícil. Naquela época, Ouro Preto, então Vila Rica, além da capital da província, era o principal centro de explotação de ouro do país. Por causa dessa descoberta, o Conde de Valadares, governador da Capitania de Minas Gerais, convocou a Junta da Fazenda, para propor que o "quinto" fosse pago com ouro e/ou topázio. O governo não obteve êxito, pois para a lavra de minerais-gemas, mesmo dos mais valiosas como o diamante, o imposto era de um por cento. Desse modo, os representantes portugueses liberaram a explotação de topázio imperial, isentando-a de impostos (Mercedes-Benz 1987).

Spix \& Martius (1831), em sua viagem pelo Brasil em 1817, já descreviam as jazidas da Fazenda do Lana e do Capão do Lana, onde era retirado o topázio imperial e o euclásio. Este último, também raro, apresenta sua maior ocorrência brasileira em Ouro Preto. A jazida de Saramenha não foi citada por Spix \& Martius (1831), talvez por já estar desativada no período de sua viagem exploratória pelo interior do Brasil.

Desde a descoberta até o início da década de setenta, a jazida de Saramenha ficou totalmente abandonada. Somente em 1971, esta jazida foi reencontrada por acaso, durante os trabalhos de terraplenagem para uma construção. Quando o tratorista retirava um barranco, ele observou o aparecimento de um grande número de cristais de topázio. A partir daí, um grupo de nove pessoas se reuniram e criaram a Mineração Vermelhão, que explotou a jazida continuamente até cerca de quatro anos atrás. Em 1989, essa mineração foi vendida para um armênio de origem americana e vem sendo trabalhada ininterruptamente.

Existe uma continuação desse veio mineralizado em Saramenha para além dos limites legais de mineração do Vermelhão. Nesse local, a família Mendes retira topázio imperial a partir de um trabalho rudimentar, semelhante ao de garimpeiros de outros pontos do Brasil. Uma outra 
continuação do Vermelhão é a jazida da Alcan, que se encontra paralisada, em função de pertencer a uma empresa de siderurgia e que não mostra interesse na sua explotação.

Outra mineração de topázio imperial, totalmente mecanizada como a Mineração Vermelhão, é a do Capão do Lana, pertencente à TIMCIL (Topázio Imperial, Mineração, Comércio e Indústria Ltda), situada próxima a vila de Rodrigo Silva, também no município de Ouro Preto.

Essas duas minerações são responsáveis pela quase totalidade da produção de topázio imperial em Ouro Preto. Mas, em vários outros pontos, tem-se uma atividade garimpeira quase contínua. Entre eles, podem ser citados Antônio Pereira, Caxambu, Dom Bosco, Boa Vista, Antônio Nery, Barraginha e muito outros, alguns sem nenhuma denominação. As extrações do topázio nas várias jazidas e/ou ocorrèncias são a céu aberto. Na Figura 14, onde pode ser vista a geologia regional, também pode ser observada a localização das várias ocorrências e jazidas de topázio imperial no município de Ouro Preto.

\section{1 - MODO DE OCORRÊNCIA}

O topázio imperial da região de Ouro Preto é encontrado, predominantemente, em rochas totalmente alteradas. Em apenas um local, é conhecido um afloramento de rocha inalterada, cortada por veios quartzosos e/ou dolomíticos portadores de topázios imperiais.

\subsection{1 - ROCHA ALTERADA}

Na rocha alterada, o topázio imperial é encontrado em geodos e veios caulinizados, de dimensões centimétricas a decimétricas. Esses geodos (chamados de buchos pelos mineradores) e veios estão encaixados em rochas dolomíticas metamorfizadas, já totalmente decompostas. Os veios mineralizados mostram uma coloração castanha avermelhada escura, onde não se vê nenhum vestígio da rocha original (Ferreira 1991). Nesses veios caulinizados, além do quartzo e dolomita, podem conter especularita, moscovita, rutilo e florencita. As Fotografias 7 e 8, da jazida do Capão do Lana, mostram um aspecto da mineração em rochas totalmente decompostas. Nesta mina, vê-se o morro escavado, que possui uma altura de $25 \mathrm{~m}$ em relação ao leito do córrego do Capão e a cava que tem $35 \mathrm{~m}$ de profundidade. Neste local, já foram feitos furos de sondagem com $55 \mathrm{~m}$ de profundidade, em rocha alterada até atingir uma camada de quartzito. Os cristais de topázio são recolhidos, numa operação de desmonte hidráulico (Fotografia 9), juntamente com o material alterado do veio mineralizado e da rocha encaixante por uma caçamba (drag line) onde são 
Mapa litológico-estrutural

\section{da região estudada}
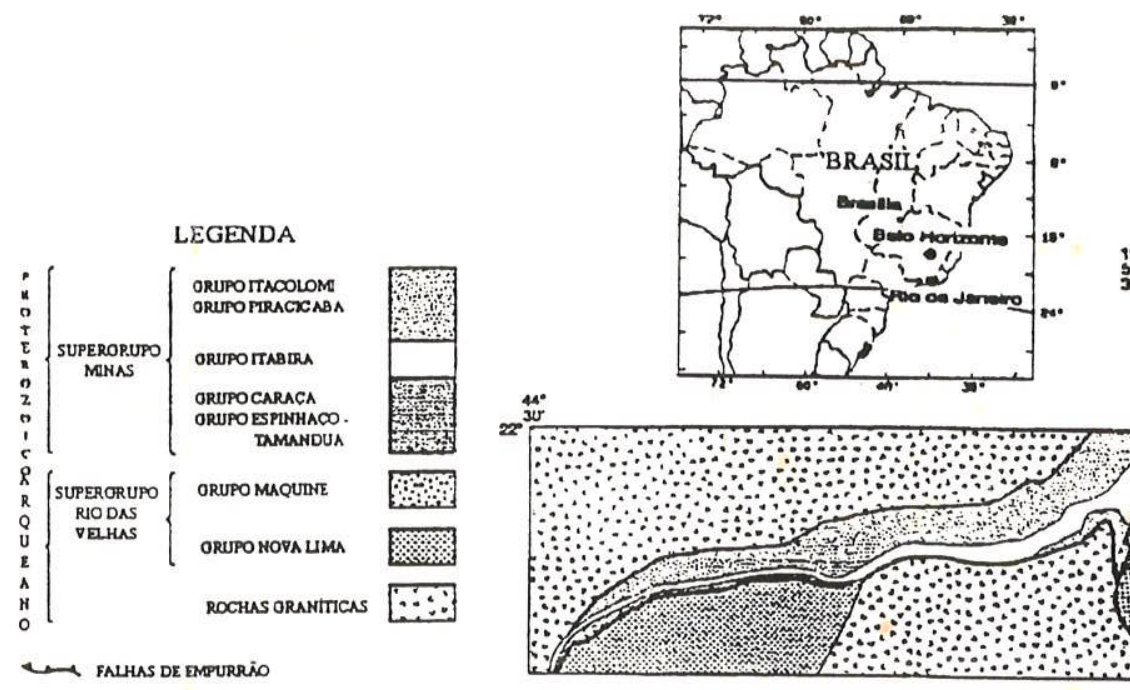
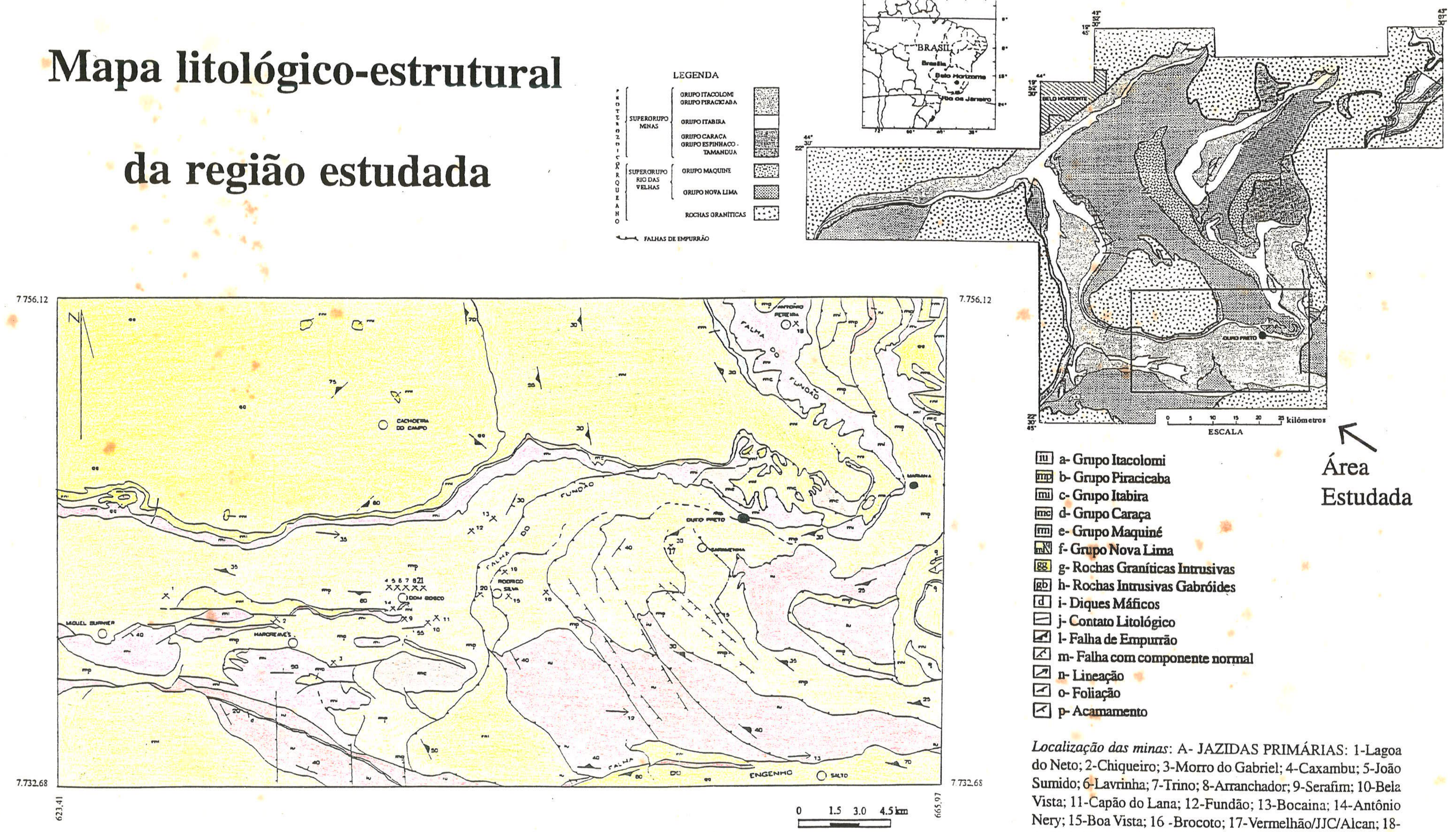

Localização das minas: A- JAZIDAS PRIMÁRIAS: 1-Lagoa do Neto; 2-Chiqueiro; 3-Morro do Gabriel; 4-Caxambu; 5-João Sumido; 6-Lavrinha; 7-Trino; 8-Arranchador; 9-Serafim; 10-Bela Vista; 11-Capão do Lana: 12-Fundão: 13-Bocaina; 14-Antôn Nery; 15-Boa Vista; 16 -Brocoto; 17-Vermelhão/JJC/Alcan; 18Antônio Pereira; 19, 20 e 21-sem nome;

FIGURA 14 - Mapa litológico-estrutural da região estudada (modificado de Nalini Jr 1993) e mapa geológico simplificado do Quadrilátero Ferrífero (modificado de Thorman et al. 1986). Em destaque as regiôes produtoras de topázio imperial. 
lavados (Fotografia 10), peneirados e passados por um jig e, por último, numa correia transportadora onde a cata desse mineral-gema é feita manualmente (Fotografias lla e 11b). Na mina é difícil achar o topázio, sendo mais fácil na operação de lavagem ou na esteira (correia transportadora).

O solo foi analisado pelo método do pó e, a partir dos difratogramas de raios $\mathrm{X}$ obtidos no DEGEO/EM/UFOP, verificou-se que a mineralogia básica, numa análise semi-quantitativa dada pela altura dos picos, é representada na sua grande maioria por argilominerais $( \pm 80 \%)$ do tipo caulinita e illita, seguido de quartzo $( \pm 15 \%)$ e, por fim, de traços de hidróxido de ferro $( \pm 5 \%)$, provavelmente a goethita. Também foram feitas análises de argilominerais, investigadas pelo método de lâminas orientadas (smearing), num intervalo angular de 2 a $32^{\circ}$, sendo preparadas três lâminas distintas, ou seja: a) amostra natural; b) amostra glicolada - exposta na atmosfera de etilenoglicol por $24 \mathrm{~h}$, para verificar a presença de minerais expansivos, os quais não foram detectados e c) amostra aquecida - levada ao forno por 5 h à uma temperatura de $490^{\circ} \mathrm{C}$, na qual foi confirmada a presença de caulinita, pela quebra da estrutura molecular da mesma, constatada pelo desaparecimento do pico deste mineral.

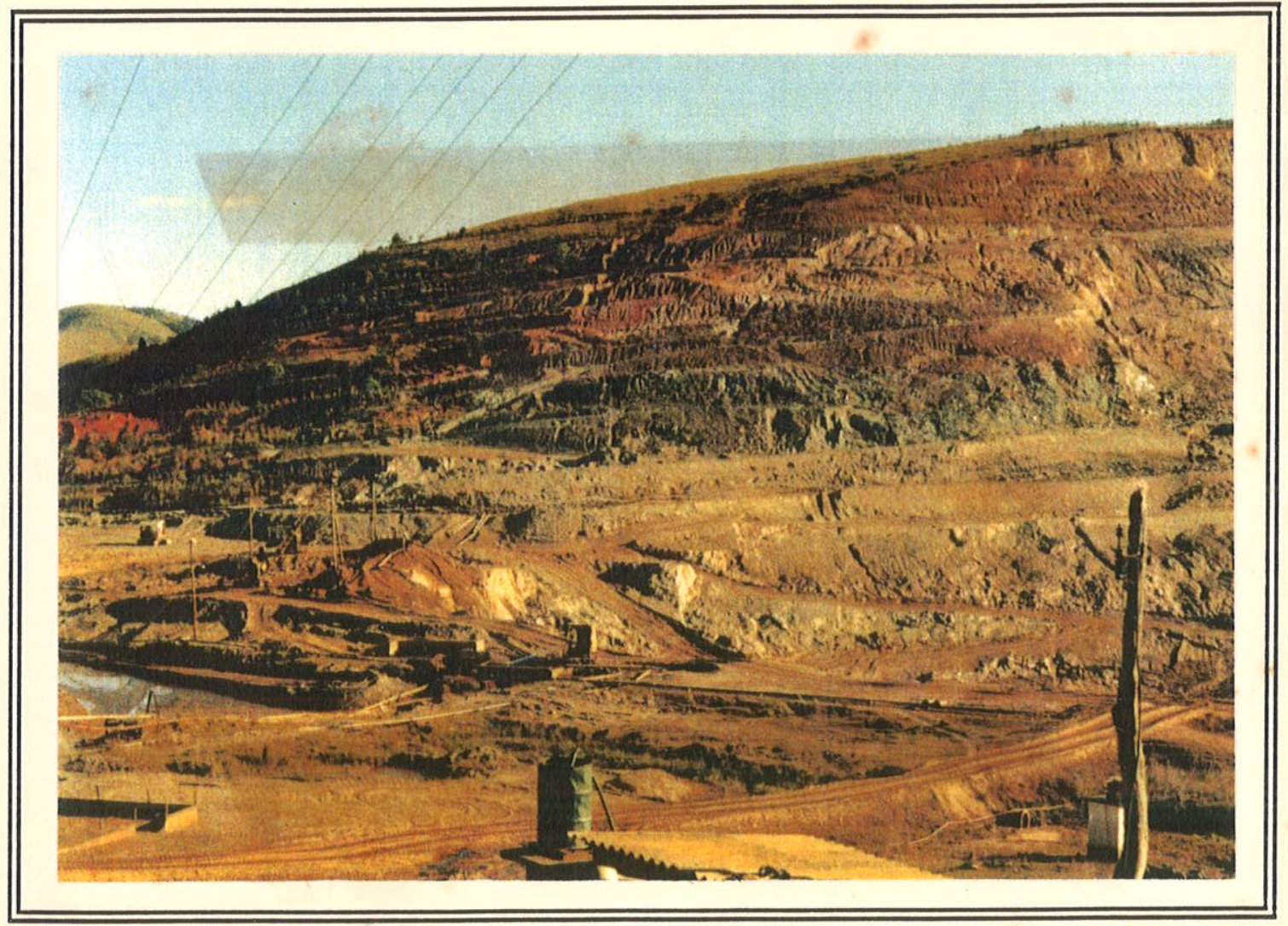

FOTOGRAFIA 7 - Vista panorâmica da mina do Capão do Lana, na região de Ouro Preto, onde podem ser observadas as bancadas para a retirada do capeamento da rocha encaixante do topázio imperial. Na base das bancadas. săo encontrados os veios mineralizados desse mineral-gema. 


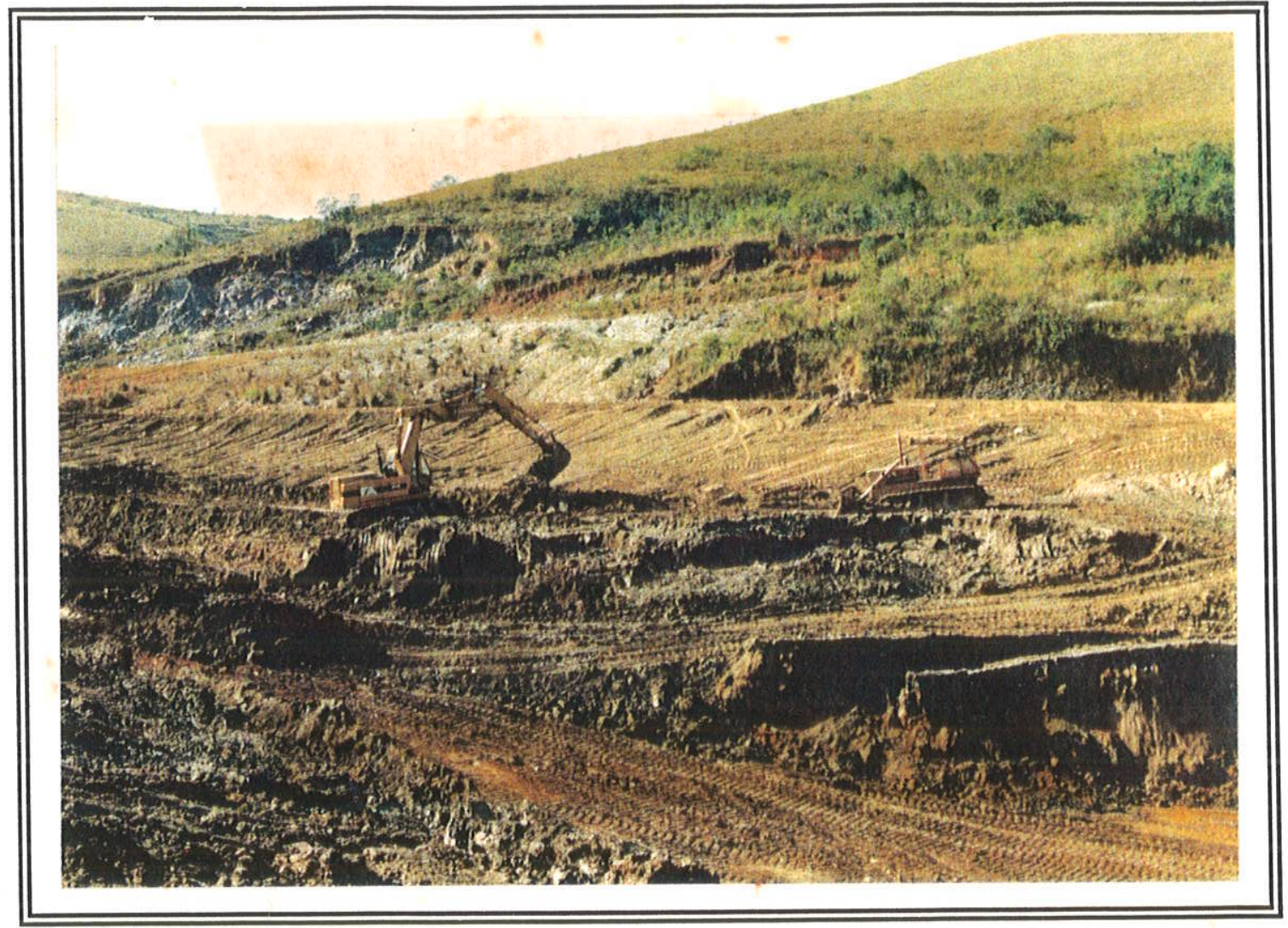

FOTOGRAFIA 8 - Detalhe de uma parte da mina do Capão do Lana, onde se observa o trabalho da retirada do capeamento do veio mineralizado em topázio imperial.

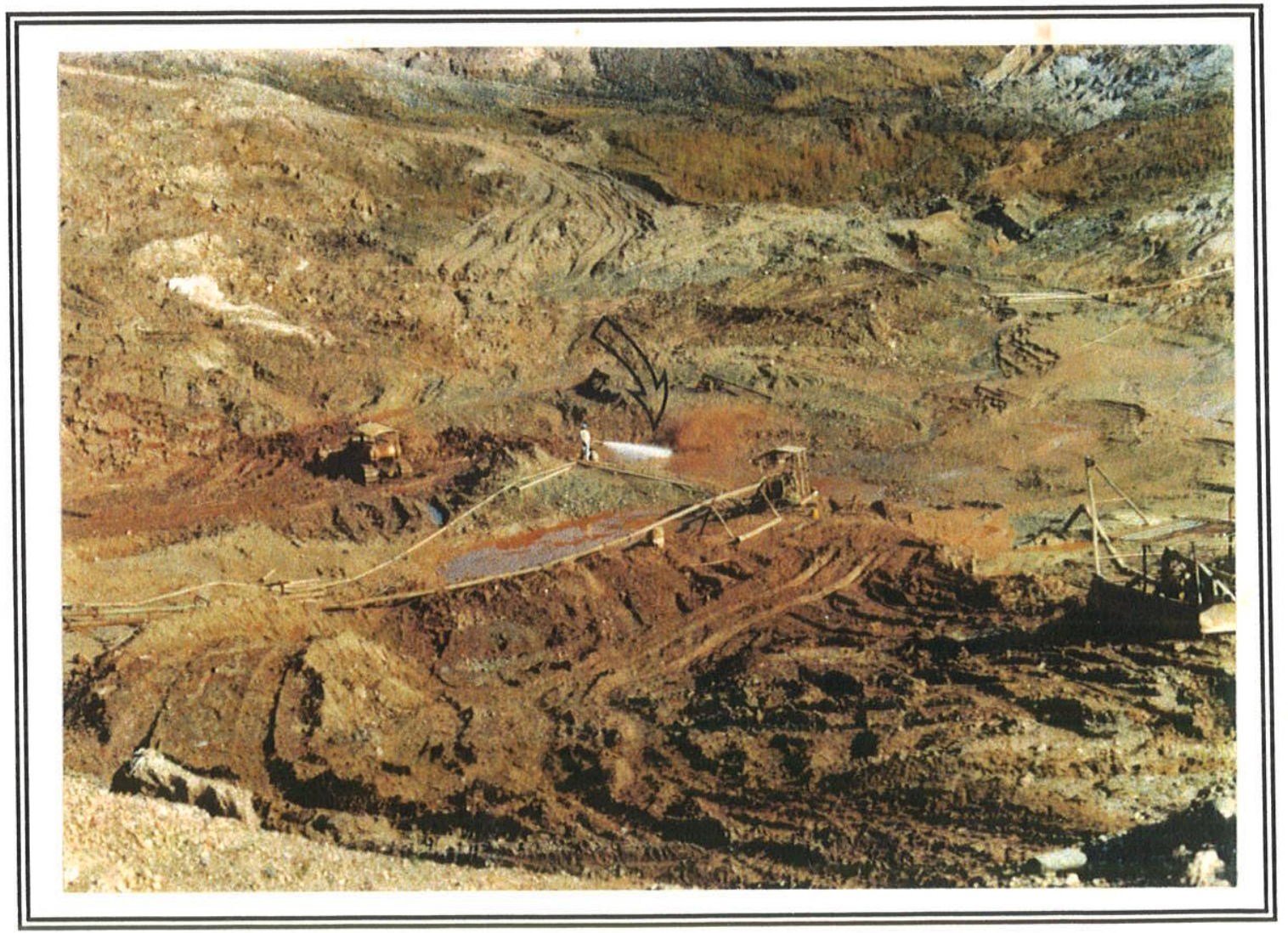

FOTOGRAFIA 9 - Vista parcial da mineração do Capão do Lana, município de Ouro Preto, destacando-se a operação de desmonte hidráulico dos veios mineralizados em topázio imperial. 


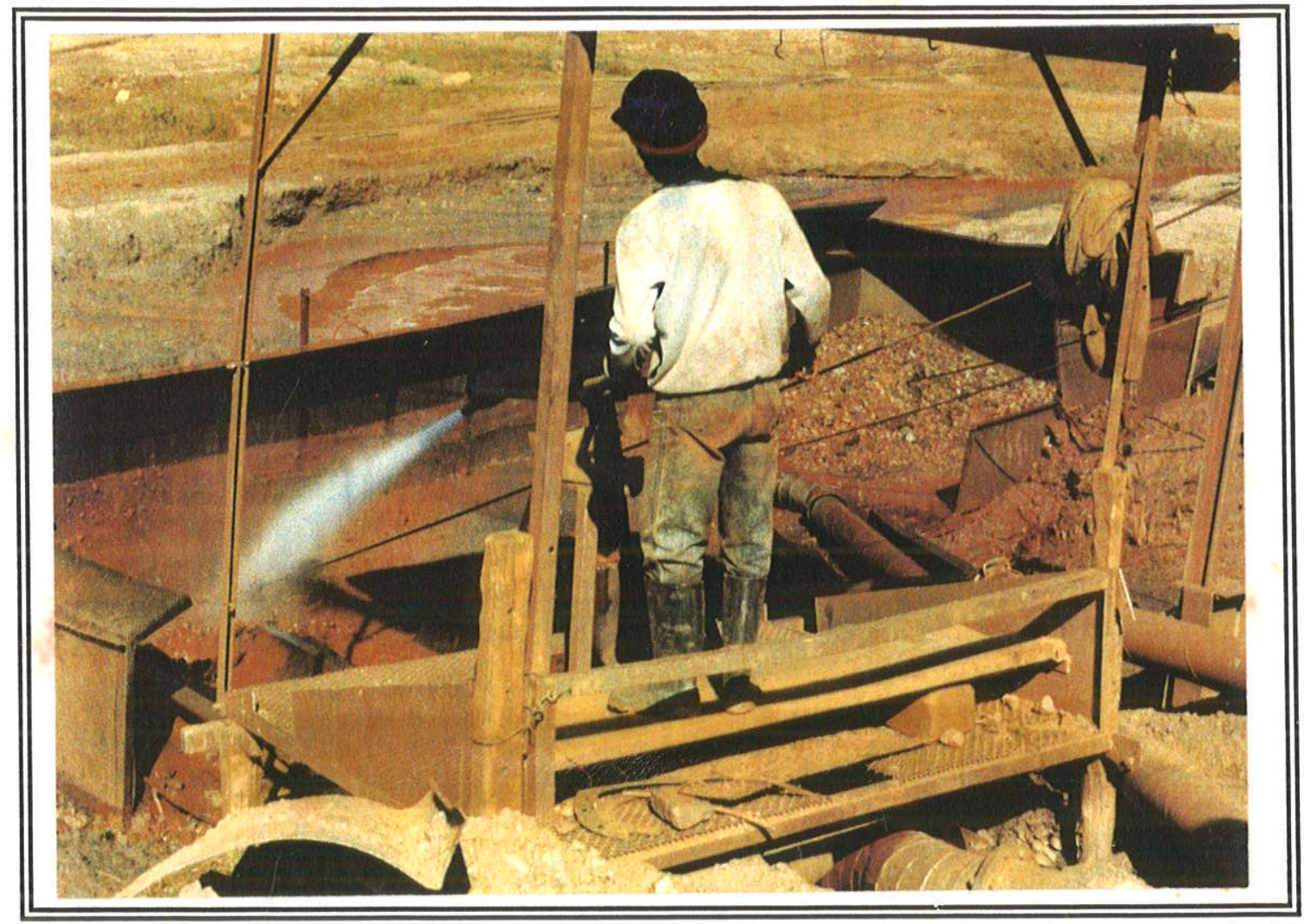

FOTOGRAFIA 10 - Operação de lavagem do material argiloso mineralizado em topázio imperial. A direita, observa-se um monte de minerais livres e fragmentos da rocha encaixante, juntamente com o topázio imperial, para ser catado.

Apesar de não ser possível a observação da rocha inalterada na maioria dos depósitos da região, relações de campo sugerem que a Formação Fecho do Funil do Grupo Piracicaba (Supergrupo Minas) seja a rocha encaixante desses depósitos de topázio imperial. Regionalmente sabe-se que, a maior parte das mineralizações ocorrem associadas a falhamentos normais, de direção predominantemente, $\mathrm{N} 60^{\circ} \mathrm{W}$, cortando filitos carbonáticos ou mármores dolomíticos do Grupo Piracicaba (Ferreira 1991). Essas rochas afloram em grande área no município de Ouro Preto, como pode ser visto na Figura 15. Possivelmente, a alteração dessas rochas produziu a "borra de café", que é composta de caulinita, carbonatos e óxidos de ferro e manganês, totalmente decompostos.

Nas zonas mineralizadas, o topázio ocorre como cristais prismáticos e terminados. Já nos aluviões, têm-se dois tipos de topázio; o primeiro, prismático mas com arestas arredondadas, e o segundo, na forma de seixos pequenos e ovais. Como exemplo do primeiro tipo, podem ser citadas as ocorrências dos ribeirões do Maracujá e Azul, dos córregos do Cipó, do Fundão e do Papa-Cobra; já o segundo caso é característico da região do Salto e da Barraginha (Fotografia 12). Esses exemplares arredondados da Fotografia 12, não são produto de transporte a grande distância, mas simplesmente o resultado do desgaste em panelões ou caldeirões formados nos 
quartzitos devido às drenagens que cortam os depósitos primários. Nessas depressões, conhecidas como panelões, o topázio fica rolando devido ao efeito do redemoinho formado pela corrente d'água e conferindo uma forma arredondada aos fragmentos de cristais, previamente clivados.

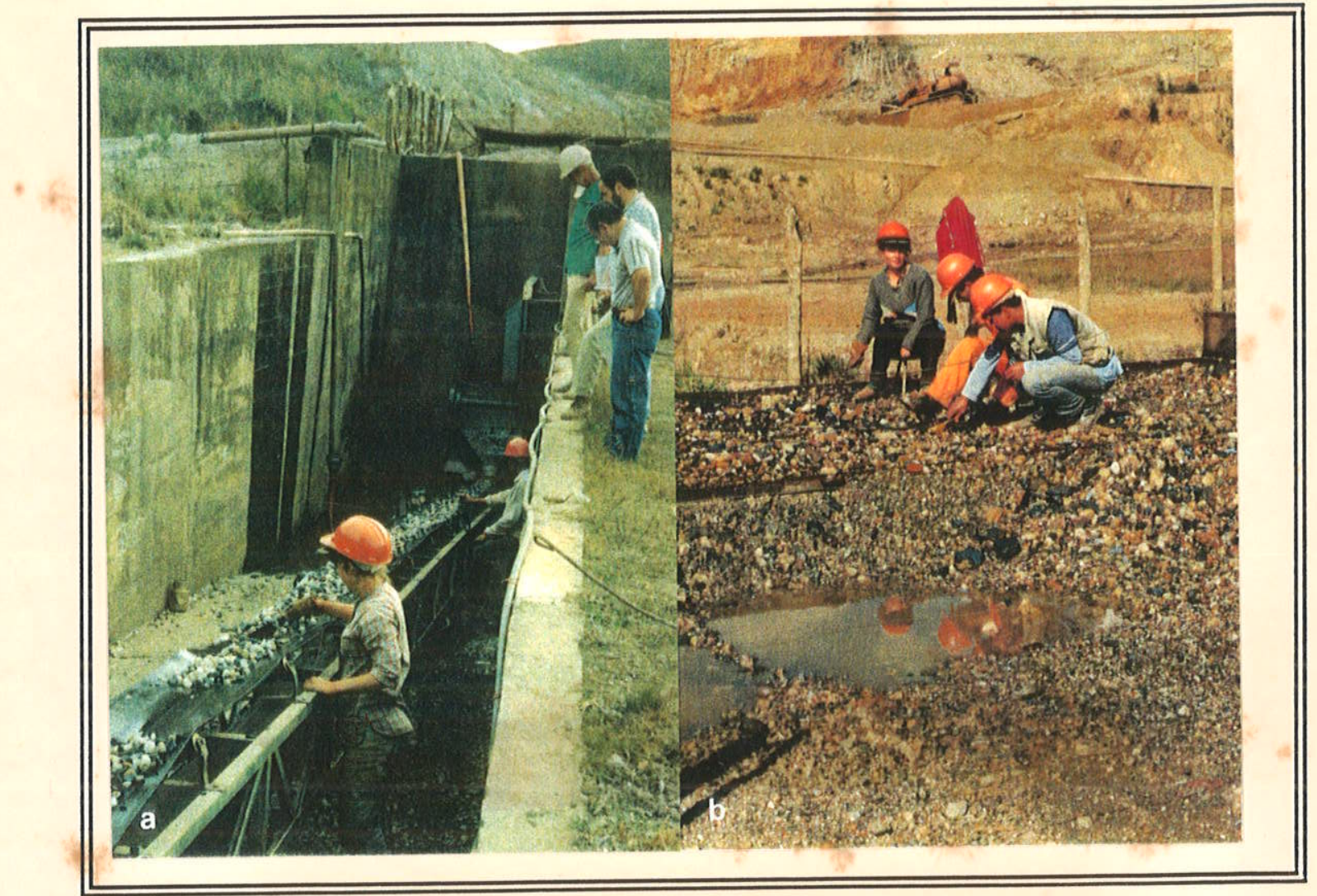

FOTOGRAFIA 11 - a) após a lavagem do material argiloso. passam-se os minerais livres por um jig (separador gravimétrico), e depois todos os fragmentos são colocados em uma correia transportadora. para a catação do topázio imperial, b) a etapa seguinte é a cata. eventual. deste mineral no monte já passado pela correia. Nesta fotografia. observam-se funcionários catando o topázio imperial.

Um exemplo interessante de mineral desses colúvios, ocorre na jazida de Antônio Pereira (Fotografia 13), onde aparecem cristais de florencita $\left[\mathrm{CeAl}_{3}\left(\mathrm{PO}_{4}\right)_{2}(\mathrm{OH})_{6}\right]$ com aspecto já um pouco alterado (Fotomicrografia 1). Também são encontrados os grãos de quartzo hialino bem cristalizados, cristais octaédricos de magnetita/martita e cristais cúbicos e pentadodecaédricos de pirita, já limonitizadas. 


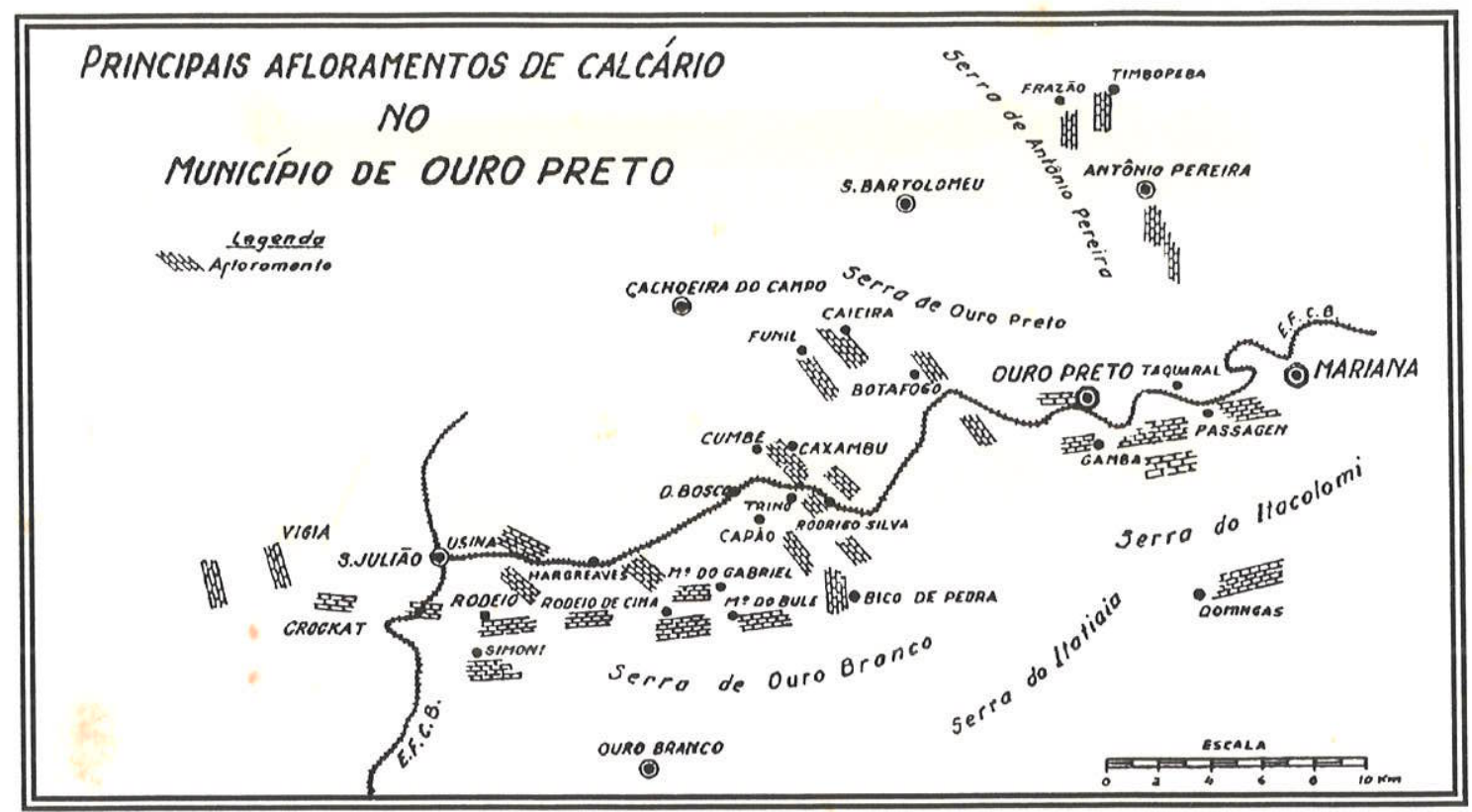

FIGURA 15 - Principais afloramentos de rochas metacarbonatadas no município de Ouro Preto (Simplificado de Rolff 1945). Todos os depósitos de topázio imperial, estão associados a ocorrência dessas rochas, pertencentes aos Grupos Itabira e Piracicaba.

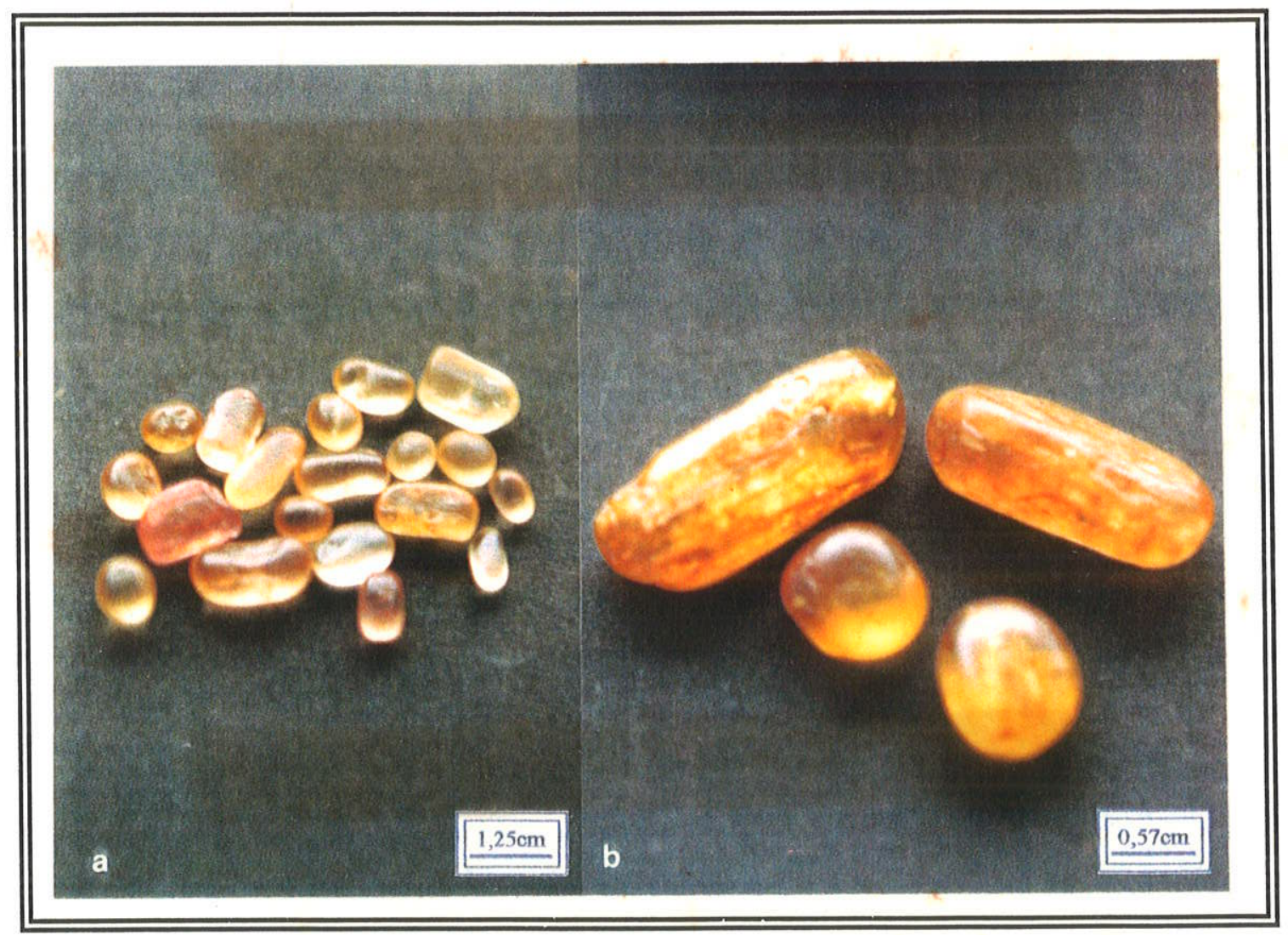

FOTOGRAFIA 12 - a) um grupo de cristais de topázio imperial que sofreu transporte, onde têmse dois tipos bem característicos. O primeiro ainda mostra seu hábito prismático e o segundo apresenta-se de forma arredondada em panelões, dando uma falsa impressão de transporte a grande distância. As amostras são da região da Barraginha e b) um detalhe dos cristais da fotografia a). 


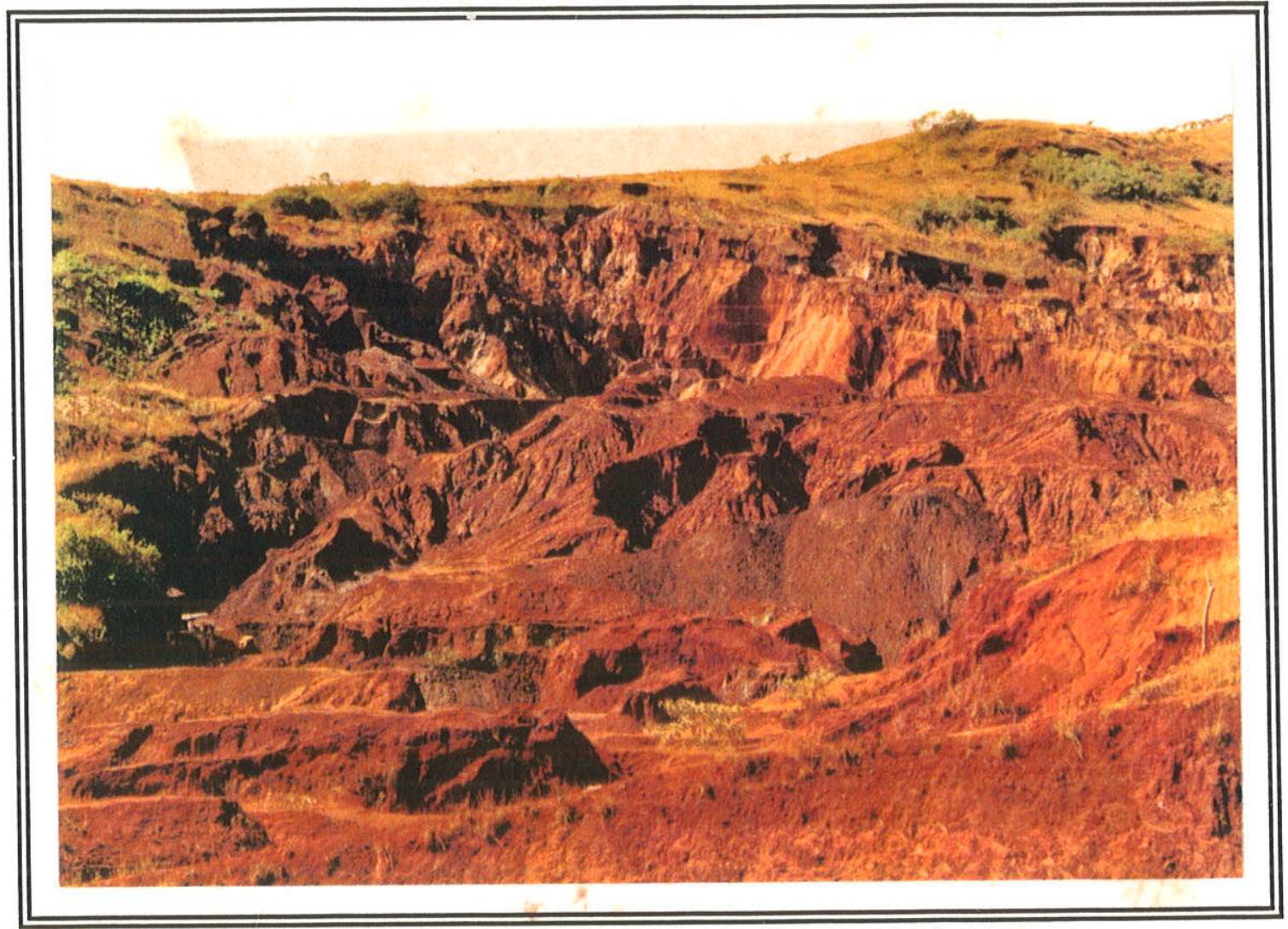

FOTOGRAFIA 13 - Vista parcial da jazida de Antônio Pereira, onde pode ser observado o alto grau de alteração das rochas, constituíndo um solo de cor castanho-avermelhado.

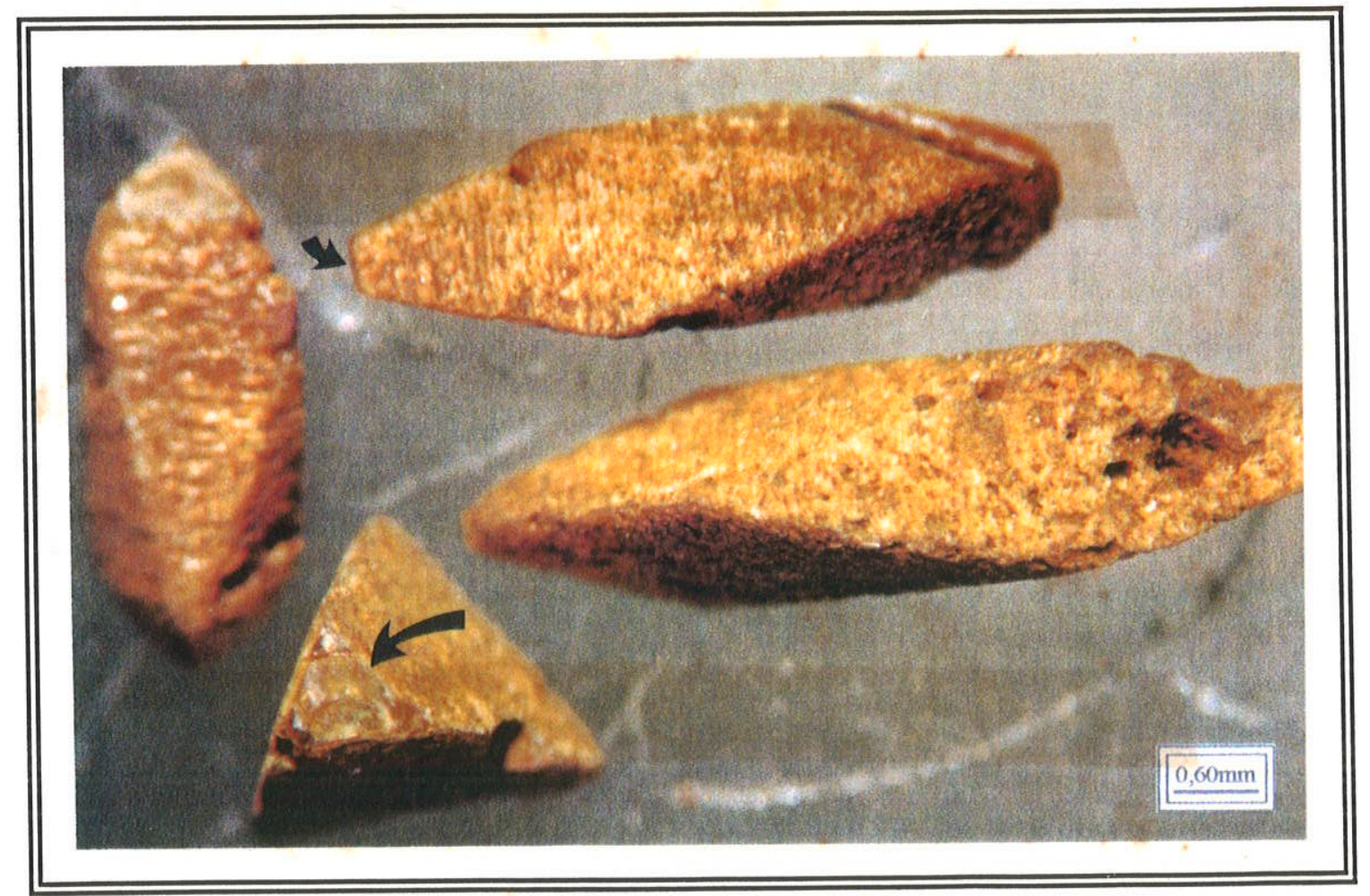

FOTOMICROGRAFIA 1 - Cristais de florencita, exibindo hábito romboédrico achatado, dois deles com uma clivagem basal, encontrados no colúvio sotopostos às rochas mineralizadas em topázio imperial na região de Antônio Pereira, município de Ouro Preto. 


\subsection{2 - ROCHA INALTERADA}

Na região de Ouro Preto, é conhecido apenas um local onde o topázio é encontrado em rocha inalterada. Este afloramento está próximo à mineração Bemil, uma empresa produtora de calcário dolomítico da Formação Gandarela. Situa-se a 500m da Rodovia dos Inconfidentes, num local denominado de Bocaina (Figura 1), sendo constituído por um mármore dolomítico pertencente à Formação Fecho do Funil (Fotografia 14). Essa rocha mostra coloração amareloclaro, com uma textura granoblástica fina e ligeiramente inequigranular seriada (Fotomicrografia 2). O tamanho dos grãos de dolomita varia de 0,04 a $0,1 \mathrm{~mm}$, tendo como média os de $0,06 \mathrm{~mm}$. Sua composição é caracterizada por mais de $98 \%$ de dolomita, além de grãos de quartzo dispersos ou agrupados e algumas palhetas de mica branca que constituem os acessórios. A dolomita é incolor e os grãos são aproximadamente equidimensionais. Com frequêencia, podem ser observadas as inclusões fluidas, cujo tamanho oscila em torna de $0,004 \mathrm{~mm}$, bifásicas à temperatura ambiente e equidimensionais. Os grãos de quartzo, dispersos no mármore, são incolores, equidimensionais com diâmetro médio de $0,02 \mathrm{~mm}$ e sem formas definidas, podendo ser observadas algumas inclusões de mica branca. Quanto ăs plaquetas de micas, estas não apresentam uma orientação definida, ocorrendo isoladas ou, às vezes, agrupadas. Mostram-se incolores, como cristais alongados, e dimensões variando de 0,01 a $0,2 \mathrm{~mm}$, ao longo do maior eixo.

No mármore dolomitico, a mineralização de topázio ocorre em veios milimétricos a centimétricos, de granulação variável, porém, significativamente maior do que a da rocha encaixante. Esses veios são compostos essencialmente por quartzo e/ou dolomita, ambos incolores, onde vê-se o contato dos grãos de dolomita com os de quartzo, este exibindo uma textura granoblástica fortemente inequigranular (Fotomicrografia 3). Este contato é ligeiramente sinuoso mostrando-se, às vezes, poligonizado. O tamanho dos grãos de dolomita nesses veios varia de 0,04 a $0,4 \mathrm{~mm}$, sendo a média em torno de $0,16 \mathrm{~mm}$. Esses cristais exibem um número muito grande de inclusões fluidas, com um diâmetro médio de $0,02 \mathrm{~mm}$. Raríssimos cristais de dolomita exibem em seu interior núcleos de calcita. Esta relação pode estar ligada com o fenômeno da dedolomitização, provocado pela ação de águas meteóricas, uma vez que 0 mármore está exposto em superfície. Pode-se observar, ainda, que o núcleo de calcita já se encontra corroído com a formação de porosidade intergranular (Fotomicrografia 4). Em alguns grãos de quartzo, observam-se inclusões de mica branca com dimensões compreendido numa faixa de 0,04 a $0,1 \mathrm{~mm}$. Já no veio constituído de quartzo, as dimensões dos grãos oscila de 0,04 a $0,24 \mathrm{~mm}$, com uma média de $0,15 \mathrm{~mm}$. Às vezes, estão presentes pequenas palhetas dispersas de mica branca, que localmente podem formar concentrações na forma de pequenos agrupamentos, e possuem um tamanho entre 0,1 a $0,12 \mathrm{~mm}$. Raramente ocorrem cristais de rutilo, de cor castanha, com hábito acicular, formando pequenos agrupamentos, cujo tamanho médio é de, aproximadamente, $0,03 \mathrm{~mm}$ (Fotomicrografia 5). 


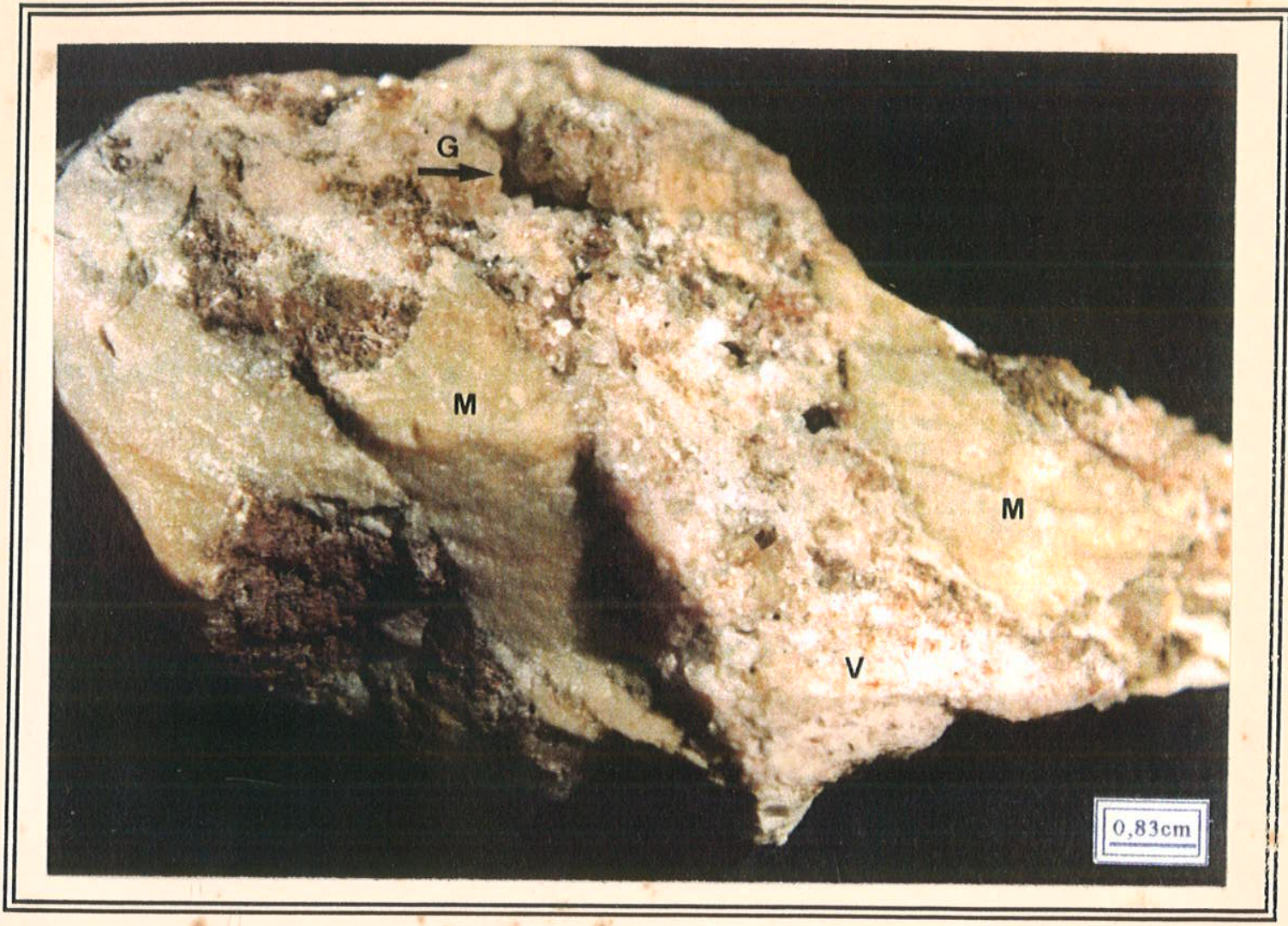

FOTOGRAFIA 14 - Mármore dolomítico (M) da Formação Fecho do Funil. cortado por um veio (V) de granulometria grosseira onde pode ocorrer o topázio imperial. Às vezes. este mineral-gema também pode estar presente em pequenos "geodos"(G) nesses veios.

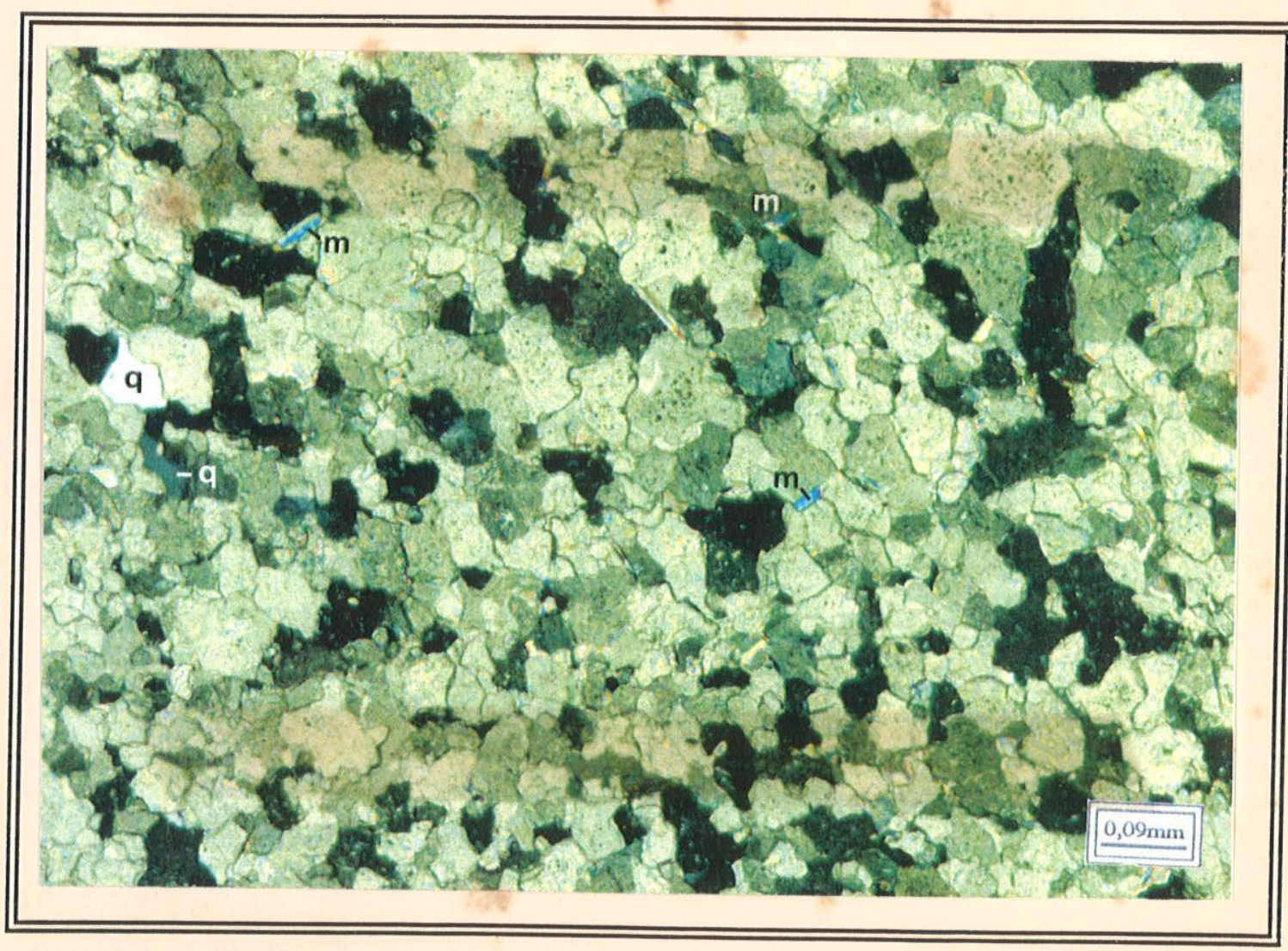

FOTOMICROGRAFIA 2 - Mármore dolomitico da Formação Fecho do Funil. mostrando uma textura granoblástica fina. Nesta rocha são encontrados os veios mineralizados em topázio imperial. Os pontos escuros nos grãos de dolomita são inclusões fluidas. O quartzo (q) e a mica branca (m) constituem os acessórios. Polarizadores cruzados. 


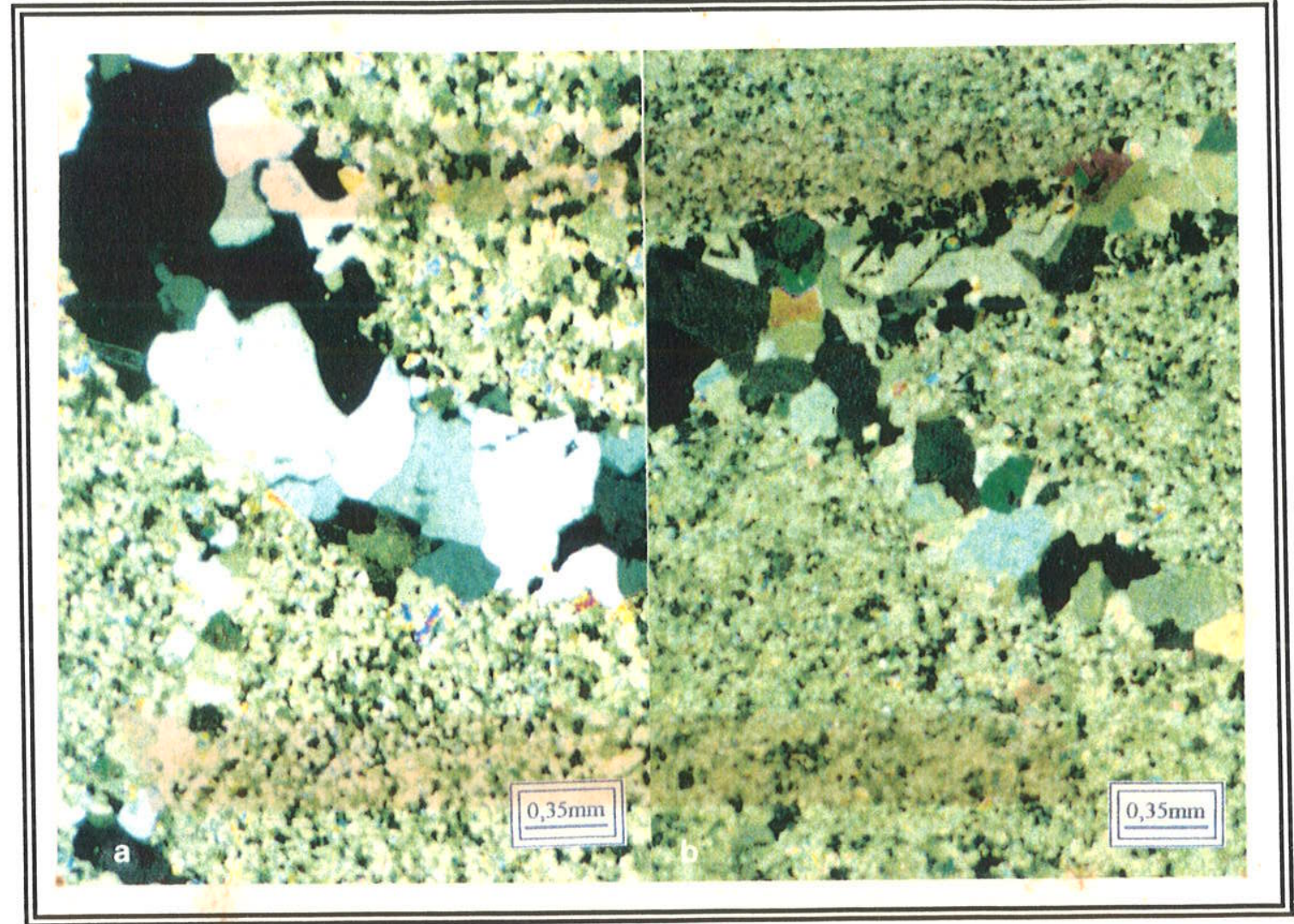

FOTOMICROGRAFIA 3 - a) mármore dolomítico da Formação Fecho do Funil, cortado por um veio secundário essencialmente quartzoso. Nessas rochas são encontrados os veios mineralizados em topázio imperial, b) outro detalhe, exibindo um veio de dolomita. Polarizadores cruzados.

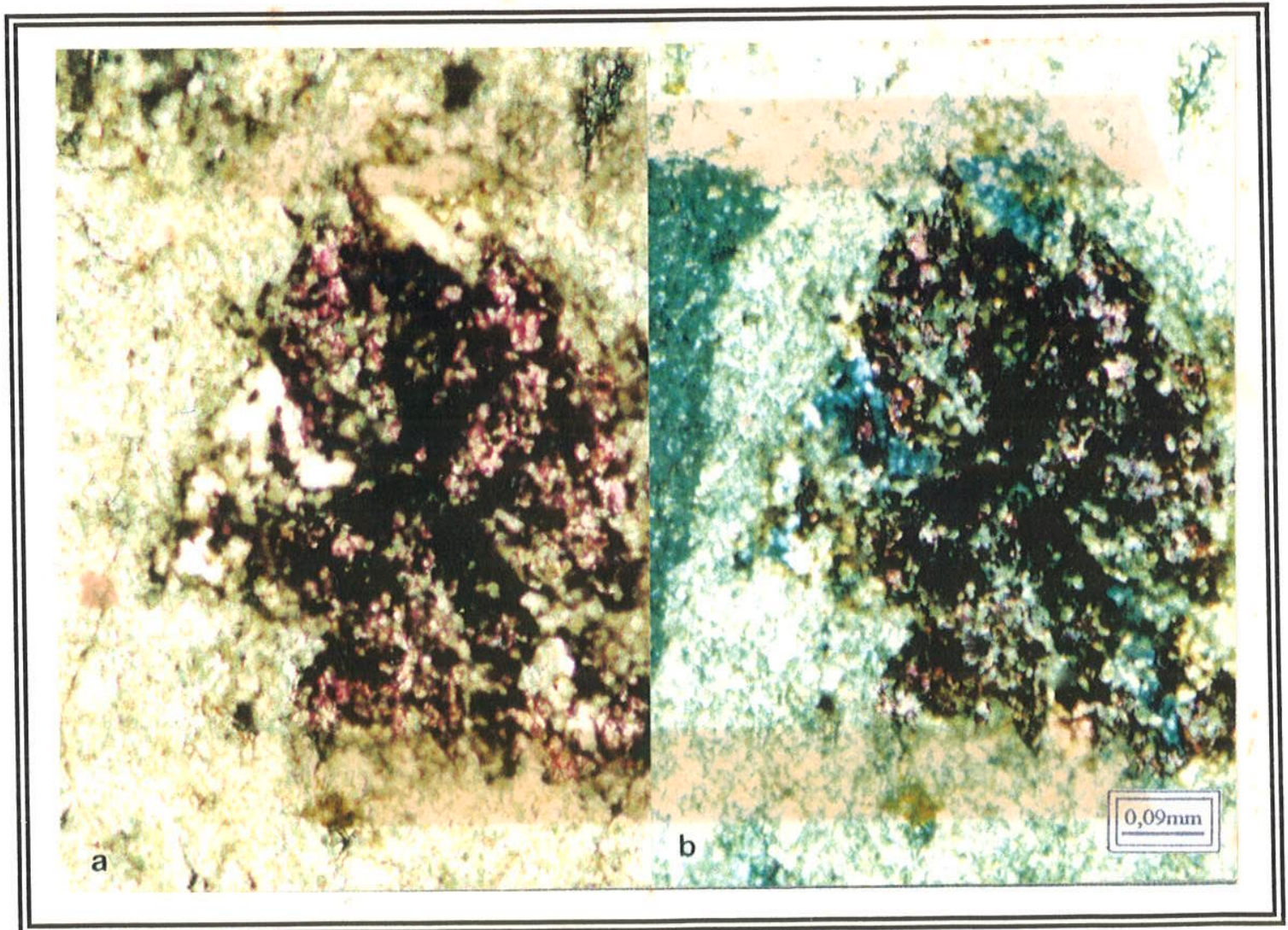

FOTOMICROGRAFIA 4 - Mármore dolomítico pertencente à Formação Fecho do Funil, constituíndo o nível mineralizado em topázio imperial. a) observa-se que após o ataque com alizarina, pode ser facilmente visto que o núcleo do cristal de dolomita é essencialmente calcítico, b) mesmo detalhe em polarizadores cruzados. 


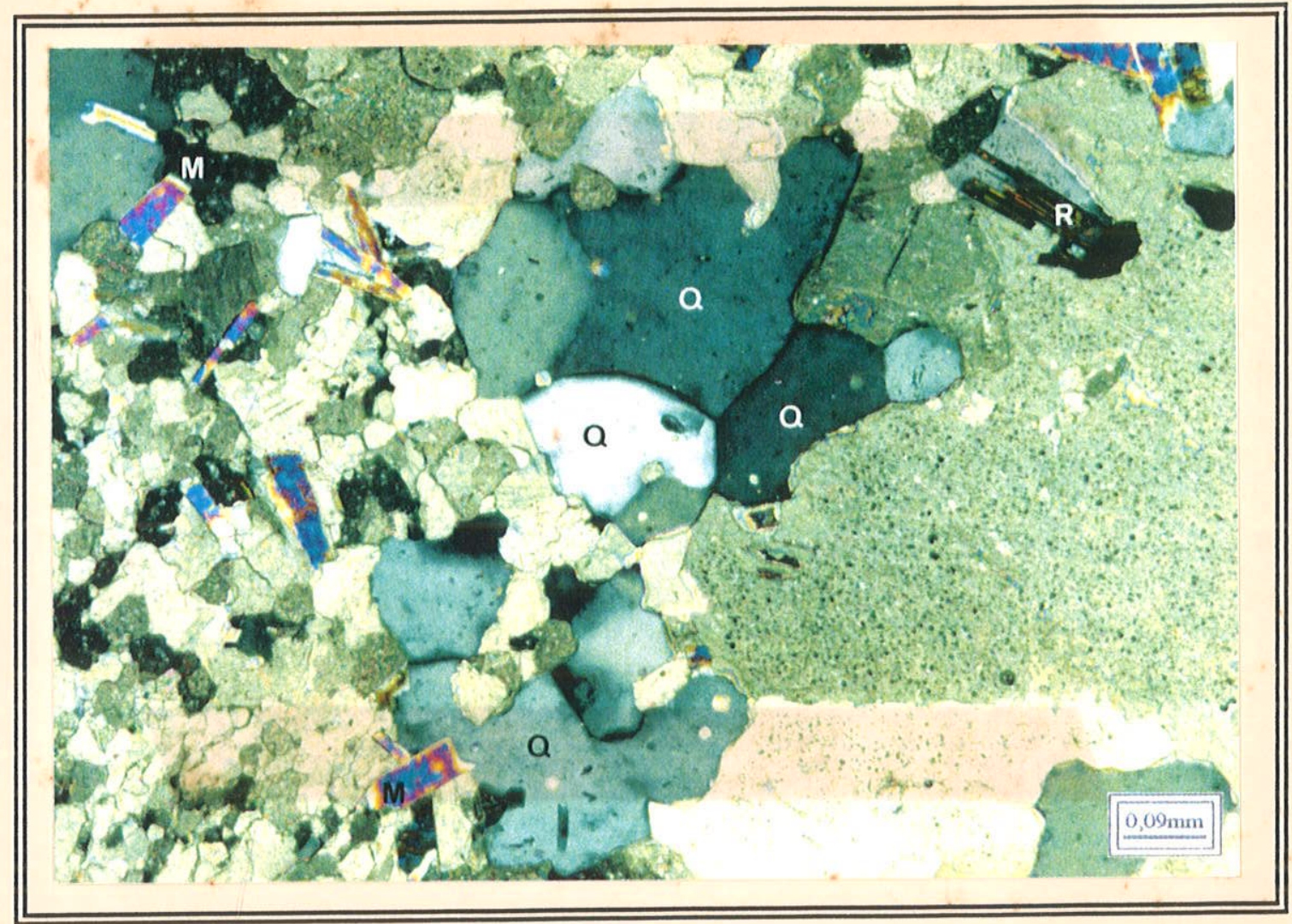

FOTOMICROGRAFIA 5 - Contato do veio mineralizado em topázio imperial, constituído essencialmente de quartzo, com o mármore dolomítico. Observa-se uma pequena concentração de mica (M) na rocha próxima ao contato com o veio e um cristal de rutilo (R) no vcio. Também os grãos de dolomita do veio são ricos em inclusões fluidas, enquanto os grãos de quartzos (Q) são pobres em inclusões.

O contato entre os grãos de dolomita, nos veios mineralizados, pode ser irregular, denteado ou microdenteado enquanto, na encaixante desses veios, tal contato, apesar de ser irregular, apresenta contornos bem mais suaves.

O topázio desses veios, inalterados, sempre aparece em cristais bem formados, associados à cristais euédricos de dolomita, quartzo, rutilo e florencita (Fotomicrografia 6). É freqüente a presença de cristais de rutilo e dolomita inclusos nesses topázios (Fotomicrografia 7). Também neste tipo rochoso, nas partes superficiais tem-se a presença da dolomita alterada, constituíndo a "borra de café" (Fotomicrografia 8).

À fluorita, referida na literatura (Rolff 1945 e 1950) em rochas dolomíticas da região de Ouro Preto, não foi identificada no mármore dolomítico da área da Bocaina, e nem nas mineralizações em rochas alteradas. Outro mineral presente nesta área é a barita, que ocorre em cristais centimétricos. No entanto, nas lâminas estudadas deste mármore não se observou esse mineral, embora o mesmo seja comum nas amostras macroscópicas. 


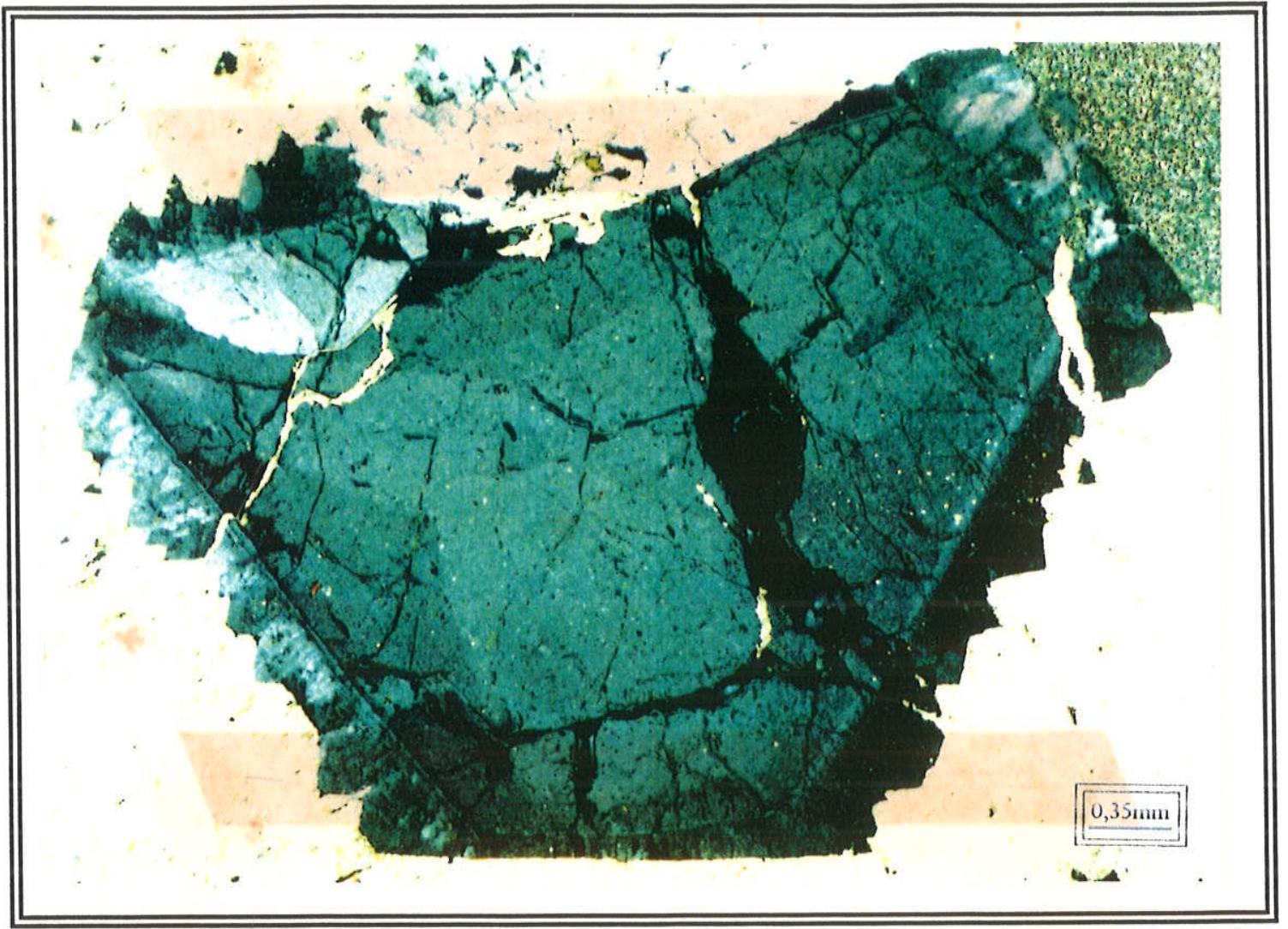

FOTOMICROGRAFIA 6 - Cristal euédrico de florencita presente no veio mineralizado em topázio. Polorizadores cruzados.

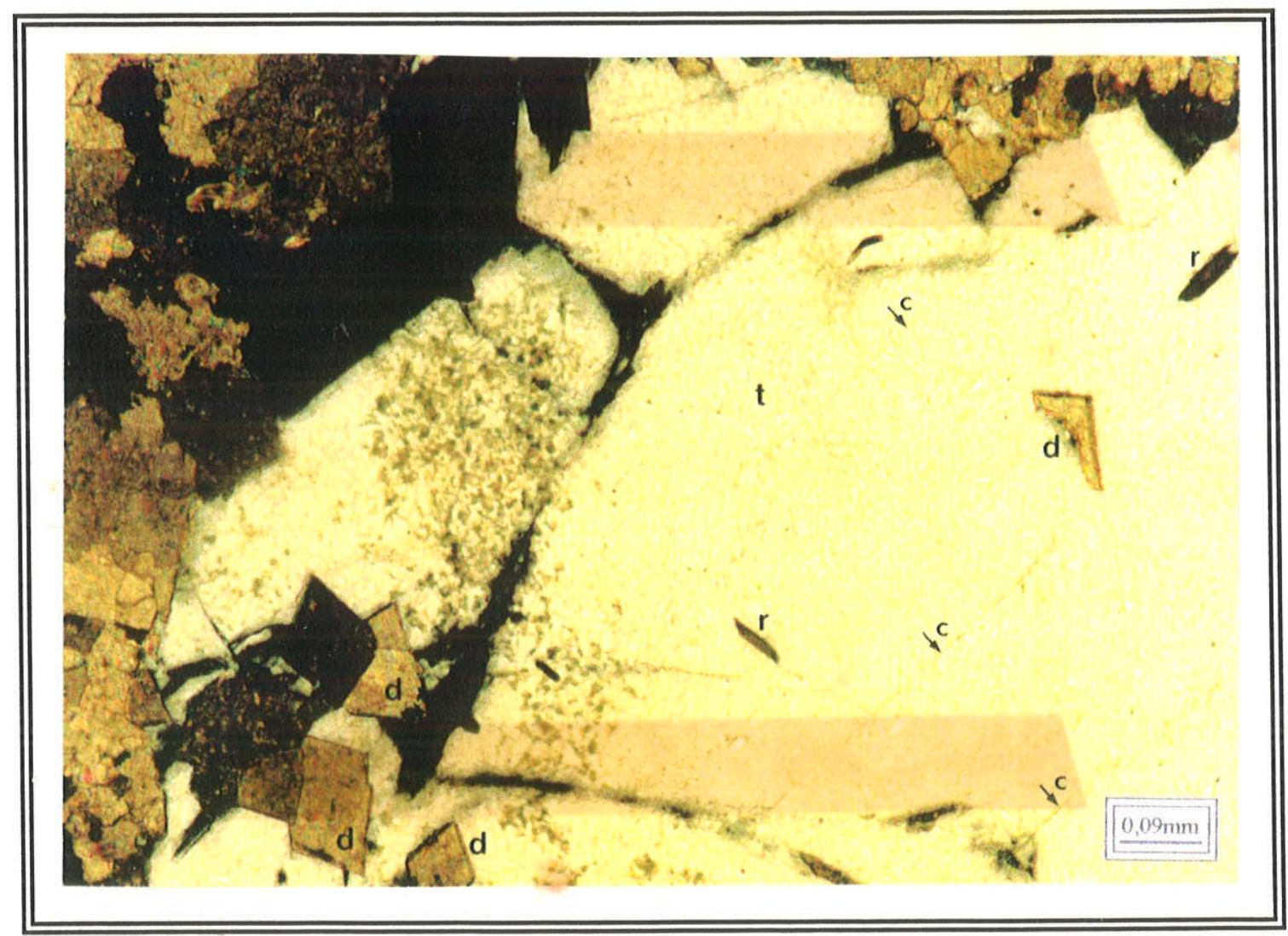

FOTOMICROGRAFIA 7 - Topázio (t) presente no veio com inclusões de dolomita (d) e rutilo (r). Pode-se observar três linhas de clivagens basais $(\downarrow c)$ Polarizadores cruzados. 


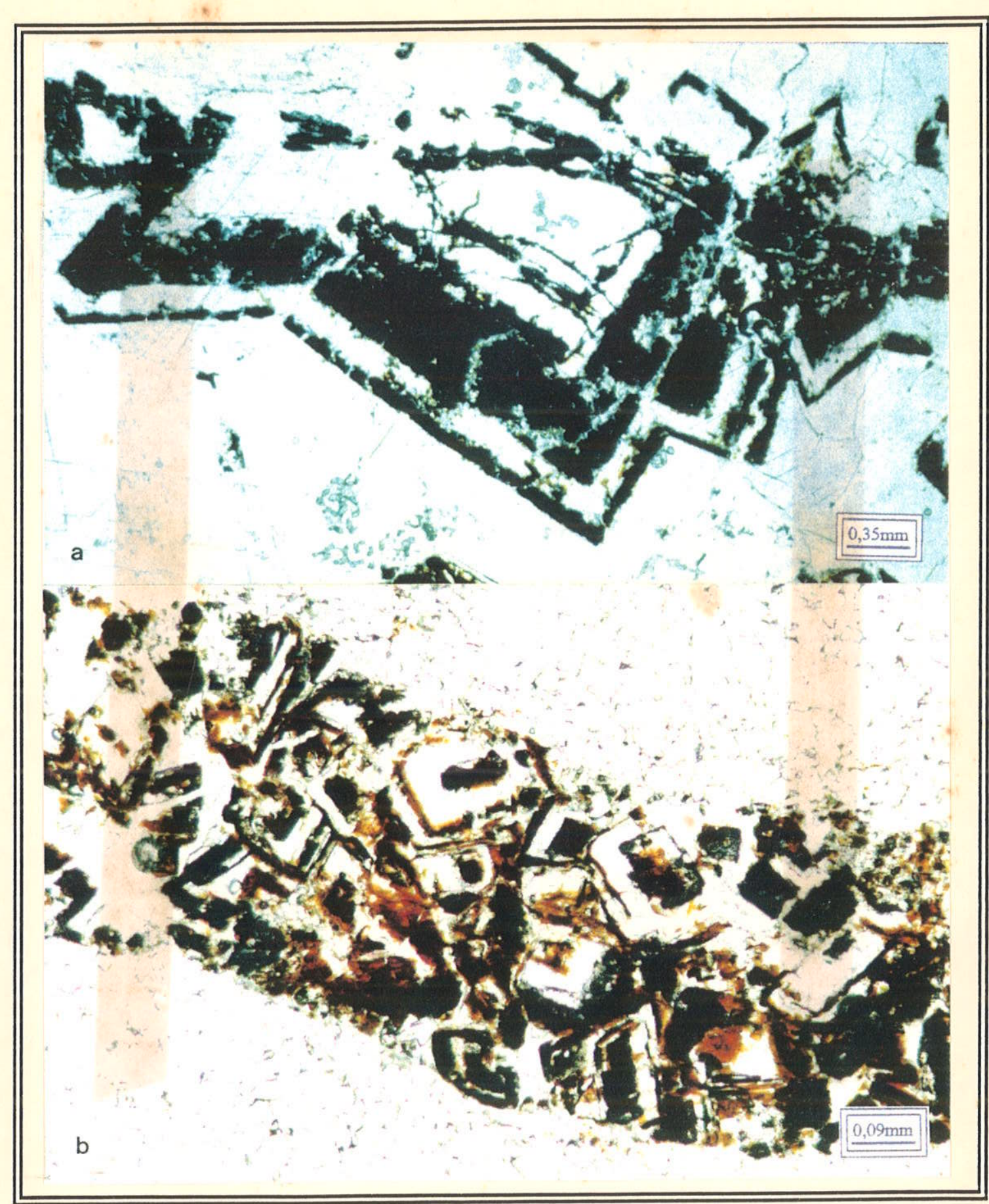

FOTOMICROGRAFIA 8 - a) cristais de dolomita perfeitamente idiomórficos, pertencentes aos veios mineralizados e mostrando o início da alteração para "borra de café", b) um micro veio de dolomita com alto grau de alteração. Polarizadores descruzados.

Além da microscopia óptica tradicional, também utilizou-se o método da catodoluminescência para uma melhor caracterização do mármore dolomítico como também de alguns cristais de topázios. Esse método foi empregado na tentativa de comprovar a presença de elementos ativadores e/ou restritivos nos veios e nas rochas encaixantes dos níveis mineralizados, bem como nos topazios imperiais da região de Ouro Preto. 
Segundo Frank et al. (1982), o principal elemento ativador da catodoluminescência dos carbonatos é o $\mathrm{Mn}^{2+}$, enquanto o principal elemento restritivo é o $\mathrm{Fe}^{2+}$, embora não se saiba ao certo o teor de cada elemento necessário para produzir o fenômeno. No caso do $\mathrm{Mn}^{2+}$, segundo Ten Have \& Heijnen (1985), de 15 a 30ppm já seriam suficientes para ativar a catodoluminescência de calcitas e de 30 a $35 \mathrm{ppm}$ em dolomitas, quando ocorrem concentrações menores que 200ppm de ferro. Para essas mesmas condições, a intensidade da luminescência é controlada pelo teor de $\mathrm{Mn}^{2+}$ e não pela razão $\mathrm{Fe}^{2+} / \mathrm{Mn}^{2+}$. Se o ambiente for um pouco redutor, os carbonatos podem incorporar $\mathrm{Mn}^{2+}$ numa substituição parcial do $\mathrm{Ca}^{2+}$. Hemming et al. (1989) mostraram várias combinações das porcentagens em ppm de $\mathrm{Fe}^{2+} / \mathrm{Mn}^{2+}$ em calcitas da Formação Lake Valley, sendo a intensidade da catodoluminescência variável.

Pode-se observar que a intensidade da catodoluminescência dos carbonatos aumenta na seguinte seqüência: condições de água subterrânea rasa, ambientes influenciados por água meteóricas, ambientes influenciados por água subterrânea profundas e finalmente em ambientes marinhos (Meyers 1974).

Quanto ao mármore dolomítico da região da Bocaina, em Ouro Preto, nas lâminas estudadas, ficou bem visível o fenômeno da catodoluminescência, especialmente nos grãos de dolomita. Pela emissão de luz no espectro visível, observaram-se cores bem vivas, com tonalidades que variaram do vermelho ao laranja. Nos grãos de dolomita e quartzo dos veios mineralizados em topázio imperial, não foi observado o fenômeno. Essa diferença índica um quimismo distinto entre a rocha e o veio mineralizado. Porém, nas micas dispersas no veio mineralizado, uma coloração azulada foi detectada devido à presença de elementos ativadores.

Já no topázio, sabe-se que o ferro quando presente em sua estrutura, inibe o fenômeno da catodoluminescência, constituíndo-se num elemento restritivo, ao passo que os topázios, onde o ferro não está presente, podem exibir uma cor azulada (Marshall 1988). Para o topázio imperial da região de Ouro Preto, por este método, não mostrou luminescência alguma, comprovando a existência de ferro na sua estrutura.

\section{2 - COMPOSIÇÃO QUÍMICA}

Os primeiros pesquisadores a estabelecer a fórmula do topázio, $[\mathrm{Al}(\mathrm{F}, \mathrm{OH})]_{2} \mathrm{SiO}_{4}$, com suas implicações na densidade e propriedades ópticas, em função da razão $\mathrm{F}^{-} / \mathrm{OH}^{-}$, foram Penfield \& Minor Jr. (1894, in Ribbe \& Rosenberg 1971). Sua composição química é razoavelmente constante, destacando-se no entanto a variação da relação entre os íons fluoreto e hidroxila. Para o flúor, o teor máximo descrito foi de $20,7 \%$, enquanto para a hidroxila o maior valor encontrado foi de, aproximadamente, 2,18\% (Deer et al. 1982). Segundo Magalhães (1989), os topázios podem apresentar em sua estrutura uma grande quantidade de elementos traços, tais como: Ag, 
As, B, Ba, Be, Bi, Br, Ca, Cd, Cl, Co, Cu, Cr, Cs, Fe, Ga, Ge, Hf, I, In, K, La, Li, Mg, Mn, Mo, $\mathrm{Na}, \mathrm{Nb}, \mathrm{Ni}, \mathrm{Pb}, \mathrm{Rb}, \mathrm{Re}, \mathrm{Sb}, \mathrm{Sc}, \mathrm{Se}, \mathrm{Sn}, \mathrm{Sr}, \mathrm{Ta}, \mathrm{Te}, \mathrm{Ti}, \mathrm{V}, \mathrm{Y}, \mathrm{Zn}, \mathrm{Zr}, \mathrm{W}$, como também os elementos $\mathrm{Ce}, \mathrm{Pr}, \mathrm{Nd}, \mathrm{Sm}, \mathrm{Eu}, \mathrm{Gd}, \mathrm{Dy}, \mathrm{Yb}$ da série dos lantanidios identificados por espectroscopia de emissão óptica e por ativação neutrônica. Posteriormente, Gandini et al. (1993) utilizando a microssonda eletrônica, além de confirmarem vários desses elementos, também identificaram a presença do fósforo em topázio esverdeado da região de Ouro Preto.

A Tabela 3 apresenta os dados referentes aos elementos químicos principais e menores de amostras de topázio de uma jazida da região de Dom Bosco (DB), município de Ouro Preto, obtidas para os seis tipos principais de cores observados entre elas, ou seja, verde (VERD), incolor (INC), amarelo-claro.(AMC), amarelo (AM), róseo (ROS) e laranja (LAR.). Observa-se pelas referidas análises, que entre as impurezas, destacam-se fósforo, magnésio, ferro, cromo, vanádio, germânio, bário, estrôncio, níquel e zircônio. Foord et al. (1988), referem aos topázios formados em ambientes pegmatíticos ou de greisens com teores de Ge entre 200 a 500ppm. Os de Ouro Preto variaram entre 100 a $700 \mathrm{ppm}$, com exceção do topázio de cor rósea, onde este elemento não aparece. Outros elementos tais como titânio, manganês, cálcio e potássio, ocorrem com valores próximos ao limite de detecção do aparelho.

Segundo Deer et al. (1982), para topázios de outros locais, os teores de $\mathrm{SiO}_{2}$ variam de 30,62 a $33.00 \%$, os de $\mathrm{Al}_{2} \mathrm{O}_{3}$ de 53,24 a $56,76 \%$ e o valor de $\mathrm{F}^{-}$de 12,40 a 20,37\%. Pela Tabela 3 , observa-se que nos topázios da região de Dom Bosco, o $\mathrm{SiO}_{2}$ varia de 32,02 a $32,91 \%$; o $\mathrm{Al}_{2} \mathrm{O}_{3}$ entre 54,10 a 55,64\%, o $\mathrm{F}^{-}$de 13,89 a $18,41 \%$ e o de $\mathrm{OH}^{-}$de 5,73 a 7,75\%. Gübelin et al. (1986) apresentam dados referentes a um topázio de cor rosa, do Paquistão, sendo que os valores mais divergentes para um da mesma cor da região de Ouro Preto são os teores de ferro (800ppm), magnésio (700ppm) e cálcio (500ppm), mostrando-se mais elevados que o material brasileiro (comparar os dados com a Tabela 3). Na Tabela 4 estão representadas outras análises de topázios de diversas localidades mundiais, com a finalidade de fazer uma comparação com os topázios da região de Ouro Preto. 
TABELA 3 - Análises quimicas de topäzios coloridos da jazida de Dom Bosco, obtidas a pariir de microssonda eletrỏnim

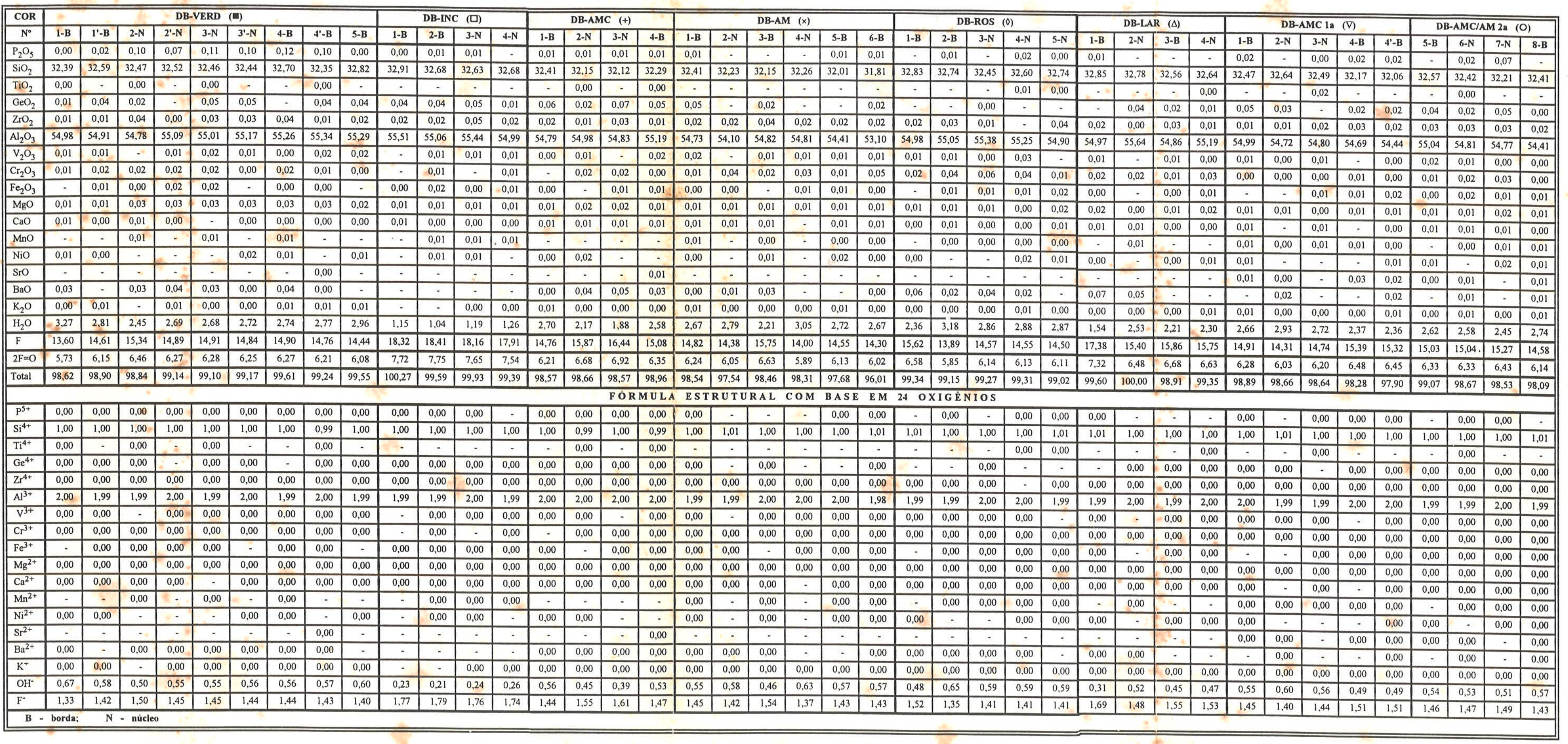

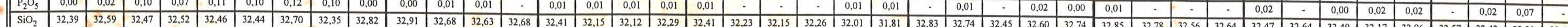

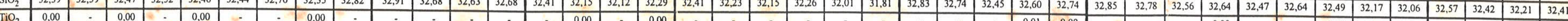

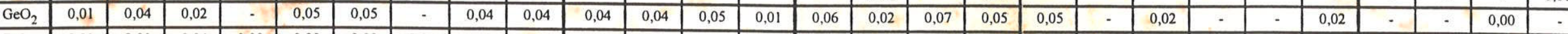

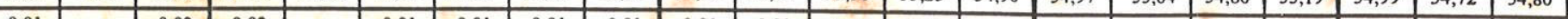

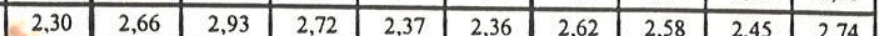

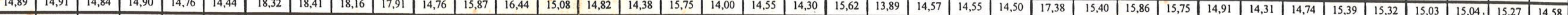


TABELA 4 - Análises quimicas de topázios de vários locais do mundo. obtidos da literatura. Na análise 8 . o autor informa ser de coloração amarelada e de Minas Gerais. porém não se sabe se é um topázio imperial da região de Ouro Preto. A tabela foi construída com valores decrescente de fluor.

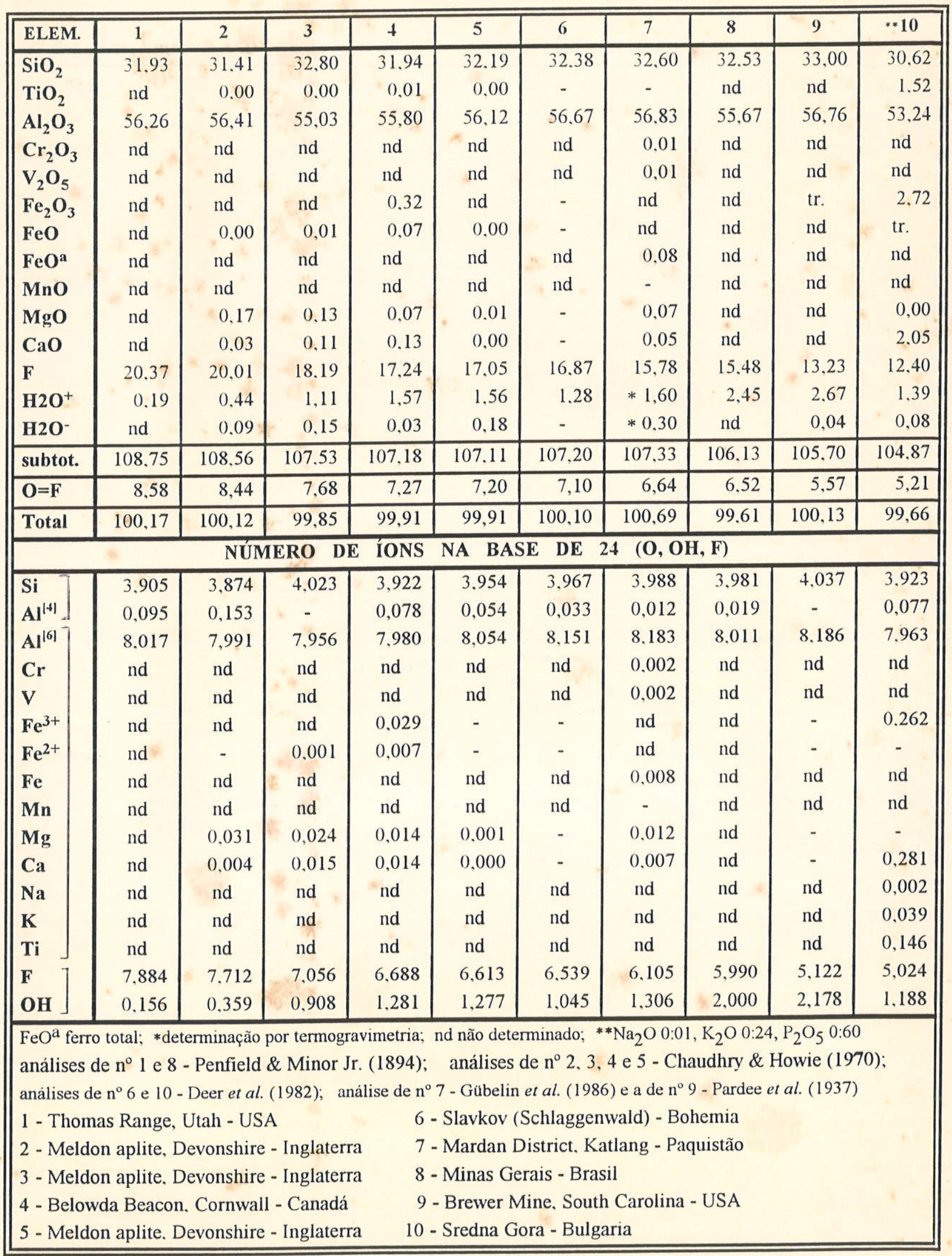


Como já foi dito, várias propriedades físicas do topázio estão relacionadas com a razão $\mathrm{F}^{-} / \mathrm{OH}^{-}$. Quanto maior o valor de flúor, maior também a densidade e o ângulo $2 \mathrm{~V}_{\mathrm{Z}}$ e menor os índices de refração e o parâmetro bo (Rosenberg 1967, Ribbe \& Rosenberg 1971). Segundo Petricorena (1989), os topázios mais ricos em flúor são os mais abundantes e ocorrem nas cores azul, amarelo, castanho, verde ou incolor. Já os topázios mais ricos em hidroxila, são mais escassos, ocorrendo nas cores amarelo forte, amarelo-acastanhada, rosa e rosa-intenso, sendo característicos da região de Ouro Preto. Neste trabalho, estes dois componentes foram analisados separadamente, por técnicas distintas de via úmida. No caso da hidroxila utilizou-se o método de perda ao fogo e no caso do flúor utilizou-se o método do eletrodo de íon específico, além da microssonda eletrônica. Os cristais róseos de topázio do morro de Ghundao, no Paquistão, também foram analisados por Gübelin et al. (1986) pelo eletrodo de íon específico para flúor, tendo sido detectado cerca de $15,78 \%$ deste elemento, com valores bem semelhantes aos de Ouro Preto, apesar da ausência da fluorita. Para as mineralizações de topázio do distrito de Mardan, no Paquistão, a fluorita não está presente nem no veio e nem na rocha encaixante. Apesar disto, os topázios contêm aproximadamente $14 \%$ de $\mathrm{F}^{-}$e deve ter sido formado in situ por atividades hidrotermal/pneumatolítica, seguido por movimentos tectônicos onde resultou em sua incorporação nos veios de calcita de formação tardia (Jam 1979).

A Tabela 5 mostra dados em porcentagens de $\mathrm{H}_{2} \mathrm{O}^{-}$e $\mathrm{H}_{2} \mathrm{O}^{+}$obtidos por gravimetria, e dados de $\mathrm{F}^{-}$obtidos pelo método do eletrodo de íon específico. Com relação a $\mathrm{H}_{2} \mathrm{O}^{+}$, os dados revelaram valores acima dos esperados, provavelmente devido à presença de outros voláteis, quando comparados com a Tabela 4. Os valores de $\mathrm{H}_{2} \mathrm{O}$ e de $\mathrm{F}^{-}$não mostraram nenhuma variação apreciável.

Os dados de porcentagens do $\mathrm{OH}^{-}$e $\mathrm{F}^{-}$estão representados na Figura 16, e a razão $\mathrm{F}^{-} / \mathrm{OH}^{-}$distribuída em cristais de cores distintas, estão ilustradas nas Figuras 17 e 18.

\section{3 - COR E PLEOCROÍSMO}

Uma das propriedades mais notáveis do topázio imperial é a cor. Os cristais podem apresentarse nos vários matizes do amarelo variando do amarelo pálido ao vermelho conhaque, sendo mais raro os de coloração verde e incolor. Considerando que o topázio é um mineral alocromático, efetuaram-se análises a partir de microssonda eletrônica em amostras apresentando diferentes colorações, com o objetivo de correlacionar a variação da cor com a presença de elementos cromóforos. Os dados obtidos mostraram que os teores de ferro, vanádio e de cromo são relativamente altos, sugerindo tratar-se de elementos cromóforos.

Os mecanismos responsáveis pelas variações da cor do topázio ainda não são bem conhecidos. O topázio da região de Ouro Preto pode se apresentar em tonalidades variáveis do amarelo, laranja, róseo e avermelhado (cor de conhaque) e raramente incolor e verde (Fotografia 15). Às vezes, é comum empregar o termo sherry (jerez ou rosé), para cristais de cor castanho-amarelado ou castanhoalaranjado (Deer et al. 1982). 
TABELA 5 - Porcentagens de $\mathrm{H}_{2} \mathrm{O}^{-}$e $\mathrm{H}_{2} \mathrm{O}^{+}$analisadas por gravimetria e porcentagens de flúor analisado pelo método de eletrodo seletivo.

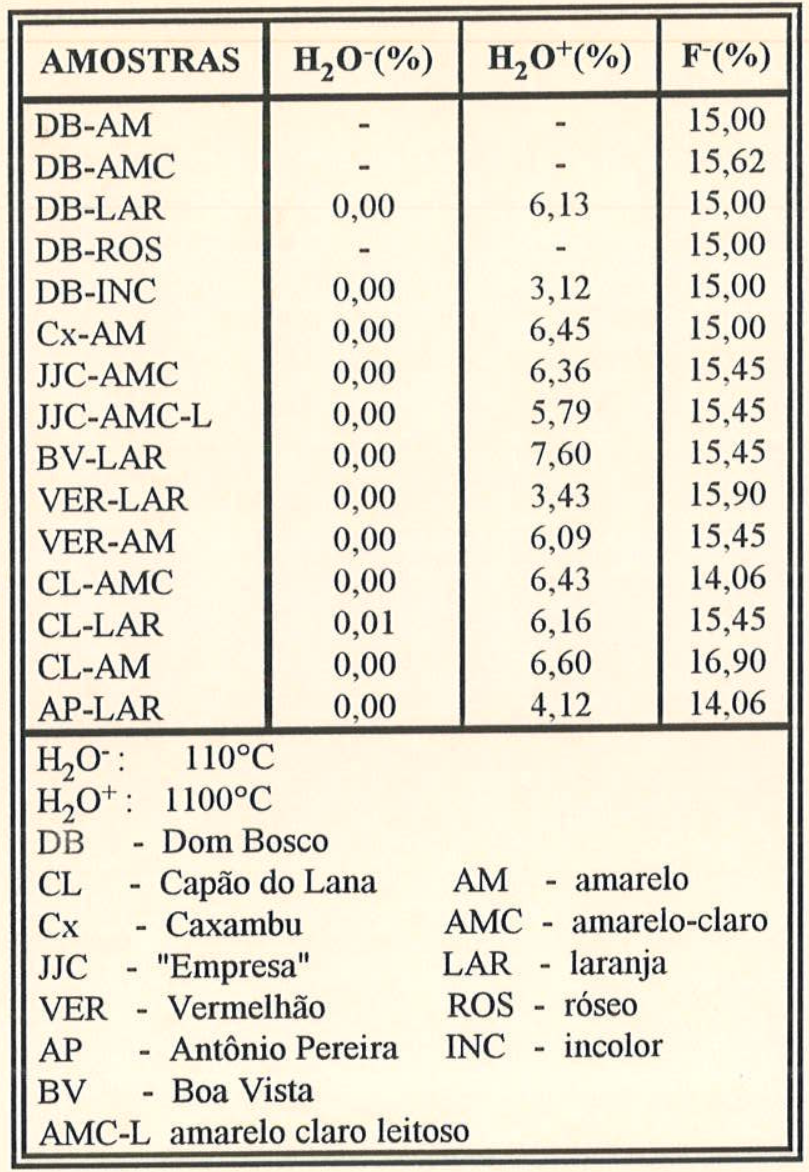

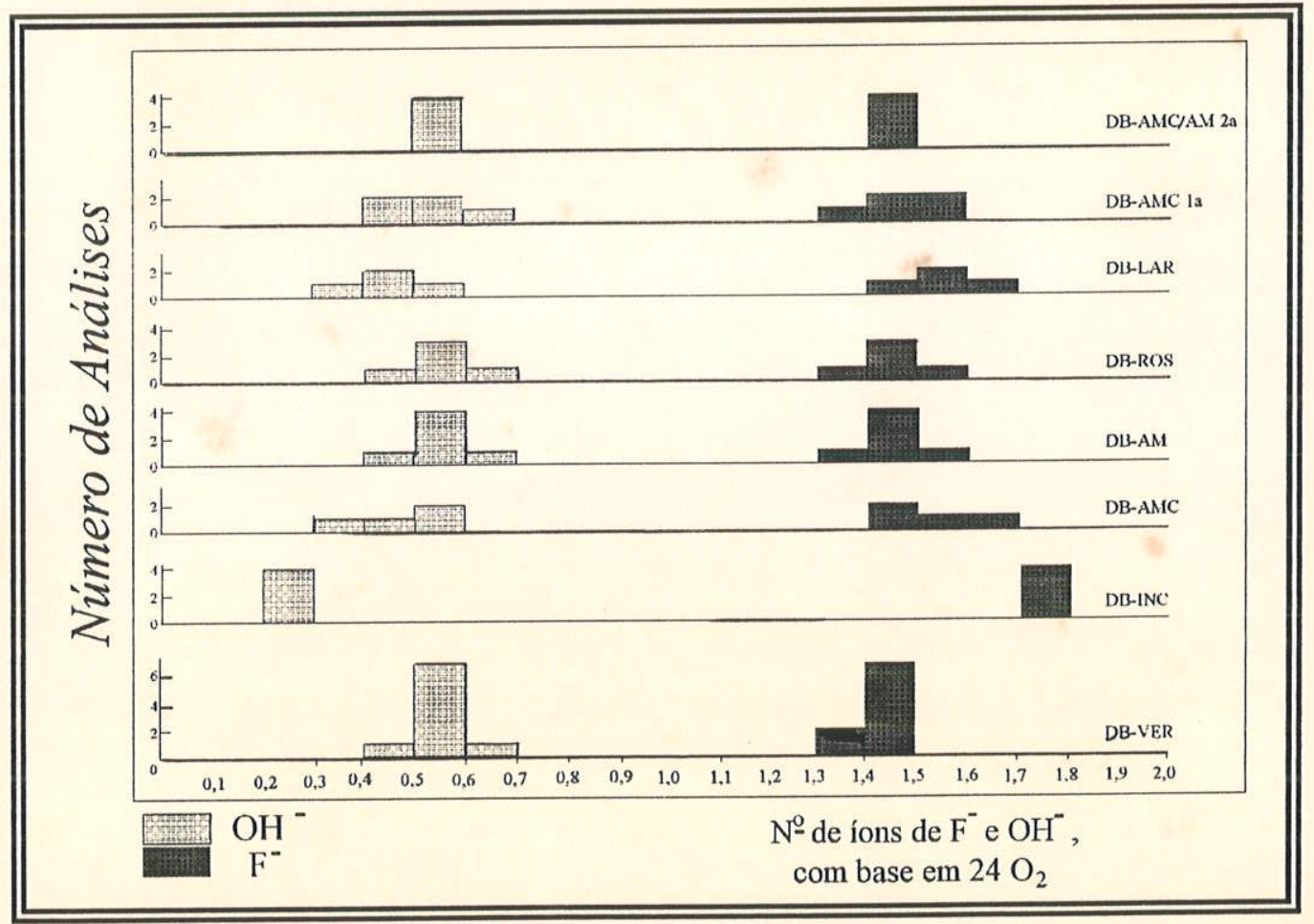

FIGURA 16 - Histogramas de $\mathrm{OH}^{-}$e $\mathrm{F}^{-}$de topázios coloridos da região de Dom Bosco, município de Ouro Preto. Observa-se que o topázio incolor apresenta um valor mais elevado de flúor se comparado com os demais cristais. 

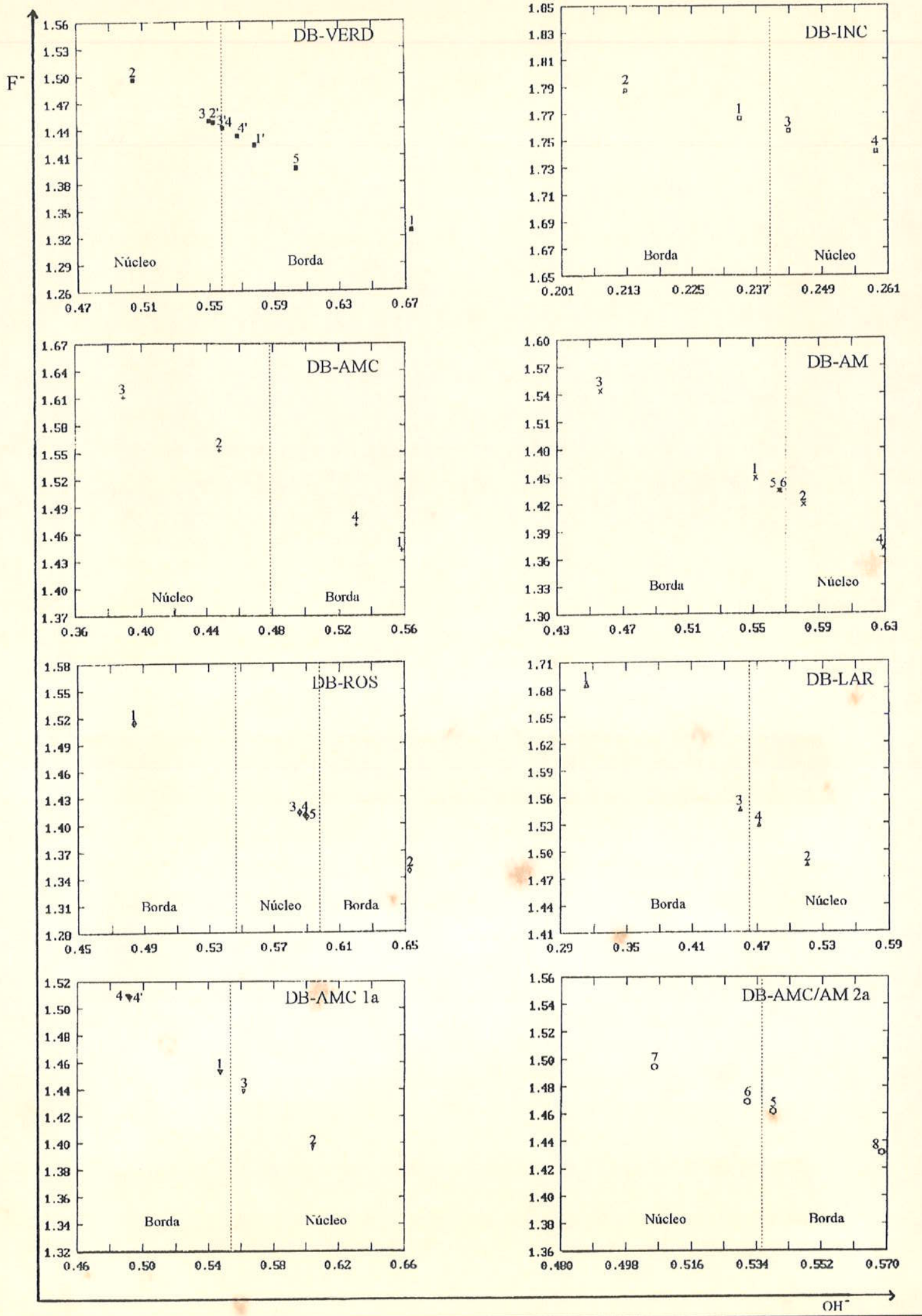

FIGURA 17 - Diagramas $\mathrm{F}^{-} \mathrm{xOH}^{-}$(nº de íons na base de 24 oxigênios) de topázios de várias cores da região de Dom Bosco, mostrando a distribuição desses elementos nos topázios. Os números dos pontos analisados correspondem aos da Tabela 3. 


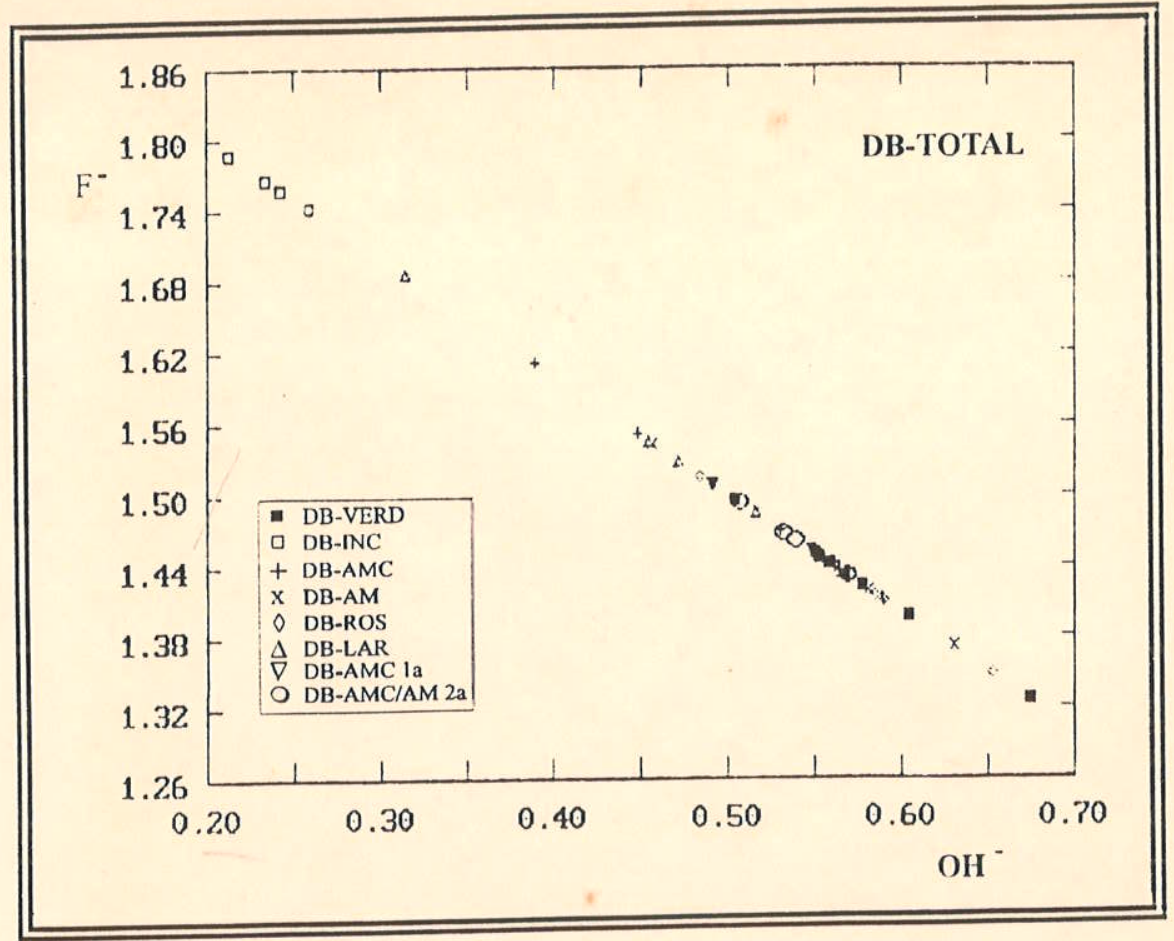

FIGURA 18 - Diagrama mostrando a relação entre $\mathrm{F}^{-} \mathrm{xOH}^{-}$( $\mathrm{n}^{\circ}$ de ions na base de 24 oxigênios) de todos os cristais da Figura 17. Observa-se que o valor de flúor varia de um máximo no incolor a um mínimo no verde.

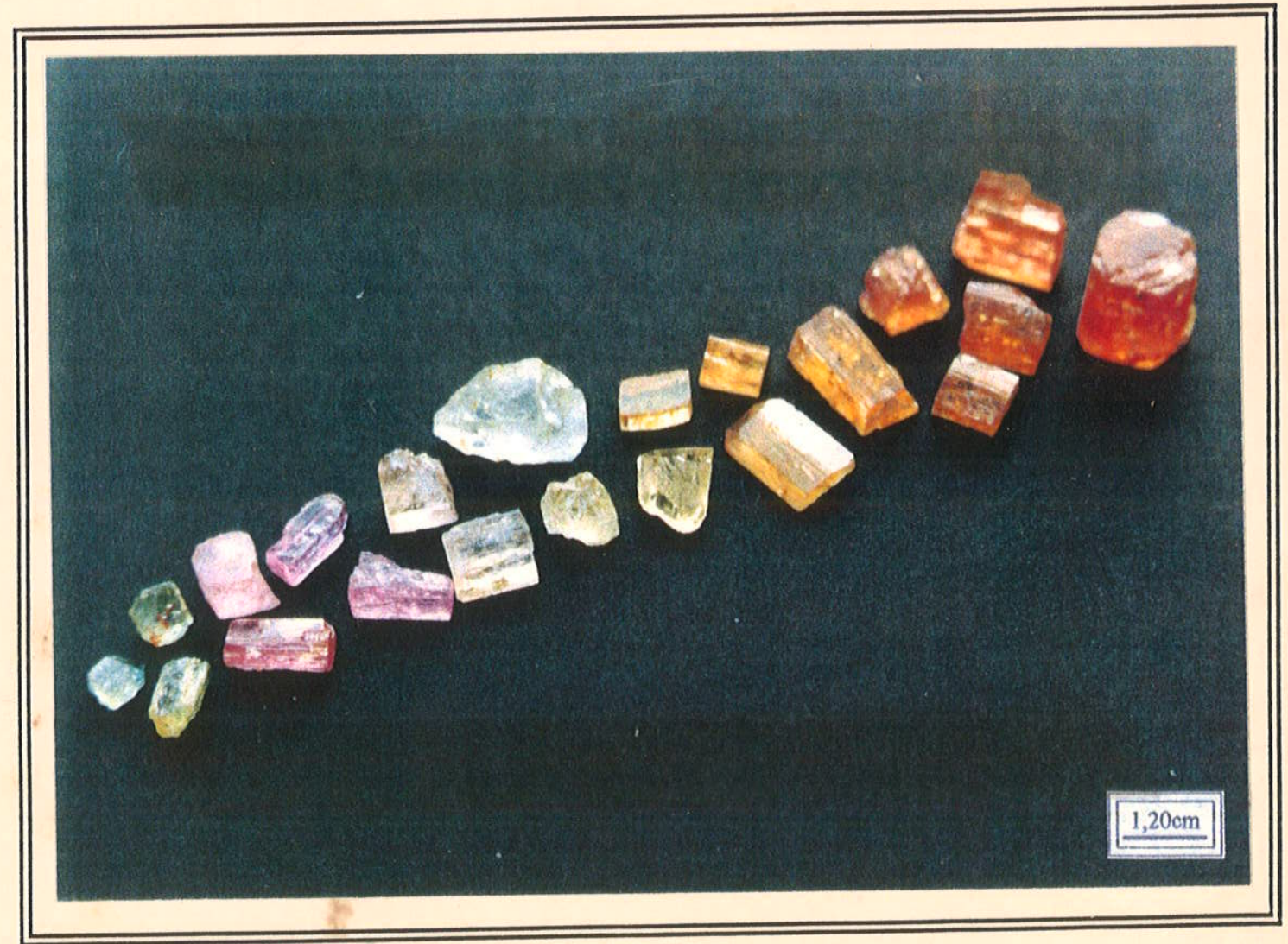

FOTOGRAFIA 15 - Conjunto de cristais de topázio imperial provenientes de várias jazidas da região de Ouro Preto. Neste lote estão presentes exemplares da maior parte das cores observadas na região. 
Para Webster (1980) e Gübelin et al. (1986), todos os cristais de topázio róseos, usados na joalheria, provêm dos topázios imperiais da região de Ouro Preto que sofreram tratamento térmico. Segundo Gübelin et al. (1986), só no Paquistão ocorre in situ esta cor nos topázios, na realidade observou-se que em Ouro Preto eles ocorrem também naturalmente. Os de cor castanho-avermelhada, aquecidos lentamente até $450^{\circ} \mathrm{C}$, a princípio ficam incolores, após o resfriamento, tornam-se rosa-salmão a vermelho-púrpura, dependendo da cor original e da intensidade do aquecimento. Segundo Webster (1980), esta mudança é devida a presença de cromo no retículo cristalino do topázio. Nassau (1985) refere-se também a essa cor pelo tratamento térmico, mas não descarta a existência natural de cristais róseos. Para Sinkankas (1981), os de coloração amarela, amarela-alaranjado e laranja-acastanhado, tornam-se róseos após um tratamento térmico entre 300 a $450^{\circ} \mathrm{C}$ seguido de resfriamento. Se a temperatura ultrapassar a $450^{\circ} \mathrm{C}$ eles perdem suas cores ficando incolores. Apesar de serem raros os cristais róseos, eles são encontrados nas jazidas e/ou ocorrências de Ouro Preto.

Outro aspecto interessante, quanto à cor dos topázios imperiais da região de Ouro Preto, é que em alguns casos, ele se apresentam bicolores. Estes são mais raros e podem ocorrer do mesmo modo que as turmalinas, ou seja, pode haver um zoneamento do centro para as bordas ou ao longo do eixo c. Os pares de cores podem ser bem variados (Fotomicrografia 9). São comuns na jazida de Bela Vista, situada nas proximidades da jazida do Capão do Lana, ocorrendo também nas jazidas do Capão do Lana e de Dom Bosco.

Com relação à cor, as variedades amarelas parecem ser enriquecidas em $\mathrm{Cr}, \mathrm{Mn}$, Co e V, como também podem ser produzidas por centros de cor (Deer et al. 1982). Para os topázios de Ouro Preto, são pobres em Mn e o elemento Co não foi analisado. Para a cor rosa, Foord et al. (1988) e Petricorena (1989), citam o Cr como elemento cromóforo.

Através das análises químicas efetuadas nos cristais mostrando cores diferentes de uma jazida da região de Dom Bosco, foi detectada a presença de vários tipos de impurezas (Tabela 3 ). As Figuras 19 e 20, mostram o comportamento desses topázios de cores diversas em relação aos seus possiveis cromóforos mais importantes que são o $\mathrm{Cr}^{3+}, \mathrm{o} \mathrm{V}^{3+}$ e o $\mathrm{Fe}^{3+}$. Em relação ao cromo, este aparece em maior porcentagem no topázio róseo, seguido do amarelo e do laranja, estando também presente no topázio esverdeado, amarelo-claro e incolor, porém em menor porcentagem. O vanádio também aparece com destaque nos topázios de cores rósea, amarela, amarelo-claro e esverdeada. O ferro se destaca no esverdeado e ocorre em menor porcentagem no róseo e incolor. Outros elementos presentes como impurezas e com teores significativos são $\mathrm{Zr}$ e $\mathrm{Ba}$. O fósforo se destaca, com mais de $1.000 \mathrm{ppm}$ no esverdeado, sendo que nos demais seu teor é bem baixo. Todas essas variações de porcentagens dos vários elementos ficam dificeis de se comparar com as diversas análises químicas de outros topázios de diferentes localidades, normalmente devido à pequena quantidade de elementos analisados. Comparando as Tabelas $3 \mathrm{e}$ 4, destacam-se as porcentagens de $\mathrm{Fe}_{2} \mathrm{O}_{3}, \mathrm{MgO}$ e de $\mathrm{CaO}$, cujos valores são muito mais altos que aquelas dos topázios da região de Ouro Preto. 


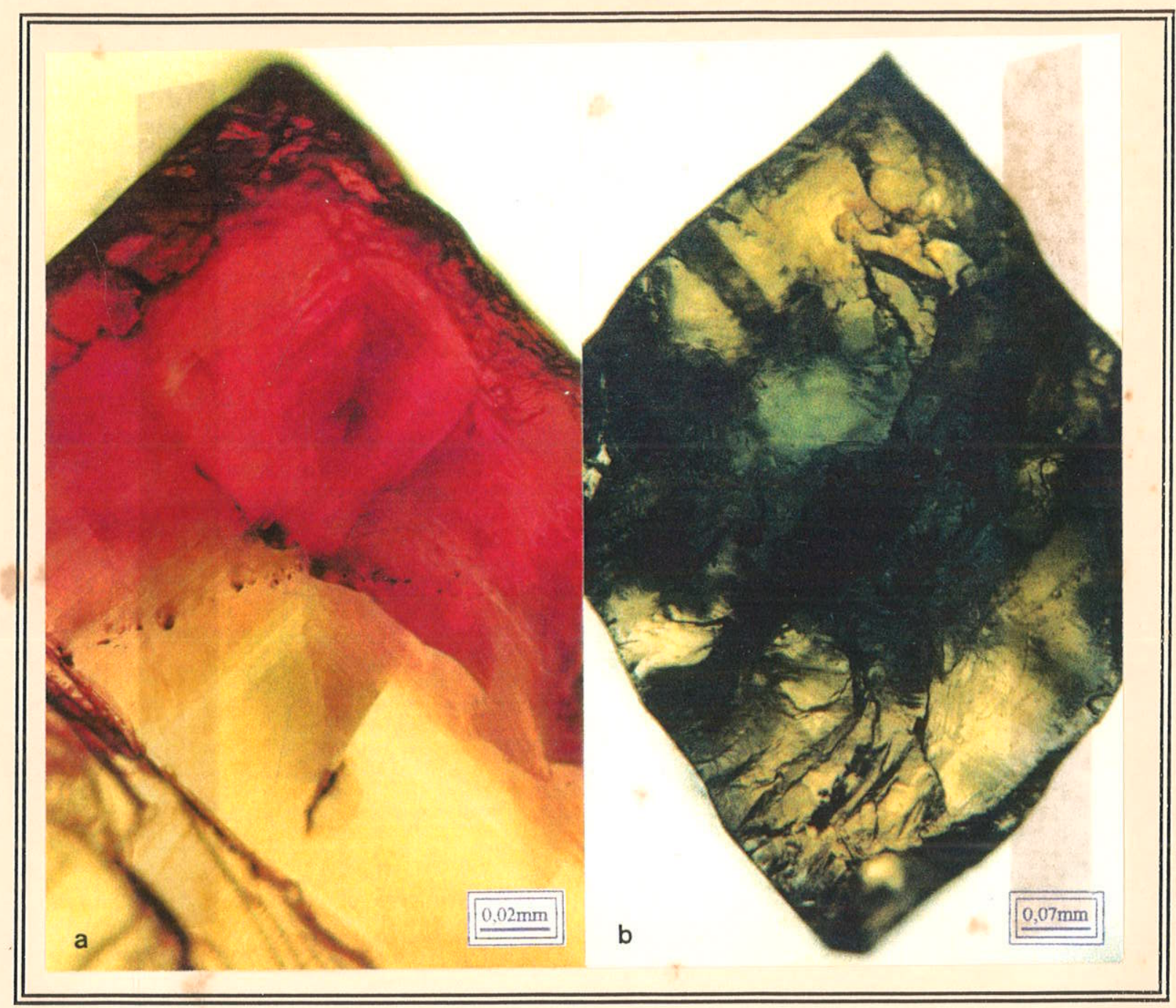

FOTOMICROGRAFIA 9 - a) zoneamento de cor de um cristal de topázio da jazida do Capão do Lana e b) idem. para um cristal da jazida de Dom Bosco. Ambos vistos pela seçăo basal.

A cor de pleocroísmo é variável e depende essencialmente da intensidade da cor dos espécimes analisados. Os cristais de topázio da região de Ouro Preto, quando observados em lupa binocular, apresentam pleocroísmo distinto, mas não muito forte. O fenômeno é bem nítido em cristais róseos, que mostram as tonalidades $\mathrm{X}=$ incolor, $\mathrm{Y}=$ rosa pálido e $\mathrm{Z}=$ rosa. Quando são observados em dicroscópio, os de tom sherry, exibem cor $\mathrm{X}=$ amarelo-mel, $\mathrm{Y}=$ amarelo-palha e $Z=$ amarelo-rosado em cada uma das três direções. Para os esverdeados, as cores de pleocroísmo são $\mathrm{X}=$ verde-pálido, $\mathrm{Y}=$ verde-azulado claro e $\mathrm{Z}=$ incolor a esverdeado. Já no topázio de coloração amarela, o pleocroísmo apresenta as seguintes variações de matizes, tais como $X=$ amarelo-limão, $\mathrm{Y}=$ amarelo-mel e $\mathrm{Z}=$ amarelo-palha (Fotomicrografia 10). 


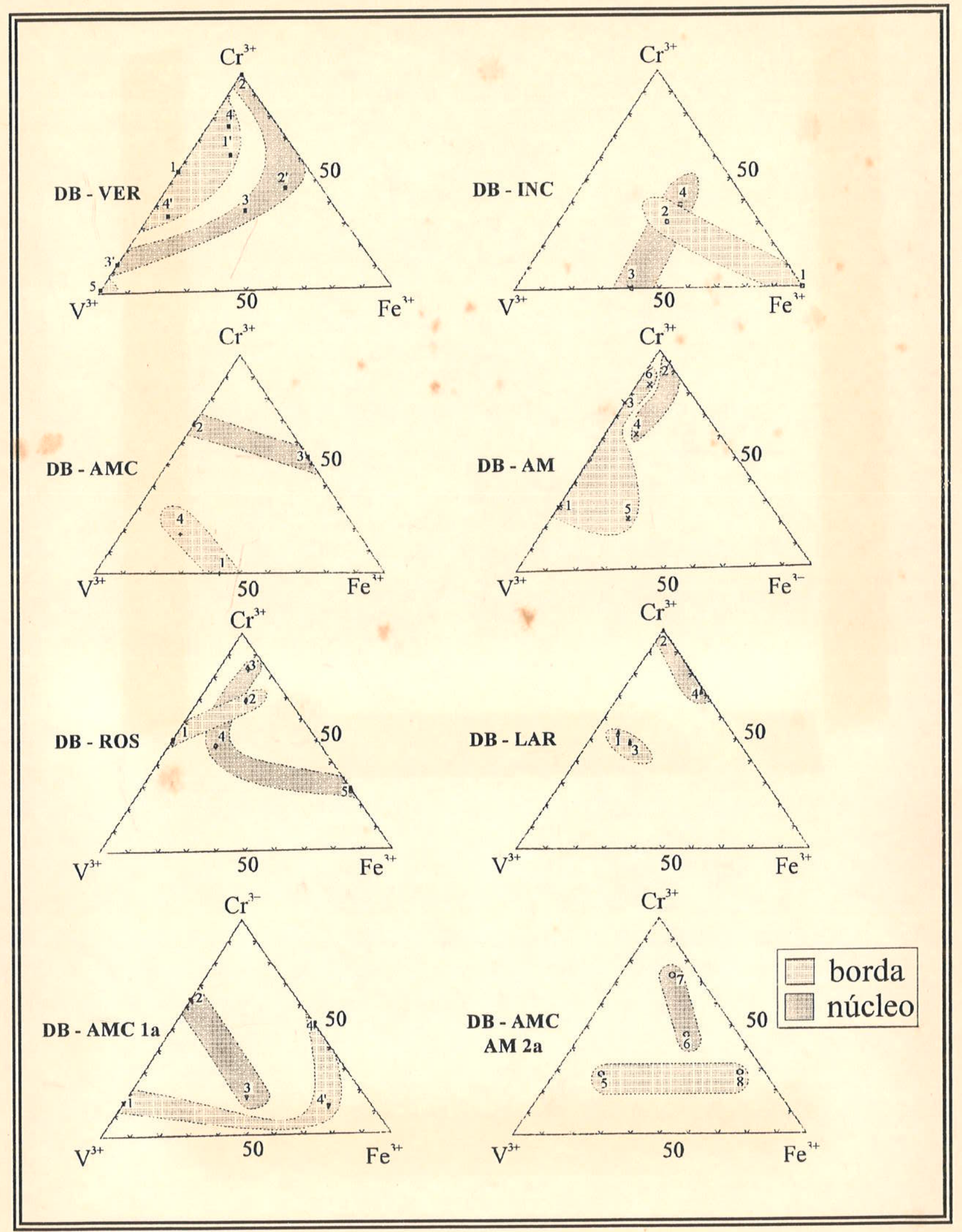

FIGURA 19 - Diagramas $\mathrm{Cr}^{3+}-\mathrm{V}^{3+}-\mathrm{Fe}^{3+}\left(\mathrm{n}^{\circ}\right.$ de íons na base de 24 oxigênios) mostrando a distribuição isoladamente desses elementos para topázios de cores diferentes da região de Dom Bosco. Estes elementos são tidos como cromóforos de várias espécies minerais. 


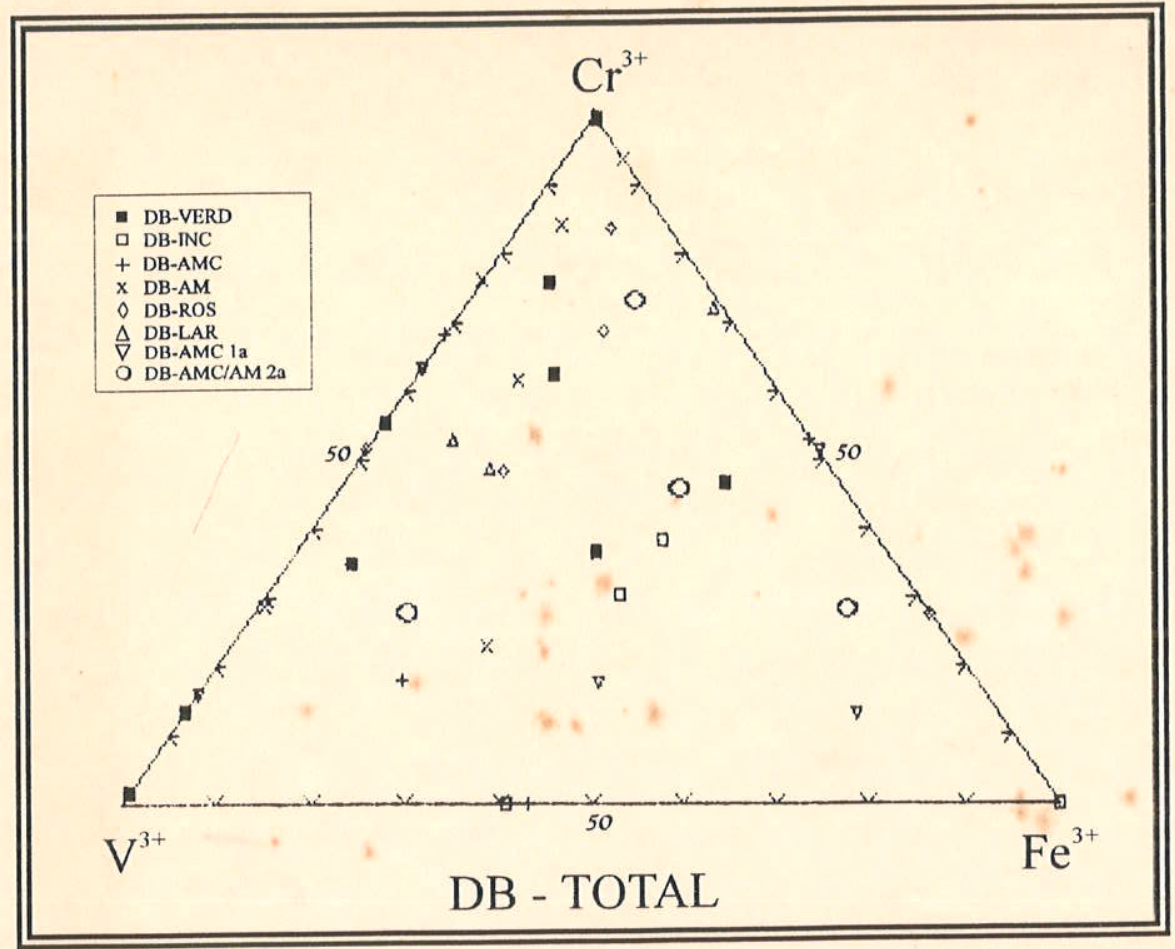

FIGURA 20 - Diagrama $\mathrm{Cr}^{3+}-\mathrm{V}^{3+}-\mathrm{Fe}^{3+}$ ( $\mathrm{n}^{\circ}$ de íons na base de 24 oxigênios) destacando a ausência de um padrão definido de relação entre esses elementos e a cor, de todos os cristais da Figura 19.

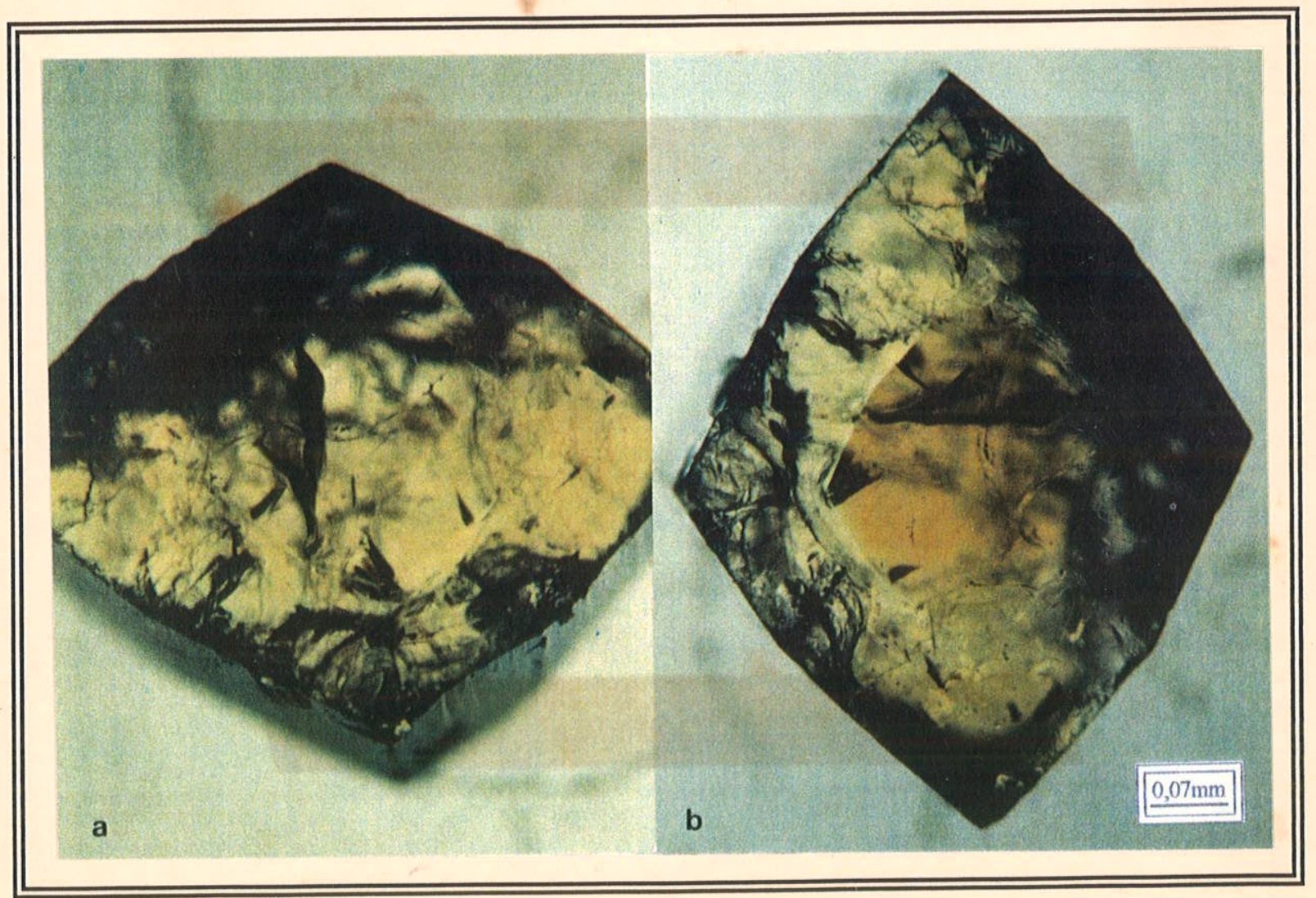

FOTOMICROGRAFIA 10 - Fenômeno de pleocroísmo observado em um topázio amarelo de Antônio Nery, na direção (001). Ambas com filtro polaróide. 


\section{4 - ÍNDICES DE REFRAÇÃO}

Algumas variações nas propriedades opticas do topázio são devidas às variações da razão $\mathrm{F}^{-} / \mathrm{OH}^{-}$, fato que vem sendo mencionado desde Penfield \& Minor Jr. (1894, in Rosenberg 1967).

Os valores dos índices de refração também apresentam variações dependendo da cor do topázio. Deer et al. (1982) e Klein \& Hurlbut Jr. (1985) fornecem os índices de refração $\mathrm{nX}=1,606-1,629 ; \mathrm{nY}=1,609-1,631$ e $\mathrm{nZ}=1,616-1,638$, sem contudo relacioná-los com a cor. Gübelin et al. (1986) foram os primeiros autores a correlacionar essas medidas com as diversas tonalidades de cores do topázio imperial do Paquistão. Os dados obtidos para o róseo variaram de 1,629 a 1,631 para $\mathrm{nX}$, de 1,631 a 1,634 para nY e de 1,638 a 1,642 para $\mathrm{nZ}$, com uma birrefringência variando entre 0,009 e 0,011. Para o incolor, $\mathrm{nX}$ varia de 1,610 a 1,612, nY de 1,612 a 1,615 e nZ de 1,620 a 1,623, com a birrefringência variando entre 0,010 e 0,011. Finalmente para o acastanhado, $n X=1,608-1,611 ; n Y=1,611-1,614$ e $\mathrm{nZ}=1,617-1,621$, com uma birrefringência variando de 0,009 a 0,010. Petricorena (1989), apesar de mencionar a cor para os topázios por ele estudados, sem fazer referência à procedência, cita apenas dois valores para o índice de refração $(1,63$ e 1,64) e uma birrefringência igual a 0,008 .

No decorrer deste trabalho, os índices de refração do topázio imperial da região de Ouro Preto foram medidos por meio de um refratômetro para sólidos, modelo TOPCON, disponível no laboratório do DEGEO/EM/UFOP. Os valores obtidos em 83 determinações estão apresentados nas Tabelas 6 e 7. As medidas dos índices de refração variam entre 1,619 e 1,625 para nX, de 1,623 a 1,631 para $n Y$ e de 1,629 a 1,639 para nZ, com a birrefringência, variando de 0,008 a 0,015 .

Como já proposto por Gübelin et al. (1986), pode-se observar pelos dados obtidos, que os valores dos índices de refração mostram uma relação com a coloração do topázio.

De posse dos valores dos índices de refração (n) (Tabela 7), juntamente com as porcentagens de flúor desses topázios, construiu-se um gráfico $\mathrm{nx}_{\%} \mathrm{~F}^{-}$(Figura 21), onde essas relações estão de acordo com as da literatura (Deer et al. 1982). Nota-se apenas que os dados do topázio de coloração amarelo-claro estão abaixo do esperado, provavelmente, ligados a algum componente químico, que pode interferir na estrutura do topázio. 
TABELA 6 - Índices de refração de um cristal de topázio, de coloração amarelada, proveniente da jazida do Capão do Lana. As medidas foram feitas com o auxilio de um refratômetro TOPCON para sólidos, em três direções cristalográficas diferentes.

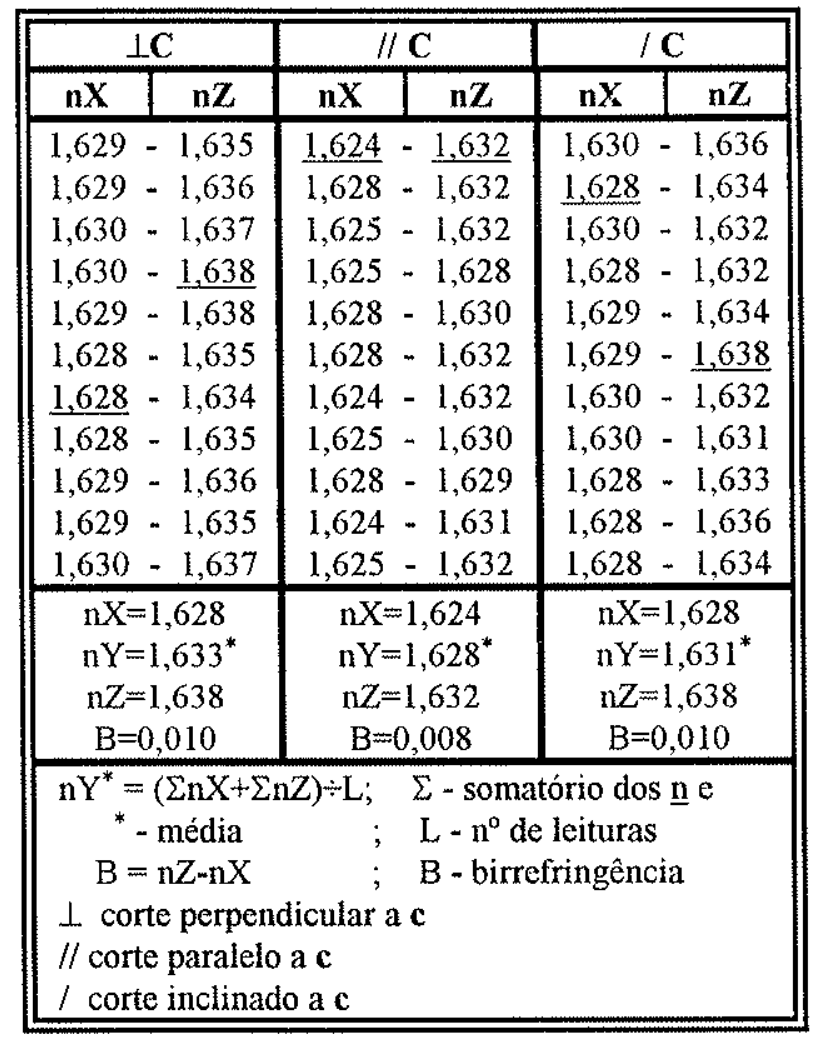

TABELA 7 - Índices de refração de cinco cristais de topázio de colorações diferentes da jazida de Dom Bosco, obtidos no refratômetro para sólidos.

\begin{tabular}{|c|c|c|c|c|c|c|c|c|c|}
\hline \multicolumn{2}{|c|}{ DB-INC } & \multicolumn{2}{|c|}{ DB-AMC } & \multicolumn{2}{|c|}{ DB-AM } & \multicolumn{2}{|c|}{ DB-LAR } & \multicolumn{2}{|c|}{ DB-ROS } \\
\hline$n X$ & $\mathrm{nZ}$ & $\mathrm{nX}$ & $\mathrm{nZ}$ & $n \mathbf{n}$ & $\mathrm{nZ}$ & $\mathrm{nX}$ & $n Z$ & $\mathrm{nX}$ & $\mathrm{nZ}$ \\
\hline \multicolumn{2}{|c|}{$1,618-1,624$} & \multicolumn{2}{|c|}{$1,620-1,628$} & \multicolumn{2}{|c|}{$1,625-1,632$} & \multicolumn{2}{|l|}{1,626} & \multicolumn{2}{|c|}{$1,626-1,633$} \\
\hline 1,618 & 1,625 & 1,619 & $-1,628$ & 1,624 & 1,632 & 1,627 & 1,632 & 1,625 & 1,632 \\
\hline 1,617 & 1,625 & 1,619 & - 1,629 & 1,628 & 1,634 & 1,625 & $-1,631$ & 1,629 & 1,638 \\
\hline 1,617 & 1,623 & 1,619 & 1,628 & 1,628 & 1,632 & 1,624 & $-1,630$ & 1,628 & 1,635 \\
\hline 1,618 & 1,624 & 1,619 & 1,628 & 1,628 & 1,633 & 1,625 & $-1,632$ & 1,630 & 1,634 \\
\hline 1,619 & 1,625 & 1,620 & - 1,628 & 1,628 & - 1,634 & 1,628 & $-1,634$ & 1,628 & 1,635 \\
\hline 1,619 & 1,623 & 1,620 & 1,628 & 1,630 & 1,639 & 1,628 & $-1,634$ & 1,628 & 1,634 \\
\hline 1,618 & 1,622 & 1,620 & $-1,629$ & 1,629 & - 1,637 & 1,629 & $-1,633$ & 1,627 & 1,634 \\
\hline 1,616 & 1,622 & 1,619 & $-1,628$ & 1,628 & 1,635 & 1,628 & $-1,633$ & 1,629 & 1,637 \\
\hline 1,615 & 1,622 & 1,619 & - 1,628 & 1,626 & 1,634 & 1,627 & $-1,632$ & 1,628 & 1,635 \\
\hline \multicolumn{2}{|c|}{$\mathrm{nX}=1,615$} & \multicolumn{2}{|c|}{$\mathrm{nX}=1,619$} & \multicolumn{2}{|c|}{$n X=1,624$} & \multicolumn{2}{|c|}{$\mathrm{nX}=1,624$} & \multirow{4}{*}{\multicolumn{2}{|c|}{$\begin{array}{l}\mathrm{nX}=1,625 \\
\mathrm{nY}=1,631 \\
\mathrm{nZ}=1,638\end{array}$}} \\
\hline$n Y=$ & 1,618 & $\mathrm{nY}$ & 1,624 & $\mathrm{nY}=$ & & & 1,629 & & \\
\hline $\mathrm{nZ}=$ & 1,625 & \multirow{2}{*}{\multicolumn{2}{|c|}{$\begin{array}{l}\mathrm{n} Z=1,629 \\
\mathrm{R}=0,010\end{array}$}} & \multicolumn{2}{|c|}{$\mathrm{n} Z=1$} & \multicolumn{2}{|c|}{$\mathrm{nZ}=1,634$} & & \\
\hline \multicolumn{2}{|c|}{$\mathrm{B}=0,010$} & & & $B=$ & 0,015 & & 0,010 & & \\
\hline
\end{tabular}




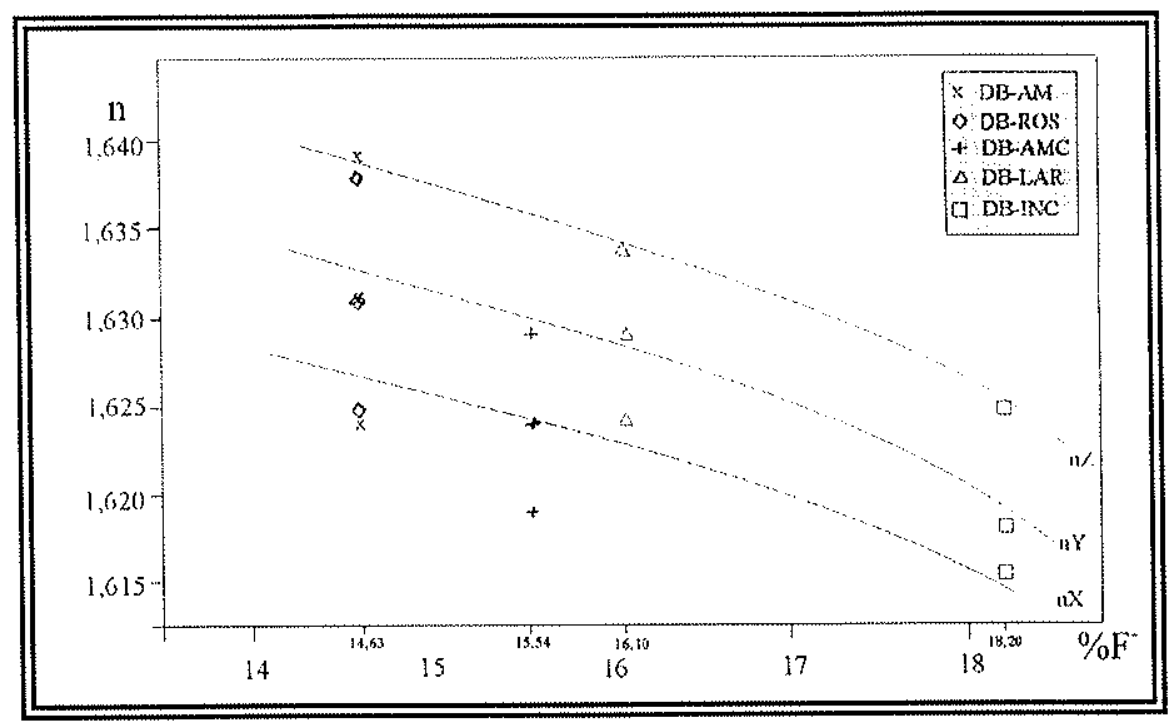

FIGURA 21 - Correlação entre os índices de refração (n) com os teores de flúor encontrados a partir de microssonda eletrônica nos topázios de uma jazida da região de Dom Bosco.

\section{5 - ÂNGULO $2 \mathrm{~V}_{\mathrm{Z}}$}

Os valores do ângulo $2 \mathrm{~V}_{\mathrm{Z}}$, por sua vez, foram obtidos através de uma platina universal, em operação no DEGEO/EM/UFOP, cujo hemisfério de vidro utilizado possui índice de refração 1,649. Como está mostrado na Tabela 8, a média dos valores encontrados no topázio imperial da região de Ouro Preto é de $64^{\circ}$. Esse número concorda com a variação encontrada na literatura que é de $44^{\circ}$ a $68^{\circ}$ (Roubault 1963, Deer et al. 1982). Gübelin et al. (1986) citam para a variedade rosa, valor de $2 \mathrm{~V}_{Z}$ igual a $53^{\circ}$, para o incolor de $53^{\circ} 04^{\prime}$ e para o acastanhado de $56^{\circ} 10^{\prime}$. Rosenberg (1967) cita apenas um cristal proveniente de Ouro Preto, cujo $2 \mathrm{~V}_{Z}$ é igual a $51,8^{\circ}$. Para Rosenberg (1967), o ângulo $2 V_{Z}$ se reduz à medida que cresce o valor de $b_{0}$. Tal fato, concorda com a relação obtida para o topázio imperial da região de Ouro Preto.

TABELA 8 - Valores de $2 \mathrm{~V}_{Z}$ encontrados em cinco cristais de topázio da região de Dom Bosco, mostrando cores bem distintas.

\begin{tabular}{|c|c|c|c|c|}
\hline DB-INC & DB-AMC & DB-AM & DB-LAR & DB-ROS \\
\hline $67^{\circ}$ & $62^{\circ}$ & $64^{\circ}$ & $64^{\circ}$ & $63^{\circ}$ \\
\hline
\end{tabular}


Como pode ser observado na Tabela 8 , dos topázios provenientes da região de Dom Bosco, o incolor é o que apresenta o maior valor de $2 \mathrm{~V}_{Z}\left(67^{\circ}\right)$ e o amarelo-claro o menor $\left(62^{\circ}\right)$. Tal fato indica que o topázio de coloração amarelo-claro deve apresentar o menor valor de $b_{0}$, o que de fato ocorreu, como será discutido posteriormente no item 5.7.2. Quando esses valores de $2 \mathrm{~V}_{Z}$ são lançados em gráficos juntamente com os teores de flúor conforme mostrado na Figura 22, observa-se que existe uma correlação direta entre o crescimento do ângulo $2 \mathrm{~V}_{Z}$ e o teor de flúor. A única medida discordante foi a relativa ao cristal de coloração amarelo-claro. Não foi encontrado nenhum trabalho científico na literatura para explicar tal fato. Pretende-se desenvolver outros trabalhos no futuro para explicar tal discordância.

Certos cristais exibem anomalias ópticas nas seções (010) e (001), quando observados sob nicóis cruzados, mostrando zoneamentos nos quais variam os valores de $2 \mathrm{~V}_{Z}$ e do ângulo de extinção. Essas variações são atribuidas a tensões causadas por mudanças de temperatura maiores do que as da época de formação do mineral. Segundo Rinne (1926, in Deer et al. 1982), aquecendo-se o cristal acima de $950^{\circ} \mathrm{C}$. durante três a cinco horas, esta anomalia desaparece. Outra hipótese é a variação da relação $\mathrm{F}^{-} / \mathrm{OH}^{-}$em determinadas porções da estrutura do cristal. Akizuki et al. (1979) mencionam este fenômeno em cinco cristais de topázio de Ouro Preto. Para Isogami \& Sunagawa (1975), este fenômeno está ligado a defeitos de crescimento. As Fotomicrografias 11 e 12 , ilustram essas anomalias ópticas, que constituem um possivel zoneamento da razão $\mathrm{F}^{-} / \mathrm{OH}^{-}$no topázio imperial da região de Ouro Preto, quando observada num corte paralelo e/ou perpendicular ao eixo c (001).

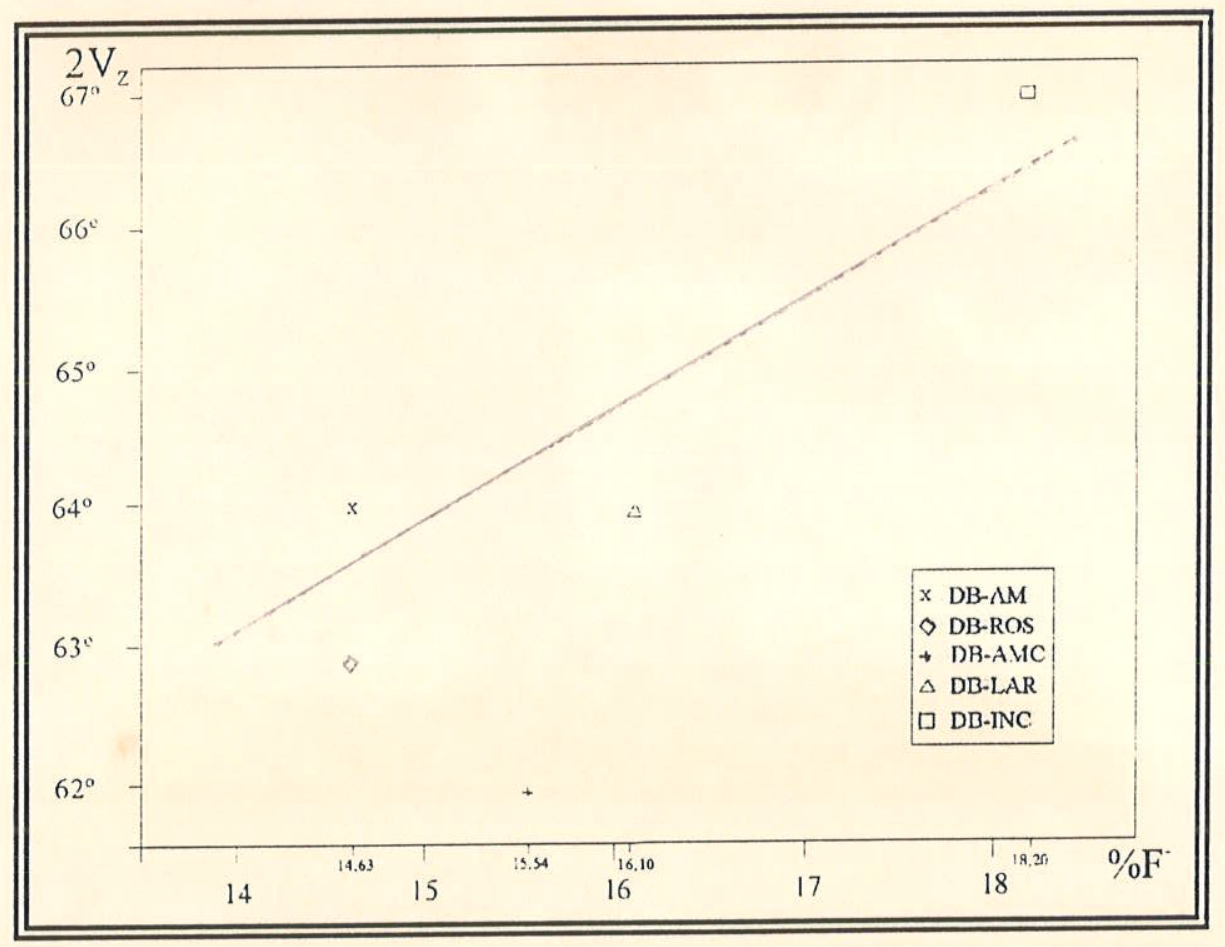

FIGURA 22 - Correlação entre o ângulo $2 \mathrm{~V}_{Z}$ medido e o teor de flúor encontrado a partir de microssonda eletrônica, nos topázios da região de Dom Bosco. 


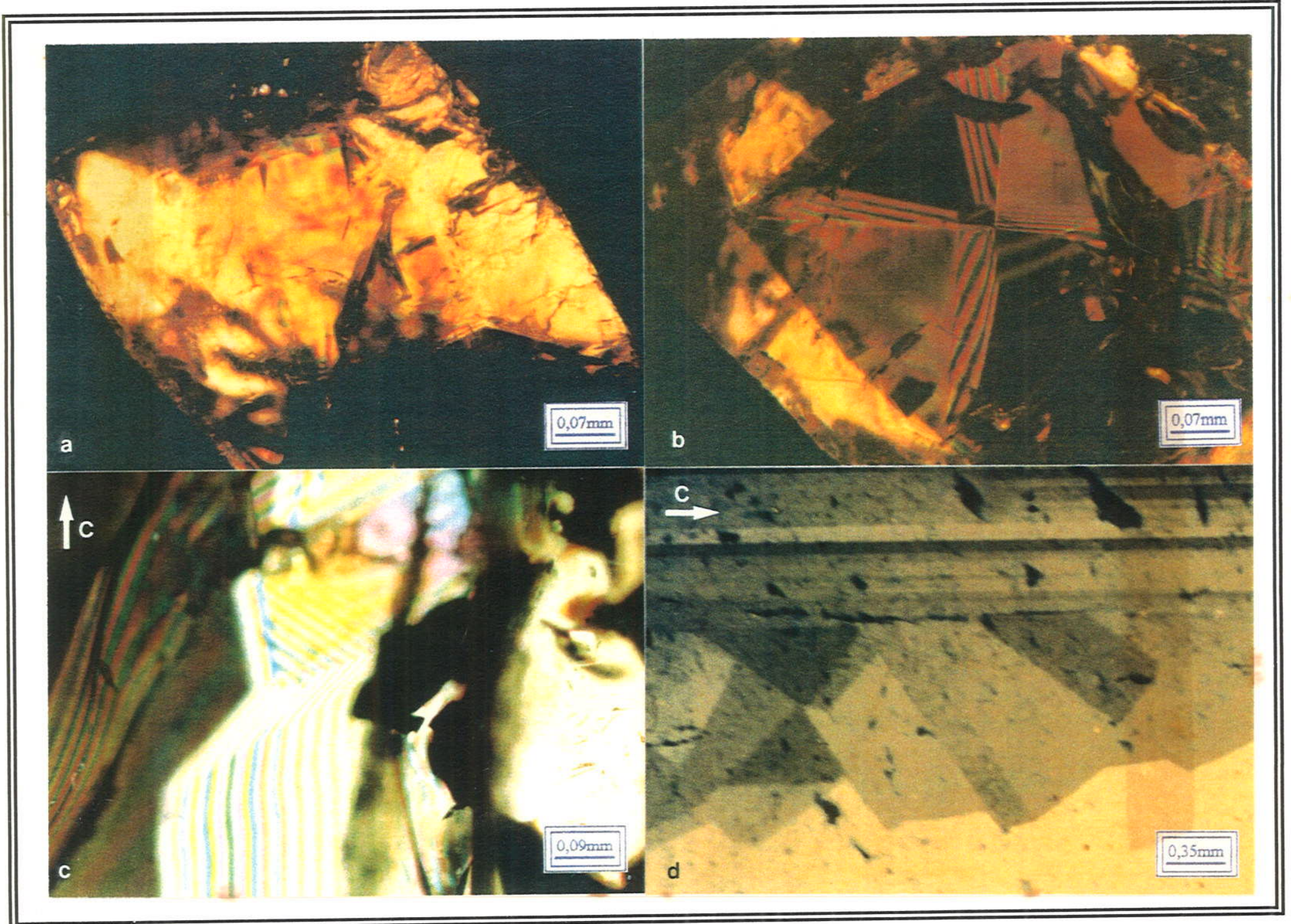

FOTOMICROGRAFIA 11 - Anomalias ópticas em topázio imperial da região de Ouro Preto: a) e b), são referentes a cristais espessos e perpendiculares ao eixo c, c) e d) representam um corte paralelo ao eixo $\mathbf{c}$, sendo o último, uma lâmina delgada. Todos com polarizadores cruzados. 


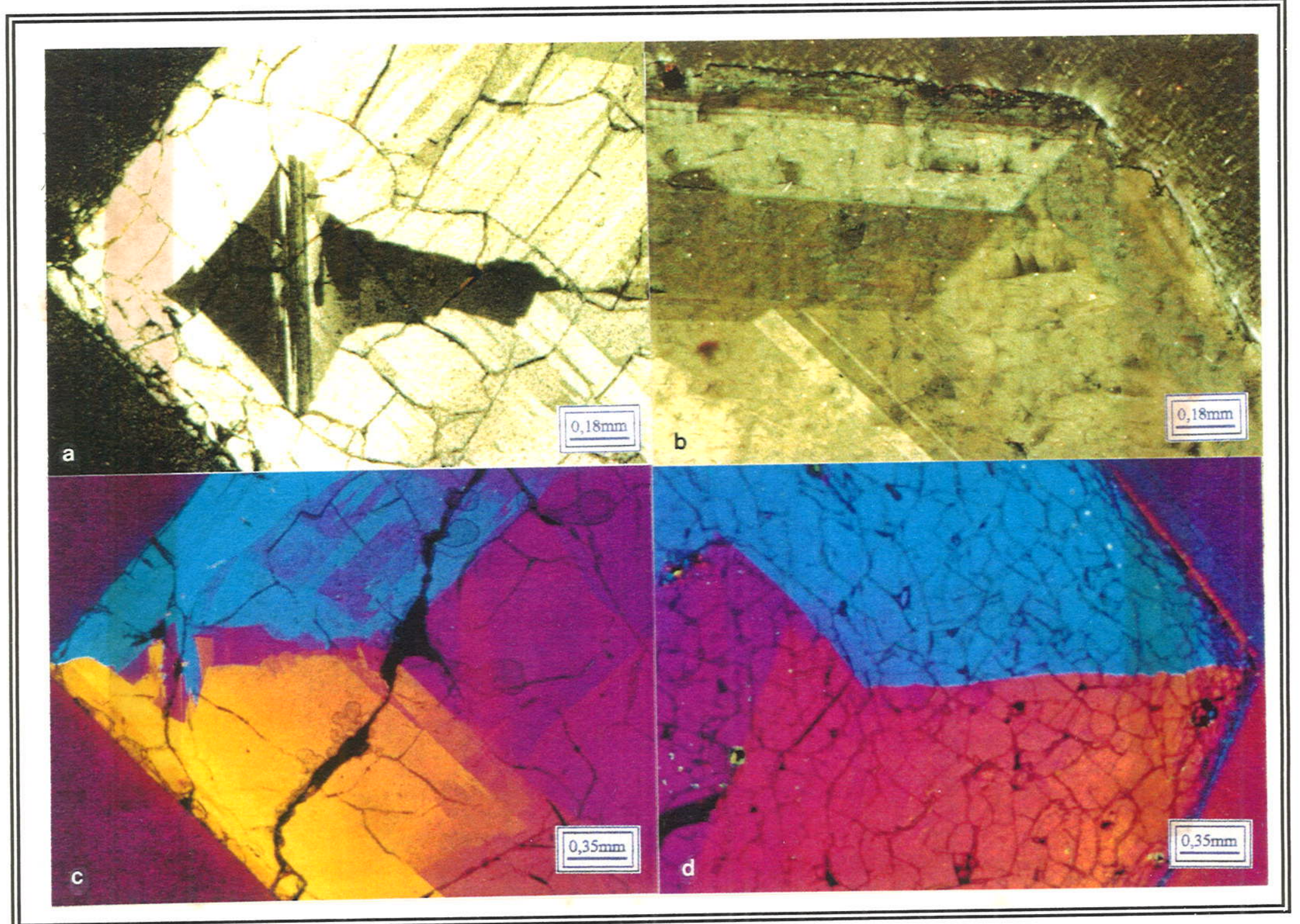

12 - Outras feições de anomalias ópticas. Em a) e b) com polarizadores cruzados e em c) e d) com polarizadores cruzados mais cunha de gipso. Todas as fotomicrografias são de seção basal. 


\section{6 - DENSIDADE RELATIVA}

Segundo Deer et al. (1982), a densidade do topázio $\left[\mathrm{Al}_{2} \mathrm{SiO}_{4}(\mathrm{~F}, \mathrm{OH})_{2}\right]$ varia de 3,49 a 3,57. Vários autores já observaram que a densidade é uma função da razão $\mathrm{F}^{-} / \mathrm{OH}^{-}$presente na estrutura do topázio. Olhoeft \& Johnson (1990) separam o valor da densidade em função da composição desse mineral, ou seja, para o tipo $\mathrm{Al}_{2} \mathrm{SiO}_{4} \mathrm{~F}_{2}$ a densidade é de 3,500 e para $\mathrm{O}$ $\mathrm{Al}_{2} \mathrm{SiO}_{4}(\mathrm{OH})_{2}$ a densidade é de 3,174. Parece existir algum problema com este valor, uma vez que este dado é muito menor do que os dados citados em todos os outros trabalhos científicos consultados. Tröger (1979), também faz uma separação semelhante, citando para o $\mathrm{Al}_{2} \mathrm{SiO}_{4} \mathrm{~F}_{2}$ uma densidade igual a 3,56 e para $\mathrm{o} \mathrm{Al}_{2} \mathrm{SiO}_{4}(\mathrm{~F}, \mathrm{OH})_{2}$ uma densidade de 3,49 . Segundo Cassedanne \& Sauer (1987), a densidade do topázio imperial da região de Ouro Preto varia de 3,45 a 3,57, e para o topázio do Paquistão, Gübelin et al. (1986) citam valores para o rosa entre 3,51 e 3,53; para o incolor 3,55 e para o acastanhado 3,56. Petricorena (1989), cita para os amarelos e róseos um valor de 3,53, sem mencionar suas procedências.

No caso específico do topázio imperial da região de Ouro Preto, a densidade relativa foi obtida utilizando-se uma balança analítica eletrônica em operação no CPMTC/IGC/UFMG, cuja precisão é de 0,0001g e também um picnômetro da CDTN/CNEN-BH. Tal fato se justifica, pois as amostras de topázio mostraram uma variação de densidade apreciável. Cristais muito pequenos, mostraram densidade muito baixa, possivelmente este fato pode ser devido a fraturas no interior do cristal e pelo deslocamento da alça que suporta o topázio amarrado ao arame. Esses cristais, apesar de terem sido devidamente escolhidos, na tentativa de selecionar apenas aqueles fragmentos mais homogêneos, livres de inclusões e/ou imperfeições que pudessem comprometer os resultados das medidas, apresentaram invariavelmente fraturas, uma vez que são raríssimos os cristais inteiros e livres de qualquer jaça. Outro cuidado tomado no uso da balança foi em relação a eliminação de todas as bolhas de ar aderidas ao mineral ou nas paredes do béquer. Para o picnômetro, este problema foi solucionado com uma bomba de vácuo ligado ao sistema.

A partir disso, obtiveram-se cerca de 70 medidas de densidade e sempre os cristais minúsculos mostraram valores muito baixos. Nenhuma explicação para o comportamento desse mineral foi encontrada na literatura. Já nos cristais maiores houve uma concordância com os valores de densidades encontrados para esses topázios. Portanto, decidiu-se utilizar apenas as medidas encontradas para os cristais maiores, e num trabalho futuro estudar detalhadamente as anomalias observadas neste estudo.

A Tabela 9 mostra os valores obtidos para os topázios de cores distintas de várias jazidas da região de Ouro Preto, que apresentaram resultados aceitos. Observa-se na Tabela 9, que os valores de densidade dos topázios da região de Ouro Preto, variaram de 3,389 a 3,517. Dois únicos valores, totalmente discordantes da literatura, foram os cristais de coloração amarelo-claro 
de Dom Bosco e do Vermelhão, que mostraram densidades 3,389 e 3,390, respectivamente, portanto bastante abaixo do menor valor encontrado na literatura, que é de 3,49 (Deer et al. 1982). Mas, para Olhoeft \& Johnson (1990), como já foi discutido, topázios ricos em $\mathrm{OH}^{-}$pode mostrar valores tão baixos quanto 3,174

Quando os valores de densidade mostrados na Tabela 9 são lançados no gráfico da Figura 23. contra o teor de flúor, obtém-se uma relação linear, ou seja, quanto maior a porcentagem de flúor, maior a densidade. Observa-se também que o valor do cristal de cor amarelo-claro encontra-se abaixo do esperado, não tendo uma explicação para este fato.

TABELA 9 - Determinação da densidade (d) de cinco cristais de topázio de colorações diferentes da região de Dom Bosco. além de outros 9 cristais de diversas localidades. por meio de balança eletrônica.

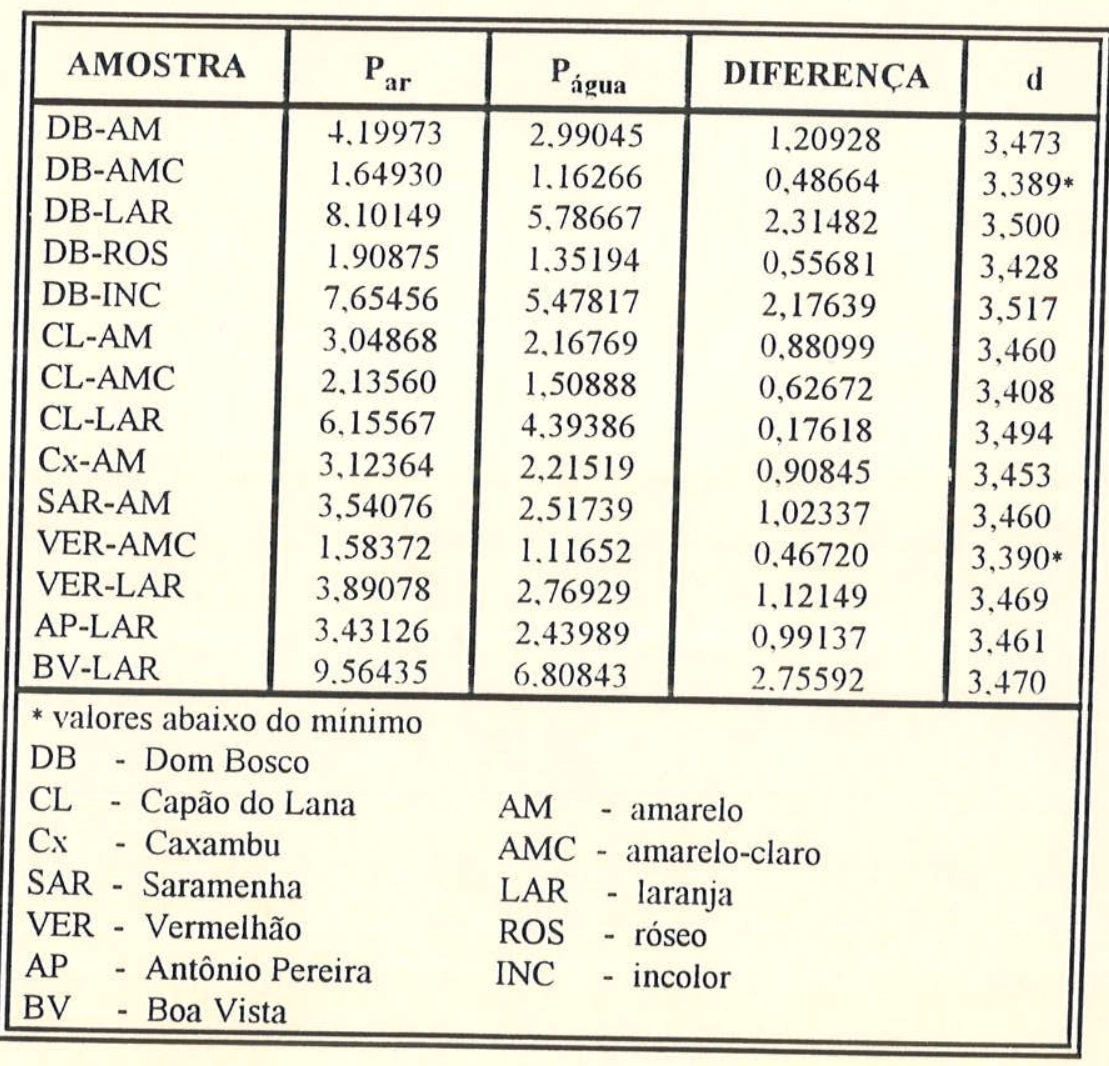

O método do picnômetro foi usado na tentativa de minimizar o erro acumulado pela balança analítica eletrônica. Foi usado um cristal pesando por volta de $7 \mathrm{~g}$, de cor amarela da região de Dom Bosco, que foi dividido em duas partes aproximadamente iguais para checar o erro relativo (Tabela 10). A massa de material usada foi obtida pela diferença de $\mathrm{P}_{2}-\mathrm{P}_{1}$ (peso do picnômetro com o pó do material menos o peso do picnômetro vazio). 


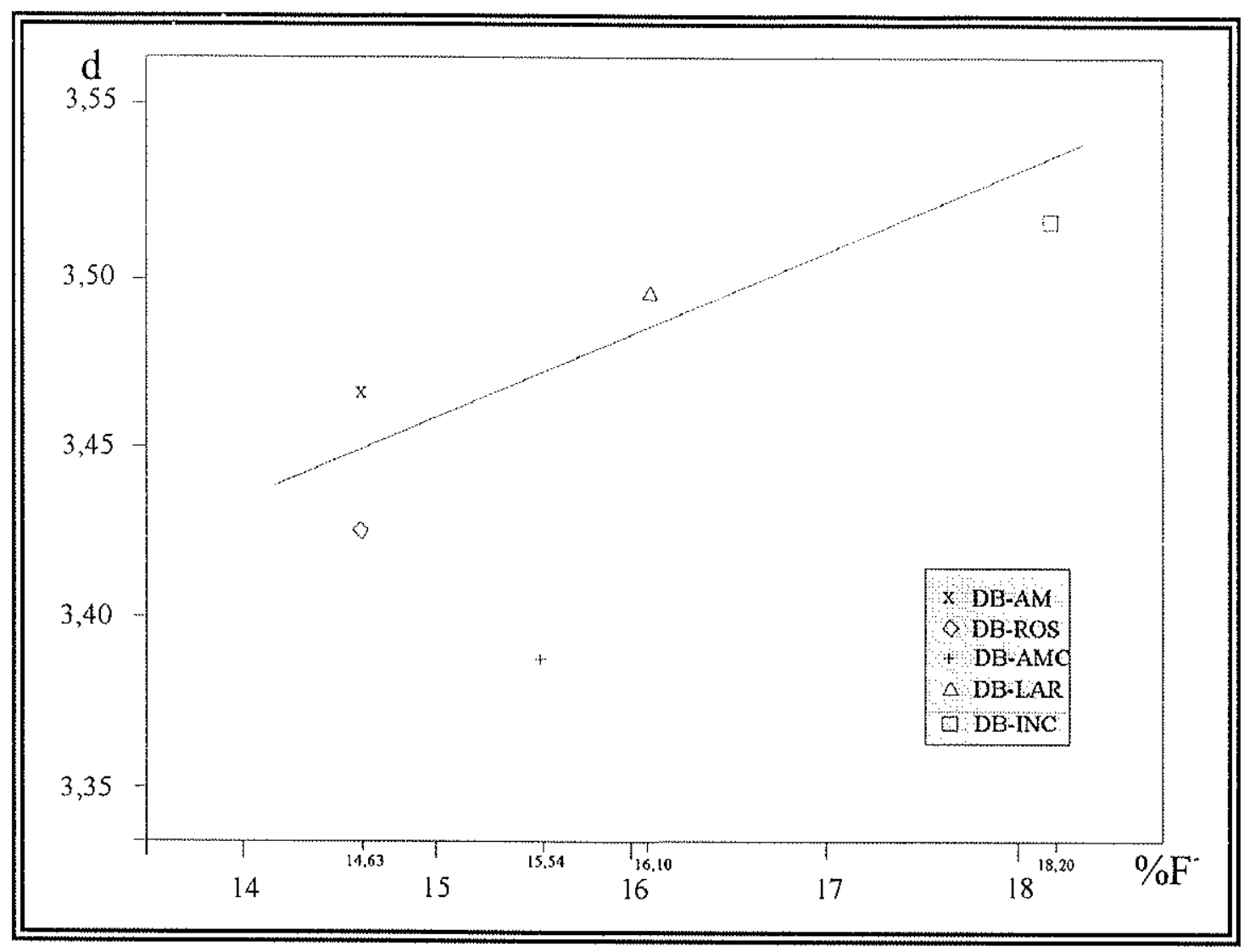

FIGURA 23 - Correlação entre as densidades com os teores de flúor, encontrados a partir de microssonda eletrônica nos topázios da região de Dom Bosco.

TABELA 10 - Análise de densidade de um cristal de topázio, através do uso do picnômetro, para se determinar o erro relativo $\left(\mathrm{P}_{2}-\mathrm{P}_{1}=\right.$ massa $)$.

\begin{tabular}{||c|c|c|c|c|c|c||}
\hline $\mathbf{n}^{\mathbf{0}} \mathbf{p i c}$ & $\mathbf{P}_{\mathbf{1}}$ & $\mathbf{P}_{\mathbf{2}}$ & $\mathbf{P}_{\mathbf{3}}$ & $\mathbf{P}_{\mathbf{4}}$ & $\mathbf{d}$ & média. \\
\cline { 1 - 6 } $\mathbf{1}$ & 11,1415 & 14,3445 & 21,6978 & 19,2309 & 3,5681 & 3,5752 \\
\hline $\mathbf{2}$ & 16,5162 & 20,1051 & 27,6174 & 24,8500 & 3,5823 & \\
\hline
\end{tabular}

A Tabela 11 mostra valores de densidades calculadas a partir do uso do picnômetro, cuja fórmula utilizada foi: $\mathrm{d}=\left\{\left(\mathrm{P}_{2}-\mathrm{P}_{1}\right) /\left[\left(\mathrm{P}_{2}-\mathrm{P}_{1}\right)-\left(\mathrm{P}_{3}-\mathrm{P}_{4}\right)\right]\right\}$.dálc. $\mathrm{O}$ álcool usado possui densidade de 0,82 . Os valores obtidos acham-se no limite máximo determinado por Cassedanne \& Sauer (1987), e ligeiramente superiores àqueles obtidos pela balança analítica eletrônica. 
TABELA 11 - Densidades de topázios de colorações diferentes de diversas localidades. obtidas pelo método do picnômetro.

\begin{tabular}{|l|c|c|c|c|c|c|c|}
\hline amostra & $\mathbf{P}_{\mathbf{1}}$ & $\mathbf{P}_{\mathbf{2}}$ & $\mathbf{P}_{\mathbf{3}}$ & $\mathbf{P}_{\mathbf{4}}$ & $\mathbf{P}_{\mathbf{2}}-\mathbf{P}_{\mathbf{1}}$ & $\mathbf{d}$ & $\mathbf{d}^{\prime}$ \\
\hline DB-AMl & 16,5162 & 20,1051 & 27,6174 & 24,8500 & 3,5889 & 3,5823 & - \\
\hline Cx -AM & 19,1434 & 17,8446 & 21,4060 & 19,3226 & 2,7012 & 3,5853 & 3,453 \\
\hline AP-L.AR & 14,1432 & 18,7263 & 22,7800 & 19,4735 & 4,5831 & 3,5901 & 3,461 \\
\hline CL-ROS & 9,6157 & 12,6283 & 19,9999 & 17,6765 & 3,0126 & 3,5843 & - \\
\hline $\begin{array}{l}d^{\prime}-\text { densidade calculada através da balança analítica } \\
\mathrm{P}_{\mathbf{2}}-\mathrm{P}_{\mathbf{1}}=\text { massa }\end{array}$ \\
\hline
\end{tabular}

OBS: a amostra DB-AM1, não faz parte dos cristais analisados pela microssonda eletrônica.

\section{7 - CRISTALOGRAFIA}

O topázio é um mineral do sistema ortorrômbico que se cristaliza na classe bipiramidal rômbica (holoédrica rômbica) de simetria mmm (Hermann-Mauguin) ou $\mathrm{D}_{2 \mathrm{~h}}$ (Schönflies), e cujo grupo espacial é representado por Pbnm. Em função desse grupo, segundo Olsacher (1946), ocorrem nesta classe formas cristalográficas constituídas pelo pinacóide frontal ou $1^{\circ}$ pinacóide $\{100\}$, pinacóide lateral ou $2^{\circ}$ pinacóide $\{010\}$, pinacóide basal ou $3^{\circ}$ pinacóide $\{001\}$, prisma rômbico vertical ou prisma de $3^{\mathrm{a}}$ ordem $\{\mathrm{hk} 0\}$, prismas rômbicos horizontais $\{0 \mathrm{kl}\}$ e $\{\mathrm{h} 0 \mathrm{l}\}$, também chamados, respectivamente, de prisma de $1^{a}$ ordem ou prisma longitudinal e de prisma de $2^{\mathrm{a}}$ ordem ou prisma transversal; e, ainda pela bipirâmide rômbica $\{\mathrm{hkl}\}$, representada por oito faces, constituídas por triângulos isósceles. De um modo geral, os cristais de topázio apresentam hábito prismático com faces estriadas paralelamente ao eixo $\mathbf{c}$, sendo terminados por pinacóides, prismas horizontais ou bipirâmides (Olsacher 1946). Também pode ocorrer combinação das formas anteriores num mesmo cristal. Nesse mineral, raramente são observadas geminações. Crescimentos paralelos segundo (010), têm sido interpretados como maclas (Gliszezynski 1949, in Deer et al. 1982).

Nesta Dissertação, além dos aspectos cristalográficos clássicos, serão discutidas a morfologia e os parâmetros unitários do topázio imperial dos vários depósitos da região de Ouro Preto. 


\subsection{1 - MORFOLOGIA CRISTALINA}

Esse mineral-gema apresenta um desenvolvimento bem peculiar em relação às formas características apresentadas pelos topázios incolores e azuis, encontrados em outros ambientes geológicos.

Quanto às dimensões do topázio imperial da região de Ouro Preto, talvez o maior cristal encontrado até hoje, nas imediações da referida cidade, é de um exemplar com mais de $30 \mathrm{~cm}$ de comprimento por $10 \mathrm{~cm}$ de diâmetro descrito por Cassedanne (1989). Outro destaque é um de $13 \mathrm{~cm}$ de comprimento achado no distrito de Antônio Pereira, cujo espécime faz parte do acervo do Museu da Mineralogia da Escola de Minas, em Ouro Preto. Também outro importante cristal é um biterminado, encontrado em Saramenha, que possui, aproximadamente, $13 \mathrm{~cm}$ de comprimento (Cassedanne 1989). A grande maioria dos topázios da região de Ouro Preto apresenta-se bem cristalizada, sendo os cristais preferencialmente encontrados sob a forma de pequenos fragmentos, variando em geral desde alguns milímetros até $30 \mathrm{~cm}$, aproximadamente, predominando a faixa em torno de $1 \mathrm{a} 4 \mathrm{~cm}$, com diâmetro entre 0,5 a $1 \mathrm{~cm}$. Os espécimes aparecem sob a forma de monocristais isolados e raramente ocorre intercrescimento de topázio na forma de agregado. Quanto ao hábito, predominam os tipos constituídos por dois prismas rômbicos verticais, terminados por uma bipirâmide também rômbica. Na jazida de Antônio Pereira os agregados são mais freqüentes (Fotomicrografia 13). Os cristais estudados neste trabalho mostraram, predominantemente, dois prismas rômbicos de $3^{\text {a }}$ ordem representados pelas faces (110) e (120) bem desenvolvidas e estriadas. Geralmente são terminados por uma bipirâmide rômbica, onde as quatro faces triangulares apresentam um baixo ângulo, constituindo-se num tipo morfológico extremamente comum nas diversas jazidas da região de Ouro Preto. A terminação por prismas horizontais de $1^{\mathrm{a}}$ ou $2^{\mathrm{a}}$ ordem é rara, fato pouco destacado nos topázios incolores e azuis de outros ambientes geológicos (Figura 24). Pouquíssimos topázios imperiais, da região de Ouro Preto, apresentam forma pinacoidal basal. Usualmente, em quase todos os cristais estudados, tem-se somente uma terminação. Já na outra extremidade, em geral quebrada, aparece um plano de clivagem pinacoidal basal, similar aos topázios incolores e azuis; porém, tal plano não é perfeito como nos últimos espécimes. Os cristais biterminados são extremamente raros e quando ocorrem, geralmente, mostram dimensões de apenas alguns milímetros. Não obstante, existem topázios biterminados com alguns centímetros.

Cada jazida e/ou ocorrência de topázio imperial, na região de Ouro Preto, parece possuir um padrão morfológico característico. Pode haver uma gama muito grande de complexidade das formas. Na jazida de Saramenha, observou-se que os cristais geralmente possuem várias bipirâmides e prismas de $1^{\mathrm{a}}$ ordem como terminações. Petrov et al. (1977) descreveram uma dessas amostras com aspecto bem peculiar, que apresentava um conjunto de vários prismas, um 
de $1^{\text {a }}$ ordem e 5 de $3^{\text {a }}$ ordem, além de duas bipirâmides e um pinacóide basal bem desenvolvido (Figura 25).

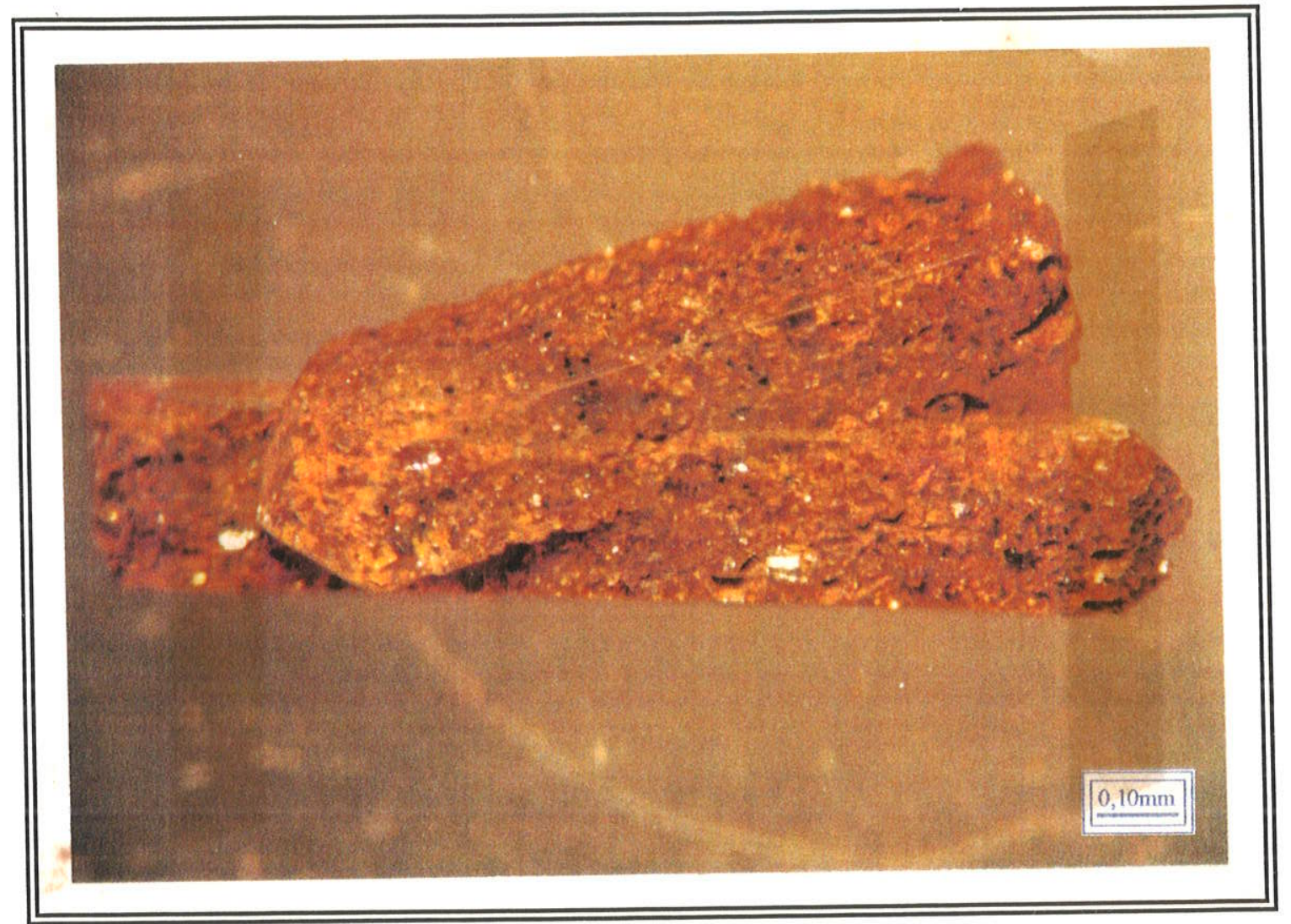

FOTOMICROGRAFIA 13 - Intercrescimento de dois cristais de topázio, sem uma lei cristalográfica definida, da jazida de Antônio Pereira. Os cristais contêm grande quantidade de inclusões cristalinas (quartzo, dolomita e especularita). (Luz refletida).

Na mina do Capão do Lana, os cristais terminam, de um modo geral, por uma bipirâmide única (Figura 24). A morfologia é uma propriedade prática importante nesse mineral, pois alguns garimpeiros da região afirmam serem capazes de saber a procedência de um determinado cristal, apenas pelo seu padrão morfológico, usando como auxílio a sua cor. Logicamente essa propriedade mostra pouco valor para os garimpeiros, mas para os estudiosos, ela pode estar relacionada a fatores genéticos dos vários depósitos.

De um modo geral, as características morfológicas do topázio da região de Ouro Preto são semelhantes as do topázio do Paquistão (Gübelin et al. 1986). 


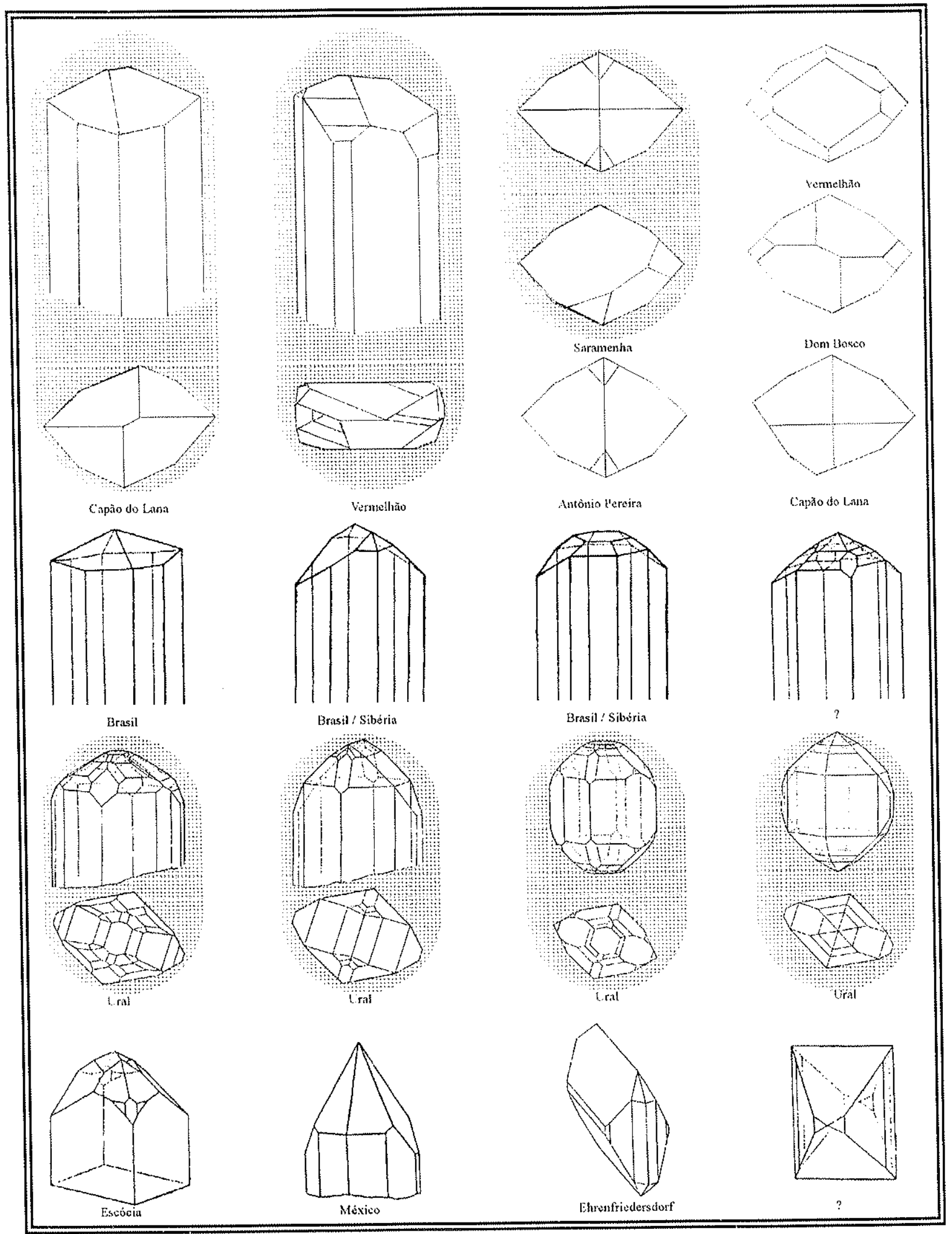

FIGURA 24 - Morfologia cristalina de alguns topázios da região de Ouro Preto comparada com outros topázios de diferentes localidades e ambientes geológicos. Os desenhos que estão circundados com uma área hachurada. as duas partes pertencem ao mesmo cristal. No caso da projeção do topázio biterminado de Saramenha. cada terminaçăo apresenta uma forma distinta. Os doze últimos desenhos foram extraidos de Goldschmidt (1922). 


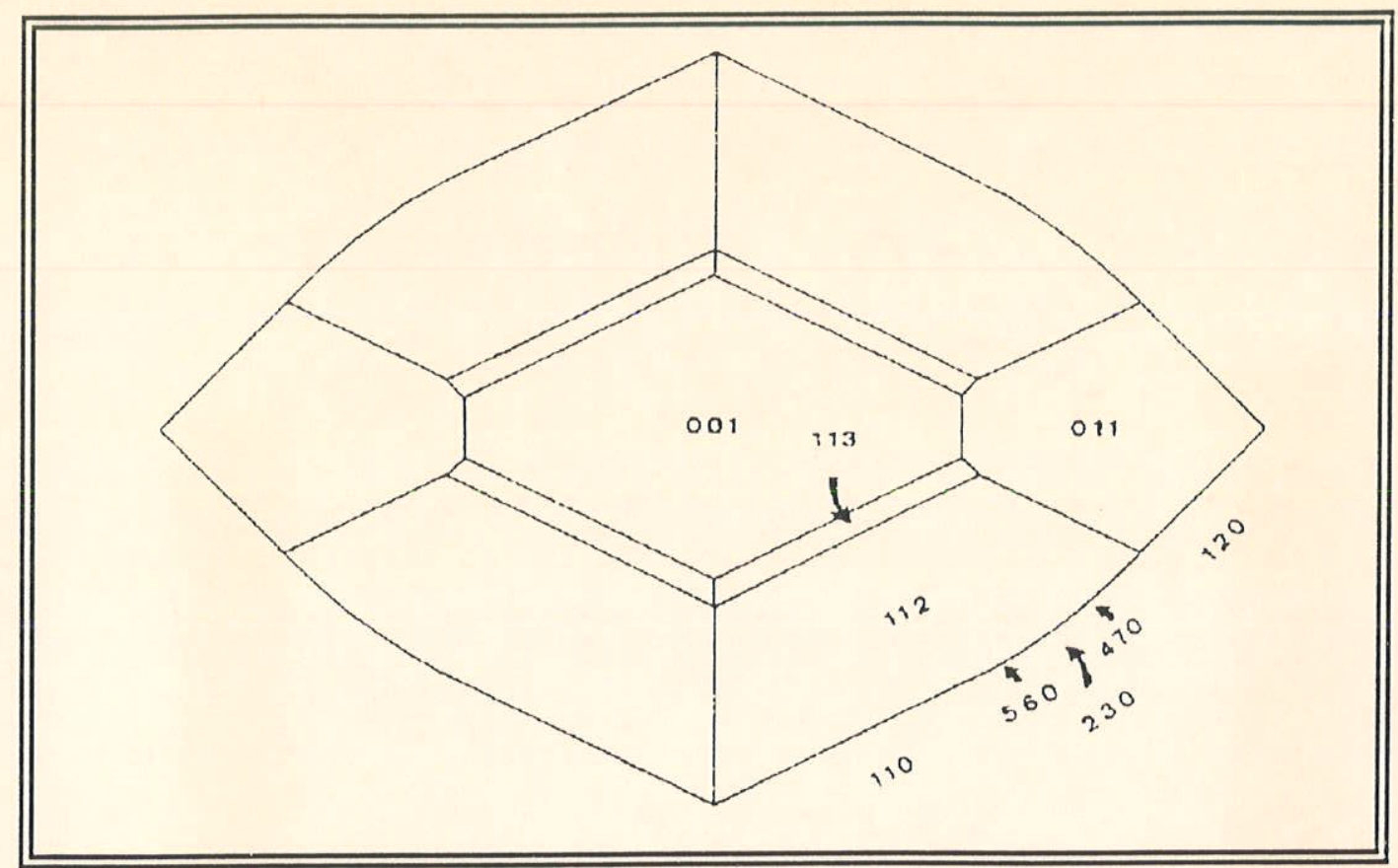

FIGURA 25 - Morfologia de um cristal de topázio alaranjado de Saramenha. destacando-se a forma pinacoidal basal e os cinco prismas de $3^{\mathrm{a}}$ ordem, além do prisma de $1^{\mathrm{a}}$ ordem e das duas bipirâmides. constituindo associação rara na região de Ouro Preto. (Extraido de Petrov et al. 1977).

\subsection{2 - PARÂMETROS DE CELA UNITÁRIA}

Todas as características estruturais, geométricas e químicas são representadas pela cela unitária, sendo esta a menor porção do cristal. No caso do topázio, isto corresponde a quatro vezes à sua fórmula estrutural $(Z=4)$. De acordo com Deer et al. (1982), os valores dos parâmetros da cela unitária deste mineral têm como média $4,65 \AA$ para $\mathrm{a}_{0}, 8,80 \AA$ para $\mathrm{b}_{\mathrm{o}}$ e $8,39 \AA$ para $\mathrm{c}_{\mathrm{o}}$.

Não foi encontrado nenhum trabalho científico na literatura relacionando a cor com os parâmetros unitários $a_{0}, b_{0}$ e $c_{0}$. Para o topázio imperial do Paquistão, Gübelin al. (1986) não citam a cor, apenas os valores dos parâmetros da cela unitária: $\mathrm{a}_{\mathrm{o}}=8,3841 \pm 0,0013 \AA, \mathrm{b}_{\mathrm{o}}=8,8335 \pm 0,0009 \AA \mathrm{e} \mathrm{c}_{\mathrm{o}}=4,6617 \pm 0,0006 \AA$, com um volume de $345 \pm 0,1 \AA^{3}$. Rosenberg (1967) cita apenas um topázio de Ouro Preto, sem citar a cor e mostra que os parâmetros unitários são $\mathrm{a}_{\mathrm{o}}=8,395 \AA, \mathrm{b}_{\mathrm{o}}=8,833 \AA, \mathrm{c}_{\mathrm{o}}=4,660 \AA$ e V $=$ $345,55 \AA^{3}$.

Segundo Rosenberg (1967), o valor de $b_{0}$ está intimamente relacionado com o teor de flúor e de hidroxila presente na estrutura do topázio. Quanto maior a porcentagem de flúor, menor será o $b_{0}$, e quanto maior a porcentagem de hidroxila, maior será o valor de $b_{0}$. Este autor, também se refere a uma relação inversa entre $b_{0} e$ 
$2 V_{Z}$. Quanto maior $b_{0}$, menor será $2 V_{Z}$. Neste capitulo será estudado a variação de $b_{0}$ com o teor de flúor. Portanto, um perfeito entendimento dos parâmetros da cela unitária nos fornece indícios da variação do teor de flúor e/ou hidroxila e também de $2 V_{Z}$. Observou-se que os topázios, também mostram uma relação entre a cor e o teor de flúor e hidroxila presente na sua estrutura. A partir disso, para os trabalhos de difração de raios $X$, foram escolhidos cinco cristais de cores diferentes, de uma jazida da região de Dom Bosco, onde já tinha sido determinada a razão $\mathrm{F}^{-} / \mathrm{OH}^{-}$pela microssonda eletrônica (Tabela 3). Para isto, utilizou-se o método do pó, onde os diagramas de pó foram obtidos em um difratômetro RIGAKU, em operação no DEGEO/EM/UFOP. Os valores dos parâmetros do topázio, referidos no fichário JCPDS, foram adicionalmente representados para efeito de comparação (Tabela 12).

Para a obtenção dos parâmetros da cela unitária, foi utilizado um programa de computação existente no laboratório de difratometria de raios X do DEGEO/EM/UFOP, gentilmente cedido pelo Prof. Dr. José Marques Correia Neves (IGC/UFMG). Os cálculos efetuados em 15 amostras diferentes mostraram que $a_{0}$ varia de 4,615 a 4,656 $\mathrm{b}_{\mathrm{o}}$ de 8,747 a $8,815 \AA$ e $\mathrm{c}_{\mathrm{o}}$ de 8,375 a $8,412 \AA$. Os parâmetros unitários com seus respectivos volumes da cela unitária de cinco cristais da região de Dom Bosco previamente escolhidos, estão representados na Tabela 13

A partir dos valores dos parâmetros unitários de $b_{0}$ e dos volumes de cela, juntamente com a porcentagem do flúor dos cinco cristais de cores distintas, foram construídos os respectivos diagramas representados nas Figuras 26 e 27. Mais uma vez, nota-se que nos dois diagramas das figuras anteriores, os valores do cristal de cor amarelo-claro estão abaixo do esperado. Não foi encontrado, também neste caso, uma explicação satisfatória para esse fato. 
TABELA 12 - Reflexões principais dos diagramas de pó de topázios de colorações variadas da regiăo de Dom Bosco. obtidas com radiação $\mathrm{CuK}_{t,}=1,54178 \AA$, sob condições de $20 \mathrm{~mA}$ e $40 \mathrm{kV}$, comparadas com o respectivo padrăo do fichário JCPDS.

\begin{tabular}{|c|c|c|c|c|c|c|c|c|c|c|c|c|}
\hline \multicolumn{2}{|c|}{ DB-INC: } & \multicolumn{2}{|c|}{ DB-AMC: } & \multicolumn{2}{|c|}{ DB-AMI } & \multicolumn{2}{|c|}{ DB-ROS } & \multicolumn{2}{|c|}{ DB-LAR } & \multicolumn{3}{|c|}{ JCPDS $12-765$} \\
\hline d $\quad I$ & $/ 1 / 10$ & II I & I/10 & (1) I & V/\%o & & $\mathrm{I} / \mathrm{IO}$ & a 1 & 1/10 & $d(A) \quad l$ & & (hkl) \\
\hline 4.384 & 4 & - & $\cdot$ & ${ }^{-}$ & & - & n & $\cdot$ & - & 4.40 & 6 & 020 \\
\hline 4,172 & 14 & - & - & 4.187 & 19 & 4.183 & 14 & 4.179 & 6 & 4,19 & 4 & 002 \\
\hline 4.103 & 10 & 4,121 & 6 & 4,107 & 12 & 4.107 & 7 & 4,103 & 3 & 4.111 & 12 & 110 \\
\hline 3.860 & 1 & 3,927 & 10 & 3,877 & 3 & 3,873 & 2 & 3,887 & 2 & 3.896 & 6 & 021 \\
\hline 3,690 & 74 & 3,710 & 82 & 3.696 & 57 & 3.690 & 45 & 3,702 & 87 & 3.693 & 60 & 111 \\
\hline 3,314 & 1 & - & . & - & - & - & - & $\cdot$ & - & - & - & - \\
\hline 3,1951 & 100 & 3,213 & 55 & $3,195 \quad 1$ & 100 & 3.191 & 100 & 3.202 & 97 & 3.195 & 65 & 120 \\
\hline 3,031 & 64 & 3,0471 & 100 & 3,037 & 42 & 3,031 & 32 & 3,039 & 73 & 3.037 & 35 & 022 \\
\hline 2.984 & 22 & 3,005 & 21 & 2,990 & 23 & 2,988 & 16 & 2,999 & 16 & 2,986 & 25 & 121 \\
\hline 2,934 & 92 & 2,947 & 84 & 2,934 & 100 & 2.934 & 56 & 2.940 & 100 & $2,937 \quad 10$ & 00 & 112 \\
\hline 2.479 & 28 & 2,488 & 29 & 2,482 & 40 & 2,479 & 21 & 2,485 & 19 & 2,4804 & 20 & 130 \\
\hline - & - & 2,404 & 14 & $\sim$ & - & - & - & - & - & - & - & - \\
\hline 2,396 & 11 & 2,392 & 28 & 2,389 & 15 & 2,387 & 14 & 2,391 & 23 & 2,3966 & 10 & 103 \\
\hline 2,353 & 67 & - & - & - & - & - & - & 2,384 & 38 & 2,3783 & 25 & 131 \\
\hline- & - & - & - & 2,356 & 60 & 2,355 & 57 & 2,363 & 54 & 2,3609 & 45 & 023 \\
\hline • & - & - & - & - & - & - & - & - & - & 2,3247 & 8 & 200 \\
\hline 2,310 & 12 & 2,316 & 8 & $2,3 ! 2$ & 12 & 2,312 & 8 & 2,309 & 5 & 2,3130 & 10 & 113 \\
\hline - & - & • & - & 2,247 & 3 & 2,249 & 2 & 2.248 & 5 & 2,2470 & 6 & 210 \\
\hline 2.196 & 9 & 2.210 & 9 & 2,199 & 6 & 2.196 & 6 & 2,204 & 6 & 2.1989 & 10 & (0)40 \\
\hline 2.163 & 8 & 2.184 & 6 & 2.170 & 14 & 2.171 & 9 & 2,172 & 14 & 2.1711 & 12 & 211 \\
\hline 2,125 & 4 & - & - & 2,127 & 4 & 2,130 & 4 & 2.131 & 6 & 2,1269 & 8 & 041 \\
\hline 2,103 & 83 & 2,108 & 84 & 2.103 & 63 & 2.103 & 46 & 2,106 & 87 & 2,1049 & 45 & 123 \\
\hline 2,053 & 30 & 2,063 & 57 & 2,055 & 30 & 2,060 & 14 & 2,058 & 25 & 2,0555 & 25 & 220 \\
\hline - & - & - & - & - & - & 1.991 & 7 & 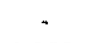 & 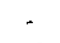 & - & - & - \\
\hline 1.987 & 13 & 2,000 & 6 & - & - & 1,988 & 7 & 1.988 & 6 & 1,9872 & 8 & 140 \\
\hline - & - & - & - & 1,982 & 8 & - & - & - & n & 1,9816 & 10 & 212 \\
\hline • & - & 1,956 & 6 & - & - & - & - & - & . & 1,9470 & 4 & 042 \\
\hline 1,929 & 3 & $"$ & 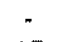 & 1,934 & 3 & 1,936 & 3 & 1,936 & 4 & 1,9340 & 6 & 141 \\
\hline 1,867 & 42 & 1,875 & 17 & 1,867 & 30 & 1,867 & 18 & 1,873 & 16 & 1.8691 & 25 & 114 \\
\hline 1,855 & 35 & 1,858 & 31 & 1.855 & 37 & 1,853 & 26 & 1,856 & 32 & 1,8553 & 25 & 133 \\
\hline • & - & 1,832 & 8 & 1,825 & 11 & 1,825 & 6 & 1,827 & 14 & • & $"$ & - \\
\hline - & . & • & - & 1,820 & 8 & - & - & - & - & 1,8212 & 12 & 230 \\
\hline 1.798 & 10 & . & - & 1.795 & 8 & 1.796 & 4 & 1.802 & 10 & 1.7969 & 8 & 142 \\
\hline 1,774 & 2 & - & 1 & 1,781 & 9 & 1,779 & 4 & . & - & 1,7796 & 6 & 231 \\
\hline - & - & 1,677 & 27 & 1.676 & 18 & • & - & • & . & - & - & \\
\hline 1.671 & 31 & - & - & 1,674 & 31 & 1,670 & 18 & 1.675 & 18 & 1.6706 & 25 & 232 \\
\hline 1,650 & 4 & 1,658 & 9 & 1,659 & 11 & 1,654 & 5 & 1,656 & 6 & 1,6561 & 8 & 223 \\
\hline 1,622 & 11 & 1,627 & 11 & 1,620 & 17 & 1.623 & 9 & 1,621 & 13 & 1,6203 & 12 & 143 \\
\hline - & - & - & - & 1,600 & 4 & - & - & - & - & 1,6014 & 2 & 134 \\
\hline 1.595 & 2 & " & - & - & - & 1.596 & 2 & 1,599 & 3 & 1,5974 & 4 & 240 \\
\hline . & 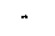 & . & " & 1,575 & 3 & - & - & 1,574 & 2 & 1.5791 & 2 & 105 \\
\hline . & - & - & . & & . & 1,571 & 1 & n & . & 1.5684 & 4 & 241,025 \\
\hline - & - & - & . & - & $\cdot$ & - & - & $"$ & . & 1.5573 & $\Leftrightarrow 1$ & 204 \\
\hline - & . & - & - & 1.551 & 3 & 1,550 & 2 & 1,553 & 3 & $\begin{array}{l}1.5544 \\
+14 \text { jinis }\end{array}$ & & 115 \\
\hline 1,551 & 2 & - & - & - & . & - & - & - & - & até 1.40 & & - \\
\hline - & - & 1,539 & 6 & - & - & - & - & - & - & - & 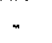 & - \\
\hline " & - & 1,536 & 14 & - & - & - & - & - & - & - & - & - \\
\hline 1,532 & 14 & 1,534 & 20 & . & - & - & - & 1.533 & 17 & - & - & - \\
\hline 1.530 & 15 & - & - & 1.530 & 22 & 1,530 & 12 & 1.531 & 25 & - & . & - \\
\hline 1,525 & 15 & - & - & 1,525 & 17 & 1,526 & 11 & 1,528 & 25 & . & . & - \\
\hline 1,480 & 1 & - & - & - & - & - & - & - & - & - & - & - \\
\hline 1.459 & 5 & 1,468 & 7 & . & . & . & . & . & . & - & - & . \\
\hline 1,439 & 6 & 1.448 & 8 & . & . & . & . & . & " & - & - & - \\
\hline 1.420 & 21 & 1,424 & 32 & . & . & . & . & . & . & - & - & . \\
\hline 1,415 & 20 & - & - & - & - & - & . & - & . & . & - & - \\
\hline • & $\cdot$ & 1,408 & 15 & . & . & . & " & . & - & - & - & " \\
\hline - & - & 1,400 & 35 & - & . & . & . & . & . & - & - & - \\
\hline 1.399 & 72 & - & • & - & - & . & . & - & - & " & - & - \\
\hline 1,391 & 27 & 1,391 & 23 & - & - & - & - &. & - & . & - & - \\
\hline - & - & 1,387 & 7 & - & - & - & - & - & - & . & - & - \\
\hline 1,370 & 2 & & - & . & . & - & " & - & . & . & - & - \\
\hline 1,358 & 11 & 1,361 & 14 & - & - & - & - & - & - & - & - & . \\
\hline 1.354 & 24 & 1.346 & 15 & - & - & - & - & - & - & - & - & - \\
\hline
\end{tabular}


TABELA 13 - Parâmetros unitários de cinco cristais de topázios de colorações diferentes procedentes da região de Dom Bosco (DB).

\begin{tabular}{||c|r|r|r|r|r||}
\hline parâmetros & DB-INC & DB-AMC & DB-AM & DB-ROS & DB-LAR \\
\hline $\mathrm{a}_{\circ}(\mathrm{A})$ & 4.615 & 4.643 & 4.654 & 4.647 & 4.656 \\
\hline $\mathrm{b}_{\mathrm{o}}(\mathrm{A})$ & 8.778 & 8.747 & 8.797 & 8.803 & 8.815 \\
\hline $\mathrm{c}_{\circ}(\mathrm{A})$ & 8.412 & 8.387 & 8.375 & 8.382 & 8.378 \\
\hline $\mathrm{V}\left(\mathrm{A}^{3}\right)$ & 340.798 & 340.639 & 342.876 & 342.945 & 343.823 \\
\hline
\end{tabular}

De acordo com a teoria de Rosenberg (1967), ou seja, quanto maior a porcentagem de flúor, menor o valor de $b_{0}$ e de V (volume da cela unitária), o topázio da região de Ouro Preto mostrou uma relação direta com esta teoria. Mais uma vez, o topázio de cor amarelo-claro foi o único que não obedeceu à regra, por motivos ainda não esclarecidos.

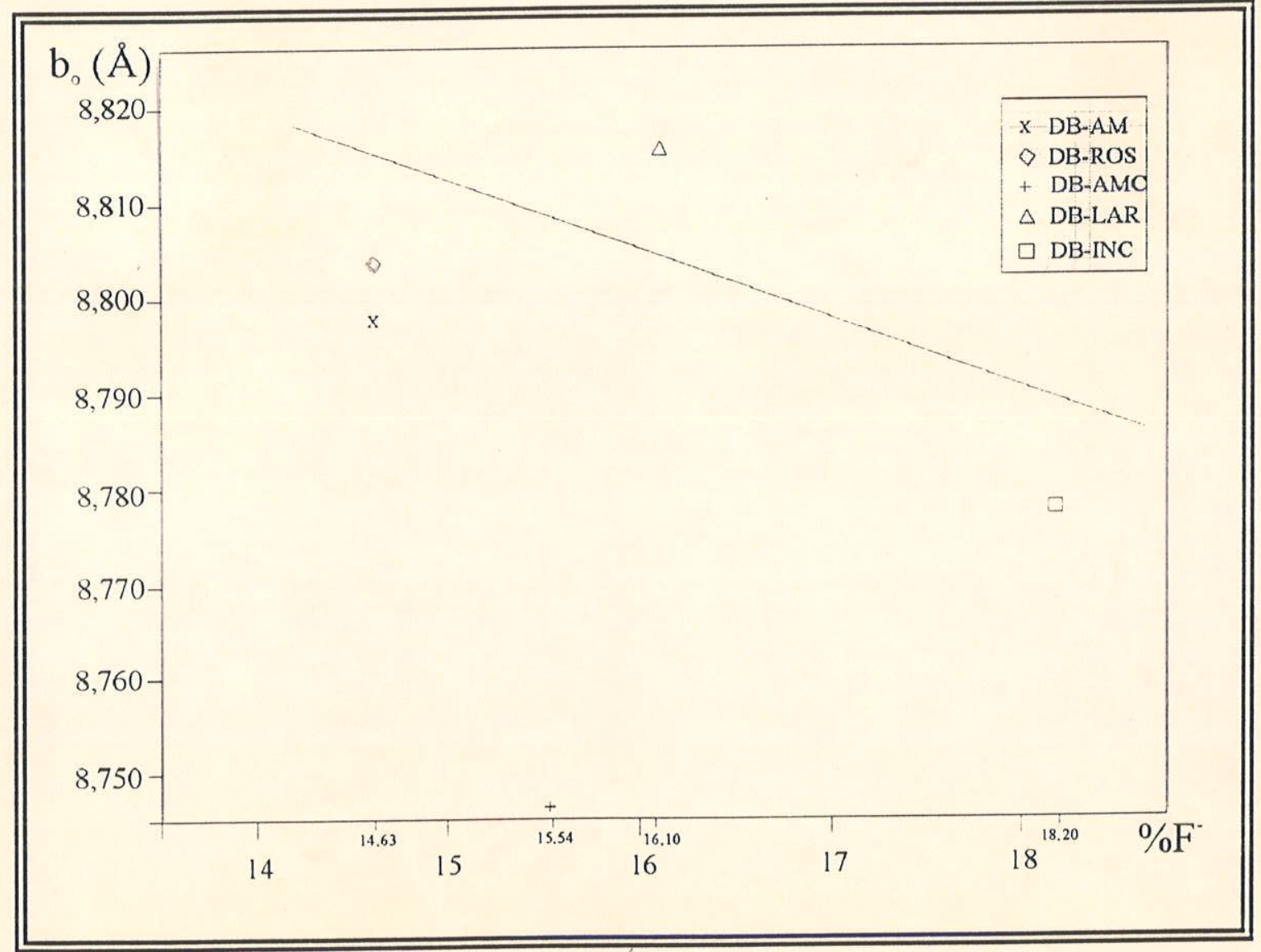

FIGURA 26 - Correlação entre os parâmetros $b_{o}$ de cinco cristais de cores distintas da região de Dom Bosco. com seus respectivos teores de flúor. Nota-se uma relação decrescente entre $b_{o}$ e flúor. 


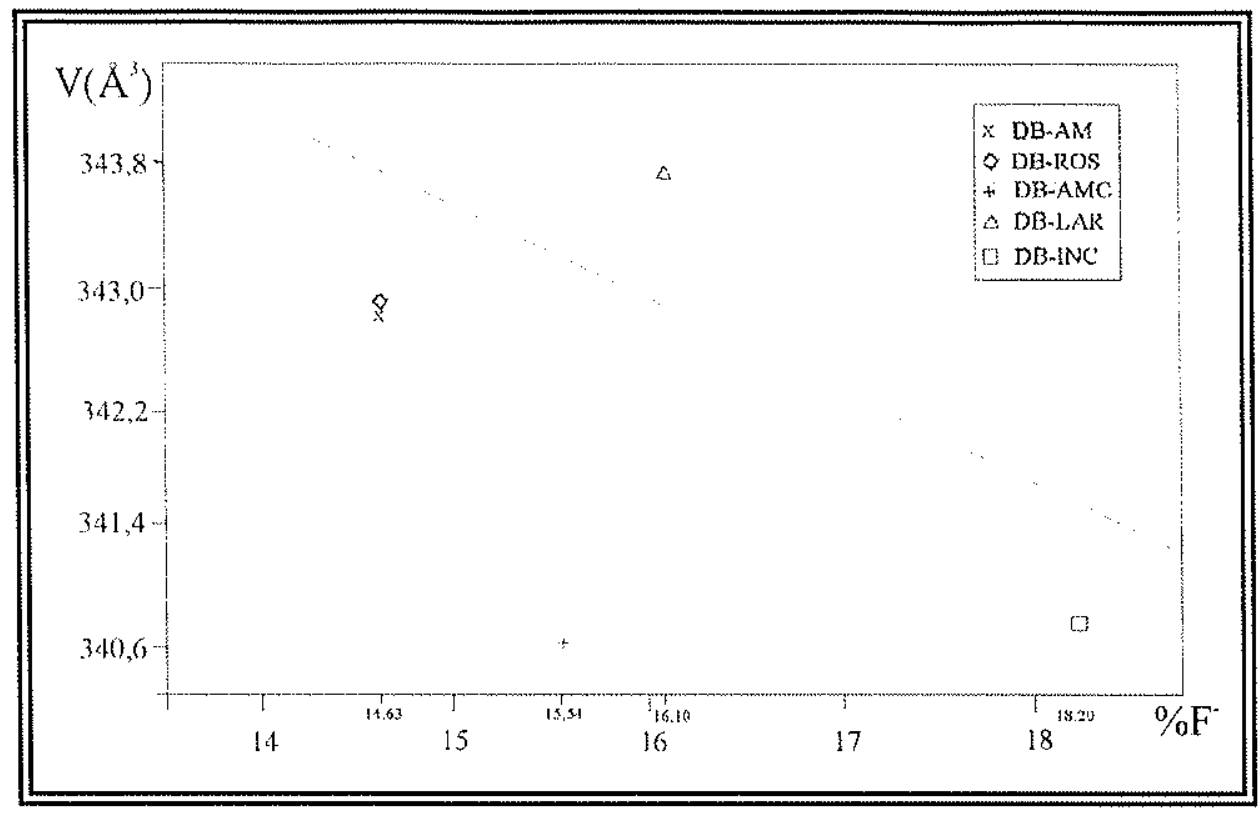

FIGURA 27 - Correlaçăo entre os volumes das celas unitárias de cada um dos cinco cristais de cores distintas da região de Dom Bosco. com seus respectivos teores de flúor. Nesta relação, há uma correspondência direta decrescente entre os dois parâmetros. 


\section{6 - INCLUSÕES CRISTALINAS}

Inclusões cristalinas são relativamente comuns em todos os minerais. Classificam-se em proto, sin e epigenéticas, dependendo de terem sido formadas antes, simultanea e posteriormente à formação do hospedeiro. Neste trabalho foi dado ênfase aos grupos proto e epigenéticos tendo em vista o interesse que o estudo dessas inclusões tem para a gênese do topázio.

No decorrer deste trabalho foram utilizados diversos métodos analíticos entre microscópio óptico, predominando a difração de raios $\mathrm{X}$, microscópio eletrônico de varredura (MEV) associado ao sistema de energia dispersiva (EDS). Quanto a difração de raios X, foi utilizada uma câmara de Gandolfi existente no DMP do IG/USP. Neste método, o topázio é fragmentado e as inclusões sólidas são liberadas do mineral hospedeiro. Com a ajuda de uma lupa binocular, o material foi separado e devidamente preparado para a obtenção dos difratogramas. As inclusões cristalinas possuem dimensões entre 10 a $100 \mu \mathrm{m}$, e em alguns casos excepcionais chegam a ter alguns milímetros. Através dessa técnica foi possível identificar várias fases sólidas representadas pela hematita (variedade especularita), quartzo descrito anteriormente como dolomita nos cristais de Antônio Pereira por Ferreira (1987 e 1991), rutilo e tremolita. Outro mineral identificado por Ferreira (1991), porém não detectado nesta Dissertação, foi a pirofilita.

Desde os trabalhos de Gorceix (1881), Derby (1901), Oliveira (1984), Cassedanne (1989) e Ragatky (1992), a turmalina é citada como inclusão no topázio ou presente nas rochas alteradas. Nos trabalhos laboratoriais efetuados para esta Dissertação, todos os minerais similares à turmalina que estavam inclusos no topázio, foram difratados em câmara de Gandolfi e determinados como tremolita (Gandini et al. 1992c). Outra fase também presente nos topázios, o euclásio foi identificado por meio de um diagrama de pó obtido em um difratômetro RIGAKU, em operação no DEGEO/EM/UFOP. Outras substâncias presentes, como carbonatos e minerais apresentando hábitos placoidais, não foram identificados por este método devido à dificuldade de serem separados das amostras hospedeiras. Neste caso, foram confeccionadas lâminas delgadas de topázio contendo estes tipos de inclusões, e analisadas através de microssonda eletrônica existente no laboratório de Metalografia do IPT/SP e do IG/UnB. Através dos dados obtidos por EDS, o material de hábito placoidal foi identificado como mica e os carbonatos como dolomita/ankerita. 
Utilizou-se também o MEV pertencente ao NUPEGEL - IAG/USP, acoplado ao espectrômetro de energia dispersiva (EDS), bem como aparelho similar do Forschunsinstitut für Mineralische und Metalleische Werkstoffé - Idar-Oberstein, na Alemanha, para complementar os dados anteriores. Por este método foram identificadas a apatita, o cloritóide e a ilmenita.

Através de um microscópio petrográfico comum, pode-se identificar opticamente a presença de cristais de topázio incluso em outros cristais da mesma espécie, além de óxidos/hidróxidos secundários. Estas duas últimas substâncias estão presentes nas fraturas dos cristais de topázio, sendo portanto epigenéticos.

Discutem-se a seguir, algumas das principais características de cada uma das inclusões, provavelmente, de carater protogenéticas, com exceção das inclusões de óxidos e/ou hidróxidos, que são epigenéticas.

\section{1 - TREMOLITA}

Este mineral aparece com pouca freqüência no topázio imperial, sendo mais comum nos cristais de quartzo. É caracterizado pelo hábito acicular, pelas faces estriadas longitudinalmente e pela cor esverdeado; suas dimensões estão compreendidas no intervalo entre 0,01 a $3 \mathrm{~mm}$. No topázio aparece como agulhas isoladas sem orientação definida, enquanto que no quartzo, é mais comum formarem agregados. Eppler (1973) cita tremolita inclusa em cristais de topázio azulado brasileiro. A tremolita foi determinada a partir de difração de raios $X$, através de câmara de Gandolfi. O diagrama do pó correspondente está apresentado na Figura 28, e as reflexões correspondentes encontram-se na Tabela 14 juntamente com o diagrama da tremolita do sistema JCPDS. Este mineral também foi confirmado pelo MEV (Fotomicrografia 14).

\section{2 - QUARTZO}

Este mineral é um dos mais abundantes, tanto na zona mineralizada em topázio como nas rochas adjacentes, onde ele varia desde transparente a leitoso, podendo ser, mais raramente, de cor amarelada ou mesmo roxa. Normalmente, as inclusões cristalinas de quartzo do topázio imperial são incolores e não apresentam uma forma bem definida. Via de regra ocorrem na forma de grãos de contornos arredondados, cujo tamanho médio varia em torno de $0,2 \mathrm{~mm}$, às vezes com uma certa orientação. Esta orientação se deve ao fato dos topázios serem "porfiroblastos" em quartzitos dolomíticos (Fotografia 16 e Fotomicrografia 15). Os grãos de quartzo também podem ocorrer concentrado no núcleo do topázio hospedeiro (Fotomicrografia 16). Também são muito freqüentes cristais de topázio, especularita, rutilo, tremolita, carbonatos e pirofilita inclusos em cristais de quartzo. A identificação do quartzo foi realizada, também, na câmara de Gandolfi. 


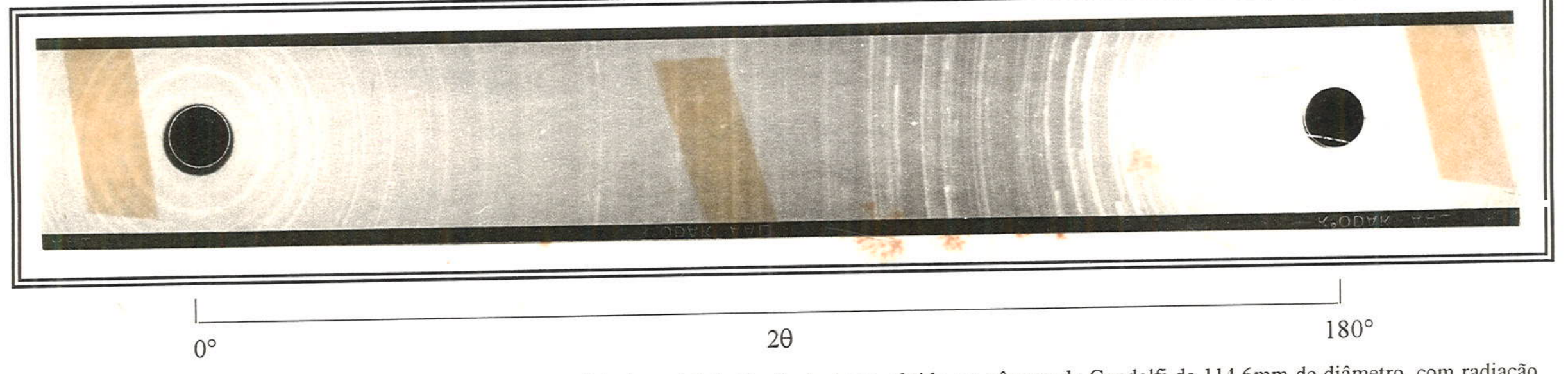

FIGURA 28 - Diagrama de pó da tremolita inclusa no topázio imperial do Capão do Lana, obtido em câmara de Gandolfi de 114,6mm de diâmetro, com radiação $\mathrm{CuK}_{\alpha}=1,54178 \AA$, exposição de 24 horas, $20 \mathrm{~mA}$ e $40 \mathrm{kV}$

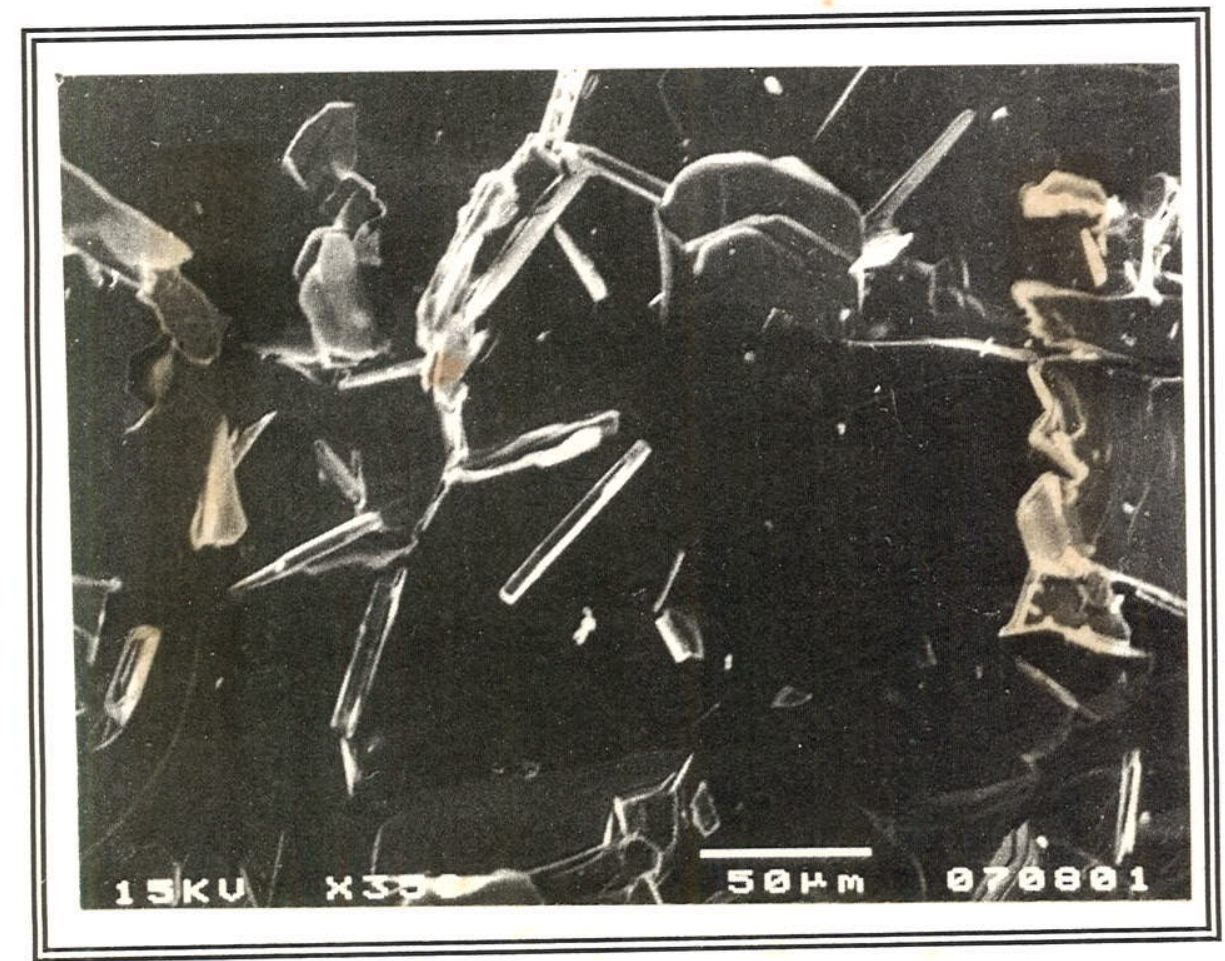

FOTOMICROGRAFIA 14 - Cristais aciculares de tremolita e fragmentos de topázio imperial da jazida do Câpão do Lana. 
TABELA 14 - Diagrama de pó da tremolita inclusa em topázio da jazida do Capão do Lana, obtido em câmara de Gandolfi com radiação $\mathrm{CuK}_{\alpha}=1,54178 \AA$ A, $20 \mathrm{~mA}, 40 \mathrm{kV}$ e 24 horas de exposição, comparado com o respectivo padrão do fichário JCPDS.

\begin{tabular}{|c|c|c|c|c|c|}
\hline \multicolumn{3}{|c|}{ Inclusão de tremolita } & \multicolumn{3}{|c|}{ JCPDS n $^{0} 13-437$} \\
\hline $\mathrm{d}_{\text {obs. }}(\mathrm{A})$ & $\mathrm{d}_{\mathrm{cal} .}(\mathrm{A})$ & $\mathbf{I} / \mathbf{I}$ & $d(A)$ & I/Io & (hkl) \\
\hline- & - & - & 8,98 & 16 & 020 \\
\hline 8,41 & 8,402 & 70 & 8,38 & 100 & 110 \\
\hline 5,08 & 5,083 & 25 & 5,07 & 16 & 130,001 \\
\hline 4,90 & 4,902 & 20 & 4,87 & 10 & 111 \\
\hline 4,75 & 4,746 & 20 & 4,76 & 20 & 200 \\
\hline 4,52 & 4,518 & 60 & 4,51 & 20 & 040 \\
\hline 4,21 & 4,211 & 20 & 4,20 & 35 & 220 \\
\hline 3,87 & 3,865 & 25 & 3,87 & 16 & $\overline{1} 31$ \\
\hline 3,37 & 3,374 & 40 & 3,38 & 40 & 150,041 \\
\hline 3,28 & 3,277 & 30 & 3,27 & 75 & 240 \\
\hline 3,12 & 3,119 & 40 & 3,12 & 100 & 310 \\
\hline - & - & - & 3,03 & 10 & 311,241 \\
\hline 2,94 & 2,938 & 25 & 2,938 & 40 & 151 \\
\hline 2,80 & 2,803 & 15 & 2,805 & 45 & 330 \\
\hline- & - & - & 2,730 & 16 & $42 \overrightarrow{1}$ \\
\hline 2,70 & 2,704 & 100 & 2,705 & 90 & 151 \\
\hline 2,59 & 2,590 & 35 & 2,592 & 30 & $\underline{1} 12,061$ \\
\hline- & - & - & 2,529 & 40 & 202,002 \\
\hline 2,41 & 2,409 & $<10$ & 2,407 & 8 & $\overline{1} 32$ \\
\hline 2,38 & 2,384 & $<10$ & 2,380 & 30 & 350,400 \\
\hline 2,33 & 2,336 & $40 \mathrm{~b}$ & 2,335 & 30 & $35 \underline{1}$ \\
\hline- & - & - & 2,321 & 40 & $42 \overline{1}$ \\
\hline 2,30 & 2,307 & $40 \mathrm{~b}$ & 2,298 & 12 & 420,071 \\
\hline- & - & - & 2,273 & 16 & 112 \\
\hline- & - & - & 2,206 & 6 & $\overline{2} 42,042$ \\
\hline- & - & - & 2,181 & 6 & $44 \overline{1}$ \\
\hline 2,16 & 2,161 & 35 & 2,163 & 35 & 171,261 \\
\hline - & - & - & 2,042 & 18 & 081,280 \\
\hline 2,01 & 2,010 & 30 & 2,015 & 45 & 202 \\
\hline- & - & - & 2,002 & 16 & $35 \underline{1}, 370$ \\
\hline 1,96 & 1,964 & 10 & 1,963 & 16 & $28 \overline{1}, 190$ \\
\hline 1,93 & 1,933 & 10 & 1,929 & 6 & 152 \\
\hline 1,89 & 1,891 & 15 & 1,892 & 50 & 510 \\
\hline 1,87 & 1,869 & 10 & 1,864 & 16 & $460, \overline{1} 91$ \\
\hline 1,81 & 1,812 & 10 & 1,814 & 16 & 530 \\
\hline 1,74 & 1,741 & 15 & 1,746 & 6 & 203 \\
\hline 1,68 & 1,686 & 15 & 1,686 & 10 & $003, \overline{2} 02$ \\
\hline 1,64 & 1,647 & 25 & 1,649 & 40 & $210 \overline{1}$ \\
\hline 1,64 & 1,617 & 20 & 1,639 & 10 & 480,511 \\
\hline 1,58 & 1,585 & 15 & $+9 \operatorname{linh}$ & & \\
\hline 1,55 & 1,555 & 10 & até & & \\
\hline 1,52 & 1,531 & $<10$ & 1,439 & & \\
\hline 1,50 & 1,509 & 20 & & & \\
\hline 1,46 & 1,467 & $<10$ & & & \\
\hline 1,44 & 1,439 & 40 & & & \\
\hline 1,36 & 1,361 & 25 & & & \\
\hline 1,33 & 1,336 & 20 & & & \\
\hline 1,30 & 1,308 & 15 & & & \\
\hline 1,29 & 1,295 & 30 & & & \\
\hline
\end{tabular}


A Figura 29 ilustra o respectivo diagrama de raios $X$ de um grão de quartzo incluso no topázio, onde estão presentes as raias mais intensas e importantes. A Tabela 15 mostra as reflexões da inclusão comparada com o diagrama do quartzo do sistema JCPDS. A presença do quartzo como pode ser visto na Fotomicrografia 17 e na Figura 30 foi confirmada também pelo MEV.

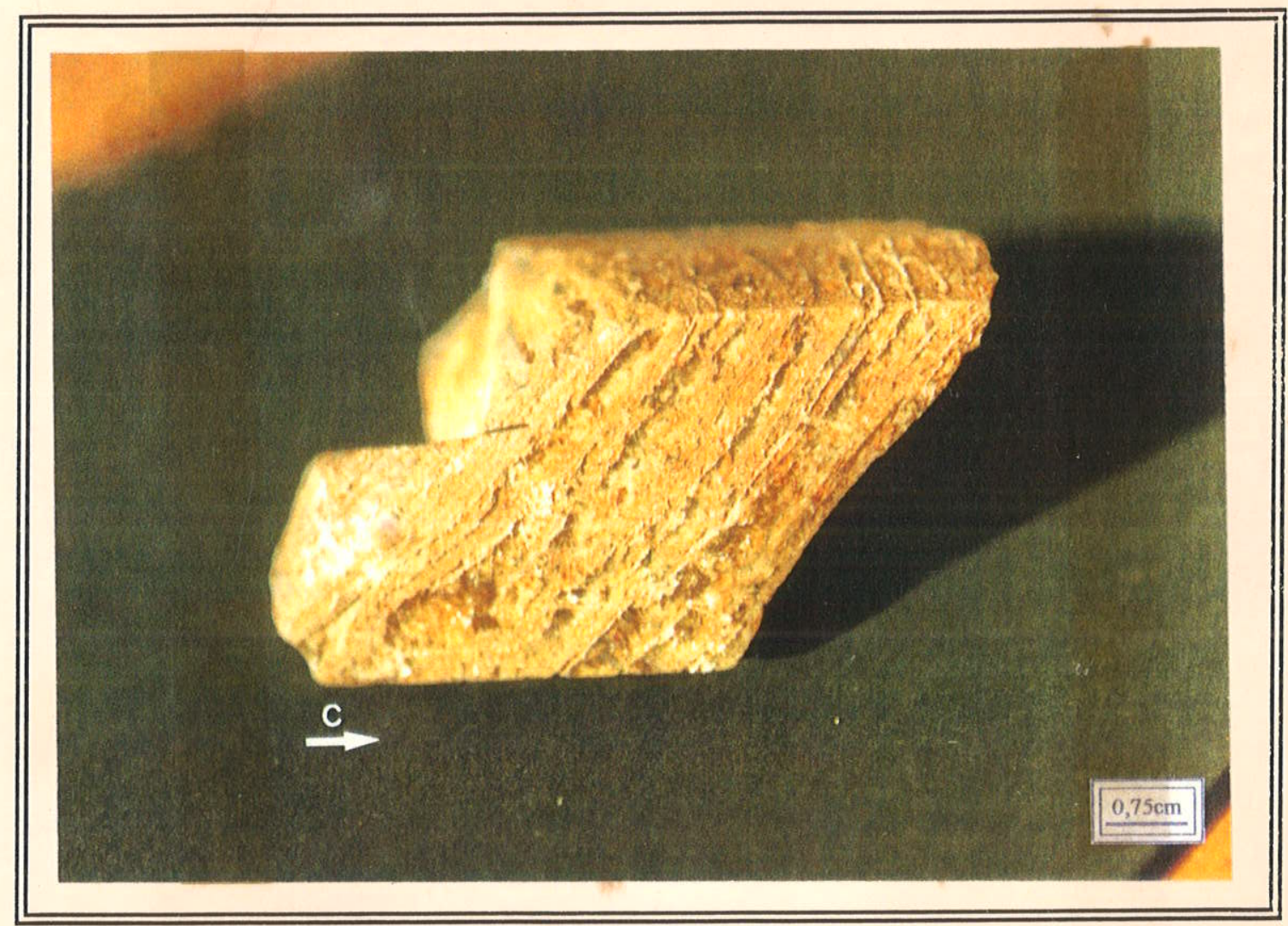

FOTOGRAFIA 16 - Cristal de topázio com inclusões de quartzo dispostas em camadas. indicando crescimento porfiroblático em quartzitos dolomíticos da jazida de Antônio Pereira.

\section{3 - RUTILO}

Koivula (1987) descreve rutilo em topázio incolor de pegmatitos no estado de Minas Gerais, e utiliza o termo "topázio rutilado" devido ao grande número de cristais aciculares de rutilo, semelhantes ao aspecto dos quartzos rutilados. 


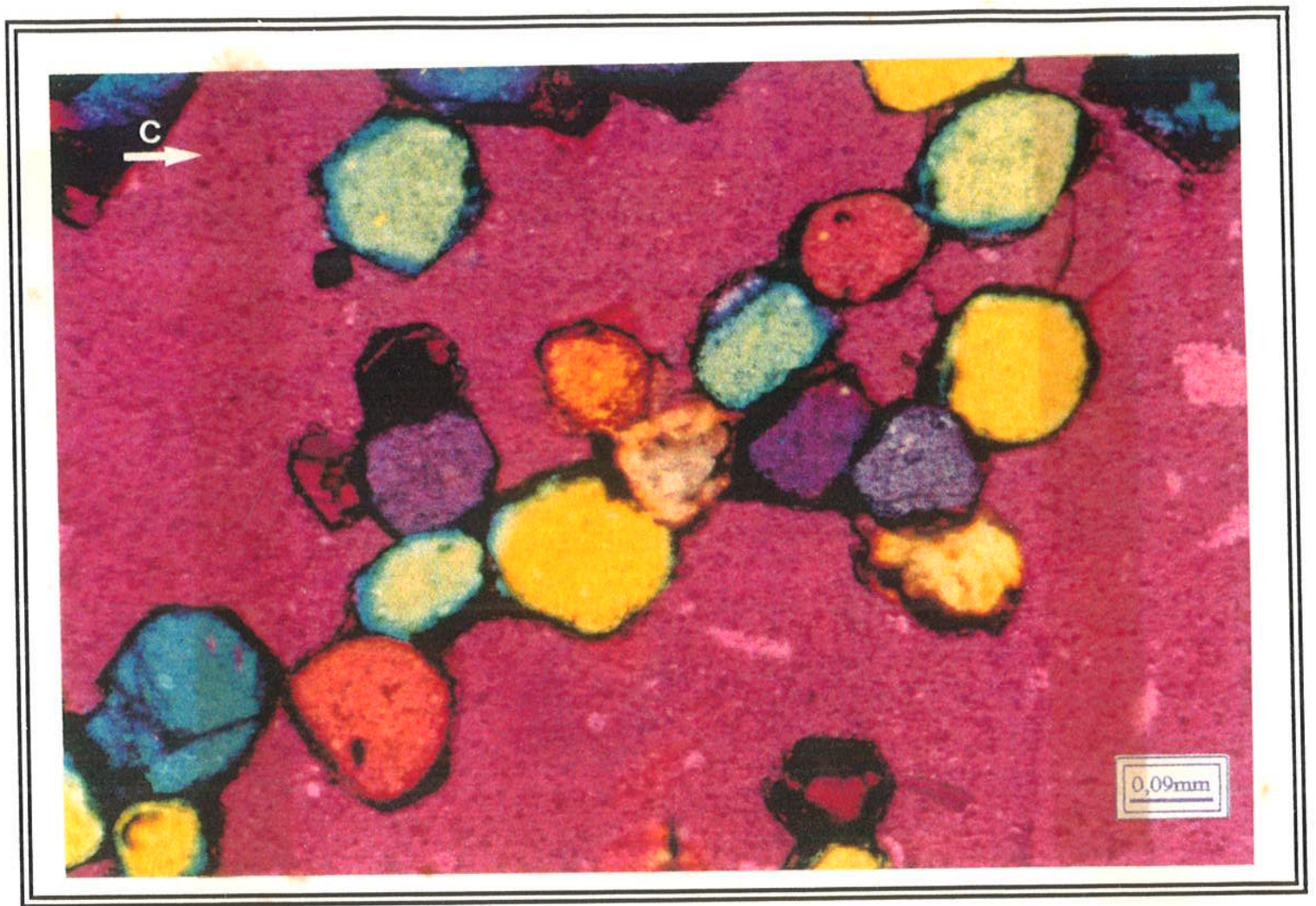

FOTOMICROGRAFIA 15 - Detalhe da fotografia 16, destacando os grãos arredondados de quartzo inclusos no topázio. Polarizadores cruzados mais cunha de gipso.

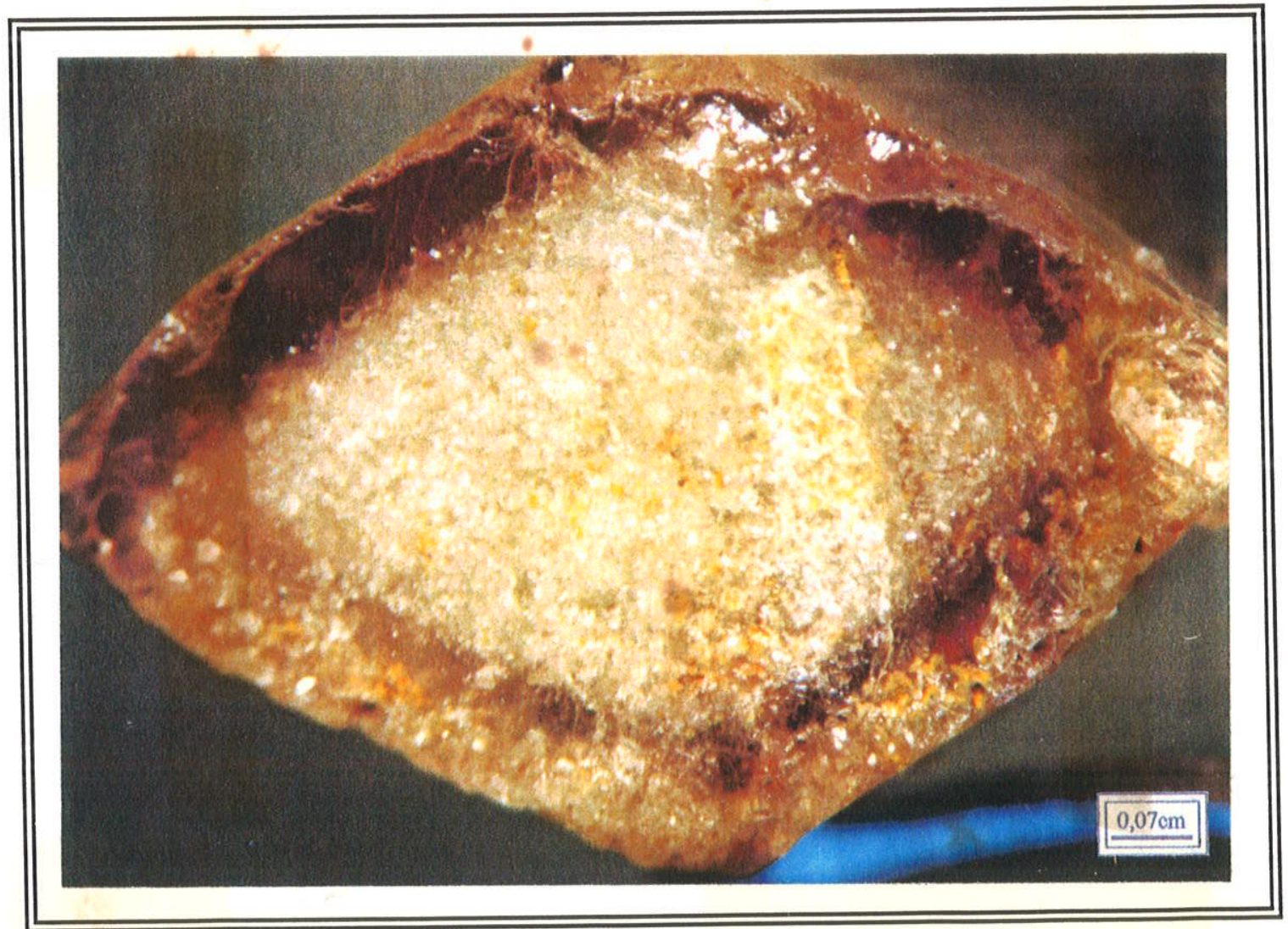

FOTOMICROGRAFIA 16 - Núcleo de um topázio da jazida de Antônio Pereira, constituído por grãos de quartzo. 


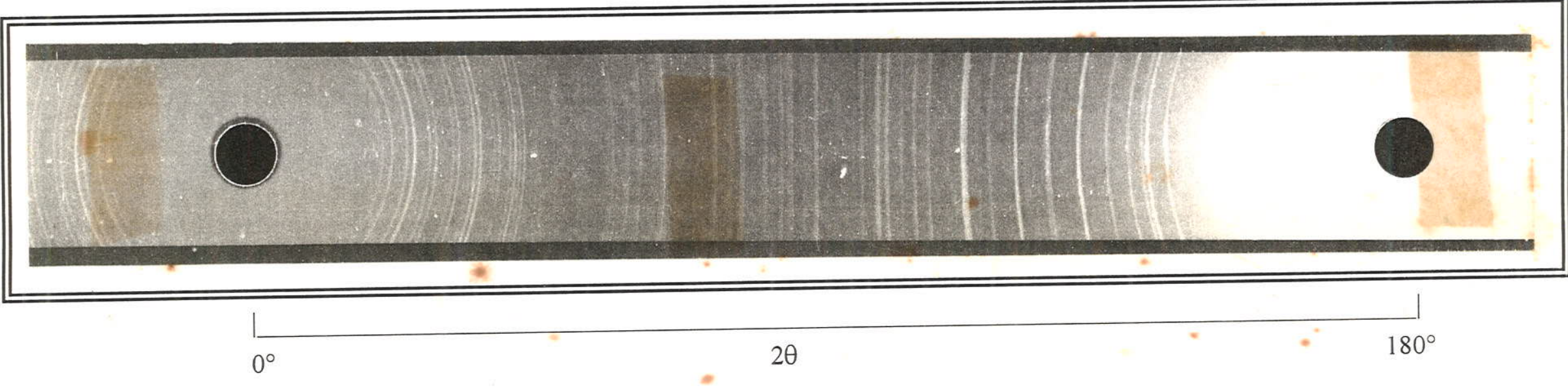

FIGURA 29 - Diagrama de pó do quartzo incluso no topázio imperial de Antônio Pereira, obtido em câmara de Gandolifi de 114,6mm de diâmetro, com radiação $\mathrm{CuK}_{\alpha}=1,54178 \AA$, exposição de 20 horas, $20 \mathrm{~mA}$ e $40 \mathrm{kV}$.

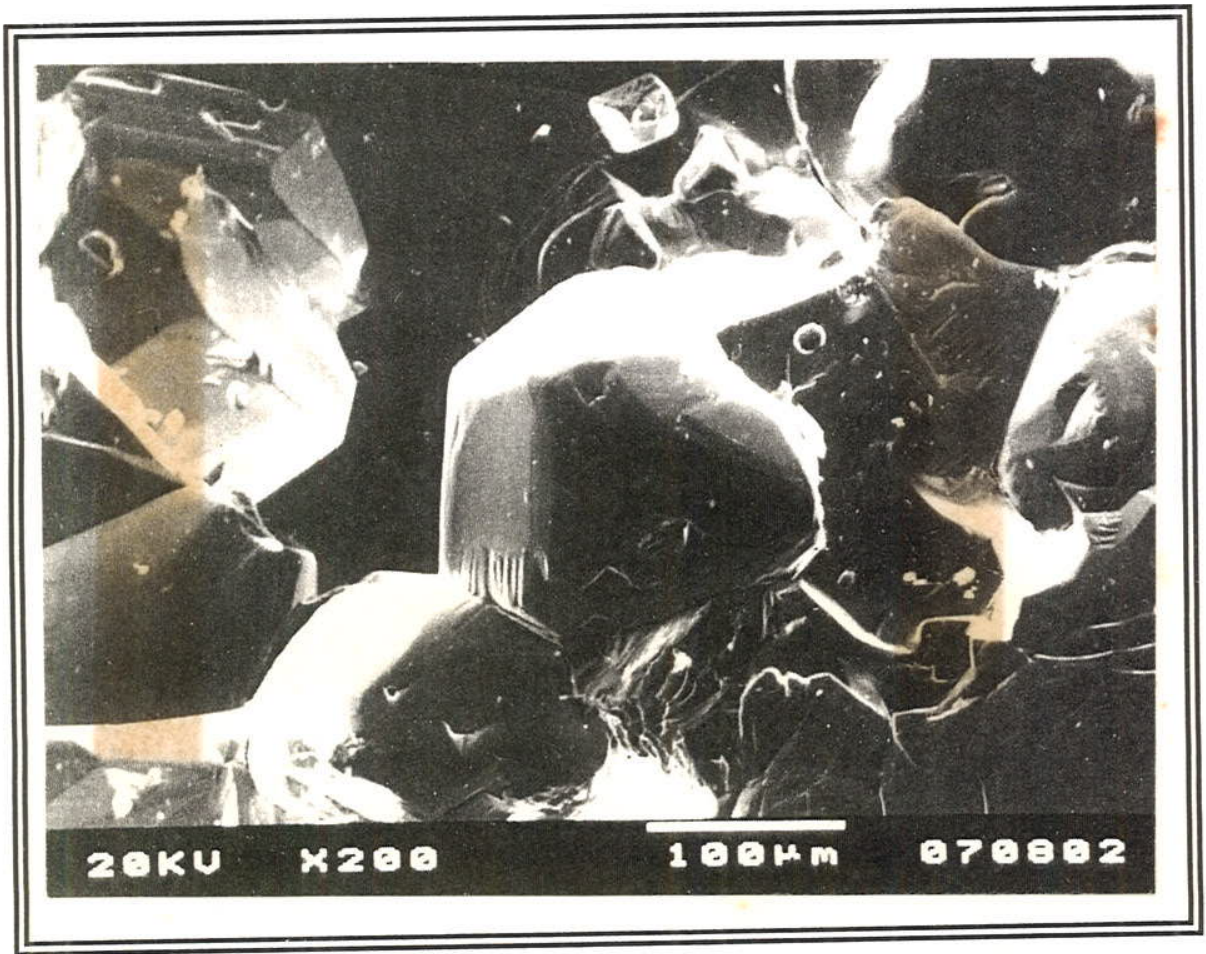

FOTOMICROGRAFIA 17 - Grãos equidimensionais de quartzo inclusos em topázio da jazida de Antônio Pereira. 
TABELA 15 - Diagrama de pó de quartzo incluso em topázio da jazida de Antônio Pereira. obtido em câmara de Gandolfi com radiação $\mathrm{CuK}_{\alpha}=1.54178 \mathrm{~A} .20 \mathrm{~mA}$. $40 \mathrm{kV}$ e 20 horas de exposição, comparado com o respectivo padrão do fichário JCPDS.

\begin{tabular}{|c|c|c|c|c|c|}
\hline \multicolumn{3}{|c|}{ Inclusão de quartzo } & \multicolumn{3}{|c|}{$\mathrm{JCPDS} \mathrm{n}^{\circ} 5-490$} \\
\hline $\mathrm{d}_{\text {obs. }}(\hat{A})$ & $d_{\text {cal. }}(A)$ & $\mathbf{I} / \mathbf{I}_{\mathrm{o}}$ & $\mathrm{d}(\hat{\mathrm{A}})$ & $\mathbf{I} / \mathbf{I}_{0}$ & (hkl) \\
\hline 4.25 & +.251 & 40 & +.26 & 35 & 100 \\
\hline 3.34 & 3.337 & 100 & 3.343 & 100 & 101 \\
\hline 2.46 & 2.459 & 20 & 2.458 & 12 & 110 \\
\hline 2.28 & 2.279 & 35 & 2.282 & 12 & 102 \\
\hline 2.23 & 2.232 & 15 & 2.237 & 6 & 111 \\
\hline 2.12 & 2,124 & 20 & 2.129 & 9 & 200 \\
\hline 1.98 & 1,979 & 25 & 1.980 & 6 & 201 \\
\hline 1.81 & 1.815 & 60 & 1.817 & 17 & 112 \\
\hline- & - & - & 1.801 & $<1$ & 003 \\
\hline 1.67 & 1,670 & $15 b$ & 1.672 & 7 & 202 \\
\hline 1.66 & 1,661 & $15 \mathrm{~b}$ & 1,659 & 3 & 103 \\
\hline- & - & - & 1,608 & $<1$ & 210 \\
\hline 1.54 & 1,537 & 35 & 1.541 & 15 & 211 \\
\hline 1.45 & 1,450 & 10 & 1.453 & 3 & 113 \\
\hline- & - & - & 1,418 & $<1$ & 300 \\
\hline- & - & - & 1.382 & 7 & 212 \\
\hline 1.37 & 1,377 & $30 \mathrm{~b}$ & 1.375 & 11 & 203 \\
\hline- & - & - & 1.372 & 9 & 301 \\
\hline & & & \multicolumn{2}{|c|}{ - 22 linhas } & \\
\hline & & & \multicolumn{2}{|c|}{ até 0.9285} & \\
\hline
\end{tabular}

Este mineral, que ocorre como inclusão cristalina no topázio imperial da região de Ouro Preto, é extremamente pequeno e fino (aciculares), e de cor acastanhada (Fotomicrografia 18). Cristais maclados, em forma de joelho, também são encontrados inclusos no topázio. O tamanho desse mineral também é muito variável, desde $0,1 \mathrm{~mm}$ até cristais que chegam a ultrapassar o topázio. Tanto nos cristais de rutilo individuais, quanto nos agregados desse mineral, não há uma predominância de orientação como inclusão. O rutilo foi identificado através de difração de raio $\mathrm{X}$ em câmara de Gandolfi e suas reflexões mais intensas estão mostradas no diagrama de pó da Figura 31. A Tabela 16, mostra as reflexões lidas comparadas com o padrão do sistema JCPDS. 


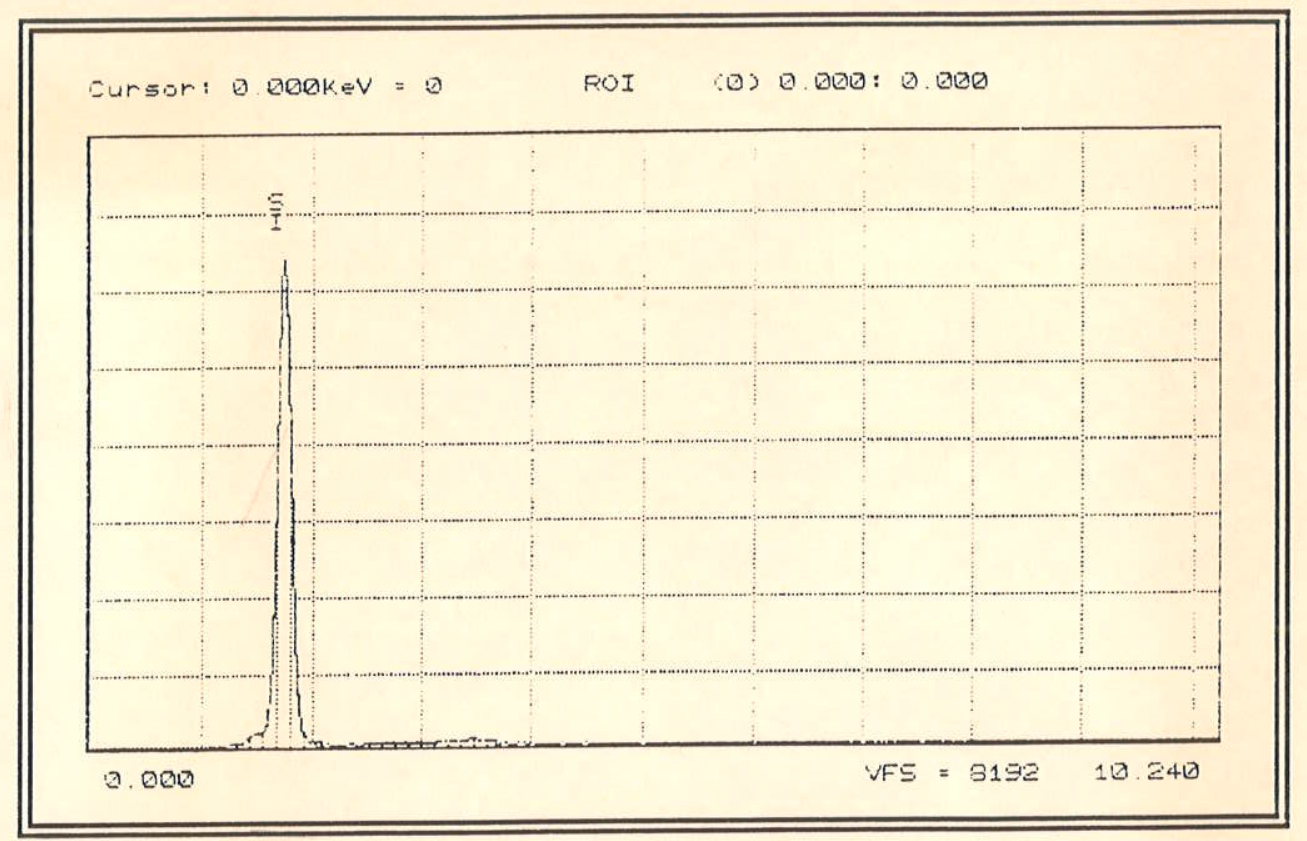

FIGURA 30 - Diagrama EDS, destacando o elemento quimico silício do quartzo, relativo à fotomicrografia 17.

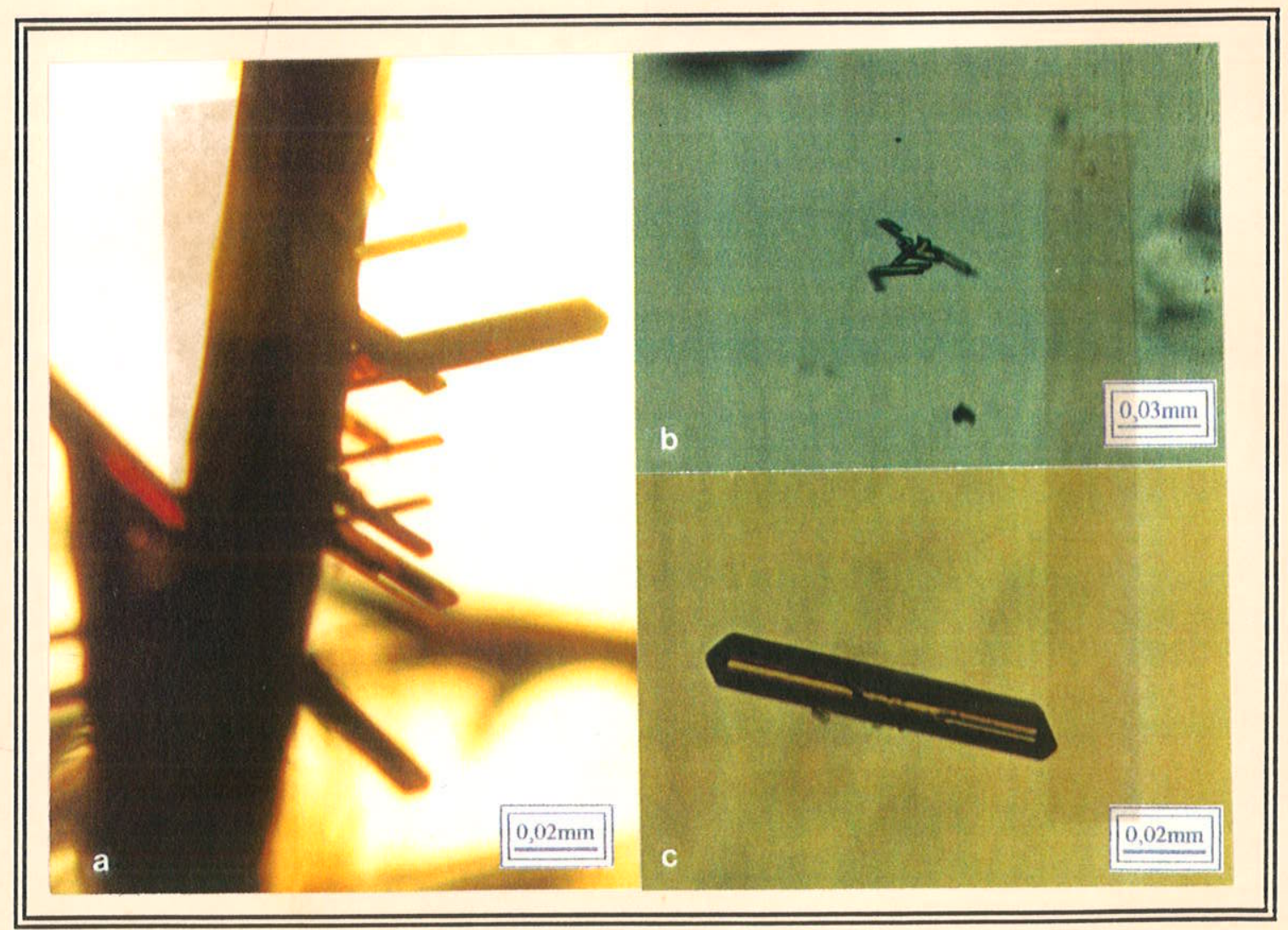

FOTOMICROGRAFIA 18 - a) agregado de cristais de rutilo inclusos em topázio imperial, b) cristal maclado em joelho e c) cristal biterminado de rutilo incluso em topázio da jazida de Antônio Pereira. 
TABELA 16 - Diagrama de pó de rutilo incluso em topázio da jazida do Vermelhão, obtido em câmara de Gandolfi com radiação $\mathrm{CuK}_{\alpha}=1.54178 \AA$, $20 \mathrm{~mA}, 40 \mathrm{kV}$ e 20 horas de exposição, comparado com o respectivo padrão do fichário JCPDS.

\begin{tabular}{|c|c|c|c|c|c|}
\hline \multicolumn{3}{|c|}{ Inclusão de rutilo } & \multicolumn{3}{|c|}{$\mathrm{JCPDS} \mathrm{n}^{\circ} 21-1276$} \\
\hline $\mathbf{d}_{\text {obs. }}(\AA)$ & $\mathbf{d}_{\text {cal. }}(\AA)$ & $\mathbf{I} / \mathbf{I}_{\mathrm{o}}$ & d $(\hat{\AA})$ & $\mathbf{I} / \mathbf{I}_{0}$ & (hkl) \\
\hline 3,24 & 3,234 & $40 \mathrm{~b}$ & 3,25 & 100 & 110 \\
\hline 2,47 & 2,463 & $30 \mathrm{~b}$ & 2,487 & 50 & 101 \\
\hline 2,28 & 2,279 & 10 & 2.297 & 8 & 200 \\
\hline 2,18 & 2,173 & 35 & 2,188 & 25 & 111 \\
\hline 2,03 & 2,026 & 15 & 2,054 & 10 & 210 \\
\hline 1,68 & 1,675 & 100 & 1,6874 & 60 & 211 \\
\hline 1,61 & 1,608 & $25 \mathrm{~b}$ & 1,6237 & 20 & 220 \\
\hline 1,47 & 1,467 & 20 & 1,4797 & 10 & 002 \\
\hline 1,44 & 1,482 & 20 & 1,4528 & 10 & 310 \\
\hline- & - & - & 1,4243 & 2 & 221 \\
\hline 1,35 & 1,354 & $30 \mathrm{~b}$ & 1,3598 & 20 & 301 \\
\hline 1,34 & 1,339 & 10 & 1,3465 & 12 & 112 \\
\hline- & - & - & 1,3041 & 2 & 311 \\
\hline 1,23 & 1,235 & $<10$ & 1,2441 & 4 & 202 \\
\hline- & - & - & 1,2006 & 2 & 212 \\
\hline 1,16 & 1,164 & 20 & 1,1702 & 6 & 321 \\
\hline 1,13 & 1,136 & 10 & 1,1483 & 4 & 400 \\
\hline \multirow[t]{3}{*}{-} & - & - & 1,143 & 2 & 410 \\
\hline & & & $+18 \operatorname{lin} 1$ & & \\
\hline & & & até 0,7 & & \\
\hline
\end{tabular}

\section{4 - HEMATITA}

É uma das inclusões cristalinas mais abundantes em alguns topázios, principalmente, de Antônio Pereira e Capão do Lana (Fotomicrografias 19 e 20). Quase que invariavelmente ocorrem como plaquetas finas na variedade especularita. Sua cor é preta com brilho metálico característico. Às vezes, este mineral ocorre distribuído em todo o cristal ou então, concentrado nas bordas do topázio. De um modo geral, as plaquetas de especularita possuem um tamanho médio de $0,2 \mathrm{~mm}$, podendo em alguns casos, ter quase $1 \mathrm{~cm}$ de diâmetro. $O$ diagrama de pó de uma hematita inclusa em topázio da jazida de Antônio Pereira, obtido na câmara de Gandolfi, está representado na Figura 32; as reflexões correspondentes, por sua vez estão contidas na Tabela 
17, juntamente com o diagrama de uma hematita do sistema JCPDS. Também na Tabela 17 mostra as reflexões principais de uma outra inclusão de hematita da jazida do Capão do Lana. Análises de MEV revelaram que a hematita contém 93,6\% de $\mathrm{Fe}_{2} \mathrm{O}_{3}$ e 6,4\% de $\mathrm{TiO}_{2}$. É freqüente também na forma de agregados designados de "rosa de hematita", que podem ter às vezes, $30 \mathrm{~cm}$ de diâmetro, sendo encontrados na jazida do Capão do Lana e adjacências. Cristais de topázio ocorrem eventualmente inclusos nas placas de hematita.

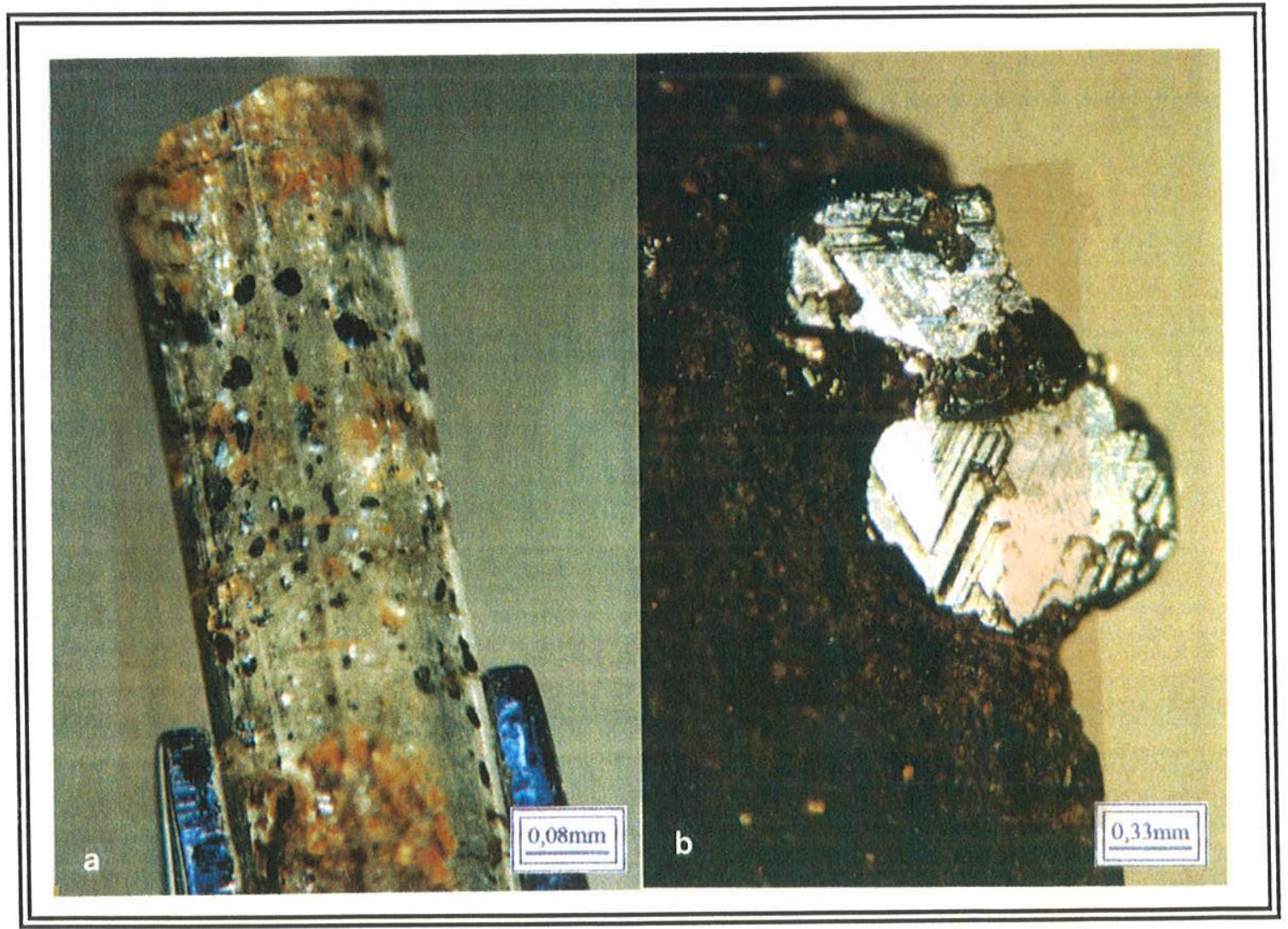

FOTOMICROGRAFIA 19 - a) cristal de topázio da jazida de Antônio Pereira, prensado por uma pinça, destacando as inclusões de especularita, b) detalhe de uma especularita crescida sobre superfície do topázio. 


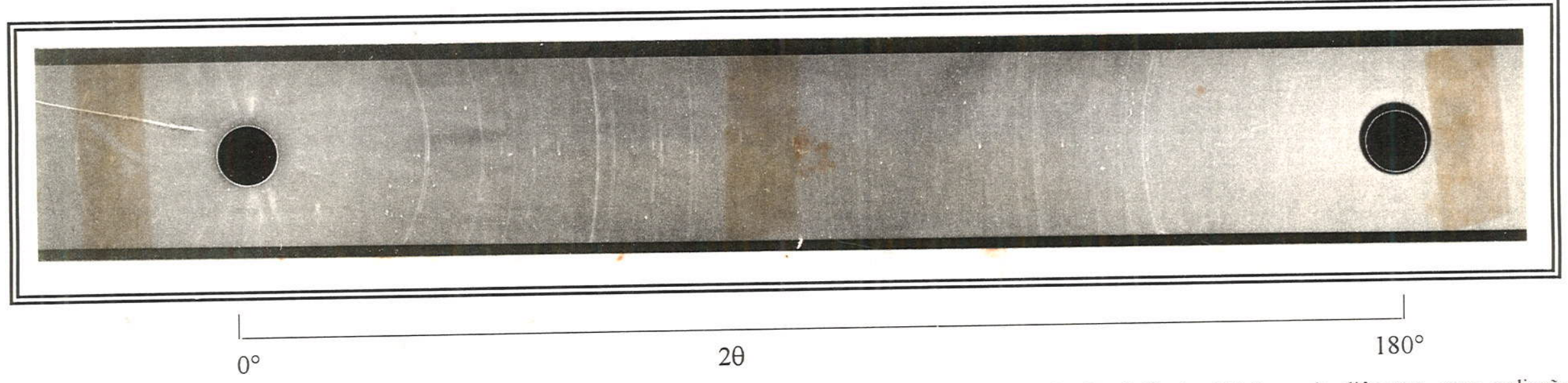

FIGURA 31 - Diagrama de pó do rutilo incluso no topázio imperial do Vermelhão, obtido em câmara de Gandolfi de 114,6mm de diâmetro, com radiação $\mathrm{CuK}_{\alpha}=1,54178 \AA$, exposição de 20 horas, $20 \mathrm{~mA} \mathrm{e} 40 \mathrm{kV}$.

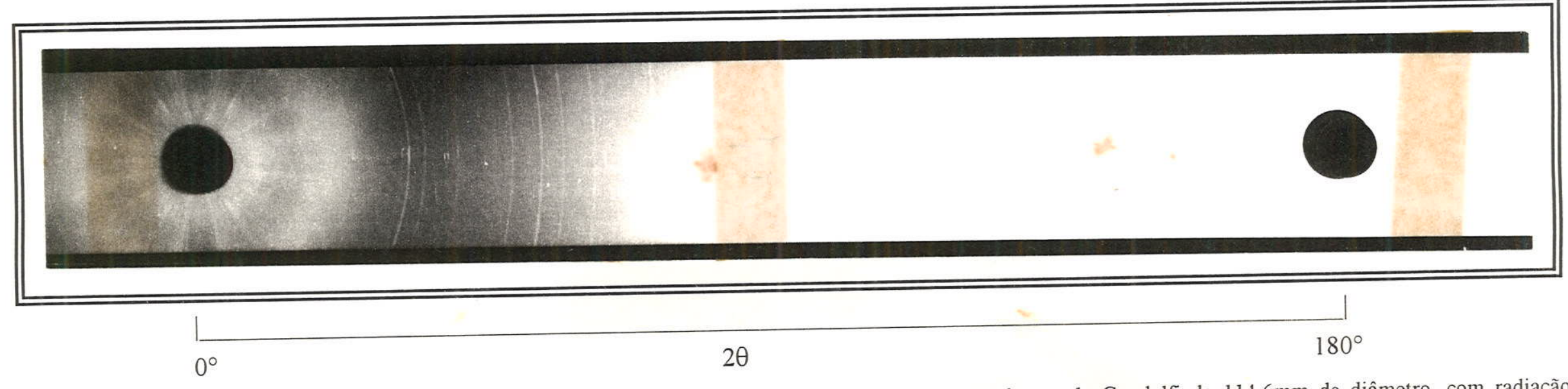

FIGURA 32 - Diagrama de pó da hematita inclusa no topázio imperial do Capão do Lana, obtido em câmara de Gandolfi de 114,6mm de diâmetro, com radiação $\mathrm{CuK}_{\alpha}=1,54178 \AA$, exposição de 24 horas, $20 \mathrm{~mA}$ e $40 \mathrm{kV}$. 


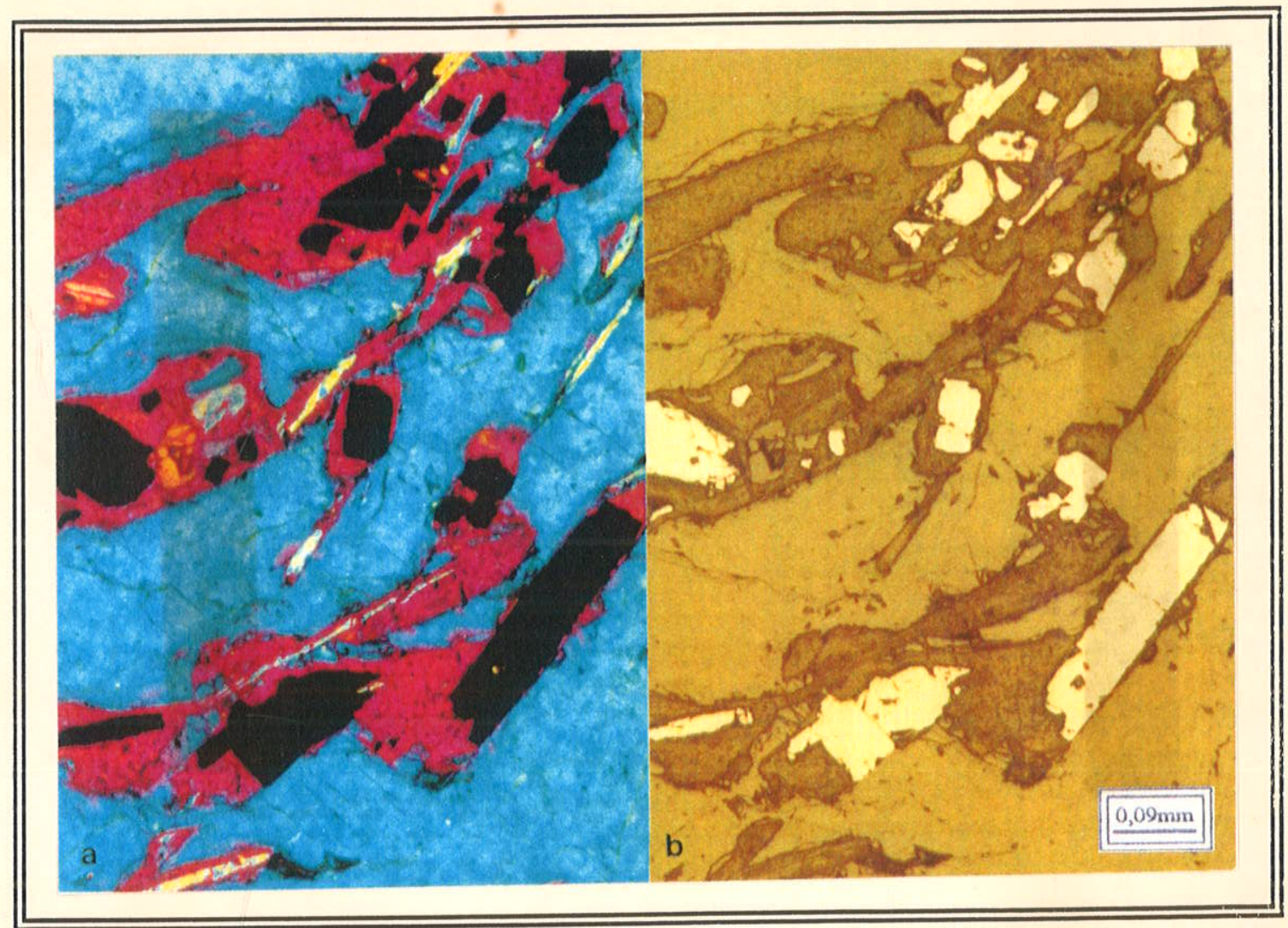

FOTOMICROGRAFIA 20 - Lâmina delgada de um topázio da jazida de Antônio Pereira. contendo inclusões de especularita. Em a), as palhetas amarelas são micas e as manchas avermelhadas são buracos; (polarizadores cruzados mais cunha de gipso) e em b), o mesmo detalhe sob luz refletida.

\section{5 - ILMENITA}

A ilmenita foi identificada somente por análises de MEV (Tabela 18). Conseqüentemente, esta inclusão não pode ser descrita com pormenores fornecidos para as outras espécies referidas.

\section{6 - EUCLÁSIO}

É um mineral raro, de fórmula $\mathrm{BeAlSiO}_{4}(\mathrm{OH})$ que pode ocorrer como inclusão cristalina no topázio imperial e também ser encontrado, em algumas jazidas, como cristal individualizado. Raramente são encontrados euclásios com intercrescimento de topázio. A cor do euclásio que ocorre incluso nos topázios varia de azul a incolor. Os demais tipos além dessas cores podem ser verde, verde-azulado, azul e amarelo. Constituem cristais bem formados de até $5 \mathrm{~cm}$ de comprimento na região de Dom Bosco, Boa Vista, Capão, Fundão e Hargreaves (Leonardos 1945, Gonsalves 1949, Bastos 1961). O hábito dessas inclusões é representado por um prisma curto e não há uma orientação predominante no cristal hospedeiro. O euclásio, incluso no topázio, foi identificado facilmente pelo método do pó (Tabela 19), tendo em vista suas dimensões favoráveis ( $5 \mathrm{~mm}$ ). 
TABELA 17 - Diagramas de pó de hematitas (especularita) inclusas em topázios das jazidas de Antônio Pereira e do Capão do Lana, obtido em câmara de Gandolfi com radiação $\mathrm{CuK}_{\alpha}=$ 1,54178A, $20 \mathrm{~mA}, 40 \mathrm{kV}$ e 24 horas de exposição, comparado com o respectivo padrão do fichário JCPDS.

\begin{tabular}{|c|c|c|c|c|c|c|c|c|}
\hline \multicolumn{3}{|c|}{ ANTÔNIO PEREIRA } & \multicolumn{3}{|c|}{ CAPÃO DO LANA } & \multicolumn{3}{|c|}{$\mathrm{JCPDS} \mathrm{n}^{0}$ 13-534 } \\
\hline $\mathrm{d}_{\text {obs. }}(\AA)$ & $\mathbf{d}_{\text {cal. }}(\AA)$ & $\mathrm{I} / \mathrm{I}_{\mathrm{o}}$ & $\mathbf{d}_{\text {obs. }}(\AA)$ & $\mathbf{d}_{\text {cal. }}(\AA)$ & $\mathbf{I} / \mathbf{I}_{\mathrm{o}}$ & d $(\hat{A})$ & $\mathbf{I} / \mathbf{I}_{0}$ & (hkl) \\
\hline- & - & - & - & - & - & 3,66 & 25 & 012 \\
\hline 2,69 & 2,693 & 70 & 2,69 & 2,694 & 70 & 2,69 & 100 & 104 \\
\hline 2,50 & 2,450 & 20 & 2,51 & 2,515 & 40 & 2,51 & 50 & 110 \\
\hline- & - & - & 2,29 & 2,289 & $<10$ & 2,285 & 2 & 006 \\
\hline 2,16 & 2,207 & 10 & 2,20 & 2.203 & 20 & 2,201 & 30 & 113 \\
\hline- & - & - & - & - & - & 2,070 & 2 & 202 \\
\hline 1,83 & 1,835 & 10 & 1,84 & 1,838 & 35 & 1,838 & 40 & 024 \\
\hline 1,69 & 1,693 & 100 & 1,69 & 1,694 & 100 & 1,690 & 60 & 116 \\
\hline- & - & - & - & - & - & 1,634 & 4 & 211 \\
\hline 1,59 & 1,597 & 30 & 1,60 & 1,600 & 50 & 1,596 & 16 & 018 \\
\hline 1,48 & 1,483 & 10 & 1,48 & 1,486 & 50 & 1,484 & 35 & 214 \\
\hline 1,45 & 1,448 & 10 & 1,45 & 1,449 & 25 & 1,452 & 35 & 300 \\
\hline - & - & - & 1,40 & 1,348 & $<10$ & - & - & - \\
\hline 1,35 & 1,347 & $<10$ & - & - & - & 1,349 & 4 & 208 \\
\hline 1,31 & 1,311 & 50 & 1,31 & 1,311 & 60 & 1,310 & 20 & $10 \underline{10}, 119$ \\
\hline - & - & - & - & - & - & 1,258 & 8 & 220 \\
\hline- & - & - & - & - & - & 1,226 & 2 & 036 \\
\hline- & - & - & - & - & - & 1,213 & 4 & 223 \\
\hline 1,17 & 1,188 & $<10$ & 1,19 & 1,190 & $<10$ & 1,189 & 8 & 128 \\
\hline 1,16 & 1,162 & $<10$ & 1,16 & 1,161 & 15 & 1,162 & 10 & $02 \underline{10}$ \\
\hline- & - & - & - & - & - & 1,141 & 12 & 134 \\
\hline- & - & - & - & - & - & 1,102 & 14 & 226 \\
\hline - & - & - & - & - & - & 1,076 & 2 & 042 \\
\hline 1,05 & 1,057 & 35 & - & - & - & 1,055 & 18 & $21 \underline{10}$ \\
\hline- & - & - & - & - & - & $+10 \operatorname{linh}$ & & \\
\hline- & - & - & - & - & - & até 0,9 & & \\
\hline
\end{tabular}

TABELA 18 - Análise da ilmenita inclusa em topázio da jazida do Vermelhão por meio do MEV.

\begin{tabular}{|c|c|c|c||}
\hline elem. & CPS & \% peso el. & óxidos \\
\hline $\mathbf{T i}$ & $92,4.8500$ & 31,37 & $\mathrm{TiO}_{2}-52,32$ \\
$\mathbf{F e}$ & 575.2000 & 33,35 & $\mathrm{Fe}_{2} \mathrm{O}_{3}-\underline{47,68}$ \\
& & & 100,00 \\
\hline
\end{tabular}


TABELA 19 - Reflexões principais do diagrama do pó do euclásio incluso em topázio da jazida de Boa Vista, obtido com radiação $\mathrm{CuK}_{\alpha}=1,54178 \AA$, sob condições de $20 \mathrm{~mA}$ e $40 \mathrm{kV}$, comparadas com o respectivo padrão do fichário JCPDS.

\begin{tabular}{|c|c|c|c|c|}
\hline \multicolumn{2}{|c|}{ euclásio } & \multicolumn{3}{|c|}{ JCPDS n $^{0}$ 14-65 } \\
\hline d & $\mathbf{I} / \mathbf{I}_{0}$ & $\mathrm{~d}(\mathbf{A})$ & $\mathbf{I} / \mathbf{I}_{0}$ & (hkl) \\
\hline 7,225 & 100 & 7,15 & 100 & 020 \\
\hline 4,562 & 9 & 4,574 & 6 & 001 \\
\hline - & - & 4,457 & 4 & 110 \\
\hline- & - & 4,331 & 2 & 011 \\
\hline 3,883 & 8 & 3,836 & 35 & 021 \\
\hline & - & 3,676 & 14 & 040 \\
\hline 3,590 & 15 & - & - & -- \\
\hline- & - & 3,493 & 4 & 111 \\
\hline 3,316 & 7 & 3,342 & 4 & 130 \\
\hline - & - & 3,292 & 4 & 031 \\
\hline 3,234 & 20 & 3,219 & 50 & 121 \\
\hline 2,955 & 2 & 2,943 & 4 & 111 \\
\hline 2,910 & 5 & - & - & - \\
\hline 2,850 & 3 & 2,871 & 4 & 131 \\
\hline- & - & 2,811 & 4 & 041 \\
\hline 2,776 & 15 & 2,773 & 35 & 121 \\
\hline 2,553 & 14 & 2,543 & 25 & 131 \\
\hline 2,448 & 34 & 2,444 & 35 & 150 \\
\hline 2,394 & 4 & 2,384 & 2 & 060 \\
\hline 2,356 & 8 & 2,347 & 10 & 200 \\
\hline - & - & 2,279 & 2 & 012 \\
\hline 2,264 & 13 & 2,252 & 14 & 201 \\
\hline- & - & 2,182 & 2 & $\overline{1} 12$ \\
\hline 2,118 & 4 & 2,111 & 4 & 061 \\
\hline 2,082 & 7 & 2,074 & 10 & 151 \\
\hline 2,042 & 3 & 2,040 & 6 & $\overline{2} 31$ \\
\hline 2,017 & 3 & - & - & - \\
\hline 2,011 & 7 & - & - & - \\
\hline- & - & 2,003 & 2 & 132 \\
\hline 1,994 & 16 & 1,991 & 18 & - \\
\hline 1,958 & 9 & 1,952 & 6 & - \\
\hline- & - & 1,924 & 2 & - \\
\hline 1,886 & 7 & 1,880 & 18 & - \\
\hline- & - & 1,805 & 2 & - \\
\hline 1,794 & 16 & 1,790 & 6 & - \\
\hline- & - & 1,778 & 4 & - \\
\hline 1,753 & 3 & 1,748 & 2 & - \\
\hline- & - & 1,748 & 2 & - \\
\hline- & - & 1,720 & 2 & - \\
\hline- & - & 1,690 & 2 & - \\
\hline 1,672 & 13 & 1,675 & 10 & - \\
\hline 1,665 & 9 & 1,664 & 10 & - \\
\hline- & - & 1,647 & 2 & - \\
\hline 1,622 & 2 & 1,621 & 4 & - \\
\hline - & - & 1,562 & 2 & - \\
\hline & & $\begin{array}{l}+40 \text { lin } \\
\text { até } 1 \text {, }\end{array}$ & & \\
\hline 1,530 & 3 & - & - & - \\
\hline $1,506=$ & 5 & - & - & - \\
\hline 1,441 & 4 & - & - & - \\
\hline 1,403 & 3 & - & - & - \\
\hline 1,366 & 13 & - & - & - \\
\hline
\end{tabular}




\section{7 - MICA}

A mica está presente, com maior frequeência, nos topázios da jazida de Antônio Pereira, e em seguida na do Capão do Lana. É incolor, possui hábito placoidal de contornos alongados e está disseminada em grande quantidade no interior do cristal, sem apresentar uma orientação preferencial em relação ao hospedeiro. Na parte mais externa do topázio é mais rara a presença de inclusões de mica e/ou quartzo para a jazida citada (Fotomicrografia 21). Possui dimensões constantes, estando compreendida no intervalo entre 0,1 e $0,2 \mathrm{~mm}$. Esta inclusão, da mesma forma que o quartzo, é mais rara nas partes mais próximas à superfície. Sua identificação processou-se por meio do MEV tal como evidenciado pelas Tabelas 20 e 21, Fotomicrografia 22 e Figura 33.

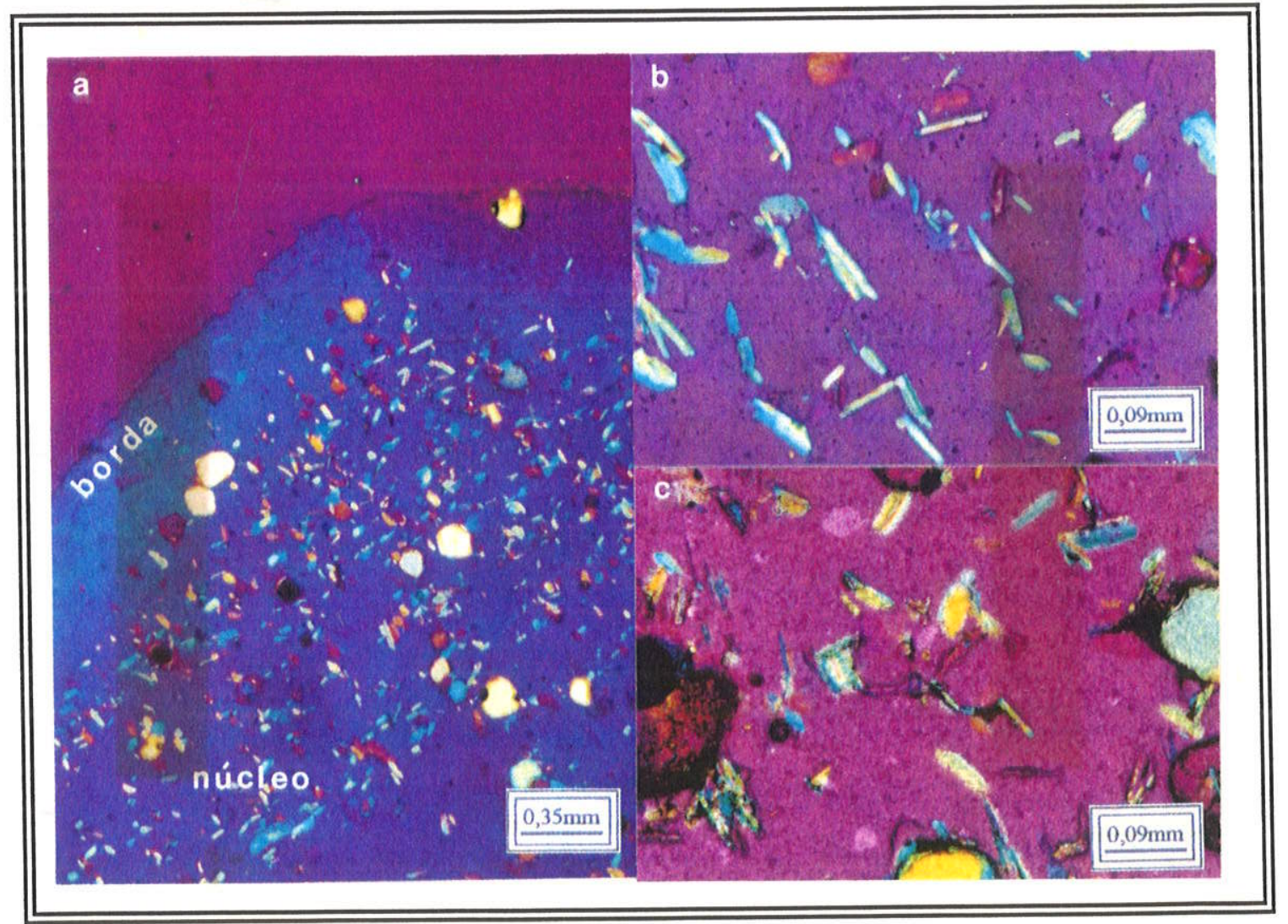

FOTOMICROGRAFIA 21 - a) lâmina delgada de topázio da jazida de Antônio Pereira, onde se vêem grãos de quartzo misturados com inúmeras plaquetas de micas sem uma orientação definida, concentrados no núcleo do topázio. Em b) e c) detalhes de a). Polarizadores cruzados mais cunha de gipso. 
TABELA 20 - Análise de mica (moscovita) inclusa em topázio da jazida de Antônio Pereira por meio do MEV.

\begin{tabular}{||l|r|r|ll||}
\hline \hline elem. & \multicolumn{1}{|c|}{ CPS } & \% peso el. & \multicolumn{2}{|c|}{ óxidos } \\
\hline $\mathbf{M g}$ & 23.6000 & 1,12 & $\mathrm{MgO}^{-}-1,86$ \\
$\mathrm{Al}$ & 601.3500 & 17,78 & $\mathrm{Al}_{2} \mathrm{O}_{3}-33.60$ \\
$\mathrm{Si}$ & 821.2500 & 23,49 & $\mathrm{SiO}_{2}-50,25$ \\
$\mathbf{K}$ & 415.3667 & 10,04 & $\mathrm{~K}_{2} \mathrm{O}-12,09$ \\
$\mathrm{Ti}$ & 8.4167 & 0,26 & $\mathrm{TiO}_{2}-0,43$ \\
$\mathbf{F e}$ & 28.0167 & 1,24 & $\mathrm{Fe}_{2} \mathrm{O}_{3}-\frac{1,78}{100,00}$ \\
\hline
\end{tabular}

TABELA 21 - Análise de mica (moscovita) inclusa em topázio da jazida do Capão do Lana por meio do MEV.

\begin{tabular}{|l|r|c|l||}
\hline \hline elem. & \multicolumn{1}{|c|}{ CPS } & \% peso el. & \multicolumn{1}{|c|}{ óxidos } \\
\hline $\mathbf{M g}$ & 18.7500 & 0,92 & $\mathrm{MgO}-1,52$ \\
$\mathrm{Al}$ & 534.3834 & 16,01 & $\mathrm{Al}_{2} \mathrm{O}_{3}-30,25$ \\
$\mathrm{Si}$ & 907.5500 & 25,27 & $\mathrm{SiO}_{2}-54,05$ \\
$\mathbf{K}$ & 328.7500 & 7,91 & $\mathrm{~K}_{2} \mathrm{O}-9,53$ \\
$\mathbf{C r}$ & 13.1667 & 0,45 & $\mathrm{Cr}_{2} \mathrm{O}_{3}-0,65$ \\
$\mathbf{M n}$ & 5.1000 & 0,20 & $\mathrm{MnO}^{-}-0,25$ \\
$\mathbf{F e}$ & 59.6167 & 2,62 & $\mathrm{Fe}_{2} \mathrm{O}_{3}-\frac{3,75}{100,00}$ \\
\hline
\end{tabular}

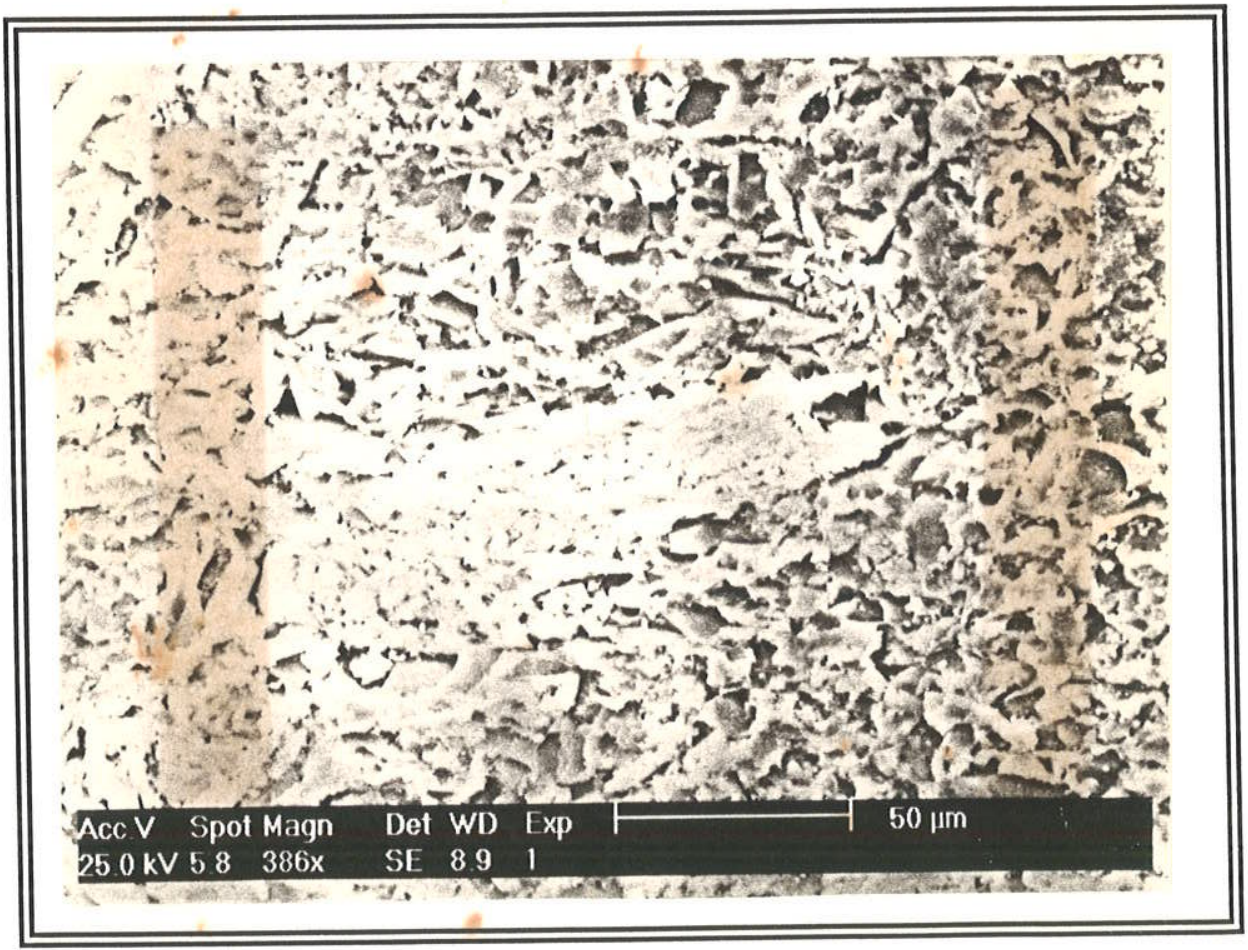

FOTOMICROGRAFIA 22 - Placas de micas inclusas em um cristal de topázio imperial da jazida de Antônio Pereira. 


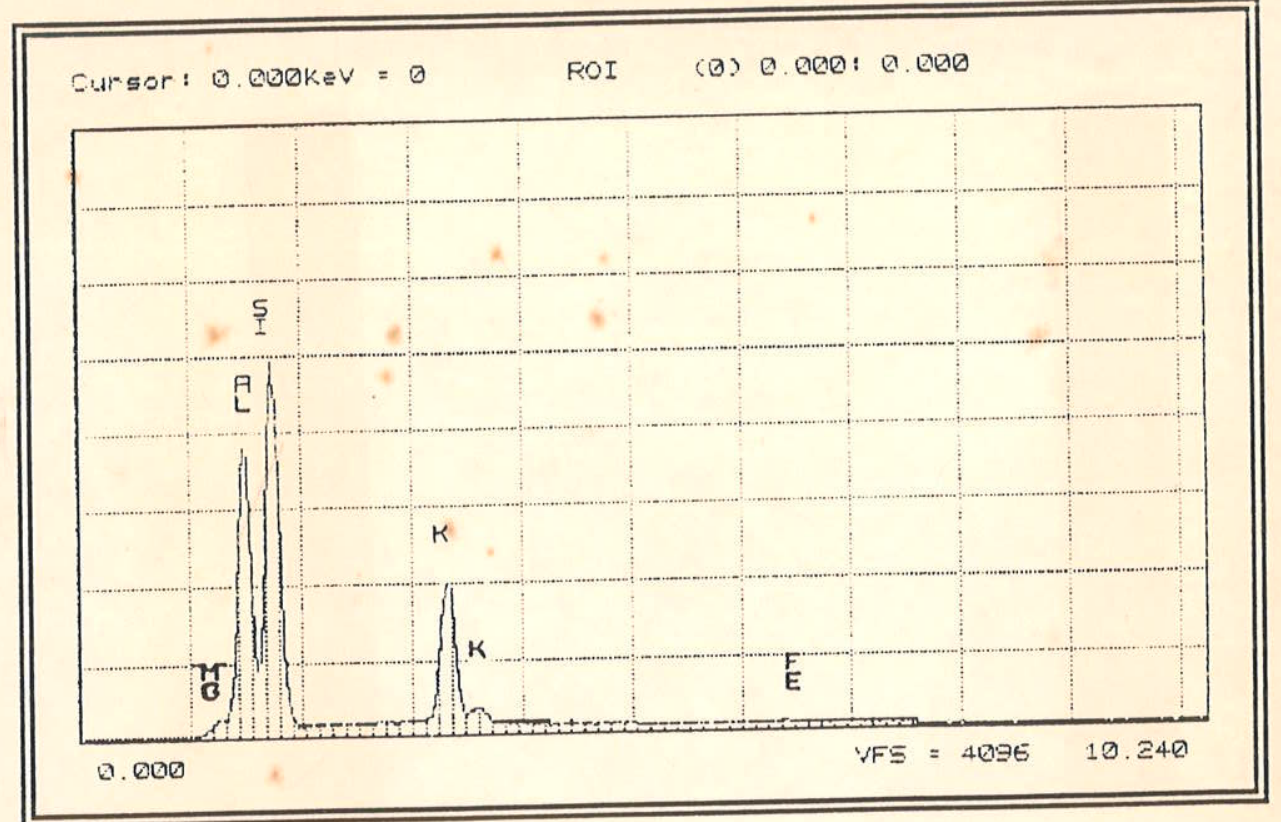

FIGURA 33 - Diagrama EDS de um cristal de mica inclusa em um topázio de Antônio Pereira. relativo à Fotomicrografia 22.

\section{8 - CARBONATOS}

Tendo em vista a dificuldade em separar o carbonato do topázio hospedeiro, esta inclusão foi identificada por MEV (Tabela 22 e Fotomicrografia 23) e EDS (Figura 34). Desta maneira, não foi possível caracterizar se a fase é uma dolomita ferrosa ou uma ankerita magnesiana, por se tratar de uma solução sólida.

Os cristais são romboédricos perfeitos e incolores. Aparecem isolados ou mais freqüentemente em agregados, embora sem orientação (Fotomicrografias 24 e 25). Apesar de pequenas variações de tamanho, o intervalo médio mais freqüente é de, aproximadamente, $0,2 \mathrm{~mm}$. Contêm inclusões opacas castanhas cuja natureza não pode ser determinada.

TABELA 22 - Análise de carbonato incluso em topázio da jazida do Capão do Lana por meio do MEV.

\begin{tabular}{|l|r|r|l||}
\hline \hline elem. & \multicolumn{1}{|c|}{ CPS } & \% peso el. & \multicolumn{2}{|c|}{ óxidos } \\
\hline $\mathbf{M g}$ & 105.1167 & 14.34 & $\mathrm{MgO}-23.77$ \\
$\mathbf{C a}$ & 1006.7333 & 48.38 & $\mathrm{CaO}-67.69$ \\
$\mathbf{M n}$ & 7.9333 & 0.69 & $\mathrm{MnO}-0.89$ \\
$\mathbf{F e}$ & 54.8669 & 5.35 & $\mathrm{Fe}_{2} \mathrm{O}_{3}-\frac{7.65}{100.00}$ \\
\hline
\end{tabular}




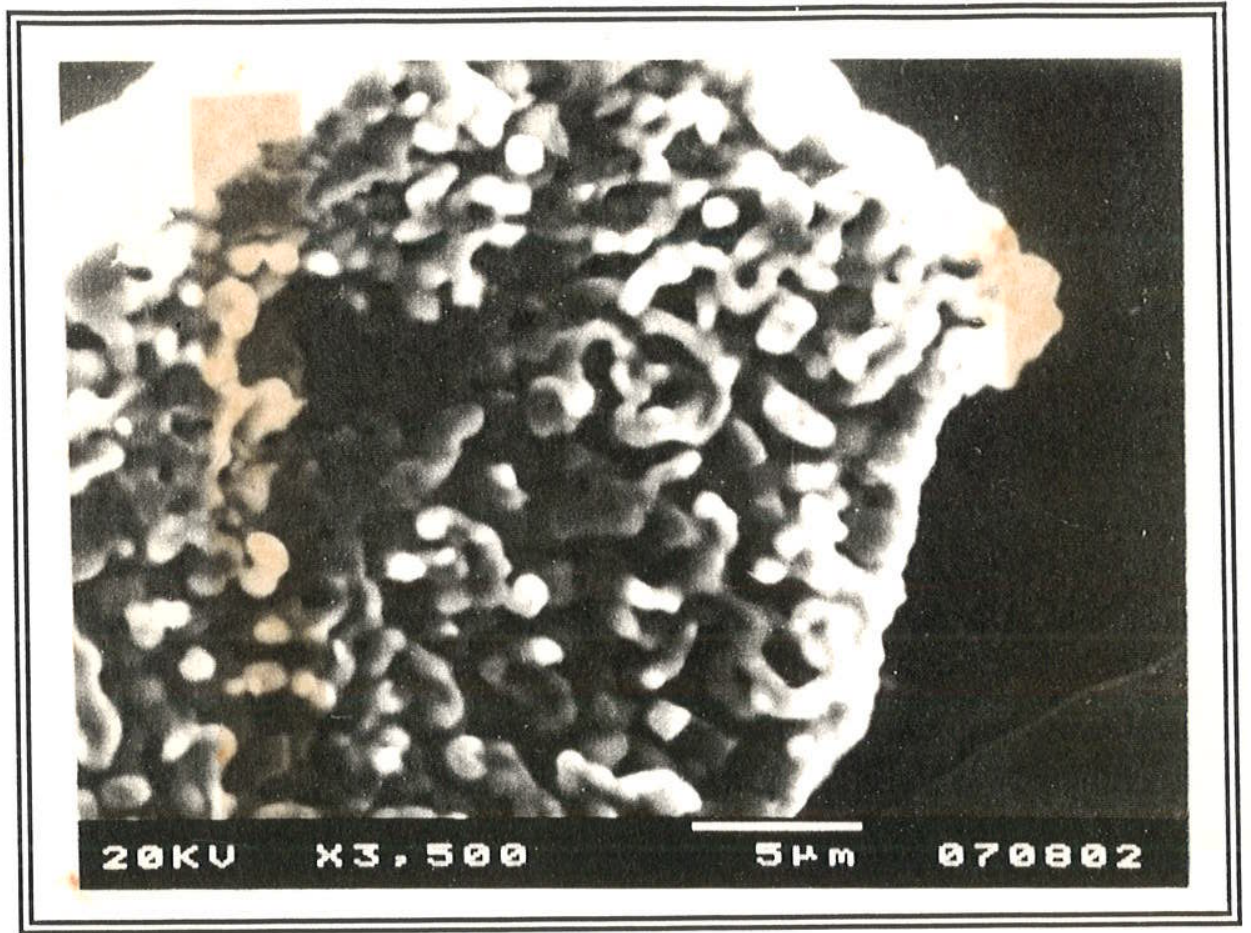

FOTOMICROGRAFIA 23 - Aspecto de um carbonato corroído incluso em um cristal de topázio da jazida de Antônio Pereira. Esta inclusão, provavelmente, estava localizada numa fratura do topázio e a corrosão deve-se a agentes intempéricos, como por exemplo a infiltração de água ácida.

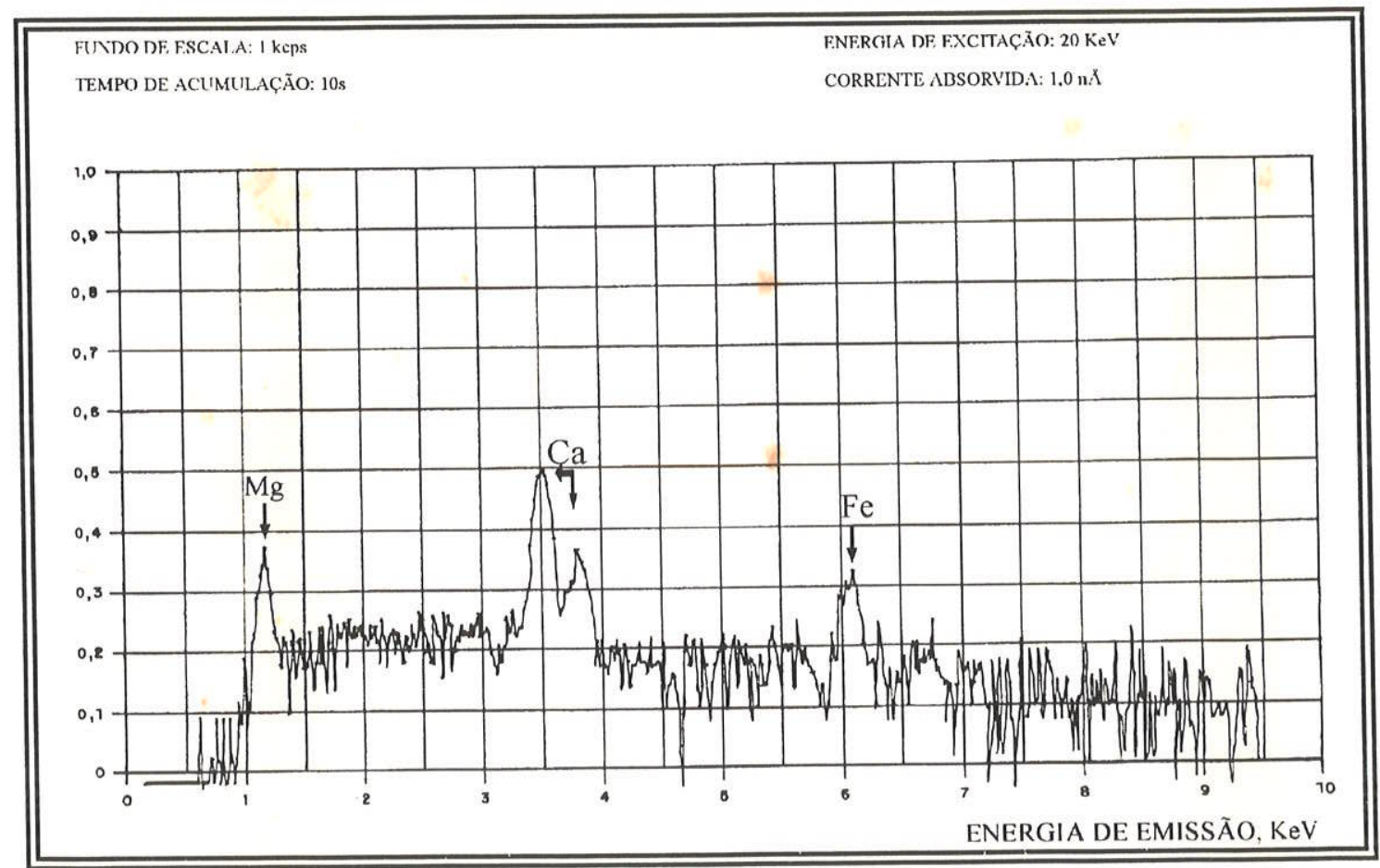

FIGURA 34 - Espectro EDS de um carbonato incluso em um cristal de topázio da jazida de Antônio Pereira. Pelos elementos detectados, pode-se tratar de uma dolomita ferrosa ou uma ankerita magnesiana. 


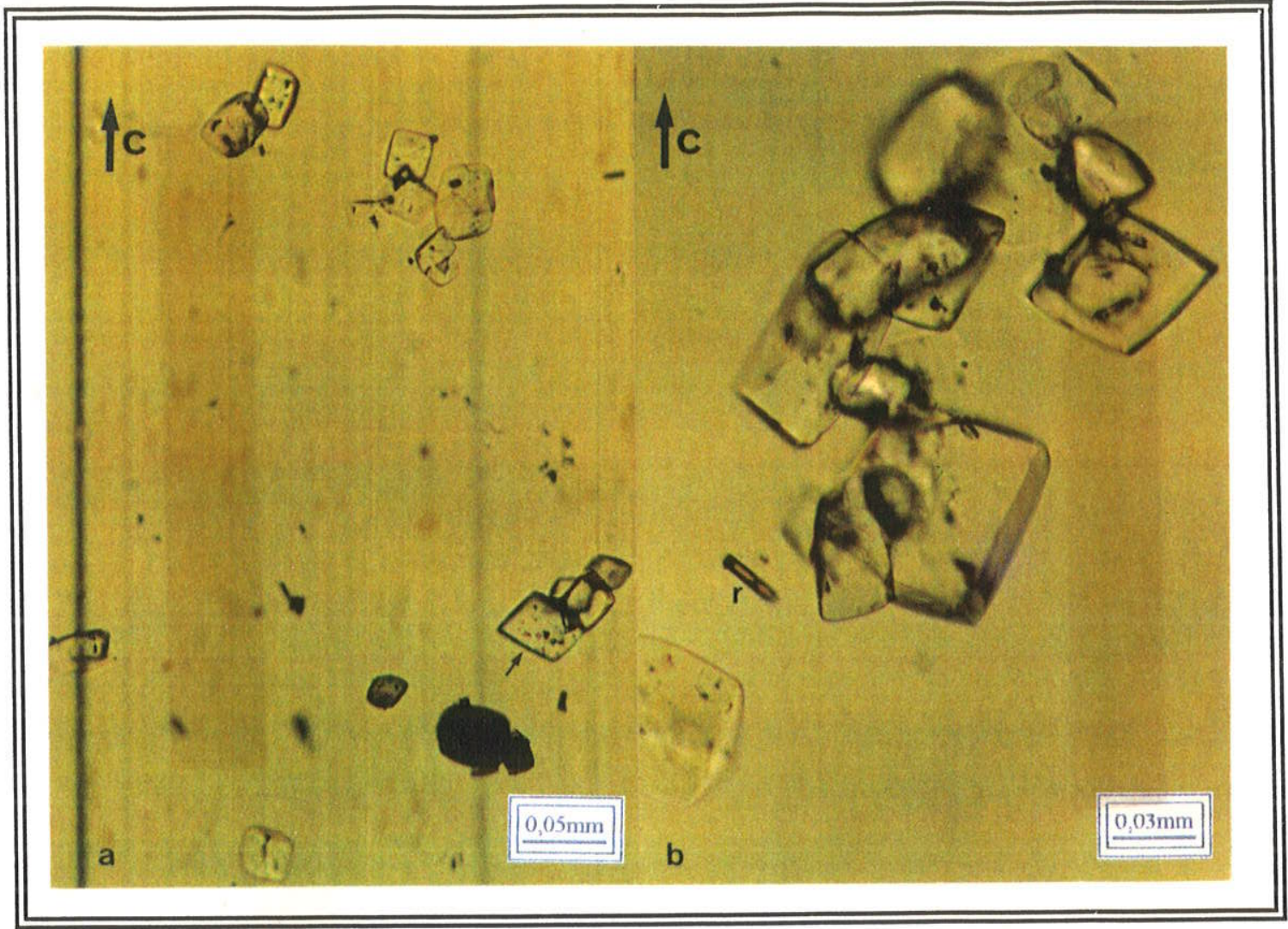

FOTOMICROGRAFIA 24 - a) romboedros de dolomita/ankerita, com inclusões opacas e acastanhadas $(\uparrow)$, dispostos aleatoriamente no interior de um cristal de topázio da jazida de Antônio Pereira. As estrias horizontais pertencem à face externa de um prisma de $3^{\mathrm{a}}$ ordem [paralelas ao eixo c]. b) outro detalhe da amostra anterior, onde aparece um grupo de cristais romboédricos, além de um cristal de rutilo (r).

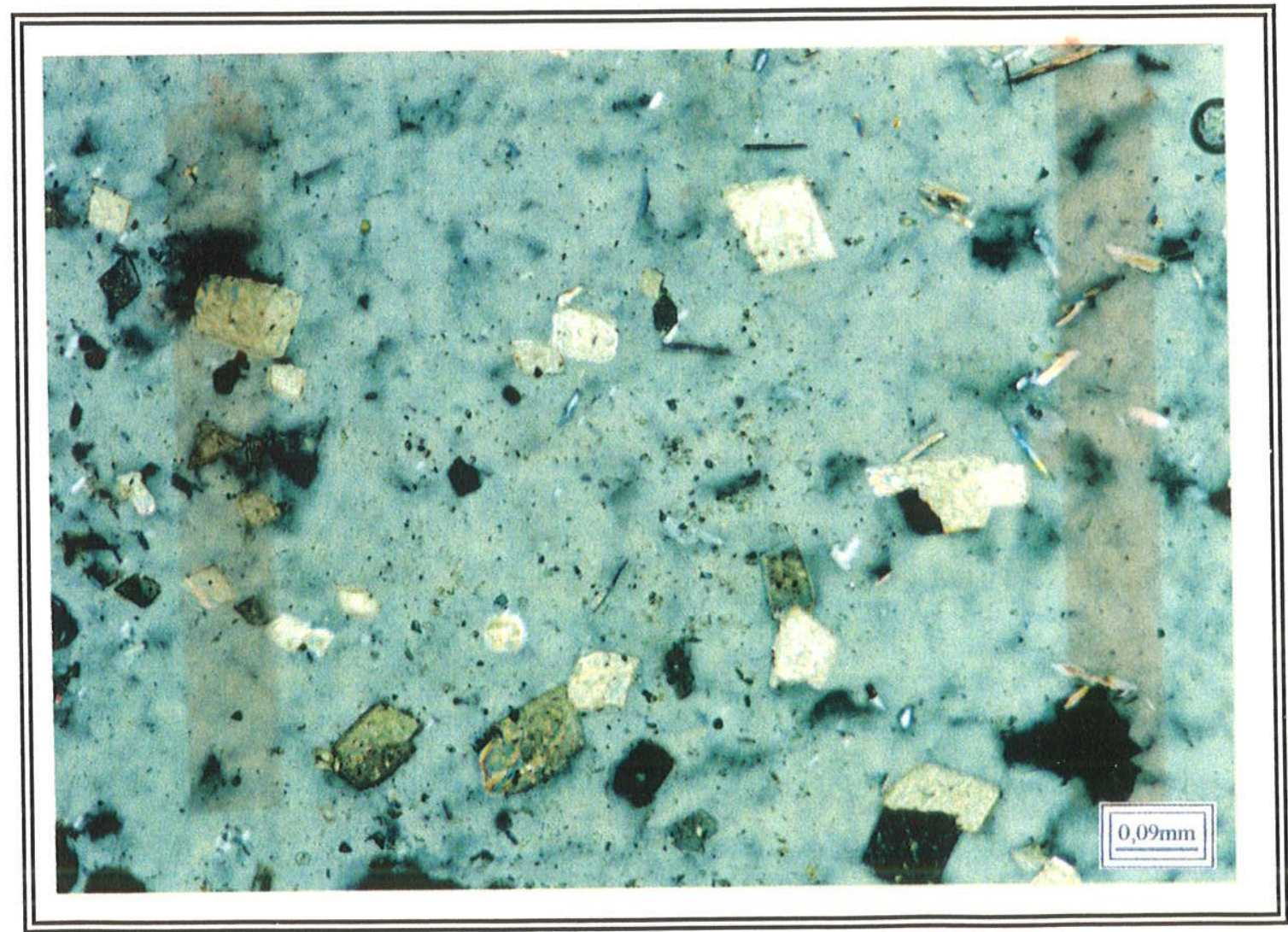

FOTOMICROGRAFIA 25 - Lâmina delgada de um cristal de topázio com inclusões romboédricas de dolomita/ankerita, dispostas aleatoriamente, e de pequenas palhetas de mica. 


\section{9 - APATITA}

Esta espécie mineral, do mesmo modo que a ilmenita, só foi identificada acidentalmente pela análise de MEV, após a fragmentação de alguns cristais hospedeiros, ficando assim, sem uma caracterização mais detalhada.

A apatita (Fotomicrografia 26), aparece revestida por um agregado pulverulento esbranquiçado, que foi identificado como sendo um carbonato (dolomita/ankerita). O tamanho dos cristais de apatita, para alguns cristais analisados, não passaram de 0,05mm de diâmetro. Este mineral foi identificado em cristais de topázio da jazida de Antônio Pereira.

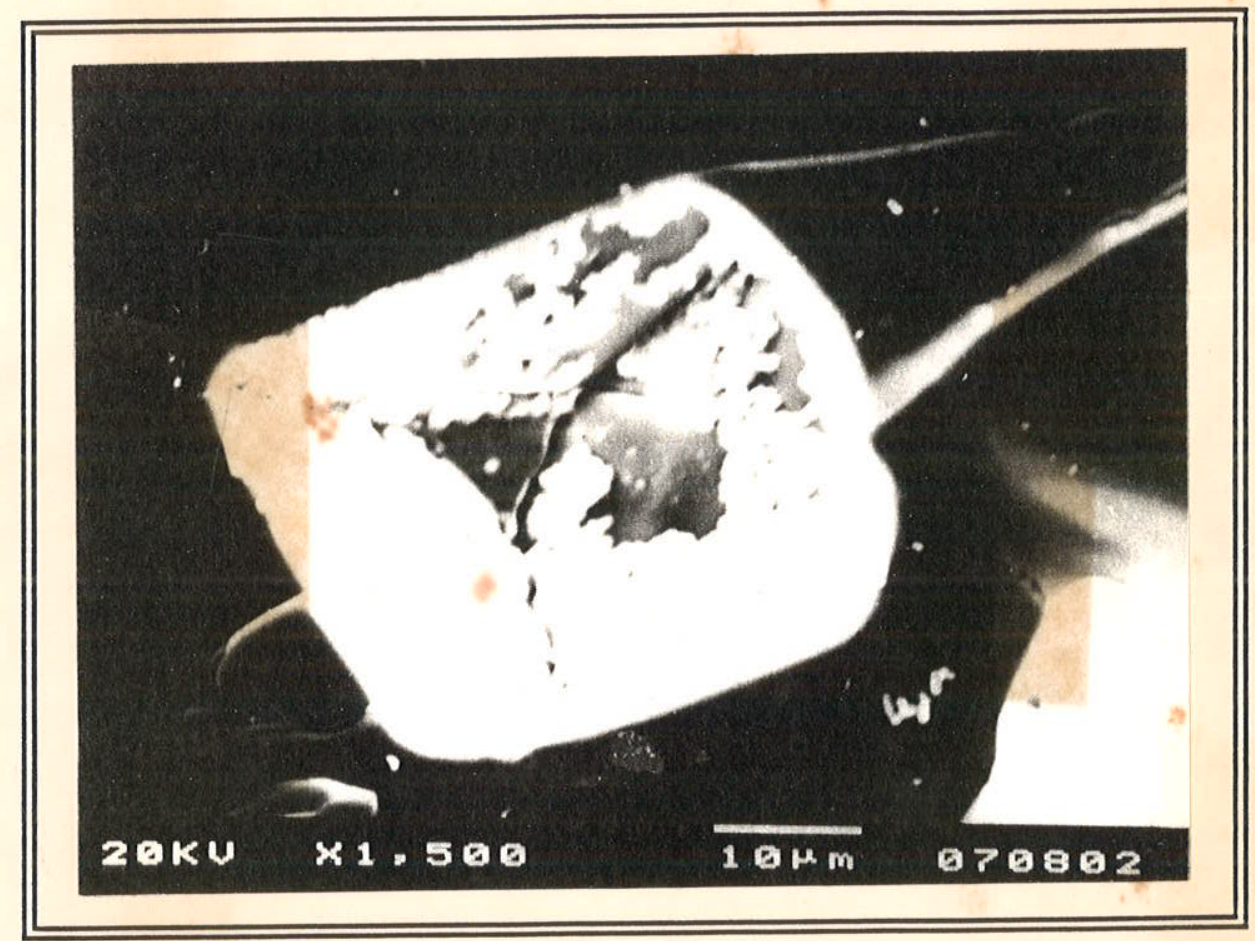

FOTOMICROGRAFIA 26 - Cristal de apatita revestido por uma crosta de carbonato, incluso em um topázio da jazida de Antônio Pereira.

\subsection{0 - CLORITÓIDE}

Analogamente, a apatita, o cloritóide também teve sua identificação acidentalmente no MEV. Desta maneira não pôde ter uma descrição pormenorizada desta fase cristalina. As únicas características observadas na imagem do MEV para o cloritóide foram o hábito tabular deste mineral e o tamanho dos cristais analisados em torno de $0,04 \mathrm{~mm}$ de diâmetro (Tabela 23, Fotomicrografia 27 e Figura 35). 
TABELA 23 - Análise de cloritóide incluso em topázio da jazida de Antônio Pereira por meio do MEV.

\begin{tabular}{|l|r|r|lr||}
\hline elem. & \multicolumn{1}{|c|}{ CPS } & \% peso el. & \multicolumn{2}{|c|}{ óxidos } \\
\hline $\mathbf{A l}$ & 396.4833 & 18,98 & $\mathrm{Al}_{2} \mathrm{O}_{3}-35,87$ \\
$\mathrm{Si}$ & 292.0500 & 12,00 & $\mathrm{SiO}_{2}-25,67$ \\
$\mathbf{K}$ & 19.0500 & 0,52 & $\mathrm{~K}_{2} \mathrm{O}-0,62$ \\
$\mathbf{M n}$ & 15.8000 & 0.69 & $\mathrm{MnO}^{2}-0,89$ \\
$\mathbf{F e}$ & 523.4500 & 25,85 & $\mathrm{Fe}_{2} \mathrm{O}_{3}-\underline{36,96}$ \\
\hline
\end{tabular}

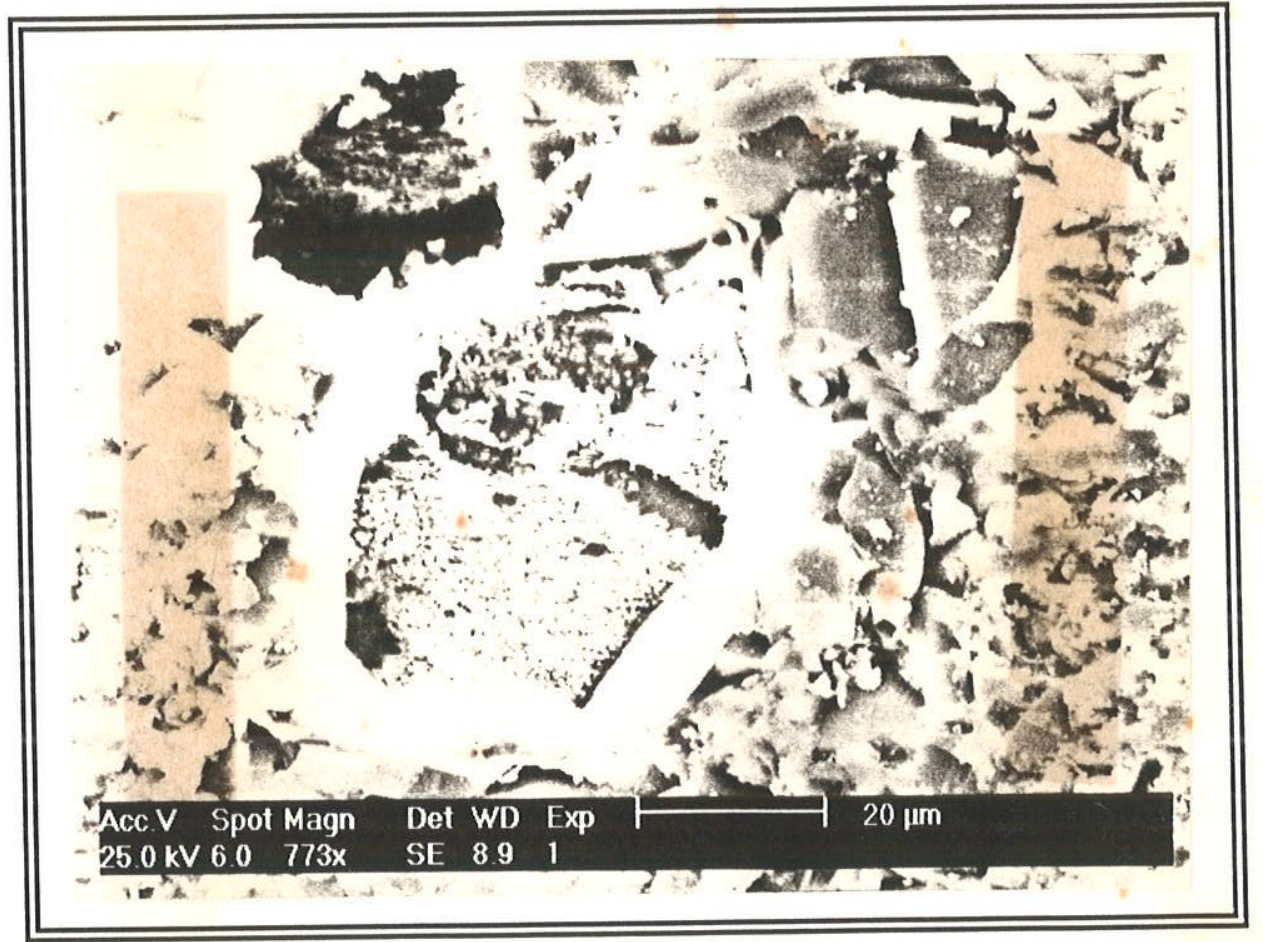

FOTOMICROGRAFIA 27 - Cristal de cloritóide com hábito tabular, incluso em um cristal de topázio da jazida de Antônio Pereira.

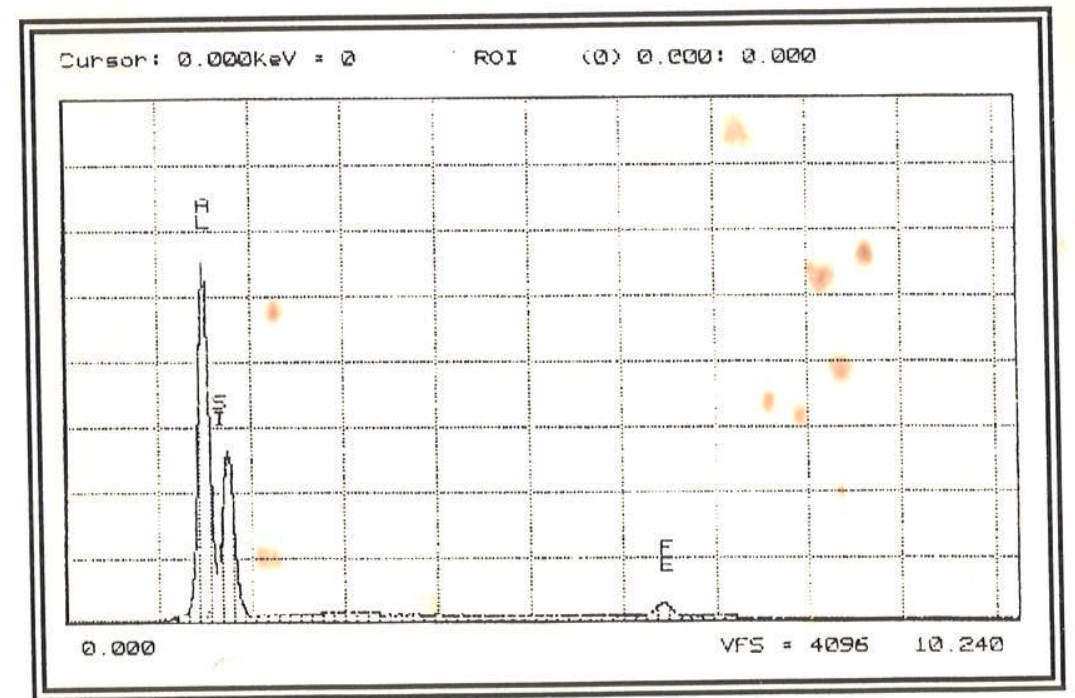

FIGURA 35 - Diagrama EDS de um cristal de cloritóide incluso em topázio da jazida de Antônio Pereira, relativo à Fotomicrografia 27. 


\subsection{1 - TOPÁZIO}

O topázio também aparece como inclusão cristalina em alguns cristais desta mesma espécie, sem uma orientação definida. Suas características são as mesmas do topázio hospedeiro. Algumas vezes, as inclusões chegam a ultrapassar a face externa do hospedeiro. A Fotomicrografia 28 exibe um cristal de topázio fraturado incluso em outro topázio. Um outro caso curioso é a de um cristal de topázio com um núcleo de quartzo incluso num outro cristal de topázio, que foi identificado por EDS e está ilustrado na Fotomicrografia 29.

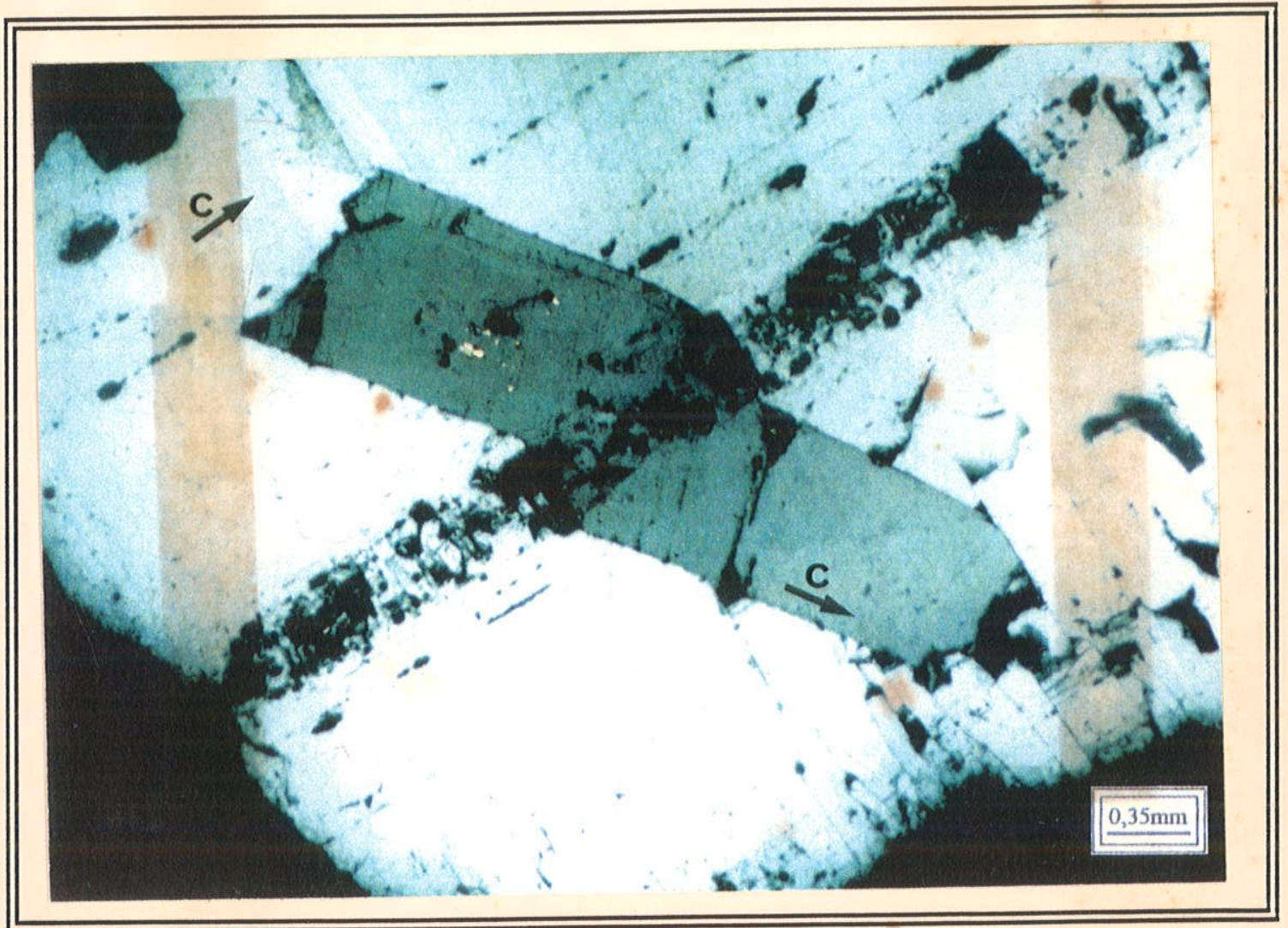

FOTOMICROGRAFIA 28 - Inclusão protogenética de um cristal de topázio fraturado incluso em outro cristal da mesma espécie. Não há uma orientação definida da inclusão. Polarizadores cruzados. 


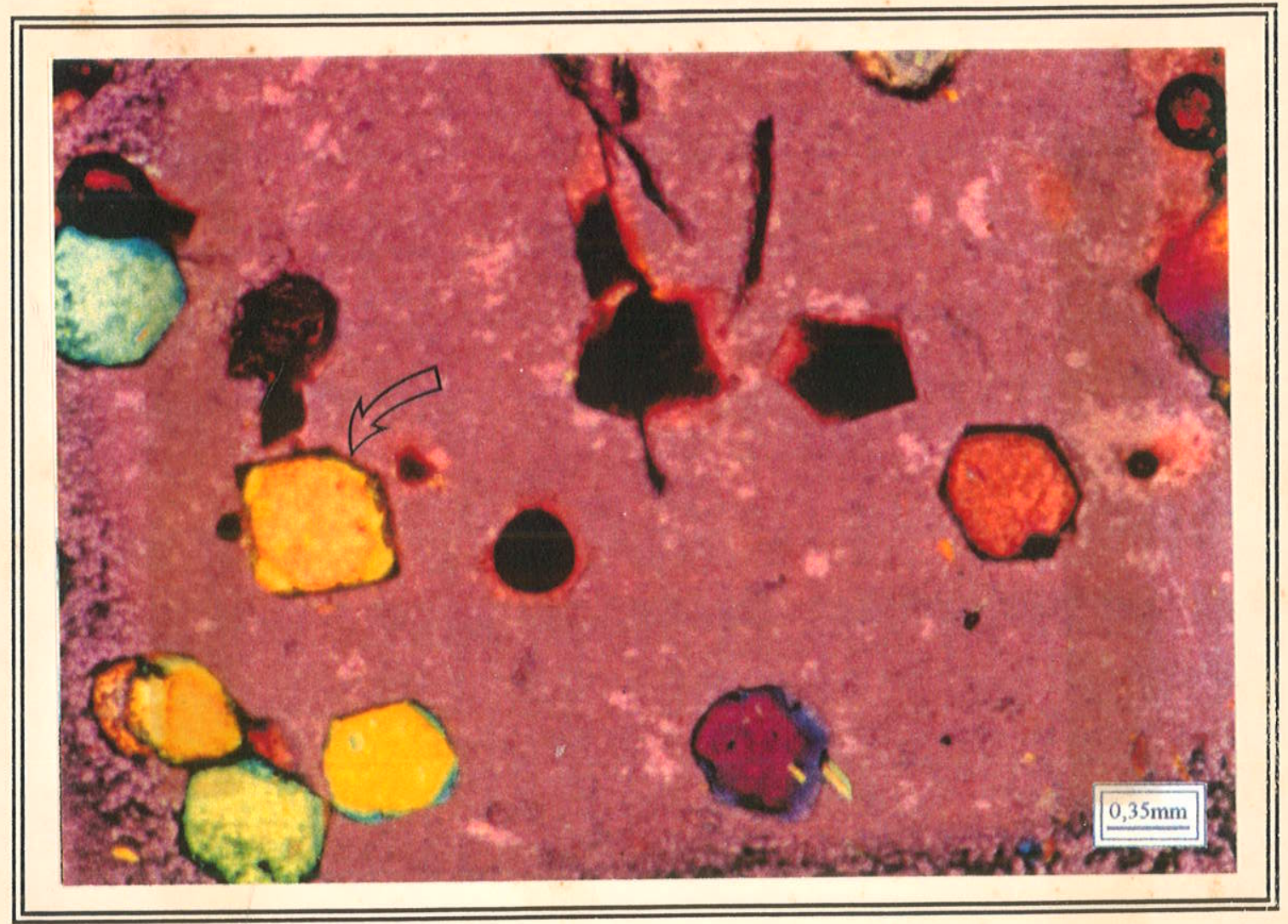

FOTOMICROGRAFIA 29 - Cristal de topázio com núcleo de quartzo incluso em outro cristal de topázio. Polarizadores cruzados mais cunha de gipso.

\subsection{2 - ÓXIDOS E/OU HIDRÓXIDOS}

Outras inclusões minerais observadas ao microscópio petrográfico, porém não identificadas analiticamente, são representadas por materiais secundários sob a forma de inclusões epigenéticas de óxidos e/ou hidróxidos. Esses materiais são comuns no solo residual das jazidas de topázio e, como estes, por sua vez, mostram fraturas não cicatrizadas, o referido material pode penetrar por meio de soluções, fixando-se nas paredes internas do topázio. As Fotomicrografias 30 e 31 ilustram dois aspectos distintos; um mostra manchas circulares, de $1 \mathrm{~mm}$ de diâmetro com uma coloração alaranjada, provavelmente de limonita ou goethita, e a outra um dendrito de $2 \mathrm{~mm}$ de comprimento com uma coloração variando de castanho ao negro, provavelmente pirolusita ou romaneckita (o mesmo que psilomelana). 


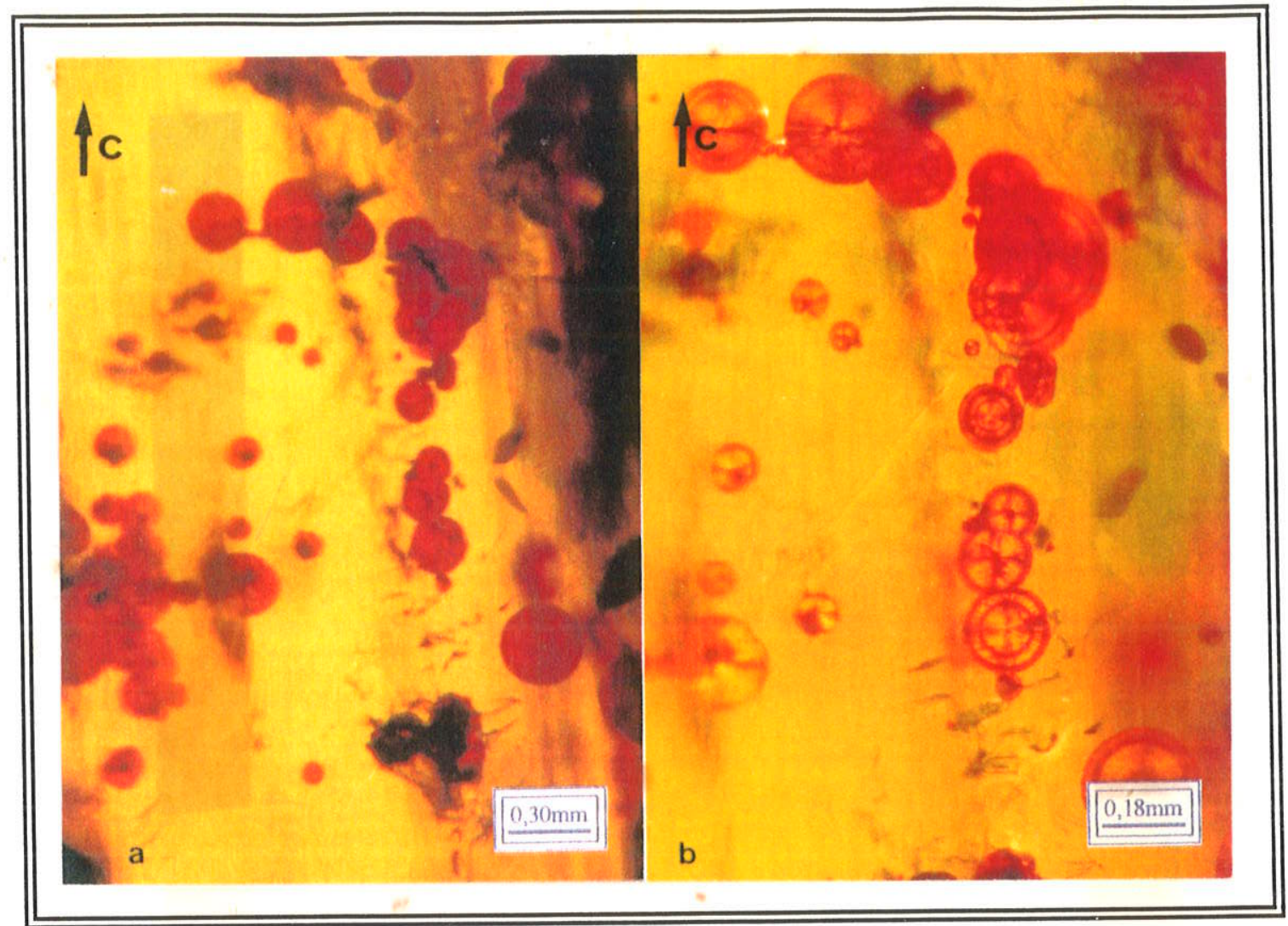

FOTOMICROGRAFIA 30 - a) nódulos de óxido de ferro (limonita ou goethita) alojados em uma fratura não cicatrizada de um topázio imperial da jazida de Caxambu. Polarizadores descruzados. b) mesmo detalhe, com polarizadores cruzados.

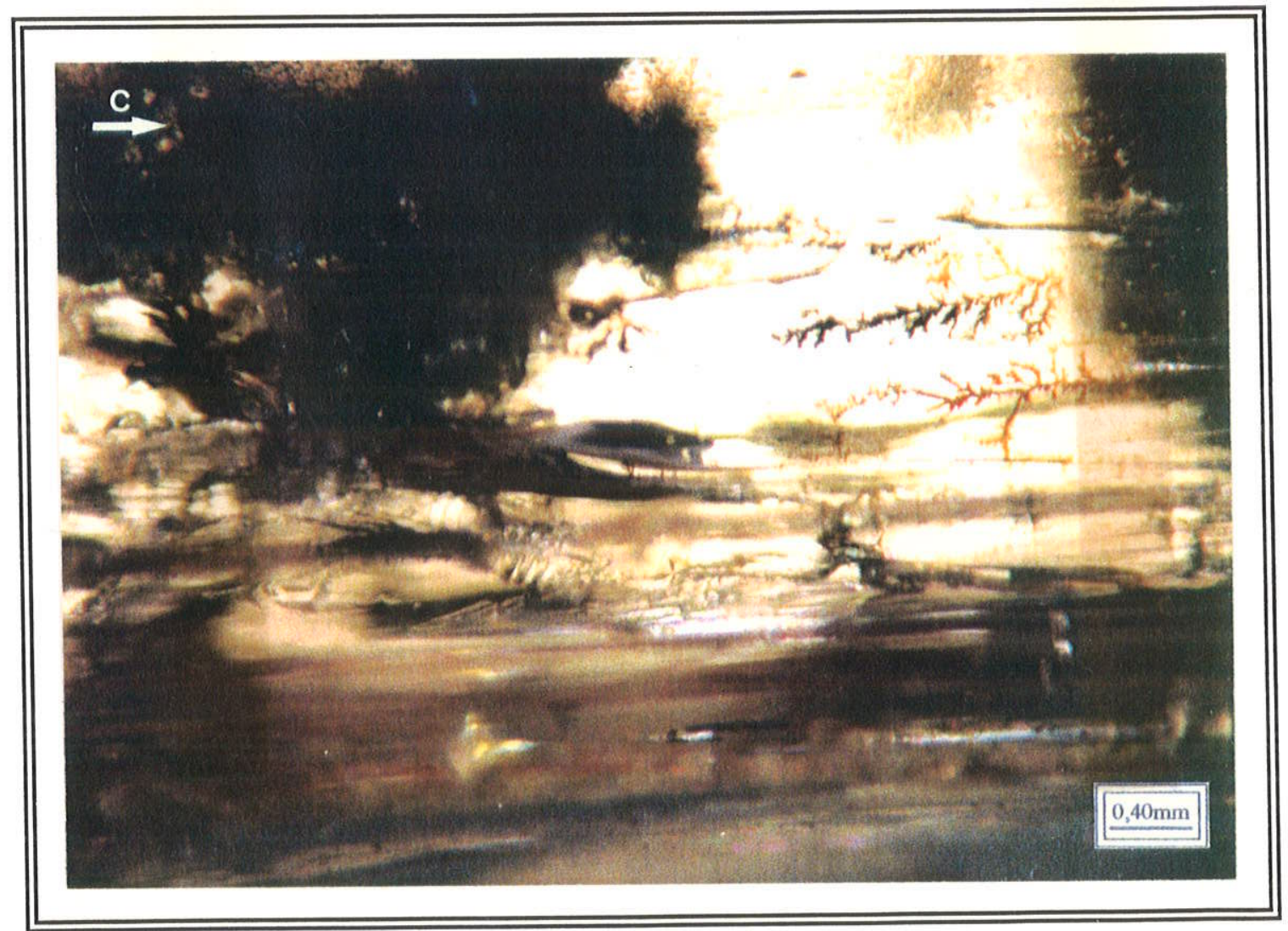

FOTOMICROGRAFIA 31 - Agregado dendrítico de uma pirolusita ou romaneckita, situado em uma fratura não cicatrizada de um topázio imperial da jazida de Boa Vista. (Polarizadores descruzados). 
Outro aspecto interessante é o preenchimento de uma cavidade de uma inclusão fluida (Fotomicrografia 32) por óxido (limonita - ?). Talvez pelo fato do cristal de topázio apresentar algumas fraturas, deve ter havido a ligação dessa inclusão fluida com a parte externa do cristal após sua formação.

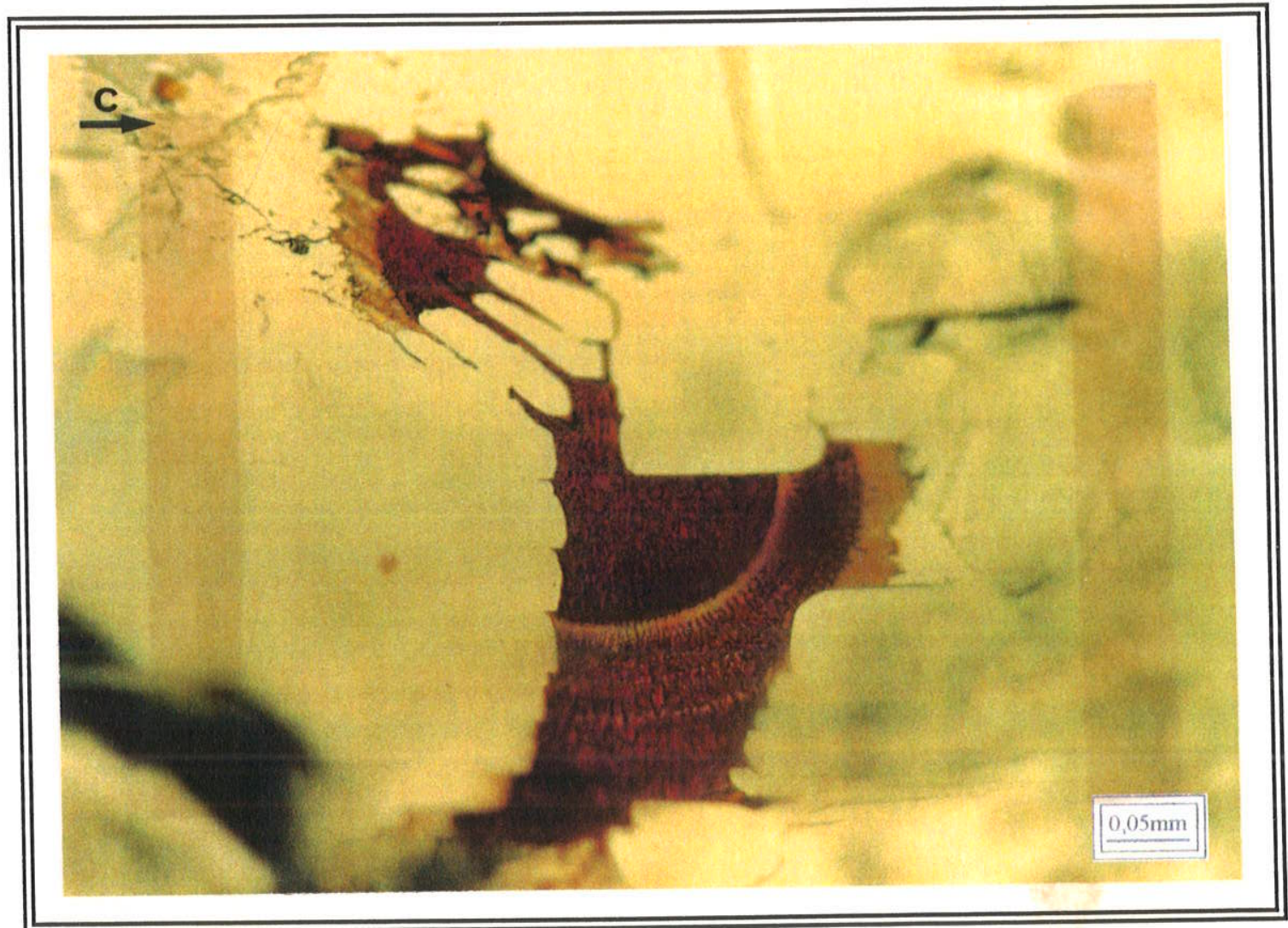

FOTOMICROGRAFIA 32 - Cavidade de uma inclusão fluida preenchida por um óxido, provavelmente limonita, presente em um topázio da jazida do Capão do Lana. (Polarizadores descruzados). 


\section{7 - INCLUSÕES FLUIDAS}

Apesar do grande número de trabalhos publicados sobre a geologia e as paragêneses minerais das rochas encaixantes das mineralizações do topázio imperial, ainda existem muitas controvérsias a respeito da gênese desse mineral em Ouro Preto. A partir de estudos localizados, alguns autores sugerem que as mineralizações originaram-se através de uma atividade pneumatolítica/hidrotermal relacionada a uma fase pré-metamórfica (Olsen 1971) ou ao pico do metamorfismo de baixo grau da região (Pires 1983a, Pires et al. 1983a e Pires et al. 1983b), ou ainda, por hidrotermalismo relacionado à última fase de vulcanismo no Quadrilátero Ferrífero (Ferreira 1983, 1991). Optou-se, assim, pela realização do estudo das inclusões fluidas e sua correlação aos dados petrológicos, estruturais e tectônicos, vastamente publicados sobre a região (Olsen 1971, Pires et al. 1983, Ladeira \& Viveiros 1984, Alkmim et al. s.d., Ferreira 1991 entre outros) na tentativa de melhor elucidar esses problemas, e de estabelecer um modelo genético mais elaborado.

\section{1 - INTRODUÇÃO}

Como a interação rocha-fluido é de grande importância dentro dos processos geológicos, o estudo das soluções envolvidas, que podem ficar retidas como inclusões em determinados minerais, deve ser correlacionado aos dados petrológicos, para uma interpretação mais precisa das condições reinantes durante a cristalização ou recristalização dos minerais. O estudo das inclusões fluidas permite, em certos casos, determinar as faixas de temperatura e pressão de cristalização de um dado mineral, bem como as salinidades, densidades e composições dos fluidos mineralizantes e, algumas vezes, estabelecer a história da evolução dessas soluções. Esses fluidos podem estar ligados a processos hidrotermais, magmáticos, meteóricos, etc. O único método que permite a obtenção direta dos dados mencionados, é o da microtermometria. Neste estudo, devese ter como premissa a não existência de modificações significativas do fluido desde o seu aprisionamento, isto é, que suas características atuais sejam, praticamente, as mesmas daquelas presentes durante a formação das inclusões. 


\section{2 - BREVE HISTÓRICO}

Provavelmente, a citação mais antiga de inclusões fluidas data do século IV e a primeira descrição do século XI, foi feita por um sábio da Ásia Central. As tentativas iniciais de análises dos fluidos datam da primeira metade do século XIX (Fuzikawa 1985).

Talvez os primeiros estudos realmente importantes tenham sido os desenvolvidos pelo geólogo inglês Henry Sorby em 1858 (in Roedder 1972), que propôs a teoria de que as bolhas presentes nos fluidos da maioria das inclusões seriam o resultado da contração diferencial do líquido e do mineral hospedeiro, durante o resfriamento, a partir de uma temperatura mais elevada de aprisionamento, até a temperatura ambiente de observação. Sorby acreditava que, se o processo fosse revertido, através do aquecimento da inclusão, poder-se-ia chegar à temperatura mínima do seu aprisionamento no momento da homogeneização do fluido, supondo-se que este fosse inicialmente homogêneo (Roedder 1984, Fuzikawa 1985). Outros autores, entre eles Zirkel em 1870 e Phillips em 1875 (in Roedder 1972), tentaram analisar as inclusões fluidas, principalmente quanto aos aspectos relacionados à sua composição. Ainda hoje, muitas das idéias propostas por esses autores continuam válidas.

O método adquiriu credibilidade a partir da década de sessenta, sobretudo com os inúmeros trabalhos de Roedder (Fuzikawa 1985), cujo nome tornou-se um dos referenciais obrigatórios nesta área do conhecimento.

\section{3 - CARACTERÍSTICAS GERAIS DAS INCLUSÕES FLUIDAS}

Entre as características mais comuns e estudadas nas inclusões fluidas, destacam-se a morfologia, dimensões, quantidade, número de fases e composição, além da sua distribuição espacial, a qual permite em muitos casos identificar sua origem (Roedder 1972, Fuzikawa 1985, Shepherd et al. 1985).

Quanto à origem, elas podem ser classificadas em primárias, secundárias ou pseudosecundárias. As primárias seriam aquelas aprisionadas durante o crescimento do mineral. As secundárias estariam ligadas a algum tipo de evento posterior à formação do mineral como, por exemplo, um fraturamento na presença de fluidos, decorrente de um esforço tectônico, seguido de cicatrização. Finalmente, as pseudosecundárias teriam sido englobadas durante processos de cicatrização de fraturas desenvolvidas ainda durante a cristalização do mineral.

As inclusões fluidas apresentam morfologias que podem variar desde cristais negativos (formas alongadas, de canalículos, de contornos losangulares, hexagonais etc) até formas bastante irregulares. No caso do topázio, segundo Webster (1980) dependendo da sua cor e da razão $\mathrm{F}^{-} / \mathrm{OH}^{-}$, as morfologias das inclusões fluidas podem ser distintas. Para os incolores, azuis e 
pardos, ricos em $\mathrm{F}^{-}$em sua estrutura cristalina, as cavidades podem variar desde a forma de gotas até formas mais arredondadas. Para os sólidos cristalinos presentes no interior das inclusões fluidas desses topázios, são citados cristais cúbicos, isolados ou em grupos, que o autor sugeriu serem constituídos por fluorita, como os da Nigéria. Já nos topázios ricos em $\mathrm{OH}^{\mathbf{*}}$ de coloração amarela acastanhada e rósea, as inclusões fluidas normalmente apresentam aspectos de tubos alongados. Para este último caso, o referido autor não cita a presença de sólidos cristalinos. Essa observação não foi confirmada nesse trabalho pois aparecem tanto as formas em tubos ou canalículos alongados, quanto as arredondadas. $O$ mesmo pode ser dito em relação a ausência de sólidos nos topázios imperiais (amarelos), uma vez que os topázios da jazida do Vermelhão apresentam com freqüência este tipo de inclusão na fase aquosa.

As inclusões fluidas podem possuir dimensões bastante variáveis, observando-se inclusive em algumas amostras de minerais gemológicos inclusões centimétricas. Fuzikawa (1985) discute que as dimensões das inclusões fluidas decrescem continuamente até o limite de um simples deslocamento atômico ou molecular do cristal, ou seja, da ordem de $2 \times 10^{-7} \mathrm{~mm}$.

A quantidade de inclusões varia enormemente de uma dada espécie mineral para outra. Há uma relação entre o tamanho e quantidade, ou seja, o número de inclusões fluidas aumenta exponencialmente com a diminuição do tamanho (Roedder 1972). Segundo Zirkel (1873, in Roedder 1972), alguns cristais de hauynita (grupo da sodalita) tornam-se translúcidos por chegarem a apresentar quantidades de $3,5 \times 10^{11}$ inclusões por $\mathrm{cm}^{3}$, enquanto para o quartzo leitoso o número de inclusões chega a $10^{9}$ por $\mathrm{cm}^{3}$.

Quanto ao número de fases presentes nas inclusões fluidas, observadas à temperatura ambiente $\left( \pm 25^{\circ} \mathrm{C}\right)$, estas podem ser classificadas em quatro tipos. $O$ primeiro, mais simples, é constituído por inclusões monofásicas, que apresentam somente uma fase líquida ou gasosa. $O$ segundo compreende inclusões bifásicas, que podem ser constituídas por líquido + gás $(1+\mathrm{g})$; líquido + sólido $(1+s)$; dois líquidos imiscíveis $\left(l_{1}+l_{2}\right)$ ou, finalmente, sólido + gás $(s+g)$, como no caso das inclusões vítreas. $O$ terceiro tipo é representado por inclusões trifásicas, sendo as mais comuns constituídas por dois líquidos imiscíveis + gás $\left(\mathrm{I}_{1}+\mathrm{l}_{2}+\mathrm{g}\right)$ ou por líquido + gás + sólido $(1+\mathrm{g}+\mathrm{s})$. Por último, as polifásicas ou multifásicas, exibindo quatro ou mais fases. Por mais numerosos que sejam os componentes gasosos, eles sempre formarão uma única fase, podendo esta se apresentar subdividida por razões morfológicas da inclusão. No caso de serem líquidos miscíveis, também formarão uma única fase (Roedder 1984, Fuzikawa 1985).

Com o aperfeiçoamento da platina de aquecimento e resfriamento, as composições das inclusões fluidas puderam ser determinadas com um grau de precisão cada vez mais elevado. A grande parte das inclusões fluidas é constituída por soluções aquosas, cujas salinidades podem variar desde valores bem elevados, relativos a salmouras hipersalinas, até quase nulos, quando as soluções são mais puras. Também ocorrem inclusões ricas em $\mathrm{CO}_{2}, \mathrm{~N}_{2}, \mathrm{H}_{2} \mathrm{~S}$, hidrocarbonetos ou misturas de duas ou mais destas substâncias (Hollister \& Crawford 1981), bem como as 
constituidas por uma fase aquosa associada a um ou mais desses voláteis. O fluido salino pode se tornar saturado com respeito a alguns ions, e desta forma precipitar fases sólidas, designadas de minerais de saturação (daughter minerals). De um modo geral, esses minerais são representados pela halita ou pela silvita, mas além do $\mathrm{Na}^{+}, \mathrm{K}^{+}$e $\mathrm{Cl}^{-}$. os fluidos mineralizantes também podem conter quantidades variáveis de $\mathrm{Mg}^{2+}, \mathrm{Ca}^{2+}, \mathrm{Fe}^{2+}, \mathrm{Fe}^{3+}$, entre outros íons (Roedder 1972).

\section{4 - ORIGEM E CLASSIFICAÇÃO DAS INCLUSÕES FLUIDAS}

Para Roedder (1984), entre outros autores, podem ocorrer duas maneiras de formação das inclusões fluidas. A origem das inclusões está relacionada com o aprisionamento de pequenas porções de fluidos no mineral hospedeiro, decorrente da atuação de processos de crescimento (inclusão primária) ou de fraturamento do mineral seguido de cicatrização (inclusão secundária), caracterizando assim suas idades relativas.

No primeiro caso, como a superfície de um cristal normalmente não se desenvolve de modo uniforme, fato este ligado a velocidade de cristalização, suprimento irregular de nutrientes, presença de impurezas, entre outros fatores, são comuns irregularidades nas suas superfícies de crescimento. Essas imperfeições podem ser seladas durante o crescimento posterior do cristal, retendo desse modo inclusões fluidas. Também no processo de ebulição de fluidos hidrotermais, ou de degaseificação de magmas, as bolhas de gás, que aderem às superfícies dos cristais em crescimento, podem ser aprisionadas como inclusões. Estes tipos de processo, ou outros quaisquer equivalentes, que ocorrem concomitantemente ao crescimento do mineral, causam o aprisionamento de inclusões primárias. As inclusões primárias, representam, em princípio, amostras do fluido original a partir do qual cristalizou-se o mineral. Em alguns casos, como elas se formam ao longo de planos paralelos às faces dos cristais, o estudo de inclusões pertencentes a uma sucessão de planos de mesma orientação, pode fornecer uma idéia de evolução seqüencial do fluido formador do mineral (Roedder 1984).

Inclusões fluidas secundárias podem ser formadas quando, após a cristalização do mineral, algum tipo de esforço causa o seu fraturamento, propiciando a penetração de fluidos, nos quais o mineral tenha algum grau de solubilidade. Esses fluidos podem ficar retidos pela cicatrização posterior dessas fraturas. Nesse processo, o fluido dissolve o mineral hospedeiro, até que seja atingido o seu limite de solubilidade, reprecipitando-o nas paredes da fratura, segundo leis cristalográficas, o que possibilita o aprisionamento de um grande número de inclusões fluidas com morfologias de cristais negativos. Deve ser observado que o fluido desses tipos de inclusões podem apresentar características e idades muito diferentes dos originais.

Um terceiro tipo, originado pela superposição dos processos anteriores, seria representado pelas denominadas inclusões pseudosecundárias (Ermakov 1949, in Touret 1977), formadas a 
partir da cicatrização de fraturas desenvolvidas durante o crescimento do mineral. É dificil o reconhecimento dessas inclusões, mas sua presença pode ser confirmada quando os planos fraturados dispõem-se internamente no cristal. Desta forma, não apresentam grande diferença temporal com relação as inclusões primárias.

A distinção entre as inclusões primárias e as secundárias é, em alguns casos, relativamente fácil. As primeiras, normalmente, ocorrem como inclusões isoladas ou dispostas segundo algumas direções cristalográficas, como a superfície ou arestas de crescimento do cristal, ou, ainda, distribuídas aleatoriamente no mineral. As segundas, normalmente, ocorrem alinhadas ou seguindo distribuições planares ao longo de fraturas cicatrizadas, onde se apresentam em grandes quantidades. Não obstante, existem casos mais duvidosos, como por exemplo, inclusões em superficies de contato entre grãos, ou ao longo de planos de geminação que podem ser tanto primárias como secundárias.

Roedder (1984) discute vários critérios utilizados na tentativa de identificar, geneticamente, o caráter primário, secundário ou pseudosecundário de uma inclusão fluida, enfatizando, no entanto, que apenas alguns deles são conclusivos. Embora as classificações não sejam seguras, pode-se estabelecer uma cronologia relativa para as inclusões fluidas, com base na sua distribuição espacial. Dessa maneira, podem ser obtidas informações sobre os fluidos e as condições físico-químicas existentes durante a formação do mineral, ou relativas a eventos posteriores, quando são estudadas as inclusões fluidas primárias e secundárias, respectivamente.

\section{5 - EXECUÇÃO DO MÉTODO MICROCALORIMÉTRICO}

Inicialmente, algumas premissas devem ser consideradas para a validade dos estudos das inclusões fluidas e interpretações dos dados microtermométricos, como discutem Weisbrod et al. (1976), Roedder e Bodnar (1980) e Fuzikawa (1985), entre outros. Entre elas destaca-se que os fluidos aprisionados nas inclusões devem ser amostras representativas das soluções presentes durante um determinado processo geológico de interesse, como a cristalização e/ou recristalização de minerais, ou meșmo eventos deformacionais. Também é assumido que o sistema deve ser isolado e quimicamente inerte, e que as propriedades físico-químicas dos fluidos, como a composição e a densidade, não tenham sofrido modificações desde a época do aprisionamento, permanecendo constantes, mesmo durante os estudos microtermométricos.

Levando-se em consideração essas premissas, devem ser tomadas certas precauções durante a obtenção das medidas microtermométricas. Estas não devem ser efetuadas em inclusões com feições de estrangulamențo ou crepitação, pois esses fenômenos, que podem ocorrer durante o resfriamento ou a recristalização dos minerais, causam mudanças no volume original das inclusões que, portanto, adquirem características diferentes das iniciais. Do mesmo modo, nas 
inclusões que tiveram perdas eventuais de fluidos, ou reintrodução de outras soluções, os dados tornam-se comprometidos. Outro fenômeno importante a ser observado é a dilatação (stretching), que ocorre em alguns minerais causando uma variação no volume das inclusões fluidas durante os procedimentos microtermométricos (Fuzikawa \& Alves 1984). Conseqüentemente, apesar dos devidos cuidados que devem ser tomados com os minerais sujeitos à dilatação inelástica e na identificação de feições que sugerem a presença de escape de fluidos e estrangulamento, para efeito prático, as mudanças de fases são consideradas como se estivessem ocorrendo em sistemas isocóricos (volumes constantes), sendo, portanto, interpretadas sobre a seção P-T de diagramas P-V-T de sistemas experimentais apropriados para cada caso (Fuzikawa 1985).

Nota-se assim, que apenas depois de uma observação preliminar cuidadosa, levando-se em conta as premissas discutidas, é que se pode iniciar o estudo microtermométrico propriamente dito, o qual é baseado na observação e registro das várias temperaturas de mudanças de fases dos componentes presentes nas inclusões.

Normalmente, em primeiro lugar, são feitas as medidas relativas às mudanças de fases a baixas temperaturas, pois com o aquecimento pode haver crepitação das inclusões ou mudanças nas suas características originais devido a escape de fluidos.

Para a interpretação dos dados relativos às várias temperaturas de mudanças de fases dos diferentes grupos de inclusões fluidas, previamente separados no estudo petrográfico inicial, deve-se obter um número de medidas suficiente para seu tratamento estatístico, minimizando assim a margem de erros que, eventualmente, possam ocorrer. Muitas vezes, os vários grupos de inclusões fluidas, previamente observados, podem ainda ser subdivididos ou mesmo reunidos em agrupamentos menores.

As temperaturas que devem ser registradas durante os estudos microtermométricos encontram-se descritas abaixo.

TEMPERATURA DE FUSÃO DO $\mathrm{CO}_{2}\left(\mathrm{Tf}_{\mathrm{CO}_{2}}\right)$ - Para a obtenção deste parâmetro a amostra deve ser inicialmente resfriada até o completo congelamento da inclusão; como esse resfriamento é em geral muito rápido, fenômenos comuns de metaestabilidade fazem com que o aparecimento do $\mathrm{CO}_{2}$ sólido não ocorra até que sejam atingidas temperaturas inferiores a $-70^{\circ} \mathrm{C}$ ou mesmo, com alguma freqüência, a $-90^{\circ} \mathrm{C}$. Por esse mesmo motivo, as medidas devem ser obtidas durante a fase de aquecimento natural e gradativo da amostra a partir dessas temperaturas mínimas. $\mathrm{O}$ ponto de fusão do $\mathrm{CO}_{2}$ puro ocorre a $-56,6^{\circ} \mathrm{C}$, sendo este, o valor do seu ponto triplo. Quando existem outros voláteis como, por exemplo, $\mathrm{CH}_{4}, \mathrm{~N}_{2}$, junto com a fase carbônica, essa temperatura sofrerá uma depressão, cujo valor depende do elemento adicional e da sua concentração. Dessa forma, a temperatura de fusão é a melhor indicação disponivel sobre grau de pureza do fluido. Muitas vezes, resfriando-se a amostra até temperatura de $-180^{\circ} \mathrm{C}$ (limite do aparelho), pode ser detectada a presença de outros voláteis, junto a fase $\mathrm{CO}_{2}$, os quais possuem 
pontos críticos com valores extremamente baixos. como por exemplo o $\mathrm{CH}_{4}$, com temperatura crítica de $-82,1^{\circ} \mathrm{C}$ e $\mathrm{N}_{2}$, com temperatura crítica de $-147^{\circ} \mathrm{C}$.

TEMPERATURA DE FUSÃO DO GELO $\left(\mathbf{T f}_{\mathrm{g}}\right)$ - No caso da solução ser composta por água pura, a $\mathrm{Tf}_{\mathrm{g}}$ ocorre à $0,015^{\circ} \mathrm{C}$, ponto triplo dessa substância. Como é freqüente a presença de íons na solução aquosa, por exemplo $\mathrm{Cl}^{-}, \mathrm{K}^{+}, \mathrm{Na}^{+}, \mathrm{Ca}^{2+}, \mathrm{Mg}^{2+}$, sua fusão inicia-se em temperaturas mais baixas, menores que $0^{\circ} \mathrm{C}$, representativas do seu ponto eutético $\left(\mathrm{T}_{\mathrm{e}}\right)$ cujo valor depende dos componentes dissolvidos. Nesses casos, a temperatura final da fusão do gelo indicará, através de diagramas, que envolvem sistemas compostos por $\mathrm{H}_{2} \mathrm{O}+$ sais, a salinidade das soluções que, geralmente, é expressa em termos equivalentes à porcentagem em peso do $\mathrm{NaCl}$, devido a sua abundância em fluidos naturais. Para a determinação desses parâmetros, devese tomar o cuidado com a metaestabilidade que ocorre durante o resfriamento rápido, e faz com que o gelo apenas comece a se formar em temperaturas abaixo de $-30^{\circ} \mathrm{C}$ ou mais baixas. Assim, o sistema deve ser resfriado até temperaturas inferiores ou iguais a $-30^{\circ} \mathrm{C}$ para que na etapa de aquecimento natural da inclusão as medidas possam ser obtidas com maior precisão.

TEMPERATURA DE FUSÃO DOS CLATRATOS ( $\left.\mathrm{Tf}_{\mathrm{cl}}\right)$ - Quando no sistema está presente também o $\mathrm{CO}_{2}$, pode haver a formação de clatratos, hidratos de gases, e nessas situações, a salinidade da fase aquosa residual aumenta consideravelmente e, portanto, não pode ser obtida diretamente a partir da $\operatorname{Tf}_{\mathrm{g}}$ (Collins 1979, Fuzikawa 1985).

Os clatratos são materiais sólidos, originados pela cristalização de uma determinada substância em presença de outra, sob condições adequadas. As moléculas da primeira substância podem constituir uma estrutura cavernosa, no estado sólido, alojando assim os átomos ou moléculas do segundo componente, sendo as forças envolvidas muito fracas (ligações iônicas). A desintegração dos clatratos pode se dar pela fusão ou dissolução do material envolvido. A rigor, o clatrato não é considerado um composto químico embora, normalmente, exista uma relação estequiométrica entre os componentes. Não necessariamente todas as cavidades são preenchidas, podendo conter de 80 a $90 \%$ da substância aprisionada (Ohlweiler 1971). No caso das inclusões fluidas, este fenômeno ocorre durante o resfriamento da amostra, onde uma estrutura cavernosa de gelo aprisiona moléculas de gases. No caso do sistema ser constituído por $\mathrm{CO}_{2}+\mathrm{H}_{2} \mathrm{O}+$ sais dissolvidos, a fórmula será $\mathrm{CO}_{2} \cdot 5,75 \mathrm{H}_{2} \mathrm{O}$, ou seja, 46 moléculas de água formariam oito "gaiolas" com moléculas de $\mathrm{CO}_{2}$ (Collins 1979, Roedder 1984, Fuzikawa 1985).

Observa-se que no caso de haver a formação de clatratos, o valor da salinidade encontrado a partir de $\mathrm{Tf}_{\mathrm{g}}$ será maior que o real, uma vez que existe uma determinada quantidade de água pura ligada ao $\mathrm{CO}_{2}$. Collins (1979) mostra, pelo estudo do sistema $\mathrm{H}_{2} \mathrm{O}+\mathrm{CO}_{2}+\mathrm{NaCl}$, que apenas a temperatura onde ocorre a completa fusão desses compostos, possibilita uma determinação mais correta da quantidade de sais dissolvidos. Essa temperatura é, normalmente, 
difícil de ser obtida, uma vez que a observação desses compostos é prejudicada devido à sua isotropia e à semelhança entre seu índice de refração e o da solução aquosa (Collins 1979 , Roedder 1984); no entanto, algumas vezes, pode ser identificado através de uma deformação na bolha de $\mathrm{CO}_{2}$ após a completa fusão do gelo (Collins 1979). Quando esses compostos se fundem e a bolha retorna a seu formato original, registra-se a temperatura de fusão do clatrato $\left(\mathrm{Tf}_{\mathrm{cl}}\right)$.

A salinidade das soluções aquosas pode ser obtida nesses casos, utilizando-se diagramas de equilíbrio de fases no sistema $\mathrm{H}_{2} \mathrm{O}+\mathrm{CO}_{2}+\mathrm{NaCl}$ (Collins 1979, Diamond 1992), obtendo-se valores de concentrações também expressas em equivalentes da porcentagem em peso do $\mathrm{NaCl}$.

Outro fator que pode influenciar na determinação da salinidade é a presença de minerais de saturação. Nesses casos, são as temperaturas de dissolução dos sais que fornecerão os resultados mais precisos sobre a quantidade dos íons presentes na solução.

Este conjunto de dados sobre as temperaturas de fusão $\left(\mathrm{Tf}_{\mathrm{g}}\right.$ e $\left.\mathrm{Tf}_{\mathrm{cl}}\right)$ e, em alguns casos, sobre as temperaturas de dissolução de sais, pode permitir, através de diagramas apropriados, a determinação da composição química do fluido e das porcentagens dos sais dissolvidos na solução (Collins 1979, Valarelli 1982, Roedder 1984, Fuzikawa 1985).

TEMPERATURA DE HOMOGENEIZAÇÃO DO $\mathrm{CO}_{2}\left(\mathrm{Th}_{\mathrm{CO}}\right)$ - Essas temperaturas permitem o cálculo das densidades médias do $\mathrm{CO}_{2}$, mediante a utilização de dados experimentais P-V-T-X, disponíveis na literatura para esses sistemas puros (Roedder 1984, Nicholls \& Crawford 1985 entre outros), bem como a construção das respectivas isócoras (curvas de densidades constantes). Deve ser ainda ressaltado que a densidade do $\mathrm{CO}_{2}$, associada com a relação volumétrica entre as fases $\mathrm{CO}_{2}$ e $\mathrm{H}_{2} \mathrm{O}$, possibilitará a determinação do conteúdo de $\mathrm{CO}_{2}$ no fluido, em termos de suas frações molares.

Observa-se a partir da seção P-T do diagrama P-V-T relativo ao $\mathrm{CO}_{2}$ puro, discutida por Roedder (1984), Shepherd et al. (1985), entre outros, que a homogeneização dessa fase pode ocorrer até $+31,1^{\circ} \mathrm{C}$, que é o valor de sua temperatura crítica.

A $\mathrm{Th}_{\mathrm{CO}_{2}}$ é caracterizada pelo desaparecimento do menisco que separa as duas fases coexistentes, ou seja, um sistema composto por $\mathrm{CO}_{2}$ líquido + vapor, que tenderia para um sistema homogêneo, com apenas uma fase. A homogeneização pode ocorrer de três formas diferentes: a) expansão total da bolha de $\mathrm{CO}_{2}(\mathrm{~g})$ até o desaparecimento da sua fase líquida, caracterizando a homogeneização para o estado gasoso, indicando um sistema de densidades baixas; b) decréscimo da bolha de $\mathrm{CO}_{2}(\mathrm{~g})$ até seu total desaparecimento, ocorrendo homogeneização para o estado líquido, caracterizando um sistema de densidades mais elevadas e, finalmente, c) desaparecimento gradativo ou súbito, do menisco que separa as fases líquida e gasosa do $\mathrm{CO}_{2}$, sem mudança aparente nos seus volumes, indicando homogeneização para o estado crítico. 
TEMPERATURA DE HOMOGENEIZAÇÃO TOTAL (Th tot $_{\text {T }}$ - Para sistemas compostos por soluções aquosas salinas e $\mathrm{CO}_{2}$, a $\mathrm{Th}_{\mathrm{tot}}$ é determinada através do aquecimento da amostra a partir da temperatura ambiente. Esta etapa só é realizada após a obtenção de todas as medidas relativas ao resfriamento pois, uma vez aquecida a amostra, podem ocorrer modificações nas características originais das inclusões, algumas vezes observadas através de um nítido aumento da bolha.

As $\mathrm{Th}_{\text {tot }}$ de inclusões no sistema aquo-carbônico podem ocorrer pela expansão da fase aquosa (diminuição da bolha), pela expansão da fase $\mathrm{CO}_{2}$ (aumento da bolha) ou pelo desaparecimento do menisco que separa as duas fases, ou seja, homogeneização crítica. No caso de haver minerais de saturação, a $T_{\text {tot }}$ será dada pela sua dissolução se esta for posterior à homogeneização relativa às fases fluidas.

A importância desta medida é que ela pode fornecer as condições mínimas de temperatura e pressão de aprisionamento do fluido quando se tratar de inclusões fluidas primárias, não modificadas posteriormente, ou mesmo as próprias condições reais de formação do mineral, no caso de inclusões formadas a partir de um sistema heterogêneo de fluidos. Além disso, quando associada aos outros dados microtermométricos, pode permitir a determinação da densidade total do fluido (Weisbrod et al. 1976, Hollister 1981, Roedder 1984, Fuzikawa 1985). Desse modo, considerando-se a seção P-T do diagrama P-V-T para o sistema de interesse, com o acréscimo da temperatura após o processo de homogeneização, a inclusão segue uma linha de densidade constante (isócora), cuja inclinação é função desse parâmetro. Deve ainda ser observado que, para inclusões fluidas de diversas gerações, as $\mathrm{Th}_{\mathrm{tot}}$ podem ajudar a delinear o caminho de evolução dos fluidos num campo P-T.

No caso de um sistema inicial homogeneo de fluidos, quando são obtidas apenas as condições mínimas de P e T de aprisionamento das inclusões, são necessárias correções de pressão que auxiliarão nos estudos da geotermometria (Roedder \& Bodnar 1980). Roedder (1977) cita alguns exemplos, onde o fator de correção pode variar entre um intervalo de, aproximadamente, $25^{\circ} \mathrm{C}$ até $300^{\circ} \mathrm{C}$. Quando a provável pressão de aprisionamento não puder ser estimada a partir de considerações geológicas ou por aplicações de geobarômetros, o estudo da paragênese mineral, aliado aos resultados microtermométricos, pode fornecer o possível intervalo de pressão e temperatura de formação das inclusões e do próprio depósito mineral. Por outro lado, quando duas fases fluidas imiscíveis coexistentes são aprisionadas simultaneamente, como inclusões distintas, por exemplo no caso de sistemas originais heterogêneos, o cruzamento de suas isócoras define as condições de $\mathrm{P}$ e $\mathrm{T}$ reais do aprisionamento. 


\section{6 - INCLUSÕES FLUIDAS DO TOPÁZIO IMPERIAL DA REGIÃO DE OURO PRETO}

Nos topázios foram observadas inclusões fluidas de diversas feições morfológicas, as quais encontram-se dispostas segundo orientações cristalográficas distintas, independentemente da jazida e/ou ocorrência, podendo haver mais de um desses tipos num mesmo cristal. Essas inclusões possuem contornos regulares, passando gradualmente a formas completamente irregulares; podem ocorrer dispersas através do cristal ou constituir um ou mais núcleos de concentração. Um aspecto muito comum é dado pela presença de inclusões fluidas alongadas, de contornos regulares, prismáticas (canais sub-retangulares), ou, às vezes, em forma de canalículos aciculares, com elongação paralela, perpendicular ou inclinada em relação ao eixo c do cristal hospedeiro. Ocorrem dispersas através do cristal e/ou agrupadas em determinadas regiões (Fotomicrografia 33). Outro aspecto observado é a ocorrência de inclusões fluidas de contornos irregulares com orientações e dimensões semelhantes às anteriores, onde algumas das feições observadas sugerem que sua forma atual seja resultante da dissolução preferencial controlada por certas direções cristalográficas (essencialmente ao longo do eixo c e dos planos de clivagem). Destacam-se, entre estas, as que possuem uma série de prolongamentos, predominantemente orientados ao longo da direção do eixo c do topázio, e as que apresentam morfologias características, como as inclusões em forma de pente ou com aspectos escalonados (Fotomicrografia 34). Em outras situações, as inclusões irregulares não possuem as feições descritas acima, e ocorrem, predominantemente, de maneira aleatória, apresentando uma certa orientação, sendo em geral inclinadas em relação ao eixo c do cristal (Fotomicrografia 35). Deve ser ainda ressaltado, que algumas inclusões irregulares observadas apresentaram feições indicativas de escape de fluido (leakage) e de estrangulamento (necking down), sugerindo, portanto, a ocorrência de modificações posteriores ao aprisionamento (Fotomicrografia 36). Por fim, foram ainda observadas inclusões fluidas com formas relativamente regulares, equidimensionais ou levemente alongadas, geralmente menores que as anteriores, com dimensões médias de $10 \mu \mathrm{m}$, podendo ser inferiores a $4 \mu \mathrm{m}$. Ocorrem distribuídas ao longo de planos de fraturas cicatrizadas, conchoidais ou não, limitadas ao interior dos cristais, o que sugere tratar-se de inclusões pseudosecundárias (Fotomicrografia 37). Algumas ilustrações dessas feições são também apresentadas em Gandini et al. (1991). 


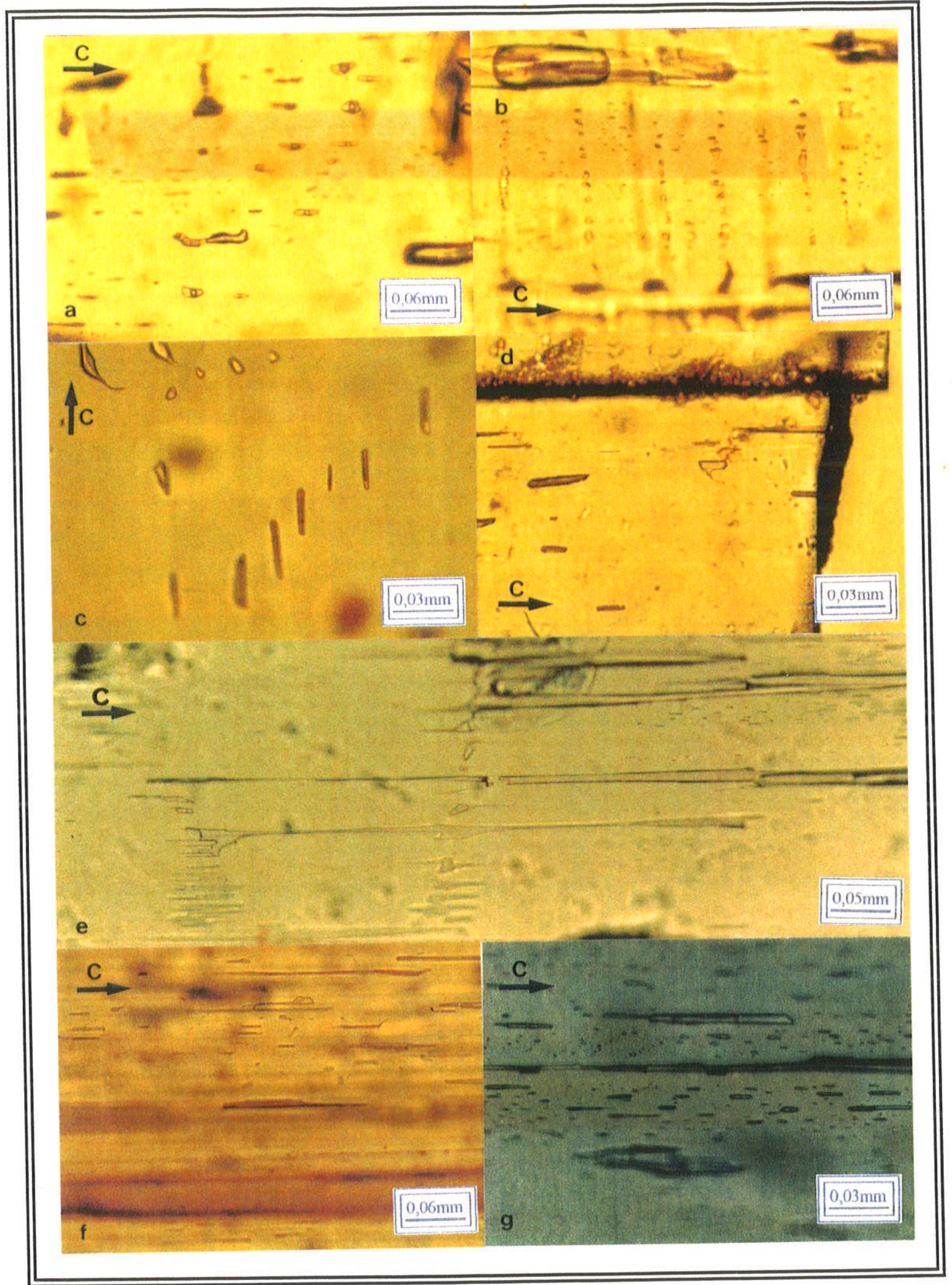

FOTOMICROGRAFIA 33 - a) inclusões fluidas alongadas, paralelas ao eixo c do topázio, com contornos predominantemente regulares, ao lado de algumas inclusões irregulares, b) inclusões de contornos ligeiramente equidimensionais, dispostas em fileiras perpendiculares ao eixo c, c) inclusões alongadas de contornos regulares e paralelos ao eixo c do cristal. No canto superior esquerdo, aparecem inclusões irregulares, distribuídas aleatoriamente, d) inclusões inclinadas ao lado de algumas perpendiculares à clivagem basal do topázio, e) inclusões na forma de canalículos, extremamente longos, paralelos ao eixo c, f) mesmo aspecto que as anteriores, porêm menores, g) um grande número de inclusões de contornos regulares, perpendiculares a clivagem. 


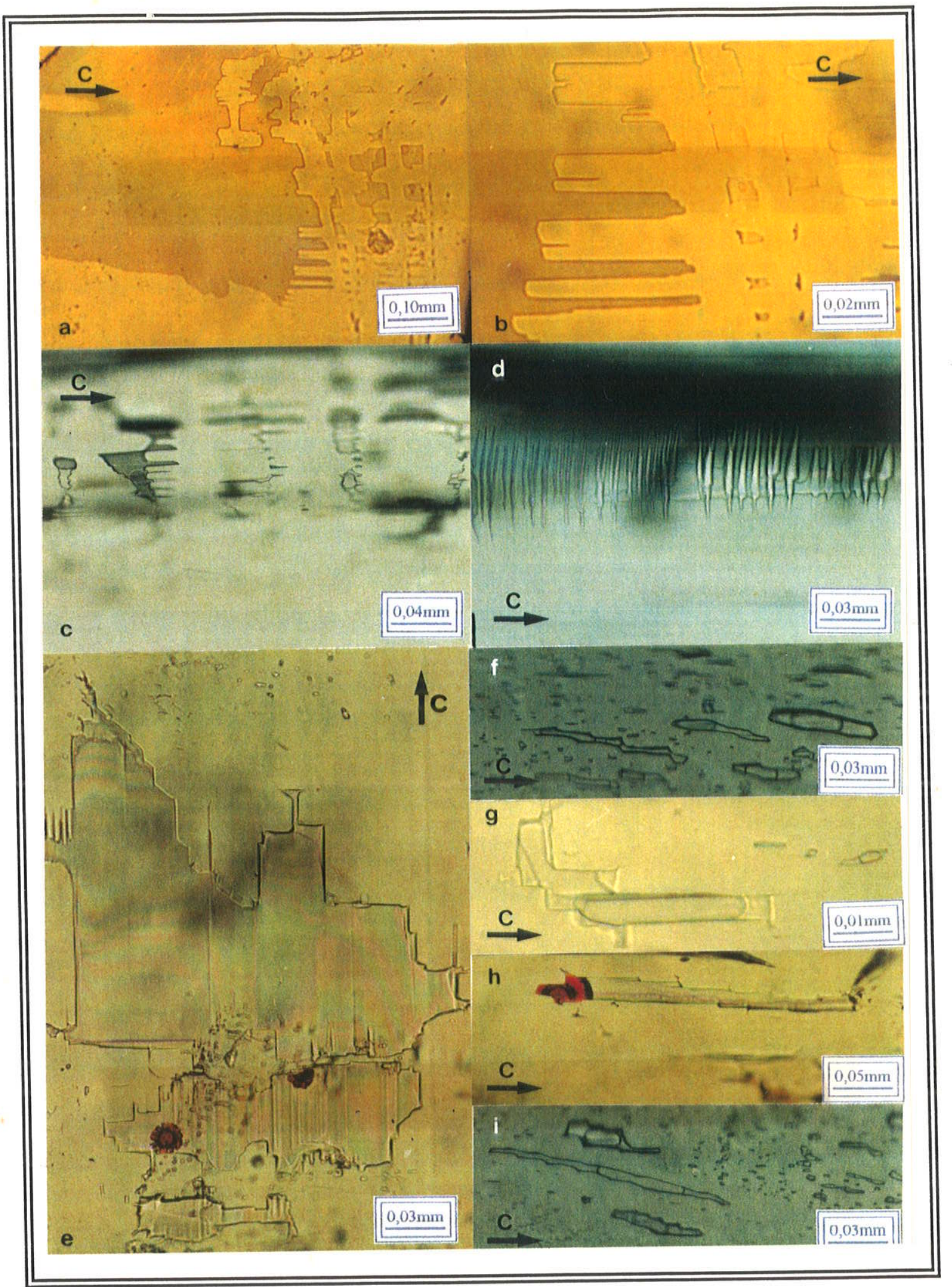

FOTOMICROGRAFIA 34 - a) inclusão fluida com prolongamentos perpendiculares à clivagem basal, sugerindo dissolução, b) detalhe da fotomicrografia anterior, c) inclusões fluidas com prolongamentos paralelos ao eixo $\mathbf{c}$ (forma de pente), d) mesmo aspecto que a anterior, porêm os prolongamentos são perpendiculares a c, e) inclusão com evidência de dissolução preferencial segundo direções cristalográficas do topázio, exibindo dois pontos de óxido de ferro, f) inclusões escalonadas inclinadas em relação ao eixo c, g) inclusão de contornos controlados pelas direções cristalográficas do topázio, h) mesmo aspecto da anterior, com a presença de óxido de ferro, i) feição semelhante a f). 


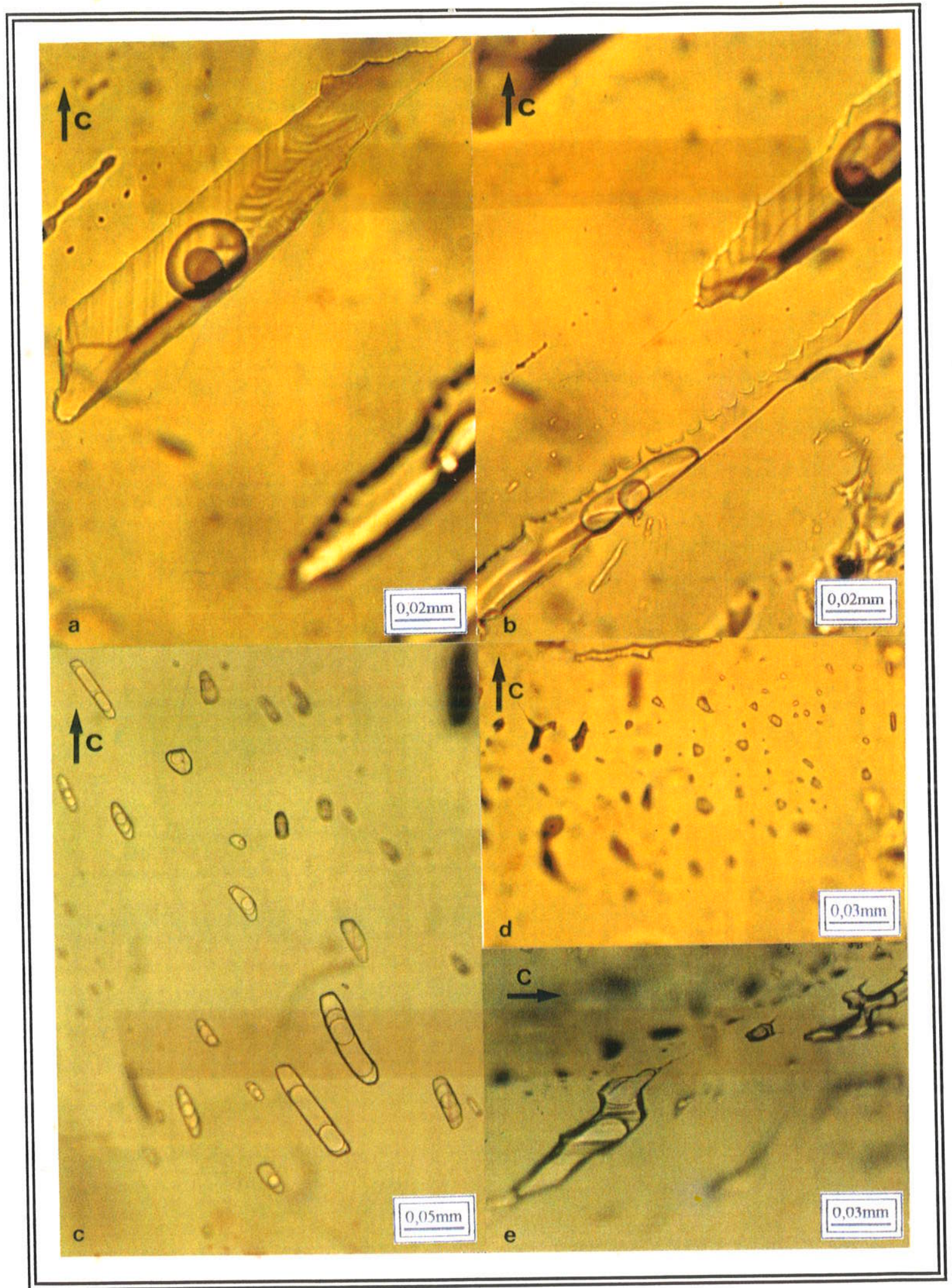

FOTOMICROGRAFIA 35 - a) inclusões fluidas inclinadas em relação ao eixo c, b) outro detalhe de a com bordas serrilhadas e alongadas na direção $\mathbf{c}, \mathrm{c}$ ) inclusões inclinadas em relação à clivagem basal, de contornos regulares, d) inclusões irregulares, distribuídas aleatoriamente no cristal, e) inclusão de contorno irregular, inclinada em relação ao eixo c. Observa-se, em um nível inferior, uma fratura de cicatrização com inclusões fluidas menores. 


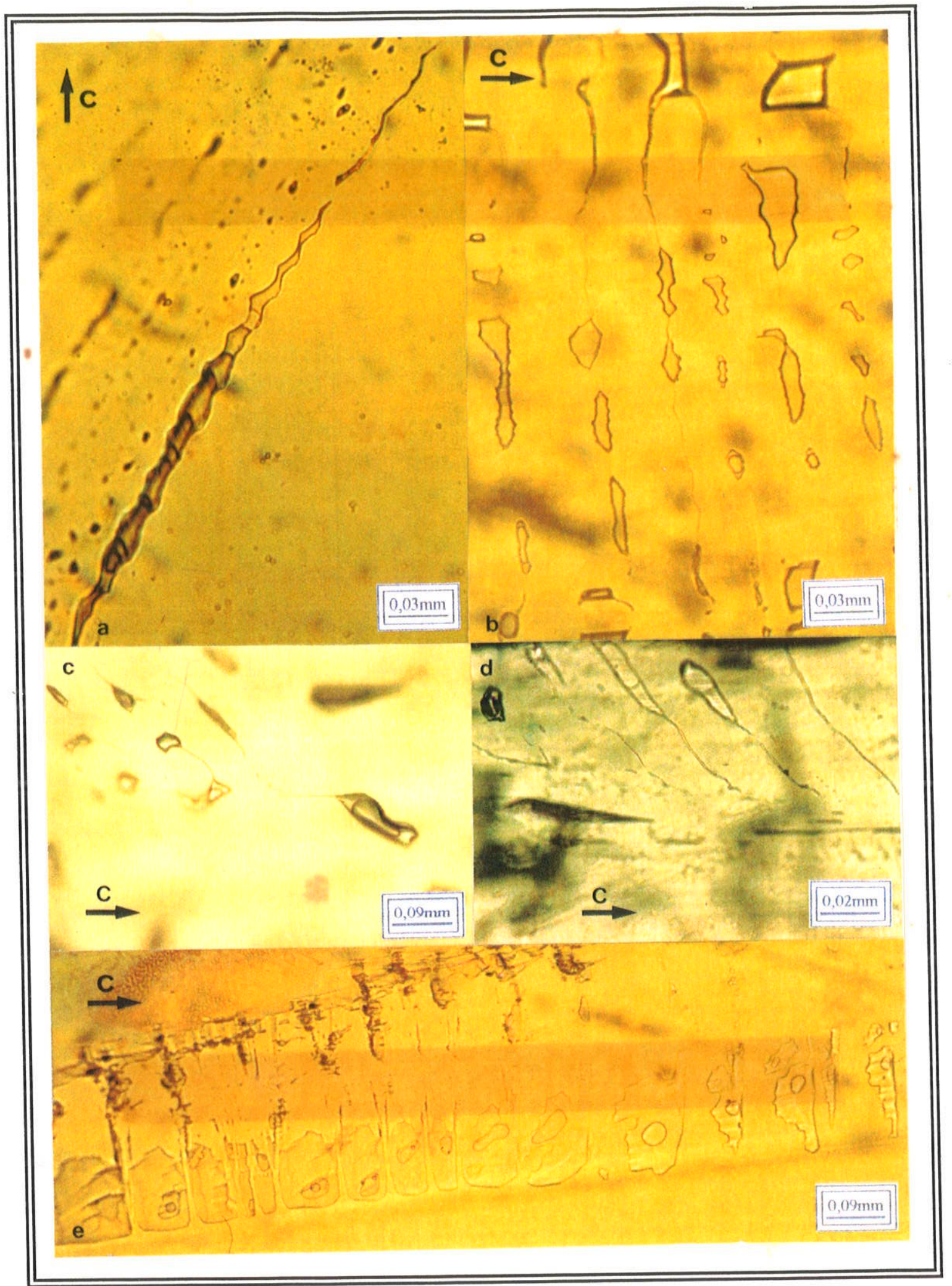

FOTOMICROGRAFIA 36 - a) inclusão fluida com feição típica de estrangulamento (necking down), b) inclusões irregulares com feições de estrangulamento, c) inclusão inclinada em relação ao eixo c mostrando feição de escape de fluido (leakage), d) inclusões irregulares e inclinadas, exibindo feições de escape de fluido, e) inclusão típica de um processo de estrangulamento. 


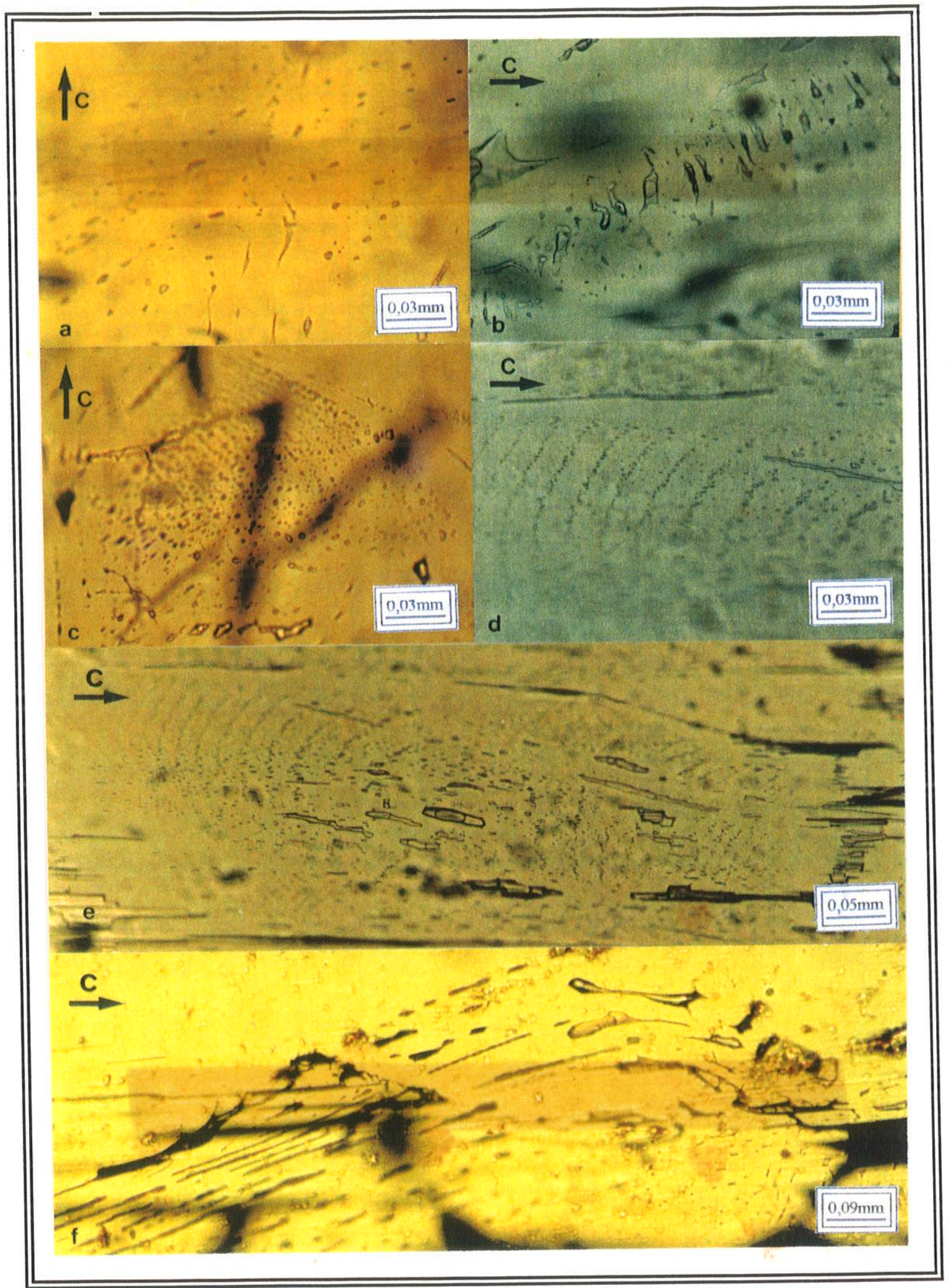

FOTOMICROGRAFIA 37 - a) fratura icatrizada, dando a idéia de uma dobra pela disposição das inclusões fluidas, b) fratura cicatrizada, com inclusões de morfologias irregulares, c) fratura cicatrizada, com uma sucessão de níveis de inclusões fluidas pequenas e regulares, d) outro aspecto de c, com uma distribuição mais regular das inclusões, e) uma visão mais ampla de $\underline{\mathrm{d}}$, com inclusões escalonadas e inclinadas em relação a c, pertencentes a outro nível da fratura, f) fratura cicatrizada, de aspecto curvo, reunindo inclusões de dimensões variadas. 
Após terem sido devidamente caracterizadas e selecionadas, as inclusões fluidas, não portadoras de feições indicativas de terem sofrido modificações posteriores ao aprisionamento, foram agrupadas, de acordo com a sua distribuição e orientação em relação ao eixo $\mathbf{c}$ do cristal hospedeiro, em quatro tipos distintos, a saber: 1) tipo a: inclusões fluidas de contornos regulares e irregulares, dispostas paralelamente ao eixo c;2) tipo b: inclusões fluidas de contornos regulares e irregulares, com vários graus de inclinações em relação ao eixo c do topázio, podendo, inclusive, ocorrer paralelamente ao plano de clivagem; 3 ) tipo c: inclusões fluidas de contornos irregulares, dispostas de modo aleatório através do cristal e 4) tipo d: inclusões fluidas distribuídas ao longo de planos de fraturas cicatrizadas limitadas ao interior dos cristais. As inclusões descritas são, predominantemente, primárias e pseudosecundárias (Fotomicrografias 33, 34, 35, 36 e 37). As Figuras 36 e 37, que representam fichas do mapeamento de dois cristais, com aspectos distintos, ilustram alguns dos tipos descritos acima.

Quanto às dimensões das inclusões fluidas do topázio, elas variaram desde algumas $\mu \mathrm{m}$ até $460 \mu \mathrm{m}$ (comprimento do maior eixo), encontrando-se a maior parte entre 4 e $160 \mu \mathrm{m}$, predominando, entre estas, as de tamanho intermediário a superior, tendo havido, portanto, uma grande facilidade em seu estudo. Em alguns casos, mais raros, ocorrem inclusões fluidas tão grandes que podem ser observadas a olho nu, possuindo um comprimento aproximado de $2 \mathrm{~cm}\left(2.10^{4} \mu \mathrm{m}\right)$. Apesar desta grande variação, as inclusões fluidas selecionadas, para o estudo microtermométrico, situaram-se numa faixa de 10 a $50 \mu \mathrm{m}$, tendo sido excepcionalmente analisadas inclusões em torno de $100 \mu \mathrm{m}$. Evitou-se a análise de inclusões de grandes dimensões, uma vez que essas podem apresentar problemas de crepitação ou escape de fluidos quando aquecidas.

A população das inclusões fluidas nesses topázios é muito grande, não chegando, no entanto, a comprometer sua diafaneidade. Talvez as maiores concentrações de inclusões fluidas estejam localizadas nas fraturas de cicatrização (Fotomicrografia 37).

Em relação ao número de fases, as inclusões fluidas estudadas, quase que invariavelmente, mostraram-se bifásicas à temperatura de $25^{\circ} \mathrm{C}$, com predominância da fase aquosa. Para os cristais de topázio imperial do Paquistão, as inclusões fluidas também são bifásicas, sendo a fase aquosa predominante (Gübelin et al. 1986). No caso particular dos cristais da jazida de Vermelhão, além das bifásicas, apareceram também, com uma certa freqüência, algumas trifásicas $(1+\mathrm{g}+\mathrm{s})$ como também polifásicas $\left(1+\mathrm{g}+\mathrm{s}_{1}+\mathrm{s}_{2}\right.$ ) (Fotomicrografia 38). Neste último caso, as fases cristalinas são diferenciadas por propriedades ópticas distintas, tendo sido observados cristais isótropos e anisótropos. 


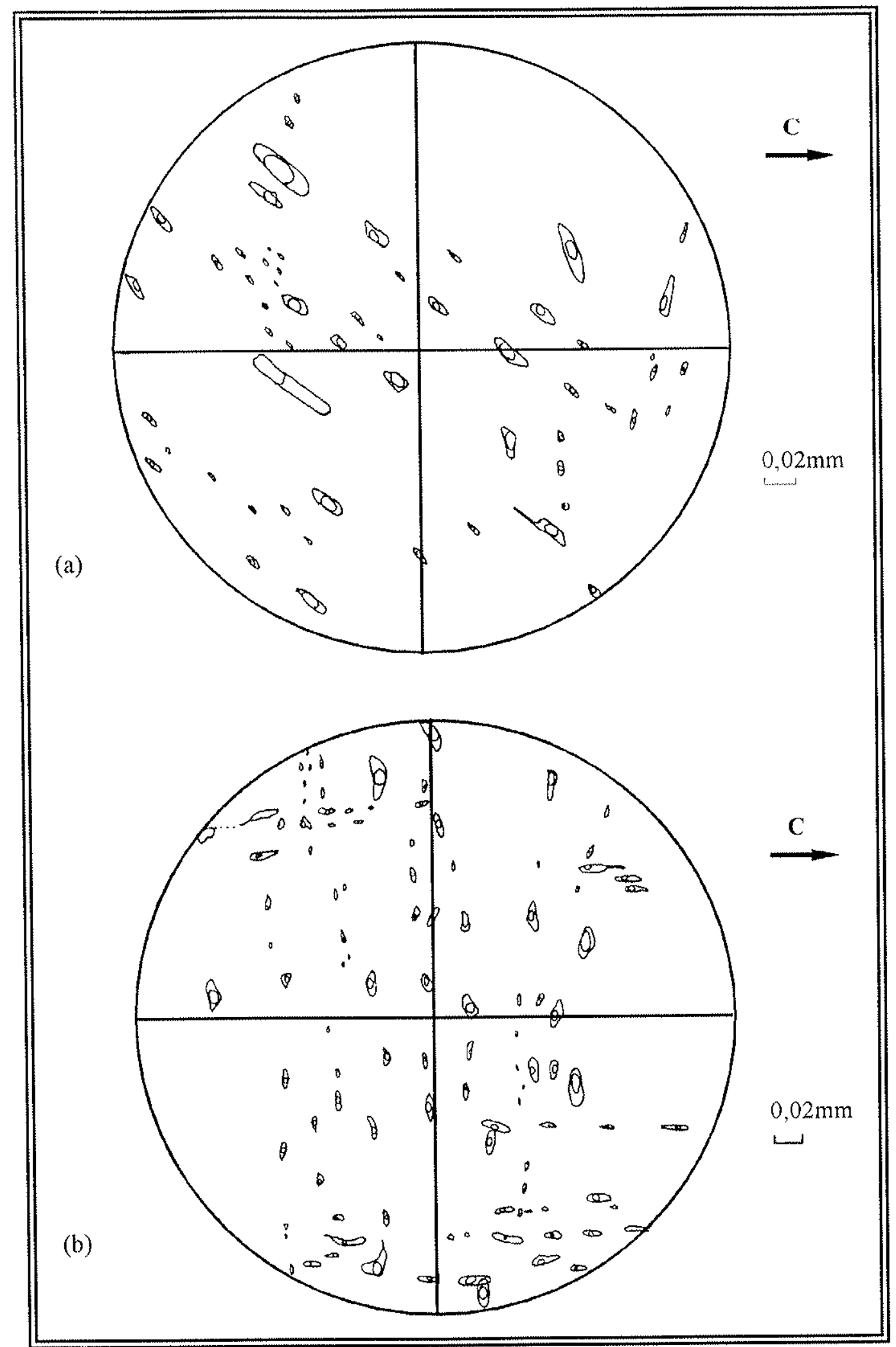

FIGURA 36 - Fichas de mapeamento de um cristal de topázio imperial da jazida de Caxambu, destacando-se dois campos distintos; a) no campo 1 aparecem inclusões fluidas de contornos regulares inclinadas em relação ao eixo cristalográfico $\mathbf{c}$, b) no campo 2 são vistas inclusões fluidas de contorno regulares a sub-retangulares, paralelos e perpendiculares a c. Desenhos feitos manualmente a partir de um microscópio petrográfico. 


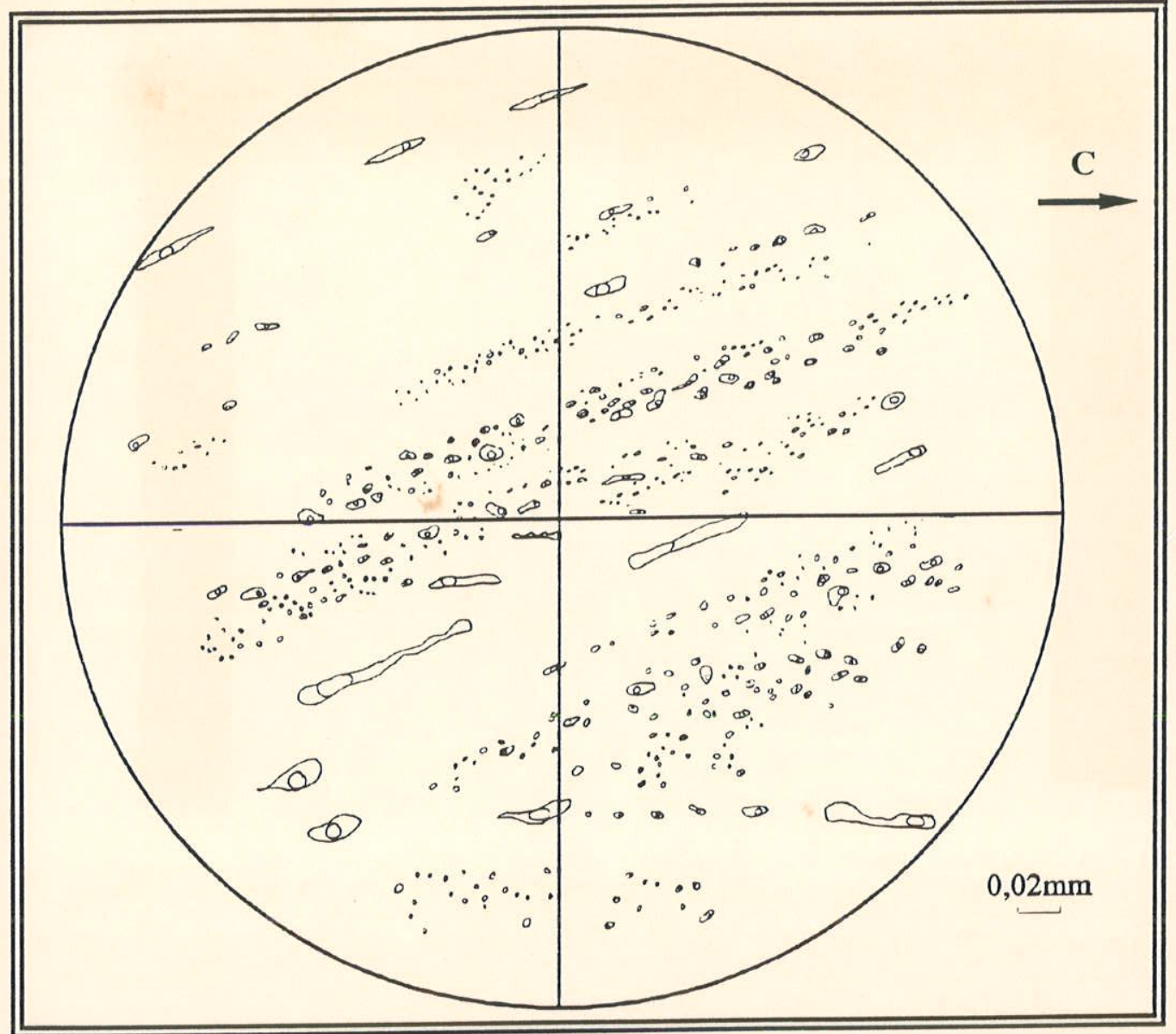

FIGURA 37 - Ficha de mapeamento de um cristal de topázio imperial da jazida do Capão do Lana. destacando-se um plano de fratura cicatrizada, com inclusões fluidas pseudosecundárias. Essas inclusões săo pequenas, e de um modo geral possuem contornos regulares. As inclusões maiores não pertencem ao referido plano. Todas as inclusões são bifásicas à temperatura ambiente. não tendo sido possivel desenhar todas, devido à escala. O desenho foi feito com auxilio de uma câmara clara.

As fases cristalinas presentes nas inclusões fluidas, que ocorrem quase que exclusivamente no caso da jazida do Vermelhão, são compostas por partículas estranhas incorporadas por estarem presentes nas soluções primitivas, constituindo, portanto, sólidos acidentais. Essas fases não representam minerais de saturação, pois não estão presentes em todas as inclusões fluidas do cristal, podendo ser abundantes em algumas e faltando em outras da mesma geração. Para serem minerais de saturação deveriam ocorrer nas mesmas proporções em todas as inclusões de uma dada geração (Roedder 1984). Os minerais acidentais presentes nessas inclusões fluidas não puderam ser identificados pela falta de instrumentação ou de padrões disponíveis nos laboratórios utilizados. Com o auxilio de um microscópio petrográfico comum, observou-se apenas que algumas são anisótropas e outras isótropas. Do mesmo modo que os cristais de topázio da região de Ouro Preto, os da região de Mardan, no Paquistão, não apresentam cristais de saturação (Gübelin et al. 1986). 


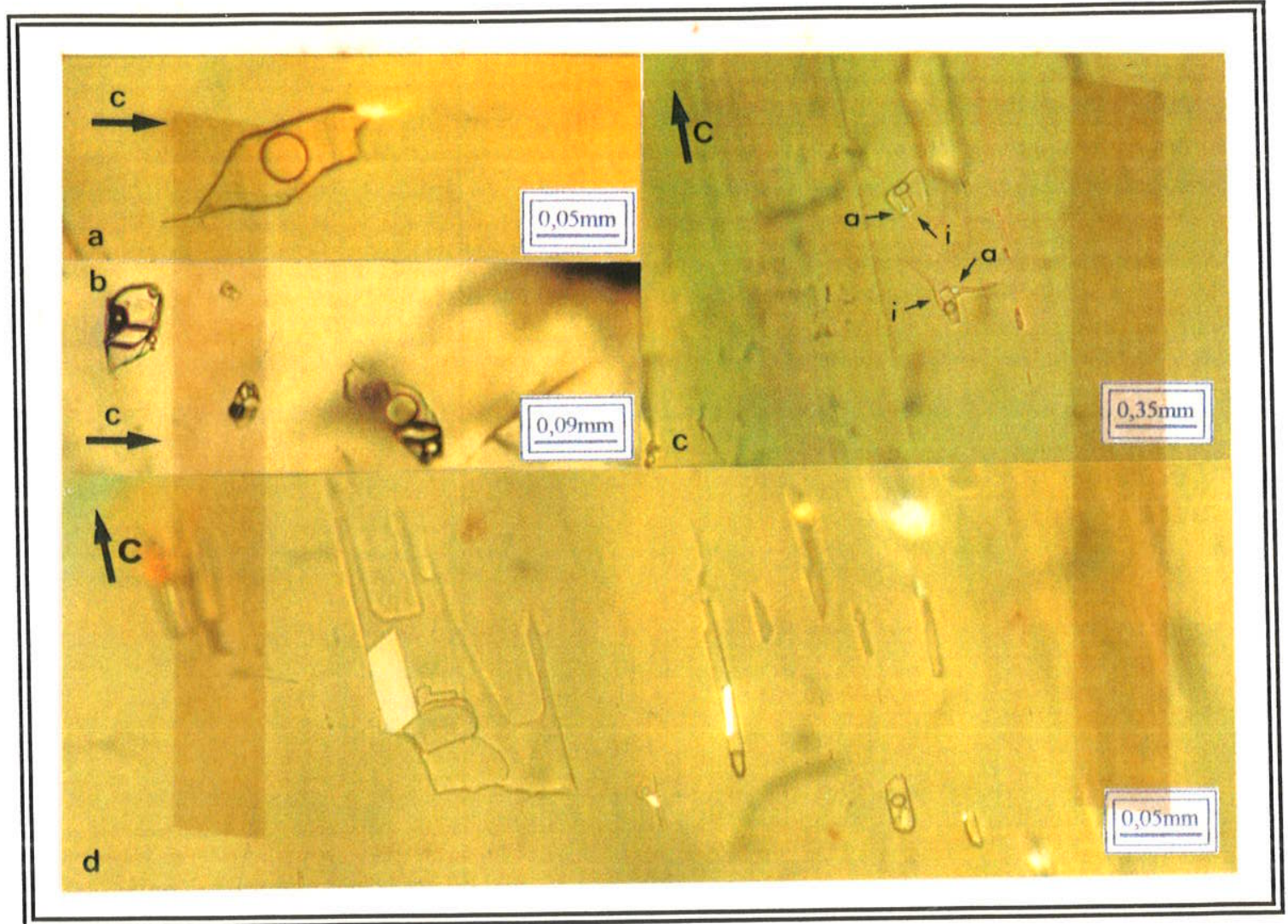

FOTOMICROGRAFIA 38 - a) inclusão fluida trifásica (líquido + gás + sólido), b) inclusões polifásicas (líquido + gás + sólido $^{1}+$ sólido $^{2}$ ), c) inclusões fluidas polifásicas. Os sólidos são de minerais diferentes, um é isótropo (i) e o outro é anisótropo (a) e d) inclusões polifásicas com cristais romboédricos no seu interior. Todas as fotomicrografias são de topázios da jazida do Vermelhão e todas foram tiradas com polarizadores semi cruzados.

Para a obtenção da composição dos fluidos das inclusões, devem ser determinadas as temperaturas de fusão dos componentes. Entre as várias substâncias voláteis existentes nas inclusões fluidas do topázio imperial, foram identificadas por este método a água e o $\mathrm{CO}_{2}$. Entre as fases líquidas predomina, na grande maioria, a composta por uma solução aquosa salina de concentração variada, seguida de $\mathrm{CO}_{2}$ líquido. A salinidade das inclusões fluidas do topázio do Paquistão varia de média a baixa (Gübelin et al. 1986), como as de Ouro Preto. A coexistência da solução aquosa com o dióxido de carbono líquido, à $25^{\circ} \mathrm{C}$, ocorre devido à grande imiscibilidade dessas substâncias a temperaturas próximas a ambiente (Roedder 1984), as quais formam, portanto, fases distintas. Outros elementos presentes, junto ao $\mathrm{CO}_{2}$, foram identificados pelos métodos de espectroscopia no infravermelho e micro Raman, descritos mais adiante. 


\subsection{1 - DADOS MICROTERMOMÉTRICOS}

Como já foi dito no início do capítulo 2 , houve dificuldades na coleta das amostras. Desta forma, não pôde ser feito o mesmo tratamento em todas as jazidas e/ou ocorrências de topázio quanto ao estudo microtermométrico. Assim sendo, as jazidas do Capão do Lana, Caxambu e Boa Vista tiveram um estudo mais detalhado, sendo possível confeccionar tabelas, histogramas e isócoras, ao passo que as demais jazidas tiveram apenas alguns dados analisados.

Para cada um dos tipos de inclusões fluidas mencionados anteriormente, foram medidas as temperaturas de fusão e homogeneização das fases presentes, determinadas as composições químicas (em frações molares dos componentes presentes), salinidades (em equivalentes da porcentagem em peso de $\mathrm{NaCl})$, as densidades do $\mathrm{CO}_{2}\left(\mathrm{~d}_{\mathrm{CO}_{2}}\right)$ e as densidades totais das inclusões $\left(d_{\text {tot }}\right)$, com base nos trabalhos de Nicholls \& Crawford (1985), Brown (1989) e Collins (1979). Foram estudadas, aproximadamente, 600 inclusões fluidas de 16 cristais do Capão do Lana, 360 inclusões em 10 cristais de Caxambu e 280 inclusões em 5 cristais de Boa Vista. Os resultados estão agrupados nas Tabelas 24, 25, 26, 27, 28 e 29, sendo descritos, separadamente, a seguir.

Entre as temperaturas medidas, merecem destaque as de homogeneização do $\mathrm{CO}_{2}$ $\left(\mathrm{Th}_{\mathrm{CO}_{2}}\right)$, pois estas permitiram a separação de vários grupos de amostras com inclusões fluidas de características distintas, independentemente da sua morfologia ou orientação no cristal hospedeiro, nas diversas jazidas e/ou ocorrências.

Para a obtenção dos valores de $\mathrm{Tf}_{\mathrm{CO}_{2}}$, foram realizados alguns resfriamentos iniciais inferiores a $-180^{\circ} \mathrm{C}$, na tentativa de se detectar outra substância volátil além da água e do dióxido de carbono. Como não houve a observação de nenhum fenômeno referente a qualquer outra substância, as demais medidas foram obtidas resfriando-se as amostras até $-120^{\circ} \mathrm{C}$, pois nesta temperatura tanto a água quanto o gás carbônico se congelam. 
TABELA 24 - Dados obtidos das inclusões fluidas presentes nos topázios da jazida do Capão do Lana. As temperaturas representam as várias mudanças de fases analisadas sob processos microtermométricos.

\begin{tabular}{|c|c|c|c|c|c|c|c|c|}
\hline \multirow[t]{2}{*}{ GR } & \multirow[t]{2}{*}{$\mathrm{T}$} & \multirow{2}{*}{$\begin{array}{c}\mathrm{Tf}_{\mathrm{CO} 2} \\
\left({ }^{\circ} \mathrm{C}\right)\end{array}$} & \multirow{2}{*}{$\begin{array}{c}\mathrm{Th}_{\mathrm{CO} 2} \\
\left({ }^{\circ} \mathrm{C}\right)\end{array}$} & \multirow[t]{2}{*}{ v } & \multicolumn{2}{|c|}{$\mathrm{Tf}_{\mathrm{cl}} \quad\left({ }^{\circ} \mathrm{C}\right)$} & \multirow{2}{*}{$\begin{array}{l}\mathrm{Th}_{\text {tot }} \\
\left({ }^{\circ} \mathrm{C}\right)\end{array}$} & \multirow{2}{*}{$\begin{array}{c}\mathrm{Th}_{\text {tot }} \\
>\text { frequiência }\left({ }^{\circ} \mathrm{C}\right)\end{array}$} \\
\hline & & & & & VAR. & MÉDIA & & \\
\hline \multirow{4}{*}{1} & a & -57.0 a -56.6 & 8.8 a 11.2 & 45 a 60 & 5 a 8 & 5.6 .7 .0 & 230 a 310 & 290 a 300 (H. crit.) \\
\hline & b & -56.8 a -56.6 & 8.8 a 10.4 & 35 a 60 & 6 a 9 & 7.3 & 280 a 300 & 290 a 300 (H. crit.) \\
\hline & c & -57.4 a -57.2 & 8.8 a 10.4 & 40 a 60 & $7: 8$ & 7.5 & 230 a 300 & 290 a $300\left(\right.$ H. p/ $\left.\mathrm{CO}_{2}\right)$ \\
\hline & d & -58.2 a -57.0 & 8.0 a 10.4 & 40 a 60 & 5 a 8 & $6.1 / 7.3$ & 290 a 320 & 300 a 310 (H. crit.) \\
\hline \multirow{4}{*}{2} & a & -57.0 a -56.6 & 10.4 a 12.8 & 30 a 50 & 6 a 8 & $6.4 / 7.7$ & 260 a 300 & 270 a 300 (H. p/ $\mathrm{H}_{2} \mathrm{O}$, crit.. $\mathrm{CO}_{2}$ ) \\
\hline & b & -57.2 a -56.6 & 12.0 a 12.8 & 30 a 50 & 6 a 8 & 6.8 & - & $\cdot$ \\
\hline & c & -57.2 a -56.8 & 11.2 a 14.4 & 30 a 40 & 6 a 8 & 7.0 & - & - \\
\hline & d & -56.8 a -56.6 & 11.2 a 12.8 & 30 a 50 & 6 a 8 & 7.17 .5 & 290 a 300 & 290 a 300 (H. crit.) \\
\hline \multirow{4}{*}{3} & a & -57.2 a -56.6 & 21.6 a 22.4 & 10 a 20 & 5 a 7 & 5.66 .4 & 280 a 290 & 280 a $290\left(\right.$ H. p $\left.\mathrm{H}_{2} \mathrm{O}\right)$ \\
\hline & b & -57.8 a -56.8 & 20.8 a 23.2 & 10 a 30 & 5 a 7 & $5.7 / 5.9$ & 270 a 290 & 280 a 290 (H. p/ $\mathrm{H}_{2} \mathrm{O}$ ) \\
\hline & c & $-56,8$ a -56.6 & 20.8 a 22.4 & 10 a 30 & 5 a 7 & 6.0 & 280 a 290 & 280 a $290\left(\mathrm{H} . \mathrm{p} / \mathrm{H}_{2} \mathrm{O}\right.$ e $\left.\mathrm{CO}_{2}\right)$ \\
\hline & d & $-57,8 a-56.6$ & 20.8 a 22.4 & 10 a 30 & 4 a 7 & $5,2 / 5,6$ & 290 a 300 & 290 a 300 (H. p/ $\left.\mathrm{H}_{2} \mathrm{O}\right)$ \\
\hline
\end{tabular}

TABELA 25 - Parâmetros calculados das inclusões fluidas dos topázios da jazida do Capão do Lana. a partir dos dados da Tabela 24.

\begin{tabular}{|c|c|c|c|c|c|c|c|c|}
\hline \multirow[t]{2}{*}{ GR } & \multirow[t]{2}{*}{$\mathrm{T}$} & \multirow{2}{*}{$\begin{array}{r}\mathrm{d}_{\mathrm{CO} 2} \\
\left(\mathrm{~g} / \mathrm{cm}^{3}\right) \\
\end{array}$} & \multirow{2}{*}{$\begin{array}{c}\mathrm{d}_{\mathrm{H} 2 \mathrm{O}} \\
\left(\mathrm{g} / \mathrm{cm}^{3}\right) \\
\end{array}$} & \multirow{2}{*}{$\begin{array}{l}\mathrm{d}_{\text {tot }}\left(\mathrm{g} / \mathrm{cm}^{3}\right) \\
\text { (variação) }\end{array}$} & \multirow{2}{*}{$\begin{array}{c}\begin{array}{c}\text { salinidade } \\
\text { eq. } \% \text { peso }\end{array} \\
\text { de } \mathrm{NaCl}\end{array}$} & \multicolumn{3}{|c|}{ composição (variação) } \\
\hline & & & & & & $\mathrm{x}_{\mathrm{H} 2 \mathrm{O}}$ & $\mathrm{x}_{\mathrm{NaCl}}$ & $\mathrm{x}_{\mathrm{CO} 2}$ \\
\hline \multirow{4}{*}{1} & a & 0.8619 & 1.0463 & 0.9322 a 0.9680 & 5.77 a 8.13 & 0.6417 a 0.7553 & 0.0121 a 0.020 & 60.3462 a 0.2240 \\
\hline & b & 0.8648 & 1.0339 & 0.9325 a 0.9747 & 5,23 & 0.6420 a 0.8257 & 0.0109 a 0.014 & 10.3470 a 0.1602 \\
\hline & c & 0.8619 & 1.0313 & 0.9297 a 0.9635 & 4.87 & 0.6436 a 0.7969 & 0.0102 a 0.012 & 60.3463 a 0.1906 \\
\hline & d & 0.8655 & 1.0411 & 0.9356 a 0.9717 & 5.23 a 7.31 & 0.6368 a 0.7932 & 0.0117 a 0.018 & 40.3481 a 0.1908 \\
\hline \multirow{4}{*}{2} & a & 0.8476 & 1,0385 & 0.9361 a 0.9866 & 4.51 a 6.81 & 0.7268 a 0.8585 & 0.0107 a 0.019 & 20.2582 a 0.1290 \\
\hline & b & 0.8435 & 1.0403 & 0.9419 a 0.9812 & 6.12 & 0.7286 a 0.8539 & 0,0146 a 0.017 & 10.2568 a 0.1290 \\
\hline & c & 0,8387 & 1,0377 & 0,9581 a 0,9780 & 5,77 & 0.7986 a 0.8555 & 0,0151 a 0.016 & 10.1864 a 0.1283 \\
\hline & d & 0,8463 & 1,0339 & 0.9400 a 0.9786 & 4.87 a 5.59 & 0.7304 a 0.8554 & 0.0115 a 0.015 & 60.2581 a 0.1290 \\
\hline \multirow{4}{*}{3} & a & 0,7518 & 1,0494 & 0,9865 a 1,0235 & 6,81 a 7,79 & 0.9044 a 0.9456 & 0,0241 a 0.025 & 10.0715 a 0.0331 \\
\hline & b & 0.7536 & 1.0525 & 0,9625 a 1.0235 & 7.64 a 7.97 & 0.8605 a 0.9418 & 0.0220 a 0.025 & 10.1170 a 0.0331 \\
\hline & c & 0.7565 & 1.0501 & 0.9620 a 1.0208 & 7.48 & 0.8613 a 0.9432 & 0,0215 a 0.023 & 50.1172 a 0.0333 \\
\hline & d & 0.7559 & 1.0572 & 0.9664 a 1.0288 & 8.13 a 8.77 & 0.8580 a 0.9409 & 0.0234 a 0.027 & 80.1177 a 0.0331 \\
\hline
\end{tabular}


TABELA 26 - Dados obtidos das inclusões fluidas presentes nos topazios da jazida de Caxambu. As temperaturas representam as várias mudanças de fases analisadas sob processos microtermométricos.

\begin{tabular}{|c|c|c|c|c|c|c|c|c|}
\hline \multirow[t]{2}{*}{ GR } & \multirow[t]{2}{*}{$\mathrm{T}$} & \multirow{2}{*}{$\begin{array}{c}\mathrm{Tf}_{\mathrm{CO} 2}\left({ }^{\circ} \mathrm{C}\right) \\
\mathrm{VT}\end{array}$} & \multirow{2}{*}{$\begin{array}{c}\mathrm{Th}_{\mathrm{CO} 2}\left({ }^{\circ} \mathrm{C}\right) \\
\text { VT }\end{array}$} & \multirow[t]{2}{*}{$\mathrm{v}$} & \multicolumn{2}{|c|}{$\mathrm{Tf}_{\mathrm{cl}} \quad\left({ }^{\circ} \mathrm{C}\right)$} & \multirow{2}{*}{$\begin{array}{l}\mathrm{Th}_{\text {tot }} \\
\left({ }^{\circ} \mathrm{C}\right)\end{array}$} & \multirow{2}{*}{$\begin{array}{c}\quad \mathrm{Th}_{\text {tot }} \\
>\text { frequiência }\left({ }^{\circ} \mathrm{C}\right)\end{array}$} \\
\hline & & & & & VAR. & MÉDIA & & \\
\hline \multirow[t]{2}{*}{1} & a & -57.4 a -57.2 & 15.2 a 16.8 & 30 & 2 a 3 & 2.3 & 300 a 310 & 300 a 310 (H. p/ $\left.\mathrm{CO}_{2}\right)$ \\
\hline & b & -57.6 a -57.0 & 14.4 a 16.0 & 30 a 40 & 2 a 7 & 2.7 .5 .3 & 300 a 340 & $\begin{array}{l}310 \text { a } 320 \text { (H. crit. p/ } \mathrm{CO}_{2} \text { e } \mathrm{H}_{2} \mathrm{O} \text { ?) } \\
330 \text { a } 340\end{array}$ \\
\hline \multirow{3}{*}{2} & a & -57.6 a -56.6 & 18.4 a 22.4 & 20 a 30 & la 7 & 3.75 .7 & 270 a 310 & 280 a 290 (H. p $\left.\mathrm{H}_{2} \mathrm{O}\right)$ \\
\hline & b & -58.2 a -57.0 & 19.2 a 21.6 & 30 & 4 a 6 . & $5.0 / 5.8$ & 280 a 300 & 290 a 300 (H. p/ $\mathrm{H}_{2} \mathrm{O}$ e p $\left./ \mathrm{CO}_{2}\right)$ \\
\hline & $\mathrm{c}$ & -58.4 a -58.0 & 19.2 a 21.6 & 30 & 4 a 6 & $4.5 / 4.9$ & 270 a 300 & 270 a 280 (H. p/ $\mathrm{H}_{2} \mathrm{O}$ ) \\
\hline
\end{tabular}

TABELA 27 - Parâmetros calculados das inclusões fluidas dos topázios da jazida de Caxambu. a partir dos dados da Tabela 26.

\begin{tabular}{|c|c|c|c|c|c|c|c|c|}
\hline \multirow{2}{*}{ GR } & \multirow{2}{*}{$\mathrm{T}$} & \multirow[t]{2}{*}{$\begin{array}{c}\mathrm{d}_{\mathrm{CO} 2} \\
\left(\mathrm{~g} / \mathrm{cm}^{3}\right)\end{array}$} & \multirow[t]{2}{*}{$\begin{array}{c}\mathrm{d}_{\mathrm{II2O}} \\
\left(\mathrm{g} / \mathrm{cm}^{3}\right)\end{array}$} & \multirow[t]{2}{*}{$\begin{array}{c}\mathrm{d}_{\text {tot }} \\
\left(\mathrm{g} / \mathrm{cm}^{3}\right)\end{array}$} & \multirow{2}{*}{$\begin{array}{c}\text { salinidade } \\
\text { eq. } \% \text { peso } \\
\text { de } \mathrm{NaCl}\end{array}$} & \multicolumn{3}{|c|}{ composição } \\
\hline & & & & & & $\mathrm{X}_{\mathrm{H} 2 \mathrm{O}}$ & $\mathrm{X}_{\mathrm{NaCl}}$ & $\mathrm{x}_{\mathrm{CO} 2}$ \\
\hline \multirow[t]{2}{*}{1} & a & 0,8123 & 1,0902 & 1,0068 & 12,89 & 0,8370 & 0,0382 & 0,1248 \\
\hline & b & 0,8203 & 1,0763 & 0,9649 a 1,0062 & 8,61 a 12,37 & 0,7844 a 0,8489 & 0,0230 a 0,0365 & 0,1837 a 0,1254 \\
\hline \multirow{3}{*}{2} & a & 0,7704 & 1,0636 & 0,9689 a 1,0142 & 7,97 a 11,01 & 0,8490 a 0,9011 & 0,0229 a 0.0341 & 0,1201 a 0,0727 \\
\hline & b & 0,7696 & 1,0583 & 0,9681 a 0,9756 & 7,81 a 9,08 & 0,8541 a 0,8584 & 0,0224 a 0,0263 & 0,1196 a 0,1181 \\
\hline & c & 0,7731 & 1,0652 & 0,9769 a 0.9783 & 9,27 a 9,84 & 0,8528 a 0,8529 & $(0,0268$ a (), ()287 & 0,1205 a 0,1184 \\
\hline
\end{tabular}

TABELA 28 - Dados obtidos das inclusões fluidas presentes nos topázios da jazida de Boa Vista. As temperaturas representam as várias mudanças de fases analisadas sob processos microtermométricos.

\begin{tabular}{|c|c|c|c|c|c|c|c|c|}
\hline \multirow[t]{2}{*}{ GR } & \multirow{2}{*}{$\begin{array}{c}\mathrm{Tf}_{\mathrm{CO}_{2}} \\
\left({ }^{\circ} \mathrm{C}\right)\end{array}$} & \multirow{2}{*}{$\begin{array}{c}\mathrm{Th}_{\mathrm{CO} 2} \\
>\text { freq. }\left({ }^{\circ} \mathrm{C}\right)\end{array}$} & \multirow[t]{2}{*}{$\mathrm{V}$} & \multicolumn{2}{|c|}{$\mathrm{Tf}_{\mathrm{cl}}\left({ }^{\circ} \mathrm{C}\right)$} & \multirow{2}{*}{$\begin{array}{l}\mathrm{Tf}_{\mathrm{g}} \\
\left({ }^{\circ} \mathrm{C}\right)\end{array}$} & \multirow{2}{*}{$\begin{array}{l}\mathrm{Th}_{\text {tot }} \\
\left({ }^{\circ} \mathrm{C}\right)\end{array}$} & \multirow{2}{*}{$\begin{array}{c}\mathrm{Th}_{\text {tot }} \\
>\text { freq. }\left({ }^{\circ} \mathrm{C}\right)\end{array}$} \\
\hline & & & & VAR. & $>$ freq. & & & \\
\hline 1 & $-57,4$ a $-56,8$ & -5.2 a -3.6 & 70 a 90 & 5 a9 & 7 a 9 & - & 200 a 280 & 230 a 260 \\
\hline 2 & $-57,8$ a -57.0 & $-2,8$ a $-1,2$ & 50 a 80 & 6 a 9 & 7 a 9 & - & 180 a 300 & 240 a 280 \\
\hline 3 & -57.4 a -57.0 & 26.8 a 28.4 & 20 & - & - & $-10 /-8$ & $>300$ & - \\
\hline
\end{tabular}


TABELA 29 - Parâmetros calculados das inclusões fluidas dos topázios da jazida de Boa Vista. a partir dos dados da Tabela 28.

\begin{tabular}{|c|c|c|c|c|c|c|c|}
\hline \multirow[t]{2}{*}{$G R$} & \multirow{2}{*}{$\begin{array}{c}1 \mathrm{CO} \\
\left(\mathrm{g} / \mathrm{cm}^{3}\right)\end{array}$} & \multirow{2}{*}{$\begin{array}{c}\mathrm{d}_{1 \mathrm{12O} O} \\
\left(\mathrm{~g} / \mathrm{cm}^{3}\right)\end{array}$} & \multirow{2}{*}{$\begin{array}{c}d_{\mathrm{tot}} \\
\left(\mathrm{g} / \mathrm{cm}^{3}\right)\end{array}$} & \multirow{2}{*}{$\begin{array}{l}\text { salin eq \% } \\
\text { peso NaC. }\end{array}$} & \multicolumn{3}{|c|}{ composiçāo } \\
\hline & & & & & $\mathrm{x}_{\mathrm{H} 2 \mathrm{O}}$ & $\mathrm{x}_{\mathrm{NaCl}}$ & $\mathrm{x}_{\mathrm{CO} 2}$ \\
\hline 1 & $0,9507 i 0.9541$ & $1,0247 / 1,0313$ & 0,9608 a 0,9765 & 4.2 a 7,6 & 0,2181 a 0.5163 & 0,0034 a 0,00 & 810.7785 a 0.4766 \\
\hline 2 & $0,93580.9416$ & $1,0313 / 1,0377$ & 0,9560 a 0.9882 & 3,8 a 7,2 & 0.3869 a 0.7105 & $0.0061 a 0.01$ & 340.6068 a 0.2777 \\
\hline 3 & 0.6675 & 1.0890 & 1.0047 & 11,6 a 14,0 & 0,8953 & 0.0407 & 0.0646 \\
\hline
\end{tabular}

\subsubsection{1 - TEMPERATURA DE FUSÃO DO CO2 ( $\left.\mathrm{Tf}_{\mathrm{CO} 2}\right)$}

As $\mathrm{Tf}_{\mathrm{CO} 2}$ dos vários tipos de inclusões, presentes nos diferentes grupos de amostras das jazidas estudadas, encontram-se representaáas na $\ddot{T}$ igura 38 (a, o e c) e nas Taveias $2 \hat{4}$, 26 e 28. Os intervalos de temperatura obtidos para as jazidas de Capão do Lana, Caxambu e Boa Vista foram, respectivamente, de $-58,2$ a $-56,6^{\circ} \mathrm{C}$; de $-58,4$ a $-56,6^{\circ} \mathrm{C}$ e de $-57,8$ a $-56,8^{\circ} \mathrm{C}$. Também foram obtidos alguns valores referentes a outra jazida da região de Dom Bosco que variaram de $-57,8$ a $-57,2^{\circ} \mathrm{C}$. Observa-se que esses valores são, muitas vezes, inferiores a $-56,6^{\circ} \mathrm{C}$, referente ao ponto triplo do $\mathrm{CO}_{2}$ puro, indicando a presença de outros componentes voláteis, em quantidades subordinadas, dissolvidos na fase carbônica. Como essas substâncias não puderam ser detectadas por microtermometria, foram necessários outros métodos de análises, tais como a espectroscopia de absorção no infravermelho e a espectroscopia micro Raman (Moenke 1966, Farmer 1974, Gadsden 1975).

Através das Tabelas 24, e 26, observa-se que, em Capão do Lana e Caxambu, existem certas diferenças nos valores de $\mathrm{Tf}_{\mathrm{CO} 2}$ em inclusões de um dado tipo pertencentes a amostras distintas e, às vezes, mesmo em uma única amostra. Em Boa Vista também observaram-se essas variações, embora as inclusões fluidas não tenham sido subdivididas em tipos distintos, uma vez que foi constatado que estes se comportam de modo semelhante dentro de cada grupo (Tabela 28). Esses dados sugerem que devem ter ocorrido modificações locais na composição do fluido mineralizante. 


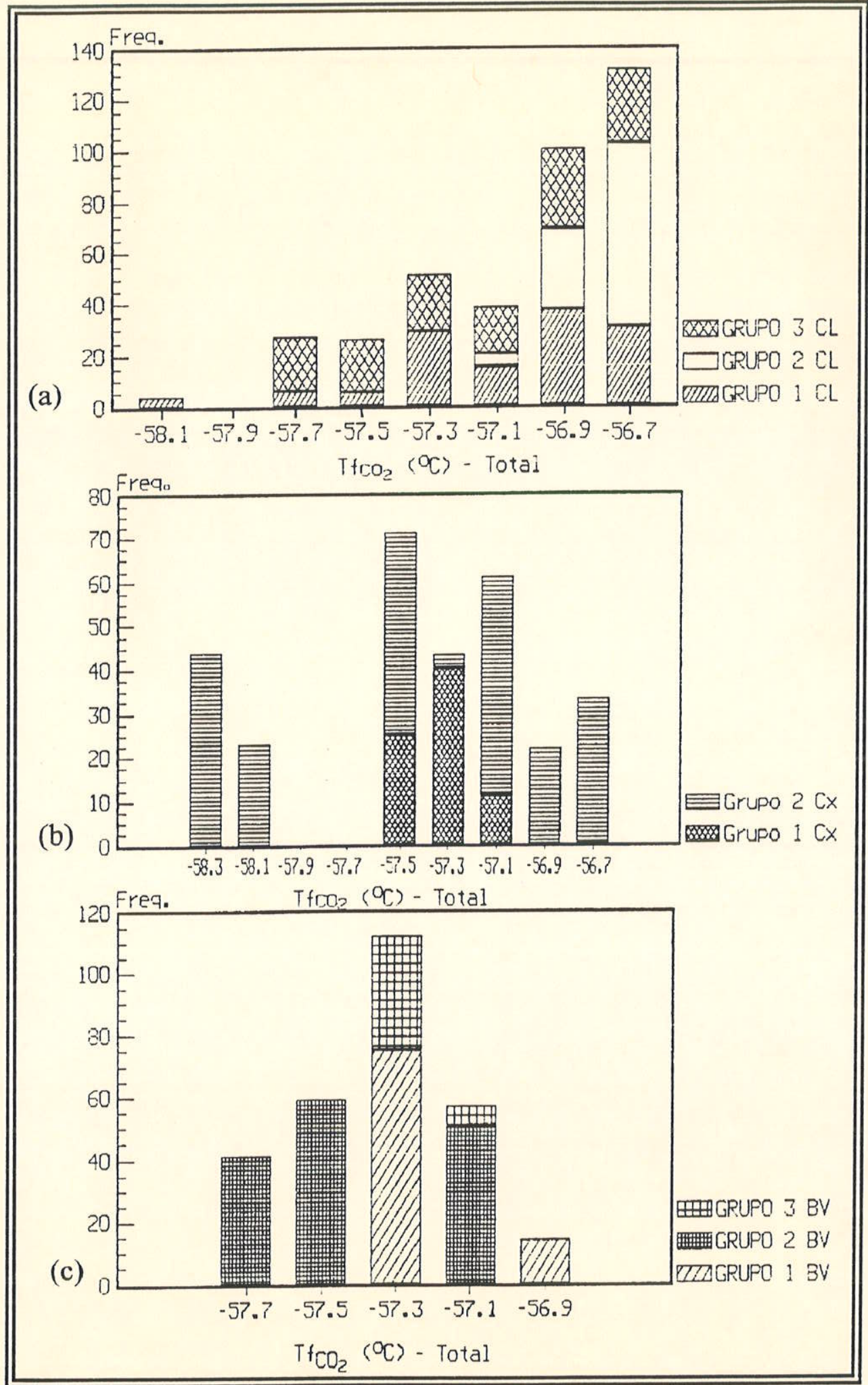

FIGURA 38 - Histogramas de frequiências de medidas das temperaturas de fusão de $\mathrm{CO}_{2}\left(\mathrm{Tf}_{\mathrm{CO}_{2}}\right)$, de inclusões fluidas presentes nos topázios das jazidas do Capão do Lana (a), de Caxambu (b) e de Boa Vista (c). Nos três casos, as $\mathrm{Tf}_{\mathrm{CO} 2}$ são menores do que $-56,6^{\circ} \mathrm{C}$, ponto triplo do $\mathrm{CO}_{2}$ puro. indicando a presença de outros componentes voláteis, dissolvidos na fase carbônica, em quantidades subordinadas. Os respectivos grupos foram divididos em função das $\mathrm{Th}_{\mathrm{CO} 2}$ (ver Figuras 44,45 e 46). 
Nos casos onde a temperatura de fusão do $\mathrm{CO}_{2}$ mostrou valores menores que $-56,6^{\circ} \mathrm{C}$, a espectroscopia no infravermelho foi utilizada para a determinação dos constituintes dissolvidos na fase carbônica (Gandini et al. 1991, Gandini et al. 1993). Os espectros obtidos em uma jazida da região de Dom Bosco encontram-se na Figura 39, na qual observa-se que além das bandas de absorção do próprio topázio, compreendidas no intervalo entre 1.300 e $200 \mathrm{~cm}^{-1}$, existem outras, referentes às várias substâncias químicas presentes nas inclusões fluidas. Essas análises confirmaram a presença das bandas de absorção de 3.420 e $1.630 \mathrm{~cm}^{-1}$, relativas, respectivamente, ao estiramento e deformação da água de absorção, e as de 2.340 e $2.325 \mathrm{~cm}^{-1}$ do gás carbônico. Além dessas, estão presentes, em alguns casos, as bandas de absorção de 2.860 e $2.930 \mathrm{~cm}^{-1}$, indicadoras da presença de hidrocarboneto e a de $1.390 \mathrm{~cm}^{-1}$, provavelmente, indicadora de boro. Foram observadas variações nas proporções dos componentes, principalmente dos hidrocarbonetos, em inclusões fluidas de diferentes cristais, mesmo em uma única lavra, como no caso da região de Dom Bosco, o que também é indicativo de variações locais nas composições das inclusões. A banda de absorção de $3.660 \mathrm{~cm}^{-1}$, estiramento do $\mathrm{OH}^{-}$, mostra uma grande absorvância indicando uma intensa substituição do $\mathrm{OH}^{-}$pelo $\mathrm{F}^{-}$, o que também é comprovado através de análises feitas com microssonda eletrônica, eletrodo de íon específico e perda ao fogo que mostram um alto teor de flúor para os topázios estudados.

Como existem várias substâncias que não podem ser detectadas por espectroscopia de absorção ao infravermelho, por exemplo, o nitrogênio $\left(\mathrm{N}_{2}\right)$ e, sendo esta passível de estar presente na fase fluida, recorreu-se, numa última etapa, à espectroscopia micro Raman, realizada apenas para a jazida do Capão do Lana. Este método foi empregado apenas na fase carbônica das inclusões fluidas. Analogamente à espectroscopia no infravermelho, existem picos referentes ao mineral e aos componentes fluidos. Nos espectros obtidos por essa última técnica, a $\mathrm{H}_{2} \mathrm{O}$ e o $\mathrm{CO}_{2}$ foram mais uma vez confirmados além de ter sido detectada a presença do $\mathrm{N}_{2}$, revelada pelo pico de absorção de $2.327,5 \mathrm{~cm}^{-1}$ (Gandini et al. 1992a, Gandini et al. 1993) (Figura 40).

\subsubsection{2 - TEMPERATURA DE FUSÃO DOS CLATRATOS (Tf $\left.\mathrm{fl}_{\mathrm{cl}}\right)$}

A salinidade das soluções aquosas das inclusões fluidas de amostras da maioria das jazidas, foi determinada a partir das temperaturas de fusão dos clatratos $\left(\mathrm{Tf}_{\mathrm{cl}}\right)$, uma vez que esses compostos foram quase sempre desenvolvidos no processo de resfriamento, encontrando-se em equilíbrio com as fases $\mathrm{CO}_{2}(\mathrm{l}), \mathrm{CO}_{2}(\mathrm{~g})$ e solução aquosa no momento em que ocorre o seu desaparecimento. Esta é a condição necessária, segundo Collins (1979), para a determinação da porcentagem em peso do $\mathrm{NaCl}$. Na grande maioria dessas inclusões, a visualização dos clatratos 


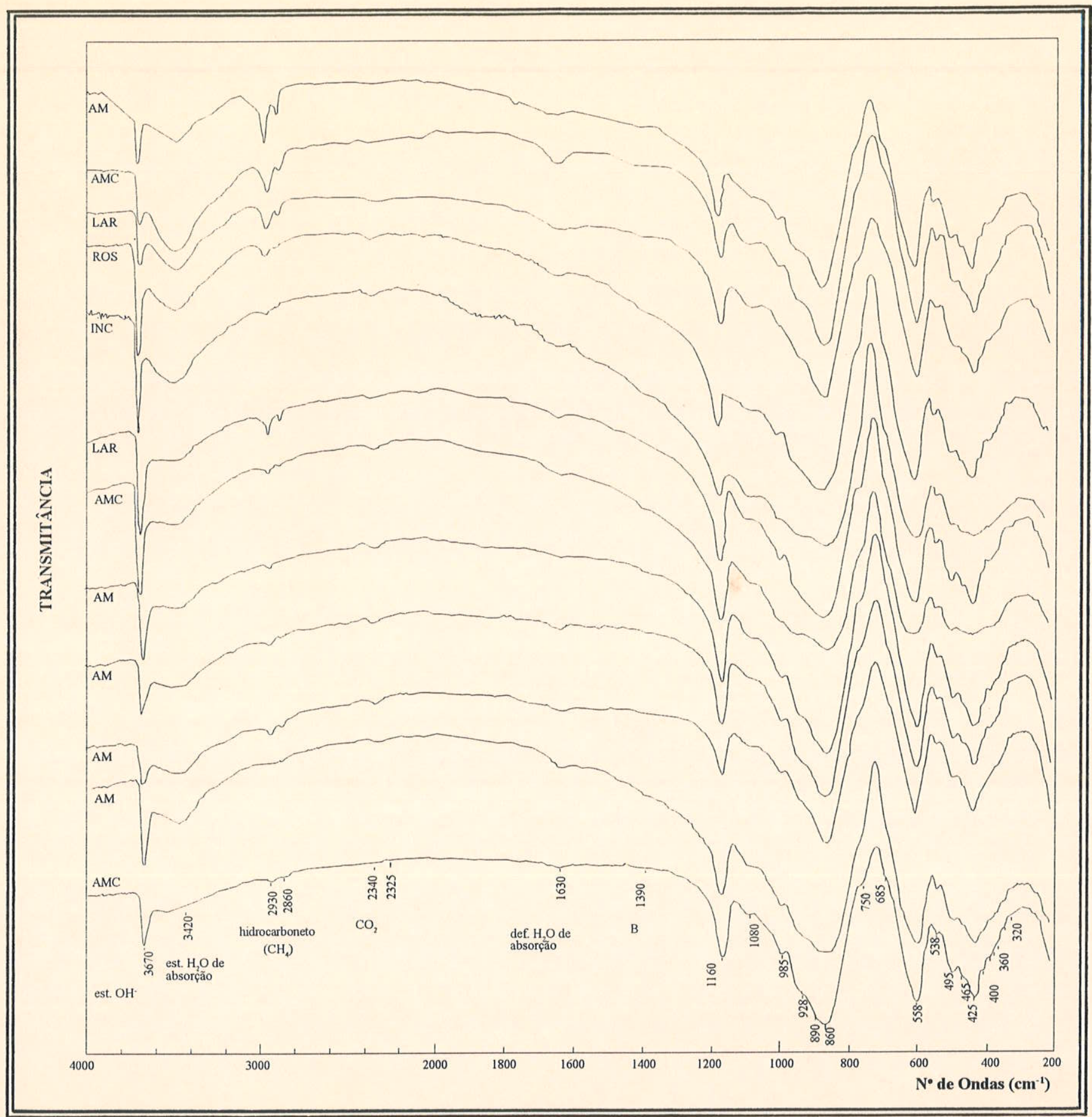

FIGURA 39 - Espectros de absorção no infravermelho de topázio de colorações diversas da região de Dom Bosco. Destacam-se as bandas de absorção 3.420 e $1.630 \mathrm{~cm}^{-1}$ de estiramento e deformação, respectivamente, da água de absorção; as de 2.340 e $2.325 \mathrm{~cm}^{-1}$ do gás carbônico; a de $3.670 \mathrm{~cm}^{-1}$ de estiramento do $\mathrm{OH}^{-}$; as de 2.930 e $2.860 \mathrm{~cm}^{-1}$ do hidrocarboneto, provavelmente a do $\mathrm{CH}_{4}$, e a de $1.390 \mathrm{~cm}^{-1}$ do boro. No trecho compreendido entre 1.300 e $200 \mathrm{~cm}^{-1}$ aparecem as bandas de absorção do topázio hospedeiro. Os cinco primeiros espectros são referentes aos cristais estudados pela microssonda eletrônica.

$\mathrm{AMC}=$ Amarelo claro; $\mathrm{AM}=$ amarelo, $\mathrm{LAR}=$ laranja $\mathrm{INC}=$ incolor; $\mathrm{ROS}=$ rosa . 
foi bem nítida, marcada por uma forte deformação da bolha de gás, após a completa fusão do gelo; algumas vezes, no entanto, ocorreram apenas modificações sutis no contorno das bolhas, dificultando a observação desses compostos. Para os cristais de topázio estudados, não foi observada a presença de minerais de saturação, os quais também poderiam influenciar na determinação da salinidade.

A partir das medidas das $\mathrm{Tf}_{\mathrm{cl}}$, verificou-se que a sua variação é relativamente pequena, sendo essas temperaturas, muitas vezes, semelhantes nas inclusões de todos os tipos observados em cada grupo de amostras das jazidas de Capão do Lana e de Caxambu, como mostram as Tabelas 24 e 26. Portanto, para a confecção dos histogramas de frequência de medidas, apresentado na Figura 41, as $\mathrm{Tf}_{\mathrm{cl}}$ dos diversos tipos de inclusões foram englobadas em cada grupo de amostras; o mesmo foi considerado na Tabela 28 , referente à ocorrência de Boa Vista.

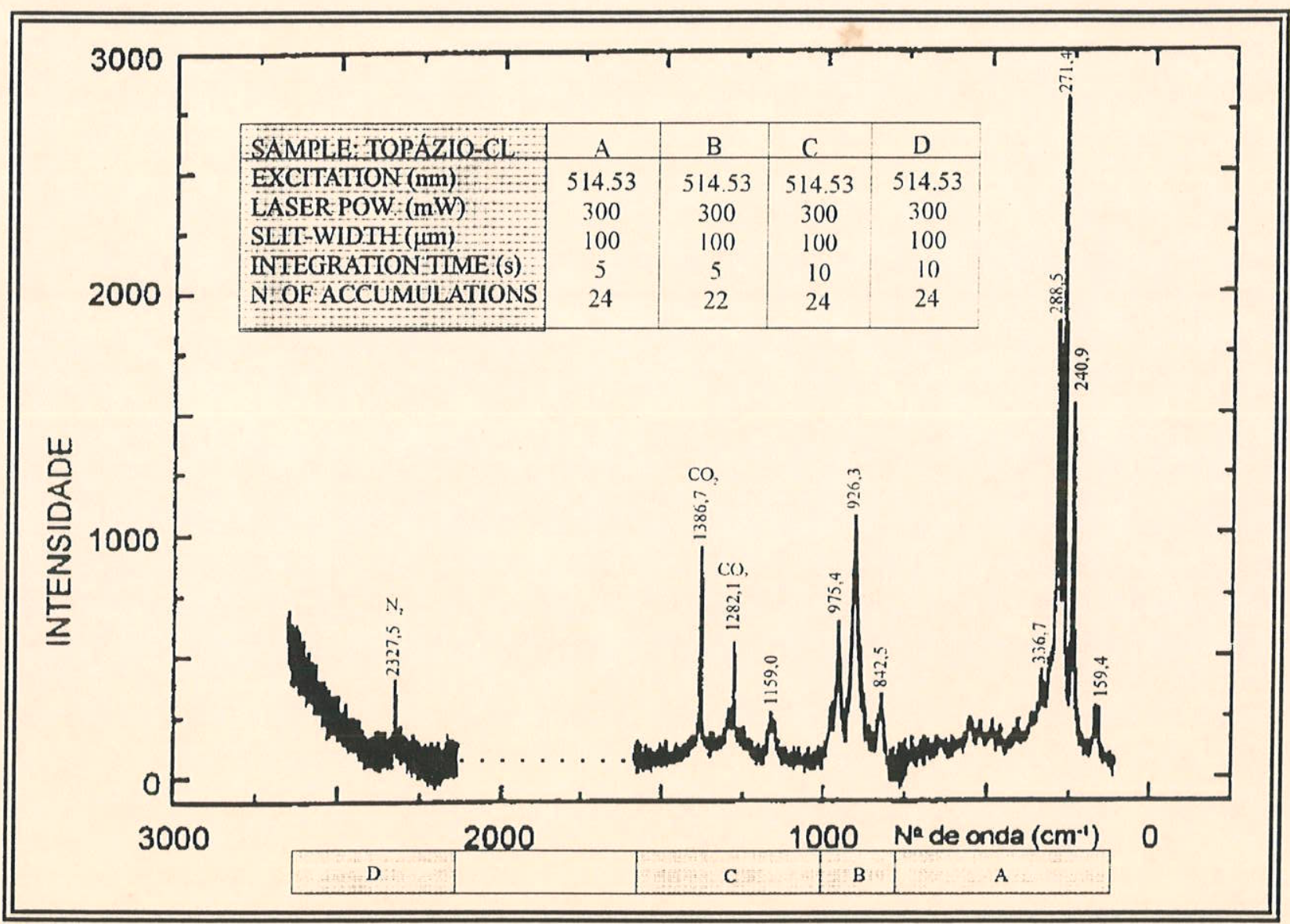

FIGURA 40 - Montagem de quatro espectros micro Raman. mostrando os vários picos de absorção do topázio $\left(1.200\right.$ a $\left.100 \mathrm{~cm}^{-1}\right)$, destacando-se os picos correspondentes ao $\mathrm{CO}_{2}$ em $1.282,1$ e $1.386 .7 \mathrm{~cm}^{-1}$ e ao $\mathrm{N}_{2}$ em $2.327,5 \mathrm{~cm}^{-1}$, presentes numa inclusão fluida de um topázio da jazida do Capão do Lana. No espaço entre C e D, não apareceu nenhum pico. 


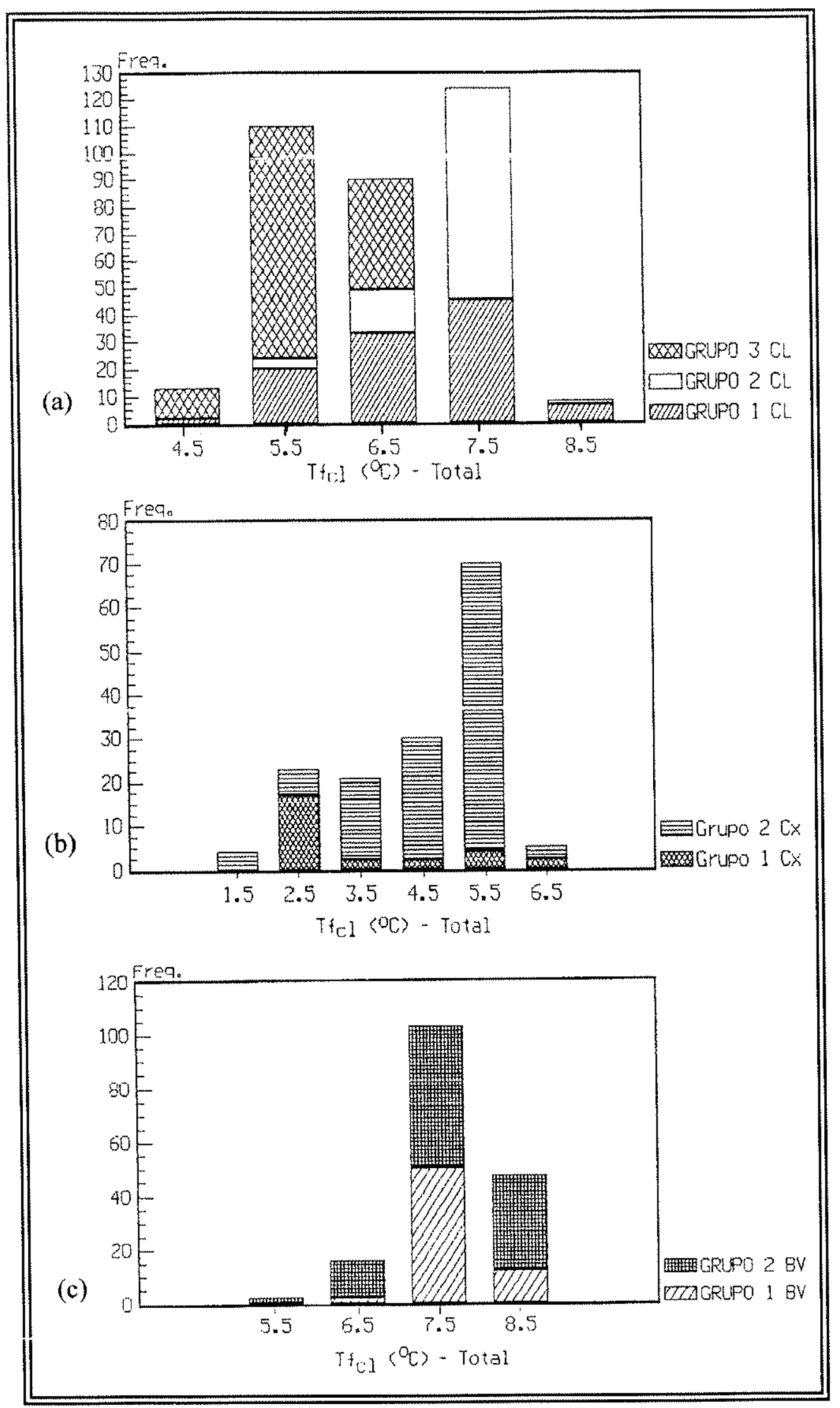

FIGURA 41 - Histogramas de frequiuencias de medidas das temperaturas de fusão dos clatratos $\left(\mathrm{Tf}_{\mathrm{cl}}\right)$, de inclusões fluidas presentes nos topázios das jazidas do Capão do Lana (a), de Caxambu (b) e de Boa Vista (c). 
As variações de salinidade das soluções aquosas (Tabelas 25 e 27) foram obtidas considerando-se apenas os picos de maior freqüência das $\mathrm{Tf}_{\mathrm{cl}}$ de cada grupo, juntamente com o diagrama da Figura 42 discutido por Collins (1979). No caso da jazida de Capão do Lana, foram considerados os seguintes valores: $\mathrm{GR} 1-\mathrm{CL}$ - para as $\mathrm{Tf}_{\mathrm{cl}}$ mais freqüentes entre 5,0 e $8,0^{\circ} \mathrm{C}$, as salinidades são equivalentes a $9,0-4,0 \%$ em peso de $\mathrm{NaCl}$; GR2-CL - para as $\mathrm{Tf}_{\mathrm{cl}}$ mais freqüentes entre 6,0 e $8,0^{\circ} \mathrm{C}$, as salinidades são equivalentes a $7,5-4,0 \%$ em peso de $\mathrm{NaCl}$ e para o GR3-CL, as $\mathrm{Tf}_{\mathrm{cl}}$ mais freqüentes encontram-se entre 5,0 e $7,0^{\circ} \mathrm{C}$, sendo as salinidades equivalentes a 9,0 - 6,0\% em peso de $\mathrm{NaCl}$. Para Caxambu, as variações mais freqüentes das $\mathrm{Tf}_{\mathrm{cl}}$ e as respectivas salinidades são: $\mathrm{GR} 1-\mathrm{Cx}-\mathrm{Tf}_{\mathrm{cl}}$ entre 2,0 e $3,0^{\circ} \mathrm{C}$, com salinidade equivalente a 13,3-12,0\% em peso do $\mathrm{NaCl}$, aproximadamente, e GR2-Cx $-\mathrm{Tf}_{\mathrm{cl}}$ entre 4 e $6^{\circ} \mathrm{C}$ com salinidades equivalentes a 10,3 a 7,6\% em peso do $\mathrm{NaCl}$. As variações gerais de salinidade para as jazidas do Capão do Lana e de Caxambu, estão representadas na Figura 42. Algumas medidas de $\mathrm{Tf}_{\mathrm{cl}}$, em inclusões de topázio de uma outra jazida da região de Dom Bosco, forneceram valores variando entre 2 e $6^{\circ} \mathrm{C}$, indicativos de salinidades situadas na faixa equivalente a 13,3 a $7,5 \%$ do $\mathrm{NaCl}$.

No caso de Boa Vista, a salinidade das inclusões não pôde ser determinada diretamente por meio das $\mathrm{Tf}_{\mathrm{cl}}$ da maneira discutida por Collins (1979), pois, durante a etapa de aquecimento natural da amostra, após o congelamento do fluido, a decomposição dos clatratos ocorre em temperaturas mais elevadas que as de homogeneização do $\mathrm{CO}_{2}$ para o estado líquido, ou seja, na presença apenas das fases $\mathrm{H}_{2} \mathrm{O}(\mathrm{l})$ e $\mathrm{CO}_{2}(\mathrm{l})$. Diamond (1992), a partir de trabalhos experimentais, apresenta um método para a determinação das salinidades em inclusões contendo $\mathrm{CO}_{2}$, nas quais os clatratos se dissociam em equilíbrio com $\mathrm{CO}_{2}(\mathrm{l})+$ soluções aquosas ou $\mathrm{CO}_{2}(\mathrm{~g})+$ soluções aquosas. Esse método é na realidade uma expansão do apresentado por Collins (1979), no qual é necessário, para a obtenção da salinidade, a coexistência das fases $\mathrm{CO}_{2}(\mathrm{l})+\mathrm{CO}_{2}(\mathrm{~g})+$ solução aquosa + clatratos. Para a aplicação desse método é necessária a determinação das $\mathrm{Tf}_{\mathrm{cl}}$ e das $\mathrm{Th}_{\mathrm{CO} 2}$ reais e, a partir de diagramas experimentais apresentados pelo autor, determinar diretamente a salinidade das soluções. Deve ser observado que as $\mathrm{Th}_{\mathrm{CO}_{2}}$ medidas na presença de clatratos, não representam valores reais, uma vez que o volume ocupado pelos sólidos altera a pressão interna das inclusões fluidas, mascarando, portanto, as densidades. No entanto, essas temperaturas podem ser obtidas em condições de ausência metaestável de clatratos, que podem ser atingidas resfriando-se as inclusões apenas até o ponto onde é nucleada a fase $\mathrm{CO}_{2}(\mathrm{~g})$, o que ocorre, em muitos casos, antes da formação desses hidratos. Nas inclusões fluidas da jazida de Boa Vista, as condições discutidas por Diamond (1992) podem ser alcançadas uma vez que as temperaturas de nucleação dos clatratos, durante o resfriamento $\left(-35\right.$ a $\left.-45^{\circ} \mathrm{C}\right)$, são inferiores às da nucleação do $\mathrm{CO}_{2}(\mathrm{~g})\left(-9,0\right.$ a $\left.-15,0^{\circ} \mathrm{C}\right)$. Desse modo foram determinados os valores de $\mathrm{Th}_{\mathrm{CO} 2}$ reais para os distintos grupos de inclusões presentes, os quais encontram-se discutidos no tópico seguinte. 


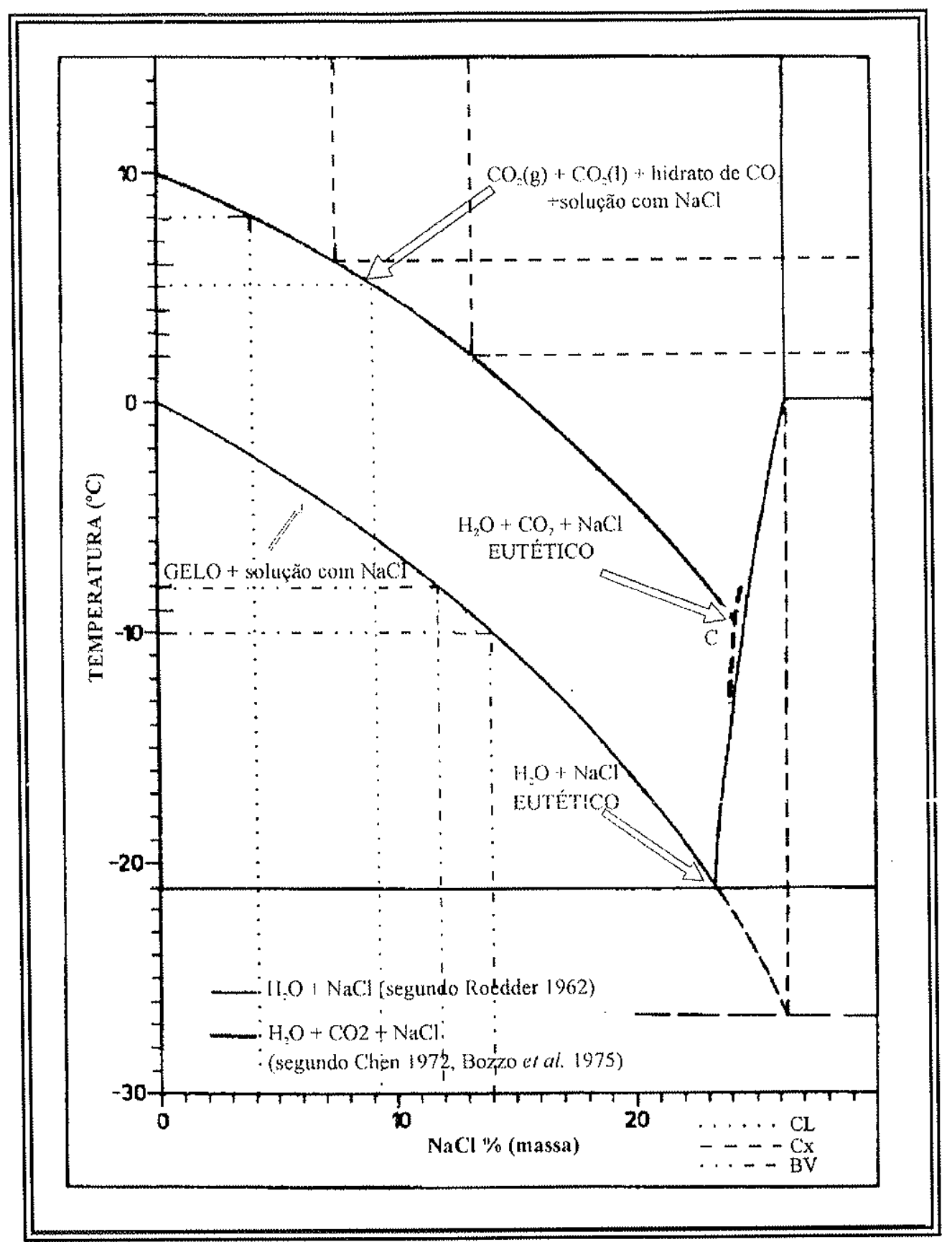

FIGURA 42 - Diagrama extraído de Collins (1979), mostrando as faixas de salinidades para as inclusões fuidas dos topázios das jazidas do Capão do Lana e de Caxambu, bem como para o grupo três da jazida de Boa Vista.

Utilizando-se os dados obtidos para $\mathrm{Tf}_{\mathrm{cl}}$ e $\mathrm{Th}_{\mathrm{CO}_{2}}$ reais dessas inclusões no diagrama da Figura 43 de Diamond (1992), foram determinadas as seguintes faixas de variação de salinidades: GR1-BV para os valores mais frequentes de $\mathrm{T}_{\mathrm{i}}^{\mathrm{Cl}}$ entre 7 e $9^{\circ} \mathrm{C}$ e de $\mathrm{Th}_{\mathrm{CO}}$ entre $-5,2 \mathrm{C}-3,6^{\circ} \mathrm{C}$, as salinidades são equivalentes à faixa de 4,2 a $7,6 \%$ em peso do $\mathrm{NaCl}$ aproximadamente; GR2-BV - os valores mais freqüuntes de $\mathrm{Tf}_{\mathrm{cl}}$ entre 7 e $9^{\circ} \mathrm{C}$ e de $\mathrm{Th}_{\mathrm{CO}_{2}}$ entre $-2,8$ e $-1,2^{\circ} \mathrm{C}$, conduziram a salinidades equivalentes ao intervalo de 3,8 a $7,2 \%$ em peso do $\mathrm{NaCl}$, aproximadamente. As inclusões do GR3-BV 
apresentaram comportamento distinto, uma vez que não houve a formação de clatratos e, por isso, suas salinidades foram determinadas a partir das $\mathrm{Tf}_{\mathrm{g}}$. Os valores mais freqüentes obtidos para as $\mathrm{Tf}_{\mathrm{g}}$ dessas inclusões situaram-se entre $-10,0$ e $-8,0^{\circ} \mathrm{C}$, indicando salinidades equivalentes ao intervalo de 11,6 a $14 \%$ em peso do $\mathrm{NaCl}$, aproximadamente (Figura 42).

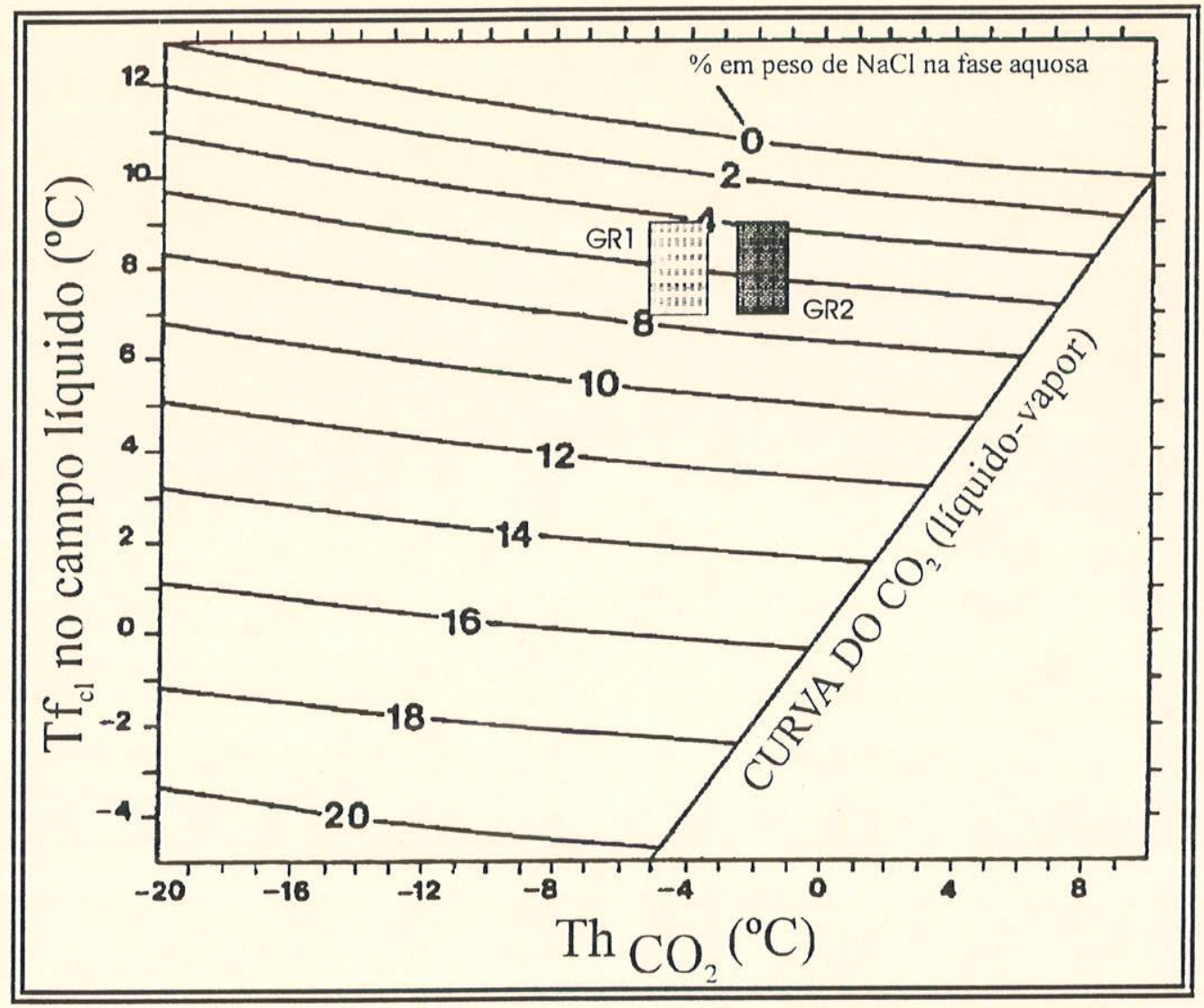

FIGURA 43 - Diagrama extraído de Diamond (1992), mostrando as faixas de salinidades para as inclusões fluidas, dos grupos 1 e 2, presentes nos topázios da jazida de Boa Vista.

À ausência da nucleação de clatratos com o resfriamento ocorre nos casos em que as inclusões possuem pressões internas de $\mathrm{CO}_{2}$ menores que $10,4 \mathrm{bar}$, à temperatura ambiente, o que corresponde a um conteúdo de cerca de $1,5 \mathrm{~mol} \%$ de $\mathrm{CO}_{2}$, como discutido em Roedder (1963), Hedenquist \& Henley (1985) e Diamond (1992), entre outros.

Na Tabela 30, referente à jazida de Capão do Lana, onde as salinidades são tratadas de modo mais detalhado, por tipos de inclusões e por grupos, são observadas pequenas variações nesses valores, as quais podem, mais uma vez, sugerir a existência de modificações locais nas composições das soluções. O mesmo parece ocorrer em Caxambu e Boa Vista, como pode ser observado nas Tabelas 27 e 29. 
TABELA 30 - Variação da salinidade em equivalente da porcentagem em peso de $\mathrm{NaCl}$ por tipos de inclusões e por grupos, referentes às inclusões fluidas dos topázios da jazida do Capão do Lana.

\begin{tabular}{|c|c|c|c|c|c|}
\hline & tipo a & tipo b & tipo c & tipo d & variaçăo \\
\hline GR tPPo ! & 7.0 & 5.2 & 4.9 & 6.2 & 1,9 a 7.0 \\
\hline GRUPO 2 & 5.9 & 6.1 & 5.8 & 5.2 & 5.2 a 6.1 \\
\hline GRUPO 3 & 7,4 & 7.8 & 7.5 & 8.5 & 7.4 a 8.5 \\
\hline variaçăo & 5,9 a 7.4 & 5.2 a 7.8 & 4,9 a 7.5 & 5.2 a 8.5 & \\
\hline
\end{tabular}

\subsubsection{3 - TEMPERATURA DE HOMOGENEIZAÇÃO DO $\mathrm{CO}_{2}$ $\left(\mathrm{Th}_{\mathrm{CO}_{2}}\right)$}

Nas inclusões fluidas de todas as amostras estudadas, a homogeneização do $\mathrm{CO}_{2}$ ocorreu, invariavelmente, para o estado líquido. Os valores mais frequentes de $\mathrm{Th}_{\mathrm{CO}}$ foram utilizados para o cálculo das densidades desse componente, através de dados experimentais para sistemas puros, disponiveis na literatura (Roedder 1984, Nicholls \& Crawford 1985, entre outros), como será discutido posteriormente.

Os dados relativos as $\mathrm{Th}_{\mathrm{CO}_{2}}$ apresentaram um intervalo amplo de valores, cujas faixas de maiores frequêencias permitiram a caracterização de vários grupos de inclusões fluidas em amostras distintas de uma dada ocorrência, que possuem relações volumétricas $\left(\mathrm{V}_{\mathrm{CO} 2} / \mathrm{V}_{\text {tot }}\right)$, diferentes. Constatou-se assim, que inclusões fluidas pertencentes a conjuntos distintos de amostras apresentaram valores diferentes de $\mathrm{d}_{\mathrm{CO} 2}$ e de $\left(\mathrm{V}_{\mathrm{CO}_{2}} / \mathrm{V}_{\text {tot }}\right)$ (Tabelas 24, 25, 26, 27, 28 e 29), e, portanto, de $d_{\text {tot }}$, independentemente de suas dimensões, morfologias, orientações e modo de ocorrência. Em Capão do Lana e Boa Vista, os valores de $\mathrm{Th}_{\mathrm{CO} 2}$ e de $\mathrm{V}_{\mathrm{CO}_{2}} / \mathrm{V}_{\text {tot }}$ das inclusões fluidas permitiram subdividir as amostras em três grupos distintos com diferentes concentrações de $\mathrm{CO}_{2}$ (Tabelas 24 e 28), tendo sido identificados dois grupos para Caxambu (Tabela 26).

Nos histogramas apresentados nas Figuras 44 ( $a, b, c$ e d) e 45 (a, b, c) para Capão do Lana e Caxambu, respectivamente, observou-se que as inclusões dos diversos tipos mostraram o mesmo intervalo geral de variação de $\mathrm{Th}_{\mathrm{CO} 2}\left(8,0\right.$ a $23,2^{\circ} \mathrm{C}$ em Capão do Lana e 14,4 a $22,4^{\circ} \mathrm{C}$ em Caxambu), com uma certa coincidência dos valores de maior freqüência, os quais permitiram a definição dos diferentes grupos de amostras. Tanto os intervalos de maior frequência de $\mathrm{Th}_{\mathrm{CO}}$, bem como as $\mathrm{d}_{\mathrm{mCO} 2}$ obtidas a partir deles, encontram-se relacionados nas Tabelas $24,25,26$ e 27. No caso de Boa Vista, a $\mathrm{Th}_{\mathrm{CO} 2}$ variou de $-6,0$ a $+28,4^{\circ} \mathrm{C}$, tendo sido observadas regiões de maiores freqüências distintas das anteriores, definindo portanto, valores diferentes de $\mathrm{d}_{\mathrm{mCO}_{2}}$ (Figura 46 e Tabelas 28 e 29). Os valores de $\mathrm{Th}_{\mathrm{CO} 2}$, nos dois primeiros intervalos, foram determinados na ausência metaestável de clatratos, uma vez que estes se dissociam posteriormente à homogeneização do $\mathrm{CO}_{2}$, como discutido anteriormente. Na outra jazida da 
região de Dom Bosco, observou-se uma dispersão muito maior nos valores de $\mathrm{Th}_{\mathrm{CO}}$, tendo sido caracterizado, com maior precisão, apenas uma região de maior freqüência de medidas, situada entre 27,2 e $28,8^{\circ} \mathrm{C}$, com $\mathrm{d}_{\mathrm{mCO}_{2}}$ de $0,65 \mathrm{~g} / \mathrm{cm}^{3}$, num intervalo geral de $-6,8 \mathrm{a}+29,6^{\circ} \mathrm{C}$.

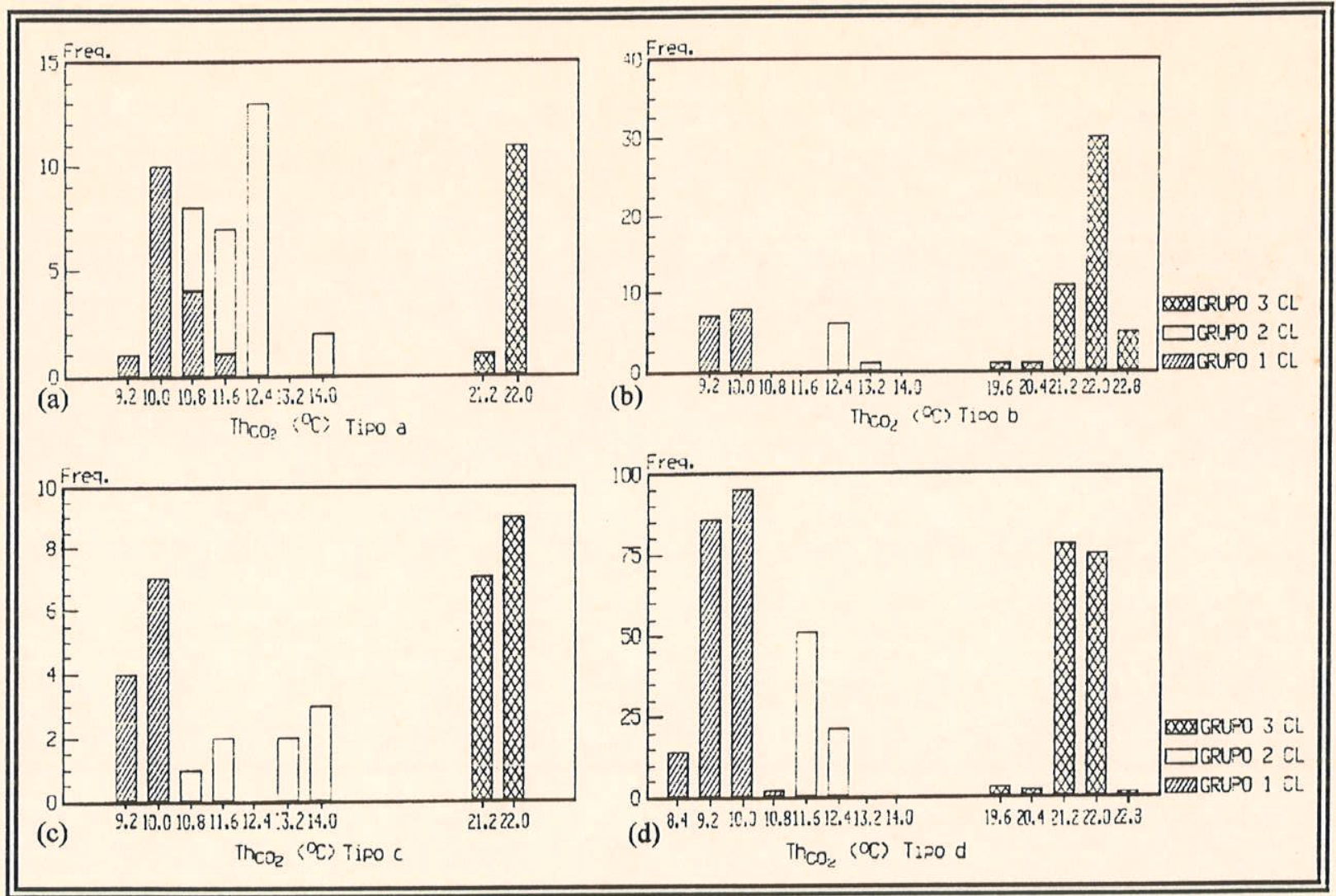

FIGURA 44 - Histogramas de frequiências de medidas das temperaturas de homogeneização do $\mathrm{CO}_{2}\left(\mathrm{Th}_{\mathrm{CO}}\right)$, de inclusões fluidas presentes nos topázios da jazida do Capão do Lana para cada tipo de inclusão. Em (a) inclusões paralelas a c; em (b), inclusões inclinadas em relação ao eixo c; em (c), inclusões dispostas aleatoriamente no interior do cristal e em (d), inclusões pertencentes a fraturas parcialmente cicatrizadas.

\subsubsection{4 - TEMPERATURA DE HOMOGENEIZAÇÃO TOTAL $\left(\mathrm{Th}_{\text {tot }}\right)$}

Os diferentes tipos de inclusões fluidas dos topázios das jazidas de Capão do Lana e Caxambu apresentaram faixas de variação de $\mathrm{Th}_{\text {tot }}$ semelhantes e, portanto, nos histogramas referentes a esse parâmetro foram considerados apenas os grupos distintos de amostras, cada qual englobando os vários tipos de inclusões fluidas. 


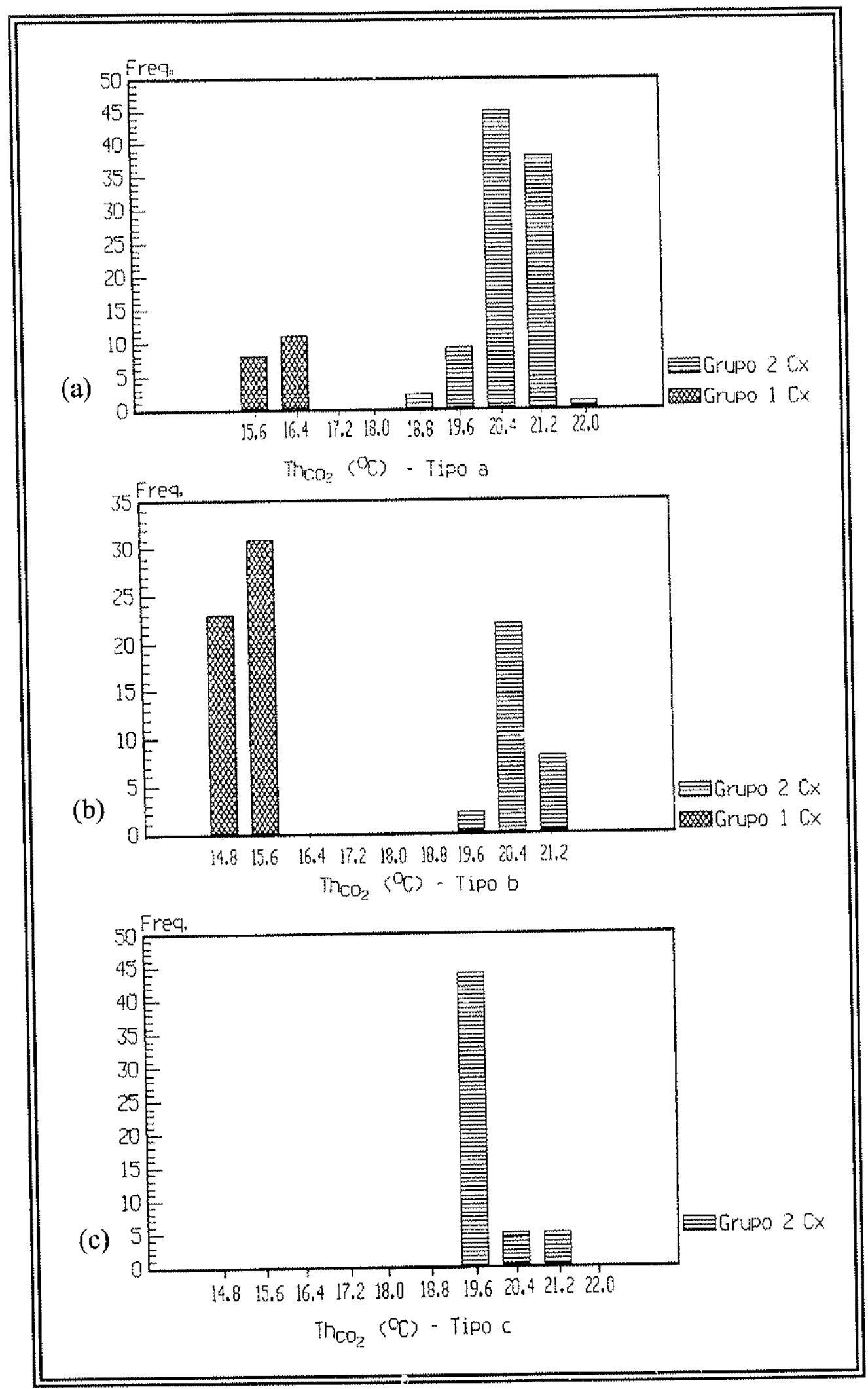

FIGURA 45 - Histogramas de frequências de medidas das temperaturas de homogeneização do $\mathrm{CO}_{2}\left(\mathrm{Th}_{\mathrm{CO}}\right)$, de inclusões fluidas presentes nos topázios da jazida de Caxambu para cada tipo de inclusão. Em (a) representam as inclusões paralelas ao eixo c; em (b), inclusões inclinadas $\mathrm{em}$ relação a c e em (c), inclusôes dispostas aleatoriamente no interior do cristal. 


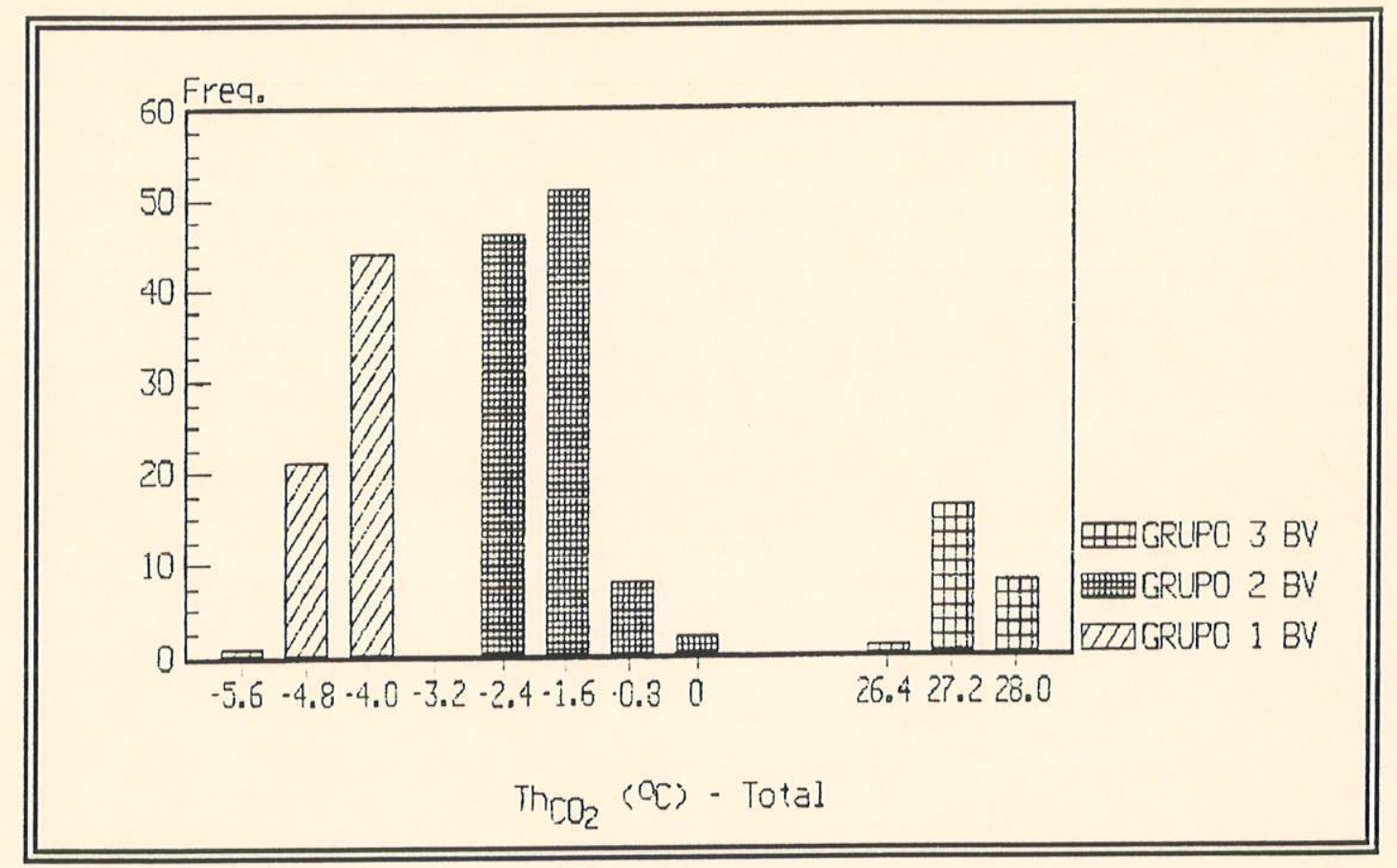

FIGURA 46 - Histograma de freqüência de medidas das temperaturas de homogeneização do $\mathrm{CO}_{2}\left(\mathrm{Th}_{\mathrm{CO}}\right)$, de inclusões fluidas presentes nos topázios da jazida de Boa Vista para todos os tipos de inclusões fluidas presentes.

Em Capão do Lana (Figura 47a), observa-se maior dispersão de medidas apenas no caso do GR1-CL, onde $\mathrm{Th}_{\text {tot }}$ varia de 230 a $320^{\circ} \mathrm{C}$, apresentando contudo um pico bem definido entre 290 e $320^{\circ} \mathrm{C}$; no GR2-CL, as $\mathrm{Th}_{\text {tot }}$ variaram de 260 a $300^{\circ} \mathrm{C}$, com maior freqüência de valores entre 290 e $300^{\circ} \mathrm{C}$ e no $\mathrm{GR} 3-\mathrm{CL}$, ocorrem variações de 270 a $300^{\circ} \mathrm{C}$. Em Caxambu (Figura 47b), no caso do GR1-Cx, as $\mathrm{Th}_{\text {tot }}$ variam de 300 a $340^{\circ} \mathrm{C}$, com maior quantidade de medidas entre 300 e $320^{\circ} \mathrm{C}$, e para o GR2-Cx ocorre uma variação geral de 270 a $310^{\circ} \mathrm{C}$, com maior freqüência entre 270 e $300^{\circ} \mathrm{C}$. Na jazida de Boa Vista as $\mathrm{Th}_{\text {tot }}$ (Figura 47c), apresentaram maiores dispersões de valores (GR1-BV : 200 a $280^{\circ} \mathrm{C}$; GR2-BV: 180 a $300^{\circ} \mathrm{C}$; GR3-BV : $>300^{\circ} \mathrm{C}$ ). Alguns desses valores podem ser decorrentes de modificações posteriores ao aprisionamento, embora no GR1 e GR2 de Boa Vista, ocorra intervalos de maior freqüência, representativos de $\mathrm{Th}_{\mathrm{tot}}$ reais. No GR3-BV foram obtidos alguns valores entre 300 e $320^{\circ} \mathrm{C}$, sendo que muitas inclusões crepitaram, próximo à sua homogeneização, nessa mesma faixa de temperatura; por isso pode ser definido apenas o valor mínimo de $\mathrm{Th}_{\text {tot }}$. Para outra jazida da região de Dom Bosco, alguns poucos valores determinados forneceram temperaturas próximas a $300^{\circ} \mathrm{C}$, porém com grande dispersão. 


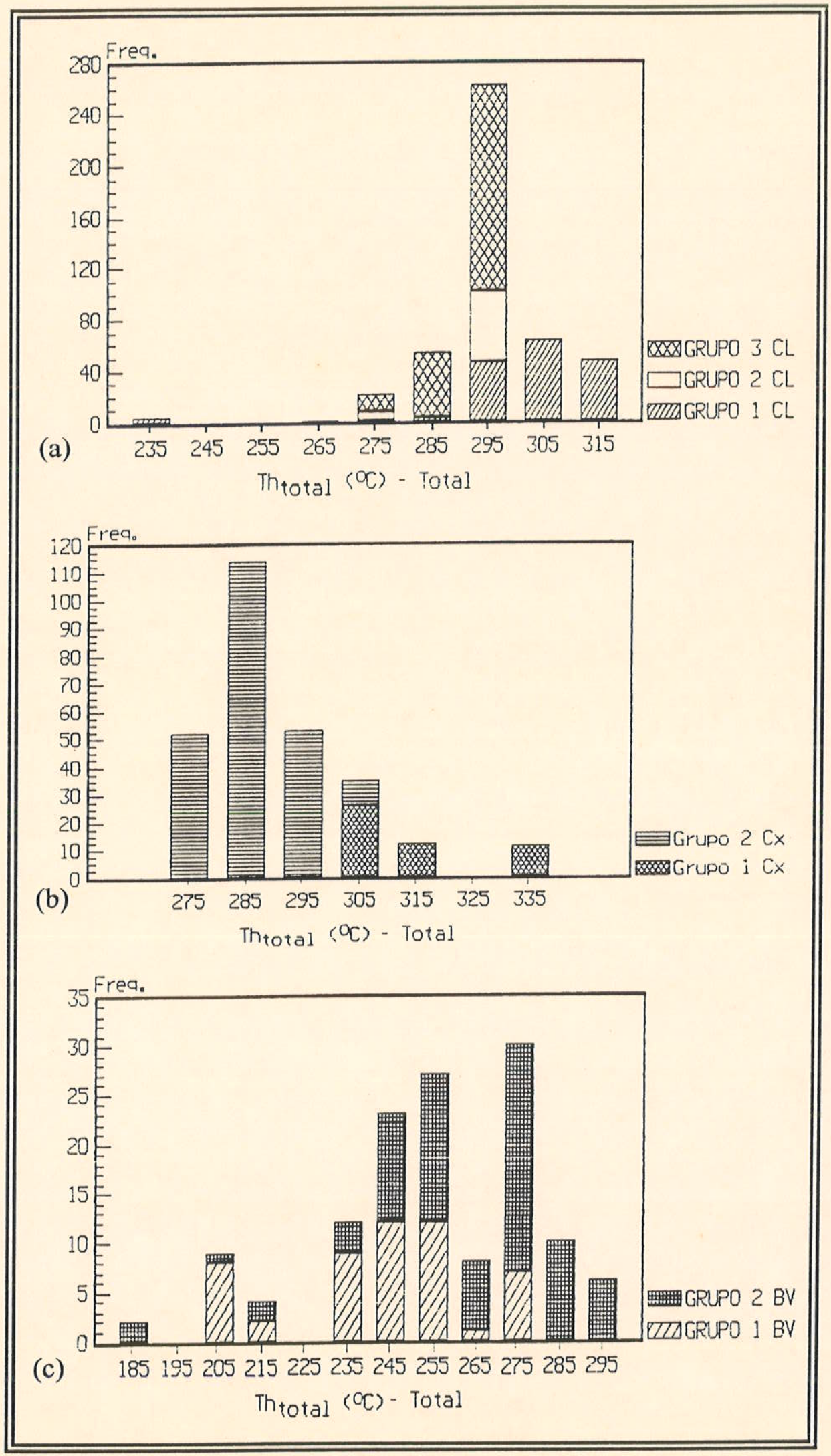

FIGURA 47 - Histogramas de frequiências de medidas das temperaturas de homogeneização total $\left(\mathrm{Th}_{\text {tot }}\right)$, dos vários grupos de inclusões fluidas presentes nos topázios das jazidas do Capão do Lana (a); de Caxambu (b) e de Boa Vista (c). No caso das medidas de Boa Vista, estas apresentaram uma maior dispersão. 
Embora, de modo geral, em Capão do Lana e Caxambu, os valores mais freqüentes de $\mathrm{Th}_{\text {tot }}$ variem dentro de intervalos estreitos e semelhantes, observa-se nos histogramas referentes às duas jazidas e nas Tabelas 24 e 26, que existem ligeiras diferenças nessas temperaturas quando são consideradas as inclusões fluidas dos diferentes grupos, e mesmo aquelas de tipos distintos dentro de um mesmo grupo.

Além dessas pequenas variações, foi observado que em cristais de um mesmo grupo, às vezes em uma única amostra, as homogeneizações ocorreram, em alguns casos, para o estado crítico, em outros, pela contração da fase $\mathrm{CO}_{2}$, havendo ainda, inclusões que se homogeneizaram pela expansão dessa fase. Embora existam essas diferenças nos tipos de homogeneização, foram observadas, em cada grupo, certas tendências definidas. Assim, para as inclusões fluidas dos topázios de Capão do Lana, no GR1-CL, a homogeneização se deu para o estado crítico e, algumas vezes, com a expansão da fase $\mathrm{CO}_{2}$; no GR2-CL, foram observados os três tipos de homogeneização e para o GR3-CL, as inclusões homogeneizaram-se predominantemente pela contração da fase $\mathrm{CO}_{2}$ e, com menor freqüência, pela sua expansão.

Em Caxambu, observou-se que inclusões fluidas de amostras do GR1-Cx homogeneizaram tanto pela expansão da fase $\mathrm{CO}_{2}$, como pela sua contração, havendo ainda, alguns poucos casos de homogeneização para o estado crítico, enquanto que nas do GR2-Cx foi apenas observada a contração da fase carbônica. Esses dados parecem sugerir que as inclusões fluidas teriam sido aprisionadas próximas ao ponto crítico, a partir de um sistema heterogêneo de fluidos (Roedder 1984). Na jazida de Boa Vista, devido ao menor número de determinações, constatou-se apenas que a homogeneização das inclusões dos GR1-BV e GR2-BV deu-se pela expansão da fase $\mathrm{CO}_{2}$, enquanto que nas do GR3-BV houve a contração dessa fase. Desse modo, se no caso dessa jazida houve aprisionamento a partir de fluidos originalmente imiscíveis, este não se deu em condições próximas ao ponto crítico.

\subsubsection{5 - DETERMINAÇÃO DOS PARÂMETROS FÍSICO- QUÍMICOS DOS FLUIDOS}

Para se calcular com maior precisão as composições, em termos das frações molares dos componentes $\left(\mathrm{X}_{\mathrm{H}_{2} \mathrm{O}}, \mathrm{X}_{\mathrm{NaCl}}\right.$ e $\left.\mathrm{X}_{\mathrm{CO}_{2}}\right)$, as salinidades das soluções aquosas, as densidades médias de $\mathrm{CO}_{2}$, bem como as densidades totais das inclusões fluidas $\left(\mathrm{d}_{\text {tot }}\right)$, que permitem a construção de isócoras, foram utilizados os dados de $\mathrm{Th}_{\mathrm{CO}_{2}}, \mathrm{Tf}_{\mathrm{cl}}, \mathrm{Tf}_{\mathrm{g}}, \mathrm{Th}_{\text {tot }}$ e $\mathrm{V}_{\mathrm{CO}_{2}} / \mathrm{V}_{\text {tot }}$ nas equações de estado do sistema constituído por $\mathrm{H}_{2} \mathrm{O}+\mathrm{NaCl}+\mathrm{CO}_{2}$. Essas equações encontramse englobadas nos programas de computação apresentados por Nicholls \& Crawford (1985) e Brown (1989), levando-se em conta que o $\mathrm{N}_{2}$ e $\mathrm{CH}_{4}$ ocorrem em quantidades subordinadas nas inclusões. 
Dentro dos diferentes grupos de amostras, para cada tipo de inclusões fluidas que ocorrem em Capão do Lana e Caxambu foram utilizados os valores médios dos intervalos de maiores freqüências de $\mathrm{Th}_{\mathrm{CO} 2}$, associados às $\mathrm{Tf}_{\mathrm{cl}} \mathrm{e}$ às variações de $\mathrm{V}_{\mathrm{CO}_{2}} / \mathrm{V}_{\text {tot }}$ correspondentes. Os resultados encontram-se nas Tabelas 25 e 27. Em Boa Vista (Tabela 29), no caso das inclusões fluidas do GR3, que não apresentaram o desenvolvimento de clatratos, houve a necessidade da utilização de outros parâmetros, tais como $\mathrm{Tf}_{\mathrm{g}} \mathrm{e} \mathrm{Th}_{\text {tot }}$.

As Tabelas 25, 27 e 29 mostram que as densidades totais das inclusões fluidas variam, às vezes, de modo significativo mesmo dentro de um mesmo grupo. Em Capão do Lana, observa-se um ligeiro acréscimo em $d_{\text {tot }}$ do GR1 para o GR2, o qual apresentamse mais

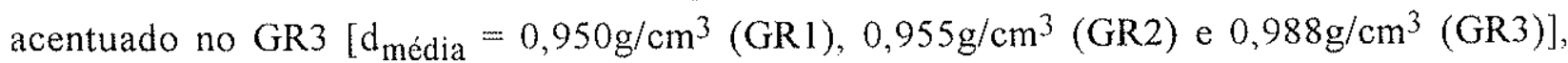
sendo essas variações menores em Caxambu $\left[\mathrm{d}_{\text {média }}=0,996 \mathrm{~g} / \mathrm{cm}^{3}(\mathrm{GRl})\right.$ e $0,980 \mathrm{~g} / \mathrm{cm}^{3}$ (GR2)], representando, em cada caso, apenas de modo aproximado as densidades reais das soluções mineralizantes. Para Boa Vista, do mesmo modo que Capão do Lana, os valores das densidades totais médias das inclusões fluidas aumentam do grupo um para o três $\left[\mathrm{d}_{\text {média }}=\right.$ $0,969 \mathrm{~g} / \mathrm{cm}^{3}$ (GR1), 0,972 $\mathrm{g} / \mathrm{cm}^{3}$ (GR2) e $1,005 \mathrm{~g} / \mathrm{cm}^{3}$ (GR3)]. Tais relações de densidade também podem ser observadas pelas diferenças nas inclinações do conjunto de isócoras (Figuras 48, 49 e 50), quando são considerados grupos distintos, sendo decorrentes das proporções crescentes da fase aquosa, mais densa, e do ligeiro acréscimo da salinidade em direção aos GR3-CL e GR3-BV. Deve ser ressaltado, no entanto, que no caso dessas jazidas, não podem ser obtidas as densidades verdadeiras para cada grupo, mas apenas os respectivos intervalos de variação, em função das diferentes proporções volumétricas $\left(\mathrm{V}_{\mathrm{CO}_{2}} / \mathrm{V}_{\text {tot }}\right)$ existentes, conforme procedimento apresentado por Brown \& Lamb (1986, 1989), uma vez que o aprisionamento das inclusões parece ter ocorrido a partir de fluidos originalmente imisciveis, como discutido anteriormente. Esses autores mostram que as isócoras reais, relativas às inclusões que aprisionam $\mathrm{H}_{2} \mathrm{O}$ e $\mathrm{CO}_{2}$ abaixo da curva de imiscibilidade do sistema, encontram-se localizadas entre as que representam as densidades das soluções aquosas salinas e do $\mathrm{CO}_{2}$, presentes nas inclusões, sendo condicionadas às proporções volumétricas desses componentes. Roedder (1984) mostrou que os dados de temperatura, pressão e densidade obtidos a partir desses sistemas são de modo geral, incorretos; porém, no caso presente, como a composição da solução original parece situar-se próxima à critica, principalmente nas amostras do Capão do Lana e Caxambu, foram obtidas faixas de densidades relativamente estreitas, uma vez que seus valores, nessas condições, não possuem grandes variações. Conseqüentemente, as densidades reais dessas soluções não devem ser muito distantes dos limites obtidos para cada grupo.

Quanto à composição, embora existindo variações dentro de cada grupo, condicionadas às diferenças nas proporções volumétricas de $\mathrm{CO}_{2}$ e nas salinidades, observase nas Tabelas 25, 27 e 29, que as maiores frações molares de $\mathrm{H}_{2} \mathrm{O}$ e $\mathrm{NaCl}$ encontram-se nos 
GR3 de Capão do Lana e de Boa Vista, e no GR2 de Caxambu, enquanto os outros grupos apresentam um enriquecimento mais acentuado em $\mathrm{CO}_{2}$. Quando o aprisionamento das inclusões ocorre a partir de sistemas heterogêneos de fluidos, o que é sugerido principalmente no caso das jazidas de Capão do Lana e Caxambu, as temperaturas de aprisionamento das inclusões podem ser determinadas com bastante aproximação, quando são considerados apenas os menores valores de $\mathrm{Th}_{\text {tot }}$ obtidos a partir de um grande número de medidas microtermométricas (Roedder 1984). Assim sendo, os valores da Tabela 24 e da Figura 47a indicam que, em Capão do Lana, as inclusões fluidas do GR1-CL e GR2-CL teriam sido aprisionadas em temperaturas próximas a 290 e $300^{\circ} \mathrm{C}$, e para o $\mathrm{GR} 3-\mathrm{CL}$, sua formação estaria compreendida num intervalo de 275 a $285^{\circ} \mathrm{C}$. Em Caxambu, as temperaturas de aprisionamento das inclusões variam de 300 a $320^{\circ} \mathrm{C}$ no $\mathrm{GR} 1-\mathrm{Cx}$ e de 270 a $310^{\circ} \mathrm{C}$ no caso do GR2-Cx (Tabela 26 e Figura 47b). Finalmente, em Boa Vista (Tabela 28 e Figura 47c), as inclusões dos GR1 e GR2-BV foram, provavelmente, aprisionadas entre 240 e $300^{\circ} \mathrm{C}$, enquanto que as do GR3-BV, em temperaturas próximas a $300^{\circ} \mathrm{C}$.

A determinação da pressão, no caso de sistemas imiscíveis de fluidos compostos por soluções aquosas salinas e $\mathrm{CO}_{2}$, é relativamente complexa, quando são aprisionadas diferentes proporções dos dois componentes (Roedder 1984). No entanto, tendo-se uma estimativa das temperaturas de aprisionamento, relacionadas acima, e os intervalos de variação de $d_{\text {tot }}$, representados pelas respectivas isócoras, podem ser obtidos, com alguma aproximação, ao menos os limites extremos das pressões envolvidas, como discutido em Brown \& Lamb (1986, 1989).

Desse modo, considerando-se nos diagramas isocóricos (Figuras 48,49 e 50) as $\mathrm{Th}_{\text {tot }}$ acima, foram determinadas as pressões de 2.000 a 2.800bar para o GR1-CL, de 2.100 a 2.900bar para o GR2-CL e de 1.750 a 3.200bar para o GR3-CL (Capão do Lana) e de 2.170 a 2.990bar para o GR1-Cx e de 1.670 a 3.000bar para o GR2-Cx (Caxambu). Em Boa Vista, as inclusões do GR1-BV foram aprisionadas entre 1.800 e $2.250 \mathrm{bar}$, as do GR2-BV entre 1.750 e 2.750 bar, enquanto que as do GR3-BV, em pressões da ordem de 2.170 a 2.560 bar.

As isócoras das Figuras 48, 49 e 50, que forneceram essas condições de pressão, foram determinadas com base na equação de Bowers \& Helgeson (1983) para o sistema $\mathrm{H}_{2} \mathrm{O}-\mathrm{CO}_{2}-\mathrm{NaCl}$, utilizada por Nicholls \& Crawford (1985) e Brown (1989) nos seus programas de computação. Pressões ligeiramente superiores, definindo um intervalo geral de, aproximadamente, 2,0 a 4,0kbar, foram encontradas a partir das isócoras definidas por Brown \& Lamb (1989). 


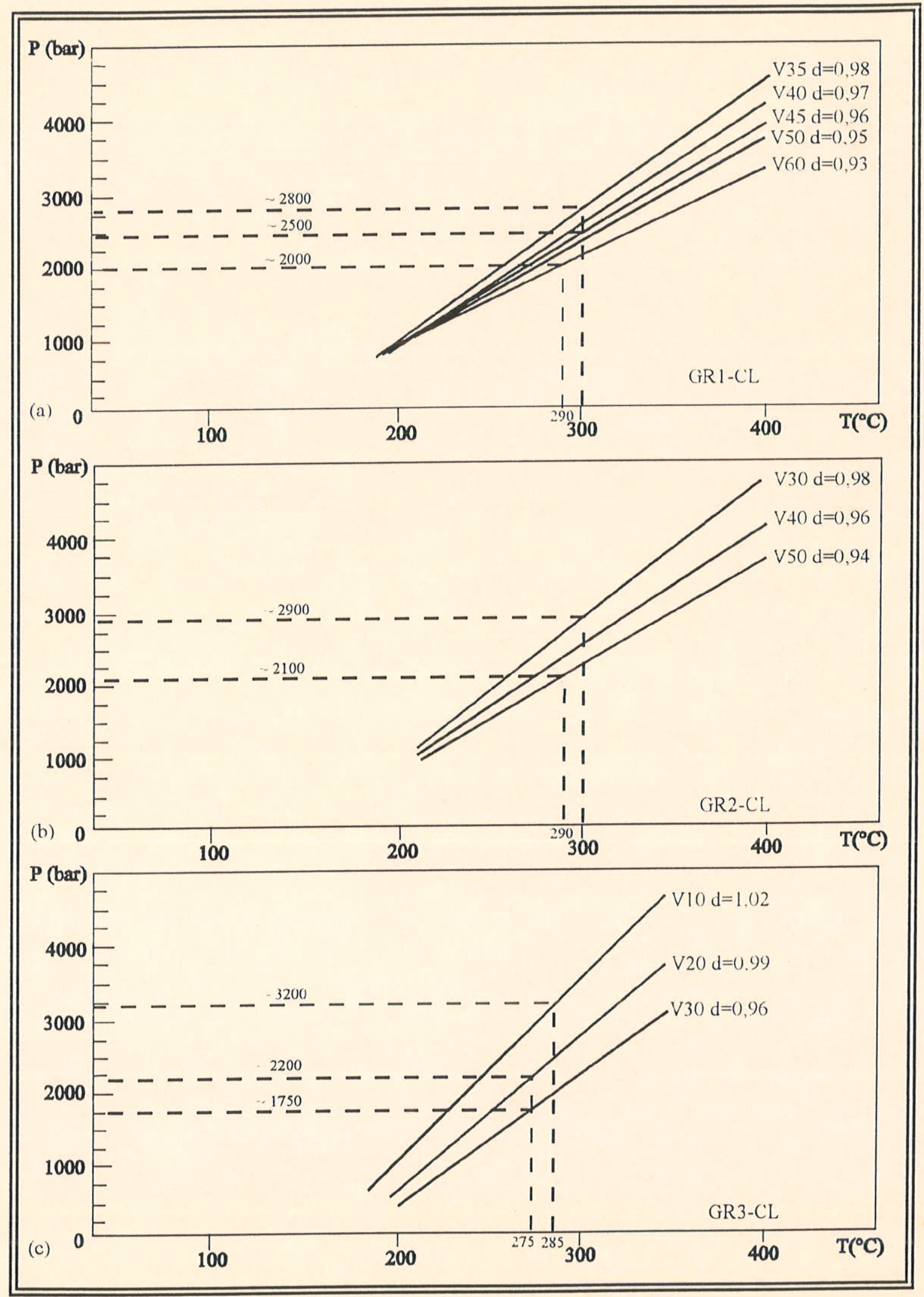

FIGURA 48 - Determinação das isócoras médias de pressão de cada grupo de inclusões fluidas presentes nos topázios imperiais da jazida do Capão do Lana, através do sistema quimico $\mathrm{H}_{2} \mathrm{O}+\mathrm{NaCl}+\mathrm{CO}_{2}$. Os resultados obtidos foram tratados no programa de computador de Nicholls \& Crawford (1985). $\left(\mathrm{V}=\mathrm{v}_{\mathrm{CO}_{2}} \mathrm{~N}_{\mathrm{tot}} \mathrm{\textrm {m }} \%\right)$. 


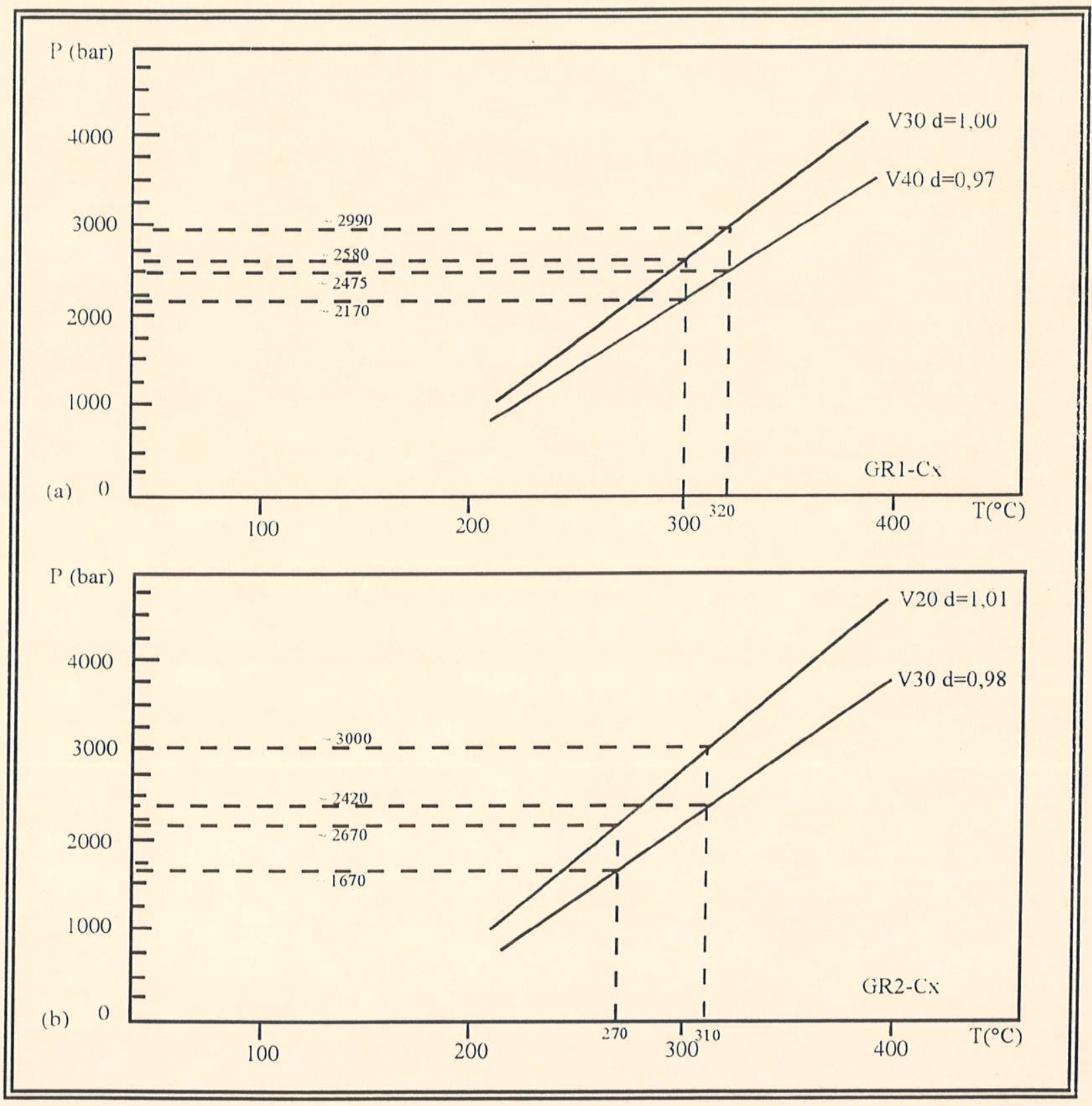

FIGURA 49 - Determinação das isócoras médias de pressão de cada grupo de inclusões fluidas presentes nos topázios imperiais da jazida de Caxambu. através do sistema quimico $\mathrm{H}_{2} \mathrm{O}+\mathrm{NaCl}+\mathrm{CO}_{2}$. Os resultados obtidos foram tratados no programa de computador de Nicholls \& Crawford (1985). $\left(\mathrm{V}=\mathrm{v}_{\mathrm{CO}_{2}} / \mathrm{V}_{\text {tot }} \mathrm{em} \%\right)$. 


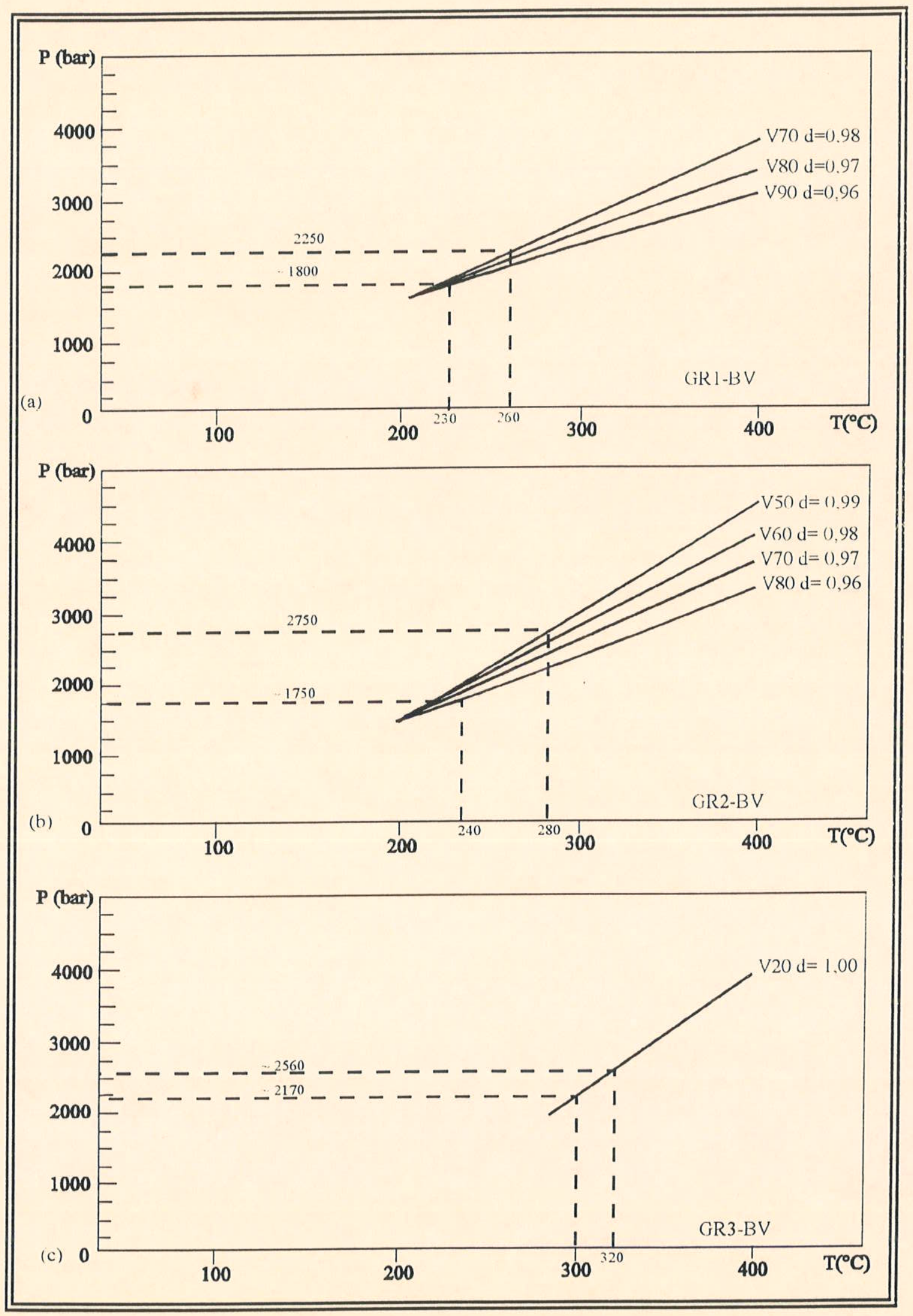

FIGURA 50 - Determinação das isócoras médias de pressão de cada grupo de inclusões fluidas presentes nos topázios imperiais da jazida de Boa Vista. através do sistema químico $\mathrm{H}_{2} \mathrm{O}+\mathrm{NaCl}+\mathrm{CO}_{2}$. Os resultados obtidos foram tratados nos programas de computador de Nicholls \& Crawford (1985) para os grupos 1 e 2. e FLINCOR (Brown 1989) para o grupo 3 devido a ausência de clatrato, $\left(\mathrm{V}=\mathrm{V}_{\mathrm{CO}_{2}} / \mathrm{V}_{\text {tot }} \mathrm{em} \%\right)$. 


\section{8 - ASPECTOS GEOLÓGICOS E GENÉTICOS DAS JAZIDAS E/OU OCORRÊNCIAS DE TOPÁZIO IMPERIAL DA REGIÃO DE OURO PRETO}

Apesar do topázio azul e incolor ser muito citado na literatura geológica mundial, por ser um mineral comum em certos tipos litológicos como os pegmatitos e os greisens (Deer et al. 1982), são raros os trabalhos a respeito da mineralogia desse mineral encontrado na região de Ouro Preto. Pelos levantamentos bibliográficos feitos até o presente momento, o número de trabalhos publicados sobre o topázio imperial da região de Ouro Preto não ultrapassa duas dezenas, excetuando-se os relatórios de pesquisas inéditos das empresas mineradoras. Uma característica marcante desses trabalhos é que todos se dedicam apenas à parte geológica não indo além da descrição petrográfica e de comentários sobre a gênese (pegmatítica ou metamórfica), sem contudo acrescentar dados mineralógicos e químicos das litologias e do mineral-gema.

Talvez um dos grandes problemas seja a complexidade das litologias e estruturas presentes no Quadrilátero Ferrífero; além disso, o alto grau de intemperismo presente nas encaixantes do topázio imperial dificulta a abordagem genética. Muitos autores divergem, inclusive quanto à posição estratigráfica dos corpos mineralizados. Por exemplo, Olsen (1971) relaciona esses corpos à Formação Sabará, enquanto Pires et al. (1983a) à Formação Gandarela e D'Elboux \& Ferreira (1975) à Formação Fecho do Funil.

\section{1 - TRABALHOS ANTERIORES}

Provavelmente a primeira citação referente ao topázio imperial encontrada na literatura, seja a de Mawe (1812). Esse historiador inglês em sua viagem pelo Brasil, referiu-se aos corpos mineralizados como sendo veios alterados de micas. Spix \& Martius (1831), naturalistas botânicos, fizeram o mesmo tipo de referência. O primeiro pesquisador a fazer um trabalho essencialmente geológico sobre o topázio imperial foi Eschwege, em 1833. Devido à sua permanência em Ouro Preto entre os anos de 1811 e 1822, este pesquisador estudou um pouco mais detalhadamente essas jazidas. Já nesta época determinou dois alinhamentos principais para as mineralizações e ainda referiu-se ao topázio como estando encaixado em litologias do tipo talco 
xistos. Claussen (1841, in Cassedanne 1989) interpretou a rocha portadora de topázio como sendo uma efusão de material fino a partir de diques que cobriram a superficie em forma de camadas.

Uma interpretação mais detalhada dessas jazidas deve-se a Gorceix (1881), que descreveu as mineralizações de topázio imperial encaixadas em uma rocha composta por caulinita, moscovita e quartzo, além de pequenas concentrações de manganês. Para este autor, os depósitos ocorrem ao longo de falhamentos em veios irregulares, apresentando entre 2 e $3 \mathrm{~m}$ de espessura. Basicamente as mineralizações estão posicionadas ao longo de duas direções $\mathrm{W} 20^{\circ} \mathrm{S}$, paralelas. $\mathrm{O}$ topázio é encontrado em um material argiloso castanho proveniente da alteração de xistos micáceos, interpretados como de origem pegmatítica. A existência de topázio está marcada pela presença de argilas micáceas, denominada "piçarra" pelos garimpeiros. Eschwege (1833), repetiu as idéias de Gorceix, exceto no tocante às rochas xistosas que são consideradas como talco por Eschwege. Para o primeiro autor, também as jazidas de diamantes estariam associadas aos quartzitos micáceos, no mesmo horizonte dos topázios nos arredores de Boa Vista, distrito de Ouro Preto. Em resumo, Gorceix refere-se, em seu trabalho, principalmente, ao tipo da rocha encaixante e à associação do topázio com o quartzo e as "litomargas", que são os produtos de alteração de feldspatos.

Derby (1901) cita um filito sericítico rico em ferro, resultante da alteração de uma rocha vulcânica intermediária, associado ao topázio nas zonas mineralizadas. Seu trabalho trata especificamente da rocha matriz do topázio, interpretada como eruptiva e do grupo dos augita ou nefelina sienitos. Sua hipótese é que a cristalização dos topázios se concentrava em drusas, numa zona félsica, onde os cristais mostravam apenas uma das terminações da bipirâmide rômbica. Da mesma maneira que Gorceix (1881) e Eschwege (1833), Derby (1901) associou o topázio a um solo de coloração escura proveniente da decomposição da rocha eruptiva. Este autor também reconheceu os alinhamentos já descritos anteriormente, interpretando-os como diques. Bauer (1968) apresentou interpretação semelhante, considerando também os cristais de topázio imperial encontrados em cavidades nos veios essencialmente quartzosos. A origem pegmatítica, proposta por Gorceix (1881), também é repetida de Boanova (1929).

Uma outra hipótese é a de um metamorfismo retrógrado em gnaisses, proposta por Guimarães \& Souza (1932). Guimarães (1933) apresentou uma descrição semelhante as de Gorceix (1881) e Derby (1901), onde também cita a existência de topázio de cor lilás, atualmente reconhecido por vários autores como devido a tratamento térmico (Franco 1955). Como as direções dos alinhamentos das ocorrências de topázio coincidem com as direções das rochas existentes na região, Lacourt (1938) sugeriu a ocorrência de rochas eruptivas na forma de soleiras. Esse mesmo autor já usou o termo gema para o topázio, ao invés do conceito errôneo de pedra semipreciosa. 
Johnson (1962), apesar de não dar nenhuma nova explicação para a gênese do topázio não concorda com a idéia dos corpos serem de origem pegmatítica.

Como pode ser observado, todos os trabalhos anteriores são muito repetitivos. A partir da década de 70 , vários pesquisadores passaram a estudar mais detalhadamente essas jazidas, apesar de não apresentarem análises mineralógicas pormenorizadas.

Para Olsen (1971), as mineralizações estão posicionadas nas adjacências dos planos de falhas ao longo de fraturas de tensão na Formação Sabará, ao contrário dos trabalhos anteriores, que consideravam as mineralizações nos planos de falhamento. A formação do topázio estaria ligada aos níveis pouco sericíticos dos filitos encaixantes. Sua hipótese é que o topázio, o euclásio, a hematita e outros minerais formaram-se a partir de soluções hidrotermais. A origem das massas cauliníticas, associadas aos topázios, pode ser explicada a partir de um metassomatismo potássico, possivelmente contemporâneo com as intrusões graníticas. O intemperismo, nessa suite hidrotermal, reduziu a composição mineralógica do veio mineralizado ao quartzo, ao topázio, à sericita e à caulinita. A origem do topázio é explicada pela reação entre a caulinita com o $\mathrm{F}^{-}, \mathrm{O} \mathrm{K}^{+}, \circ \mathrm{Be}^{2+}$ e o $\mathrm{SiO}_{2}$ que percolaram nessas falhas. Olsen (1971) introduziu também o termo brown terrena para a zona mineralizada em topázio. Pires (1983) traduziu este termo para terreno mineralizado.

Fleischer (1972) discutiu as teorias de Olsen (1971), criticando sua comparação dos vulcanismos terciários das Montanhas Rochosas (USA) com o Quadrilátero Ferrífero. Posteriormente, Olsen (1972) explicou a sua teoria em uma curta discussão apresentada no Economic Geology.

Com relação aos eventos tectônicos ligados ao Quadrilátero Ferrifero, D'Elboux \& Ferreira (1974, 1975 e 1978) classificaram os depósitos de topázios em dois tipos genéticos: a) as rochas hospedeiras são itabiritos e filitos do tipo mangano-dolomíticos da Formação Gandarela; b) as hospedeiras são filitos, possivelmente dolomíticos, da Formação Fecho do Funil, além de filitos típicos da Formação Sabará. Nos itabiritos, o principal fator genético são as intrusivas, possivelmente ácidas, enquanto nos filitos, predomina o caráter pneumatolítico pegmatítico. Para esses autores, nas associações mineralógicas do primeiro tipo não ocorre o euclásio, enquanto nas do segundo tipo ele está sempre presente. De um modo geral, eles consideram as mineralizações de topázios controladas por falhas de empurrão "em conchas" apresentando sentido NW.

Cassedanne \& Cassedanne (1975) fazem uma descrição geral da Mina de Topázio de Saramenha, situada dentro do perímetro urbano de Ouro Preto. Neste trabalho são fornecidos alguns dados mineralógicos do topázio tais como a $\mathrm{d}=3,50 \pm 0,02 ; \mathrm{nX}=1,622, \mathrm{nZ}=1,632$ e $\mathrm{B}=0,010$. Petrov et al. (1977) estudaram o topázio de Saramenha sob o ponto de vista cristalográfico, descrevendo as formas cristalográficas encontradas. 
Também podem ser citados os trabalhos de Rolff (1971), Buskirk \& Buskirk (1974) e Bastos (1976), onde praticamente são citados dados anteriores, não apresentando nenhum novo resultado geológico-genético.

Trabalhos científicos, com um melhor embasamento geológico, são apresentados por Ruplinger (1983) e Keller (1983), onde defendem a origem pegmatítica para as mineralizações do topázio. Para o segundo autor, esses depósitos foram formados devido ao arqueamento de rochas provocados pelas intrusões graníticas portadoras de fluidos ricos em flúor. Neste processo, deu-se a origem de apófises pegmatíticas, que foram as responsáveis pela formação de veios de quartzo. Nesses veios são encontradas as cavidades, contendo feldspatos, totalmente caulinizado, além do quartzo e topázio.

Ferreira (1983) correlacionou algumas das ocorrências de topázio à rochas vulcânicas de afiliação ácida. Além do Morro de Saramenha, onde o referido autor fez um estudo detalhado, têm-se outros pontos do Quadrilátero Ferrifero com situação semelhante. No Morro de Saramenha, foi caracterizado um "corpo laterítico", praticamente vertical, em um saprólito de rocha dolomítica de origem vulcânica, não afetada pelo metamorfismo dinamotermal, sugerindo que essa atividade vulcânica deu-se após o Ciclo Brasiliano. A interpretação de uma origem vulcânica baseia-se no fato do corpo não apresentar a mesma estrutura da rocha encaixante e que na fração argilosa observam-se apenas grãos monocristalinos de quartzo angulosos e com vértices agudos, além de arestas cortantes. Nestes grãos não são observadas extinções ondulantes; apresentam poucas inclusões sólidas e nenhuma inclusão fluida. Para o signatário, a falta de inclusões fluidas não dá embasamento para um autor dizer sobre a origem ígnea ou não de uma rocha. Ferreira (1983) sugeriu também que a mineralização originou-se a partir de atividades pneumatolíticas, oriunda do vulcanismo já descrito.

Pires et al. (1983a) sugeriram que as mineralizações de topázio são do tipo stratabound, ocorrendo em quatro faixas descontínuas e orientadas segundo NW. Os controles estratigráficos dessas mineralizações, freqüentemente, estão situados na zona de contato entre os sericita xistos da parte superior da Formação Gandarela e os quartzitos ferruginosos de coloração negra da Formação Cercadinho. Esses depósitos foram formados durante ou imediatamente após um intenso metamorfismo seguido de um evento de deformação regional. Durante esse metamorfismo formaram-se as rochas peraluminosas potássicas e ricas em flúor, responsáveis pela cristalização do topázio. Essas rochas também são ricas em hidroxila, que além de estar presente na estrutura dos topázios, faz parte das sericitas e das fengitas. Este metamorfismo seria de baixo grau, do fácie xisto verde, devido à paragênese metamórfica apresentando cianita, sericita, moscovita, quartzo e topázio. Dependendo das variações das condições de $\mathrm{pH}_{2} \mathrm{O}$ e pressão dos voláteis, particularmente do $\mathrm{F}^{-}$, além do topázio, também a cianita pode-se cristalizar. Para esses autores, durante a fase hidrotermal, houve a formação do topázio, pirita, pirofilita, caulinita e magnetita, 
juntamente com o quartzo e berilo que foram formados na fase pegmatítica. Posteriormente, o berilo alterou-se para o euclásio.

Oliveira (1984) chega aos mesmos resultados obtidos por Pires et al. (1983a). Uma característica interessante deste trabalho é que o autor cita a ocorrência abundante de turmalinas associadas ao topázio e que serviria como um metalotecto na prospecção desse mineral-gema. Gandini et al. (1992c) analisaram este material através de difração de raio X na câmara de Gandolfi e verificaram tratar-se de tremolita. Segundo Oliveira (1984), os minerais do horizonte portador de topázio foram formados pela oxidação em condições hidrotermais, onde a magnetita passa para hematita sendo a pirita limonitizada. Esses resultados foram obtidos a partir do estudo de concentrado de bateia no nível, denominado por Pires (1983) de terreno mineralizado.

Ferreira (1987) complementando seu trabalho de 1983, onde trata do tectonismo e vulcanismo, correlaciona as ocorrências de topázio com rochas dolomíticas e o último evento de vulcanismo da região. Devido ao fato dos topázios ocorrerem em veios e apresentarem inclusões fluidas abundantes, ele sugeriu origem a partir de processos pneumatolíticos.

Cassedanne (1989) fez um resumo histórico de vários trabalhos já publicados sobre o topázio imperial da região de Ouro Preto e discutiu as várias idéias a respeito de sua gênese. Descreveu as várias minerações deste mineral-gema, na região de Ouro Preto, dando destaque aos minerais que ocorrem associados ao topázio.

Baseado nos trabalhos elaborados por Alkmim et al. (s.d.) e Marshak \& Alkmim (1989), onde são mostrados vários eventos tectônicos para o Quadrilátero Ferrífero, Ferreira (1991) relacionou as ocorrências de topázio com o último evento de idade cretácica ou do início do Terciário, onde teria ocorrido a reativação de algumas estruturas resultantes dos eventos anteriores e que geraram falhamentos normais com predomínio de direção $\mathrm{N} 60^{\circ} \mathrm{W}$ na região sul do Quadrilátero Ferrífero. Neste evento surgiram vários focos de vulcanismo que deram origem às rochas saturadas em sílica e não metamorfizadas. Ferreira (1991) cita dois fatos como conclusão de seu trabalho: o condicionamento litológico e o rígido controle estrutural das mineralizações. Segundo Ferreira (1991), a hipótese de uma origem metamórfica para o topázio como proposta anteriormente por Olsen (1972), Pires et al. (1983) e outros autores, não pode ser aplicada a todas as ocorrências da província topazífera da região de Ouro Preto. Numa análise química feita em dois cristais de topázio, um de coloração amarelada e outro avermelhado, ele concluiu que o cromo é o principal elemento cromóforo desse mineral-gema. Este autor descreve a primeira ocorrência de topázio em rocha inalterada encaixada numa rocha carbonatada e onde o veio mineralizado é constituído, predominantemente, por dolomita e quartzo. Esta ocorrência está situada no distrito de Bocaina, em Ouro Preto (Figura 1).

Cassedanne (1991) refere-se, mais uma vez, à origem do topázio imperial como ligada a um evento metamórfico e associado a rochas do tipo sericita xisto da Formação Gandarela e em 
contato com "arenitos" ferruginosos da Formação Cercadinho. Parece-me que este autor enganou-se quanto ao termo arenito, pois trata-se de um cinturão metamórfico.

\section{2 - PRESSÕES E TEMPERATURAS DE FORMAÇÕES DOS DEPÓSITOS DO TOPÁZIO E NATUREZA DOS FLUIDOS MINERALIZANTES}

Os depósitos de topázio, de natureza primária, estão geneticamente relacionados à ação de voláteis ricos em flúor, eventualmente existentes, emanados nos estágios finais de formação das rochas plutônicas. Desse modo, há uma afinidade geoquímica do topázio à paragênese ígnea plutônica, essencialmente pegmatítica; entretanto, este também pode estar associado a lavas riolíticas ácidas, greisens e xistos. O topázio é considerado importante indicador da fase pneumatolítica tardia, sendo, às vezes, o mineral mais representativo dos veios estaniferos (Deer et al. 1982).

Através dos resultados microtermométricos, correspondentes a, aproximadamente, 1.100 inclusões fluidas estudadas em 35 cristais de várias jazidas, foram caracterizadas, com alguma aproximação, as condições físico-químicas dos fluidos mineralizantes, importantes para o entendimento da natureza e da seqüência dos processos geológicos envolvidos na formação do topázio.

Os dados obtidos permitiram a identificação de três grupos de amostras com propriedades físico-químicas distintas, independentemente de sua morfologia e orientação, com diferentes concentrações de $\mathrm{CO}_{2}$, nas jazidas de Capão do Lana e Boa Vista. Para a jazida de Caxambu, por outro lado, tem-se a presença de dois grupos distintos de amostras, como discutido em Gandini $e t$ al. (1992b).

As temperaturas de fusão dos componentes, determinadas pela microtermometria, aliadas aos resultados da espectroscopia de absorção no infravermelho e micro Raman, permitiram caracterizar melhor a composição do fluido mineralizante. Além das soluções aquosas salinas, ocorrem, nessa fase fluida, quantidades variáveis de $\mathrm{CO}_{2}, \mathrm{CH}_{4}$ e $\mathrm{N}_{2}$. Os resultados sugerem que as inclusões fluidas do topázio podem ser representadas pelos sistemas químicos $\mathrm{H}_{2} \mathrm{O}+\mathrm{CO}_{2}$, $\mathrm{H}_{2} \mathrm{O}+\mathrm{CO}_{2}+\mathrm{NaCl}, \mathrm{H}_{2} \mathrm{O}+\mathrm{CO}_{2}+\mathrm{CH}_{4}$ e $\mathrm{H}_{2} \mathrm{O}+\mathrm{CO}_{2}+\mathrm{N}_{2}$, ou mesmo por combinações mais complexas desses componentes. Foi ainda constatado que existem variações nas quantidades dos componentes voláteis das inclusões, e também certas diferenças nas salinidades, implicando em densidades totais $\left(d_{t o t}\right)$ mutias vezes distintas; essas relações sugerem a existência de modificações locais nas composições dos fluidos mineralizantes, mesmo dentro de uma única jazida. 
As temperaturas de homogeneização total, referentes às jazidas de Capão do Lana e Caxambu (Figura 47a e 47), também podem apresentar certas variações. Observa-se que as amostras dos GR1-CL e GR1-Cx possuem, de modo geral, inclusões fluidas com $\mathrm{Th}_{\text {tot }}$ mais elevadas em relação aos outros grupos. Esses dados parecem refletir a existência de pequenas diferenças nas condições de aprisionamento das inclusões de grupos distintos de ambas as jazidas. Já na jazida de Boa Vista, esse fato é marcado por uma dispersão dos valores obtidos, não tendo sido possível caracterizar melhor os intervalos de temperaturas existentes.

De posse de todos os dados obtidos e dos parâmetros calculados, foram construídas as isócoras referentes às jazidas de Capão do Lana, Caxambu e Boa Vista (Figuras 48, 49 e 50), onde encontram-se representados os valores mínimos mais freqüentes das temperaturas de homogeneização total, que permitiram a determinação das condições de pressão de aprisionamento das inclusões. Uma vez que foram selecionadas para estudo apenas as inclusões primárias e pseudosecundárias, de modo geral os resultados microtermométricos levaram ao estabelecimento das condições aproximadas de pressão e temperatura da própria cristalização do topázio. Os valores desses parâmetros, relacionados na Tabela 31, indicam que as inclusões dos diversos grupos, das várias jazidas, foram aprisionadas em condições ligeiramente distintas, cujos valores parecem ser indicativos de condições hidrotermais, responsáveis pela formação desse mineral.

TABELA 31 - Temperaturas e pressões mínimas de aprisionamento das inclusões fluidas das várias jazidas de topázio imperial, indicando a cristalização deste mineral.

\begin{tabular}{||l|c|c|c||}
\hline GRUPOS & GR1 & GR2 & GR3 \\
\hline Capão do Lana & $290-300^{\circ} \mathrm{C}$ & $290-300^{\circ} \mathrm{C}$ & $275-285^{\circ} \mathrm{C}$ \\
& $2.000-2.800 \mathrm{bar}$ & $2.100-2.900 \mathrm{bar}$ & $1.750-3.200 \mathrm{bar}$ \\
\hline Caxambu & $300-320^{\circ} \mathrm{C}$ & $270-310^{\circ} \mathrm{C}$ & - \\
& $2.170-2.990 \mathrm{bar}$ & $1.670-3.000 \mathrm{bar}$ & - \\
\hline Boa Vista & $240-300^{\circ} \mathrm{C}$ & $240-300^{\circ} \mathrm{C}$ & $300-320^{\circ} \mathrm{C}$ \\
& $1.840-2.670 \mathrm{bar}$ & $1.750-3.000 \mathrm{bar}$ & $2.170-2.560 \mathrm{bar}$ \\
\hline
\end{tabular}

\section{3 - CORRELAÇÃO DOS ASPECTOS GENÉTICOS DO TOPÁZIO IMPERIAL DA REGIÃO DE OURO PRETO COM OS DO PAQUISTÃO}

A gênese do topázio imperial da região de Ouro Preto está subordinada às litologias e estruturas características do contexto geológico local, ou seja, relaciona-se a zonas falhadas nos 
filitos, quartzitos e mármores, todos dolomíticos, principalmente do Grupo Piracicaba, do Supergrupo Minas (Ferreira 1991). As mineralizações ocorrem em veios pegmatíticos centimétricos e descontínuos ou em geodos decimétricos compostos por concentrações variáveis de quartzo e dolomita, podendo conter, ainda, especularita, moscovita, rutilo e florencita, encontrando-se ambos caulinizados ou transformados num material proveniente da decomposição de carbonatos, denominado pelos garimpeiros de "borra de café". As rochas metamórficas encaixantes também encontram-se intensamente decompostas, conservando, atualmente, apenas algumas de suas estruturas antigas; a única exceção é representada pela ocorrência de Bocaina, onde as encaixantes são mármores compostos essencialmente por dolomita, em quantidades superiores a $98 \%$, contendo, ainda, quartzo e moscovita, como acessórios. Essas mineralizações encontram-se associados a uma zona de falhas normais e em blocos, que cortam as rochas do Supergrupo Minas, com direção predominante $\mathrm{N} 60^{\circ} \mathrm{W}$, resultante de um processo de distensão e reativadas posteriormente. A reativação dessa zona de falha estaria ligada a um evento tectônico, possivelmente do final do Cretáceo ou início do Terciário, designado de $\mathrm{D}_{5}$ por Alkmim et al. (s.d.). Nesse evento mais recente, teriam sido reativadas as estruturas anteriores de eventos maiores, sendo o mesmo considerado por Ferreira (1991) como relacionado ao aparecimento de vários focos de vulcanismo sintectônico, produzindo rochas saturadas em sílica, não metamorfizadas e estando o mineral-gema relacionado a um evento hidrotermal ligado à fase final do referido vulcanismo na região.

Os dados obtidos, a partir dos estudos das inclusões fluidas, mostraram, principalmente, no caso das jazidas de Capão do Lana, Caxambu e Boa Vista, a ocorrência de grupos distintos de amostras com características termodinâmicas próprias.

Salvo as imprecisões já mencionadas, decorrentes das dificuldades de obtenção das amostras in situ, os resultados microtermométricos mostraram que existem características diferenciadas das soluções mineralizantes dos diferentes grupos de amostras. Essas características seriam indicativas de condições ligeiramente distintas de aprisionamento das inclusões dos vários grupos e, portanto, de cristalização do referido mineral-gema, podendo também ter havido interações dos fluidos com as rochas encaixantes, ou, ainda, de modificações das inclusões devido a eventos pós-cristalização. No entanto, a ausência de feições indicativas de modificações posteriores ao aprisionamento e a coerência nas medidas relativas a cada grupo, e mesmo em uma única amostra, parecem sugerir que as duas primeiras hipóteses são as mais consistentes. Por esses processos, poderiam ser explicadas certas variações composicionais observadas nos fluidos, bem como as diferenças nas $\mathrm{d}_{\mathrm{CO}_{2}}$ das inclusões de grupos distintos e, conseqüentemente, nos demais parâmetros determinados a partir desses valores.

Deve ser ainda mencionado que as pequenas variações que ocorrem em inclusões pertencentes a cada grupo de amostras, geralmente relacionadas a valores ligeiramente distintos de $\mathrm{V}_{\mathrm{CO}_{2}} / \mathrm{V}_{\text {tot }}$ e aos tipos de homogeneização total observados, são características de sistemas de 
fluidos originalmente imisciveis, como discutido anteriormente. Desse modo, além da interação das soluções mineralizantes com as rochas encaixantes, os cristais de topázio, representativos de cada grupo de amostras, foram formados em condições ligeiramente distintas, a partir de um sistema de fluidos originalmente heterogêneos, compostos por $\mathrm{H}_{2} \mathrm{O}$ com sais dissolvidos, $\mathrm{CO}_{2}$ e pequenas quantidades de $\mathrm{N}_{2}$ e $\mathrm{CH}_{4}$, cujos valores de pressão e temperatura de aprisionamento das inclusões são indicativos de condições hidrotermais.

Comparando-se as jazidas de topázio imperial da região de Ouro Preto com as do Paquistão, observa-se que ambas encontram-se encaixadas em rochas dolomíticas metamorfizadas, diferenciando-se as primeiras apenas pelo elevado grau de alteração dos veios mineralizados e das encaixantes, com exceção da ocorrência de Bocaina.

Os veios mineralizados em topázio do morro de Ghundao, no vale de Katland, Paquistão, localizam-se em falhas subverticais que cortam rochas carbonáticas de idade Siluriano-Devoniano. Tal datação deve-se a estruturas algálicas e gasterópodes fósseis presentes nas rochas carbonáticas intercaladas com filitos pertencentes a um anticlinal. $\mathrm{O}$ veio mineralizado é composto por calcita, quartzo leitoso e incolor, moscovita verde, talco verde e cristais euédricos de quartzo hialino e de topázio incolor, róseo e púrpuro (Jam 1979, Spengler 1985, Gübelin et al. 1986). Segundo Gübelin et al. (1986), o topázio foi formado por um processo sintectônico tardio, juntamente com uma atividade ígnea, do tipo hidrotermal/pneumatolítica, pertencente ao estágio final da consolidação de uma intrusão granítica eocênica, próxima a essa mineralização. Isso é sugerido uma vez que o topázio róseo é rico em cromo, do mesmo modo que o possível granito fonte, de idade eocênica, tendo, portanto, a mineralização uma idade semelhante.

Deve ser também enfatizado que a geologia das jazidas de topázio do distrito de Mardan, Paquistão (Jam 1979), é bastante semelhante à da ocorrência de Bocaina, único local, na região de Ouro Preto, onde esse mineral-gema ocorre em rocha inalterada. Esta última ocorrência é representada por veios de dolomita e quartzo, mineralizados em topázio, que cortam rochas encaixantes constituídas por mármore dolomítico.

Estudos sobre a geologia da região de Ouro Preto, disponíveis na literatura, aliados aos resultados obtidos neste trabalho, sugerem que a gênese do topázio, das jazidas e/ou ocorrências analisadas, estaria ligada a um processo hidrotermal, desvinculado de um metamorfismo regional ou local. Esse fato é indicado pela composição química do topázio [ $\pm 5 \%$ de $\mathrm{OH}^{-}$e $\pm 15 \%$ de $\left.\mathrm{F}^{-}\right]$, pelas características de suas inclusões fluidas primárias, indicativas de um sistema de fluidos originalmente imiscíveis, pelas temperaturas $\left( \pm 300^{\circ} \mathrm{C}\right)$ e pressões $(2$ a $2,5 \mathrm{Kbar})$ de aprisionamento, que são relativamente baixas, e pela ausência de deformação nos cristais de topázio, quartzo, rutilo, dolomita e florencita tanto dos veios alterados como dos inalterados. 


\section{9 - CONSIDERAÇÕES FINAIS}

As jazidas e/ou ocorrências do topázio imperial da região de Ouro Preto, localizadas na porção centro-sudeste do estado de Minas Gerais, se destacam por ser esta a única área produtora desse mineral-gema em rochas alteradas no mundo, uma vez que os depósitos conhecidos do Paquistão ocorrem em rochas inalteradas. Este fato faz com que o topázio imperial brasileiro seja mais facilmente explotado, sem acarretar perdas do material coletado.

Quanto ao estudo mineralógico do topázio, os resultados mais importantes sào relacionados a seguir. Os cristais de topázio possuem colorações variando do amarelo-claro ao avermelhado, passando pelo laranja e róseo, apresentando todos os matizes dessas tonalidades. Com menor freqüência, ocorrem topázios incolores e esverdeados. A grande maioria desses cristais é encontrada sob a forma de fragmentos pequenos medindo, geralmente, de 1 a $4 \mathrm{~cm}$. Seu hábito é sempre prismático, podendo haver uma variação no número de prismas e bipirâmides. Nesses topázios, predominam dois prismas de $3^{\mathrm{a}}$ ordem, uma bipirâmide, e com menor freqüência, prismas de $2^{\mathrm{a}}$ ordem e, ainda, mais raramente pinacóides. A densidade relativa dos cristais estudados variou de 3,428 a 3,517 , sendo o valor médio da ordem de 3,44. Apresentam índices de refração variando de 1,615 a 1,628 para $n X$, de 1,618 a 1,631 para $n Y$ e de 1,625 a 1,639 para o $n Z$, implicando num intervalo de birrefringência entre 0,008 e 0,015 , e ângulo $2 V_{Z}$ situado entre $62^{\circ}$ e $67^{\circ}$. Medidas dos parâmetros da cela unitária, permitiram caracterizar variações de 4,615 a 4,656§ para $a_{0}$, de 8,747 a $8,815 \AA$ para $b_{0}$, de 8,375 a $8,412 \AA$ para $c_{0}$, estando o volume da cela unitária situado entre 340,639 e $343,823 \AA^{3}$. A variação da razão $\mathrm{OH}^{-} / \mathrm{F}^{-}$é compatível com as outras propriedades mineralógicas analisadas, ou seja, com a densidade, índices de refração, ângulo $2 \mathrm{~V}_{\mathrm{Z}}$, parâmetro $\mathrm{b}_{\mathrm{o}}$ e volume da cela unitária (Figura 51). O único cristal que apresentou comportamento anômalo a todas as propriedades mineralógicas, foi o de coloração amareloclara, não tendo sido possível encontrar uma explicação para este fato. Quanto às inclusões cristalinas identificadas por difração de raios X, EDS e MEV-EED, foram caracterizadas as seguintes fases que constituem, provavelmente, inclusões protogenéticas: quartzo, hematita/ilmenita, mica, carbonatos (dolomita/ankerita), rutilo, tremolita, apatita, cloritóide, euclásio e o próprio topázio, sendo mais abundantes as quatro primeiras. Minerais como a tremolita, apatita e o cloritóide não foram observados na associação presente nos veios estudados. 
Parecem ocorrer apenas nas rochas encaixantes, tendo sido, portanto, englobados no topázio como minerais ocasionais. As relações texturais observadas nos veios mineralizados, destacando-se a presença de inclusões de topázio em cristais da mesma espécie, são indicativas de sua cristalização em mais de uma etapa. Como inclusões epigenéticas, foram identificados óxidos e hidróxidos, provavelmente de ferro e/ou manganês, presentes nas fraturas não cicatrizadas dos topázios.

De modo geral, o topázio apresenta um grande número de inclusões fluidas primárias e pseudosecundárias, invariavelmente bifásicas à temperatura ambiente, as quais possuem orientações e morfologias variáveis, podendo constituir desde canalículos, de contornos regulares, até cavidades bastante irregulares. Em alguns casos foram observados minerais aprisionados acidentalmente junto às inclusões fluidas, identificados, através de microscópio petrográfico, apenas como fases isótropas e anisótropas.

Os estudos microtermométricos, associados às análises de espectroscopia no infravermelho e micro Raman, permitiram caracterizar a composição dos fluidos mineralizantes das jazidas analisadas. Estes são constituídos por proporções distintas de $\mathrm{H}_{2} \mathrm{O}$, com sais dissolvidos, e de $\mathrm{CO}_{2}$, estando também presentes, em quantidades variáveis, $\mathrm{CH}_{4}$ e $\mathrm{N}_{2}$. Outras propriedades termodinâmicas obtidas para as inclusões, no caso dos topázios das várias jazidas, encontram-se discutidas abaixo.

a) Capão do Lana: salinidades, em valores equivalentes à porcentagem em peso do $\mathrm{NaCl}$, variando de 4,51 a 8,77 ; valores de $\mathrm{d}_{\text {tot }}$ situados entre $0,9297 \mathrm{e} 1,0288 \mathrm{~g} / \mathrm{cm}^{3} ; \mathrm{X}_{\mathrm{H}_{2} \mathrm{O}}$ de 0,6368 a $0,9456, \mathrm{X}_{\mathrm{NaCl}}$ de 0,0102 a 0,0278 e $\mathrm{X}_{\mathrm{CO} 2}$ de 0,0331 a 0,3481 ; temperaturas de 275 a $300^{\circ} \mathrm{C}$ e pressões da ordem de 1,7 a $3,2 \mathrm{kbar}$.

b) Caxambu: salinidades, em valores equivalentes à porcentagem em peso do $\mathrm{NaCl}$, situadas entre 7,81 e 12,$89 ; \mathrm{d}_{\text {tot }}$ entre 0,9649 e $1,0142 \mathrm{~g} / \mathrm{cm}^{3} ; \mathrm{X}_{\mathrm{H} 2 \mathrm{O}}$ de 0,7844 a 0,9011 , $\mathrm{X}_{\mathrm{NaCl}}$ de 0,0224 a 0,0382 e $\mathrm{X}_{\mathrm{CO} 2}$ de 0,0727 a 0,1837 ; temperaturas de 270 a $320^{\circ} \mathrm{C}$ e pressões de 1,7 a $3,0 \mathrm{kbar}$.

c) Boa Vista: salinidades, equivalentes à porcentagem em peso do $\mathrm{NaCl}$, variando de 3,95 a 12,$85 ; d_{\text {tot }}$ de 0,9560 a $1,0047 \mathrm{~g} / \mathrm{cm}^{3} ; \mathrm{X}_{\mathrm{H} 2 \mathrm{O}}$ de 0,2181 a $0,8953, \mathrm{X}_{\mathrm{NaCl}}$ de 0,0034 a 0,0407 e $\mathrm{X}_{\mathrm{CO}_{2}}$ de 0,0646 a 0,7785 ; temperaturas de 240 a $300^{\circ} \mathrm{C}$ e pressões de 1,75 a $3,0 \mathrm{kbar}$.

Algumas determinações microtermométricas, realizadas em uma outra jazida da região de Dom Bosco, permitiram determinar apenas as salinidades equivalentes à porcentagem em peso do $\mathrm{NaCl}$, que variou de 7,5 a 13,3 , e temperaturas de aprisionamento próximas a $300^{\circ} \mathrm{C}$. 


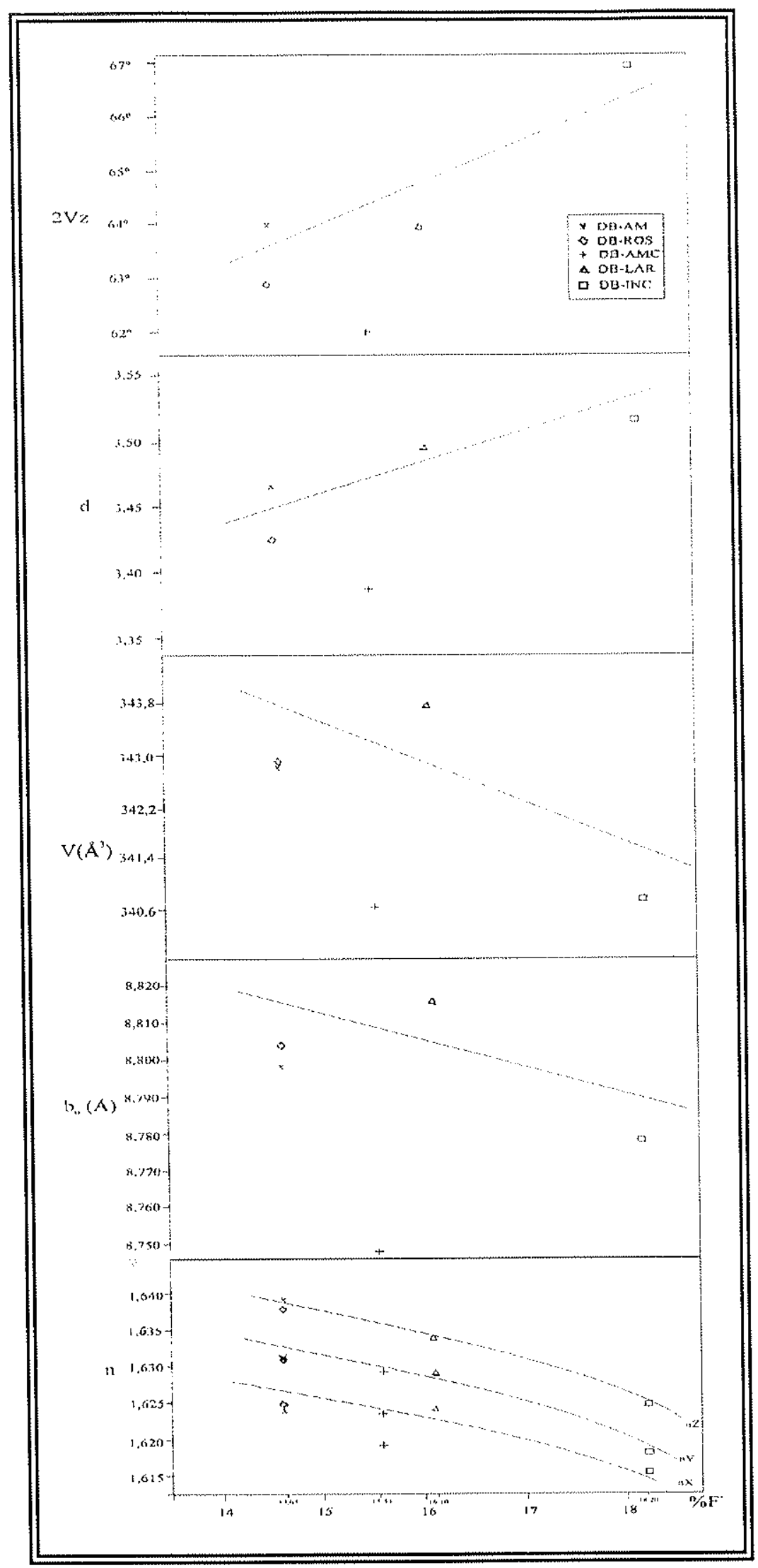

FIGURA 51 - Correlação entre os valores de $n, b_{o}, V$, d e $2 V_{Z}$, com o teor de flúor, de topázios coloridos da região do Dom Bosco. 
Com relação à gênese desse mineral, na região de Ouro Preto, alguns autores sugerem que a mineralização teria sido originada através de uma atividade pneumatolítica/hidrotermal relacionada a uma fase pré-metamórfica (Olsen 1971), ao pico do metamorfismo de baixo grau em sedimentos peraluminosos ricos em flúor, que caracteriza as rochas do Supergrupo Minas (Pires et al. 1983a), ou mesmo logo a seguir, porém anteriormente ao evento tectônico $\mathrm{D}_{2}$ ((Pires et al. 1983b). Por outro lado, estudos realizados, em diferentes ocorrências, por Ferreira (1983 e 1991) indicaram que os veios mineralizados estão intimamente relacionados a falhas nas rochas dolomíticas do Grupo Piracicaba, e que o topázio teria sido gerado por hidrotermalismo associado à fase final do último evento de vulcanismo ácido que afetou a região, no final do Cretáceo e/ou início do Terciário.

As duas primeiras hipóteses parecem não ser válidas, uma vez que existem trabalhos (Alkmim et al. s.d.) evidenciando que as fraturas, onde ocorrem as mineralizações, podem ser, na realidade, relacionadas a uma fase posterior ao Ciclo Brasiliano, que constituiu o último grande evento termo-tectônico no Quadrilátero Ferrífero. Isso também é atestado pela ausência de deformação nos veios, uma vez que os cristais de quartzo, dolomita, rutilo, florencita e topázio ocorrem com formas euédricas. Estes veios, pós-cinemáticos, provavelmente, foram gerados durante um campo de esforços muito baixo, o que foi comprovado pelos estudos das inclusões fluidas.

Os valores de pressão e temperatura de aprisionamento das inclusões, determinados pelo estudo microtermométrico, são compatíveis com as condições de hidrotermalismo que parece ser o processo responsável pela mineralização (Olsen 1971, Oliveira 1984, Ferreira 1991). Essas soluções, por interação com as encaixantes que possuem quantidades variáveis de dolomita, teriam incorporado proporções diferentes de $\mathrm{CO}_{2}$. Tais processos são sugeridos pela presença de três intervalos de maiores freqüências das temperaturas de homogeneização do $\mathrm{CO}_{2}\left(\mathrm{Th}_{\mathrm{CO}_{2}}\right)$ e pelos valores das relações volumétricas, $\mathrm{V}_{\mathrm{CO}_{2}} / \mathrm{V}_{\text {tot }}$, nos diferentes grupos de amostras, onde foram caracterizadas inclusões com concentrações distintas de $\mathrm{CO}_{2}$ (ver Tabelas 25, 27 e 29).

Os dados obtidos, a partir dos estudos das inclusões fluidas, sugerem que os cristais de topázio dos diversos grupos foram formados em condições de pressão e temperatura ligeiramente distintas, a partir de fluidos hidrotermais, originalmente imiscíveis. Assim sendo, pode ter ocorrido uma evolução do fluido por interação com as encaixantes, ao longo de sua percolação em diferentes profundidades. Todavia, não deve ser descartada a influência de eventos póscristalização nos fluidos originais, embora sejam poucas as evidências indicativas de tais processos. Desse modo, soluções hidrotermais, portadoras de elementos tais como o berílio e o flúor, teriam formado, entre outros minerais, o euclásio e o topázio imperial.

Outros dados que corroboram com a hipótese de hidrotermalismo são representados pelos valores elevados obtidos para a razão $\mathrm{OH}^{-} / \mathrm{F}^{-}$, ou seja, o topázio imperial da região de Ouro Preto é rico em hidroxila $\left[ \pm 5 \%\right.$ de $\left.\mathrm{OH}^{-}\right]$. Segundo Rosenberg (1967), topázios ricos em $\mathrm{OH}^{-}$têm uma origem pegmatítica e segundo Foord et al. (1988), seriam gerados em veios hidrotermais.

Por todas as características e valores encontrados, aliados à ausência de deformação dos cristais, alto teor em $\mathrm{OH}^{-}$e $\mathrm{T}$ e $\mathrm{P}$ relativamente baixos, o processo hidrotermal desvinculado de um metamorfismo, parece ser a hipótese mais provável da gênese do topázio imperial da região de Ouro Preto. Em resumo, esse mineral teria sido cristalizado a partir de fluidos hidrotermais de composição essencialmente aquo-carbônica, com salinidade baixa a moderada, em condições de temperatura variando de 240 a $320^{\circ} \mathrm{C}$ e pressões de 1,7 a $3,2 \mathrm{kbar}$. 


\section{0 - REFERÊNCIAS BIBLIOGRÁFICAS}

ABREU, A.S.; DINIZ, H.B.I.; PRADO, M.Q.B. do; SANTOS, S.P. dos. (1986) Mina de ouro de São Bento, Santa Bárbara, Minas Gerais. In: SCHOBBENHAUS, C. \& COELHO, C.E.S. Principais depósitos minerais do Brasil. Brasilia, DNPM. v. 3, p. $393-411$.

AKIZUKI, M.; HAMPAR, M.S.; ZUSSMAN, J. (1979) An explanation of anomalous optical properties of topaz. Mineralogical Magazine, 43: 237-241.

ALECRIM, J.D. (1982) Recursos minerais do estado de Minas Gerais. Belo Horizonte, METAMIG. 299p.

ALKMIM, F.F.; QUADE, H.; EVANGELISTA, M.T.R. (s.d.) Sobre a história da deformação dos metassedimentos do Supergrupo Minas e Grupo Itacolomi no Quadrilátero Ferrífero, Minas Gerais. UFOP. 45p. (publicação interna).

ALMEIDA, F.F.M. de. (1977) O Cráton do São Francisco. Revista Brasileira de Geociências, 7 (4): 349-364.

ALMEIDA, F.F.M. de. (1981) O Cráton do Paramirim e suas relações com o do São Francisco. In: SIMPÓSIO SOBRE O CRÁTRON DO SÃO FRANCISCO E SUAS FAIXAS MARGINAIS, Salvador, 1981. Anais. Salvador, SBG. p. 1-10.

AZÁROFF, L.V. \& BURERGER, M.J. (1958) The powder method in x-ray crystallography. New York, McGraw-hill Book Company, 342p.

BARBOSA, A.L.M. (1961) Tectônica do Quadrilátero Ferrifero de Minas Gerais. SICEG, (1): $49-53$. 
BARBOSA, A.L.M. (1979) Variação de fácies na Série Minas. In: SIMPÓSIO DE GEOLOGIA DE MINAS GERAIS, 1., Belo Horizonte, 1979. Atas. Belo Horizonte, SBG. p. 89-100. (Boletim n'1).

BARBOSA, A.L.M. (1983) Contribuições recentes à geologia do Quadrilátero Ferrífero. Ouro Preto, Escola de Minas. 44p. (Conferência Proferida na SBG, Belo Horizonte, 1968).

BARBOSA, G.V. (1967) Características Geomorfológicas. In: BARBOSA, G.V. \& RODRIGUES, D.M.S. (ed.). Quadrilátero Ferrifero. UFMG - Instituto Central de GeoCiências. p. 46-60. (publicação interna).

BARBOSA, G.V. (1980) Superficies de erosão no Quadrilátero Ferrifero, Minas Gerais. Revista Brasileira de Geociências, 10 (1): 89-101.

BARBOSA, G.V. \& RODRIGUES, D.M.S. (1967) Quadrilátero Ferrifero. UFMG, Instituto Central de Geociências. Belo Horizonte. 130p.

BARBOSA, O. (1949) Contribuição à geologia do centro de Minas Gerais. Mineração e Metalurgia, 14 (79): 3-19.

BASTOS, F.M. (1961) The gemstones of Brazil. Gems \& Gemology, 10 (7): 195-201.

BASTOS, F.M. (1976) Imperial topaz from Brazil. Lapidary Journal, 30: 1836-1838.

BAUER, M. (1968) Precious stones. New York, Dover, v. 2, p. 327-340.

BELLO, R.M. da S.; SVISERO, D.P.; GANDINI, A.L.; MENDES, J.C.; VALARELLI, J.V.; SCHULTZ-GÜTTLER, R.A. (1991) Inclusões fluidas em gemas brasileiras. Boletim IGUSP. Publicação Especial, 9: 9-12.

BETEKHTIN, A.G. (s.d.) A course of mineralogy. Moscow, Peace Publishers. 642p.

BOANOVA, F. de P. (1929) Jazida de blenda. Relatório Annual do Director. Serviço Geológico e Mineralógico do Brasil, 1928: 157-171. 
BOWERS, T.S. \& HELGESON, H.C. (1983) Calculation of the thermodynamic and geochemical consequences of nonideal mixing in the system $\mathrm{H}_{2} \mathrm{O}-\mathrm{CO}_{2}-\mathrm{NaCl}$ on phase relations in geologic systems: Equation of state for $\mathrm{H}_{2} \mathrm{O}-\mathrm{CO}_{2}-\mathrm{NaCl}$ fluids at high pressures and temperatures. Geochimica et Cosmochimica Acta, 47: 1247-1275.

BRANCO, P. de M. (1984) Glossário gemológico. Porto Alegre, Editora da Universidade. $203 p$.

BROCARDO, G. (1986) Pedras preciosas e outros minerais: guia de identificação. Itália, Editora Siciliano. 218p.

BROWM, P.E. (1989) FLINCOR: a fluid inclusion data reduction and exploration program (abstract). Second Biennial Pan-American Conf. on Research on Fluid Inclusions Prog. with Abstract. 14.

BROWM, P.E \& LAMB, W.M. (1986) Mixing of $\mathrm{H}_{2} \mathrm{O}-\mathrm{CO}_{2}$ in fluid inclusions; geobarometry and archean gold deposits. Geochimica et Cosmochimica Acta, 50: 847-852.

BROWM, P.E \& LAMB, W.M. (1989) P-V-T properties of fluids in the system $\mathrm{H}_{2} \mathrm{O} \pm \mathrm{CO}_{2} \pm \mathrm{NaCl}$ : New graphical presentations and implications for fluid inclusion studies. Geochimica et Cosmochimica Acta, 53: 1209-1221.

BUSKIRK, D. \& BUSKIRK, D.V. (1974) Imperial topaz mine Brazil. Lapidary Journal, 28: 1458-1459.

CASSEDANNE, J.P. (1989) Famous minerals locaties: The Ouro Preto Topaz Mines. The Mineralogical Record, 20: 221-233.

CASSEDANNE, J.P. (1991) Tipologia das jazidas brasileiras de gemas. In: SCHOBBENHAUS, C.; QUEIROZ, E.T. de; COELHO, C.E.S. (1991). Principais depósitos minerais do Brasil. Brasilia, DNPM/CPRM. v. 4, p. 17-36.

CASSEDANNE, J.P. \& CASSEDANNE, J.O. (1975) La topaze imperiale de Saramenha, Minas Gerais, Bresil. Monde et Minéraux, 8: 174-177.

CASSEDANNE, J.P. \& SAUER, J. (1987) La topaze impériale. Revue de gemmologie, (91): 2-9. 
COMPANHIA ENERGÉTICA DE MINAS GERAIS (1987) Ortofotos folhas: Itabirito 42-11-20; Ouro Preto 42-12-10 a 42-12-12 e 42-12-14 a 42-12-20; Mariana 43-07-05, 43-07-09, 43-07-10, 43-07-13 e 43-07-14. Esc. 1:10.000. [Curitiba], Esteio / Belo Horizonte, CEMIG. (Projeto 03/86).

CHAUDHRY, M.N. \& HOWIE, R.A. (1970) Topaz from the Meldon aplite, Devonshire. Mineralogical Magazine, 37 (290): 717-720.

CHEMALE JR., F.; ROSIÉRE, C.A.; ENDO, I. (1991) Evolução tectônica do Quadrilátero Ferrifero, Minas Gerais. Revista Pesquisa, 18 (2): 104-127.

CIPRIANI, C. (1986) Natural stones and gems. In: The Macdonald encyclopedia of precious stones. London, Macdonald. p. 10-269.

COLLINS, P.L.F. (1979) Gas hydrates in $\mathrm{CO}_{2}$-bearing fluids and the use freezing data for estimation of salinity. Economic Geology, 74 (6): 1435-1444.

CORDANI, U.G.; KAWASHITA, K.; MÜELLER, G. ; REIMER, V.; RÖESER, H. (1980) Interpretação tectônica e petrológica de dados geocronológicos do embasamento no bordo sudeste do Quadrilátero Ferrífero, Minas Gerais. Anais da Academia Brasileira de Ciências, 52 (4): 785-799.

CROOKES, W. (1879) Contributions to molecular physics in high vacua. Philosophical Transactions of the Royal Society of London, 170: 641-662.

DEER, W.A.; HOWIE, R.A.; ZUSSMAN, J. (1982) Rock-forming minerals: orthosilicates 2.ed. London, Longman. 919p. (v. 1A).

D'ELBOUX, C.V. \& FERREIRA, C.M. (1974) O topázio na região de Ouro Preto. In: CONGRESSO BRASILEIRO DE GEOLOGIA, 28., Porto Alegre, 1974. Boletim de Resumos. Porto Alegre, SBG. p. 586-588.

D'ELBOUX, C.V. \& FERREIRA, C.M. (1975) Topázio na região de Ouro Preto. Boletim do Departamento de Geologia da Escola de Minas e Metalurgia, (Publicação Especial) 1 , 73-79.

D'ELBOUX, C.V. \& FERREIRA, C.M. (1978) Topázio na região de Ouro Preto. SICEG, (14/15): 47-52.

DEPARTAMENTO NACIONAL DE PRODUÇÃO MINERAL. (1993) Gemas. Boletim de preços. Bens minerais e produtos metalúrgicos. Brasília, DNPM, 84: 25-44. 
DERBY, O.A. (1879) Observações sobre algumas rochas diamantíferas da provincia de Minas Gerais. Archivos do Museu Nacional, (4): 121-132.

DERBY, O.A. (1901) On the mode of occurence of topaz near Ouro Preto, Brazil. The American Journal of Science, 11 (61): 25-34.

DERBY, O.A. (1906) The Serra do Espinhaço, Brazil. Journal of Geology, 14 (3): 374-401.

DIAMOND, L.W. (1992) Stability of $\mathrm{CO}_{2}$ clathrate hydrate $+\mathrm{CO}_{2}$ liquid $+\mathrm{CO}_{2}$ vapour + aqueous $\mathrm{KCl}-\mathrm{NaCl}$ solutions: experimental determination and application to salinity estimates of fluid inclusions. Geochimica et Cosmochimica Acta, 56 (1): 273-280.

DOROBEK, S.L. \& WATKINSON, A.J. (1988) Cathodoluminescence petrography of microstrutural fabries in deformed limestones. Journal of Strutural Geology, 10 (3): 305-309.

DORR II, J.V.N. (1958) Symposium on the stratigraphy of the Minas Series in the Quadrilátero Ferrifero, Minas Gerais, Brazil. Boletim da Sociedade Brasileira de Geologia, 7 (2): 57-69.

DORR II, J.V.N. (1959) Esboço geológico do Quadrilátero Ferrífero de Minas - Brasil. Boletim do DNPM. Publicação Especial, 1: 7-8.

DORR II, J.V.N. (1969) Physiographic, stratigraphic and strutural development of the Quadrilátero Ferrífero, Minas Gerais, Brazil. U. S. Geological Survey Professional Paper, 641 A: $1-109$.

DORR II, J.V.N. \& BARBOSA, A.L.M. (1963) Geology and ore deposits of the Itabira District, Minas Gerais, Brazil. U. S. Geological Survey Professional Paper, 341 C: 1110 .

DORR II, J.V.N.; GAIR, J.E.; POMERENE, J.B.; RYNEARSON, G.A. (1957) Revisão da estratigrafia pré-cambriana do Quadrilátero Ferrifero. Avulso. DFPM/DNPM, (81): 1-31.

DUARTE, L. (1958) Annonaceae fósseis da bacia Terciária de Fonseca, Minas Gerais. Boletim. DGM/DNPM, 178: 1-27. 
EDMOND, C.R. (1969) Direct determination of fluoride in phosphate rock samples using the specific ion eletrode. Analytical Chemistry, 41 (10): 1327-1328.

ENDO, I; ROSIÈRE, C.A.; CHEMALE JR., F. (1992) Roteiro de excursão geológica no Quadrilátero Ferrifero e regiões adjacentes. Adendo da Revista da Escola de Minas. $U F O P, 45(1 / 2): 1-69$.

EPPLER, W.F. (1973) Praktische gemmologie. Stuttgart, Ruehle-Diebner-Verlag. 410p.

ESCHWEGE, W.L. V. (1822) Geognostisches Gemälde von Brasilien und wahrscheinliches Muttergestein der Diamanten. Berlin, Weimer. $44 \mathrm{p}$.

ESCHWEGE, W.L. v. (1832) Beitraege zur Gebirgskunde Brasiliens. Berlin, G. Reimer. $488 \mathrm{p}$.

ESCHWEGE, W.L. v. (1833) Pluto Brasiliensis. G. Reimer, 622p.

EWING, G.W. (1989) Métodos instrumentais de análises química. 5.ed. São Paulo, Edgard Blücher Ltda. 296p. (v. 1).

FARMER, V.C. (1974) The infrared spectra of minerals. London, Mineralogical Society. 539p. (Mineralogical Society Monograph, 4).

FERREIRA, A.B. de H. (1975) Novo dicionário da lingua portuguesa. Rio de Janeiro, Editora Nova Fronteira. 1499p.

FERREIRA, C.M. (1983) Vulcanismo ácido no Quadrilátero Ferrífero e sua relação com algumas ocorrências e/ou depósitos minerais. In: SIMPÓSIO DE GEOLOGIA DE MINAS GERAIS, 2., Belo Horizonte, 1983. Anais. Belo Horizonte, SBG. v. 3, p. 128133.

FERREIRA, C.M. (1987) Geologia da jazida de topázio do Morro de Saramenha. Revista da Escola de Minas. UFOP, 40 (3): 15-17.

FERREIRA, C.M. (1991) Topázio de Ouro Preto, Minas Gerais. In: SCHOBBENHAUS, C.; QUEIROZ, E.T. de; COELHO, C.E.S. Principais Depósitos Minerais do Brasil. Brasília, DNPM/CPRM. v. 4, p. 303-308. 
FISCHER, K (1986) Orientieren und vorbereiten zun schlifen. In: Edelsteinbearbeitung-Band 2. Stuttgart, Rühle-Diebener-Verlag. p. 112-134.

FLEISCHER, R. (1971) Le gisement aurifère à tourmaline de Passagem de Mariana, Minas Gerais, Brèsil, et son cadre. Influence de l'évolution structurale et du métamorphisme sur une minéralization syngénétique familière. Paris $110 \mathrm{p}$. (These de Docteur de l'Universite, Faculté de Sciences de Paris, França).

FLEISCHER, R. (1972) Origin of topaz deposits near Ouro Preto, Minas Gerais, Brazil. Discussions. Economic Geology, 67 (1): 119-120.

FLEISCHER, R. \& ROUTHIER, P. (1973) The "consaguineous" origin of a tourmaline bearing gold deposit: Passagem de Mariana, Brazil. Economic Geology, 68 (1): 11-22.

FLEISCHER, R. \& ROUTHIER, P. (1974) The "consaguineous" origin of a tourmaline bearing gold deposit: Passagem de Mariana, Brazil: A reply. Economic Geology, 69 (3): 419-422.

FONSECA, M.A. (1990) O sinclinal de Ouro Fino: análise descritiva e cinemática de um segmento do sistema Fundão, Quadrilátero Ferrífero, Minas Gerais. Ouro Preto, 120p. (Dissertação de Mestrado - Departamento de Geologia/UFOP).

FOORD, E.E.; JACKSON, L.L; TAGGART, J.E.; CROCK, J.G.; KING, T.V.V. (1988) Environmemt of crystallization of topaz as determined from crystal chemstry and infrared spetra. Geological Society of America Abstract with Programs. p. 224.

FORMOSO, M.L.L. (1980) Difratometria de raios X. In: CONGRESSO BRASILEIRO DE GEOLOGIA, 31., Camboriú, 1980. Boletim. Camboriú, SBG, Núcleo Santa Catarina. v. 4, p. $5-26$.

FRANCO, R.R. (1955) A cor da pedra preciosa. Gemologia, 1 (1): 23-37.

FRANK, J.R.; CARPENTER, A.B.; OGLESBY, T.W. (1982) Cathodoluminescence and composition of calcite cement in the Taum Sauk limestone (upper Cambrian), southeast Missouri. Journal of Sedimentary Petrology, 52 (2): 631-638. 
FREITAS, M.E. de; CROCCO-RODRIGUES, F.A.; ROSIĖRE, C.A. (1992) A correlação do quartzito Cambotas com a seqüência Espinhaço apoiada por mapeamento geológico em escala 1:10.000. REM. Revista da Escola de Minas, 45 (1-2): 51-53.

FUZIKAWA, K. (1985) Inclusões fluidas: métodos usuais de estudo e aplicações. In: COMPANHIA BRASILEIRA DE METALURGIA E MINERAÇÃO. CONTRIBUIÇÕES À GEOLOGIA E PETROLOGIA. Belo Horizonte, SBG/CBMM p. $29-44$.

FUZIKAWA, K. \& ALVES, J.V. (1984) Dilatação de inclusões fluidas em plagioclásios da provincia uranifera de Lagoa Real, Caetité - BA. In: CONGRESSO BRASILEIRO DE GEOLOGIA, 33., Rio de Janeiro, 1984. Anais. Rio de Janeiro, SBG. v. 9, p. 4453-4462.

GADSDEN, J.A. (1975) Infrared spectra of minerals and related inorganic compounds. London, Butterworths. 277p.

GAIR, J.E. (1958) The Sabará formation. Boletim da Sociedade Brasileira de Geologia, 7 (2): 68-69.

GAIR, J.E. (1962) Geology and ore deposits of the Nova Lima and Rio Acima Quadrangles, Minas Gerais, Brazil. U. S. Geological Survey Professional Paper, 341 A: 1-67.

GALLUP, J. (1936) The vacuum cell luminescence microscope and its use in study of luminescent materials. Journal of Optics Society of America, 26: 213-215.

GANDINI, A.L.; BELLO, R.M.; FUZIKAWA, K.; GASPAR, J.C.; BOTELHO, N.F.; COELHO, S.V.; MARCIANO, V.R.; PIMENTA, M.A.; SVISERO, D.P. (1993) Aspectos mineralógicos, geoquímicos e genéticos do topázio imperial da região de Ouro Preto, Minas Gerais, Brasil. In: SEMANA DE GEOQUÍMICA, 9./ CONGRESSO DE GEOQUíMICA DOS PAÍSES DE LÍNGUA PORTUGUESA, 2. Porto, 1993. Memórias. Porto, FCMLMG - Universidade do Porto, 1993. 3, p. 233-237.

GANDINI, A.L.; BELLO, R.M. da S.; FUZIKAWA, K.; MARCIANO, V.R.P. da R.O.; PIMENTA, M.A.; SVISERO, D.P. (1992a) Microtermometria, absorção no infravermelho, espectroscopia micro Raman dos componentes químicos das inclusões fluidas dos topázios imperiais de Ouro Preto, MG. In: CONGRESSO BRASILEIRO DE GEOLOGIA, 37., São Paulo, 1992. Boletim de Resumos Expandidos. São Paulo, SBG, Núcleo São Paulo. v. 2, p. 111-113. (Sessões temáticas). 
GANDINI, A.L.; BELLO, R.M. da S.; FUZIKAWA, K.; SVISERO, D.P.; FERREIRA, C.M. (1991) Caracterização das inclusões fluidas dos topázios imperiais da região de Ouro Preto, MG. Boletim IG-USP. Série Cientifica, 22: 61-72.

GANDINI, A.L.; BELLO, R.M. da S.; FUZIKAWA, K.; SVISERO, D.P.; FERREIRA, C.M.; VALARELLI, J.V. (1992b) Estudos microtermométricos de inclusões fluidas em topázios imperiais da jazida de Caxambu, Ouro Preto-MG. REM. Revista da Escola de Minas, $45(1 / 2): 191-193$.

GANDINI, A.L.; MENDES, J.C.; SVISERO, D.P. (1992c) Dados mineralógicos preliminares de topázio imperial da região de Ouro Preto, Minas Gerais. In: CONGRESSO BRASIleIRO DE GEOLOGIA, 37., São Paulo, 1992. Boletim de Resumos Expandidos. São Paulo, SBG, Núcleo São Paulo. v. 2, p. 110-111. (Sessões temáticas).

GANDINI, A.L.; SVISERO, D.P.; BELLO, R.M. da S.; CARVALHO, F.M.S.; VALARELLI, J.V. (1990) Inclusões fluidas de topázio imperial das jazidas de Capão do Lana e Caxambu, Ouro Preto, MG. In: CONGRESSO BRASILEIRO DE GEOLOGIA, 36., Natal, 1990. Boletim de Resumos. Natal, SBG, p. 227-228.

GANDOLFI, G. (1967) Discussion upon methods to obtain X-ray "powder patterns" from a single crystal. Acta Mineralogica-Petrographica, 13: 67-74.

GEMOLOGICAL INSTITUTE OF AMERICA. (1980) Topaz. In: Colored stones; identification, production, marketing, buying, appraising. Santa Monica, California, Gemological Institute of America. 26: 1-12.

GLÖCKNER, K.H. (1981) Lithostratigraphie, sedimentologie, tektonik und metamorphose der proterozoischen Itacolomi Serie bei Ouro Preto, Minas Gerais, Brasilien. Clausthal, 221p. (Ph.D. Dissertation, Tech. Univ. Clausthal, Clausthal - Zellerfeld, Federal Republic of Germany).

GOLDSCHMIDT, V. (1922) Tafen Bard VIII, safflorit - topas. Atlas der krystallformen. Heidelberg, Carl Winters Universitätsbuchhandlung. p. 168-179. (Tafel 107-149).

GOMES, C.B. (1980) Microssonda eletrônica. In: CONGRESSO BRASILEIRO DE GEOLOGIA, 31., Camboriú, 1980. Boletim. Camboriú, SBG, Núcleo Santa Catarina. v. 4, p. $89-111$. 
GOMES, C.B. (coord.) (1984) Microssonda eletrônica: princípios e aplicações na geologia. In: Técnicas analiticas instrumentais aplicadas à geologia. São Paulo, Edgard Blücher. p. 159-208.

GOMES, C.B. (coord.) (1984) Técnicas analiticas instrumentais aplicadas à geologia. São Paulo, Edgard Blücher. 218p.

GOMES, C.B. \& GIRARDI, V.A.V. (1973) Principios e aplicações de microssonda eletrônica. Ciência e Cultura, 25 (8): 711 -722.

GOMES, N.S. (1985) Petrologish-geochemische untersuchungen im Bação-Komplex Eisernes Viereck, Minas Gerais, Brasilien. Clausthal, 209p. (Doctoral, Technischen Universität Clausthal, Clausthal - Zellerfeld, Federal Republic of Germany).

GOMES, N.S. \& VORTISCH, W. (1990) Catodoluminescência: breve retrospectiva da técnica e exemplos de sua aplicação ao estudo de rochas sedimentares. REM. Revista da Escola de Minas, 44 (1): 16-27.

GONSALVES, A.D. (1949) As principais pedras e elementos outros considerados como preciosos. In: As pedras preciosas na economia nacional. Rio de Janeiro, Gráfica Olímpio Editora. p. $81-239$.

GORCEIX, H. (1881) Estudo geológico das jazidas de Topázio da Província de Minas Gerais, Brasil. Anais da Escola de Minas de Ouro Preto, 1: 13-34.

GORCEIX, H. (1884) Bacias terciárias de água doce nos arredores de Ouro Preto (Gandarela e Fonseca), Minas Gerais, Brasil. Anais da Escola de Minas de Ouro Preto, 3: 95-114.

GROSSI SAD, J.H. \& LADEIRA, E.A. (1968) Esboço tectônico do Estado de Minas Gerais. Belo Horizonte, Departamento Nacional da Produção Mineral. Escala $1: 1.000 .000$.

GÜBELIN, E.; GRAZIANI, G. ; KAZMI, A.H. (1986) Pink topaz from Pakistan. Gems $\boldsymbol{\&}$ Gemology, 22 (3): 141-151.

GUIMARÃES, D. (1931) Contribuição à geologia do Estado de Minas Gerais, Brasil. Boletim. SGM/DNPM, (55): 1-36. 
GUIMARÃES, D. (1933) A província magmática do Brasil. Monografias do Serviço da Produção Mineral, (1): 1-64.

GUimaräES, D.; MELO, S.M.G.; MELO, E.A.V. (1967) O Complexo do Bação. Boletim do Instituto de Geologia. Escola Federal de Minas de Ouro Preto, 2 (1): 1-12.

GUIMARÃES, D. \& SOUZA, H.C.A. de. (1932) - Estudos sobre o euclásio de Trino, Hargreaves, município de Ouro Preto. Anais da Academia Brasileria de Ciências, 4 (2): 33-37.

HARDER, E.C. \& CHAMBERLIN, R.T. (1915a) The geology of Central Minas Gerais, Brazil. Journal of Geology, 23 (4): 341-378.

HARDER, E.C. \& CHAMBERLIN, R.T. (1915b) The geology of Central Minas Gerais, Brazil. Journal of Geology, 23 (5): 385-424.

HEDENQUIST, J.W. \& HENLEY, R.W. (1985) The importance of $\mathrm{CO}_{2}$ on freezing point measurements of fluid inclusions: evidence from active geothermal systems and implications for epithermal ore deposition. Economic Geology, 80 (5): 1379-1406.

HEMMING, N.G.; MEYERS, W.J.; GRAMS, J.C. (1989) Cathodoluminescence in diagenetic calcites: the roles of $\mathrm{Fe}$ and $\mathrm{Mn}$ as dedriced from electron probe and spectrophotometric measurements. Journal of Sedimentary Petrology, 59 (3): 404-411.

HERZ, N. (1959) Metamorfismo. In: Esboço geológico do Quadrilátero Ferrífero de Minas Gerais, Brasil. Boletim do DNPM. Publicação Especial, 1: 38-44.

HERZ, N. (1970) Gneissic and igneous rocks of the Quadrilatero Ferrifero, Minas Gerais, Brazil. U. S. Geological Survey Professional Paper, 641 B: 1-58.

HERZ, N. (1978) Metamorphic rocks of the Quadrilátero Ferrífero, Minas Gerais, Brazil. $U$. S. Geological Survey Professional Paper, 641 C: 1-81.

HERZ, N. \& DUTRA, C.V. (1958) Preliminary spectrochemical and age determination results on some granitie rocks of the Quadrilatero Ferrifero, Minas Gerais, Brazil. Boletim da Sociedade Brasileira de Geologia, 7 (2): 81-95. 
HERZ, N.; HURLAY, P.M.; PINSON, W.H.; FAIRBAIRN, H.W. (1961) Age measurements from a part of the Brazilian Shield. Bulletin of the Geological Society of America, 72. (7): 1111-1120.

HOLLISTER, L.S. (1981) Information intrinsically available from fluid inclusion. In: HOLLISTER, L.S. \& CRAWFORD, M.L. (ed.). (1981). Fluid inclusions: application to petrology. Calgary, Mineralogical Association of Canada. p. 1-12. (Short course handbook, v. 6).

HOLLISTER, L.S. \& CRAWFORD, M.L. (1981) Fluid Inclusions: Application to Petrology. Calgary, Mineralogical Association of Canada. 304p. (Short course handbook, v. 6).

HURLBUT JR., C.S. (1971) Dana's manual of mineralogy. New York, John Wiley \& Sons. 579p.

HURLBUT JR., C.S. \& SWITZER, G.S. (1979) Descriptive gemology. In: Gemology. New York, John Wiley \& Sons. p. 124-220.

INDA, H.A.V.; SCHORCHER, H.D.; DARDENNE, M.A.; SCHOBBENHAUS, C.; HARALYI, N.L.E.; BRANCO, P.C. de A.; RAMALHO, R. (1984) O Cráton do São Francisco e a faixa de dobramentos Araçuaí. In: SHOBBENHAUS, C.; CAMPOS, D.A.; DERZE, G.R.; ASMUS, H.E. (1984) Geologia do Brasil - Texto explicativo do mapa geológico do Brasil e da área oceânica adjacente. Brasília, Ministério das Minas e Energia/DNPM. p. 193-248.

ISOGANI, M. \& SUNAGAWA, I. (1975) X-ray topographic study of a topaz crystal. The American Mineralogist, 60 (9/10): 889-897.

JAFFE, H.W. (1990) Introduction to crystal chemistry. Student edition. Cambridge. Cambridge University Press. 161p.

JAHNS, R.H. (1975) Gem materials. In: LEFOND, J.S. (ed.). Industrial minerals and rocks. New York, Americam Institute of Mining, Metallurgical and Petroleum Engineer Inc. p. 271-326. 
JAM, M.Q. (1979) Topaz occurrence in Mardan, north-west Pakistan. Mineralogical Magazine, 43: 175-176.

JAMES, H.L. (1954) Sedimentary facies of iron formation. Economic Geology, 49 (3): 235293.

JOHNSON, R.F. (1962) Geology and ore deposits of the Cachoeira do Campo, Dom Bosco and Ouro Preto quadrangles, Minas Gerais, Brazil. U. S. Geological Survey Professional Paper, 341 B: $1-39$

KELLER, P.C. (1983) The Capão Topaz Deposits, Ouro Preto, Minas Gerais, Brazil. Gems \& Gemology, 19 (1): 12-20.

KING, L.C. (1956) A geomorfologia do Brasil Oriental. Revista Brasileira de Geografia, 18 (2): $147-265$.

KLEIN, C. \& HURLBUT JR., C.S. (1985) Manual of mineralogy. 20. ed. New York, John Wiley \& Sons. 596p.

KNECHT, T. (1958) Decomposição das pedras preciosas em suas jazidas pelos agentes de intemperismos. Gemologia, 13 (4): 15-21.

KOIVULA, J.I. (1987) The rutilated topaz misnomer. Gems \& Gemology, 23 (2): 100-103.

LACOURT, F. (1936) Resumo da geologia da Folha de Ouro Preto. Anais da Escola de Minas de Ouro Preto, 27: 1-48.

LACOURT, F. (1938) Topázio em Ouro Preto, Minas Gerais. Mineração e Metalurgia, 3 (13): 24 .

LADEIRA, E.A. (1980) Metallogenesis of gold at the Morro Velho mine and in the Nova Lima District, Quadrilátero Ferrifero, Minas Gerais, Brazil. Canadá, 272p. (Ph. D. Thesis. Univ. Western Ontario).

LADEIRA, E.A. (1986) Metalogenia dos depósitos de ouro do Quadrilatero Ferrífero, Minas Gerais. In: SCHOBBENHAUS, C. \& COELHO, C.E.S. (1986) Principais depósitos minerais do Brasil. Brasilia, DNPM. v. 3, p. 301-375. 
LADEIRA, E.A.; RÖESER, H.; TOBSCHALL, H.J. (1983) Evolução petrográfica do cinturão de rochas verdes Rio das Velhas, Quadrilátero Ferrifero, Minas Gerais. In: SIMPÓSIO DE GEOLOGIA DE MINAS GERAIS, 2. Belo Horizonte. 1983. Boletim. Sociedade Brasileira de Geologia. Núcleo Minas Gerais, (3): 149-165.

LADEIRA, E.A. \& VIVEIROS, J.F.M. (1984) Hipótese sobre a estruturação do Quadrilátero Ferrifero com base nos dados disponíveis. Boletim. Sociedade Brasileira de Geologia. Núcleo Minas Gerais, (4): 1-18.

LAPEDES, D.N. (1977) Encyclopedia of the geological sciences. 4. ed. New York, McGraw Hill Book Company. p. 827-828.

LENZEN, G.; GÜNTHER, B.; GRÜN, W. (1984) Das refraktometer. In:

Edilsteinbestimmung mit gemmologischen geräten. Kuschweiler, Verlagschhandlung Elisabeth Lenzen. p. 39-118.

LEONARDOS, O.H. (1945) Ocorrência de euclásio no Brasil. Mineração \& Metalurgia, 48 (8): 383m384.

LEPREVOST, A. (1978) Flúor. In: Minerais para a indústria. Rio de Janeiro, Livros Técnicos e Científicos. p. 68-70.

LIMA, M.R. \& SALARD-CHEBOLDAEFF, M. (1981) Palynologie des bassins de Gandarela et Fonseca (Eoceno de l'etat de Minas Gerais). Boletim IG-USP, 12: 33-54.

LONG, J.V.P. \& AGRELL, S.O. (1965) The cathodoluminescence of minerals in thin section Mineralogical Magazine, 34: 318-326.

MACHADO, N. \& CARNEIRO, M. (1992) U-Pb evidence of late Archean tectono-thermal activity in the southern São Francisco shield, Brazil. Canadian Journal of Earth Sciences, 29 (11): 2341-2346.

MAGALHÃES, N.M. (1989) Estudo geoquímico de topázio e de suas propriedades termoluminescentes. Belo Horizonte, 125p. (Dissertação de Mestrado - Instituto de Ciências Exatas / UFMG). 
MARSHAK, S. \& ALKMIM, F.F. (1989) Proterozoic extension/contraction tectonics of the southern São Francisco Cráton and adjacent regions, Minas Gerais, Brazil: a kinenatic model relating Quadrilátero Ferrifero, São Francisco Basin and Cordilheira do Espinhaço. Tectonics, 8 (3): 555-571.

MARSHALL, D.J. (1988) Cathodoluminescence of geological materials. Boston, Unwin Hyman Ltd. 146p.

MAURIÑO, C.D. (1976) Silicatos. In: Iniciación prática a la mineralogía. Madrid, Editorial Alhambra. p. 366-511.

MAWE, J. (1812) Travels in the interior of Brazil. London, Longman Green. 366p.

MAXWELL, C.H. (1958) The Batatal Formation. Boletim da Sociedade Brasileira de Geologia, 7 (2): 60-61.

MERCEDES-BENZ. (1987) Gemas do Brasil (Gems of Brazil). São Bernardo do Campo, Mercedes-Benz. 130p.

METAIS DE MINAS GERAIS. (1981) Gemas de Minas Gerais. Belo Horizonte, METAMIG. 74p.

MEYERS, W.J. (1974) Carbonate cement stratigraphy of the Lake Valley Formation (Mississipian) Sacramento Moutains, New Mexico. Journal of Sedimentary Petrology, $44(3): 837-861$.

MILLER, J. (1988) Cathodoluminescence microscopy. In: TUCKER, M. (ed.). Techniques in sedimentology. Oxford, Blackwell Scientific Publications. p. 174-190.

MILOVSKY, A.V. \& KONONOV, O.V. (1985) Mineralogy. Moscow, Mir Publishers. 320p.

MOENKE, H. (1966) Mineralspektren, II. Berlim, Akademic Verlag. (coleção de fichas).

MÜELLER, G.; SCHUSTER, A.; HOEFS, J. (1982) Oxgen isotope variation in polimetamorphic iron ores from the Quadrilatero Ferrifero, Brazil. Revista Brasileira de Geociências, 12 (1-3): 348-355. 
NALINI JR., H.A. (1993) Análise estrutural descritiva e cinemática do flanco sul e terminaçäo periclinal do anteclinal de Mariana e adjacências, região sudeste do Quadrilátero Ferrifero, MG, Brasil. Belo Horizonte, 134p. (Dissertação de Mestrado Instituto de Geociências/UFMG).

NASSAU, K. (1985) Altering the color of topaz. Lapidary Journal, 39 (9): 49-57.

NICHOLS, E.L.; HOWES, H.L.; WILBER, D.T. (1928) Cathodoluminescence and the luminescence of incandescent solids. Plublication. Carnegie Institution Washington, 384.

NICHOLLS, J. \& CRAWFORD, M.L. (1985) Fortran Programs for calculation of fluid properties from microthermometric data on fluid inclusions. Geochimica et Cosmochimica Acta, 11 (5): 614-645.

OHLWEILER, O.A. (1971) Sólidos. In: Introdução a química geral. Porto Alegre, Editora Globo. p. 240-299.

OLHOEFT, G.R. \& JOHNSON, G.R. (1990) Densities of rocks and minerals. In: CARMICHAEL, R.S. (ed.). Practical handbook of physical properties of rocks and minerals. Boston, CRC Press. p. 139-176.

OLIVEIRA, C.M.M. de. (1984) Composição mineralógica e química do nível topazífero nas proximidades de Rodrigo Silva (Ouro Preto) - MG. In: CONGRESSO BRASILEIRO DE GEOlOGIA, 33., Rio de Janeiro, 1984. Boletim de Resumos. Rio de Janeiro, SBG. p. 265-266.

OLSACHER, J. (1946) Introduccion a la cristalografia. Córdoba, Imprenta de la Universidad. 493p.

OLSEN, D.R. (1971) Origin of topaz deposits near Ouro Preto, Minas Gerais, Brazil. Economic Geology, 66 (4): 627-631.

OLSEN, D.R. (1972) Origin of topaz deposits near Ouro Preto, Minas Gerais, Brazil: A reply. Economic Geology, 67 (1): 120-121.

ONASCH, C.M. \& DAVIS, T.L. (1988) Strain determination using cathodoluminescence of calcite overgrowths. Journal of Strutural Geology, 10 (3): 301-303. 
O'ROURKE, J.E. (1957) The stratigraphy of the metamorphic rocks of the Rio de Pedras and Gandarela Quadrangles, Minas Gerais, Brazil. Wisconsin, 106p. (Ph.D. Thesis. University of Wisconsin, USA).

PARDEE, J.T.; GLASS, J.J.; STEVENS, R.E. (1937) Massive low-fluorine topaz from the Brewer Mine, South Carolina. The American Mineralogist, 22 (10): 1058-1064.

PENFIELD, S.L. \& MINOR JR., J.C. (1894) On the chemical composition and related physical properties of topaz. The American Journal of Science, 47 (281): 387-396.

PENTEADO, M.M. (1978) Fundamento de geomorfologia. Rio de Janeiro. IBGE. 171p.

PERKINS, P.H. (1981) Gemstone of the bible. 2. ed. Georgia, Library of Congress. 142p.

PETRICORENA, M.B. (1989) Gemas, tratado de gemologia. Zaragoza, Ediciones Aguaviva. $441 \mathrm{p}$.

PETROV, I.; SCHMETZER, K.; BANK, H. (1977) Orangefarbene topaskristalle von Saramenha bei Ouro Preto, Minas Gerais, Brasilien. Aufschluss, 28: 219-220.

PIRES, F.R.M. (1983) Greenstones as a part of the Minas Supergroup in the Quadrilatero Ferrífero, Minas Gerais, Brazil. Revista Brasileira de Geociências, 13 (2): 106-112.

PIRES, F.R.M; FREITAS, C.O; PALERMO, N.; SARCIÁ, M.N.G. (1983a) Geologia e gênese dos depósitos de topázio do Distrito de Ouro Preto - Minas Gerais. In: SIMPÓSIO DE GEOLOGIA DE MINAS GERAIS, 2. Belo Horizonte, 1983. Anais. Belo Horizonte, SBG. v. 3, p. 283-296.

PIRES, F.R.M.; SARCIÁ, M.N.G.; PALERMO, N. (1983b) Ánalise estrutural e revisão litoestratigráfica do Supergrupo Minas na região do sinclinal Dom Bosco, Quadrilátero Ferrifero, Minas Gerais. Anais da Academia Brasileira de Ciências. Resumo das comunicações. 55 (3): 326-327.

POMERENE, J.B. (1958a) The Cercadinho Formation. Boletim da Sociedade Brasileira de Geologia, 7 (2): 64-65. 
POMERENE, J.B. (1958b) Taboões Quartzite. Boletim da Sociedade Brasileira de Geologia, 7 (2): 66-67.

POMERENE, J.B. (1958c) Barreiro Formation. Boletim da Sociedade Brasileira de Geologia, 7 (2): 67-68.

POMERENE, J.B. (1964) Geology and ore deposits of the Belo Horizonte, Ibirite and Macacos Quadrangles, Minas Gerais, Brazil. U. S. Geological Survey Professional Paper, 341 D: $1-84$.

POTY, B.; LEROY, J.; JACHIMOWICS, L. (1976) Un nouvel appareil pour la mesure des temperatures sous le microscope: L'installation de microthermometrie CHAIXMECA. Bulletin de la Societe francaise de Mineralogie et de Cristallographie, 99 (2/3): 182186.

POVARENNYKH, A.S. (1978) The use of infrared spectra for the determination of minerals. The American Mineralogist, 63 (9-10): 956-959.

QUADE, H. (1985) Deformation pattern of the Precambrian Iron Quadrangle, Brazil. In: INTERN. CONF. ON TECT. AND STRUCT. PROCES. UTRECHT. Abstracts. p. 113114.

RAGATKY, D. (1992) Geoquímica das rochas da Formação Gandarela na região da Mina do Capão do Lana, Ouro Preto, Minas Gerais. In: CONGRESSO BRASILEIRO DE GEOLOGIA, 37., São Paulo, 1992. Boletim de resumos Expandido. São Paulo, SBG, Núcleo São Paulo. v.2, p. 35-36. (Sessões Temáticas).

RIBBE, P.H. \& ROSENBERG, P.E. (1971) Optical and X-ray determinative methods for fluorine in topaz. The American Mineralogist, 56 (9/10): 1812-1821.

ROBERTS, W.L.; RAPP JR., G.R.; WEBER, J. (1974) Encyclopedia of minerals. New York, Van Nostrand Reinhld Company. 693p.

RODRIGUES, D.M.S. (1967a) Topografia. In: BARBOSA, G.V. \& RODRIGUES, D.M.S. (ed.). Quadrilátero Ferrifero. UFMG - Instituto Central de Geo-Ciências. p. 9-13. (publicação interna). 
RODRIGUES, D.M.S. (1967b) Clima e Vegetação. In: BARBOSA, G.V. \& RODRIGUES, D.M.S. (ed.). Quadrilátero Ferrífero. UFMG - Instituto Central de Geo-Ciências. p. 1421. (publicação interna).

RODRIGUES, D.M.S. (1967c) Aspéctos Geológicos. In: BARBOSA, G.V. \& RODRIGUES, D.M.S. (ed.). Quadrilátero Ferrífero. UFMG - Instituto Central de Geo-Ciências. p. 2245. (publicação interna).

ROEDDER, E. (1963) Studies of fluid inclusions II: freezing data and their interpretation. Economic Geology, 58 (2): 167-211.

ROEDDER, E. (1972) Data of geochemestry, composition of fluid inclusion. U. S. Geological Survey Professional Paper, 440 .JJ: 1-164.

ROEDDER, E. (1977) Fluid inclusions as tools in mineral exploration. Economic Geology, 72 (3): $503-525$.

ROEDDER, E. (1984) Fluid inclusions. Reviews in Mineralogy, 12: 1-644.

ROEDDER, E. \& BODNAR, R.J. (1980) Geologic pressure determinations from fluid inclusions estudies. Annual Review of Earth and Planetary Sciences, 8: 263-301.

RÖESER, H.; MÜlLER, G.; TOBSCHALL, H.J. (1980) Petrogênese dos esteatitos do sudeste do Quadrilátero Ferrífero. In: CONGRESSO BRASILEIRO DE GEOLOGIA, 31., Camboriú, 1980. Anais. Camboriú, SBG. v. 4, p. 2230-2245.

RÖESER, H.; RÖESER, U.; LADEIRA, E.A.; TOBSCHALL, H.J. (1982) The petrology and geochemical evolution of the basement of the Quadrilatero Ferrifero, Minas Gerais, Brazil. In: CONGRESSO LATINOAMERICANO DE GEOLOGIA, 5,. Buenos Aíres, 1982. Actas. Buenos Aíres, Servicio Geologico Nacional. v. 3, p. 675-690.

RÖESER, H.M.P.; ALKMIM, F.F.; EVANGELISTA, H.J.; COELHO, J.; MENEZES, M.G.; VARAJÃO, C.C.; SOUZA, J.L. de; FERREIRA, C.M.; GOMES, N.S. (1989) Quadrilátero Ferrífero. In: XIII INTERNATIONAL GEOCHEMICAL EXPLORATION SYMPOSIUM e II BRAZILIAN GEOCHEMICAL CONGRESS., Rio de Janeiro, 1989. Excursions. Rio de Janeiro, SBGq/CPRM/DNPM. p. 11-18. 
ROLFF, A. (1971) Brazilian imperial topaz. Lapidary Journal, 25: 1556-1562.

ROLFF, P.A.M. de A. (1945) Nota sobre algumas jazidas de fluorita. Revista da Escola de Minas, 10 (2): 427-429.

ROLFF, P.A.M. de A. (1950) Calcáreos dolomíticos no município de Ouro Preto. Revista da Escola de Minas, 15 (1):5-13.

ROSENBERG, P.E. (1967) Variation in the unit-cell dimensions of topaz and their significance. The American Mineralogist, 52 (11/12): 1890-1895.

RÖSLER, H.J. (1981) Quarz und silikate. In: Lehrbuch der mineralogie. Leipzig, VER Deutscher Verlag für grundstoffindustrie. p. 484-490.

ROUBAULT, M. (1963) Détermination des minéraux des roches au microscope polarisant. Paris, Lamarre-Poinat. 365p.

RUPLINGER, P.K. (1983) Topaz and andalusite mining in Brazil. The Journal of Gemmology, $18(7)$ : 581-591.

SAUER, J.R. (1982) Topázio imperial. In: Brasil, paraíso de pedras preciosas. São Paulo, Gráfica Editora Hamburg. p. 56-59.

SCHORSCHER, H.D. (1978) Komatítos na estrutura "greenstone belt" Série Rio das Velhas, Quadrilátero Ferrífero, Minas Gerais, Brasil. In: CONGRESSO BRASILEIRO DE GEOLOGIA, 30., Recife, 1978. Resumo das Comunicações. Recife, SBG. p. 292-293.

SCHORSCHER, H.D. \& BRITO, I.M. (1979) Evolução geotectônica e petrogenética do embasamento arqueano do Quadrilátero Ferrífero. Anais da Academia Brasileira de Ciências, 51 (4): 767-768.

SCHORSCHER, J.H.D. (1992) Arcabouço petrográfico e evolução crustal de terrenos precambrianos do sudeste de Minas Gerais: Quadrilátero Ferrífero, Espinhaço Meridional e domínios granito-gnáissicos adjacentes. São Paulo 274p. (Tese de LivreDocente, Instituto de Geociências/USP). 
SCHUMANN, W. (1985) Descrição das gemas. In: Gemas do mundo. Rio de Janeiro, Ao Livro Técnico. p. 102-103.

SCHWARZ, D. (1987) Inclusões - classificação das inclusões observadas em gemas. In: Esmeraldas: inclusões em gemas. Ouro Preto. Imprensa Universitária da UFOP. p. 231-256.

SHEPHERD, T.J.; RANKIN, A.H.; ALDERTON, D.H.M. (1985) A practical guide to fluid inclusion studies. Glasgow, Blackie \& Sons Limited. 239p.

SILVA, A.T. da. (1979) Granulometria. In: Tratamento de minérios. Ouro Preto. v.1, p. 27-37. apostila da UFOP.

SIMMONS, G.C. (1958) The Fecho do Funil formation. Boletim da Sociedade Brasileira de Geologia, 7 (2): 65-66.

SIMMONS, G.C. \& MAXWELL, C.H. (1961) O Grupo Tamanduá da Série Rio das Velhas. Boletim DFPM/DNPM, (211): 1-30.

SINKANKAS, J. (1966) Mineralogy: a first course. New Jersey, D. Van Nostrand Company. $587 \mathrm{p}$.

SINKANKAS, J. (1981) Coloring gemstones and minerals. In: Gemstone \& Mineral Data Book. New York, Van Nostrand Reinhold. p. 108-122.

SMITH, J.V. \& STENSTROM, R.C. (1965) Electron-excited luminescence as a petrologic tool. Journal of Geology, 73: 627-635.

SMYTH, J.R. \& BISH, D.L. (1988) Crystal structures and cation sites of the rock-forming minerals. Boston, Allen \& Unwin. 332p.

SORBY, H.C. (1858) On the microscopic structure of crystals, indicating the origin of mineral and rocks. The Quartely Journal of the Geological Society of London, 14 (1): 453-500.

SPENGLER, W.H. (1985) The Katlang pink topaz mine north west frontier province, Pakistan. The Journal of Gemmology, 19 (8): 664-671. 
SPIX, J.B. v. \& MARTIUS, C.F.P. v. (1831) Reise in Brasilien, auf Befehl Sr. Majestät Maximilian Joseph I, Königs von Baiern in den Jahren 1817 bis 1820. Lindauer, Munich. 300p.

SUSZCZYNSKI, E.F. (1975) O nióbio, o berílio, o lítio, as micas, o bismuto, o quartzo, a esmeralda e as pedras preciosas. In: Os recursos minerais reais e potenciais do Brasil e sua metalogenia. Rio de Janeiro, Livraria Interciência. p. 463-484.

TEIXEIRA, W. (1985) A evolução geotectônica da porção meridional do Cráton do São Francisco, com base em interpretações geocronológicas. São Paulo, 207p. (Tese de Doutorado - Instituto de Geociências/USP).

TEN HAVE, T.T. \& HEIJNEN, W. (1985) Cathodoluminescence activation and zonation in carbonate rocks: an esperimental approach. Geologie en Mijnbouw, 64: 297-310.

THE ASIAN INSTITUTE OF GEMOLOGICAL SCIENCES. (s.d.) Optic character. In: Gem identification I. p. 4.1-4.9.

THOMAN, C.H. \& LADEIRA, E.A. (1986) Introduction to a workshop on gold deposits related to greenstone belts in Brazil. In: THOMAN, C.H., LADEIRA, E.A., SCHNABEL, D.C. Gold deposits related to greenstone belts in Brazil; deposit modeling workshop. Part A - Excursions. Belo Horizonte. 1986. U. S. Geological Survey Bulletin, 1980 A: A5-A20.

TOURET, J. (1977) The significance of fluid inclusions in metamorphic rochs. In: FRASER, D.G. (ed.). Thermodynamics in geology. Dordrecht, D. Reidel. p. 203-227. (NATO advanced study institute series: Serie C, mathematical and physical sciences, V. 30).

TOURET, J. (1982) An empirical phase diagram for a part of the $\mathrm{N}_{2}-\mathrm{CO}_{2}$ system at low temperature. Chemical Geology, 37 (1/2): 49-58.

TRÖGER, W.E. (1979) Optical determination of rock forming minerals. Stuttgart, E. Schweizerbart'sche Verlagsbuchhandlung. $188 \mathrm{p}$.

TROLL, G.; FARZANEH, A.; CAMMANN, K. (1977) Rapid determination of fluoride in mineral and rock samples using an ion-selective eletrode. Chemical Geology, 20: 295305. 
URABE, T. \& SATO, T. (1978) Kuroko deposits of the Kosaka mine, northeast Honshu, Japan - Products of submarine hot springs on Miocene sea floor. Ecomomic Geology, 73 (2): 161-179.

VALARELLI, J.V. (1982) Determinação das condições de mineralização através de medidas calorimétricas de inclusões fluidas de minerais. Relatório IPT, $\boldsymbol{n}^{0}$ 21.215. p. 1-11.

VERNET, M.; MARIN, L.; BOULMIER, S.; LHOMME, J.; DEMANGE, J.C. (1987) Dosage du fluor et du chlore dans les matériaux géologiques y compris les échantillons hyperalumineux. Analusis, 15 (9): 490-498.

VILLAÇA, J.N. (1981) Alguns aspectos sedimentares da Formação Moeda. In: SIMPÓSIO DE GEOLOGIA DE MINAS GERAIS, 1. Belo Horizonte. 1981. Boletim. Sociedade Brasileira de Geologia. Núcleo Minas Gerais, (2): 93-137.

WEBSTER, R. (1980) Gems; their sources, description and identification. London, Butterworths. 938p.

WEISBROD, A.; POTY, B.; TOURET, J. (1976) Les inclusions fluides en géochimiepetrologie: tendances actuelles. Bulletin de la Societe francaise de Mineralogie et de Cristallographie, 99 (2/3): 140-152.

XAVIER, R.P. (1987) Estudos de inclusões fluidas na mina de ouro Fazenda Brasileiro, "Greenstone Belt" do rio Itapicuru, Bahia. São Paulo, 142p. (Dissertação de Mestrado - Instituto de Geociências/USP).

YPMA, P.J.M. (1966) An instrument for geobarometry of fluid inclusions (abs.). Special Paper, Geological Society of America, 87: 1-190.

ZINKERNAGEL, U. (1978) Cathodoluminescence of quartz and its application to sandstone petrology. Stuttgart, E. Schweizerbart'sche Verlagsbuchhandlung. 1-69. (Contributions to sedimentology, 8). 